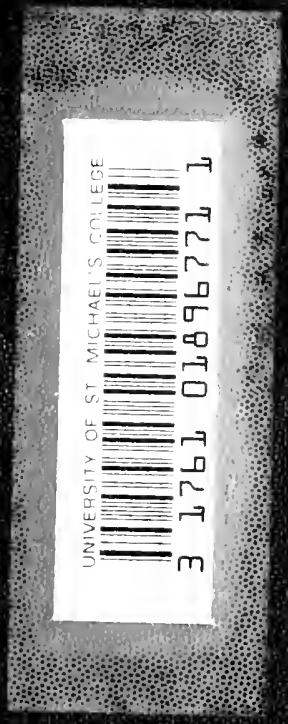



(2) 

THE BOOK OF DANIEL 

THE INTERNATIONAL CRITICAL COMMENTARY

\author{
A CRITICAL AND \\ EXEGETICAL COMMENTARY
}

$\mathrm{ON}$

\title{
THE BOOK OF DANIEL
}

BY

JAMES A. MONTGOMERY, Ph.D., S.T.D.

PROFESSOR IN THE UNIVERSITY OF PENNSYLVANL AND IN THE PHILADELPHIA DIVINITY SCHOOL

Edinburgh : I. \& T. Cl.AkK, 38 George Street 
PRINTFD IN GRF TT BRITAIN BY MORRISON AND GIBB IIMITED

FOR

T. \& T, C L A R K, EDINBURGH NEW YORK: CHAKLES SCRIBNER'S SONS

First Printfon . • . 1927

SFCUNh IMPRESSION . • . I950

THIRL IMHRESSION • • • 1959 
TO THE MEMORY OF JOHN P. PETERS MORRIS JASTROW, JR. ALBERT T. CLAY

ILLUSTRIOUS MEN 



\section{PREFACE。}

In the summer of I9I8 Doctor John P. Peters did me the honor of asking me to collaborate with him on this commentary, which volume had long been assigned to him, but which his manifold activities had not permitted him to undertake. Extraordinary duties prevented me from accepting until the following year. I had then but one brief interview with Doctor Peters on our common task. He died November Io, I921. The publishers generously acknowledged me as heir to his undertaking, and the inheritance has given me an added sense of responsibility for a work which should have borne his name.

With Doctor Peters, my early teacher and friend, I associate the names of two close and dear friends who also during the prosecution of these labors have passed away-Professor Morris Jastrow, Jr., who died in I92 I, and Professor Albert T. Clay, whose loss befell us last year. These three men were remarkable types of a brilliant generation in American Oriental studies. May they indulge me in recalling their ancient association with one another and my own intimate relations with them in work and friendship by the dedication to them of this volume.

The mandate laid upon me in this commission was, it appeared obvious, the presentation of a primarily philological commentary. With all honor to the several brief commentaries on Daniel in English and German during the last generation or longer, we had still to depend, with the exception of the elaborate apologetic commentary of d'Envieu, upon works of the third quarter of the last century and earlier; indeed, in large measure upon commentators of the first third of that century. Meanwhile, within very recent years the philological apparatus has been enormously enlarged by the discovery of the Elephantine papyri, along with a wealth of other new materials, in correspondence with the rapirl development of all Orientalistic studies. Not that Daniel has been neglected. He has been the objective of higher criticism and apology to an unparalleled extent, especially since the revelations of Assyriology. But all such vii 
studies have necessarily been one-sided, have not met the need of a commentary devoted primarily to philology. Even in the field of Biblical Aramaic grammar no comprehensive grammar has appeared since that of Kautzsch in 1884, and none which includes the new sources for study of that dialect. And the lack in this line has been especially evident in English and American scholarship.

In the second place, my interest has been attracted to the textual criticism of the book. I have gone so far afield in this respect that that part of my work may be regarded as an avocation, but I trust that on this score it may claim some originality, if its results be approved. Again, with the treatment of the texts of the versions goes their interpretation. In the first place, their bearing on textual criticism cannot be valued unless they be understood as in the large interpretative documents, to be studied in and for themselves; and in the second place, as the earliest interpretations of the Biblical books, they have an inestimable interest to the exegete, even if the results do not much affect the original text-as in Daniel they do not.

In regard to the literary and historical criticism of the book, I have taken positive position, as one must in the clashing Entweder-Oder of the long discussion. The briefs have long been at hand in the cause celèbre, nor is there sight of its adjudication. I have not been able to do much more than to register my reasoned decisions, opinions which I trust will not appear captious or arbitrary to those from whom I differ. In some respects, e.g., the dating of cc. I-6, I have broken, along with a number of recent scholars, with the regnant view of one camp that the whole book is Maccabæan. A positive contribution, however, may be found in my attempt to respect Daniel as a work of literature and as containing documents of real interest and value for the understanding of the Orient of its day. To this end I have tried to illustrate my work as far as possible from the history and traditions of its age-an eclectic world in which mingled Semitic, Persian, and Hellenic cultures.

It has been my desire to do full justice to my predecessors, not only for honor's sake but from interest in the study of exegesis, in the case of Daniel a peculiarly fascinating study. I have been concerned to discover and record the initiators of interpretations, and it has often been surprising to find how much that 
passes as "modern" may appear in an old-time Protestant or Jewish or Patristic commentator. On the other hand, except in cases of peculiar interest, I have not deemed it necessary to give catence of all the witnesses of interpretation, for one scholar or a few may be right, and the majority does not count as in a democracy. My regret is that I have not been able to make greater use of the Jewish commentators-the initial key to Biblical exegesis, and of the great Protestant and Catholic scholarship immediately subsequent to the Reformation. As far as possible I have economized space and labor by reference to generally accessible authorities. But there has been expansive treatment of certain subjects, especially those in the fields of Aramaic and comparative Semitic grammar, so that the work may serve as a guide to the reader who desires introduction to fields which largely lie beyond the scope of usual Biblical studies. I should be gratified if my work may prosper the cause of Aramaic studies. The English reader may welcome the constant registration of the four current English versions, and the opportunity to trace their dependence upon both elder and modern scholarship.

The fully articulated Table of Contents will, it is hoped, facilitate reference for the reader, while at the same time it avoids the necessity of elaborate indexes.

In conclusion I have acknowledgments to make to several kind friends: to Professors G. A. Barton and R. P. Dougherty for painstaking contributions which will be acknowledged in the pertinent places; to Professors R. Butin, E. M. Grice, A. V. W. Jackson, M. L. Margolis, A. T. Olmstead, and D. M. Robinson for drafts upon their skilled knowledge; to Doctors C. D. Benjamin, H. S. Gehman, and M. J. Wyngaarden, for the pleasure as well as profit I have had in co-operative studies with them; and very particularly to Doctor Gehman for his generous assistance in reading much of the manuscript and all the proof. And I acknowledge my obligations to the publishers for their patience with my delay and with a volume that is swollen beyond original expectations.

December I5, 1926 .

James A. Montgomery. 



\section{CONTENTS.}

PREFACE .

PAGE

vii

BIBLIOGRAPHY • • • • • • • • • • • • • • $\quad$ xV

KEY TO ABBREVIATIONS . . . . . . . . . . xxvii

SYMBOLS AND ABBREVIATIONS IN THE TEXTUAL APPARATUS . . . . . . . . . . . . . . $\mathrm{x} x \mathrm{xi}$

\section{INTRODUCTION}

I. THE BOOK . . . . . . . . . . . . . . I §. The Contents . . . . . . . . . . . . . . . I

§ 2. Early Testimony to the Book and Its Place in the CANON . . . . . . . . . . . . . . 2

§ 3. Literary Divisions of the Book . . . . . . 5

§ 4. a. Apocryphal Additioss . . . . . . . . . . . 8

b. Later Pseudepigrapha . . . . . . . . . . Io

c. Legends . . . . . . . . . . . . . . IO

II. TEXT AND LANGUAGE . . . . . . . . . . II

§ 5. The Hebrew-iramaic Text . . . . . . . . I

§6. The Hebrew . . . . . . . . . . . . 13

§. The Ar.maic . . . . . . . . . . . . . . . I5

§ 8. FOREIGN WORDS . . . . . . . . . . . . 20

a. Words from the AKkAdiaN . . . . . . . . 20

b. Persian Words . . . . . . . . . . . . 2 I

c. Greek Words . . . . . . . . . . . . . 22

§ 9. The Literary Forir of the Book . . . . . . 23

III. ANCIENT VERSIONS . . . . . . . . . . 24

§ 10. Sumira according to Languages. . . . . $\quad 24$

a. Greek . . . . . . . . . . . . . . 24

(1) The Old Greek or 'Septuagint' . . . . . 25

(2) Tie Theodotionic Group . . . . . . . $\quad 26$

(3) The Versions of Aquila and Sxmmaciuds . 27

(4) Tie Medieval Graco-Venetus . . . . . 29

b. Latin. . . . . . . . . . . . . . 29

(i) Tile Old Latin . . . . . . . . . . 29

(2) Tife Vulgate . . . . . . . . . . . . 34 
c. Coptic

d. Syriac

e. Arabic

$f$. Other Languages .

§ix. The Old Greek Version

§ 2. Theodotion. . . . . . . . . . . . . . 39

a. The Greek B-Group . . . . . . . . . . 39

b. The Sahidic-Coptic . . . . . . . . . . . . 442

c. The Old Latin. . . . . . . . . . . . . 43

\$ 13. Theodotion: Triumpil over the Old Greex; Age;

The Problem of 'Ur-Theodotion' . . . . . . 46

§ 14 . The Hexaplaric Revisions: OR ${ }^{\mathrm{P}}$ (V 62 I 47 ) ANd ORC

(the A-Group, Arabic, Bohairic) . . . . . 5 r

§ 15. The Lucianic Revision . . . . . . . . . 53

§ 16. The Old Syriac Version . . . . . . . . . 55

\$ 17. Jerome's Version: the Vulgate . . . . . . $55^{6}$

$\S$ i8. Method and Use of the Textual Apparatus . . 56

IV. HISTORICAL CRITICISM OF THE BOOK . . . 57

§ I9. The Historical Data . . . . . . . . . 57

a. The Appearance of the Book in Literature. 58

b. The Phrlological Evidence . . . . . . 58

c. The Historical Objective of the Book: the Four Monarches . . . . . . . . . . . 59

d. Darius the Mede. . . . . . . . . . . 63

e. Belshazzar . . . . . . . . . . . . 66

f. The Third Year of Jeholakim; the Chaldeans, ETC. . . . . . . . . . . . . 72

g. The Book as an Apocryphon . . . . . . 76

§ 20. The Theology of the Book and Its Place in Jewish Religion . . . . . . . . . . . 78

$\S 2$ I. The Problem of the Unity of the Book and of the Two Languages . . . . . . . . . . . . 88

a. The Two Books, the Stories and the Visions 88 -

b. The Problem of the Two Languages . . . 90

c. Further Divisive Theories. . . . . . . . 92

d. The Dating of the Two Sections . . . . 96

e. Losses and Additions to the Original Book . 99

\$ 22. An Appreciation of the Literary and Religious

Character of the Book . . . . . . . . IOO

a. The Stories . . . . . . . . . . . . IOO

b. The Visions . . . . . . . . . . . . $102-$

๖ 23. Review of the Literature on Daniel . . . . ro5 
PAGE

I. THE HISTORIES . . . . . . . . . . . . II3

Chapter i: The Education of Daniel and His Three ComPANTONS . . . . . . . . . . .

Chapter 2: Nebuchadnezzar's Dream and Its Interpretation by Daniel

Note on the Symbolisir of the Image and Its InterpreTATION

Chapter 3: The Golden Image and th" Three Confessors

Chapter 4: Nebuchadnezzar's Madnesís . . . . . . 220

Note on the Translation of $\mathbb{G}$. . . . . . . . . 247

Chapter 5: Belshazzar's Feast . . . . . . . . 249

Note on the Translation of 6 .

Chapter 6: Dantel in the Lions' Den . . . . . . 268

Note on the Translation of 6 . . . . . . . . . 280

II. THE VISIONS . . . . . . . . . . . . . ${ }_{2} \mathrm{~S}_{2}$

Chapter 7: The Vision of the Beasts and the Man . 282 Note on 'SON OF MAN' . . . . . . . . . . 317

Chapter 8: The Vision of the Ram and the Buck . - 324

Textual Note on 811b.12 . . . . . . . . . . 356

Note on VSS at $8^{13 \mathrm{~b}}$. . . . . . . . . . . . . 358

Chapter 9: The Revelation of the Seventy Weeks - 358

Note on the Interpretation of the Seventy Weeks 390

Note on tile Greek Texts of $9^{24-27}$

(I) $\mathrm{OF}$ (5 . . . . . . . . . . . . . . . . . $40 \mathrm{I}$

(2) of the Texts of $\Theta$. . . . . . . . . . . 402

Chapters io-i2: The Final Revelation. . . . . . 404

Note on tile Princes and Angels in c. to . . . . 4ig

Note on the Interpretation of C. II . . . . . . 468

\section{INDEXES}

I. Index VARIorum . . . . . . . . . . . . $48 \mathrm{I}$

II. Philological Indexes . . . . . . . . . . 484

III. Literary References, Biblical, etc. . . . . . 486 



\section{BIBLIOGRAPHY.}

The following select Bibliography includes books and articles bearing upon the whole of Daniel or upon general questions involved. Reference is made ad locos to special monographs. There are included works of philological and historical bearing upon the subject. Titles not directly known to the author are listed on account of their worth or historical interest; these are marked with an asterisk.

AbEn EzRA: text in Miksraoth Gedoloth.

Abrabanel:* Comm. on Dan., for edd. s. Rosenmüller, p. 39.

Achelis, H.: Hippolytstudien, TU, vol. I, Heft 4.

Albertus Magnus:* Commentarius in Danielem, Lyons, I65 I, etc.

Anderson, R.: Daniel in the Critics' Den (answer to Professor Driver and

Dean Farrar), n.d.

Aphrem Syrus: Comm. on Dan., Roman ed., vol. 2, I 740.

Apollinaris: excerpts of comm. in Mai, q.v.

Auberlen, K. A.: Der Prophet Daniel u. die Offenbarung Johannis, i 854 . Auchincloss, W. S.: The Book of Daniel Unlocked, N. Y., 1905.

Ball, C. J.: Daniel and Babylon, Expositor, I9 (I920), 235.

Bär, S.: Libri Danielis Ezrae et Nehemiae, I882.

Bardenhewer, O.: Des heiligen Hippolytus von Rom Commentar zum Buche Daniel, i877.

* Polychronius . . . ein Beitrag zur Geschichte der Exegese, r879.

Bar Hebreus:* J. Freimann, Scholien zu Dan., 1892; * A. Heppner, Scholien z. Ruth u. z. d. apok. Zusätzen zu Dan., I 888.

Barth, J.: Die Nominalbildung in den semitischen Sprachen, I889, I89 I $(=N b g$.$) .$

Barton, G. A.: The Composition of the Book of Daniel, JBL IS98, 62 (rev. by König, Theol. Literaturblatt, I908, no. 46).

Bauer, H., and Leander, P.: Historische Grammatik der hebräischen Sprache, vol. I, I922.

BAyER, E.: Danielstudien, Alttestamentliche Abhandlungen (Münsteri. W.) 3, Heft 5, I9 2 .

Behrmann, G.: Das Buch Daniel, in Nowack's HK, I894 (rev. by Rothstein, DLZ Nov. 28, Dec. 26, I896).

Benjamin, C. D.: Collation of Holmes-Parsons 23 (Venetus)-62-147 in Daniel from Photographic Copies, JBL 44 (I925), 303-326.

Bergsträsser, G.: Hebräische Grammatik (announced as ed. 29 of Gesenius' Grammatik), pt. I, I9 8 .

Bertholdt, L.: Daniel, i 806 .

Bertholet, A.: s. under Stade. 
Bevan, A. A.: A Short Commentary on the Bk. of Dan., I892 (rev. by Nestle, LCB i892, no. 37).

Bevan, E.: House of Seleucus, 2 vols., 1902.

- Jerusalem under the High-Priests, 1904.

Bianchini, J.: Dissertationes, on Chigi text; s. Int. §Io, $a$ (I).

BleEK, F.: Einleitung in das Alte Testament, edd. 4 and 5 (1886) by J. Wellhausen.

* Über Verfasser u. Zweck des Buches Dan., Theol. Zts., I822, I7r.

* Die mess. Weissagungen im Buche Dan., Jahrb. f. deutsche Theologie, I860, 47 .

Bludad, A.: De alexandrinae interpretationis libri Danielis indole critica et hermeneutica, Münster i. W., I891

— Die alexandrinische Übersetzung des Buches Daniel und ihr Verhältniss zum massorethischen Text $=$ Biblische Studien ii, Heft 2-3, Freiburg i. B., I897.

- Die Apokalypse und Theodotions Danielübersetzung, Theol. Quartalschrift, I897, p. I.

Bochart, S.: Omnia opera, Leyden, i 7 r 2.

Bonwetsch, G. N.: Studien zu den Kommentaren Hippolyts zum Buche Daniel und Hohenliede, TU I ( 1897 ).

-- and Achelis, H.: ed. Hippolytus' Comm. to Dan., GCS I, 1897.

BouchÉ-LECLERCQ, A.: Histoire des Lagides, 4 vols., r9o3 seq.

— Histoire des Séleucides, I9I3.

Bousset, W.: Die Religion des Judentums im neutestamentlichen Zeitalter's, 1906.

Boutflower, C.: In and Around the Bk. of Dan., London, r923 ( $c f$. Rowley, The Belsh. of Dan. and of History, Exp. Sept., Oct., I924).

Breithaupt, J. F.: R. Salomonis Jarchi [= Rashi] commentarius hebraicus in Prophetas [etc.] latine versus, Göttingen, I 713.

Briggs-Driver-Brown: A Hebrew and English Lexicon of the O. T., I89I$1906(=\mathrm{BDB})$.

Brockelman, C.: Lexicon Syriacum, 1895, ed. 2, I923 seq. (Lex.).

- Grundiss der vergleichenden Grammatik der semitischen Sprachen, 2 vols., I908-19I3 $(=V G)$.

Broughton, H.:* Danielis visiones chaldaicae et ebraeae, London, 1596 .

Brown, C. R.: An Aramaic Method, I886 (in Harper's series).

Buhr, F.: ed. Gesenius' Heb. u. Aram. Handwörterbuch ${ }^{16}$, I9I5 (= GB). - Daniel, PRE 3 , I8g8.

Burkitt, F. C.: Texts and Versions, in EB.

- Jewish and Christian Apocalypses, London, Igr3.

Buttenwieser, M.: Apocalyptic, JE.

BUxTORF, JoHN: Lexicon chaldaicum, talmudicum et rabbinicum (ed. by his son), Basel, 1640 .

Buzy, D.: Les symboles de Daniel, RB I5, 403. 
Calmet, A.:* Commentaire littéral sur tous les livres de l'Ancien et du Nouveau Testament, r 707 , etc.

Calvin, John:* Praelectiones in librum prophetiarum Danielis I. Budaei et C. Ionuillae labore et industria exceptae, Geneva, I 56I (Eng. tr., Edinb., I852).

Caspari, C.: Zur Einführung in d. Buch Dan., Lpzg., i 869.

Ceriani, A.: Codex syrohexaplaris ambrosianus photolithographice editus $=$ Monumenta sacra et profana, vol. 7, 1874 (rev. by Nestle, TLZ 1876 , I 79).

Charles, R. H.: A Critical History of the Future Life in Israel, Judaism, and Christianity, I9Io.

ed. Apocrypha and Pseudepigrapha of the Old Testament, 2 vols., I9I3 (= Apoc.).

— Book of Daniel, New Century Bible, n.d.

Religious Development between the Old and the New Testaments, n.d.

Cocceius (Cock), J.: Observata ad Danielem, Leyden, I 666.

Collins, A.:* The Scheme of Literal Prophecy Considered, i726.

Cooke, G. A.: A Text-Book of North Semitic Inscriptions, Oxford, I903 $(=N S I)$.

Cornelius À Lapide: Commentarii in Scripturam Sacram, Lyons, 1885 .

Cornill, C. H.: Einleitung in das A. T. ${ }^{2}{ }_{1} 8_{92}$ (Eng. tr. I907).

Corpus inscriptionum semiticarum, i88 I seq. (=CIS).

Corpus scriptorum ecclesiasticorum latinorum, I $866 \mathrm{seq} .(=$ CSEL $)$.

CORRodr:* Freimüthige Versuche über verschiedene in Theologie u. bibl.

Kritik einschlagende Gegenstände, I 783 .

Cowley, A.: Aramaic Papyri of the Fifth Century B.C., I923 $(=A P)$;

also s. under Sayce.

CozzA, J.: Sacrorum Bibliorum vetustissima fragmenta graeca et latina, Rome, $1867-77$ (s. Int. §Io, $a$ ).

Creelman, H.: An introduction to the O.T. Chronologically Arranged, N. Y., I917.

Critici sacri, editor Cornelius Bee (London, I660), Amsterdam, I698.

Curtis, E. L.: Daniel, DB, 1898.

Dalman, G.: Worte Jesu, Lpzg., i 898 (also Eng. tr., Scribner's).

- Grammatik d. jüdisch-palästinensischen Aramäisch ${ }^{2}, 1_{905}(=G r$.).

Aramäisch-neuhebräisches Handwörterbuch zu Targum, Talmud u.

Midrasch', I923 (=IIwb.).

Davidson, Samuel: Introduction to the O.T., vol. 3, I863.

DeANe, H.: Daniel, his Life and Times, London, r 888.

—_ Daniel, in Ellicott's Old Testament Comm.

Delrtzsch, Franz: Daniel, in PRE edd. r. 2.

Delitzsch, Friedrich: Philological Contributions to Bär's text, pp. vi-xii. 
DeLitzsch, Friedrich: Assyrische Grammatik, i889 (= Gr.).

- Assyrisches Handwörterbuch, I896 (= Hwb.).

-D Die Lese- und Schreibfehler im A. T., I9zo.

De Wette, W.: Lehrbuch d. . . . Einleitung in die Bibel Alten und Neuen

Testamentes, ed. 4, I 845 .

Dold, A.: Konstanzer altlateinische Propheten- und Evangelienbruchstücke, $=$ Texte u. Arbeiten herausgegeben durch die Erzabtei Beuron,

I Abt., Ifefte 7-9, Lpzg., I923.

Dougherty, R. P.: Nabonidus and Belshazzar (to appear in YOS).

Driver, G. R.: The Aramaic of the Book of Daniel, JBL I926, Iro-iIg.

Driver, S. R.: Introduction to the Literatu re of the Old Testament, ed. Io, I900, N. Y. = ed. 6, I897; also an ed. 8, ig09.

- A Treatise on the Tenses in Hebrew ${ }^{3}, \mathrm{I}_{892}$.

- Daniel, in CBS, I900, last imprint 1922.

Duval, R.: Traité de grammaire syriaque, I88I $(=G S)$.

EhrLich, A. B.: Randglossen zur hebräischen Bibel, vol. 7, 19r4, pp. r26155 on Dan.

Eichrorn, J. G.: Einleitung in das A. T.4, 1823-25.

ElLiott, E. B.: Horae apocalypticae, London, I862 (vol. 4 contains history of interpretation).

L'Empéreur, C.:* ed. with tr. of Ben Yachya's comm., Amsterdam, I633. D'Envieu, J. F.: Le livre du prophète Daniel, 4 vols., Paris, I888-9r.

Eusebius: Demonstratio evangelica, ed. Gaisford, r852 (Eng. tr. by Ferrar, 1920).

- Praeparatio evangelica, ed. Gifford, 1903.

Ewald, H.: Daniel, in Die Propheten d. Alten Bundes², vol. 3, I868 (Eng. tr. I88I, vol. 5).

Ausführliches Lehrbuch der hebräischen Spraches, I870.

Fabricius, J. A.: Codex pseudepigraphus Veteris Testamenti, Hamburg, $17 \mathrm{I} 3$.

FARRAR, F. W.: The Book of Dan., in Expositor's Bible, 1895.

FIELD, F.: Origenis hexaplorum quae supersunt, 1875.

Ful.LeR, J. M.: Daniel, in the Speaker's Commentary, I876.

- Bk. of Dan. in the Light of Recent Discoveries, Exp., March, June, r885.

Gall, A. von: Die Einheitlichkeit des Buches Daniel, 1895 .

Gallé, A. F.: Daniel avec commentaires de R. Saadia, Aben-Ezra, Raschi, etc., et variantes des versions arabe et syriaque, Paris, 1900 .

Gebhardt, O. von: Graecus Venetus, Lpzg., I875 (rev. by Kamphausen, TSK, 1876,577$)$.

Geriman, H. S.: The "Polyglot" Arabic Text of Daniel and Its Affinities, JBL +4 (1925), 327-352. 
Geier, M.: Praelectiones academicae in Danielem prophetam ( 1667 ), Lpzg., 1684.

Gesenrus, W.: s. under Briggs-Driver-Brown, Buhl, Kautzsch.

Ginsburg, C. D.: Hebrew Bible, London, 1894 .

- Introduction to the Massoretico-Critical Edition of the Hebrew Bible, London, 1897 (=Int.).

Giron, N.: for monographs on OAram. texts s. Int., \$7, n. 2.

Graetz, H.: Beiträge zur Sach- u. Wörtererklärung des Buches Daniel, MGWJ 20 (1871), 339-352, 385-406, 433-449.

Graf, C. H.:* Daniel, in Schenkel's Bibellexicon, i86r.

Die griechischen christlichen Schriftsteller der ersten drei Jahrhunderte, $1897 \mathrm{seq}$. (= GCS).

Griesinger, G. F.:* Neue Ansicht der Aufsitze im Buche Daniel, Stuttgart, I8I5.

Grotius, H.: Annotationes in Vetus et Novum Testamentum, London, 1727.

Gunkel, H.: Schöpfung u. Chaos in Urzeit u. Endzeit, I895 (s. Giesebrecht, GGA I895, 596 ff., Wellhausen, in Skizzen u. Vorarbeiten, 6 (1899), 21 5249 , and Gunkel in reply ZWT 42 (1899), 581-6rir).

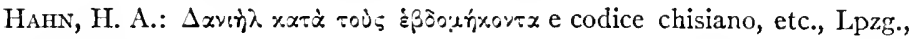
$\mathrm{r} 845$.

Hamburger, J.: Daniel, in his Real-Encyclopädie f. Tibel u. Talmud, vol. I, 1870 , also on the bk., p. 920.

Hatch, E., and Redpath, H. A.: A Concordance to the Septuagint, 139297, Oxford.

Hacpt, P.: Notes to Kamphausen in SBOT.

Hävernick, H. A. C.: Commentar über das Buch Dan., I832.

__ Neue kritische Untersuchungen über d. B. Dan., Ilamburg, i $8_{3} 8$.

HeBbelynck:* De auctoritate libri Danielis, Löwen, i 887.

Heller, B.: Das Traumerraten im Buche Daniel, ZATW i925, 243-246.

Hengstenberg, E. W.: Authentie des Daniel, 1831.

Hilgenfeld, A.:* Die Propheten Esra u. Daniel, 1863.

Hippolytus: s. under Bonwetsch.

Hrtzig, F.: Das Buch Daniel, 1850.

Holm, A.: Griechische Geschichte, vol. 4, I894.

Holmes, R., and Parsons, J.: Vetus Testamentum graecum cum variis lectionibus, 4 vols., $1798-1827$, Oxford.

IIöLscher, G.: Die Entstehung des Buches Dan., TSK 1919, Ir3.

Н̈̈нN, E.: Die messianische Weissagungen, I899, vol. I, §3०.

IBN JANÂ!̣: The Book of Hebrew Roots, ed. A. Neubauer, I875.

Jackson, F. J. FoAkes, and LAKE, K.: The Beginnings of Christianity, vol. I, London, 1920 (with contributions by Montefiore, G. F. Moore).

JAnN, G.: Das Buch Daniel nach der Septuaginta hergestellt, I904. 
Jastrow, Marcus: Dictionary of the Targumim, etc., I903.

Jastrow, Morris: Die Religion Babyloniens und Assyriens, I905 seq.

LE JAY, G. M.: Biblia Sacra polyglotta, Paris, 1645 .

Jephet ibs 'Alî: Comm. on Daniel, ed. D. S. Margoliouth, in Anecdota

Oxoniensia, 1889 .

Jerome: In Danielem prophetam, ed. Vallarsi, vol. 5, i 768.

Joüon, P.: Grammaire de l'Hébreu biblique, Rome, 1923.

Junius, F.:* Expositio prophetae Danielis, Heidelberg, 1593.

Kahle, P.: Masoreten des Ostens, IgI3.

— Ed. texts with Babylonian punctuation in Strack's Grammatik.

- Sections on Bab. punctuation in Bauer-Leander's Grammatik.

Kamphausen, A.: Das Buch Daniel u. die neuere Geschichtsforschung, I893.

- Daniel, in SBOT, 1896 .

- Daniel, in EB, r899.

KaUtzsch, E.: Grammatik des Biblisch-Aramäischen, I884 (rev. by Nöldeke, GGA, I 884, 1014-23).

— Wilhelm Gesenius' Hebräische Grammatik ${ }^{26}$, 1896 (= GK); Eng. tr., by A. Cowley.

— Die Apokryphen und Pseudepigraphen des A. T., 2 vols., 1900.

- Die Aramaismen im Alten Testament, rgo2.

KeIL, C. F.: Biblischer Commentar über den Propheten Daniel, I869.

Kennedy, J.: The Book of Daniel from the Christian Standpoint, London, I 898 .

Kennicott, B.: Vetus Testamentum hebraicum cum variis lectionibus, 2 vols., r776, i780, Oxford.

Kent, C. F.: Sermons, Epistles and Apocalypses of Israel's Prophets, N. Y., I9IO.

KIrchner, G. S. L.:* Die Hauptweissagungen des Buches Daniel, r8g8.

KIrMss, H. G.:* Commentatio historico-critica exhibens descriptionem et censuram recentiam de Danielis libro opinionum, 1828 .

KıTteL, R.: Biblia hebraica, ed. I, I905, ed. 2, I9I 2.

KLIEfoth, T.: Das Buch Daniel, I868.

Knabenbauer, J.: Commentarius in Danielem prophetam Lamentationes et Baruch, Paris, I89r, in Cursus Scripturae Sacrae.

KöNIG, E.: Historisch-kritische Lehrgebäude der hebräischen Sprache, 2 vols., I $88 \mathrm{I}$, I $\mathrm{I}_{5} 5(=L g b$.).

- Syntax der hebräischen Sprache, $1897(=S y n$.$) .$

— Hebräisches und aramäisches Wörterbuch zum A. T., ed. I, Ig10, ed. $3,1922(=I I \omega b$.$) .$

— Die messianischen Weissagungen des A. T., I923.

- Theologie des A. T.4, 1923 .

Kranichfeld, W. P.: Das Buch Daniel, i868.

Kuenen, A.: Hist.-kritische Einleitung in die Bücher des A. T., 2 vols., I $887-92$. 
LAMBERT, M.: ספר רניאי in Cahana's,

Lengerke, C. von.: Das Buch Daniel, I835.

Levias, A.: A Grammar of the Aramaic Idiom contained in the Babylonian Talmud, Cincinnati, I900.

LEvy, J.: Neuhebräisches und chaldäisches Wörterbuch über die Talmudim und Midraschim, 1876 seq.

LmzBARSki, M.: Handbuch der nordsemitischen Epigraphik, I898 (=NE).

- Ephemeris für semitische Epigraphik, 3 vols., I902-I5 (=Eph.).

Altaramäische Urkunden aus Assur, 192r.

Mandäische Liturgien (including Euting's Qolasta), I920.

Lightfoot, John (i6o2-1675): Works, ed. Pitman, I 2 vols., I825.

LöHr, M.: Textkritische Vorarbeiten zu einer Erklärung des Buches Daniel, ZATIV ז 895, 75-103, 193-225; 1896, 17-39.

ed. critical apparatus in Kittel's Bible.

Lowth, WM.: Commentary upon the Prophecy of Daniel and the Twelve Minor Prophets, 1726.

Luther, M.: Die Bibel, print of the National-Bibelgesellschaft.

* Auslegung des Propheten Daniel (compilation of three works, in Walch's ed., vol. vi; for bibhography s. Rosenmüller, p. 44).

Luzzatro, S. D.: Grammatik der biblisch-chaldäischen Sprache und des Idioms des Thalmud Babli, 1873 .

MACLER, F.: Les apocalypses apocryphes de Daniel, Paris, I895.

- L'Apocalypse arabe de Daniel, Paris, I904.

Mahaffy, J. P.: The Empire of the Ptolemies, I895.

MAI, A.: Scriptorum veterum nova callectio e vaticanis codicibus edita, 2 vols., I825-3x; vol. I contains Polychronius and commentarii variorum on Daniel.

(DE MAîtres, S.) : Daniel secundum Septuaginta ex tetraplis Origenis, Rome, I 772 .

Maldonat, J.:* Commentarius in Jeremiam, Ezechielen, Danielem, Leyden, I6II.

Manchester, George, Duke of:* Times of Daniel, Chronological and Prophetical, 1849 .

Margolioutit, D. S.: s. under Jephet.

MARgolis, M. L.: Lehrbuch der aramäischen Sprache des babylonischen Talmuds, I9ro.

Marsham, John:* Canon chronicus, Frankfurt, I697.

Marti, K.: Daniel, in Kautzsch, Die Heiligen Schriften des A. T., I894.

— Das Buch Daniel, Igor, in Marti's KHC.

- Kurzgefasste Grammatik der biblisch-aramäischen Sprache, ed. I, I806 (rev. by Nöldcke, LCB 1896, 702, by Rahlfs, TLZ 1896, 585), ed. 2, i9 I : (ed. $3^{*}, 1925$ ).

Maurer, F.: Commentarius grammaticus criticus in Vetus Testamentum, vol. 2, Eze., Dan., Lpzg., 1838 . 
McCown, C. C.: Hebrew and Egyptian Apocalyptic Literature, in Harvard Theol. Rev. I8 (1925), 357-4 I I.

Mernhold, J.:* Die Komposition des Buches Daniel, $188_{4}$ (Diss.).

- Beiträge zur Erklärung des Buches Daniel, i 888 (rev. by Budde, TLZ Dec. 29, I 888).

Das Buch Daniel, is89, in Strack and Zöckler's Comm.

Merssner, B.: Babylonien und Assyrien, 2 vols., 1920-25.

Melancrithon, P.:* Commentarius in Danielem prophetam, i 543 .

Merx, A.: Cur in libro Danielis iuxta hebraeam aramaca adhibita sit dialectus, I865.

Meyer, E.: Geschichte des Altertums, vol. 3, rgor.

- Ursprung und Anfänge des Christentums, vol. 2, r92 r (ed. 4-5, I925).

Mrchaelis, C. B.: Uberiores annotationes philologico-exegeticae in hagiographos Veteris Testamenti, Daniel in vol. 3, Halle, I 720.

Mrciraelis, J. D.: Orientalische und exegetische Bibliothek, iz7I seq.

- Neue or. u. cx. Bibliothek, i $786 \mathrm{seq}$.

- Supplementa ad lexica hebraica, n.d.

- Reprint of de Maîtres, Daniel secundum Septuaginta, Göttingen, I 773, 1774 .

Mrchaelis, J. H.: Biblia hebraica ex aliquot MSS, etc., Magdeburg, 1720.

Mrgne, J. P.: Patrologia latina, $1878 \mathrm{seq}$. $(=P L)$.

- Patrologia graeca, i886 seq. $(=P G)$.

Mikraoth Gedoloth (Hebrew title): Warsaw ed., vol. 6, I874.

Mrlis, L. H.: Avesta Eschatology compared with the Book of Daniel and Revelation, I908.

Moffatt, James: The Old Testament, a New Translation, 2 vols., I924-25.

Mommsen, T.: Römische Geschichte 5 , vol. 5, I885.

Montgomery, J. A.: Aramaic Incantation Texts from Nippur, Philadelphia, 1913.

- The Hcxaplaric Strata in the Greek Texts of Daniel, JBL 44 (1925), 289-302.

Müller, C.: Fragmenta historicorum graecorum, I84I seq.

Musaeus, J.: Scholae in prophetas Danielem Micham et Joelem, i 7 I 9

Nestle, E.: Bibelübersetzungen, in $\mathrm{PRE}^{3}$.

- Marginalien und Materialien, 1893 (Marg., ref. to first part).

s. under Tischendorf.

Neubauer, A.: s. under Ibn Janâh.

Newton, Srr Isaac: Observations upon the Prophecies of Daniel and the Apocalypse of St. John, I732, etc. (also Lat. tr., Amsterdam, I737); an ed. from 'unpublished MSS.' by IV. Whitla, Daniel and the Apocalypse, London, I922.

Nicolas de LyRa:* Commentary, in Migne's Cursus completus Scripturae Sacrae, vol. 20 . 
NöLdEkE, T.: Mandäische Grammatik, 1875 (= $M G)$.

- Kurzgefasste syrische Grammatik ${ }^{2}$, 898 ( = SG); Eng. tr. by Crichton, Compendious Syriac Grammar, London, I904.

Neue Beiträge zur semitischen Sprachwissenschaft, I9Io (= NBSS).

Oecolampadits, J.:* In Danielem libri duo, Basel, I 530.

Pereira (Pererius), B.:* Commentariorum in Danielem prophetam libri xvi, Rone, I 586 .

Perles, F.: Analekten zur Textkritik des A. T., ed. I, 1895, ed. 2, r922.

Philippe, E.:* Daniel (prophet and book), in Vigouroux, Dictionnaire de la Bible, 2, coll. 1247-1 $28_{3}$.

Pognon, H.: Inscriptions sémitiques de la Syrie, etc., 1907-08.

Polanus, A.:* In Danielem . . . commentarius, Basel, I606.

PCie, Matthew: Synopsis criticorum, vol. 3, I694, Frankfurt.

Polychronius: s, under Miai.

Porter, F. C.: The Messages of the Apocalyptical Writers, N. Y., r905.

Powell, H. H.: The Supposed Hebraisms in the Grammar of Biblical Aramaic, Univ, of Calif. Publications, vol. I, I907.

PreISwerk, II.: Der Sprachenwechsel im Buche Daniel, Berne Diss., I902 (rev. by Meinhold, TLZ 1904, 353).

Preuschen, E.: Handwörterbuch zu den Schriften des N. T., i9io.

Prince, J. D.: A Critical Commentary on the Book of Daniel, Lpzg., I899. Pusey, E. B.: Daniel the Prophet (ed. I, IS64), ed. 2, I 868.

RAHLFS, A.: Verzeichniss der griechischen Handschriften des A. T., vol. 2 of his Mitteilungen des Septuaginta-Unternehmens, I9I4.

Ranke, E.: Monographs on OLat. texts, s. Int. §Io, b (I).

'RAsHI' (R. Solomon b. Isaac): text in Miliraoth Gedoloth; s. under

Breithaupt.

Pawlinson, G.: The Seven Great Monarchies of the Ancient Lastera

World, ed. 2, Chicago.

Trckendorf, H.: Arabische Syntax, I92x.

Recss, E.: La Bible, Traduction nouvelle avec introduction et commentaires, vol. 7, 1 $879=$ Das A. T., vol. 7,1894 .

Riessler, P.: Das Buch Daniel, 1899.

Rosenmüller, E. F. C.: Scholia in Vetus Testamentum, pt. Io, I 832.

DE Rossi, J. B.: Variae lectiones Veteris Testamenti, 4 vols., $1784-88$, and supplement, Scholia critica in V. T. libros, I 798, Parma.

SAadia: s. under Spiegel. Text of Pscudo-Saadia in Misraoth Gedoloth. Sabatier, P.: Latinae versiones antiquac seu Vetus Italica, Rome, i 75I seq. SACHaU, E.: Aramäische Papyrus und Ostraka, igi $(=A P O)$.

SANCTIUS, C.:* Commentarius in Danielem prophetam, Lyons, I6I 2. 
Sayce, A. H., and Cowley, A.: Aramaic Papyri Discovered at Assuan, Igo6 $(=A P A)$.

Scheftelowitz, I.: Arisches im A. T., Königsberg Diss., ı 90 I.

- Die altpersische Religion und das Judentum, I920.

Schöttgen, C.: Horae hebraicae et talmudicae, 2 vols., I733, 1742, Dresden and $\mathrm{Lpzg}$.

Schrader, E.: (Keilinschriften und das A. T. ${ }^{2}$ ) = Eng. tr. by Whitehouse The Cuneiform Inscriptions and the Old Testament, 2 vols., ISSS $(=C O T)$; also s. under Zimmern.

Schultens, A.: Opera minora, Leyden, I769; pp. 320-327 Animadversiones philologicae in Danielem.

Schulthess, F.: Lexicon syropalästinum, I903.

and Litrmann, E.: Grammatik des christlich-palästinischen Aramäisch, 1924 .

Schürer, E.: Geschichte des jüdischen Volkes³, 3 vols., 1904-09.

Seltin, E.: Introduction to the Old Testament, 1923 (Eng. tr.).

Sinker, R.: Daniel, in Temple Bible.

Smiti, R. Payne: Thesaurus syriacus, 3 vols., i 879 seq.

— Daniel i-vi, an Exposition, I 886 .

Söderblom, N.: La vie future d'après le Mazdéisme, rgor.

Solá, J. M.:* La profecia de Daniel.

Spieger, II.: Saadia al-Fajjûmi's arabische Danielversion, Berne Diss., igo6. StaDE, B.: Lehrbuch der hebräischen Grammatik, i879.

— Biblische Theologie des A. T.; vol. 2, ig I I, by A. Bertholet.

Stevenson, W. B.: Grammar of Palestinian Jewish Aramaic, I924.

StrACK, H. L.: Einleitung in das A. T. ${ }^{6}, 1906$.

- Grammatik des Biblisch-Aramäischen ${ }^{8}$, I92I (rev. by Laible, Theol. LB, 1922, 90, Lidzbarski, TLZ, 1922, I 27; earlier ed. rev. by Nöldeke, LCB 1896,304$)$.

Strossmann, G.:* Die Erlebnisse und Geschichte des Propheten Daniel, 1922.

Stuart, Moses: A Commentary on the Book of Daniel, Boston, 1850.

Swete, H. B.: The Old Testament in Greek, 3 vols., I 887 seq., ed. 2, I 895 seq.

— An Introduction to the Old Testament in Greek, igoo.

Texte und Untersuchungen zur Geschichte der altchristlichen Litteratur, 2d Series, $1897 s c q .(=T U)$.

Texts and Studies, Cambridge, $1893 \mathrm{seq} .(=T S)$.

Thackeray, H. St. John: Grammar of the Old Testament in Greek, vol. I, 1909.

The Septuagint and Jewish Worship, I92 I.

Thayer, J. H.: A Greek-English Lexicon of the New Testament, N. Y., I 887 . 
Thiefenthal, P. F.:* Daniel explicatus, Paderborn, 1895 (rev. by Ryssel, TLZ I895, 557).

Thiцo, M.: Die Chronologie des Danielbuches, pp. 43, Bonn, I926.

(Thomas Aquinas): for In Danielem postillae attributed to him s. Int., \$23.

Thompson, J. E. H.: Daniel, in Pulpit Commentary, I897.

Trschendorf, C.: Biblia sacra latina Veteris Testamenti Hieronymo interprete . . . testimonium comitatur Codicis Amiatini, Lpzg., 1873 .

— Vetus Testamentum graece iuxta LXX Interpretes, ed. 7 by Nestle, 2 vols., I 887 .

Tisdall, W. St. Clair: The Aryan Words in the Old Testament, JQR I, $335 f f . ; 2,2$ 1 3 ff., $365 f f . ; 4,97 f f$.

- Egypt and the Book of Daniel, Exp. 47 (I92 I), 340.

Torrey, C. C.: The Composition and Historical Value of Ezra-Nehemiah, Beiheft to ZATW, I 896 .

- Ezra Studies, Chicago, I9ro.

Notes on the Aramaic Part of Daniel, in Transactions of the Conn. Academy of Arts and Sciences, I5 (I909), 24I (= Notes, I).

- Stray Notes on the Aramaic of Daniel and Ezra, JAOS 43 (I923), 229 (= Notes, II).

Venema, H.:* Dissertationes ad vaticinia Danielis emblematica (to cc. 2,7 , 8), I745.

* Commentarius in Dan. cc. xi. 4-xii. 3, $175^{2}$.

Volz, P.: Jüdische Eschatologie von Daniel bis Akiba, I903.

WALD, S. G.:* Curarum in historiam textus Danielis specimen i, Lpzg., 1783 .

Walton, B.: Biblia Sacra polyglotta, London, ed. $16_{57}$.

Weber, F.: Jüdische Theologie auf Grund des Talmud ${ }^{3}$, I897.

Wellhausen, J.: s. under Bleek.

Westcott, B. F.: Daniel, in Smith's Dictionary of the Bible, 1863.

Wicks, H. J.: The Doctrine of God in the Jewish Apocryphal and Apocalyptic Literature, London, I9 5.

Wilson, J. D.: Did Daniel write Daniel? N. Y., n.d.

Wilson, R. D.: The Aramaic of Daniel, in Biblical and Theological Studies (Princeton Theol. Sem.), N. Y., I9I2.

Studies in the Book of Daniel, N. Y., I9I7 (rev. by Paton, Am. Journ. Theol., 1919, 225, by Fullerton, Bull. W. Theol. Sem., Oct., 1918).

- The Book of Daniel and the Canon, Princeton Theol. Rev., I3 (I915), $35^{2-408 .}$

The Silence of Ecclesiasticus concerning Daniel, ib. I.4, 4.48 .

The Title 'King of Persia' in the Scriptures, ib. I5, 90- 145 (also, Titles of the Kings of Persia, Festschrift E. Sachau, I915).

Apocalypses and the Date of Daniel, ib. 19, 529-545.

Daniel not quoted, ib. 20, 57-68. 
Wilson, R. D.: Darius the Mede, $i b$. I 77-21 I.

- 'The Origin of the Ideas of Daniel, $i b .21,161-200$.

- Influence of Daniel, ib. 21, 337-37I, 54I-584.

The Background of Daniel, ib. 22, I-26.

- The Prophecies of Daniel, ib. 22, 377-401.

Winer, G. B.: Chaldäische Grammatik ${ }^{3}$, i882 (ed. Fischer).

Wrighr, C. H. H.: Daniel and his Critics, I906.

- Daniel and his Prophecies, I906 (Comm.).

Wright, William: A Grammar of the Arabic Language 3 , 2 vols., i $896-8$.

Wyngarden, M. J.: The Syriac Version of the Book of Daniel, Pennsylvania Thesis, Lpzg., I923.

Zimmern, H., and Winckler, H.: Die Keilinschriften und das A. T. (ed. 3 of Schrader), I905 (=KAT).

Zöckler, O.: Daniel, in Lange's Theol.-homiletisches Bibelwerk, 1870, Eng. tr. in Schaff's Commentary by James Strong, N. Y., 1876.

Zotenberg, H.: Geschichte Daniels (Persian text), in Merx, Archiv, vol. I, I869.

Zuexdel, D.: Kritische Untersuchungen über die Abfassungszeit des Buches Daniel, I861. 


\section{KEY TO ABBREVIATIONS.}

Names of authors and works frequently cited, especially the commentators and philologians, have been abbreviated. In cases where a work is cited under the name of the author alone, the title is given in this Key in parentheses. Further abbreviations of titles are given under the authors' names in the Bibliography, or the abbreviation can easily be understood. It has not been deemed necessary to give here the customary abbreviations for Biblical and other books, nor those of common use in such an apparatus, grammatical and otherwise, and only a few such are recorded here.

Abh.: Abhandlung(en).

AEz.: Aben Ezra (comm).

$A J A$ : American Journal of Archeology.

AJSL: American Journal of Semitic Languages and Literatures. Akk.: Akkadian ('Assyrian' language).

$A P$ : Cowley, Aramaic Papyri.

$A P A$ : Sayce and Cowley, Aramaic Papyri.

Aph. Syr.: Aplrem Syrus (comm.). APO: Sachau, Aramäische Papyrus. Aq.: Aquila.

Arab.: Arabic.

Aram.: Aramaic.

Ass.: Assyrian.

Aug.: Augustine.

AV: 'Authorized Version,' King James' Bible, the modern text.

$B A$ : Beiträge zur Assyriologie.

Bab.: Babylonian.

Bär: edition of Heb. Bible.

BDB : Briggs-Driver-Brown, Hebrew Lexicon.

BDD : Bible Dictionaries.

BE: Babylonian Expedition, University of Pennsylvania.

Behr.: Behrmann (comm.).
Bergstr.: Bergsträsser (Hebräische Grammatik).

Bert(h).: Bertholdt (comm.).

Bev.: Bevan (comm.).

bk., bks.: book(s).

BL: Bauer-Leander, Grammatik d. hebr. Sprache.

Blud.: Bludau (d. alex. Übersetzung d. B. Daniel).

Boutflower (In and Around the Bk. of Dan.).

Brock.: Brockelmann.

BSira: The Heb. text of Ecclus.

Duxt.: Buxtorf (Lexicon).

c.: circa.

c., cc.: chapter(s).

Calv.: Calvin (comm.).

CBMich.: C. B. Michaelis (comm.).

CBS: Cambridge Bible Series.

Cha.: Charles (comm.).

ChrPal.: Christian-Palestinian dialect.

Chrys.: Chrysostom (comm.).

CIS: Corpus inscriptionum semiticarum.

Clem. Alex.: Clement of Alexandria.

Comm.: main text of this Commentary. 
comm.: commentator(s), commentary (-ies).

Corn.: Cornill.

COT: Schrader, Cuneiform Inscriptions and the O.T.

CSEL: Corpus scriptorum ecclesiasticorum latinorum.

Cypr.: Cyprian.

Dalm.: Dalman.

$D B$ : Hastings' Dictionary of the Bible.

$D C B$ : Dictionary of Christian Biography.

Del.: Friedrich Delitzsch.

de R.: de Rossi, critical apparatus. dittog.: dittograph(y).

$D L Z$ : Deutsche Litteraturzeitung.

Dr.: Driver (comm.).

EAram.: East Aramaic.

$E B$ : Encyclopædia Biblica.

ed., edd.: editor(s), edition(s).

Ehr.: Ehrlich (Randglossen).

Enc. Brit.: Encyclopædia Britannica.

dEnv.: d'Envieu (comm.).

Epiph.: Epiphanius.

ERE: Encyclopædia of Religion and Ethics.

Eth.: Ethiopic.

Eus.: Eusebius Pamphili.

Ew.: Ewald (comm.).

Exp.: The Expositor.

Exp.T.: The Expository Times.

Field: Field's Hexapla.

vGall: von Gall (Einheitlichkeit d.

B. Dan.).

GB: Gesenius-Buhl: Heb. Hwb. ${ }^{16}$.

GCS: Die griechischen christlichen

Schriftsteller der ersten drei Jahrhunderte.

Ges.: Gesenius.
GGA : Gelehrte Anzeigen of the Göttingen Academy.

Gin.: Ginsburg (ed. of Heb. Bible).

GK: Gesenius-Kautzsch, He-

bräische Grammatik ${ }^{26}$.

Gr., Grr.: Greek; Greek version(s).

Gr.: Grammar, Grammatik.

Graetz: (Beiträge).

GV: Luther's German Version.

haplog.: haplograph(y).

Häv.: Hävernick (comm.).

Heb.: Hebrew.

Hengst.: Hengstenberg (Authentie).

Her.: Herodotus.

Hipp.: Hippolytus (comm.).

Hitz.: Hitzig (comm.).

HP: Holmes-Parsons.

HR: Hatch-Redpath, Concordance

to the Septuagint.

Hwb.: Handwörterbuch.

Iren.: Irenæus.

$J A$ : Journal asiatique.

Jahn: (comm.).

$J A O S$ : Journal of the American Oriental Society.

JAram.: Jewish-Aramaic dialect.

Jastr.: Jastrow (Dict. of the Talmud).

$J B L$ : Journal of Biblical Literature.

JDMicn.: J. D. Michaelis.

$J E$ : Jewish Encyclopadia.

Jeph.: Jephet (comm.).

Jer.: Jerome.

Jos.: Josephus; $+A J$, Antiquitates judaicae; $+B J$, Bellum judaicum.

JPOS: Journal of the Palestine Oriental Society.

$J Q R$ : Jewish Quarterly Review, New Series.

$J R A S$ : Journal of the Royal Asiatic Society. 
JThSt.: Journal of Theological Studies.

Jul. Afr.: Julius Africanus.

Jun.: Junius (comm.).

Just. M.: Justin Martyr.

JV: 'Jewish Version,' i.e., The Holy Scriptures acc. to the Massoretic Text, Philadelphia, I9I 7 .

Kamp.: Kamphausen (text in SBOT).

$K A T$ : (Schrader-)Zimmern-Winckler, Keilinschriften u. d. A. T. ${ }^{3}$.

Kau.: Kautzsch (Gramm.d.BAram.).

$K B$ : Schrader's Keilinschriftliche Bibliothek.

Ken.: Kennicott, critical apparatus.

Kit.: Kittel (ed. of Hebrew Bible).

Klief.: Kliefoth (comm.).

Knab.: Knabenbauer (comm.).

Kön.: König.

Kr.: the Krêे.

Kran.: Kranichfeld (comm.).

$\mathrm{Kt}$.: the $K t \hat{\imath} b$.

Lamb.: Lambert (comm.).

Lat.: Latin.

$L C B$ : Literarisches Centralblatt.

Lex $(\mathrm{x})$.: lexicon, lexica.

Lidz.: Lidzbarski.

Löhr: critical apparatus in Kittel's Bible.

Lucif.: Lucifer Calaritanus.

Luzz.: Luzzatto (grammar).

Mar.: Marti (comm.; grammar cited by sections).

Mass.: Massora, Massoretic.

Maur.: Maurer (comm.).

Mein.: Meinhold (comm.).

MGWJ : Monatschrift für Geschichte und Wissenschaft des Judenthums.

Mich.: J. H. Michaclis (ed. of IIeb. Bible).
Midr.: Midrash.

Moab.: Moabite.

Moff.: Moffatt, Eng. tr. of Bible.

MVAG: Mitteilungen d. Vorderasiatischen Gesellschaft.

Nab.: Nabatæan.

$N E$ : Lidzbarski, Nordsemitische Epigraphik.

NHeb.: New Hebrew (i.e., postBiblical).

Nöld.: Nöldeke.

Notes: philological notes in this Commentary.

NSI: Cooke, North-Semitic Inscriptions.

NSyr.: New Syriac.

N.T.: New Testament.

OAram.: Old Aramaic.

Occ.: Occidental (Mass. tradition).

OLat.: Old Latin (i.e., pre-Hieronymian).

Olsh.: Olshausen.

$O L Z$ : Orientalistische Literaturzeitung.

OPers.: Old Persian.

Or.: Oriental (Mass. tradition).

Or.: Origen.

OSlav.: Old Slavonic.

O.T.: Old Testament.

PAboth: Pirke Aboth.

Palm.: Palmyrene.

pap(p).: papyrus, papyri.

Pers.: Persian.

$P G$ : Migne, Patrologia graeca.

Phœn.: Phœnician.

$P L$ : Migne, Patrologia latina.

Pole (Synopsis criticorum).

Polyb.: Polybius.

Polych.: Polychronius.

Irr.: Prince (comm.).

$P R E$ : Realenzyklopädie für protestantische Theologie und Kirche. 
PSBA : Proceedings of the Society of Biblical Archæology.

PSmith: Payne Smith (Thesaurus).

PsSa.: Pseudo-Saadia (comm.).

QS: Quarterly Statement of the

Palestine Exploration Fund.

Ra.: Rashi (comm.).

$R B$ : Revue biblique, New Serics.

$\operatorname{rdg}(\mathrm{s})$. $\operatorname{reading}(\mathrm{s})$.

ref.: reference.

resp.: respectively.

rev.: review.

Riess.: Riessler (Das Buch Daniel). rt.: root.

Rosen.: Rosenmüller (comm.)

RV: English Revision of AV, I88.4. RVV: RV + SV.

Sa.: Saadia (Arab. tr.).

Sab.: Sabæan.

Sach.: Sachau.

Sam.: Samaritan Aramaic.

$S B A$ : Sitzungsberichte, Berlin

Academy.

$S B E$ : Sacred Books of the East.

$S B O T$ : Haupt's Sacred Books of the O.T.

Schr.: Schrader.

Schult.: Schultens (Opera minora). seq.: and following.

Sib. Or.: Sibylline Oracles

Str.: Strack (text; grammar cited by sections).

Stu.: Stuart (comm.).

suppl.: supplet, -ent.

SV: 'Standard Version,' American

Revision of AV, Igor.

s.v.: sub voce.

Sym.: Symmachus.

Syr.: Syriac.

Talm.: Talmud.

Targ.: Targum.

Tert.: Tertullian.
Test. XII Patr.: Testaments of the XII Patriarchs; Test. Jos. = Test. of Joseph, etc.

Theod.: Theodotion.

Theodt.: Theodoret.

$T L Z$ : Theologische Literaturzeitung.

tr., trr.: translate, translation(s).

Trem.: Tremellius (cited from Pole).

$T S$ : Texts and Studies.

TSBA : Transactions of the Society of Biblical Archæology.

$T S K$ : Theologische Studien und Kritiken.

$T U$ : Texte und Untersuchungen, Second Series.

v., vv.: verse(s).

$\operatorname{var}(\mathrm{r}) .:$ variant(s).

vs.: versus.

VS, VSS: (ancient) Version(s).

WAram.: West Aramaic.

WII: Westcott-Hort, N.T. in Greek.

Wilson: R. D. Wilson (Studies in the Bk. of Dan.).

Wright: C. H. H. Wright (Daniel and his Prophecies).

WSern.: West Semitic.

WZKM : Wiener Zeitschrift für die Kunde des Morgenlands.

IOS: Yale Oriental Series.

$Z A$ : Zeitschrift für Assyriologie.

Zad. Frag.: Schechter's 'Zadokite Fragments,' vol. 1 .

$Z A T W$ : Zeitschrift für die alttestamentliche Wissenschaft.

$Z D M G$ : Zeitschrift der Deutschen Morgenländischen Gesellschaft.

ZKR Inscr.: Pognon, Inscriptions sémitiques, no. 86 .

ZNTW : Zeitschrift für die neutestamentliche Wissenschaft. 
Zöck.: Zöckler (comm.).

$Z P T:$ Zeitschrift für protestantische Theologie.
Zts.: Zeitschrift.

$Z W T$ : Zeitschrift für wissenschaftliche Theologie.

\section{SYMBOLS AND ABBREVIATIONS IN THE TEXTUAL APPARATUS.}

A: Codex Alexandrinus.

A: Arabic Version.

Aq.: Aquila.

B: Codex Vaticanus.

$\mathfrak{C}^{\mathrm{B}}$ : Coptic-Bohairic Version.

(ts: Coptic-Sahidic Version.

c: $\Theta$ text of the Chigi MS.

(b): Old Greek Version ('Septuagint').

(GG: Gr. text.

(Gs: Syro-hexaplar text.

GrVen : 'Graecus Venetus.'

3ebrew-Aramaic text.

$\mathrm{h}: \Theta$ text of Hippolytus.

hG: Gr. text.

$\mathrm{h}^{\mathrm{s}}$ : OSlav. text.

If: Old Latin Version(s). [Wng: Weingarten Fragments. IWzb: Würzburg Fragments.

Lu.: Lucian.
fAt: Massoretic apparatus to $\mathrm{fH}^{\mathrm{B}(\mathrm{ab})}$ : the Babylonian punctuation.

fnoc: the Occidental tradition. fmor: the Oriental tradition.

$\mathrm{Or}^{\mathrm{C}}$ : Constantinopolitan - Origenian text (A-group).

Or ${ }^{\mathrm{P}}$ : Palestinian-Origenian text $(\mathrm{V}$ 62 I 47 ).

Q: Codex Marchalianus.

: Syriac Version.

Sym.: Symmachus.

V: Codex Venetus (= HP 23).

Ii: Vulgate.

2im: Codex Amiatinus.

$\Gamma$ : Codex rescriptus Cryptoferratensis.

$\Theta$ : Theodotion $(=\mathrm{B}$, unless otherwise defined.)

The following symbols are also used:

$\dagger$ indicates that all the cases in the Hebrew Bible are cited.

* a theoretical form.

+ a critical plus.

II parallelism.

$>$ etymological process toward.

$<$ etymological origin from.

[ ] used to give context of word or words discussed. In the translation [ ] has bearing on the text of tg $_{\text {, }}($ ) expresses an interpretative addition. 



\title{
INTRODUCTION.
}

\author{
I. THE BOOK. \\ §. THE CONTENTS.
}

The Book of Daniel is a composition partly in Hebrew, partly in Aramaic, found in the third place from the end of the Kethubim or Hagiographa, the third division of the Hebrew Bible. It purports to give the story of one Daniel who suffered the first exile under Nebuchadnezzar and lived in the Eastern Diaspora. The story begins with the hero's youth, when he is a boy at school, and continues the story to an age when the promise of a life beyond the grave is a comfort ( $\left.\mathrm{I}_{2}{ }^{13}\right)$. The bk. is divided into two nearly equal portions (not coincident with the two languages).

I. The first section presents six anecdotes of his life in company with certain compatriots (one of the anecdotes being confined to the experiences of the latter) as a confessor of the Religion and a seer of the future.

C. I. Year 3 of Jehoiakim and on. The faithfulness of Dan. and three companions in their education at the Bab. court.

C. 2. Year 2 of Nebuchadnezzar. Dan. interprets Neb.'s dream of a monstrous Image.

C. 3. The martyr-constancy of his three companions in refusing to worship a golden Image.

C. 4. Dan. interprets Neb.'s dream of a great Tree.

C. 5. Last year of Belshazzar. Dan. interprets Belshazzar's vision of an Inscribing Hand.

C. 6. His deliverance from the Lions' Den, whither he was cast for refusal to worship Darius. His subsequent elevation in the reigns of Darius and Cyrus.

II. The second section details four visions granted to Daniel.

C. 7. Year I of Belsh. A vision of the conflicts of four monstrous Beasts, of the Fourth Beast and its Horns, and the Theophany which introduces the divine dominion.

C. 8. Year 3 of Belsh. A vision of the conflict of a Ram and a Buck and of the Little Horn of the latter's four horns, which 
grew great. The vision is expounded by the angel Gabriel as of the Medo-Persian and Greek empires, the latter to culminate in a blasphemous tyrant, whose end is foretold.

C. 9. Year I of Darius. Dan.'s prayer for the restoration of Israel; the appearance of the angel to him and his exposition of the 'seventy years' of prophecy.

CC. IO-I 2. Year 3 of Cyrus. In answer to Dan.'s pious exercises undertaken for the boon of greater illumination, the angel again appears to him ( $\mathrm{IO}-\mathrm{II}^{\mathrm{ia}}$ ), and unrolls a panorama of Kingdoms and Kings culminating in a godless and inhuman tyrant, whose end is depicted along with the transcendental vindication of saints and sinners $\left(\mathrm{II}^{\mathrm{lb}}-\mathrm{I}^{4}\right)$; with a supplementary confirmatory vision and a word of personal assurance to Dan. $\left(12^{5-13}\right)$.

It will be observed that parallel historical sequences are followed in the two sections, following a Jewish tradition of the progress of secular history: I. Neb., Belsh., Darius, the continuance of the seer's career into the reign of Cyrus being denoted $I^{21}, 6^{27}{ }^{(28)}$; II. Belsh. (two visions), Darius, Cyrus.

\section{§2. EARLY TESTIMONY TO THE BOOK AND ITS PLACE IN THE CANON.}

The hero's name was given to the bk. with the usual traditional implication that he was the author, a surmise which was naturally supported from I $2^{4}$. The name, דניאל, was wide-spread in Sem. antiquity; s. at $\mathrm{I}^{6}$. It is also the name of an evidently traditional saint (דניאל) who is associated by Ezekiel with two other primitive worthies: "Though these three men, Noah, Daniel and Job were in it (the land), they should deliver but their own souls by their righteousness,' $14^{14.20}$; and, $28^{3}$, the Prince of Tyre is thus apostrophized: 'Behold, thou art wiser than Daniel, there is no secret thing they can hide from thee.' These passages written in the years 6 and in of the Exile (i.e., dating from 597) cannot refer to the youthful hero of our book, but to a figure of antique and cosmopolitan tradition, like the Noah-Utnapishtim of the Flood story and the Job of the Arabian steppes, one of the Wise of the East. If we seek an assimilation of the two Daniels it would be due to the fact that the writer most arbitrarily adopted the name of the otherwise un- 
sung sage of the past, even as Enoch, Noah, Baruch, Ezra were made titular authors of Apocryphal bks. But the hypothesis is unnecessary. The name was taken from living Jewish folkstory. ${ }^{1}$

There is then no reference to our Daniel as an historic person in the Heb. O.T., although his life is attributed by the bk. to the 6 th cent. B.C. Nor is his name found in the list of Worthies presented by Ecclus. 44-50 (c. 200 B.C.), although the writer names the three other 'Major Prophets' and 'the Book of the Twelve,' i.e., the 'Minor Prophets.' The earliest allusions to, or citations from, our bk. appear in the Jewish literature of the $2 d$ cent. B.C. ${ }^{2}$ There are many such in Enoch, of which the Dream-Visions, cc. $83-90$, may go back to the days of Judas Maccabee. ${ }^{3}$

A section of the Sibylline Oracles, viz.: iv, 388-400, which dates back toward the middle of the same cent., certainly cites our bk.'s description, cc. 7,8, of the godless tyrant; the passage is cited in Comm. at $7^{3-8}$.

I Mac., composed at the end of the same cent., after the reign of John Hyrcanus, has many reminiscences of Dan.; e.g., the citation of 'Abomination of Desolation,' $I^{54}$ after 6 of Dan., and the specific allusion to the deliverance of the three companions of Dan., by name, and of Dan. 'in his perfectness,' $2^{59} \mathrm{fr}$., cf. Dan. $3^{6}$. Cf. a list of chief instances given by Wright, p. 65 .

1 Traditionalist comm. differ in their treatment of the possible identification; some ignore it, e.g., Stu., Pusey; others insist that Eze.'s ref. is corroboration of the historicity of our hero and bk., so Heng., $70 \mathrm{ff}$.; Keil, $25 \mathrm{f}$.; Wright, 48 . It is idle to debate over appropriateness of the name, a fancy indeed which induced the story of Susanna, in which Daniel ('God-judges') did 'come to judgement,' with Shakespeare; or as though the judgments of God are the theme of the bk.; or as if a Pers. origin were to be sought, e.g., from OPers. dânu, 'wise,' with Cheyne, Origin . . . of the Psalter, 105, note $t$. The name was of a type that rendered it available for angels, and so it appears for one of the fallen angels, En. $6^{7}, 69^{2}$, and of an evil spirit in the Mandaic Ginza.

${ }^{2}$ The innumerable correspondences between Dan. and the Chronicler (e.g., the prayers Dan. 9, Neh. 9) are insisted upon by Pusey (p. $355 . f f$.) and others as proof of the priority of Dan, to Neh. Wright recognizes the weakness of this argumentation. After accepting Pusey's argument, he proceeds to remark: "The true lines of 'defense' of the Bk. of Dan. do not rest upon the foundations laid by Heng. or Pusey. ... But the real defense . . . ought to a large extent to be based upon the internal evidence presented in the bk." For dependence of Dan.'s prayer on the Chronicler s. the extensive argument by the Catholic scholar Bayer in his Danielstudien.

s For a full list of these reff. s. Charles, Book of Enoch ${ }^{2}$, Index, p. 312. For a review of this literature s. Wright, c. 2. 
The Testaments of the XII Patriarchs, which was written about the same time, has many current citations; s. index in Charles, Eng. tr., p. 238. Jubilees, a bk. of the same age, has in common with Dan. the scheme of year-weeks. And the Apocryphal Baruch has, $I^{15}-2^{19}$, a mosaiclike resetting of the prayer in Dan. $9^{4-19}$, s. $\S \mathrm{I}_{3}$. Also the Apocryphal Wisdom $3^{7}$ cites Dan. $\mathrm{I}^{3}$, and gives, $3^{8}$, an interpretation of Dan. $7^{22}$. The Psalms of Solomon, written after Pompey's death, cites Dan. I $2^{2}$, a true Pharisaic theme.

Schechter's Hebrew 'Fragments of a Zadokite Work' (misleadingly so called) is a product, probably or possibly, of an early 'Pharisaic' sect and of the $2 \mathrm{~d}$ cent. B.c. ${ }^{4}$ Its parallelisms with Dan. have not been sufficiently remarked by Schechter, but the correspondences in terminology are very instructive as to its date. Note: p. 4 (Heb. text), 1. 4, 'those who stand up at

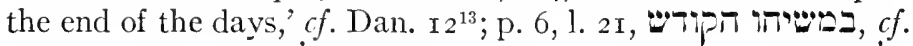

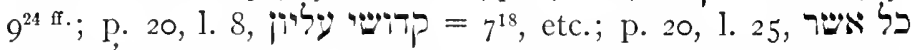

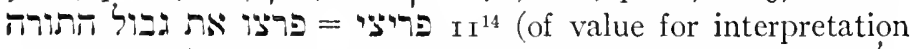

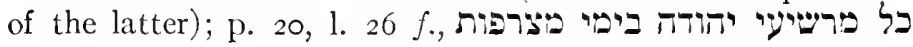

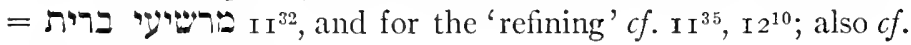
p. $20,1.28$, with $9^{5} .^{5}$

The existence of the 'Septuagintal' tr. of Dan., doubtless to be assumed for the $2 \mathrm{~d}$ cent. B.C., and also of a 'pre-Theodotionic' tr. prior to the N.T. further attests the immediate wide-spread authority of the bk.; s. $\$$ I I ff.

There is no question of the authoritative character of Dan. in the N.T. The name is mentioned but once and with the title of 'prophet,' Mt. $24^{15}$ (not in the approved text of the parallel Mk. I $\left.3^{14}\right)$. Heb. I I ${ }^{33}$ f., 'stopped the mouths of lions (after $\Theta$ ), quenched the power of fire,' recalls the stories in cc. 3,6 . But the influence and language and the spirit of the bk. are powerful

\footnotetext{
${ }^{4}$ In vol. I of his Documents of Jewish Sectaries, igio; also Charles, Apoc., vol. 2 (appearing in earlier separate form); E. Meyer, 'Die Gemeinde des Neuen Bundes,' Abhandlungen of the Berlin Academy, igrg (dating the document about I 70 B.c.); cf. also his Ursprung u. Anfänge des Christentums, 2, 47 ff.; Bertholet, Zur Datierung der Danaskus-Schrift, Beiheft of ZATW, 1920; W. Stärk, Die jüd. Gemeinde des Neuen Bundes; Ginzberg, Eine unbekannte jüd. Sekte, New York, 1922 (in Selbstver$\mathrm{lag})$; F. J. Foakes Jackson, Beginnings of Christianity, I, $97 . f$., on the sect of the 'Covenanters,' also noting other literature.

${ }^{5} \mathrm{Cf}$. also the expression p. $9,1.2 \mathrm{I}$, "the man shall be excluded from the Purity

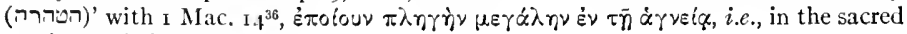
precincts of the temple.
} 
throughout the apocalyptic sections of the N.T., the Parousia passages of the Gospels, 2 Th. and esp. Rev. ${ }^{6}$

Josephus presents the story of Daniel as a 'prophet' quite at length $A J$ x, IO-II. The contemporary 2 Esd. draws largely upon it. And by the final canonization of the Heb. Scriptures about the end of the ist cent. A.D. our bk. was included without question or doubt. The bk. and those of the Chronicler are found at the end of the Canon. ${ }^{7}$ For those who defend the 6 th cent. origin of the bk. this fact is indifferent, for they hold that these 'closed-up words' ( $\left.12^{4}\right)$ were not published until late. But they do not explain how the bk. was published just at the right time or why it agrees exactly with the apocalyptic literature with which the 2 d cent. B.C. was rife.

The Christian Church, fed on the Gr. trr. of the bk., took it over con amore, and along with it certain Apocryphal accretions; s. $\$ 4$. The literary rearrangement effected by the Hellenistic Jews in the order of their Canon attached Dan., with its Apocryphal satellites regarded as one with it, to the Major Prophets, where it ranked fourth (but in the lists of Melito and Eusebius as preceding Eze.); s. Swete, Int., Part II, c. I. For a full catena of the evidence s. R. D. Wilson, 'The Bk. of Dan. and the Canon,' Princeton Theol. Rev., I3, 352-408.8 For the views of the authorities in the Talmud, for whom Daniel was not a 'prophet,' s. \$23; this lower rating of course never derogated from the actual canonicity of the bk.

\section{§3. LITERARY DIVISIONS OF THE BOOK.}

For the eldest tradition of 'chapter' divisions we must go to the Christian tradition. ${ }^{1}$ The Theodotionic order placed the

'There are also several reminiscences of Dan. which have been generally overlooked by N.T. editors in consequence of their failure to diagnose the Grr. texts.

E.g., I note as signal instances $2^{20}, c f .{ }_{1}$ Cor. $1^{24} ; 2^{44}, c f$. Mt. $21^{44} ; 7^{9}, c f$. Mt. $27^{3}$; $7^{13}, c f$. Rev. $\mathrm{I}^{14}$ (dependent on $65^{\prime}$ 's corrupt text).

7 This general statement is to be precised more exactly that in the classical Talm. passage on the Canon, Baba bathra $1_{4} b$ seq., Dan. and Est. exchange places, prob. a shifting on historical grounds; s. Ginsburg, Int., pt. I, c. 2, and Ryle, Canon of the O.T., Exc. C.; also de Rossi, Variae lectiones, 1, p. xxvi. Ryle, Exc. B., gives the Talmudic passage in translation.

${ }^{8}$ Dr. Wilson's learned article combats the chimæra that the claim of later age for the bk. contradicts its canonicity. He brings absolutely no new evidence to show that the bk. was even known before the ad cent. B.c.; how he can 'possibly' find a ref. to Dan. at Ecclus. $49^{10}$ passes comprehension, and as for the witness of I Mac. he overlooks the fact that this bk. was composed near the close of that cent.

${ }_{1}$ On this subject s. Swete, Int., Part II, c. I, and for Dan. in particular p. 260. 
Apocryphal Susanna first, ${ }^{2}$ then our Dan., and at the end the Apocryphal Bel and the Dragon; and this is the order of the uncials $\mathrm{A} \mathrm{B} \mathrm{Q}$, also $\mathrm{I} 47$ and $\mathrm{II},{ }^{3}$ but the reverse order in $\mathrm{V} 62$ $\mathbb{G}^{\mathrm{G}} \mathbb{6}^{\mathrm{S}}$. Consequently the Gr. Dan. was divided into twelve 'Visions' (so A Q): Susanna = no. I, Dan. cc. I-9 = nos. 2-10 (inclusive of the Song in Vision 4), Dan. IO-I $2=$ no. II, $\mathrm{Bel}$, etc. $=$ no. I2. MSS 62 I47 have occasional notation of the Visions, but begin them with Dan. I; s. Benjamin, p. 305. There was also another division current in the Gr. Mss, that of Lections, e.g., B indicates 2 I such (for the whole Gr. bk.), one cursive has 9 , etc. ${ }^{4}$

The Syro-Hexaplar (s. §8), although casting Susanna after our Dan., enumerates the cc. after the traditional system so that our c. I is c. 2, the series terminating, however, with cc. 8-I 2 (the whole regarded as one vision, or scribal neglect after this point?). ${ }^{5}$ I have no information as to main divisions in the early Latin Bible. Cod. Amiatinus of H, containing also Jer.'s Preface to his translation, indicates for our bk. 27 capitula with specific rubrics, phus four additional capp. covering Susanna, etc. $=3$ I capp.; s. Tischendorf, Biblia Sacra Latina V. T., pp. lxiv seq.

The Mediæval division of the Bible into chapters ${ }^{6}$ is that which all Western use appears to have followed for Dan. Unfortunately the unity of cc. IO-I 2 was ignored and the one Vision was divided into three chapters (after the ancient scheme of twelve Visions?).

2We can trace this tradition back to Hipp.; s. Bonwetsch, 'Studien zu den Kommentaren Hippolyts,' $T U$ 1897, pt. 2; so the Bohairic; but the Slav. tr. places Susanna at the end.

${ }^{3}$ I do not understand why Swete has not followed this order of his authority Cod. B in his edition; it is disconcerting, in lack of explanation, to the student, who immediately finds in the marg. to the int. of Dan. I that Codd. A Q entitle it 'Vision 2.' Swete's order is that of Origen's arrangement. Tischendorf-Nestle places Susanna first. An extraordinary mistake has been made by Swete in his $I n t$., p. 260, with his statement: "In the Greek MSs no break or separate title divides these Greek additions from the rest of the text, except that when Danicl is divided into 'visions,' the first vision is made to begin at i. I, Susanna being thus excluded from the number." This statement is contradicted by his own apparatus.

"See Swete, pp. 351 ff.; $c f$. the divisions of 11 and $v$ inf. A has the division into Visions, enumerated as in $\mathrm{A}$; $\mathrm{s}$. $\$ \mathrm{r} 4, n$.

'Similarly in the Chigi MS, containing our sole Gr. MS of the Septuagint and also a Theodotionic text (c), the order is that of the Syro-Hexaplar.

'See in addition to Introductions to the Canon, etc., G. F. Moore, 'The Vulgate Chapter and Numbered Verses in the Hcb. Bible,' $J B L$ I2, 73-78. 
The Jewish divisions have been obscured to the reader of the Heb. Bible by the most unfortunate practice of dividing the printed Bibles according to the Mediæval chapter division. This procedure, which still obtains in Bär's professedly Massoretic text, has been corrected by Ginsburg and Kittel (best by the former, throwing the chap. and v. numerals into the margin). There was an ancient Seder or Lection division in the Heb. bks., which has survived in the Mass. tradition. In the apparatus to his text of Dan., p. 95, Bär gives a list of these Sedarim, which are denoted by as seven in number. Ginsburg, who finds vast fault with Bär (Int., 2I) for his registration of the Sedarim in general, gives a slightly variant division (ib., 60):

$\begin{array}{llllllll}\text { Bär } & \mathrm{I}^{1} & 2^{36} & 3^{30} & 5^{13} & 6^{11(10)} & 9^{4} & \text { I I }^{1} \\ \text { Gin. } & \mathrm{I}^{1} & 2^{35} & 3^{30} & 5^{12} & 6^{29(28)} & 9^{4} & \text { IO }^{21}\end{array}$

Gin. also conveniently notes these Sedarim in the marg. of his text. It will be observed that these seven divisions are about quantitatively equal, the last two being somewhat shorter than the preceding ones; they possess no literary reason and must have been made on the pious principle of 'a chapter a day.' The editors of the printed Heb. Bibles introduced the Christian system of chapter division, but altered it in two respects: they followed the Seder division about $3^{30}$, actually making it at $3^{31}$ $\left(4^{1}\right)$, so perpetuating the error of including Neb.'s profession within c. 4 ; and at the end of c. 5 , following a pasîk-pathîh (a greater paragraph division), they began c. 6 with $5^{31}$ of the Christian use (here the exact point of division may be indifferent).

Throughout this Comm. citation will be made after the use of the printed Heb. Bibles; where the Christian use varies, the correspondent figures will be given also in parenthesis, where at all necessary. This practice will also be followed in the case of the plus of vv. in c. 3 of the Gr., due to the insertion of the Song. The Jewish chapter divisions may be followed, very conveniently, in $\mathrm{JV}$; they are noted in the marg. of RVV. 
\$4. A. APOCRYPHAL ADditions; B. LATER PSEUdEPIGRAPHA; C. LEGENDS.

\section{a. A pocryphal Additions.}

As far back as the testimony for them goes the 'Septuagint' $(\mathbf{B})$ and Theodotion $(\Theta)$ included with our bk. certain Apocryphal accretions. ${ }^{1}$ This material comprises: (I) Susanna, which in the tradition of $\Theta$ at least always preceded our bk. (for the reason that Dan. appears in it as a young and unknown man). (2) What the English Bible calls 'The Song of the Three Holy Children,' $67 \mathrm{vv}$. inserted in c. 3 between vv. ${ }^{23}$ and ${ }^{24}$; this piece actually comprises: (a) vv. ${ }^{24-45)}$, a Prayer of Azarias, ${ }^{2}$ being a prayer of confession and supplication; $(b)$ a prose Interlude, vv. ${ }^{46-51}$, describing the heating of the fire and the descent of the Angel of the Lord to cool the flames ${ }^{3} ;(c)$ the Benediction (the liturgical 'Benedicite') of the Three, vv. ${ }^{51-90}$. Then appended to our bk. is a collection, treated as one 'Vision,' containing: (3) the story of $B c l$, and (4) that of The Dragon, to which is added a manifest supplement introducing the prophet Habakkuk.

The discussions over the originality of these Additions, which of course involves that of the original language, are manifold; s. Schürer, $G J V 3,45^{2-45}$, and the Introductions to the Apocrypha. Despite Jer.'s desire to separate the Apocrypha from the O.T. and his scholarly rubrics that these Additions are not found in the Heb., ${ }^{4}$ the Latin Church appears to regard them as integral parts of the bk., even as they are physically such in the edd. of $1 .{ }^{5}$ This position is not wholly confined to that Confession; e.g., Howorth, 'Some Unconventional Views on the Text of the Bible: VII. Dan. and Ch.', PSBA 29 (r9o7), 31-38, $6 \mathrm{I}-69$, holding these additions to be integral parts of the bk.

I Swete conveniently gives the text of Cod. A for the two Odes in c. 3 at end of vol. 3 , pp. $80_{4} f f$; ed. 2 , pp. $826 . f f$.

'Not of Ananias, otherwise the first-named of the three Companions. The change appears to have been effected by the alphabetical rearrangement of the names in the Gr.

3 There is a verbatim allusion to this-the earliest notice of these Additions-in 3 Mac. $6{ }^{6}, \delta p o \sigma t \sigma \alpha \varsigma \times x<\mu \ell v o v=$ our v. ${ }^{\left({ }^{(0)}\right)}$.

4 Before the Apocryphon in c. 3 and before $B e l$.

E.g., the comm. of d'Envieu and Knabenbauer; and so Székely, Bibliotheca apocrypha, Freiburg, vol. I, 1913, excludes them from his contents. 
More particularly there has been considerable recent debate as to the authenticity of the prose Interlude. Rothstein, in his comm. on the Additions, in Kautzsch, Apok. u. Pseud., I, I 75, has proposed ${ }^{6}$ a theory whereby the Interlude is original, but the Apocryphal intrusion, first of the Benediction, then of the Prayer, has upon ultimate censorship caused the loss of the included genuine Interlude. André, Apocryphes de l'Ancicn Testament, Florence, I903, pp. 2 I 4 ff., agrees with Rothstein, but regards only vv. ${ }^{(24.46-50)}$ as original; Jahn (an enthusiast for (5) retains only $v v^{49-51}$. Bennett, upon this Apocryphon, in Charles, $A p o c .$, I, 629, inclines haltingly to the same position. That is, modern editors of the Apocrypha incline to save some flotsam of this Apocryphon; but, on the other hand, all comm. of the Heb., outside of the Latins and Jahn, have excluded this as well as the other Additions from serious consideration.

The present writer at first, years ago, hailed Rothstein's view as correct. Subsequent cooler consideration has made him renounce it, not for reasons philological or critical but dramatic. He avers that the Heb. story is far more striking in leaving the discovery of the marvel to the heathen king's eyes, rather than with the banal explanation made to precede it. Which is all a matter of taste! He is thus relieved from further treatment of the subject in this $\mathrm{Comm}^{7}$

- After brief suggestions of vGall, Einheitlichkeit, 23, n., Bludau, Die alexandrinische Uebersetzung d. B. Daniel, 207.

${ }^{7} \mathrm{~A}$ few notes may be added here. In orig. $\Theta v{ }^{22 \mathrm{~b}}$ has been lost whether through homoiotel. in the orig. Ti or in the Gr., or because it was excised in view of ${ }^{\left({ }^{(48)}\right.}$. $(\mathfrak{S}$ and $\Theta$ present but variant texts of the Prayer and the Benediction. The bulk of the interlude in $\mathbb{6}$ (the balance being evidently supplemental) appears in $\Theta$ (in -

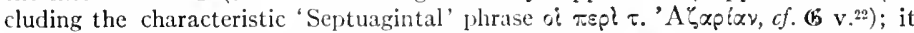
looks as though the whole Apocryphon first appearing in $\mathbb{G}$ has been subsequently inserted in $\Theta$, which would explain how the latter's text includes it despite his scrupulosity for the veritas hebraica. The Syr. is translated from the Gr., not from a Sem. original at all; not only is this the general judgment upon all Apocrypha in the present Syr. O.T. as secondary (e.g. Duval, Litterature syriaque, 36), but it is distinctly so stated for this Apocryphon by Polychronius at $3^{24}$ " this hymn is found neither in the Hebrew nor in the Syriac Scriptures," while Aphrem Syrus ignores it in his comm. The Daniel Apocrypha of the Syr. are to be found in the London Polyglot in vol. 4 ; for c. 3 only the Prilyer and the Benediction (without the Interlude), which were prob. introduced from some Gr. collection of 'Odes.'

M. Gaster has published an alleged 'Aramaic Original of 'Theodotion's Additions to the Bk. of Dan.' in PSB.1 I6, 280 ff.; $312 f f ; 17,75 . f 7$. But as Dalman remarks, Worte Jesu, 11, n. I, the texts are pieces from the Chronicle of Jerahmeel which the author himself says he translated from the Greek Bible. 


\section{b. Later Psendepigrapha.}

Naturally enough, 'secret books' continued to amass about the appropriate name of Daniel. Fabricius collected in his Codex Pseudepigraphus Vet. Test., nos. cxx seq., a number of extracts and references bearing upon such literature, including astrologies and oneirocritica, of a species that flourished also in the vernaculars of the Middle Ages. Tischendorf, Apocalypses apocryphae, I 866, xxx-xxxiii, published some extracts of Daniel literature in the Gr., and E. Klostermann a Gr. 'Apocalypse of Dan.' and two other oracles in his Analecta, II3-r28. 'The Armenian 'Seventh Vision of Dan.' has been edited by G. Kalemkiar, $W Z K M$ 6 (r892), ro9-136, 227-240 (text and tr.). See also Zahn, Forschungen, V (1893), Ir8 ff., Harnack, Gesch. d. altchristl. Litt., 9r6 ff. For the Syriac Duval, Litt. syr., 93, notes the apocalypse of 'The young Daniel concerning our Lord and the end of the world'; Baumstark, Gesch. d. syr. Lit., 230, 250, signalizes Syr. astrological mss under the same name, for which cf. Furlani, $Z A$ 33, 162, etc. J. Darmesteter has published a Persian composition, L'A pocalypse persane de Daniel, 1886. From the Arabic F. Macler has published L'A pocalypse arabe de Daniel, 1904, text and tr. (text first published in Heb. type by Zotenberg in Merx's Archiv, pt. 4, 1869, pp. 385-427), cf. Bousset, The Antichrist Legend, rog; and also a corpus of Oriental texts in Les apocalpyses apocryphes de Daniel, r895, containing additional material of Darmesteter's Pers. text, the tr. of a Coptic Apocalypse, tr. with notes of Kalemkiar's Arm. Apocalypse (noting that it is the 'seventh vision' because of the Arm. division of Dan. into six visions), and tr. of Klostermann's Gr. text.

The following literary note may be added. In his fascinating book, Heaven and Hell in Comparative Religion, N. Y., r921, President K. Kohler recalls that the Jew Immanuel of Rome, the admirer and imitator of Dante, takes Daniel as guide in his Hebrew poem on Hell and Paradise.

\section{c. Legends.}

Legendary amplification of Dan.'s history grew apace. Josephus, $A J \mathrm{x}$, ro, I, makes him offhand a prince of the blood royal, an easy deduction from $\mathrm{I}^{3}(q . v$.$) , and Bel v.1. \mathbb{B}$ makes 
him a priest. (Ps.-)Epiphanius knows his father's name as Sabaan and his birthplace as Bethabara, Aav. hacr., lv, 3, Vita proph., x. For various Jewish and Arabic legends s. $J E 4,427$, 429. His tomb has been shown, since the 6th cent., at Susa, a little west of the acropolis; s. Loftus, Chald aa and Susiana, I857, pp. 3I $7 \mathrm{ff}$. (with illustration reproduced as frontispiece in Dr.'s comm.); JE p. 429 (with another picture). There is a ref. to this tomb in Tabarî, s. Nöld., Gesch. d. Perser $u$. Araber, 58. See also F. W. Hasluck, 'The Caliph Maimun and the Proph. Dan.,' Journal Hell. Studies, 42, 99-103, with full bibliography; he notes that there is another tomb of Dan. at Tarsus. This tradition agrees with Josephus' datum that Darius took Dan. with him to Media $(A J \mathrm{x}, \mathrm{II}, 4)$, borrowed by Jer. in his comm. at $5^{25}$. Jos. himself has $(i b ., \S 7)$ the tradition of a tower the prophet built at Ecbatana which is the place "where they bury the kings of Media, Persia and Parthia to this day."s

The Jewish Aggada on Dan. is collected in Rabnitzki and Bialik, Sepher Haaggadah (Heb. title), Berlin, I922, vol. 4, pp. I $87 f f$., and in tr. in L. Ginsberg, vol. 4, Philadelphia, I9r3, pp. 326-350 (a memorandum kindly contributed by Dr. E. Speiser).

\section{TEXT AND LANGUAGE.}

\section{\$. THE HEBREW-ARAMAIC TEXT.}

The bk., as at hand, is written in two languages, i.e., Hebrew and, for $2^{4 b}-7$, Aramaic, this section being introduced by a rubric gloss, ארטית Aramaice. The problems of text are the same for both languages. But the Aram. text appears to be far less definitely fixed by tradition than that of the Heb.; this being due to the fact that the later editors were primarily occupied with the literature and phonetics of a language in theory divine, and so were less sure or more careless in the treatment of the Aram.;

${ }^{8}$ Dr. E. Sukenik, of the Dropsie College, kindly reminds me of the design of Daniel in the Lions' Den worked in the mosaic pavement of the $2 d$ cent. synagogue at "Ain-dûk in the Jordan Valley (s. Vincent, $R B$ 1919, $532 . f$.; plan p. 535, showing one of the lions). To cite Dr. Sukenik: "Clermont-Ganneau's suggestion that we have here Daniel in the lions' den was confirmed by Père Vincent's excavations, when they found on the other side of the man the inscription means 'Daniel rest in peace!' or 'Daniel in peace.' The field was apparently regarded as the most honorable spot in the synagogue. Père Dhorme's first impression of the synagogue was that it was dedicated to Daniel." 
also the latter was the Jewish vernacular, and this rendered it susceptible to current contamination in contrast with the rigidity of classical Heb. Withal the whole bk. exhibits an extraordinary amount of variation, not only in $K t \hat{\imath} b$ and $K r \hat{e}$ and in their exchanges, but also in actual variant rdgs. of mss, many of which correspond to those of the VSS. Hence the problem of original text is peculiarly accentuated for this bk.

The Massoretic text ( $M$, as distinguished from if $^{2}$ the consonantal text, which alone lay before the eyes of the ancient translators) is the result of an idealistic striving after a final, flawless text of Holy Scripture, with a fixed $K t \hat{\imath} b$ or consonantal basis, accompanied with an apparatus to indicate the exact pronunciation and reading of the words and phrases (involving syntax), along with corrections of the Kt. to be observed in the actual enunciation,- - the $K r \hat{e}$. This ideal unity was never perfectly achieved. In the latter half of the first millennium two Schools had formulated variant Massoretic texts, the Oriental and the Occidental, and another complication exists as between the rival texts of Ben Asher and Ben Naphtali of the first half of the Ioth cent. The Western tradition prefers the authority of Ben Asher and naturally and professedly follows the Occidental Massora; even when an editor, e.g., Ginsburg, critically prefers an Oriental rdg. he presents it only in the marg. ${ }^{1}$

In view of such an artificial condition of text, the writer has made it his practice to cite, quite regularly, the variant rdgs. of four standard editions of $\mathfrak{A H}$, namely those of J. H. Michaelis, Bär, Ginsburg, Kittel, and, in addition, of Strack's Aram. text. ${ }^{2}$

To this apparatus of the Occidental Massora can now be added a partial apparatus for an Oriental Massora brought to light in recent years: texts provided with the 'Babylonian' vowel-system, one less adequate than ours, the 'Tiberian,' but of great

${ }_{1}^{1}$ Consult Strack, Prolegomena critica in V.T. hebr., I873, Pt. I; Ginsburg, Int.; Buhl, Kanon u. Text d. A.T., pp. 82-108; Kahle in BL $\$ \S 0-9$; also Briggs, Study of Holy Scripture, c. 7; Geden, Outlines of Int. to the IIeb. Bible, c. 2.

${ }^{2}$ See Bibliography. Bär gives an extensive Appendix of Mass. apparatus; Gin. in his mg. presents a summary apparatus. The primary value of Kit.'s Bible lies in its being a reproduction, with slight changes (s. Preface) of Jacob Chayyim's Bomberg Bible, I524-5, which became the standard exemplar for Bible prints. The non-Mass. critical apparatus in the mg. of this ed. is the work of M. Löhr, and this part will be duly attributed to him. The traditional differences between the Oriental and Occidental Schools are denoted by $\mathfrak{A n O}^{\circ}$, $\mathfrak{A n O}^{\mathrm{O}}$. Strack in his Gr. (v. inf.) has given collations of a Berlin Codex $=$ Ken. 150, and Cod. Erfurtensis 3 . 
interest to the philologian. For the material of this apparatus and discussion summary reference may be made to P. Kahle, 'Masoreten des Ostens,' Heft 15, Beiträge z. Wiss. vom A.T., r9r $3 \cdot{ }^{3}$ Kahle has rendered particular service to the student of Dan. by publishing accessible portions of this Oriental text of our bk.: viz., op. cit., pp. 8I ff. for $2^{31-49}$, and in Strack, Gr., edd. $3^{-6}$, for $3^{12-15.20-24}, 4^{21}-7^{7}$ (all Aram. passages). Where citation of this apparatus is necessary the signature $\mathfrak{H}^{\mathrm{Bab}}$ is used.

But the critic is concerned in going behind this ideal unity of a Textus Receptus, back to the Mss. For this comparison he has at hand the two great collections of variant rdgs. compiled by the labors of Kennicott and de Rossi, for which s. the Bibliography. The study of these variants in Dan. has proved interesting but may not be enlarged upon here. As a sample there may be noted the cases where the variants agree with

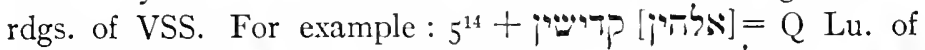
$\Theta$ tradition and $\$ ; S^{27}+$ - רים

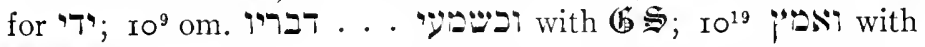
$\mathbb{G} \Theta \subseteq$ for piri. The most notable of all variants is in Ken. 3 I 3

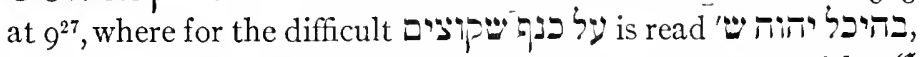
such a rdg. as the translator desiderates, and supported by $\mathfrak{6}$ (one text) and $\boldsymbol{H}$. 'This rdg., first detected by Ken., was enthusiastically accepted by JDMich., who proclaimed it 'masorethica lectione ueriorem.' But de R. acutely observes that the MS has an accompanying Latin tr. and that the unique rdg. is doubtless a Christian contamination. ${ }^{4}$

\section{\$6. THE IIEBREW.}

For this subject a large lexical and grammatical apparatus is now accessible. ${ }^{\mathrm{I}}$ For the language and diction of the Heb. ref-

${ }^{3}$ Cf. his earlier Der masorethische Text d. A.T. u. die Ueberlicferung d. babylon. Juden, 1902. For the punctuation system s. Bergsträsser, Hebr. Gramm., pp. 50.ff., and esp. Kahle in BL $\$ 7$.

'This instance opens up an interesting line of inquiry as to $35 s ; n . b$. Ken. 93 has its bks. arranged, as Ken. notes, 'acc. to the English order.' The same order is found in the Complutensian Polyglot (= Ken. 270), whose rdgs. there is no reason to cite, for the edition is contaminated (as is evident in Dan.) from the Christian Bible by the ecclesiastical scholarship which edited it.

${ }^{1}$ For dictionaries, those of Briggs-Driver-Brown, Gesenius-Buhl, and König. Grammatical ref. is made as far as possible to Gesenius-Kautzsch (also in Eng. tr. by Cowley). More recent grammars are those by Bergsträsser (191\$), BauerLeander (I922), and Joüon (I923). 
erence may be made to the statistics in the opposing arguments of Pusey, pp. 575-598, and Dr., Int., 504-508, summarized in his Comm., pp. lx-lxiii; $c f$. his list of peculiarities in Chr. in the former work, pp. 535-540, and Curtis, Chron., pp. 27-36. It is universally accepted that the language of our bk. is that of Chr.-Ezr.-Neh. and Est., while its literary use of Eze. is acknowledged as term. a quo for the bk. Whether Dan. is anterior (with Pusey), or subsequent (with Dr., dating it in the $2 \mathrm{~d}$ cent.) to the Chronicler, is the primary moot point. The writer agrees with Dr., Int., 504, that "the great turning-point in Heb. style falls in the age of Nehemiah . . . and not, as is sometimes supposed, the Captivity." If this literary judgment is true, then Dan. can hardly be earlier than the 5 th century, and Pusey's argument falls. If the Chronicler belongs to the $4^{\text {th }}$ century, as critics now generally hold, and if Ezra's activity is subsequent to Neh., c. 400 , as many have come to see, the a quo limit is still further lowered. ${ }^{2}$

Statistical arguments are not conclusive. E.g., the brief summary given by Belır., Dan., p. iii, is not rigorous and contains fallacies; he notes the loss of sense for the modes of the vb. and their consecution ( $c f$. F. T. Kelly, 'The Imperf. with Simple Waw,' $J B L_{39}$, 2I); the absence of the article (but this in cases where the noun becomes 'proper,' e.g., ברית 'Covenant'; at most a stylism); irregularities and inconsequences within the book, but most of these may be laid to the account of intentional or accidental change. ${ }^{3}$ The Aramaisms of vocabulary are

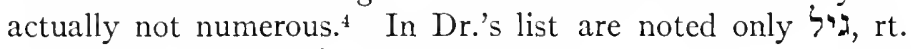

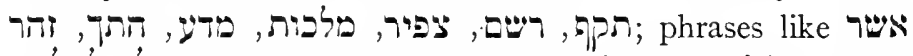
נתין לב ל, למהז; there may be added as features of late usage the use of Hif. for Kal in certain vbs., and the development of process as between Piel and Hif., corresponding to that of NHeb. and the Aram. dialects. The little we possess of comparable prose diction of the post-classical Heb. (Neh. is still classical) is not adequate to provide exact dating. Ben Sirach, $c$. Iso, wrote in rhetorical poetry, and can only be related to our

\footnotetext{
${ }^{2}$ Torrey, Composition, regards the Memoirs of Ezra as part of the Chronicler's handiwork, a position that would date that document still later.

${ }^{3} \mathrm{Cf}$. the very suggestive thesis by O. H. Boström, Alternative Rdgs. in the Heb. of the Bks. of Sam., Rock Island, rgis.

"See in general Kautzsch, Aramaismen im $A T$, rgoz.
} 
bk. in the general characteristic of words, forms and syntax which are constant in NHeb. It is quite impossible to compare with Dan. the somewhat earlier Eccl., with its barbaric but masterful diction. The opinion of such a connoisseur of Heb. diction as Franz Delitzsch, $P R E^{2} 3,470$, himself no radical, must weigh in casting what is more a literary than a philological decision: the Heb. of Dan. in "general character resembles the Heb. of the Chronicler, who wrote shortly before the beginning of the Gr. period, and, as compared either with the ancient Heb. or with the Heb. of the Mishnah, is full of singularities and harshnesses of style." For a document which reads most akin to the diction of Dan., attention must be called to the so-called Zadokite Fragments, the cross-references of which with Dan. have been noted above, $\S 2$. In both there are the same obscure diction and halting grammar, which are only lit up by the moral earnestness of the authors. As literature the Aram. of the bk. is of higher order than the Heb. To sum up, the argument from the Heb. points to a late age in comparison with the known Biblical literature, and it can be assigned with entire philological satisfaction to the 2 d cent.; while a date earlier than the $4^{\text {th }}$ cent. cannot on comparative evidence be easily attributed to it.

\section{\$7. THE ARAMAIC.}

The Biblical texts in this language are found Dan. $2^{4 \mathrm{~b}}-7$ and Ezr. $4^{8}-6^{18}, 7^{12-26}$, along with a glossated verse, Jer. Io $^{11}$, and an Aram. phrase of two words in parallelism with its Heb. equivalent, Gen. $3 \mathrm{I}^{47}$ - the earliest literary evidence of the language.

This subject requires more attention than should ordinarily be given in a commentary, for several reasons: the lack of proper grammatical apparatus for BAram. in English; the great increase of practically contemporary documents bearing on the language which have not been registered in the manuals; and the general condition that Aram. is still treated as a luxury and exotic in the study of the O.T. and, one might add, the N.T.

The one compendious grammar on the subject is still that by E. Kautzsch, I884. With this there are the excellent brief grammars by $\mathrm{H}$. Strack and $\mathrm{K}$. Marti (the latter now in a $3 \mathrm{~d}$ ed., I 925 , which appeared too late for use in this work). Strack and Marti include the Aram. texts with glossaries, the glossary 
in Marti being enriched by the contributions of the Iranist scholar C. F. Andreas. Strack adds some critical apparatus and also sections of Aram. text with the Bab. punctuation, edited by Kahle (v. sup. \$5). Marti attempts a critically emended text with the original referred to the marg.; in ed. 2 he adds also the first three numbers of Sachau's papyri. For grammatical bibliography s. Kautzsch, \$8. The grammars of Luzzatto, Winer and Brown unfortunately treat the Biblical material along with later Jewish dialects. To his text of Ezr.-Neh.-Dan. Bär has prefixed 44 pp. of a 'Chaldaismi biblici adumbratio,' which Nöldeke criticised as a 'ganz misslungene Skizze,' $G G A$ I884, IOI4. With this apparatus must now be compared the grammatical surveys in Sayce-Cowley's and Sachau's editions of the Elephantine papyri (resp. pp. I4-20, pp. 26I-274), as also in Lidzbarski, $N E$ 389-399.

For lexicographical material BDB (final title-page of date, I906) cites Sayce-Cowley, but it appeared too early to include Sachau's material; both collections are fully used in GB. The Biblical apparatus is now supplemented by the fully collated Index of the papyrus vocabulary in Cowley, $A P$.

'Biblical Aramaic' (also Chaldee, Chaldaic, Syriac, s. at $2^{4}$ ) is an inadequate name, due to its application to what was until recently the unique Aram. literature found in the O.T.; the term was in contrast with the later Jewish Aramaic dialects. With the discovery of Aram. inscriptions going back into the 8th cent., and the gradual unearthing of various brief texts on clay, papyri, etc., hailing from Mesopotamia and Egypt and the lands between, culminating in large papyri finds at Elephantine, at the first Cataract of the Nile, in the first decade of this century, archives of a Jewish garrison colony existing there from the 6 th cent. till $c .400$ B.C., we are now in a position to recognize the dominant language of the later Semitic world, an official tongue of the empires on the one hand, and on the other a literary language with products similar to those found in the O.T. ${ }^{1}$

For the Aramæans and their language and the earlier material the reader is referred to the rich material on the sub-

${ }^{1}$ The Story of the Three Pages, I Esd. $3^{1} 4^{42}$, is a tr. from a Pagan Aram. original, s. Torrey, Ezra Studics, c. 3. The theme may have motived the Story of the Three Confessors, Dan. 3. The A hikar romance now found in the papyri is a similar product. 
ject. $^{2}$ For the dialectic differences which arose in the language and the later division into Eastern and Western with their dialects, similar reference is to be made to the authorities. Fortunately the later dialects and literatures are so close to the earlier language, with which we are concerned, that their grammar and vocabulary are in constant requisition; indeed, the whole Aram. field is indispensable to the close student of the present subject. $^{3}$

'In addition to current Dictionary articles, s. Streck, 'Über d. älteste Gesch. d. Aramäer,' Klio, 6 (1906), i 85; Schilfer, Die Aramäer, 191 I; E. Kraeling, Aram and Israel, N. Y., I918; S. A. Cook, cc. 13-14 of The Cambridge Ancient History, 2 (I924), s.ข. 'Aramzans' in Index.

For the elder epigraphic material s. CIS ii; selected texts with full vocabulary and gramm. synopses in Lidzbarski, $N E$, continued in his Ephemeris, vols. I-3 (1902-1915), publishing the current fresh material, as does also the Répcrtoire d'épigraphie sémilique, $190 \mathrm{r}$ seq.; and G. A. Cooke, NSI 1903, with texts, tr. and comm. Of specially noteworthy discoveries and finds outside of the papyri may be noted: for Babylonian dockets, A. T. Clay, 'Aram. Indorsements on the Documents of the Murashû Sons' (5th cent.) in O.T. and Sem. Studies in Memory of W. R. Harper, vol. 1, IgoS, pp. $2 S_{5-322}$, and Delaporte, Épigraphes araméens, I9 12; the ZKR Inscription (now known to have been found near Aleppo, and at last lodged in the Louvre), Pognon, Inscriptions sémitiques de la Syrie, r907, no. 86. The wide-spread existence of the language is indicated by an Indian Aram. text, s. Cowley, 'The First Aram. Inscr. from India,' JRAS 1915, $34^{2} .7$., and the Aram.Lydian Bilingual, s. Littmann in Publications of the Amer. Soc. for the Excavation of Sardis, 1916, cf. S. A. Cook, Journ. Hell. Studies, 37 (1917), pp. 77 fJ., 21 5 ff., and Torrey, AJSL 34 (rgrS), I $85 f f$. The oldest Aram. literary document, outside of the inscriptions, is the ostrakon letter of Asshurbanapal's age published by Lidz., Altaram. Urkunden aus Assur, 192 I. The writer would enter his caveat against the listing, with the handbooks, of the Senjirli inscriptions as Aramaic; only the latest one, the so-called Building Inscription, can be so classed: the others are Hebrew. The ZKR Inscr. is a medley of both languages.

The standard editions of the two Elephantine collections of papyri are those of Sayce-Cowley, 1906, and Sachau, IgI (with complete photographic reproductions and inclusion of earlier published papyri material). Sayce-Cowley's papyri appear in Lietzmann's Kleine Texte, nos. 22, 23, and the first three papyri, ib., no. 32 (as also in Mar. Gr., s. above), both edited by W. Stärk; Sachau's material is completely reproduced in Ungnad, Aram. Papyrus aus Elephantine, IgIr; and finally the whole of the material, with introductions, bibliography and Index of vocabulary in Cowley, $A P$ 1923. Cowley has also published an Eng. tr. of selected texts in Jewish Documents of the Time of Ezra, S.P.C.K., I grg. Noël Giron has made some interesting additions to our sources for Egyptian Aramaic: 'Fragments de papyrus araméens provenant de Memphis' (known to me only in offprint); 'Glanures de mythologie égyptienne'; Bull. de l'Institut Frans. d'Arch. Orientale, 23 (1925), 1-25; 'Tomb with Aram. Inscriptions,' Ancient Egypt, 1923, 38-43, epigraphs of great historical interest, containing reference to king Tirhaka (read רהרקא), placed by the writer between the middle of the 7 th cent. and end of the 6th, prob. the oldest known Egypt. Aram. text.

' For the Aram. in general s. Nöldeke, 'Semitic Languages,' Enc. Brit. ${ }^{\circ}$, reproduced in his Semitische Sprachen, 1887 , and his series of arts. on several dialects, $Z D M G 21,18_{3} f f . ; 22.4+3 . f f . ; 24,85 . f . ;$ Chabot, Les langues et les litteratures ara- 
The assimilation of all this fresh material, especially that from Egypt, rich not only in personal letters and business and official documents but also in a noteworthy literary composition (the Wisdom of Ahikarar), has not yet been fully made with BAram. studies. It has therefore been necessary in the following Comm. to make as complete current reference as possible to the philological phenomena of the fresh texts. The language of this pre-Christian Aram. was, it is manifest, plastically set, and had attained literary form. The orthography of our BAram. texts has suffered in the development of the vowel-letters (in this in company with all Biblical documents), and there is to be noticed the subsequent scribal confusion of final $\aleph$ and $\pi$, which in the elder Aram. were neatly distinguished. There has always been question as to the amount of Hebraism in our texts, with the general tendency on part of modern critics (e.g., Marti, Löhr) to regard these cases as later contaminations. But the papyri, for the most part written also by Jewish hands, show similar conditions of Hebraism, both in form and vocabulary, and we may not lightly emend such cases. ${ }^{4}$ Also contamination from the later Jewish dialects has been alleged, but such charges must be very sharply scrutinized.

The Aram. papyri date from the reign of Darius I, with the transcript of his Behistun Inscription, to a document of the reign of the pretender Amyrtæus, c. 400 (s. Sachau, $A P O$ p. xi, Cowley, $A P$ no. 35$)$. Their philological bearing upon the date of the Aram. of Ezr. and Dan. has become at once a moot question. Sayce and Cowley remark, APA 20: "Much of the inter-

méennes, r910. For a survey of the WAram. dialects s. Kautzsch, §5; for publications on the modern Syriac (Lebanon) dialect add Bergsträsser, Abh. f. $d$. Kunde d. Morgenlandes, 13 (I9I5), nos. 2, 3; I5 (I921), no. 4; $Z A 23$ (1918-19), 103 ff.

For the later Jewish Palestinian Aram. (JAram.) s. Dalman's Gr. and the recent brief Grammar by Stevenson; for the Christian-Palestinian, Schulthess' Lex. and the recently published $G r$. by Schulthess-Littmann, 1924. For the vocabulary of the later Jewish literature, Talmud, Midrashim, etc., s. the Dictionaries of Buxtorf, Levy, Jastrow, Dalman. For Syriac there should be named especially the Grammars by Duval and Nöldeke, and for its lexicography Payne Smith's Thesauras, the manual Dictionary by Payne Smith-Margoliouth, and Brockelman's Lexicon, now in process of a greatly enlarged $2 \mathrm{~d}$ ed., I $923 \mathrm{seq}$. Nöldeke's M andäische Gr. is an indispensable adjunct.

1See the excellent Thesis by H. H. Powell, The Supposed IIebraisms in the Gram. mar of the Biblical Aramaic, whose positions, sometimes too stringent in claiming unnecessarily overmuch as Aramaic, have in general been approved by the language and grammar of the papyri. 
est lies in the many points of contact which they show as represented by the bks. of Ezr. and Dan."; similarly Sachau, in the preliminary publication of his first three papyri, p. 3: "Die Sprache, in der sie geschrieben sind, ist in allen wesentlichen Stücken identisch mit derjenigen der aram. Kapitel in den Büchern Esra u. Daniel," an observation omitted in the fuller edition. R. D. Wilson has pressed this identity of dialect in his paper, 'The Aram. of Dan.' I9r2, followed independently by C. Boutflower, In and Around the Bk. of Dan., I923, c. 21. The primary impression the student obtains is in agreement with this position, which has a crucial bearing upon the dating of the Aram. sections of the Bible. But Torrey has subjected this alleged identity to a searching test in 'The Aram. of the Bk. of Dan.,' AJSL 1908, 232 ff. = Ezra Studies, r910, r6r ff. He lays particular stress on the historical process of Aram. $i$ (when $=$ Arab. ) ) to $T$; in BAram. $T$ alone appears, whereas in the papyri $\bar{T}$ is predominant, and is universal in the Bab. dockets. The dental demonstratives are of the theme $i$ except in the combinations דבי, דכא, דילכי (each once, in APA, E, F, of resp. dates $447,44 \mathrm{I}$ ); also, including papyri published after

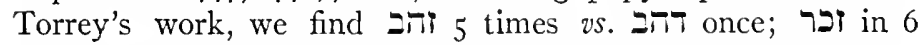
papp. vs. דכו 2 (?); and each once apiece. It is objected by Wilson and Boutflower that in Akk. the OAram. $z$ is represented by $d$, e.g., $i d r i=7 \%$; but the Bab. dockets always have $i$ (s. Delaporte, cited above, n. 2). Thus this process is only at its beginning in the papyri. On the other hand the process of $\because=$ Arab. $t$ into $\Omega$ had already taken place by the 6 th cent. Also it may be noted that OAram. $p=$ Arab. $d=$ later Aram. $\boldsymbol{\nu}$ appears in the dockets, e.g. אר in the papyri both אר cient Aḅikar narrative; but outside of the early Aram. gloss Jer. $\mathrm{II}^{10}$ never in BAram. Torrey also notes that the papyri have for the $3 \mathrm{~d}$ pl. pron.

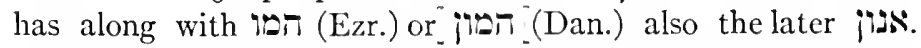
Dan. again alone uses the latter as a demonstrative $\left(2^{44}\right)$ and has the unique ${ }^{2}$ T; but the papyri exhibit a variety of pronominal forms, and little argument can be laid on these forms.

Such evidence is not extensive, but the whole weight of differences (as Torrey says: "the points of difference are what we 
need most to consider") forces the present writer to hold that the Aram. of Dan. is not earlier than within the $5^{\text {th }}$ cent., is more likely younger, certainly is not of the 6th cent. As he holds that cc. I-6 are earlier than cc. $7^{-\mathrm{I} 2}$ (s. $\left.\$ 2 \mathrm{I}, b\right)$, he has no disposition to date down the former section too far. ${ }^{5}$

\section{\$8. FOREIGN WORDS.}

Foreign importations into the vocabulary of Dan. have, apart from their philological interest, a crucial bearing upon the problem of the age of the bk., and so require some detailed notice. See, in addition to the Lexx., Friedr. Delitzsch in Bär, pp. vi-xii, Kautzsch, $\$ 6_{4}$, Behrmann, Dan., p. ix. Dr., Comm., pp. Ivi seq.; and for arguments in rebuttal of the alleged witness of such words for the late composition of the bk., inter al., Pusey, Notes A seq. (at end of vol.), Boutflower, cc. 21, 22, containing a useful exposition of the possible influences of Greece upon the Orient; $c f$. his Chronological Table III, p. xvii, for early contacts of the Greeks with the Orient. In the following summary listing, the place in the Comm. is cited where discussion of the word in question is given; if it occurs elsewhere in the O.T. the bks. are indicated.

a. Wrords from the 1kkadian.

Cf. Zimmern in KAT 678 ff. Omitting ancient borrowings,

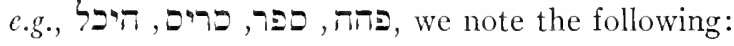

ארגמן = elsewhere in O.T.

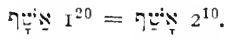

82, Ch., Neh., Est.

?! $2^{31}$.

䌸 $2^{16}$ Ecc., Est., BSir.

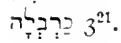

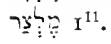

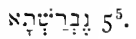

Ezr. $6^{11}$

iุ $2^{48}$, Is. 4 I, Jer., Eze., etc.

בi: Shaf. ב?יז $3^{15}$.

约 $2^{41}$.

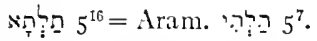

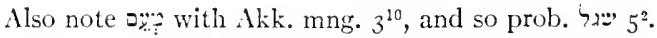

${ }^{5}$ Wilson rightly takes issue with Dr. over the latter's contentions for the late character of the Aram. of Dan., many of which the papyri invalidate. But Wilson commits the same fallacy of indiscriminatingly appealing to the later dialects. It may be remarked that we have no evidence from this age for a distinction, as Nöldeke and most postulate, between EAram. and WAram. 


\section{b. Persian words.}

אדרגז $3^{2}$, an officer.

אָרוּ $2^{5}$, 'made known.'

, 3 , 'satrap,' Ezr., Est.

I

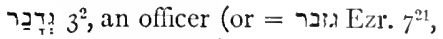
or a dittograph).

דָ $7^{25}$ 'law,' Ezr., Est. (occurrence Dt. $33^{2}$ an error).

רִּרִ $3^{2}$, an officer.

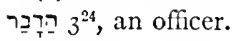

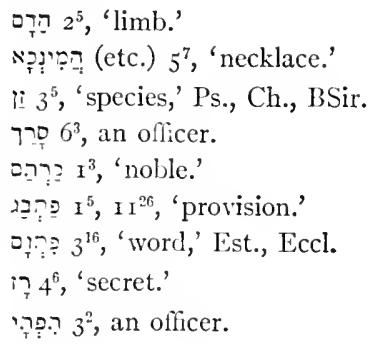

פטיש at $3^{21}$.

All these words are found in the Aram. section, exc. three, and two of these in C. I, which is possibly a tr. from the Aram. Eight are official titles. As the history of Dan. through cc. I-5 is enacted under Bab. kings, it is passing strange that so much Pers. vocabulary, actually including Pers. titles, is included. Sachau, $A P O$ 268, enumerates (prob. not exact list) for his papyri of the $5^{\text {th }}$ cent. about twelve words of Pers. origin, and Sayce-Cowley, p. 20, three or four more. The correspondence between the Elephantine colony and the Pers. governor (Sachau's papp. I-3) contains only one Pers. word, פרתר 'governor,' I, 1. 5. In the Aram. copy of Darius I's Behistûn Inscr. there are no Persian words exc. proper names. Accordingly the Pers. must have made its way very slowly into the Aram., as we might expect for the language of the conquerors of a highly civilized people. Boutflower notes, p. 244, 'the fourtcen words which belong to court life,' and argues: "That these words should be expressed in the OPers. by a writer in the position occupied by Dan. is really nothing to be wondered at, nay, is almost what we might expect." But why should even a royal official, who was a Semite and had enjoyed most of his life and experiences under Bab. monarchs, be so contaminated in the diction of his old age with the vocabulary of the new empire? Indeed his Pers. vocabulary is more extensive than his Babylonian.

This fairly large proportion of Pers. words in the Aram. section of the bk. is an argument for the distinction of the first and 
the second half of the volume, and further points to the origin of the first part in Babylonia, not Palestine; s. $\S 2 \mathrm{I}, a .^{1}$

\section{c. Greek words.}

There are three words of undisputed Gr. origin, and one generally so accepted. The latter is Sem. formation from $\kappa \eta \rho u ́ \sigma \sigma \epsilon \iota \nu$; s. Behr., p. ix; but Nöldeke, $G G A$ I884, IoI9, doubts the Gr. origin. The other words appear in the list of musical instruments in $3^{5}$, etc.:

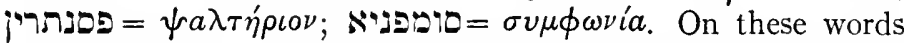
s. Dr., Comm., p. lviii. The $\kappa i \theta a \rho s$ is an ancient instrument; the $\psi a \lambda \tau \eta ́ p \iota \nu$ first appears in Aristotle; the word $\sigma v \mu \phi \omega \nu$ ía, 'harmony,' first in Plato, while in the sense of a musical instrument it is first used, probably, in Polybius. And this latter authority uses it, as Dr. notes, "singularly in his account of the festivities in which Antiochus Epiphanes indulged (xxvi, I0, 5 ; xxxi, 4, 8)."

The rebuttal of this evidence for a low date lies in the stressing of the potentialities of Gr. influence in the Orient from the 6th cent. and on; cf., e.g., J. Kennedy, The Bk. of Dan. from a Christian Standpoint, I898, App. II, and Boutflower, c. 22. The latter offers arguments based upon alleged Hellenic influences in the Orient, e.g., the introduction of the Ionic column, while the tiling in Nebuchadnezzar's throne-room, discovered by Koldewey, is even ascribed to that influence. Without doubt we may no longer close our eyes to the interchanges of the currents of the Eastern Mediterranean civilizations; yet we are equally learning more and more of the profound influences exerted by the East upon the West. In the matter of music, for instance, the Orient was far developed; s. the literature on the subject in the Comm. at c. 3. If our bk. were otherwise an approved document of the 6th cent., we should be forced to allow that the words in question were of early coinage. But as the evidence stands, these Gr. words must incline the scales toward a later dating. We may allow that the cautious Driver speaks too

${ }^{1}$ The Pers. had very slight influence upon the Gr., at least to the lower limits of the Hellenic Golden Age. The present fancy of postulating an extensive Pers. influence in the West must reckon with this philological fact. Sayce, The Higher Criticism and the Monuments, $493 f$., notes the absence of Pers. vocabulary in the Bab. documents. 
positively in his categorical statement, p. lxiii, that "the Gr. words demand . . . a date after Alex. the Great"; we might prefer to express his opinion in terms of likelihood; but with every decade as we move back the likelihood would diminish progressively toward zero. The Gr. words are, until more light comes, to be put in the scales with those from Persia, and both categories require a heavy counterweighting to resist their logical pressure. ${ }^{2}$

In addition to the above words Torrey has argued for the

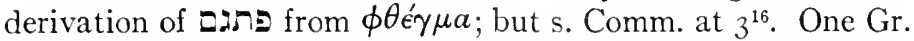
word appears in the papyri, $\lceil\Omega \Omega=\sigma \tau a \tau \eta \hat{\rho} \rho s$, in Sachau, APO Pap., 35, of date c. 400 , dated in the reign of the Græcizing Amyrtæus, also in a few other undated papyri. In one or two places the writer has suggested Gr. influence upon the diction,

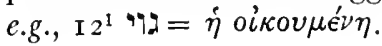

\section{§.. THE LITERARY FORM OF THE BOOK.}

It is to the credit of Bertholet in his comm., I 806 , to have first recognized poetic passages in the bk., distinguishing them by aligning their (poetic) verses in his translation, but without further discussion of their form. Ewald in his comm., after his usual method, cast his whole translation into apparently metrical form by a system of cæsuras. Otherwise this literary characteristic has been generally disregarded by comm. and ignored in histories of O.T. Literature. Marti has given very meritorious attention to this feature, s. his Dan., p. xi, and has cast many passages into poetic form with attempt at metrical analysis. This cue has been taken up, fortunately, by the Jewish Version, as well as by Löhr and Charles. An extreme attempt was made by E. Bayer, Danielstudien, the second Study in which is 'Der Strophenbau des Buches Dan.', with a translation of the whole bk. in verse and strophe. But this is an exaggerated feat without metrical control. Szold has attempted something similar for c. I I, s. Int. to that chap.

The writer has made a moderate attempt at marking out such poetic passages in the translation, with pertinent remarks, but not going as far as Marti. The forms are too spontaneous to

2 Dalman notes 25 Gr. words (acc. to the count of Wilson, op. cit., 296) in Targ. Onk.., s. his Gr. $\$ 37$. 
be allowed to control the text. The cases exhibit the fact that Aram. diction could break out into poetry as does Heb. and Arab., in both of which we find the art of the improvisatore as in the Italian, a well-known literary phenomenon which has been ignored by many critics who would put the Hebrew writers into metrical strait-jackets. Charles has taken the pains of pointing out the same phenomenon in the Apocalyptic literature.

The form of Aram. poetry is similar to that of Heb. with measured beats, generally trimeter; $c f$. the recognition by Torrey of a 3 -beat rhythm in the Story of the Three Pages in 2 Esd., s. Ezra Studies, p. 47, and by Lidzbarski for the Mandaic, Mandäische Liturgien, p. xiii, a form which he believes was carried over into the Manichæan Turkish, Göttingen Nachrichten, I9ı8, 5 or.

I find definite metrical structure in $3^{31}, 4^{1-2.7 b-9.11-14}$, and the greater part if not all of vv. ${ }^{31-34}$; in $6^{27-28}, 7^{9-10 .}{ }^{13-14} \cdot{ }^{23-27}, 9^{24}, \mathrm{I} 2^{3}$. But metrical criticism may not be pushed too far in the premises.

\section{ANCIENT VERSIONS.}

§IO. SUMMARY ACCORDING TO LANGUAGES.

The ancient VSS often present an older form of text than that of if, or at least worthy and interesting primitive varieties. The only method for the study of the VSS lies in the way of their genetic relationships, their language is a very secondary item. But it is convenient to give a preliminary survey of them according to language.

\section{a. Greek.}

For introduction to the ancient Gr. VSS, their Mss, editions, etc., reference can be made to Swete's Introduction, and in detail for the Greek and all important VSS to the often indispensable articles, s. vocc. 'Versions,' 'Septuagint,' 'Theodotion,' and the like, in the BDD, $D C B, P R E^{3}$. C $C$. also the more popular Handbook to the Septuagint by Ottley, I920. The texts primarily followed in this Comm. are those presented by Swete in vol. 3 of his O.T. in Greek (the Int. to which vol. should be consulted for further discussion of the Mss employed); the text of Theodotion appears (but not based on photographic material) in Tischen- 
dorf-Nestle's text (Nestle being also a large contributor to Swete's ed.). For the bk. of Dan., Swete offers a more extensive and varied apparatus than usual for the Gr. books. On the lefthand page he gives the vulgarly called 'Septuagint' text, taken from Cozza's transcript of the unique as in the Vatican, and in the marg. the variants of the parallel 'Syro-Hexaplar' (v. inf.), retranslated from Syriac into Gr. On the right-hand page appears the VS of 'Theodotion' after the text of the uncial B, with the variants of the other uncials $\mathrm{A} Q$ and the fragmentary $\Gamma$, the texts of A B Q being collated from the photographic reproductions of those codices now at hand, that of the palimpsest $\Gamma$ from the collation of Cozza, Sacrorum Bibliorum retustissima fragmenta graeca et latina, vol. I.

The standard list of Gr. Mss of the O.T. is now that published by Rahlfs in his Verzeichness. For the rdgs. of all other Mss except those named above the student of Dan. has had to rely upon the vast variorum work of Holmes and Parsons (HP), I 798-I 827 , now accordingly a century old. The writer and his collaborators have been able to add some fresh photographic and other material, $v$. inf.

The material may be conveniently divided into the following groups:

(I) The Old Greek or 'Septuagint.'

The Old Greek VS of Dan., belonging to that corpus of translations which is roughly called 'Septuagint' in distinction from later VSS, was early banned by Christian scholarship because of its glaring discrepancy from the ueritas hebraica. A unique cursive us of that earliest translation alone exists, in the Codex Chisianus, where it is followed, after selections from Hippolytus' comm. on Dan., by a text of the Theodotionic type. Its discovery and publication have a romantic history. Pope Alexander VII, a member of the Chigi family, to which the ms belonged, intrusted it to Leo Allatius, librarian of the Vatican (b. I 586, d. I609) for publication, but the undertaking was not carried out. It was resumed a century later by Vincent de Regibus and Joseph Bianchini, both of whom died before their labors were over, and the work was finally brought to the press, anonymously, as far as the imprint shows, by Simon de Magistris (de Maîtres) in $\mathrm{I}_{772}$ in folio, a title in Greek and Latin, s. Bibliography. The vol. contains also Hipp.'s comm. and the 
Theodotionic text noticed above, along with five long dissertations, the work of Bianchini. The edition was not copied directly from the us but from a copy made by de Regibus. Several reprints of the text rapidly appeared, but they are now antiquated for 15 by the critical edition of Cozza in his Sacrorum Bibliorum vetustissima fragmenta graeca et latina, part 3 , Rome, 1877 . This is the text published by Swete as noted above. There is used for this text the symbol $\mathbf{6}$, which covers equally the Syro-Hexaplar; where the two differ in their rdgs. they are distinguished by the sigilla $\mathscr{G}^{\mathrm{G}}$ and $\mathfrak{G}^{\mathrm{S}}$. This avoids the unfortunate confusion which appears to have arisen through the confusing of Holmes-Parsons' symbol; Parsons used 88 (for both $\boldsymbol{B}$ and $\Theta$ ), Field corrected this to 87 , and the error has been perpetuated by Swete; s. the writer's note, $J B L$ I925, p. 289 , n. $5 .{ }^{1}$

(2) The Theodotionic group.

The remaining Gr. Mss belong to the stock of the translation ascribed by ecclesiastical tradition to Theodotion (s. \$I2). The name $(\Theta)$ is used here in a general way as including the later Hexaplaric and Lucianic revisions with much material of Aquila and Symmachus in glosses. But in case of variation among the strata, $\Theta$ is used strictly of the primitive translation. For the material we have:

The uncial codices A (Alexandrinus), B (Vaticanus), Q (Marchalianus), the fragmentary $\Gamma$ (Codex rescriptus cryptoferratensis, text of Cozza, op. cit., vol. I), the first three in photographic reproduction and all in Swete's apparatus; and V (= HP 23), of which a collation from photographs in connection with this work has been published by C. D. Benjamin (s. §I4).

${ }^{1}$ A reprint of the editio princeps, in small format and with the exclusion of the Dissertations, was published at Göttingen in 1773 (also the imprint ${ }_{1774} 7$ appears), anonymously but at the hand of J. D. Michaelis. This was followed by editions by Segaar, Utrecht, I775, and H. A. Hahn, Lpzg., I845. See for bibliography and earlier discussions Bludau, De alexandrinae interpretationis libri Danielis indole critica et hermeneutica, Münster, I89r, pp. $37 . f f$., and the same scholar's Die alex. Uebersetzung d. Buches Daniel, $1897=$ Biblische Studien, ii, parts 2, 3, pp. 25 ff. For a note on the authorship s. Nestle, $D B_{4}{ }_{44}{ }_{4}$ I $b$. The earlier editions still have a value for their presentation of the text of the little studied Theodotion of the us. An unregistered edition is a print by S. Bagster, London, n.d., The Gr. Sept. Vs. of the O.T. according to the Vatican Edition together with the Real Septuagint Vs. of Dan., etc. The us has been generally assigned to the oth cent.; but Tischendorf (Prolegomena to his Vetus Testamentum Graece, ed. 4, p. xlviii, n. 3), Vercellone (s Field, Hexapla, 2, 567), Bleek-Wellhausen, Einl.4, 588 , Löhr, ZATIV 1895, 76, put the date in the I th cent.; $c f$. also Swete, O.T. in Gr., 3, p. xii. 
Cursives HP 62 I 47 have been similarly collated and published (v. ibidem). Of HP's remaining thirty numbers four ( 37 45 6I I32) are lectionaries, mostly confined to cc. 2, 3; 149 contains cc. $3-6$, I05 is a fragment of 3 vv., 229 is the Bible text in a MS of Theodoret's comm. For HP $\Theta 88$ I have adopted the sigillum c (chisianus), so as to avoid the confusion noted above, following the editio prima and Michaelis' reprint.

In addition the very full Bible text-by rough calculation about four-fifths of the whole-contained in Hipp.'s comm., now published in full by Bonwetsch, has been adduced for the apparatus, $=h$. A Jerusalem $\mathrm{MS}$ of the Prophets from the Holy Sepulchre has been studied from a photographic copy; for the Ms s. Swete, Int., p. 268, at end of list, Rahlfs, p. 84, Holy Sepulchre, no. 2. The latter text is Lucianic without particular value. Tisserant has published Lucianic fragments of $3^{2-15}$ in his Codex zuquinensis, Rome, I9I.$^{2}$

(3) The Versions of Aquila and Symmachus.

Theodotion has been noticed first against the usual academic traditional custom; for the reasons s. $\S I_{3}$. Aq. and Sym. may be grouped together, for their fragmentary remains are found in the same sources. The thesaurus of these materials is Field, Origenis hexaplorum quae supersunt, etc. (II ex.), 2 vols., I875. ${ }^{3}$

A close study of the Gr. of Dan. adds considerably to our knowledge of those translators, especially of Aq. As in the other O.T. bks. our prime source of information is the Syro-Hexaplar, with the respective initials generally marking the glosses from 'the Three,' Aq., Theod., Sym. These materials, redone into Gr., most usefully appear in Swete's marg. to the $\mathbb{6}$ text. There come next the citations of the Three found in the Fathers, Eusebius, Theodoret, Chrysostom, etc., and especially in Jer.'s very ample and close comm. And in addition we have glosses of

${ }^{2}$ The writer has not had opportunity to try out thoroughly the ingenious and reasonable theory of $\mathrm{F}$. Wutz for a transcription of the Heb. into Gr. letters as basis for the Gr. VSS: 'Die Transkriptionen von der Septuaginta bis zu Hieronymus,' Beilr. z. Wiss. d. A.T., Heft 9, 1925. Wutz applies his theory to the two VSS of Dan., pp. 168-175. But many of his alleged proofs can be explained far more satisfactorily from corruptions, oral and scribal, in the Sem. field. $C f$. for example my Notes at $2^{5}, 2^{32}$ for satisfactory explanations which do not require his theory. The theory is hardly applicable to much of (5's free and fluid rendering.

${ }^{3} \mathrm{~N} . b$. also the Auctarium at end of vol. 2, p. 57 , for additional notes. Add to the abundant literature on this subject J. Reider, Prolegomena to a Gr.-Heb. and IIeb.-Gr. Index to Aquila, Dropsie College, 1916. The only drawback to this valuable treatise is that it lacks the necessary indices. 
scholiasts to MSs, marked or unmarked. Q has some of this marked material, S. at $4^{12}, \mathrm{IO}^{4 .}{ }^{10}, \mathrm{II}^{14}$, with a case in A at $9^{4}$, all which uncial evidence is given in Swete's marg. Still more material to be diagnosed as Aquilanic or Symmachian is found in certain other mss (v.inf.). And probing of the Hexaplaric additions to $\mathbb{B}$ and $\Theta$ discovers much more material (from which contaminations no Ms is free, not even B), that is also to be referred to those translators.

In the following Comm. the material of this order which is had in Field, much of which is handily given by Swete, is not cited except for reason. The two translations have little bearing upon the text, for their text is with a minimum of slight exceptions that of . Their importance, apart from their testimony to the fixation of the text, consists in their interpretations, representing as they do, in Aq. at least, authoritative Rabb. exegesis of the first third of the $2 \mathrm{~d}$ cent., and hence invaluable for the substance and history of interpretation. For brevity's sake reference must be made $a d$. loc. to the Notes for notable rdgs. In general both translators exhibit the same characteristics as appear elsewhere in the O.T.

In addition to these definitely annotated glosses and the Patristic citations, which are fully given by Field, there are many unique rdgs. and some marginal glosses, most of which are probably to be referred to those Jewish translators. Most of such glosses are found in $\mathrm{HP} 36$ (10 in number); $\mathrm{V}$ and $26^{4} \mathrm{fol}-$ low in number of peculiar rdgs. There are over 30 such cases not noticed by Field, the character of which refers them to those translators. These will be noted when of interest ad loc. For a sample there is the unique and correct rendering by $\mathrm{c}$ of

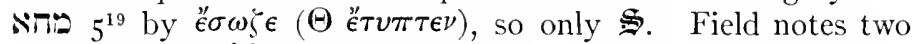
citations from ó 'Eßpaîos (s. Hex., I, p. lxxi seq.), at $\mathrm{I}^{3}$ and at $9^{26}$ (Auctarium, p. 58).

But the influence of these translations amounts to far more than a list of citations can show. Origen's Hexapla rested largely for form at least, much less in peculiar vocabulary, upon Aquila. This element will be discussed more at length in connection with the Hexaplaric revisions, s. \$I4. An exemplary case of filling a lacuna from Aq. is found in $\mathbb{B}^{\mathbb{B}} \mathrm{II}^{41 \mathrm{~b}-42 \mathrm{a}}$.

\footnotetext{
${ }^{4}$ Klostermann on this MS, Analecta, IO: "Der als Repräsentent der Rezension des Hesychius (Cornill, Ceriani) [?] wichtige Codex ist nicht gut kollationiert."
} 
(4) The Mediæval Græco-Venetus.

This is a version $\left(\mathrm{Gr}^{\mathrm{ven}}\right)$ contained in a unique as at Venice, first made known in the i 8 th cent. It has been partly published in an exemplary edition by O. Gebhardt: Graecus Venetus: Pentateuchi Proverbiorum Ruth Cantici Ecclesiastae Threnorum Danielis versio graeca, 1875 , with pref. by Franz Delitzsch. It was probably made toward the end of the I 4 th cent. by a cosmopolitan Jew (one Elissaeus of Constantinople, as Delitszch suggests), and is done in a way that has earned for him the title of a 'second Aquila.' The Aram. section of Dan. is rendered, by a remarkable tour de force, in Doric in contrast to the Attic of the rest of the tr. It has no value for text criticism, but is of interest as representing Jewish interpretation of the age, Kimhi being the translator's master. See Kamphausen, TSK I 876, 577-586; $J E$ 'Elissaeus,' and vol. 3, I 876 .

\section{b. Latin.}

(I) The Old Latin.

By this title is meant a version, or rather group of versions, of sporadic origin, which preceded Jerome's translation, the Vulgate, which was published early in the $5^{\text {th }}$ cent. The latter is in general so original that its predecessors can easily be distinguished, even in texts compounded of the old and the new. ${ }^{5}$

The OLat. texts are sub-versions from the Gr., and in respect to pre-Hieronymian citations are based upon $\mathbb{E}$ and $\Theta$. For the change from the former to the latter, which appears in Tertullian and his disciple Cyprian (the date of the Latin of Irenæus is now a moot question), reference is to be made to the discussion in $\S_{12}, c$. The MS fragments and the great majority of the preHieronymian citations are based on $\Theta$, and the symbol if will denote Latin texts of that character.

The citations present very complicated problems. But scholarship has been for some time in the fortunate possession of several extensive fragments of Dan. These were published by E. Ranke: Fragmenta versionis sacrarum scripturarum latina antehieronymiana, Vienna, I868 (the 'Weingarten' Fragments), covering Dan. ${ }^{18-33}, 9^{25}-\mathrm{IO}^{11}\left(=\mathrm{II}^{1 \mathrm{Wn}}\right)$; Par palimpsestorum wircc-

${ }^{5}$ See H. A. A. Kennedy, $D B_{3} 5^{2} . f f$., for a full and compact art., 'Old Latin Versions,' with good bibliography; and now IDold's vol., to be mentioned immediately, with its citations of more recent literature. 
burgensium, Vienna, I 87 I (the Würzburg Fragments $=\mathbb{\Psi}^{\mathrm{W} z \mathrm{~b}}$ ), containing Dan. $\mathrm{x}^{15-29}, 3^{13-(50)}, 8^{5}-9^{10}, \mathrm{IO}^{3}-1 \mathrm{I}^{6}$; a nother fragment, $\mathrm{II}^{35-39}$ in Stutgardiana versionis sacrarum scripturarum latinae antehieronymianae fragmenta, Vienna, I 888 (so the copy at handI suppose identical with the variant title noted by Dold, p. 3, n. I, Antiquissimae Veteris Testamenti latinae fragmenta stutgardiana, Marburg, I888); and by P. Corssen, Zwei neue Fragmente der Weingartner Prophetenhandscrift nebst einer Untersuchung iiber das Verhältniss d. Weing. u. Wïrzb. Prophetenhandschrift, Berlin, I 899 (which I have not seen).

Since the practical conclusion of this apparatus there has come to hand a most important and exhaustive volume by A. Dold: 'Konstanzer altlateinische Propheten- u. Evangelien-Bruchstücke: mit Glossen,' etc., Lpzg., I923, in Texte $u$. Arbeiten herausgegeben durch die Ersabtei Beuron, I Abt., Heft 7-9. The learned author appears to have substantiated the fact that the so-called 'Weingarten' Fragments (a fortuitous name) and the Stuttgart Fragment came originally from the cathedral library in Konstanz. He has accordingly edited under attribution to that place all the ms material which he and his predecessors have been able to ferret out in various parts of Germany (often found made up in bookbindings!), including the Weingarten and Stuttgart material. (The earlier editors with their notes and commentaries are by no means antiquated; but there is constant revision of the earlier rdgs. of the obscure, often palimpsest, texts.) Dold has also contributed considerable fragments of an unpublished text from the monastery at St. Gall: $I^{1-8}$, $4^{20-22}, 4^{30}-8^{16}$ (some sections fragmentary), $9^{26}-\mathrm{IO}^{6}$, I I ${ }^{6}-\mathrm{I}^{13}$; also fragments of the Apocryphal Additions. This fresh material came too late for digestion for this work; but important data will be registered in the Comm. Dold's volume is encyclopædic in character; it contains, inter al., a comparison of the Dan. texts with the Patristic citations, pp. I $54^{-1} 58$; $c f$. the summary, p. 279. The present writer allows his own list of citations, given below, to stand, as representing his own sources. Naturally the apparatus of the Comm. depends primarily upon these authentic fragments for its use of the OLat.

For the OLat. Patristic citations the one corpus is the classic collection by $\mathrm{P}$. Sabatier, Bibliorum sacrorum latinae versiones antiquae seu vetus Italica, Rheims, I 739-49, reprinted Paris, I 757 . 
Its material for Dan. is meagre, and the writer has had to make his own collation. ${ }^{6}$ He has found gleanings of interest, some of them of textual importance, and presents the survey of citations in outline; it will serve at least for registration of the OLat. references in the Comm. The Fragments of II are also included. The whole material covers perhaps three-quarters of the bk. ${ }^{7}$ For critical discussion of this material s. $\$ \$ 12$, I3.

$\mathrm{I}^{15-2^{29}} \mathrm{Wzb}$.

$2^{18-33} \mathrm{Wng} .=$ Const.

$2^{21}$ Cassiod., In Ps., Ior.

$2^{31-35}$ Cypr., Test., ii, I 7 ; Maternus,

c. $2 \mathrm{I}$.

$2^{33}$ t. Iren., v, 26; $c f$. iv, 34, 10.

$2^{34}$ f. Tycon., p. 2.

$2^{4 L-44}$ Iren., v, 26, 1 .

$3^{15-(50)} \mathrm{Wzb}$.

$3^{16-18}$ Cypr., Test., iii, I; cf. Ep. ad

Fort., c. I I, Epp. vi, viii; Spec., c.

44 .

$3^{(25-37)}$ Aug., Ep., p. 646; cf. Cypr.,

De laps., c. 3 I.

$3^{(37-12)}$ Cypr., Test., iii, 20.

$3^{(38-45)}$ Aug., Ep., cxi.

$3^{(51)}$ Cypr., De dom. or., c. 8 .
$3^{(57 \mathrm{ff} .)}$ Aug., De civ., xi, 9.

$3^{24 \mathrm{~b}-25}$ Iren., v, 5, 2.

$4^{17-19}$ Spec., c. II 4 .

$4^{20-22}, 4^{30}-8^{16}$ Const.

$4^{24}$ Cypr., De opere ct elcom., c. 5 .

$5^{11}$ Spec., c. 3 .

$5^{25.28}$ De prom., ii, 34 .

$6^{24}$ (23)-28 (27) Cypr., Test., iii, 20.

$7^{1-27}$ Lucif., c. 30 .

$7^{8}$ Iren., v, 25, 2; Victor., In A poc., xiii, 2.

$7^{9-10}$ Ps.-Cypr., Ad Nov., c. I 7 .

$7^{10}$ Iren., ii, 6, 2 ; Tycon., p. 60.

$7^{13}$ \&. Iren., iv, 34, 10, cf. iii, 20, 2, iv, 50, I, iv, 55, I; Cypr., Test., ii, 26; Maternus, c. 25; Aug., De civ., xviii, 34 .

'I acknowledge particular debt to Burkitt's studies, 'The Rules of Ty'conius,' $T S$ iii, and 'The Old Latin and the Itala,' $i b$., iv, to which further reference will be made. Cf. now Dold's register of citations, p. 279, noted above.

${ }^{7}$ The texts used are:

Augustine, De civ. Dei, ed. Dombert, IS77; Epistolde, ed. Goldbacher, CSEL vol. 34 , pt. 2 .

Cassiodorus, In Psalmos, PL 70.

Commodianus (c. 250), ed. Dombert, CSEL vol. I 5 (for citation of Biblical phrases s. his Index).

Cyprian, ed. Hartel, CSEL vol. 3, pt. I; Ps.-Cyprian, Ad Novatianum, ib., pt. 3. Irenæus, ed. Harvey.

Julius Firmicus Maternus (A. 350), PL vol. I 2.

Julius Hilarianus, De mundi duratione libellus, $P L$ vol. I 2, pp. I102 ff.

Lucifer Calaritanus (c. 350), De non parcendo in Deum delinquentibus, ed. Hartel, CSEL vol. I3.

Tertullian, $A d v$. Iudaeos, ed. Oehler.

Tyconius, ed. Burkitt, TS vol. 3, pt. I.

Victorinus of Pettau, ed. Haussleiter, CSEL vol. 39 (against Bludau, p. I9, Vict. also uses $\Theta$ ).

De Pascha computus (c. 253 ?), ed. Hartel, CSEL vol. 3, pt. 3.

De promissionibus et praedictionibus Dei (Ps.-Prosper), $P L_{51}, 733$ ff. (largely cited by Sabatier). 
$7^{15-28}$ Aug., Dc civ., xx, 23.

$7^{20-25}$ Iren., v, 25, 2.

$7^{27}$ Ireii., v, 34, 2.

$8^{4}$ Spec., c. II 4 .

$8^{5}-9^{10} \mathrm{Wzb}$.

$8^{11 \mathrm{~b}-12}$ Iren., v, 25, 3 .

$8^{23-25}$ Iren., $i b$.

$9^{1-2 \mathrm{~b}}$ Tert., Adv. Iud., c. 8.

$9^{3-20}$ Aug., Ep., cxi.

$9^{4-7}$ Cypr., Dc laps., c. 3 I.

$9^{21-27}$ Tert., c. 8.

$9^{23-27}$ De prom., ii, 35 .

$9^{24-27}$ De pascha, c. I3.

$9^{25}-10^{11}$ Wng. $=$ Const.

$9^{25}$ Victor., De fabrica mundi, c. 8.

$9^{26-1} \circ^{6}$ Const.

$9^{26}$ Commod., A pol., 1l. $267 f$.

$9^{27}$ Iren., v, 25, 3.

$10^{3}-I^{6}$ Wzb.

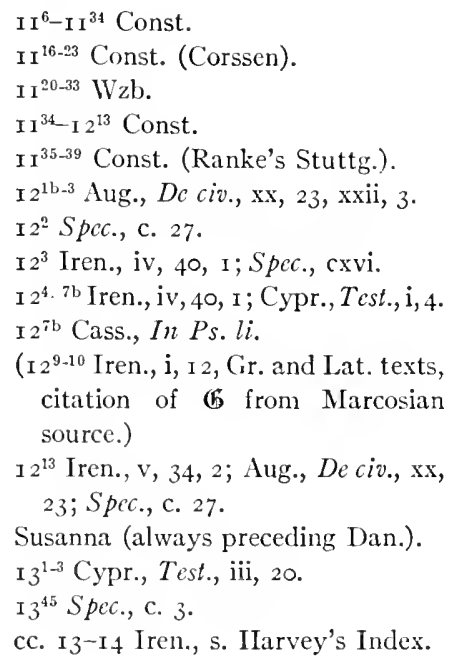

(2) The Vulgate.

For Jerome's Version (1T) s. the full article by H. J. White, 'Vulgate,' $B D$. The text used in this Comm. is 'Tischendorf's Biblia sacra latina Veteris Testamenti, I873, being the official Clementine text, with the rdgs. of the Codex Amiatinus in the marg. These rdgs. will be distinguished by $\mathfrak{U}^{\mathrm{Am}}$, they are almost always preferable to the received text. It may be noted that in his comm. Jer. does not always follow his tr., probably in such cases borrowing from 䜣.

\section{c. Coptic.}

There are two printed texts of Coptic translations of Dan., both of them being sub-versions from the Gr. ${ }^{8}$.

(I) The elder, in the Sahidic dialect of Upper Egypt, was published by A. Ciasca, Fragmenta copto-sahidica Musei Borgiani, Rome, I889. Its fragments of Dan. are $7^{9-15}, 8^{18-27}, 9^{1-27}$, I01. 4-11, 65 vv. in all. For my knowledge of this VS, as yet untranslated, I am indebted to Prof. G. A. Barton for a translation he kindly made for me, and to Dr. Gehman, who has assisted me

${ }^{8}$ See Vaschalde, $R B_{20}, 25.3$, for other fragments and citations in a series entitled 'Ce qui a été publić des versions coptes de la Bible.' On the general subject s. Hyvernat, 'Étude sur les versions coptes,' $i b ., 3,429$. 
in a critical examination of the text. It belongs to the Theodotionic tradition and will be treated in $\S_{I_{2}}, b$ as $\mathfrak{C}^{\mathrm{S}}$.

(2) The VS in the Bohairic dialect, of Lower Egypt, was published by $\mathrm{H}$. Tattam in Prophetae Majores in dialecto linguae aegyptiacae memphitica scu coptica, Oxford, I852, vol. 2, accompanied with a Latin tr. As $\mathfrak{C}^{B}$ it belongs to the Hexaplaric group, s. §I4.

\section{d. Syriac.}

There are two distinct translations accessible:

(I) The earlier translation (vulgarly called Peshitto) made directly from the original $(=\mathbb{S})$ appears in practically identical texts in the Paris and London Polyglots, the Lee (I823) and Urmia (1852) editions, and the photographic copy of the Ambrosian Codex published by A. Ceriani, Translatio syra Peschitto Vcteris Testamcnti cx cod. ambrosiano, Milan, 1876 seq. ${ }^{9}$ The London Polyglot has been generally consulted in this Comm.

(2) The Ambrosian 'Syro-Hexaplar' text has been sumptuously published by Ceriani in photographic facsimile, Codex syro-hexaplaris ambrosianus, I874, as vol. 7 of his Monumenta sacra et profana, Milan. ${ }^{10}$ It is a literal translation of a copy of Origen's Hexapla made, as the scribal notes attest, for Paul of Tella (Tella de-Mauzelath), in 616-7. It is provided with the Origenic asterisks and obeli, and with an extensive apparatus of variant rdgs. in the marg., mostly ascribed to Aq., $\Theta$, Sym., as the case may be. The colophons of the bks. attest this origin, asserting, variously, that the copy was made from the Hexapla, Tetrapla or even Heptapla. The text is practically the Syriac counterpart of the unique 'Septuagint' Gr. text noticed above. For Dan. they' have identical colophons: "It was written from copies having this subscription: written from the Tetrapla, with which it has been compared." The colophon to Prov. states that the original was in the hands of Pamphilus and Eusebius;

\footnotetext{
'See M. J. Wyngaarden, The Syr. VS of the Bk. of Dan., Lpzg., I9z3 (Univ. Penn. Thesis), p. 15. Some variant rdgs. are given in the London Polyglot, vol. 6, pp. $37 f$. ${ }^{10}$ It had been previously edited by Norberg, I 787 , and in part by Middeldorpf, 1835 , and the text of Dan. by C. Bugati, Dan. sec.ed. LXX . . excod. syro-esthrangelo, etc., Milan, i788. For the mS and its history s. Ceriani's preface; Field, Proleg. to his Hex., p. Ixvii seq.; Bludau, p. $26 . f f$.; Swete, $O . T ., 3$, p. xiii, Int., I $2 f$. Also s. in general and for a detailed comparison of the texts of the Syro-Iex. and the Chigi Ms, Löhr, ZATW i 895 , pp. 75.7 ., 193.ff.; 1896, pp. I 7 ff.
} 
the colophon to Isaiah tells that those scholars corrected the text from 'the library of Origen.' The contents of this text will be treated in connection with the Hexaplaric revisions, $\$$ I 4 .

(3) There may be noted finally a Daniel text in the remains of Jacob of Edessa's revision of the O.T.; a MS of it is in Paris, s. Field, Hex., r, $649 f$., for a description, and for further statement s. Baumstark, Gesch. d. syr. Lit., 25I, n. 2.

\section{e. Arabic.}

There is only one type of ancient Arabic text of Dan. in print, namely, the identical text in the Paris and London Polyglots. On this text s. the full treatment by H. S. Gehman, "The "Polyglot" Arabic Text of Daniel and Its Affinities,' JBL 44 (I925), 327-352; outside of studies on the Pentateuch this is the most thorough treatment of any bk. of the Arabic Bible. As $\mathrm{A}$ it will be considered below in $\S \mathrm{I} 4$.

A tr. of Dan. into Arabic in Heb. characters was made by the great Jewish master Saadia, first part of the roth cent. This has been published by $\mathrm{H}$. Spiegel (s. Bibliography). It is of great exegetical interest and will be cited currently in the Comm. Saadia often avails himself of interpretative paraphrases.

For very interesting evidence for an early translation of the Bible into Arabic in Spain, s. introduction to Gehman's monograph, and to his art. in Speculum, I, 2 I9. There may be noted here two references to early Muslim use of Dan., given by Margoliouth, Early Development of Mohammedanism: p. 4I, a son of the conqueror of Egypt read the works of Dan. and made prophetical calculations therefrom (Tabarî, ii, 399); and p. 235, cf. p. 24I, Abû Nu'aim identified the Stone of c. 2 with Mohammed.

\section{f. Other languages.}

No Ethiopic text exists in print.

Holmes-Parsons gives (s. Pref. to Gen., p. iv seq.), apparently via translations, variants from printed edd. of the Armenian, Georgian and Slavonic Bibles, the last-named from the Ostrogozok and Moscow edd. Of these the Armenian is of special interest for criticism, but having no control over the original the writer has made no reference to it. Dr. Gehman plans to make a critical study of it. 
However, one Slavic VS has been used in this apparatus, namely the Slavic VS (appearing in German tr.) printed in parallelism with the Gr. text of Hipp.'s comm. published by Bonwetsch. This version, as will be noticed in $\S_{\mathrm{I} 2}$, is of critical value, at times offering a better text than its Gr. partner.

A Hebrew tr. of the Aram. of Dan. and Ezra is presented by Kennicott ${ }^{2} \mathrm{~s}$ MS 240 in parallel column with the Bible texts. The Ms was written by a scribe Menahem in 1327 , according to de Rossi, vol. r, p. lxiii. It has been discussed by I. L. Schulze, Chaldaicorum Danielis et Esrae capitum interpretatio hebraica, Halle, $\mathrm{I} 782$. The tr. follows the text of not earlier than the roth cent., but is of interest as representative of current Jewish exegesis; s. Bertholdt, Daniel, 52, note. Another MS, Ken. 512, gives a similar tr. of the Aram. sections at the end of the respective bks.; it does not appear to have been studied.

\section{§II. THE OLD GREEK VERSION.}

As indicated in $\$ 10, a(\mathrm{I})$ and $d(2)$, we are confined for the

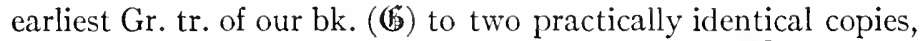
albeit in different languages, the Chigi Gr. Ms $\left(\mathfrak{G}^{\mathrm{C}}\right)$ and the Syro-Hexaplar $\left(\mathfrak{G}^{\mathfrak{S}}\right)$. Ever since their comparatively modern publication in the r8th cent., scholars have been keenly interested in the character and worth of that translation. The most recent extensive study of it is that of Bludau, 'Die alexandrinische Übersetzung d. Buches Danicl,' r 897. He has collated most thoroughly the work of preceding scholars and contributes much in the way of elucidation, although his work is more important for its accumulation of material and registration of difficulties than for solutions obtained. The problem as to the character of $\mathfrak{B}$ is expressed in the pertinent section, $\S_{4}$, in which the author sums up the views of scholars: "Fast alle Beurtheiler . . . machen dem Übersetzer zum Vorwurf Willkür, Unkenntniss, Tendenzkrämerei, Fälschung, u.s.w. Nöldeke nennt ihn einen 'Pfuscher,' u. Field bemerkt: 'Danielem ab Alexandrino absurde conversum est.' . . . Nur wenige . . . lof moderns, Cornill, Bevan, Behrmann, von Gall] scheinen sich vom Banne dieses Urtheils ein wenig frei gemacht zu haben."

Bludau proceeds, p. 3I, to make an acute critical distinction 
between cc. $3^{-6}$, at which most of the condemnation is directed, and the rest of the bk. For this balance the present writer's opinion, independently attained, agrees with Bludau's, that a careful study relieves much of the odium that has been cast upon the translation. The translator worked with three drawbacks: first, the inherent difficulty all translators have ever since contended with, the intentionally mystifying subject-matter of the apocalyptic portions hampering interpretation; secondly, the text with which he worked, especially in the last three cc., was to all appearances execrably written; and finally Aram. and not Heb. was his vernacular. This last point has not been specifically diagnosed in the several summaries of characteristics, e.g., Bevan, pp. 48-52, Behrmann, p. xxxi. See for typical cases

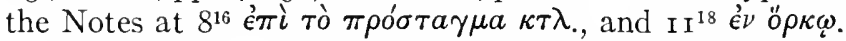

These points are rightly insisted upon by Bludau, who comes to the final judgment that the tr. is a 'staunenswerthe Leistung' (p. 87). But he has not recognized one feature, the observation of which clears up the greatest difficulties: the presence of genuine glosses, both primary and secondary, which may occur lines

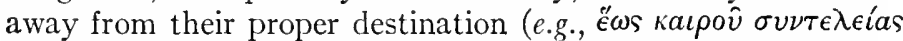
I $2^{7}$ is gloss to a lacuna in $v .^{9}$ ), and also of doublet translations. The Notes will abundantly illustrate this statement, and for ocular proof reference is made to the tabulated criticisms of $\mathfrak{G}$ $8^{11 \mathrm{~b} .12}$ and $9^{24-27}$ at the end of the respective $\mathrm{cc}$. When we have analyzed such portions we see that the translator worked faithfully word by word, especially in the obscure passages, and that the present muddled condition is largely due to the shuffling into the text of true glosses or doublets which once stood in the marg. An exactly similar case has occurred in almost all MSS of $\Theta$ at end of c. 9; s. Note at end of that chap. These glosses, and in some cases the duplicates, are evidently mostly prior to the Origenian revision, which itself has tended further to cover up original $\mathfrak{G}$; for we have always to bear in mind that we are dealing with a thoroughgoing Hexaplaric text, and hence 'Septuagint' is a doubly erroneous term. It would be worth while for some student to attempt the reconstruction of original $\mathfrak{6}$, rejecting the Hexaplaric additions, correcting manifest errors of text-tradition, transferring the glosses to the marg., and arranging doublets in parallel columns. Literarily the translator was worthy of such a task, for he was a writer of skill in Greek and 
of ingenious spirit. We may note such elegances as $\dot{a} \gamma \omega \nu \iota \hat{\omega}{ }_{\mathrm{I}}{ }^{10}$,

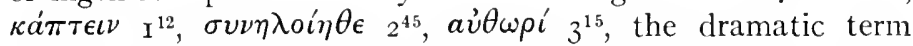
$\kappa a \tau a \sigma \tau \rho \circ \phi \eta \eta^{22}$, the neat 'sophists and philosophers' $\mathrm{I}^{20}$, 'Kittim' I I $^{30}=$ 'Romans'; the avoidance of monotonous repetition

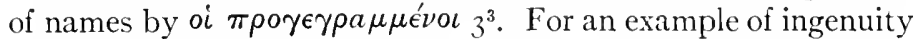

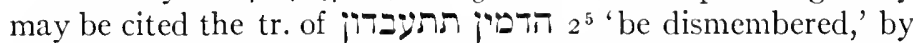
$\pi a \rho a \delta \epsilon \iota \gamma \mu a \tau \iota \sigma \theta \eta \sigma \epsilon \sigma \theta \epsilon$ 'be made an example of,' as though  further listings of the characteristics of $\mathbf{6}$.

As observed, cc. 4-6 must be considered separately. See the Notes appended to those cc. resp. in the Comm. and $c f$. Bludau, $\S \S_{18-20}$. In the Notes the conclusion is reached that there is considerable evidence for a translation from a Sem. copy which is responsible for much of the additions, largely midrash, now in $\mathbf{6}$. The case would be comparable to a similar origin of the Apocryphal Prayer, Interlude, Benediction in c. 3 by progressive interpolation (s. above, $\left.\S_{4}\right) ; n . b$., the bombastic character of that Interlude. The phenomenon appears to point to the actual circulation of cc. $3^{-6}$ as a distinct collection of stories at some stage ( $n . b$. , the Gr. Lectionaries appear to contain only these cc.), a point perhaps worthy of consideration in regard to the compilation of the bk. Another view (e.g., J. D. Michaelis, Bev., Kamp.) holds to a separate tr. of those cc., which after attaining its present garbled form was borrowed by the translator of the other cc. in editing the whole bk. But the proof presented from vocabulary is not stringent.

The recognition of the character of $\mathbb{6}$ and of the fatalities that happened to the Sem. 'Vorlage' and then to the copies of text, diminishes the range of possible corrections of from that quarter. The very ingenuity of the translator must put us on guard against accepting his facile translations as representing a better text than ifi. The lists assembled by the writer for cases where $\mathbf{6}$ may be used against if yield a small modicum of positive betterments, many of them hanging in the balance.

In the light of this view, Jahn's thoroughgoing adoption of $\mathfrak{B}$ (Das Buch Dan., I904) as representing the original text, which he reverts into Heb. as the language of that original, results only in an exercise in Hebrew composition, which may be left to Jewish literati. An earlier, more moderate opinion but specifically challenging Bludau's judgment of the worth of the text 
of 6 is that of Riessler, Das Buch Dan., I 899 . Of this booklet of $5^{6} \mathrm{pp}$. only a half, pp. $28-5^{2}$, is devoted to a treatment of certain select passages for the defence of the writer's theories, one of which is that adopted by Jahn that the original language of the whole bk. was Heb., and that this was the text before the translator. And similarly Charles, Daniel, p. xxx, comments on the value of $\mathbb{6}:$ : A long-sustained and minute study of the text and versions has led him [the writer] to conclude that it is just in these chapters (cc. $4^{-6}$ ) that the LXX makes its greatest contribution to the reconstruction of the original text, particularly in chap. iv." Such theories appear to the writer entirely baseless, as will appear in the Comm.

As for the date of $\mathbb{B}$, some of its phraseology appears in our Greek I Mac., although not to the extent sometimes assumed. Of the correspondences listed by Bludau, p. 8, n. 6, only the

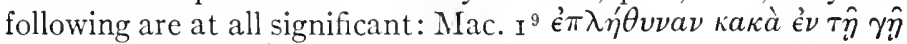

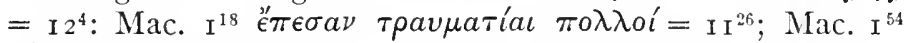

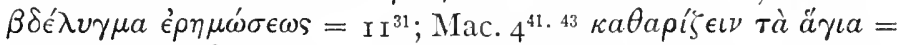
$\delta^{14}$. As for $\beta \delta$. $\epsilon \rho$., that may have arisen contemporaneously with Antiochus' sacrilege. Comm. have long observed the iden-

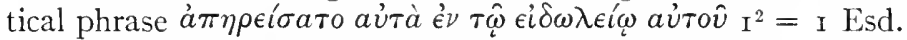
$2^{9}$, and so the origin of 1 both bks. from the same hand has been proposed by Givyn, $D C B$ 'Theodotion,' note p. 977; Thackeray, $D B$ г, 76 r $b$; Riessler, with a long list of (often merely nominal) parallels, pp. 52-56; Torrey, Ezra Studies, 84. On rather scanty evidence, that the Jewish historian Eupolemus, c. 150 B.c. (text given by Swete, Int., 370 = Eus., Praep., ix, $3 \mathrm{I}$ ) lnew $\mathbb{6}$ of 2 Ch. I $2^{12 \pi}$, Torrey holds, p. 82, that the OGr. tr. of Ch.-Ezr.-Neh. (containing 2 Esd.) existed by the middle of the $2 \mathrm{~d}$ cent. If so, with the equation of $\mathbb{b}$ of that series and of Dan., the latter would then precede the Gr. of I Mac., which is quite likely, as the Gr. of the latter bk. cannot be earlier than roo B.C. Torrey holds, p. $\delta_{3}$, that the home of the tr. of his $\mathbb{6}$ text "may well have been Egypt," a position naturally to be assumed. This is corroborated by (שु's rendering of Dan. $\mathrm{I}^{3}$ by $\mathrm{A} \beta \iota \epsilon \sigma \delta \rho \iota$, simply an Egyptian transliteration of the Sem.; a parallel Coptism is found in the Egyptian Cod. A,

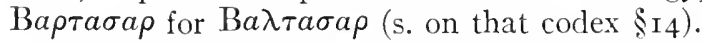

For the Hexaplaric additions, which are for the most part noted in $\mathfrak{G}^{\mathrm{G}}$ and $\mathfrak{G}^{\mathrm{S}}$ by asterisk and obelus (more correctly 
and consistently in the latter), s. \$I4 on the Hexapla. For the usurpation of $\mathbb{6}$ by $\Theta$, entailing almost its extinction, s. $\S$ I 3 .

\section{§I2. THEODOTION.}

Before the end of the $2 \mathrm{~d}$ Christian cent. another translation than that of $\mathbf{6}$ was making its way into the use of the Church, and within the first half of the $3 \mathrm{~d}$ cent. it had become mistress of the field. This is the translation assigned by all Patristic and MS evidence to Theodotion, whose age is traditionally put in the second half of the 2 d cent. after Christ. On this subject s. $\S$ r 3 .

The ms evidence for this version in its earliest form is found in the Gr. and in two sub-versions from the latter, the OLat. and Sahidic-Coptic. This triple chain of evidence is distinguished by the absence of the marks of the Origenian revisions, so that it must be assigned as a tradition to an age anterior to the middle of the 3 d cent.

\section{a. The Greek B Group.}

We possess in the eldest of the uncials, the Codex Vaticanus, the best type of $\Theta$ 's text. This apparently dogmatic statement is supported by all the tests tried by the writer. That text stands almost alone in its thoroughgoing correspondence with the OLat. and $\mathfrak{C}^{\mathrm{s}}$, and it is the one which, with exceptions to be noted in a subsequent section, is the basis of all subsequent revisions. Empirical analysis has discovered uss 89 I 30 as standing closest to $\mathrm{B}$, more distantly (with Origenian elements) $264^{2}$; and the text in Hippolytus (h) which is freshly adduced in this Comm. has particular interest in both its Gr. and Slav. forms. It is adequate to consider $B$ as the master text of its group and to observe its characteristics.

This high opinion of $B$ is expressed despite the recognition of certain shortcomings; but it is as text far cleaner than any of its colleagues, and is infinitely superior to Cod. A, a most imperfect document. Naturally the interest of critical scholars has been devoted to $\mathbb{B}$, but unfortunately $B$ has been neglected both in respect to its intrinsic worth and to critical study of it as an undoubted representative of a pure Theodotionic text, the like of which can only be discovered with pains in other parts 
of the Gr. O.T. Withal scholars have perpetrated the mistake of baldly citing $B$ as though it were ultimate, with no attempt to criticise it apart from its group and to recover the original text. Accordingly, in this Comm. special attention has been paid to $\mathrm{B}$ and its congeners, with the purpose of arriving at that original. ${ }^{1}$

For faults of all kinds in the text of $B$ the writer has counted some 65 cases, in most of which $B$ is supported by very respectable authority. It contains a small number of unique scribal errors. About 25 interpolations have been counted, but most of them from $\mathbb{6}$, some of which are supported by $\mathbb{i}$, hence primitive contaminations. The resultant verdict agrees with that expressed upon the text of B in the N.T. by Westcott-Hort, Int., $233 f_{\text {.: }}$ "The scribe by no means reached a high standard of accuracy, and on the other hand his slips are not proportionately bad... he occasionally omits necessary portions of text," etc.

There are many cases where $\Theta$ as represented by B has misread or mispronounced his text or had a faulty text (some 30 cases have been listed); e.g., $2^{34 .} 35$ jian with two different erro-

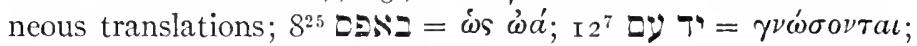
etc. Judgment of these errors in so difficult a text as Dan. (a large proportion of the errors occur in c. II) must be lenient.

The well-known characteristics of $\Theta$ appear in B, and they need not be diagnosed at length here. His tr. depends primarily upon $\mathbb{G}$, and hence his independent value often fails, especially in difficult passages, where he simply repeats $\mathbb{G}$, a weakness common to all translators. At the same time he handles $\mathbb{b}$ generally with fine discrimination; the opening vv. of the bk. might be observed for this point. His characteristic of literalness ap-

${ }^{1}$ With the development of photographic processes it is only sluggishness when scholarship does not acquaint itself with the exact texts of mss. The advance now needed is the formulation of a critical apparatus to a group such as that represented by $\mathrm{A}$ or $\mathrm{B}$, etc., and to attempt to restore the basis of the group. And this work should be done quite apart from thought of effect on the text of 2 ; that is another matter. Another requirement is the study of each of the great MSS in extenso throughout the O.T., the kind of work which has been done in the N.T., but which fails utterly in the O.T. field. What is said about the characteristics and the excellences of $\mathrm{B}$ is based entirely on its text for Dan. Now exactly opposite results are obtained by Torrey, p. 95, in the comparison of A and B. For his Biblical portion: "The best uncial by far is A; and the worst by far is B." What shall we say, then, to these things in the case of $\mathrm{A}$ and $\mathrm{B}$ as wholes? 
pears in his frequent transliterations of words (sometimes with reason, e.g., $\beta a \delta \delta \epsilon \iota$, possibly a current loan from the Sem., sometimes with tact in case of an unknown word, e.g., $\phi o \rho \theta o \mu \mu \epsilon \iota \nu$ $\left.I^{13}\right)$. His usual but not constant word-for-word tr. of the Heb. lands him in frequent barbarisms, especially in the case of assimilation of the new with the old, e.g., $6^{16}{ }^{(15)}$. Withal he drops his literalism quite often, as though impatient of Sen. stylisms and repetitiousness.

One feature of $\mathrm{B}$, worthy of notice in text criticism, is the frequency of abbreviation, ranging all the way from omission of single words of no essential importance to the abbreviation of repetitious phrases. In some cases $\mathbf{I} \mathfrak{C}^{\mathrm{S}}$ do not run with $\mathrm{B}$ in these omissions, and the phenomenon must be regarded then as secondary. While often the omissions might be ascribed to subsequent scribes, especially in cases of homocoteleuta, the writer has come to the conclusion that this tendency is an original characteristic of $\Theta$ (Torrey has noticed the same for his section of $\mathrm{B}, \mathrm{p} .95$, but charging them to 'incredible carelessness'). The lacunæ can hardly be attributed to scribal losses, so well supported are they. In most cases $\mathbb{6}$ supports if $_{\text {S }}$ as against $\mathrm{B}$, and that combination is generally to be respected. A case of simplification from an original status where two parallel antique texts were once present in $\Theta$ texts appears at end of c. 9, where B has selected one of them, with consequently the remission of the more interesting duplicate into the marg. of our Gr. edd. (s. Note at end of c. 9). In general B represents the authentic text of 'Theodotion' for Dan.

A note is due on Hippolytus' Theodotionic text in his comm. to Dan.; see $\S$ Io, $a(2)$. The Biblical text used by Hipp. is present in double form, in Gr. and in Slavonic, and as the latter varies from the former to some extent we possess an inner apparatus for Hipp.'s text. In some cases the Slav. has better rdgs. than the Gr.; I note: $3^{30(97)}$, P. II 4 (of Bonwetsch's edition); $4^{24}$, p. I $28 ; 5^{11}$, p. $152 ; 6^{8}$, p. I $62 ; 7^{9}$, p. I $84 ; 8^{5}$, p. 250 (s. Notes ad loc.). The Slav. text has thus its own tradition, a fact suggesting the worth of critical examination into the translations in that language. As the doubly witnessed text has not been studied hitherto for its bearing on text criticism, it is useful to note that it is very closely related to $B$, agreeing with the latter, in the large, in its characteristic rdgs. and omissions. In a few 
cases it is better than B, e.g., in the omission of $\dot{\epsilon} \xi$ ópous $2^{34}$

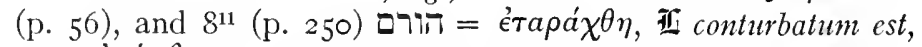
is. B $\epsilon \rho a ́ \chi \theta \eta$. In two places Hipp. has independent renderings of i and this suggests that that Father had control of Heb. Compare the tradition about him as the 'Expositor of the Targum' and his undoubted acquaintance with Rabbinic learning; s. Achelis (cited in the next note), pp. II3-I20. The cases in point are $\mathrm{II}^{6}$, p. 300 , and $\mathrm{II}^{30}$, p. 298. The not considerable variations from $B$ are Hexaplaric-Lucianic, more particularly Lucianic. This latter characteristic belongs to the general problem of 'pre-Lucianic rdgs.,' s. §I 2 end, $\S_{5} 5$ end.

Now Hipp.'s text is one of our most primitive proofs not only for $\mathrm{B}$ but also for the tradition of $\Theta .^{2}$ Bardenhewer, p. 68, and Bonwetsch, p. 2, assign the comm. to Dan. quite confidently to the time of Septimius Severus' persecution, 202 A.D., in this followed by Zahn and Harnack, as against Salmond, who places it 'a good deal later,' p. Iо4 $b$. Whatever may be the fact in that point, Salmond's statement (p. $87 b$ ) that Hipp.'s activity may go back to the beginning of the last decade of the $2 \mathrm{~d}$ cent. (he may have heard Irenæus) argues for the existence of the Theodotionic tr. as authoritative well back into the $2 \mathrm{~d}$ cent. The date of the Latin tr. of Irenæus being now held by many to be much later (v. inf. $[c])$, this fact as to Hipp.'s text is of great importance. The 'pre-Lucianic rdgs.' in Hipp. point to a Syrian, Antiochian origin, as do also the OLat. texts, and Hipp. may have been instrumental as purveyor of that form of $\Theta$ in contrast to the $B$ text, which is prob. of Egyptian origin.

\section{b. The Sahidic-Coptic.}

My list of variations from $B$ in the 56 vv. of the Sahidic numbers all told about 20. 'This count includes particles and other easily variable factors. In many cases they help to correct $B$ where it can otherwise be proved to be untrue to its group, e.g. the intrusion in $9^{8}$; in several cases there is correspondence with I against B. The most frequent correspondences are with $Q$ $26233=$ ir. This establishment of some links between the Coptic and Q agrees with the findings of Ceriani, De codice

\footnotetext{
'See Salmond, 'Hipp.,' in $D C B$, and consult Bibliography under Achelis, Bardenhewer, Bonwetsch.
} 
marchaliano, etc., Rome, I890, as reported by Swete, OTG 3 , pp. viii seq. There are agreements with $\mathbb{b}$, also with some of the Origenic groups and so indirectly with Lu. Reference is made to the Note at the end of c. 9 for its interesting form of the text of the last vv. of that chap.

This close correspondence between $\mathrm{B}$ and $\mathfrak{C}^{\mathrm{S}}$ adds weight to my opinion that $\mathrm{B}$ represents the Egyptian type of $\Theta$, as against others, Palestinian and Syrian. As to the importance of $\mathfrak{U}^{\text {s }}$ the writer's belief has only grown stronger with repeated study that if the whole of the Sahidic Dan. existed it would be a worthy peer to $B$.

\section{c. The Old Latin.}

The sources of materials for this subject have been given above, §io, $b$ (I). The OLat. Ms texts are distinctly pre-Hexaplaric, corroborating Burkitt's dictum upon Patristic citations that the OLat. nowhere exhibits the Hexaplaric earmarks. ${ }^{3}$ And the text is in general that of B. Ranke has placed scholars in his debt by giving an apparatus of comparison of rdgs. with Holmes-Parsons, but with these drawbacks, that he has taken as his basis the faulty Sixtine text (against which the user of HP must always be on his guard), that he simply compares $B$ with no attempt at criticism of its text, and finally that as a purely classical scholar he does not know the Sem. Lackground. Also he often leaves unnoticed many evident faults of the texts that can be easily corrected. ${ }^{4}$ This OLat. material bears as a translation the same relation to its Gr. copy as the latter, $\Theta$, does to is, and hence the work of comparison is immensely simplified. Is of great value in showing the antiquity of errors, glosses, etc., in B, e.g., the doublet $2^{32}$ pectus et bracchia; and conversely it often exhibits a better rdg. which may also be in

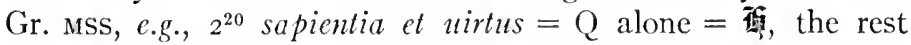
with a third glossed doublet, which also appears in Cassiodor, ad Ps. ci, + intellectus. As for agreements with the Gr. groups as against $B$ the most correspondences are with the Lucianic group (I 4 cases), then with the Origenian mss (no Hexaplaric additions!), e.g., with A I 3 cases, Q I I cases, 106 Io cases, etc.

\footnotetext{
3 "No (asterisked) passage is found in any form of the African Latin," Rules of Tyconius, p. xcvi.

tE.g., $8^{25}$ sermone for $\delta 0 \lambda \omega$ arose from the misreading of $\delta$. as $\lambda \circ \gamma \omega$.
} 
The citations of the Patristic material have been given in $\S$ Io. These numerous cases, which often present three or four parallels, have been fully digested for this work; much chaff had to be winnowed, but valuable gleanings were attained; $c f$. the Note on $\Theta$ at end of c. 9 for a very important rdg. in Tertullian. The criticism of this whole material would be a work in itself, for which important preliminary studies have been made by Burkitt in his Rules of Tyconius and The Old Latin and the Itala. ${ }^{5}$

It has generally been held that the earliest Patristic text using II is the Latin Interpretation of Irenæus, whose Against the Heresies was probably written in the eighties of the $2 \mathrm{~d}$ cent. ${ }^{6}$ This view of the early origin of 1 of Irenæus has been upset by the studies of Jordan and Souter, who very positively refer the Latin tr. to the $4^{\text {th }}$ cent. ${ }^{7}$ If this judgment be true, Irenæus' primacy for the critical student of the OLat. is dislodged. But the Lat. of Iren. still remains incontestable proof of Iren.'s thoroughgoing $\Theta$ text, for, as Burkitt remarks, Old Latin, p. 6, n. 2, the translator would have revealed traces of the Septuagintal character of his original, if it had such. If, with Venables, p. 254, Irenæus' birth is to be put between the limits I 26 and I 36 A.D., the text of $\Theta$ must be carried back into the first half of the $2 \mathrm{~d}$ cent., when as a schoolboy he was initiated into the one text we know he used; and at the other end there is the unadulterated $\Theta$ text of Hippolytus, providing us with a continuou; catena for a large part of that cent. In addition to Irenæus we have evidence for $\Theta$ in the early part of the $3 \mathrm{~d}$ cent. in Tertullian in part, while his scholar Cyprian uses both $\mathbf{6}$ and $\Theta$, sometimes in conflate form. ${ }^{8}$

Jerome's well-known criticism of fif for its 'diuersa exempla-

${ }^{5}$ See now the Patristic apparatus presented by Dold, pp. 279 f.; for an earlier listing, Bludau, De indole, $20 . f$. Oesterley has collated Ranke's Fragments and Patristic Citations for the Minor Prophets in JThSt., vols. 5,6 .

'So Venables, $D C B$ 3, 258. All the citations from Dan. are found only in the Latin, with one exception, Dan $12^{9} \mathrm{f}$. in $\mathrm{i}, \mathrm{1} 2$, a citation from a heretic, which interestingly enough is from $\mathbf{6}$.

${ }^{7}$ H. Jordan, 'Das Alter u. d. Herkunft d. latein. Übersetzung d. Hauptwerkes d. Iren.,' Theol. Studien, Th. Zahn dargebracht, igos, and Souter in Sanday and Turner, Novum Testamentum S. Irenaei, I923; it may be noted that the editor Dr. Turner still remains unconvinced. Cf. rev. by Lagrange, $R B 1924,260 . f$.

${ }^{8}$ See in general Burkitt, Old Latin and the Itala. For a theory of a Marcionite Vetus Latina as the first attempt at a Latin tr. of the Bible s. d'Alès, Biblica, 4, 1923, pp. $5^{6} . f f$., esp. $85 . J$. 
ria' and the 'interpretum uarietatem' (s. Kennedy, $D B_{3}, 48$ ) appears to be substantiated by the large amount of variation among the Patristic citations and the authentic texts of $\mathrm{if}$. It leads nowhere to make the hypothesis of an indefinite number of versions; this did not occur in the primitive Gr. Church. But it may be suggested that there arose early in the Latin-speaking Church an oral 'Targum,' since in important dogmatic and also popular passages a crystallized translation would have come in vogue, which itself allowed much room for variation even after it was written down. For instance, the Interpreter of Irenæus with the Gr. before his eyes at the same time had the current Targum in his head; the latter would be modified by his scholarly attention to the text as well as by existing variants in the oral translation. A study of these OLat. texts induces a high appreciation of the fidelity and, comparatively speaking, the scholarship of the early Latin translators.

Finally, the problem of 'Lucianic' rdgs. in the OLat. must be touched upon. It has long been observed by students ${ }^{9}$ that the OLat. of the O.T. is markedly 'Lucianic.' In his Par palimps. wirc., 4ro, Ranke lists in order the Gr. Mss most closely corresponding to if in the latter's variations from B; and the Lucianic MSS $22364^{8} 5^{\mathrm{I}} 23 \mathrm{I}$ stand, almost all, at the head of the list. The problem must be discussed in connection with Lucian, \$15. There can be but one explanation, that Lucian himself used as a basic text one that varied primitively from that of $B$. That is, there existed a Syrian or Antiochian form of $\Theta$, which, as 11 shows, early made its way from Syria to the West and became the basis of the OLat. translation. Direct connections of the West with Syria, not only via Egypt and the north coast of Africa, as so often assumed, must be allowed. Irenæus came from Asia Minor. Hippolytus probably came from the East. Note also that on Irenæus' authority Theodotion was an Ephesian. The problem is accordingly connected with that of the Western Readings in N.T. text criticism. Sanday, as cited by Kennedy, has suggested that the text of the N.T. in OLat. and Syriac came from Antioch. It can be positively insisted upon that despite the alleged 'Lucianisms' none of the Hexaplaric

\footnotetext{
${ }^{9}$ See Kennedy, $D B 3,6$ I $f$., Schürer, $G J I^{\prime} 3,31,3,43$ I, n. I., Dieu, 'Retouches lucianiques sur quelles textes de la vieille version latine (I et II Samuel), $R B$ i $6,372 f f$., summary. p. 403 .
} 
interpolations, none of the characteristic Lucianic doublets appears in 2 .

Finally it is to be remarked that with this coincidence of $\mathrm{II}$, $\mathfrak{C}^{\mathrm{S}}$ and Patristic citations with $\mathrm{B}$ the text of the latter must represent that of $\Theta$ back toward 200 A.D. at least; and this judgment, reached independently, agrees with that of Westcott and Hort for the N.T., Int., 222: the text of B and Sinaiticus is 'essentially a text of the second or early third century.'

\section{§I3. THEODOTION: TRIUMPII OVER THE OLD GREEK; AGE;} THE PROBLEM OF 'UR-THEODOTION.'

Little direct information is at hand for the replacement of the Old Greek ('Septuagint') VS of Dan. by $\Theta$. The triumph, starting as we have seen in the $2 \mathrm{~d}$ cent., rapidly became an accomplished fact, as witnessed by sub-versions which go back at least to the beginning of the $3 \mathrm{~d}$ cent. Jerome gives the fullest statement in the Preface to his comm.: "Danielem prophetam iuxta septuaginta interpretes Domini Saluatoris ecclesiae non legunt, utentes Theodotionis editione, et hoc cur acciderit nescio. . . Hoc unum affirmare possum, quod multum a veritate discordet, et recto iudicio repudiatus est." Origen in his Hexapla fully edited and revised both $\boldsymbol{G}$ and $\Theta$ of Dan., although his work in other bks. shows that he depended upon $\Theta$ for filling up lacunae in $\boldsymbol{G}, e . g$. , Jer. and Job. It is assumed by many (s. Schürer, $G J V 3,442$ ) that the immediate cause of rejection of (5) was its false interpretation of the Weeks, c. 7 (s. Note at end of that chap.); but the patent incorrectness of $\mathscr{G}$ was sufficient ground to prefer a better translation, which had its own good tradition.

Of Theodotion we know next to nothing as to his person and date. ${ }^{1}$ The earliest mention of him is in Irenæus, Adv. Haer. iii, 24: "Theodotion the Ephesian made a translation, and Aquila the Pontian, both Jewish proselytes." No confidence can be placed in Epiphanius' statement, De mens. et pond., $\S_{1} 7$, placing him under Commodus' reign, $c$. I 80 , which is at once contradicted by Irenæus' use of $\Theta$ (s. also Gwyn, arguing for a mistake in the imperial names). As Irenæus names him before

\footnotetext{
'See Gwyn, 'Theodotion,' DCB; Bludau, De indole, \$3; Swete, Int., 4z ff.; Schürer, $G J V 3,439$ ff.
} 
Aquila, there is clear presumption that he antedated the latter, and the convention of naming him after the latter has no more reason than the fact that in Origen's columns Aquila preceded Theodotion; it is unfortunate that his presumable priority, urged by Schürer, p. 442, is ignored in the authoritative works. ${ }^{2}$ $C f$. Jer.'s ignorance as to this translator's age, in the Pref. to his comm.: "qui utique post aduentum Christi incredulus fuit."

But the age of the translator Theodotion, which must logically be referred back at least to the first third of the $2 \mathrm{~d}$ Christian cent., cannot date for us the rise of the 'Theodotionic' elements in the Greek Bible. The problem has long been noticed and solutions attempted. Credner, Beiträge aur Einleitung in die bibl. Schriften, I838, 2, 61 ff., proposed that there was an carly Christian version of Dan. which would explain the N.T. citations. Gwyn's hypothesis is the boldest, $D C B$ p. 976: "Side by side with the Chisian LXX there was current among the Jews, from pre-Christian times, another version of Daniel, more deserving of the name, claiming to belong to the LXX collection and similar in general character to the LXX versions of other books of the Hagiographa; that this was the version known to the author of the bk. of Baruch . . . and to St. Matthew," etc. Swete's criticism of this position, Int., p. 49, is cautious and non-committal. Bludau in his full discussion of the evidence from Dan. (Die alex. Übers., \$2, p. 23) comes to the result of an older Gr. tr. 'reformed' by the historic Theod. of the $2 \mathrm{~d}$ Christian cent. Schürer expresses himself similarly, p. 442: "Dieses ganze Material lässt nur zwei Erklärungen zu: entweder Theod. ist älter als die Aposteln, oder es hat einen 'Theod.' vor Theod. gegeben, d. h. eine Revision der LXX in ähnlichem Sinne, die dann von Theod. weitergeführt worden ist."

Only a brief résumé of the evidence, and that for Dan. alone, can be given here; for fuller data reference can be made to Bludau, l. $c$.

In Clement of Alexandria, $c$. I 50-200 (not included by Bludau) the citations are (after Stiihlin's ed. in GCS with cross-reference to Potter's ed.):

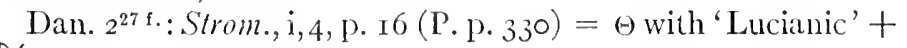
$\delta \dot{v} \nu a \mu \iota s$.

${ }^{2}$ See the author's Samarilans, 77, 202, for Samaritan reminiscences of Theod.; there is ref. to a 'Targum of Nathanael,' i.c., Theodotion. 
$7^{9 \mathrm{a}}:$ Paed., ii, Io, p. 222 (P. p. 235$)=\Theta$.

$7^{9 \mathrm{~b}}:$ ib., iii, 3, p. 246 (P. p. 262) $=\Theta$.

$8^{13 \text { f.: }}$ Strom., i, 2 I, p. 9I (P. p. 408) $=\Theta$ (Stählin's text much improved).

$9^{24-27}$ : ib., p. 78 (P. p. 393) in general $=\Theta$; s. further Note at end of c. 9 .

I $2^{11 \text { f. }}: i b$., p. 9I (P. p. 409$)=\Theta$, but $\delta \circ \theta \hat{\eta} \nu a \iota$ for $\delta \circ \theta \eta \dot{\sigma} \sigma \tau a \iota$ with V Q 62 Lu. al.

Justin Martyr (†c. I65) cites $7^{9-28}$ at length, Tryph., xxxi. His other citations are all from the same chapter, except $2^{45}$ in Tryph., lxx, I, where the text is indifferent between $\mathbf{5}$ and $\mathbf{I}$; and $\mathrm{I}^{36}$ in $\mathrm{cx} .2$, where $\mathbb{b}$ is the basis (n.b. 'ै ${ }^{\prime} \xi a \lambda \lambda a$ ). Archambault's ed. of Trypho in Hammer and Lejay's Textes et Documents has been consulted. Swete has conveniently presented the long passage from c. 7 in parallel with $\mathbb{G}$ and $\Theta, I n t$., p. $42 \mathrm{I}$, to which the reader may refer. My result of comparison is that this mosaiclike composition is not due to the intrusion of a later scholiast into Justin's original $\mathbf{6}$ text; the care with which the variations are made points to the first hand. In most cases the intentional variations from $\mathbb{G}$ were made where $\boldsymbol{6}$ has a corrupt or complicated text, for which $\Theta$ offered improvements.

Of three 'Apostolic Fathers' (Gebhardt's text), toward the end of the ist cent., Shepherd of Hermas appears indifferent between $\mathscr{G}^{3}$ and $\Theta$, except for the citation of $\Theta 6^{23(22)}$ in $V$ is., iv, 2, 4 against $\mathbf{6}^{3} .^{3}$ The citation of $2^{35}$ in Sim., ix, 2, I is independent.

Ep. Barnabas, iv, $4 f$., contains memoriter citations of $7^{24-27}$; against Bludau's judgment that $\mathbf{6}$ is visible, nothing definite can be postulated; Swete, Int., 48, holds that the correspondence is closer with $\Theta$.

Ep. Clement, xlv, recalling Dan. $6^{17(16)}$, is closer to $\Theta \epsilon^{\prime} \beta \lambda \eta^{\prime} \theta \eta$

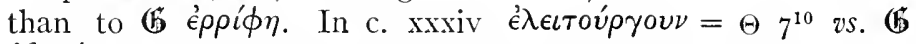

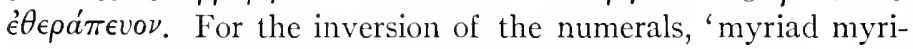
ads,' 'thousand thousands,' in company with old ecclesiastical use, s. Burkitt, Old Latin, 22 ; it follows Rev. $5^{11}$.

Josephus' Bible text has been variously diagnosed, but without positive results. ${ }^{4}$

${ }^{3}$ The writer also depends upon Sem. tradition in his reference to the angel who

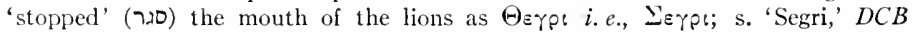
Schürer, 3, 44I, for the discussions by J. Rendel Harris and Hort.

${ }^{4}$ See Bludau, Ryssel, and for other literature Schürer, 3, 422. 
But the New Testament, with its wealth of citation from Dan., offers the best touchstone for the problem. To begin with the kindred Apocalypse of John, we discover propinquity to both $\mathscr{6}$ and $\Theta$, often with apparent conflation, and equally with a sovereign independence of known Gr. texts. ${ }^{5}$ The following cases of Theodotionic character may be noted and analyzed:

Rev. $9^{20}$ : Dan. $5^{23}=\Theta$, but $\epsilon \iota \delta \omega \lambda a=\left(\mathfrak{b}^{*}\right.$.

Rev. $10^{5 \mathrm{f}}:$ Dan. $\mathrm{I} 2^{7}=\Theta \mathscr{\omega}^{\prime \prime} \mu \sigma \sigma \epsilon \nu \hat{\epsilon}^{\prime} \nu \tau \hat{\omega} \zeta \hat{\omega} \nu \tau \iota=\Theta, \mathscr{b} \tau \dot{\nu} \nu \zeta \hat{\omega} \nu \tau a$.

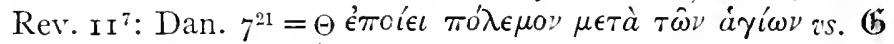

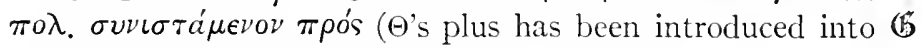
$\left.v{ }^{8}\right)$; the same correspondence at Rev. $I_{3}{ }^{7}$ but with more variations in the fuller citation.

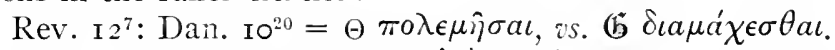

Rev. $16^{18}$ : Dan. $12^{1}$ the plus $\dot{\epsilon} \pi \hat{\imath} \tau$. $\gamma \hat{\eta} s=$ Or., Lu., but $\Theta \dot{\epsilon} \nu$ $\tau \hat{\eta} \gamma \hat{\eta}$. (Has this plus entered the Gr. of Dan. from Rev.? I have noticed some cases of the kind in Cod. A.)

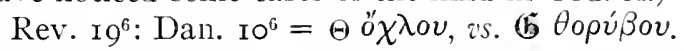

Over against these correspondences with $\Theta$ are to be reckoned those with $\mathfrak{6}$, some seven in number, while yet other reminiscences are more or less independent of either.

But the closest correspondence is found in Heb. $\mathrm{II}^{33},{ }^{6}$ where

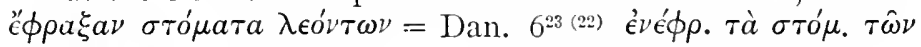
$\lambda \epsilon \sigma^{\prime} \nu$., $\mathbb{6}$ failing here wholly. An interesting case, rather ignored in N.T. apparatus, is $\lambda \iota \kappa \mu \eta \dot{\sigma} \sigma \iota$ Mt. $21^{44}=\mathrm{Lu} .20^{18}$ from Dan. $\Theta 2^{44}$. Further: Mt. $28^{3 \mathrm{~b}}=\Theta 7^{9}$ (overlooked in N.T. apparatus);

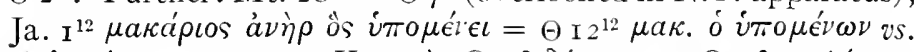

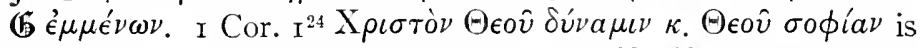
a citation of the true text of $\Theta$ acc. to $Q \mathrm{I}=\mathrm{f}$, vs. B al. The

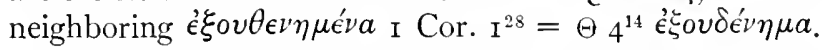

But the most striking parallelism of an early Gr. document with $\Theta$ of Dan. is found in the Epistle of Baruch, the date of which is now most commonly placed about A.D. 70.7 In Bar. $\mathrm{I}^{15}-2^{19}$ is

${ }^{5} C f$. Bludau, 'Die Apokalypse u. Theodotions Danielübersetzung,' Theol. Quartalschrift, $1897,1-26$. The author holds that by the N.T. age a new tr. of Dan. had replaced $\mathbf{6}$, which then was already antiquated, that $t r$. being eventually incorporated in $\Theta$. But some of the most striking correspondences of N.T. with $\Theta$ lie outside of Dan. A critical survey of the O.T. citations in Rev. is given by Swete in his Apocalypse, Int., c. I3.

'See Overbeck, $T L Z$ I 885 , col. 34 I.

7 But s. now R. R. Harwell's Yale thesis, The Principal Versions of Baruch, I9I5. Cf. Thackeray's criticism in his Septuagint and Jezish H'orship, pp. 85.ff. Pp. 24 ff. he discusses the problem of 'Theodotion or Ur-Theodotion?' and expresses belief in the necessity of some such theory as the latter. 
found a long prayer mostly composed of excerpts, arbitrarily arranged, from Dan's prayer, c. 9. This appears from the following exhibit of the order of the fragments of Dan.: vv. 8b. Iо.

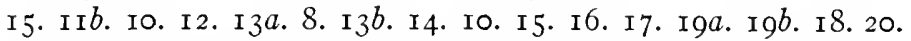
It is small wonder that the parallelism has induced scholars to make $\Theta$ the basis of the Gr. Gwyn, p. 976, appears to have been the first to develop this thesis at length; he is corroborated by Schürer, $G J V$ 3, 44I, and so $T L Z$ I904, $255 \mathrm{ff}$.

The many agreements are obvious; Gwyn has presented the most striking ones. But the disagreements must not be ignored.

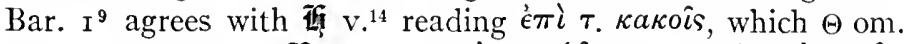

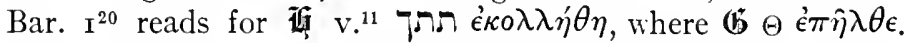
Bar. ${ }^{17}, 2^{20}$ use the non-Theod. word $\pi \rho 0 \sigma \tau a^{\prime} \gamma \mu a \tau a$. But the crucial case for showing that the Gr. translator was citing ultimately (memoriter?) from the Heb. appears at $2^{12}=$ Dan. v. ${ }^{16}$, where he follows a different syntax as well as a different translation from $\mathscr{G}^{\mathfrak{B}}$ and $\Theta$, differing also from the pointing of $\boldsymbol{f l}$. That is, he is making his own free version of

To interpret these phenomena we have to realize that the passage in Bar. is a prayer following Biblical and liturgical forms. In passing over into the Hellenistic Synagogue Gr. Targums arose, these for long oral in character. In the present case the translator had language ready made, which again he might correct from his knowledge of the original Heb.

And this argument presents experimentally the writer's judgment on the problem of 'Ur-Theodotion.' 'That there existed some such body of received translation before the Christian age lies beyond doubt; but we must not too quickly assume a written version. Very much can be explained by the hypothesis of a Hellenistic oral Targum, necessary in the first place for correction of faulty renderings, and especially of lacunæ in $\mathbb{G}$. (It is found that early 'Theodotionic' rdgs. generally appear in such cases.) And then we may link up this oral tradition with the Theodotion of Church tradition of the early part of the $2 \mathrm{~d}$ Christian cent. He is the Hellenistic Onkelos, whose work was facilitated by the presence of a large amount of customary oral translation of the Scriptures, possessed by him memoriter. Of course such a theory does not exclude the possibility of literary predecessors of the historical Theodotion. 


\section{§I4. TIIE HEXAPLARIC REVISIONS: $\mathrm{OR}^{\mathrm{P}}$ (V 62 I 47 ) AND $\mathrm{OR}^{C}$ (THE A-GROUP, ARABIC, BOHAIRIC).}

In his Hexapla (the Tetrapla is included in this generic term) Origen revised both $\mathbb{6}$ and $\Theta$, the Gr. and Syr. texts of the former offering the best example we have of the Origenian apparatus. To a large extent he entered the same plusses into both, but in general most of the lacunæ were in the abbreviating $\Theta$. But in very many cases the conflate character of $\mathscr{G}$ is due to earlier revisions; s. $\$ \S$ I I. I2. As for the $\Theta$ text, the great bulk of the Gr. uss are Hexaplaric (Lucian being sub-Hexaplaric), a contamination that has not spared one of them, even $B$.

Most of the work for the present apparatus has been devoted to the Hexaplaric group. The argumentation for the results obtained have been presented by the writer in $J B L$ I925, pp. 287-300, 'The Hexaplaric Strata in the Greek Texts of Dan.', followed by the corroborative studies of C. D. Benjamin, 'Collation of Holmes-Parsons 23 (Venetus)-62-147 in Daniel from Photographic Copies,' pp. 303-326, and H. S. Gehman, 'The "Polyglot" Arabic Text of Dan. and Its Affinities,' pp. 327-352.

The stress has been applied to Cod. A, an alleged master codex, and the Venetian Codex $\mathrm{V}$ (now recognized as an uncial $=\mathrm{HP} 23$ ) and the Oxford cursives 62 I47. The last three have been collated by Benjamin from photographs procured by the Yarnall Library in the Philadelphia Divinity School for this work. ${ }^{1}$

The chief result obtained is that $\mathrm{V} 62$ I 47 represent the earliest form of Origen's revision of $\Theta$, a position which can be adjudged from Benjamin's collation and the comparisons registered there with the other groups. The group in question is the basis of a subsequent revision-critically retrograde in its approximation toward the elder Textus Receptus-represented by what we may call the A-group; and again this was succeeded by the Lucianic group. For the group V 62 I 47 the descriptive epithet 'Palestinian' has been taken, as typifying Origen's own work $=\mathrm{Or}^{\mathrm{P}}$; for the A-group the epithet Constantinopolitan, on the hypothesis that it represents the Eusebian revision or-

\footnotetext{
${ }^{1}$ The whole of $\mathrm{V}$ in photographe copy is now in the Library of that School, subject to the use of scholars. Similar reproduction of the whole of 62 and 1.47 is now in process of preparation for the same Library.
} 
dered by Constantine for the use of the Church in his new capital (Eus., Vita Const., iv, 36. 37) $=\mathrm{Or}^{\mathrm{C}}$. $\mathrm{Or}^{\mathrm{C}}$ and Lu. would then be approximately contemporary revisions, made for identical ends, of the Origenian work, one for Constantinople, the other for Antioch. And, however the origin of the A-group is to be explained, the writer has more and more become convinced of the correctness of his opinion that the above hypothesis explains all the essential facts of the problem.

For $\operatorname{Or}^{\mathrm{P}}$ nothing more need be added than has already been published. Of the three Mss, $62 \mathrm{I} 47$, although degraded and contaminated types, are closer to the mother text than $\mathrm{V}$, which has rather made an eclectic choice of rdgs. (largely marked with the Hexaplaric asterisks). The group is Aquilanic in the secondary sense that it presents Origen's work in its closest approximation to his Jewish master.

For $\mathrm{Or}^{\mathrm{c}}$, of the Gr. Mss A Q $\Gamma$ IO6 3523042 (the cursives arranged in the order of their worth as empirically determined) are the best representatives of the group; with them go the Arabic (A) and the Bohairic-Coptic $\left(\mathfrak{C}^{\mathbb{B}}\right)$. Codex A must be extremely discounted as a witness; an early listing has disclosed more than $\mathrm{I} 75$ errors, some of them most glaring, ${ }^{2}$ a large number solecisms of $\mathrm{A}$. Its closest mate in character and faults is ro6, the two serving admirably to supplement one another. Cod. A is Egyptian in physical origin, this revealed for Dan. by its Coptic pronunciations, $\beta a \rho \tau a \sigma a \rho \mathrm{I}^{7}, a \mu \epsilon \rho \sigma \alpha \rho \mathrm{I}^{11}$ (s. $a d$ locc. and $J B L 298, \mathrm{n}$. I2), but Constantinopolitan in text, as a codex of the Melchite Church in Egypt. Its colleague $\mathbf{A}$ is then the early tr. made for the Arabic-speaking Melchites. $\mathbf{A}$ is infinitely superior in the text it represents to $\mathrm{A}$ and its Gr. fellows, and is the truest specimen of $\mathrm{Or}^{\mathrm{C}}$ that we have; it must have been made from an early authoritative codex of which A is a base offspring. ${ }^{3}$ See in general Gehman's full and important

${ }^{2}$ No attempt has therefore been made to register all the rdgs. of A in the Notes; they are at hand for the curious in Swete's apparatus. The codex only has value as one of a group.

${ }^{3}$ Ryssel announced categorically, $T L Z$ I 895,56 r, similar results for the relation of $A$ to $A$ and for the avoidance by the former of the latter's glaring errors. It may be observed that A follows A's enumeration of the 'Visions'; but through (editorial?) neglect $\mathrm{c}$. $\mathrm{I}$ is not so marked in the London Polyglot, but c. 2 is Vision 3, etc., proving that Susanna preceded. An independent partial chapter distinction appears at $I^{1}, 2^{34}, 4^{7}$, but then lapses. The Paris Polyglot has the additions in their proper order, but no 'Vision' rubric until c. $2=$ Vis. 3 , with an additional chapter rubric at $3^{48}$. 
discussion of the whole subject. Finally the Bohairic appears, from the translation, which has been carefully examined, to be a true and thoroughgoing representative of this group, probably superior again to A. Dr. Gehman fortunately promises a critical study of it.

The Armenian VS has not been studied. It apparently presents many striking identities with $\mathrm{Or}^{\mathrm{P}}$; and its possible relations to $\mathrm{Or}^{\mathrm{C}}$ and Lu. deserve careful examination.

A word is to be said on the very individual Cod. Q. Its text is distinctly Origenian, in its plusses and in its faults, as a comparison with A easily shows. It has several Hexaplaric annotations (s. §ı, $a[3]$ ) indicating its pedigree and its scholarly

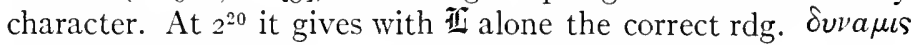
for $\sigma v \nu \epsilon \sigma \iota s ; 5^{13}$ end, a unique, poss. authentic, plus, $\kappa a \iota \epsilon \iota \pi \epsilon \nu$ $\nu a \iota \beta a \sigma \iota \lambda \epsilon \nu \kappa a \iota \epsilon \iota \pi \epsilon \nu$; I I ${ }^{14}$ with $33232 \pi a \rho a \beta a \sigma \epsilon \omega \nu$ from Sym. vs. $\Theta \lambda o \iota \mu \omega \nu$; also some errors of its own, e.g., $8^{9} \delta v \sigma \iota \nu, 9^{11}$ $\epsilon \pi \lambda \eta \theta v \nu \theta \eta$ (but neither absurd). The prevailing theory is that Q represents the Egyptian Hesychian text, for which in Dan. some correspondences with $\mathfrak{U}^{\mathrm{S}}$ and $\mathrm{II}$ may be noted.

For the considerable balance of minor pre-Origenian variations from $\mathrm{B}$ in these groups $\mathrm{S}$. $\$ 5$.

\section{\$I5. THE LUCIANIC RETISION.}

Field (Hex., I, p. lxxxiv seq.), corroborated by Lagarde, gave demonstration for the recognition of texts of Lucianic origin. ${ }^{1}$ For the Prophets, including Dan., he selected as Lucianic HP 223648 5 I 629093 I 44 I 47233 308. Most of these titles have been accepted by subsequent students of the Prophets. ${ }^{2}$ The writer's independent study of the text of Dan. revealed a solid group of five uss, often unanimous, often standing alone, obviously representing Lucian, namely the group 223648 5I $23 \mathrm{I}$. Of these all but 23I are contained in Field's list, while they are the ones which Cornill in his Ezechiel, p. $65 f f$., signalized as Lucianic. With this group are to be associated some others which run closely with it, esp. 229 (a Ms of Theodoret's comm. containing most of the Bible text), and the Chigi Theodotion

\footnotetext{
${ }^{1}$ See the convenient summary of the bibliography by R. K. Yerkes, 'The Lucianic Version of the O.T. as illustrated from Jeremiah $1-3, J B L$ 19r8, 163.

${ }^{2}$ See Yerkes, p. I 7 I, for the selections propounded by Cornill, Klostermann, Nestle, Liebmann, Procksch, Burkitt. Cf. also Montgomery, JBL 1925, 293.
} 
text, $c^{3}$ As for 62 I 47 the theory advanced in $\$ I 4$ has defined them as primitive-Origenian, therefore pre-Lucianic, and as the basis on which Lucian worked.

The Gr. stylism of Lu. in Dan. is that so well known and often observed in other bks., and requires no further remark. An interesting phenomenon (also noted elsewhere, e.g., Driver, Samuel ${ }^{2}$, p. li) is the presence of doublets in the text, viz.: at $4^{1}$, $6^{23}{ }^{(22)}, 7^{2}, 8^{11}, 8^{25}, 9^{24}, \mathrm{II}^{10}, \mathrm{II}^{36}, \mathrm{II}^{40}, \mathrm{I}^{7}$. Including these doublet corrections there may be noted not more than about twenty cases where $\mathrm{Lu}$. exhibits variations representing a better translation or at least points of interest in interpretation. His actual contributions therefore are rather small. In two cases at least he follows a tradition which appears in $\$$, at $\mathrm{I}^{11}, 3^{22}$ (q.v.), which presuppose original information local in Syria. In some cases his text has retained the original, correct form, which has been otherwise corrupted, e.g., $\mathrm{II}^{35}$, $\mathrm{II}^{10}$. We may have to allow that he made some contributions, but withal with most constant dependence upon Origen, whom he knew in practically the shape of $\mathrm{Or}^{\mathrm{P}}$. Accordingly he represents one fork from that master root, as $\mathrm{Or}^{\mathrm{C}}$ represents another, as has been argued above.

But another condition in $\mathrm{Lu}$. has long since given rise to aggravated discussion, the appearance of 'Lucianic rdgs.' in texts antedating Lu. These appear in the OLat. par excellence, also in primitive Gr. texts of the Ist and $2 \mathrm{~d}$ centuries, perhaps going back to 'Ur-Theodotion.' These variations are all slight in value, nowhere exhibit Hexaplaric rdgs. or the plusses characteristic of Origen and Lucian. At times they offer more literal translations in word order, particles, etc., than we find in B. As has been observed above, $\S \_2, c$, the explanation must be that $\mathrm{Lu}$. was following a form of $\Theta$ text which was variant from that represented by $\mathrm{B}$. We must put the historical Theodotion back into the first third of the 2 d cent. A.D. at least; we may have to carry the tradition of that text still farther back, and this stretch of time would have involved variations in differen $i$ regions. A minute examination reveals the fact that Origen's basal text differed from B: Lucian's appears to have differed

'See $\$ 10,4$ (I), and the writer's note in $J B L \mathrm{n}$. 5. This Chigi text is the only Lucianic text that has been edited and printed for Dan. The Lucianic doublets appear in it asterized; the text has many interesting features. 
still more. We have then to postulate different types of text, as we may surmise, one in Egypt $=B$, one in Palestine $=$ Origen's basis, and one in Syria = Lucian's. The correspondences with the Western texts, as observed at end of $\S_{12}$, the OLat., would then have to be explained by a straight inheritance of the West from Antioch. It is a case similar to the 'Western Readings' in the N.T. ${ }^{4}$

\section{§I6. THE OLD SYRIAC VERSION.}

For critical results obtained from study of $S^{2}$, the ancient and simple Bible text as distinguished from the Hexaplaric, summary reference is made to Wyngaarden's Pennsylvania thesis, The Syriac Version of the Bk. of Dan., Lpzg., I923. The earliest Syr. comm., Aphraates and Aphrem, offer no essential variations and depend upon our s. Wyng., p. 33, cf. Riessler, Dan., I8. The Old Syr. Gospels (Euangelion de-Mefarrešê) do not depend upon it, and are prob. anterior; but it precedes the general publication of the Hexaplaric apparatus, of which it shows no trace, and may therefore be assigned toward the first half of the $3 \mathrm{~d}$ cent. The tr. appears to come from a Christian hand, s. Wyng., pp. $30 \mathrm{ff}$.

$\$$ is generally a literal tr. of except in evident cases of interpretation or theological modification. There are a few

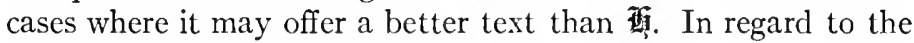
VSS, it is slightly, if at all, dependent upon $\mathbf{6}$. On the other hand, the translator made constant use of $\Theta$ (Wyng., pp. I9 ff.). Wyng. discusses, pp. $22 \mathrm{ff}$, the possible affinities with Origen and Lucian (never in cases of Hexaplaric additions), but no dependence can be proved, beyond that of identical basal texts. There are a few cases of identical interpretation between and Lu., but these point only to the root of a common interpretation in Syria $\left(c f . \S_{15}\right)$. The correspondences with $\mathbb{H}$ are considerable; many of them are due to the identical Theod. background, upon which Jer. depended as did ${ }^{3}$, others are identities of text or of interpretation; e.g., $9^{26.27}$. It is to be observed

'My conclusions are the same as those of Burkitt, Rules of Tyconius, pp. cxvi seq., cf. his Fragments of . . A Aquila, pp. $26 . f$.; s. also the writer, op.cil., JBL $1925,299 f$. As for the alleged possible influence of Lu. upon as suspected by Wright and Duval, the relation must be chronologically the reverse; see the next §. Parsons' remarks on Lu., Pref. to vol. 1, c. I, $\$ 8$, are noteworthy for their good sense. 
that both were composed in the same environment, Christian but subject to vital Jewish influences.

\section{§i 7. JEROME'S version: the vUlGate.}

This VS has not been particularly studied by itself in the present preparation, its general characteristics being, it is assumed, well known. Jerome was acquainted with all his predecessors, at least through the Hexaplaric apparatus, and his translation as also his comm. are invaluable as summarizing the results of earlier scholarship. His text is that of if $_{\text {, varying }}$ from it, almost entirely, in cases of dependence upon his predecessors, in paraphrases, and sometimes prob. through carelessness. It is fatuous to lay any stress upon $\mathbf{I t}$ as evidence where it agrees with one or other of the preceding VSS. Its chicf interest is as an interpretation, reflecting by Jer.'s predilection the Jewish scholarship of which he availed himself; indeed, there occur several cases in which he anticipates the interpretations of the mediæval Jewish comm. Any study of Jewish commentation upon the Scriptures should certainly include Jerome as almost the sole witness for an age otherwise dark, since the Jewish interest in Dan. as an object of learned or midrashic comment appears only in later literature.

\section{§I8. METHOD AND USE OF THE TEXTUAL APPARATUS.}

The preparation of this apparatus has the object of gaining precision of terms and simplification of reference.

㨁 is the Ktîb, $\mathfrak{A l}$ its Massoretic apparatus. The inner variants to these traditional data are noted, the rdgs. of the chief printed editions of $\mathfrak{A}$ being carefully registered, along with important Ms rdgs. As far as textual criticism is concerned, there is no need of registering all the translations of later VSS, Aq, sil.

No single ms authorities are cited as final proof of their respective VSS. $\quad 6$ is not the unique Gr. text alone but can only be obtained by composition between that and the Syro-Hexaplar, while the text must then be discounted in respect to its contaminations and Hexaplaric additions. Especially is $\Theta$ not $\mathrm{B}$, although that codex is by far the best exemplar of the VS, and will be cited for $\Theta$ where there is no dispute. Similarly there 
is no use in citing Cod. A as a final authority for anything; it has not that importance even for its own group. The aim has been to discover the groups which represent the various versions and revisions, and to present the results of critical analysis of the witnesses in each group. In general the Mrs, uncials as well as cursives, will be comparatively rarely cited; reference will be made to the groups in which they belong, $e . g$., in the complicated field of the Theodotionic tradition, to $\Theta$ (the literary text antecedent to Origen), $\mathrm{Or}^{\mathrm{p}}, \mathrm{Or}^{\mathrm{C}}$, Lu., the results being based upon careful digestion. Where there is no true variation of testimony, $\Theta$ will stand for the whole Theod. tradition.

As for the valuation of the testimony of the VSS, therr real evidence is not obtained by the counting of noses-a theory generally accepted, but not generally practised. In Dan. there is such an interlocking of evidence, $\Theta$ depending upon $\mathbb{6}, \approx$ and II depending upon $\Theta$, that their combined evidence may not count more than one unit.

Again it is not the coincidence of testimony that evokes confidence, rather the disagreements must be appraised. The identity of $\mathscr{G}$ and $\Theta$, of $\Theta$ and $\rightarrow$ disagreements of such pairs are worthy of inspection. And especially the principle must be laid down that the older the VS the greater its interest and perhaps its authority for the primitive text. Accordingly in this Comm. (א)'s rdgs. are always respected as against $\Theta$, even against the writer's prejudice; the combination $+\mathfrak{G}$ is not easily overcome; and similarly the combination 4 if $+\Theta$ against the later field. On the other hand, the witness of $\mathscr{G}+\Theta$ against if is of precarious value, for $\Theta$ may be dependent upon $\mathbb{G}$.

The sub-versions have to be handled with care. They may not be treated as though they were prime versions, but only as representatives of their groups. So treated they are invaluable, but without laying down their genetic history such comparison is most fallacious.

IV. HISTORICAL CRITICISM OF THE BOOK.

\$I9. THE IIISTORICAL DATA.

Dr. Pusey, distinguished as scholar and Churchman, opens his book on Daniel the Prophet with these words: "The book of 
Daniel is especially fitted to be a battle-ground between faith and unbelief. It admits of no half-way measures. It is either Divine or an imposture." Dr. Pusey proposes a theological dilemma. But there is involved also a critical dilemma. For the student must take position as between a view of the bk. which assigns it, along with tradition, to the 6th cent. B.C., as practically the composition of the seer whose name it bears; and a view which regards it as a product of the Hellenistic age. There is a gap of 400 years between the two parties, an extent of time so vast that it is impossible for either to understand the other, or for either to make impression upon the other's argumentative bulwarks. While the majority of philological commentaries and standard articles upon the bk. now accept the late date for its origin, ${ }^{1}$ nevertheless this tendency may not arrogate to itself the whole of scholarship, as there still remain excellent modern scholars who vigorously defend the traditional position. ${ }^{2}$ On the ground of the apparent impossibility of the two parties coming to terms or even understanding one another, this Comm. must pursue its own line of logical development, meeting respectfully, if often too summarily, the opposing views on its way. The lines of argumentation have not much changed since d'Envie'l and Driver; the fresh archæological data seem to lead to more dispute with no greater prospect of composition of the debate.

\section{a. The appearance of the book in literature.}

The absence of any possible citation from or allusion to the bk. before the middle of the 2 d cent. B.C. has been indicated in $\S 2$.

\section{b. The philological coidence.}

It has been shown above that the character of the Heb. of the bk. points at least to a century after the Exile $(\$ 6)$, that the actual variations of the Aramaic indicate a later age than that of the papyri, although our bk. traditionally belongs to the

${ }^{1}$ For the past generation the writer can name for comm. on the conservative side only those by the Roman Catholic scholars d'Envieu and Knabenbauer, and those by Fuller, Thompson, and Wright.

${ }^{2}$ In addition to the comm. named, there are the collections of studies by Wright (in a complementary vol. to his comm.), Wilson, Studies, and Boutflower, along with a series of articles by Wilson in the Princeton Theol. Rev.; for earlier works those by Deane and Kennedy. For the titles s. Bibliography. 
century before these documents $\left(\S_{7}\right)$, and that the presence of foreign words argues almost indubitably for the age of the Persian settlement well after the Exile, and very reasonably for the Hellenistic age (\$8).

\section{c. The historical objective of the book: the four monarchies.}

The historical objective of the bk., whether it is understood as contemporaneous to the writer or as prophetically foreseen, is the Hellenistic age. This appears definitely in the climax, the final vision, cc. IO-I2, in the exact survey of history from the end of the Persian empire (after 'the fourth' king 'in Persia') down through a clearly limned sketch of Hellenistic history to the time of Antiochus Epiphanes. It may be said that the great bulk of exegesis admits this; opinions vary as to whether or just where the Antichrist appears in the story; c.g., Jerome follows history through $\mathrm{II}^{20}$, and where others find Antiochus entering the stage, he makes a bold lcap in finding the Antichrist in the personage of $\mathrm{vv}^{21 \mathrm{ff}}$. Most critics allow that Antiochus is the character from that point, the proposed Antichrist being then often found at the end of the chap. In fact, some of the Fathers could pursue the history well into the Maccabæan age. See at length the Note at the end of c. I I.

This chapter is the greatest stumbling-block to the 'traditionalist' interpretation of the bk. On the one side its defenders only grudgingly allow the Hellenistic features, accepting them as merely prophetic 'examples' out of the future, so Keil. The position of Wilson, Studies, 274, is unique, that the whole of $\mathrm{II}^{3}$ "is absolutely within the sphere of ordinary predictive prophecy, and puts one in mind of the indefiniteness of the verse of Balaam: "There shall come forth a star out of Jacob."' 3 If there is one sure and definite bit of secular history in the bk., it is this chap., which, intentionally obscure as it is, can nevertheless be interpreted and approved by historical scholarship. It is interesting to observe that certain conservative scholars have ventured to regard this chap. as practically inauthentic; so Zöckler, who was inclined to reject it as too utterly alien to

\footnotetext{
'Smend, 'Über jüd. Apokalyptik,' ZATW I 885,222 .ff., believes that c. II is an historical document of first-rate importance-a more honorable treatment of it than Wilson's ascription of utter vagueness.
} 
other parts of Holy Writ, $c f$. the comparative indefiniteness of the earlier Visions, while Wright has actually advanced the theory that the chapter has been overlaid with Targum (for which he most unconservatively cites parallels from the late Jewish literature), and confesses that "the closing prophecy of Daniel, in its present form, cannot be proved to go back to an earlier period than I64 B.c." Wright's theory is a pure assumption. Nevertheless Boutflower adopts the speculation. ${ }^{4}$

After any possible 'analogy of Scripture,' and indeed any possible interpretation of a book regarded as a unit, the atheistic and inhuman personage described in $\mathrm{II}^{21 \mathrm{If}}$, who fully corresponds to the rôle of Epiphanes, the tyrannical persecutor of the Religion and forerunner of the idea of the Antichrist, must be identical with the similar personage described $8^{24 \text { rf. }}$, a king in 'the latter time of the kingdom' of 'Greece,' as is specified v. ${ }^{21}$; and again with 'the little horn' of the Fourth Beast of the first Vision, $7^{7 \mathrm{f}}$. In the Vision of c. 9 , with the avoidance of personal portraiture, the 'prince that shall come,' who 'shall destroy the city and the sanctuary,' $\mathrm{v}^{29}$, is evidently the same personage. That is, all four Visions of the second half of the bk. culminate in one and the same execrable tyrant, in one and the same expected catastrophe of the Nation and the Holy City. He and his doings are the climax of the 'kingdom of Greece.' It is indeed difficult to understand how any exegete can dodge this exact specification of the last Monarchy.

The kingdom of Greece is introduced in c. I I with 'a mighty king,' who 'shall rule with great dominion and do according to his will,' upon whose death 'his kingdom shall be broken,' etc., vv. ${ }^{3 \pi}$. This is absolutely parallel to the symbol in c. 8 of the Buck with the 'conspicuous horn,' v. ${ }^{6}$, which horn was broken, being replaced by four horns, v. ${ }^{8}$, the whole range of symbolism being historically interpreted in vv. ${ }^{20 \mathrm{ft}}$ : the Buck is the king (collectively) of Greece, the great horn the first king, the four horns succeeding the four kingdoms into which his kingdom is divided; and so $\mathrm{II}^{4}$ his kingdom is divided to the four winds of heaven. The Buck annibilates the Ram, whose two horns represent the kingdoms of Media and Persia. Here without doubt

\footnotetext{
${ }^{4}$ See Wright, Dan. and his Prophecies, $3 \mathrm{I} 7$ ff., Boutflower, pp. $4 . f f$. The citation from Wilson given above is his only reference to c. II.
} 
we have Alexander, the conqueror of the traditional Medo-Persian empire, as it is known to Greek historiography.

In cc. 2 and 7 we find a parallelism of a system of four kingdoms, which parallelism is admitted by all. In c. 2 the four are symbolized by the successive series of metals composing a composite Image; in c. 7 by a series of successive monstrous Beasts. The first of these kingdoms thus symbolized in parallel is admitted by almost all interpreters to be Babylonia, as it is specifically incarnated in the person of Nebuchadnezzar, $2^{37 \text { fr. }}$. Now, analogy requires the identification of the fourth Beast with its successive horns in c. 7 with Greece as specified in c. 8 . According to the equally specific statements at the end of c. I I and the beginning of c. I 2 the predecessor of Greece is the kingdom of Persia, i.e., the third kingdom. The remaining, second kingdom can be nothing else than Media, which according to ancient historiography, as still maintained by historians, e.g., Rawlinson, up to our own day, was one of the Great Monarchies of the ancient Orient. That Media and Persia are assembled in $S^{20}$ as the two horns of the Ram is not to be pleaded against this identification, if we are justified in seeking the missing second kingdom. Media did actually empty into Persia, as Greece did into Rome. But the distinction between the two is maintained in the clear-cut separation between Darius 'the Mede,' or 'of the seed of the Medes,' absolute monarch, dynastically speaking, over a Median empire, $6^{\text {If }}, 9^{1}$, and Cyrus 'the king of Persia,' $10^{1.5}$

Support for this postulate of a Median negemony succeeding

\footnotetext{
${ }^{5}$ For the history of the interpretation of the Four Monarchies s. Note after c. 2. Consult Rawlinson's 'Third Monarchy' for what was earlier known, almost entirely from the Gr. historians, concerning the alleged Median empire. In the ancient periodic composition of history place had to be found for the Medes, the reputed conquerors of Assyria, and so they were given a distinct position in the hierarchical succession of 'Great Powers.' The history of 'the Medes' remains most obscure still. From the latest datum on the desteuction of Nineveh, in Gadd, The Fall of Nineveh, 1923, it was the Umman-Manda which took the city. In just what way we are to harmonize 'Manda' and 'Madai,' whether as identical or confused in tradition, historians have not yet determined; $\varepsilon f$. Práśek, Gesch. d. Meder u. Perser, I, I28. For a writer of the 6th cent., holding office under Belshazzar, the last Bab. scion, and Cyrus, conqueror of Babylon acc. to Biblical, Greek and his own royal proclamations, to have interpolated an intervening Median kingdom, were an absurdity. If he was a writer of much later age, his method is perfectly intelligible; he was following the schematism of the Cir. historians, itself derived from Oriental tradition, and some such empire did exist, $f$. Prásek, pp. 12 -169. Thus there falls
} 
that of Babylon was had in the Bible itself. Several prophetic oracles had announced the coming destruction of Babylon by the Medes-doubtless a true reflex of the triumph of the UmmanManda over Nineveh-and this expectation affected the Jewish retrospection. Such passages are Is. $I 3^{17}, 2 \mathrm{I}^{2}$, Jer. $5 \mathrm{I}^{11.27-29}$ (n.b., 'the kings of the Medes').

There is one ancient and very respectable reason why the Fourth Monarchy has been sought in Rome. With the putting off of the fulfilment of the Apocalyptic expectation of the consummation of the Kingdom of God, interpretation simply proceeded to keep the prophecy up to date. Accordingly the Jews under Rome found that Monarchy in their new mistress, teste Josephus; and this ruling Jewish interpretation was naturally carried over by the Church with its vivid eschatological hopes. Subsequently the Jewish comm. found that Monarchy in Islam, and in the same spirit Protestant theologians were content to work out the fulfilment of prophecy through the Middle Ages down to their own day (the feet and toes of the Image were German states and what-not), and the Papacy could be identified with the Antichrist. ${ }^{6}$ But the early Christian exegesis followed the Jewish interpretation in finding the desecration of the sanctuary, end of c. 9 , in the Roman destruction of Jerusalem, an interpretation followed by Jesus himself in expecting the future setting up of the 'Abomination of Desolation'; it was only subsequently, with the rise of Christian historical scholarship that the chronologers came to devote themselves to the task of reading the mystery of the 490 years, and to find it cul-

to the ground such an assertion as is made by Wilson, p. I47: "It will be perfectly evident that all educated men living in and before the second century B.c. must have had access to so much information with regard to the number and history of the Babylonian and Persian kings, as to render it highly improbable that any writer of the second century B.C. could have been as ignorant of the history of Persia as certain critics represent the writer of Daniel to have been." If the author of Dan. had read the Gr. historians he would have been corroborated in the scheme of successive monarchies he here presents-which shows that his lack of historical knowledge does not prove him to have been an unlearned and foolish writer. For the still obscure subject of the Median kingdom, or rather kingdoms, s. Justi in Geiger and Kuhn's Grundriss d. iran. Philologie, 2, 406-413; Winckler, KAT $104 f_{\text {.; }}$ and the brief Outline of Pers. II istory Based on the Cunciform Inscriptions, 1922, by Ahl. Supplementarily there is to be added the valuable discussion by Forrer, $Z D M G 76$ (I922), 247, acc. to which Manda = Madai can be traced back in Akk. and Hittite documents to the reign of Naram-Sin.

- This latter identification still figures in Boutflower's presentation of 'The Roman Scheme,' p. I4, where the Little Horn = the temporal power of the Papacy! 
minating somewhere in the history of the first-century Christian Church. On the history of this interpretation s. the Note at end of c. 9 and also that after c. 2. It is a vast mistake that has been perpetrated, especially by Protestant theologians in their disregard of the history of exegesis, to hold that the identification of the lower term of the 490 years with the epoch of Jesus Christ has always been the 'Christian' exegesis. This is false to the fact of the great variety of Christian interpretation.

\section{d. Darius the Mede.}

How then can we identify Darius the Mede? Such is his designation, and he was 62 years old, according to $6^{1(2)} \cdot 9^{1}$ makes him 'son of Xerxes, of the seed of the Medes,' who succeeded as king over the kingdom of the Chaldæans. ${ }^{7}$ In the Bible we learn of four Persian kings: Cyrus, e.g., Ezr. I; Artaxerxes, $4^{7}$; Darius $4^{5}, 5^{5 \text { ff }}$, probably Darius the Persian, Neh. $\mathrm{I}^{22}$ - So the actual order in Ezr.-Neh.; and Xerxes, Est. I, etc. Likewise according to Dan $\mathrm{II}^{2}$ there were four Pers. kings, $c f$. the 'four heads' of the symbolic beast $7^{6}$. This abbreviation of the length of the Persian empire has its counterpart in the later Jewish reckoning of but 34 years to the Pers. régime; s. Note on the Interpretation of the 70 Weeks, end of c. 9, sub (3). Our Darius the Mede is evidently distinguished from Darius the Persian. Boutflower, p. I43, notes six identifications that have been proposed for the Mede, two of them of recent origin. One of the elder identifications (s. Dr., p. liii) is Astyages, the Median king conquered by Cyrus, whom the latter is gratuitously supposed to have installed as viceroy in Babylon; another Cyaxares (II), who, according to Xenophon's Cyropaedia, viii, 5, 8, married his daughter to Cyrus; but according to i, 2, I, Cyrus married a daughter of Astyages. We see how little confidence we can place upon Xenophon's romance. This lightness of later tradition is carried on by Josephus, who states, $A J \mathrm{x}, \mathrm{II}, 4$, that this Darius "with his kinsman Cyrus put an end to the dominion of Babylon; he was the son of Astyages (acc. to Dan., of Xerxes!), and had another name among the Greeks."

\footnotetext{
7 There is nothing cryptic in the expressions translated 'received the kingdom,' $6^{1}$, and 'was made king,' $9^{1}$, v. ad loce.; this against those who hold to indications that Darius was only a viceroy.
} 
One recent identification is that with Cambyses, on the ground that the latter appears to have enjoyed the title of king from the beginning of Cyrus' reign; this was proposed by Winckler, $K A T$ 287 , and has been warmly adopted by Boutflower, p. I45. But no explanation of the equation 'Darius the Mede $=$ Cambyses the Persian' is offered, and Boutflower appeals in vain (pp. I $53 . f f$.) to a hypothesis that the Pers. names were epithetical, titular.

The more popular recent identification is that with Gubaru, Cyrus' lieutenant, who made the actual entry into Babylon in the name of his master, and subsequently was governor of that province according to the Nabonidus-Cyrus Chronicle. Other texts have since come to light which indicate that Gubaru was a high officer under Neb., probably toward the end of his reign; that under Cambyses he was governor both of Babylon and Abar-Nahara ('Across-Euphrates'). He appears also in the Behistûn Inscription as one of Darius I's field-marshals. Herodotus makes frequent reference to him in the history of Darius, and Xenophon gives extensive notices of him in the Cyropaedia (as Gobryas). This material has now been assembled and amply discussed by W. Schwenzner, who presents a plausible and most romantic reconstruction of the history of this Persian magnate, who probably as a mercenary enjoyed high rank under Neb., who appears to have made defection from Nabonidus (of the anti-Nebuchadnezzar party) and gone over to Cyrus, then received his high commands in the new empire, and subsequently became one of Darius' doughty lieutenants in the establishment of his kingdom. ${ }^{8}$

But 'Darius = Gubaru,' as far as names go, is still as fallacious an equation as is 'Darius = Cambyses'; such attempts are no bet-

\footnotetext{
${ }^{8}$ IV. Schwenzner, 'Gobryas,' Klio, is (1922), 4I-58, 226-252. The texts in their chronological order appear: in Scheil, Rev. d'ass. I I (I9I4), r65.ff., a text indicating that Gubaru held high rank under Neb. (so Scheil and Schwenzner, but Clay, JAOS 4I, 466 argues that the date is under Cyrus); in the Nabonidus-Cyrus Chronicle (for literature s. note $\mathrm{I} 2$ below), acc. to which 'Gubaru, governor of Gutium, and the soldiers of Cyrus entered Babylon without a battle,' and after Cyrus' entry into the city and proclamation of peace 'he appointed Gubaru his satrap and prefects also in Babylon'; in Nies and Keiser, Bab. Inscriptions in the Collection of James B. Nies, pt. 2, 1918, nos. 69 and II4, of Cambyses' accession year, in both of which transgression against the terms of the documents involves 'sin against Gubaru, governor (bêl pihati) of Babylon and of Abar-Nahara (ebir nari) '; in Clay (not the editor, Hilprecht), $B E$ viii, I, no. So, of Cambyses' ist year, recording a 'canal of Gubaru'; in Strassmaier, Inschriften v. Cambyses, no. 96 , relating to his private affairs, barns,
} 
ter than those of $\mathbb{5}$ and Josephus to rectify the order of Pers. kings in the later bks. of the O.T. The Behistun Inscr. knows Gubaru as a Persian, against Wilson's vain attempts to prove the possibility of his being a Mede. Further, the more we know of Gobryas the less can we assign him royal rank. It is wellnigh impossible that a highest noble could have been given the title even popularly, still less by a member of the Pers. court, as the seer Daniel is alleged to have been. Such a title could have been nothing less than high treason, involving the subject as well as the writer. But the Biblical Darius the Mede acts as omnipotent autocrat over a vast empire of I 20 satrapies, ${ }^{9}$ and the ne plus ultra of royal autocracy appears in the edict he signs that none should worship any god or man but himself. Neither Gobryas nor Cambyses, in his father's lifetime, could have perpetrated such an absurdity. For explanation of the story we can only make surmises. For local reasons not known to us the great Darius I, who made Cyrus' domain into an organized empire, who had to punish Babylon for its rebelliousness in his early days, may have passed as a Mede, and there being no place for him in the line of the four Pers. kings known to the Bible, may have been made the representative of the supposititious Median kingdom and so been placed before Cyrus. In him the captures of Babylon by Gobryas and Darius I may have been compounded, and in so far we may have a residuum of tradition..$^{10}$

etc.; in Pinches, PSBA 38 (1916), $29 f$., of Cambyses' 4th year, similar to the Nies texts (the title of governorship of Abar-Nahara is omitted). In the Behistûn Inscr. there is ref. to Gubaru-Gaubaruua, in $\$ 68$ in trilingual form, in $\$ 71$ in OPers. alone, Gubaru being termed 'son of Mardonia, a Persian,' and appearing as one of Darius' field-marshals (s. Weissbach, 'Die Keilinschriften d. Achämeniden,' in Vorderas. Bibliothek). Gobryas appears as a leading personage in Herodotus for the events in Darius I's reign (iii, 70, etc.), while he figures largely in Xenophon's Cyrus Romance, the Cyropaedia. Below in sub-section (e) will be given a summary of the story told in viii, 5 , of his seizure of the palace in Bavylon and the killing of the Bab. king; most of the anecdotes about Gobryas concern his relations with Darius. The historical value of these Gr. traditions is fully discussed by Schwenzner. See also for an earlier discussion C. F. Lehmann-Haupt, 'Gobryas u. Belsazar bei Xenophon,' Klio, 1902, 34I-5.

- Technically a woful exaggeration, excusable only from the later degenerated use of 'satrap'; s. at $3^{2}$.

${ }^{10} \mathrm{Cf}$. Behrmann, p. xix, Dr., p. liv, Cornill, $I n t ., 258$, against which line of argument cf. Wilson, cc. I0-12. Cambyses' acts of sacrilege in Egypt may have given rise to this fable of royal claim of deity, yet Darius appears in the story as a friendly character. But the theme belonged to the common satire of Jewish story; acc. to Judith $3^{8} \mathrm{Neb}$. gave an edict that he alone should be worshipped. 


\section{e. Belshazzar.}

The existence of a Belshazzar at the end of the Chaldæan dynasty was strikingly demonstrated by the discovery of his name on the Nabonidus Cylinder, in which he appears as Nabonidus' son. ${ }^{11}$ Otherwise Belsh. had entirely disappeared from history except for the reff. in Dan. and the dependent ref. in Bar. ${ }^{11}$, where the Jews are bidden to 'pray for the life of Nebuchadnezzar king of Babylon and for the life of Baltasar his son,' which appears at first sight to be an echo of Dan. A large number of cuneiform references have since been discovered. The following treatment concerns itself only with the main facts and their interpretation. ${ }^{12}$

In the cuneiform texts Belsh. is called either by his name or, as in the Nabonidus-Cyrus Chronicle simply 'son of the king,' i.e., anglice, 'crown prince.' In the Chronicle for years 7,9 , I0, I I of Nabonidus' reign it is recorded that "the king was in Teima; the son of the king, the princes and his (or, the) army were in the land of Akkad." In the texts hitherto known Belsh. is never given the title of king, and this has been ground for argument against one detail of our story which represents Belsh. as absolute king. But Sidney Smith's presentation of a new text (s. end of Note 12 ) shows that royal dignity was actually con-

${ }^{11} \mathrm{Cf}$. for the first discoveries COT 2, 130.

12 The writer is deeply indebted to Prof. R. P. Dougherty, late of Goucher College, now of Yale, for his generosity in affording him the full use of his materials for a forthcoming volume entitled Nabonidus and Belshazar, in the Yale Oriental Series. Only as this volume was being finally prepared for the press did the us copy of Dr. Dougherty's volume come to hand. The data here presented, as, indeed, all the earlier studies, will be much antiquated by Dr. Dougherty's exhaustive volume. But it seems wise to the writer to leave his study in its present state with the presentation of his conclusions as already reached, while referring the reader to that forthcoming volume.

For the literature used here I note the following: Rogers, Cuneiform Inscr. and the $O . T ., 378 \mathrm{ff}$, and $K A T$ vol. 3 , give the Nabonidus Cylinder already mentioned, as also the Cyrus Cylinder celebrating his conquest of Babylon; these also appear in Barton, Archcology and the Bible, c. 20, along with the Nabonidus-Cyrus Chronicle, first published by Pinches, PSBA I882, $167 \mathrm{ff}$. Recently published reff. to Belsh. are those of Pinches, PSBA 1916, $27 \mathrm{fJ}$.; Clay, Miscell. Inscr. in the Yale Bab. Collection, 1915, no. 39; Dougherty, Records from Erech, Time of Nabonidus (Yale Or. Series), 1920, no. 134, and Archives from Erech, Time of Nebuch. and Nab. (Goucher College), 1923, no. 294. For successive presentations of the material s. Pinches, O.T. in the Light of the Hist. Records of Ass. and Bab. ${ }^{2}, 1003$, C. 12; Wright, C. 4; Wilson, c. 6; Boutflower, c. II. Finally, a new text of Nab. describing his conquest of Arabian Teima has been published by Sidney Smith, Bab. IIist. Texts, 1924, $S_{4} f f$. 
ferred upon Belsh. This text, of the third full year of Nabonidus, detailing that king's victorious campaign against Arabian Teima (as this place has elsewhere been identified by Dougherty), records: "He intrusted a camp to his eldest, his first-born son; the troops of the land he sent with him. He freed his hand; he intrusted the kingship (sarritam) to him." That is, in the early part of Nabonidus' reign, in his third year, his son was invested with royal dignity, which, in view of the active position he held throughout the subsequent years, must have continued throughout his life. That is, the Bible story is correct as to the rank of kingship given to Belsh. Now in several texts the prince's name is coupled with his father's in the latter's prayers and in the omens interpreted for him; and in Pinches' text and two texts in the Yale Museum his name is associated with his father's in an oath; on which Dougherty remarks: "There is no other instance in available documents of an oath being sworn in the name of the son of the king." The induction therefore that had been made from earlier data by Pinches, Dougherty, and others, is now brilliantly corroborated; as in a previous statement of the latter scholar: "It appears that he was invested with a degree of royal authority, not only at the close of the reign of his father, but throughout large part, if not the whole, of the reign of Nabonidus."

For the capture of Babylon, the fall of Nabonidus and the disappearance of Belsh. from history, the Nabonidus-Cyrus Chronicle is our immediate authority. The following translation is taken from Dougherty: "In the month Tishri, ${ }^{12 a}$ when Cyrus fought at Opis on the Tigris river against the troops of Akkad, he destroyed the people with burning; he put the people to death. On the 14th day Sippar was captured without fighting. Nabonidus fled. On the r6th day Ugbaru the governor of Gutium, and the troops of Cyrus entered Babylon without fighting. Afterward, when Nabonidus returned, he was taken captive in Babylon. Until the end of the month the arms of Gutium surrounded the gates of the temple Esagila. No one's weapon was placed in Esagila or the sanctuaries, and no appointed time was disregarded. In the month Marchesvan, the $3 \mathrm{~d}$ day, Cyrus

12a E. Meyer, $Z A T W$ I $898,339 \mathrm{ff}$., corrected 'Tammuz' to 'Tishri,' as the sequence of events demands; Dougherty reads 'Tishri' without comment. 
entered Babylon. Harine (?) were carried before him. Prosperity was established in the city; Cyrus decreed prosperity for all in Babylon. Gobryas, his governor, placed governors in charge of Babylon. From Kislev to Adar the gods of Aklkad, whom Nabonidus had brought up to Babylon, they returned to their cities." There follow, as Dougherty notes, the death of a prominent personage and a period of mourning, in the following fragmentary lines: "In the month Marchesvan, on the night of the I Ith, Ugbaru ... In the month (?) the . . . of the king died. From the 28 th day of Adar to the third day of Nisan there was weeping in the land of Akkad. . . . All the people prostrated their heads." Who this personage was is quite doubtful; most scholars, while recognizing the uncertainty, have filled the lacuna with 'the son [of the king],' i.e., Belsh.; so, e.g., King, Barton, Clay, Boutflower (p. I29), and Dougherty earlier; but the latter now does not venture to fill the gap. He writes later on: "Accurate interpretation ... is impossible owing to the illegible condition of the text. However, there is strong probability that Belsh. was slain in connection with the fall of Babylon, as indicated in the fifth chapter of Daniel and intimated by the record of Xenophon." On this point the writer admires Dougherty's candid scepticism, for he himself must enter a demurrer against the theory that the conqueror's own record could have so distinguished the death of a prince who was, when free and alive, a hopeless rebel.

How and where Belsh. came to his end we do not learn from the Akk. documents. But some Gr. data, which have often been alleged as history, must be considered. Herodotus, i, I9I, describes at length Cyrus' capture of Babylon. According to his story the city had been stoutly fortified and provisioned against Cyrus' attack. But the latter diverted the Euphrates into a great basin, which had been made by Neb.'s queen Nitocris when she was building the water-walls of the city; and by this dry channel he entered the city unawares (by night?-although this is not stated), "as they were engaged in a festival, dancing and revelling until they learned of the capture but too surely." The story is paralleled by a much longer narrative in Xenophon's Cyropaedia, vii, 5 (noticed above under the title 'Darius the Mede'). Cyrus formed the plan of draining off the river into a trench which he had dug; he drained off the waters on a night 
when "he heard that there was a festival in Babylon, in which all the Babylonians drank and revelled the whole night." The attacking party was headed by Cyrus, with his officers Gadatas and Gobryas acting as guides. They entered the city, taking advantage of the revelry in the streets, and easily reached the palace. They entered and found the king standing with his sword drawn; he was made away with by Gadatas and Gobryas and their party, and then ensued a massacre of those found in the streets. Soon after Cyrus held a public reception and entered into the palace.

Certain parallels with the story in Dan. 5 are obvious and interesting, and the reconstruction often made is that this unnamed king of the Cyropacdia is Belshazzar, that he was functioning as king, even without the actual name, and that Gobryas who killed him is Darius the Mede, the Gubaru of the Bab. records.

On these stories it is to be remarked that historians now universally reject the tradition of a forcible capture of Babylon in view of the plain record of the Nabonidus-Cyrus Chronicle that Cyrus' troops under Gubaru peacefully occupied the city and captured Nabonidus in it, he himself celebrating his triumph a little later. Furthermore we have the account of Berossus preserved by Josephus, C. Apionem, i, 20, which varies somewhat from the official records but gives no room for a 'king Belshazzar.' We read: "When Nabonnedus perceived that Cyrus was coming to attack him, he met him with his forces, and, joining battle with him, was beaten and fled away with a few of his troops, and was shut up within the city Borsippa. Hereupon Cyrus took Babylon and gave order that the outer walls of the city should be demolished, because the city had proved very troublesome to him, and cost him great pains to take it. He then marched away to Borsippa to besiege Nabonnedus; but as Nabonnedus did not sustain the siege, but delivered himself into his hands, he was at first kindly treated by Cyrus, who gave him Carmania as a place for him to inhabit and sent him out of Babylonia." It is to be noticed that there are variations from the Chronicle, especially in regard to the resistance put up by Nabonidus and the difficulty of taking the city promptly. It must be borne in mind that Berossus himself is a witness 240 years after the events he narrates, although withal a much 
more reliable authority than the earlier Herodotus and Xenophon. ${ }^{13}$

There remains, however, but only after Xenophon's Romance, the death of an unnamed king of Babylon in his palace on a night of revelry at the hands of two Persian officers, one of them Gobryas, doubtless a reminiscence of the historical Gubaru. That the unfortunate Belsh., abandoned by his father in his chivalrous resistance to the conqueror, should have been popularly called king by his faithful subjects is not impossible, and, as Lehmann-Haupt remarks, in note 8 , he would have passed in native tradition as the last Bab. king. Nor, it must be allowed, would the Chronicle, edited by the new administration, have granted him that title even if he had actually assumed it, as Cyrus regarded himself as the legitimate successor of $\mathrm{Na}$ bonidus. ${ }^{14}$ But whether a Jewish writer, contemporaneous with the conqueror and one of his court, would have desired or dared to use the title 'king' of the prince Belshazzar, whom the Pers. dynasty could only have regarded as a rebellious upstart, is a matter for serious deliberation for those who must pass upon the historicity of the Biblical story.

Yet other data are given in Dan. 5 which have a bearing upon our investigation. The 'Queen,' recognized by all to be the queen-mother, enters the banquet-hall to bid her son call in the sage Daniel, who 'in the days of king Neb. thy father had been made by him master-magician.' What is to be said about this asserted paternity of Nebuchadnezzar? And can we identif the lady?

In the foundation cylinder of Nabonidus, already cited and existing in duplicate $\left(K B_{3}, 96\right)$ Belsh. is spoken of as 'the first son proceeding from my heart' (libbia). Wilson, pp. I I 7-122, considers at length 'the possibility of a man having two fathers.' After an excursus on the vague use of 'son' in Oriental languages, he presents eight different ways in which Belsh. may have been called 'son' of Neb. ${ }^{15}$ E.g., he may have been Neb.'s

is A longer account by Berossus of the Chaldæan empire has been preserved in the Armenian Chronicle of Eusebius, first published by Mai; s. C. Müller, Fragm. hist. graec., 2, 504. Berossus' narratives appear to be generally ignored by the apologists for c. 5 .

"See the arguments by Wilson, c. 5, "The Use of the Word "King.",

${ }^{15}$ He gives as an instance of the ideal or spiritual use of 'offspring of my heart' the application of that term to Nabonidus by the high priest of Harran. 
own son adopted by Nabonidus, in which case the family history in Dan. is literally exact; or he may have been Nab.'s son, but a grandson of Neb. through a possible marriage of Nab. with a daughter of Neb.; etc., etc. Boutflower advances and prefers yet another possibility, pp. I I $f f$. Recognizing that Belsh. must have been born before his father's accession to the throne, and doubtless the latter as a private citizen not being eligible to a queen-mother's hand, he argues that Nab. had married the queen of Neb., the famous Nitocris of Herodotus, after his accession, and so in this way by a complicated legal casuistry had made his own son legal son of Neb. ${ }^{16}$ There are indeed all sorts of possibilities and combinations, but in lack of evidence it is simplest to accept the family relationship at its face value, and this would agree with Herodotus' foreshortened view of the Chaldæan dynasty (i, I88); he makes Labynetos (II = Nabonidus) the son of Labynetos ( $\mathrm{I}=$ Nebuchadnezzar $)$ by Nitocris. And so, more correctly as to the names, Abydenus, cited by Eus., Praep., xi, 4I , 6, knows only two kings, Neb. and Labynetos. And this is equally the understanding of Bar. I, which presents Neb. and his son Belsh. in the fifth year after the destruction of the city. The historical bks. of the O.T. know only of Neb. and his son Evil-Merodach; but between the latter and Nabonidus history now certainly inserts Neriglissar and his son Labashi-Marduk after Berossus, Jos., C. Ap., i, 20.

Yet another item in c. 5 involves discussion. Whosoever should read the mystic inscription was to be called 'third' in the kingdom. The elder popular view was that the second after the king was the queen-mother; and to this view the writer would subscribe in case 'the Third' is not in itself a proper title, like Heb. sâllı̌s ; s. at $5^{7}$. But the discovery of Belshazzar's name as 'king's son,' and coregent with his father has quite naturally induced the supposition that the triple hierarchy should begin with Nabonidus; so Wright, p. 133, Boutflower, p. I I9, and such is Dougherty's conclusion. We should then have to think of a traditional reminiscence of Nabonidus as in the background of

\footnotetext{
18 Wright also assumes identification with Nitocris. Nab. ascended the throne i7 years after Neb.'s death, but Boutflower does not observe that the lady in question was probably rather advanced in years to enter a new harem. As I understand Dougherty's position, the queen-mother is the daughter of Neb. and wife of $\mathrm{Na}$ bonidus and so mother of Belsh. Why, however, he gives her the name Nitocris, which is that of the consort of Neb., i.e., Labynetos I, acc. to Her., I do not see.
} 
Belsh.'s 'reign.' But for the story itself, considered as a dramatic unity, only the queen-mother can be included. When a king is pictured in the plenitude of royal estate, as is Belshazzar, a super-king cannot easily be surmised.

To sum up, the story of Belshazzar is not imaginary fiction, but possesses true historical traditions, as do Herodotus and Xenophon, and is superior to the two Greeks in knowing the name of the last Bab. prince. The parallelism demands-and Dan. is closer to Xenophon than to Herodotus-that we recognize in all three traditional developments of the popular memory of the fall of Babylon.

\section{f. The third year of Jehoiakim; the Chaldaans; etc.}

Other points, almost innumerable, in the alleged history of Daniel, are impugned by the critics; and they are defended with equal tenacity by the apologists. The minor points should be approached from the judgment obtained for the main historical considerations, the questions of Darius the Mede, Belshazzar, the Fourth Monarchy. If the decisions fall out in favor of these points as historical, it remains for the historian but to discount. minor difficulties and inaccuracies. The argument depends upon the accumulation of evidence pro or con. ${ }^{17}$

The datum at the opening of the bk. that there was a captivity of Jehoiakim and his people in the $3 \mathrm{~d}$ year of his reign, a year before Neb.'s defeat of Necho at Karkemish (Jer. $46^{2}$ ), is inexplicable from anything we know of Oriental history at that time or from inner-Biblical data, except a statement in $2 \mathrm{Ch} .36^{6.7}$ that Neb. came against Jeh., bound him in fetters to carry him to Babylon, and carried off the vessels of the temple. Nothing is known of this captivity in the parallel in $2 \mathrm{Ki}$. 24. Our author has preferred $\mathrm{Ch}$. to $\mathrm{Ki}$., and appears to have combined the datum of Ch. with that of $2 \mathrm{Ki}$. $24^{1}$, that Jehoiakim served Neb. three years, then rebelled, and Neb. sent against him marauding

${ }^{17}$ It is a vast pity that apologists have gone so far as they have in attempting to maintain every iota of statement in the bk.- this in their zeal to support not so much its historical accuracy as its divine infallibility. In consequence they demand an extreme of respect for Dan. which is not required by conservative critics for the historical bks. of the O.T. or even for the Gospels, in which the play of human limitation and inexactness is generally allowed. Equally some radical critics have overreached themselves in finding 'absurdities' throughout the bk. 
bands, so obtaining the third year by a very daring deduction -very likely an interpretation that had already been made before the composition of the bk. ${ }^{18}$

There is internal trouble with the date of year 2 of Neb. at $2^{1}$ because of the prima facie disagreement with the three years' discipline required of the youths $I^{5} ; \mathrm{s}$. Comm. at $2^{1}$. For Dan.'s continuing unto year $\mathrm{I}$ of Cyrus, $\mathrm{I}^{21}$, v. ad loc. The remaining regnal years: $7^{1}$ Belsh. year $\mathbf{I} ; 8^{1} d o$. year $3 ; 9^{1}$ Darius year I; ${ }_{10}{ }^{1}$ Cyrus year 3, appear to be arbitrary; or was 3 years the traditional term for the reigns of Belsh. and Cyrus? Darius' age of 62 years, $6^{1}\left(5^{31}\right)$ must depend upon some kind of historical tradition. ${ }^{19}$

Perhaps transcending the obvious historical difficulties recorded above is the naïve use of 'Kasdim-Chaldæans' as a class of magicians: see Comm. at $2^{2}$, Dr., p. xlix seq. Schrader, for the first generation of Assyriologists, says (COT 2, I 25): "This is in itself a clear indication of the post-exilic date of the bk."; and equally the conservative Sayce, Monuments, 535: "In the eyes of the Assyriologist the use of the word Kasdim . . . would alone be sufficient to indicate the date of the work with unerring certainty." It is an anachronism similar to an identification of the historical Egyptians with the Gypsies and their magic practices. ${ }^{20}$

In regard to the whole background of classes of soothsayers, omen-diviners, etc., among whom the Chaldæans are rated as a distinct class (e.g., $\left.4^{4(7)}\right)$, F. Lenormant, the first student of the Bab. omen texts and magic, has been often cited by apologists for the early origin of Dan. in his appeal to the Bab. coloring of

\footnotetext{
${ }^{18}$ See Comm. at $\mathrm{I}^{1}$. This is really a case of Scripture vs. Scripture, despite Wilson's arguments, cc. 3.4 .

19 followed by $\Theta$ texts assigns year is of Neb. for the story of the Three Confessors, $3^{1}$, i.c., the date of the destruction of Jerusalem; this is repeated in $3^{31}$ $\left(4^{1}\right)$.

${ }^{20}$ Wilson's discussion of this technical term, c. I8, has value for its chain of testimonies for this particular professional sense among the Greeks from Herodotus down, the Greeks in general coming to confine it at last to that sense; withal the historical mng. survived among them down to Strabo, just as this sense appears in 'Belshazzar the Chaldæan king,' $6^{30}$. The first evidence for the latter sense, outside of the disputed bk. of Dan., is in Herodotus, who wrote some I50 years after the opening dates of Dan.; which would seem to argue for the lateness of the bk.'s use of the word in that sense. The new slant to the word is easily explained as arising after the intrusion of the new Pers. empire and religion, when 'Chaldxan' became a religious designation just as 'Jew' became.
} 
the bk. with its description of the soothsayers, their classes and their methods, as a proof of its origin in the Bab. empire. His latest statement, as known to the writer, is as follows:"1 "The further we advance in the knowledge of the Cuneiform texts, the greater does the necessity appear of reversing the condemnation much too prematurely pronounced by the German exegetical school against the date of the writings of the fourth of the greater prophets. The language of the book of Daniel, interspersed as it is in various places with Greek words, proves without doubt that the definitive translation (Fr. 'rédaction'), as we possess it, is posterior to the time of Alexander, but the foundation of the work dates much further back; it is tinged with a very decided Bab. tint, and certain features of the life at the court of Neb. are there pictured with a truth and exactitude, to which a writer a few centuries later could hardly have attained." But passing by some of his critical admissions, we note that Lenormant was not aware of a fact which has since his day been well established, although many still ignore it: the survival of the Bab. religious practices long after the fall of the empire. At the Leginning of the Hellenistic period Bab. astronomy was at its acme in the person of Berossus, the Bab. priest and historian who migrated to $\mathrm{Cos}$ and founded a school there. And the religious literature continued far later; the youngest specimen known to the writer is a hymn written in 80 B.C., published by Reisner, Sumerische Hymnen, i 896, no. 49, cf. p. xiv.

Now we actually know far more of the religion of the New Babylonian empire than we do of its history. We are wofully ill informed of the data of the reign of that admirable monarch Nebuchadnezzar. But his many inscriptions, like those of Nabonidus, are almost entirely religious. And on this score the religious actions and attitudes ascribed to Neb. and Darius the Mede are incomprehensible. For each of these kings a story is told (cc. 3. 6) of an attempt to foist a single and strange object of worship upon the realm, in the one case a golden Image, ${ }^{22}$ in the other the king's person to the exclusion of any god. No

${ }^{21}$ See his Chaldcean Magic, Eng. tr. of his La magic chez les Chaldéens, I 874 , without date but with preface dated 1877 , and so this authorized and improved ed. is subsequent also to the author's La divination et la science des présages, 1875 . The citation above is found p. 14 of the Eng. tr.

${ }^{22}$ For this legend there may be a basis in Berossus' account of Ochus being the first to erect images; s. Comm. at c. 3 . 
trace of any such legislation can be found in antiquity, not even in the consummate religious tyranny of Antiochus Epiphanes. And, on the other hand, the extreme terms of the royal confessions, $3^{31-33}\left(4^{1-3}\right), 4^{31-34(34-37)}$, and especially of the legal decree of Darius, 626-29(25-28), are, to say the least, hardly probable, although they are not beyond the scope of the story-teller. The subtle inference that Neb. became a worshipper of the one God is not borne out by any known facts or any possible hypothesis based on facts. It is erroneous, as many have done, to argue that the portraiture of these two kings was modelled after the arch-tyrant Antiochus. Neb. and Darius are friendly, human natures; the latter immediately regrets the impulsive action into which he has been inveigled by Dan.'s enemies; the former swells with pride, is punished, but is given opportunity of repentance and is rewarded. On the whole they are models of what kings, when corrected, may become. The milieu of the story is rather that of an earlier age than the Maccabæan, when there were already many ill-wishers of the Jews, much popular anti-Semitism, like that expressed in Judith. ${ }^{23}$

In general it must be said that the atmosphere of the Pagan world and its contrast with Judaism are capitally presented. There is but one serious fault, when in his zeal over his hero's triumph the writer makes Dan. actual 'master-magician' of the royal court, $4^{6(9)}$. Were the story true, Dan.'s position as a pious Jew would have been intolerable and impossible for all parties. If it be a romance the naïve faux pas is quite excusable.

The upshot of this survey of the facts is that when the alleged historical data are examined, the principal stumbling-blocks can only be explained by ingenious combinations of infinite possibilities and alternatives which daze rather than satisfy the mind. That a series of hypothetical events may, one by one, have happened, no historian can deny; on the other hand, in the large paths of history he cannot become a detective, putting together all the possibilities to make a hypothetical case. He must stand by the ascertained facts, allowing them to be modified only by sure or probable data.

But if the bk. be regarded as a work of religious romance, it

${ }^{25}$ The story of Judith presents Neb. in a very different light, as a man who would be a god, $3^{8}$. None of the usual apologists would allow the credibility of this, and yet, as has been recognized, Judith is not devoid of historical reminiscences. 
becomes entirely intelligible. It reflects well the forces of the Babylonian-Persian-Greek civilization, in which there was a continuity of Orientalism slightly altered by the successive political phases. There is the inheritance of the age-old $\mathrm{Bab}$. religion, the stage-setting of the barbarous Persian Empire, all of which rather swallowed up Hellenism than was affected by it. It contains historical legend, which may possibly be woven in with other late traditions to add to our knowledge. But its essential historical value lies in its reflection of the conditions of that Oriental complex of life on which we are too ill informed. This dominant interest of the bk. has been too much overlooked by both radical critic and apologist in their zeal for attack or defence, and the religious and literary merits of the bk. have accordingly suffered. What is here said refers almost entirely to cc. I-6; the milieu of cc. $7-12$ is quite different, s. $2 \mathbf{2}$.

\section{g. The book as an apocryphon.}

The bk. as a unit is an apocryphon, that is, a volume of alleged antiquity that had been purposely 'hidden away' until the emergency arrived for its publication. ${ }^{24}$ The injunction for such disposal of our bk. is given at the end of the final vision, $\mathrm{I} 2^{4}$ : 'Thou, Daniel, shut up the words and seal the book even to the time of the end [= 'Endzeit'].' It is the first specimen of technical apocrypha that we possess in Jewish literature, and the forerunner of a very extensive series of similar but far more elaborate productions of the $2 \mathrm{~d}$ cent. B.c. and after, all the apocalypses being characterized by this fiction, the Christian Apocalypse of John being the exception. ${ }^{25}$ In most cases the fiction is implied,

${ }^{24}$ This is the most plausible explanation for the primary mng. of the many-sided word; see, e.g., Porter, 'A pocrypha,' $D B$ p. I I 2, Charles, Int. to his $A$ poc. Schürer takes opposite ground in favor of relating it to the Jewish term geniz, used of bks. withdrawn from public use and stored away in the Geniza; s. his art. 'Apokrypha,' $R E$, and his review, $T L Z$ I900, 202, of Kautzsch, A pok. u. Pseudepig., who contradicts this etymology. But the preference for the view here accepted is supported ty 2 Esd. $12^{37}$, where the apocryphal bks. are to be put away 'in loco abscondito,' which

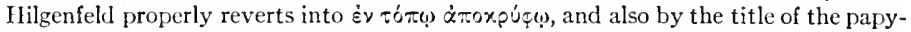
rus text of the Eighth Book of Moses published by Dieterich, Abraxas, I69, Mwu-

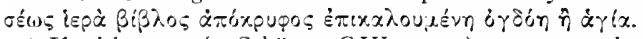

${ }^{25}$ If with some (s. Schürer, $G J V 3,273$ ) we are to place the Dream Visions of Enoch, cc. 83-90, before the death of Judis Macc. (acc. to Charles, Bk. of Enoch, I 8o, 'possibly before his purification of the temple'), the bk. of Dan. may be but a specimen of an already established type of literature. 
e.g., the bk. of Enoch, the antediluvian sage, or Jubilees, the Kabbala of Moses that had been esoterically handed down. In 2 Esd. appears the fullest expression of the fiction, $12^{37}$ : 'Write all these things that thou hast seen in a book and put them in a secret place'; and still more specifically in c. I4, where Esdras is commissioned to write the bks. vouchsafed him, vv. ${ }^{45.46}$ : "The 24 Books [i.e., the Heb. Canon] that thou hast written publish, that the worthy and unworthy may read. But the seventy last thou shalt keep to deliver to the wise among thy people.'

As a specimen of this genre of literature, which first appears in the $2 \mathrm{~d}$ cent., the apocalyptic portion of Dan., cc. 7-1 2, must logically be placed about that age. ${ }^{26}$ The idea of such ancient mystical literature may go back early in Babylonia. Berossus (Eus., Chron., i, ed. Schoene, p. I4) tells how the mythical monster Oannes not only taught men civilization but "committed this book ( $\lambda o$ 'rov-i.e., on politics) to men," a story exactly comparable to the legends of Enoch and of Moses as author of Jubilees. ${ }^{27}$ This was a kind of literature that naturally came to the fore in the competitions of the wisdoms of the peoples in the Hellenistic age and their precipitation in Greek literary form, in which movement Berossus, Manetho, and Sanchuniathon stand forth; the latter records (Eus., Praep. ev., i, Io) that the seven Kabiri and their eighth brother Asklepios 'set down these things in memoirs (i $\pi \circ \mu \nu \eta \mu a \tau a)$,' a datum which would easily have induced, if it was not actually based upon, literary compositions. But the closest examples of prophetic apocalyptic pseudographs like those of the Jews in the $2 \mathrm{~d}$ cent. are found in Egyptian literature. Of these the most striking is the so-called Demotic Chronicle. ${ }^{28}$

This Demotic text, in script and composition, belongs to the $3 \mathrm{~d}$ cent. It contains a series of obscure prophecies, accompanied with an interpretation, oracle by oracle, with the fiction that the interpretation was composed under the native king Tachos

${ }^{26}$ The case is entirely different from the anonymous prophecies of the O.T. and the supplements made to the Prophets. It is also different from the ancient Heb. Apocalyptic like the Songs of Jacob and Moses, the Balaam Cycle, to which no apocryphal flavor is attached; s. $\$ 20$, n. 4 .

${ }^{27} \mathrm{Cf}$. Zimmern, $K A T 530 \mathrm{ff}$.

${ }^{28}$ For this document, first pullished by Spiegelberg and commented upon by him and E. Meyer, and for the similar Egyptian literature see now the admirable discussion by C. C. McCown, 'Ilebrew and Egyptian Apocalyptic Literature,' Harvard Theol. Rev., 1925, 357-41 I. 
(360 в.с.); up to his time the series of Egyptian kings is presented by name; but after Tachos the history is sketched in ambiguous allusions to the subsequent kings and to the dominion of the Persians and the Greeks, after which there is to be a national restoration with the glorification of the Law, i.e., the Egyptian religion. The parallelism particularly with Dan. IO-I I is evi' dent; here the alleged writer of the 6th cent. presents the series of the ostensibly future Persian and Greek kings in a veiled way, but entirely intelligible to one possessing the key of history. The Visions of Dan. appear then to belong to a definite genre of religious literature exemplified very clearly in Egypt in the $3 \mathrm{~d}$ cent., although the phenomenon of Apocalyptic there as in Israel is of much older origin.

§2O. THE THEOLOGY OF THE BOOK AND ITS PLACE IN JEWISH RELIGION.

In its contributions to Apocalyptic, Eschatology, etc., the bk. of Dan. erjoys a sovereign place in O.T. theology. At the same time, as the connecting hinge between the Heb. Canon and later Apocalyptic, the bk. serves as an introduction to the later Judaistic literature, with the result that it has been exhaustively handled from every angle. It seems therefore unnecessary to repeat much of the detail of what has been so well and thoroughly said and it suffices to confine this Section to a reasoned presentation of the theology of the bk. that will help fix it in its genetic and chronological relations. ${ }^{1}$

The bk. belongs as a whole to the category of Apocalyptic, which itself is a process out of Prophecy. The term itself does not express a distinction from Prophecy, for the latter equally 'reveals' the things known only to God. ${ }^{2}$ And it is difficult to

${ }^{1}$ Among recent comm. Dr. has an exceptionally full and lucid treatment of the theology of the bk., pp. lxxvi-xcviii; and Behrmann's treatment, pp. xxii-xxvi, deserves notice for its compactness and independence of judgment. In addition to standard Dict. articles and O.T. Theologies (n.b. Stade-Bertholet and König) and the Introductions to the Apocrypha and Pseudepigrapha, there may be noted particularly the works of Volz, Bousset, Charles, Wicks, Meyer (Ursprung, 2, cc. 2, $4,6)$, Foakes Jackson (1, I 26 ff.) and the well-balanced and sympathetic Introduction to the subject by Porter (Messages); also the treatments by Bousset and Charles in the Introductions to their comm. on the Apocalypse of John.

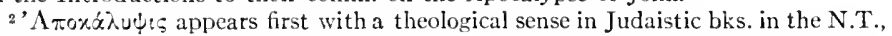
although it is used of the telling of human secrets Ecclus. $22^{22}, 42^{1}$. But the vbs.

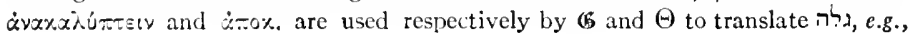


draw any hard-and-fast line between Prophecy and Apocalyptic, for we find in many prophetic oracles of the O.T., especially those of uncertain date and authorship, a process leading up to the more definite characteristics that stamp our bk. and others of its class. ${ }^{3}$ Ezekiel has a full-blown Apocalyptic, both in his Gog and Magog prophccy, cc. $38 f$., and in his prospect of the physical remaking of the Holy Land, cc. $47 f$. From that time on we have an increasing stream of such apocalyptic prophecy, e.g., Joel, Zech., Is. $24-27 .^{4}$

The feature that in general distinguishes later Apocalyptic from earlier Prophecy so called consists in the transcendent element. As we move down through this literature there more and more appears the sharp division between this world and another world, or, as it is put in Dan., between the kingdoms of this world and the Kingdom of God. It comes to be no longer, as in the Ezekielian Apocalyptic, a provincial matter of this earth, the setting off of a Holy State and People which the rest of the world dare not touch. But the antithesis now covers the whole world; it is man's organized empire as against God's. And the several parabolic schemes of Dan. picture this antithesis in ever sharper terms until at last there is the incarnation of this worldly defiance of God in one atheistic person. The rupture between the divine régime and the empire of man has grown wider and wider, until as in the days before the Flood there is required a divine interference to restore the Rulc of God.

It is in this respect that Apocalyptic differs from Prophecy, in the ever increasing accent laid upon the necessity which will involve not merely the political and military triumph of God, of

${ }^{22}$. The Syr. equivalent noun is gelyânâ. The technical terms of Apocalyptic appear

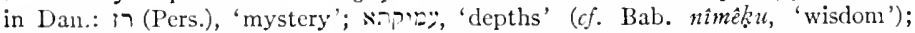

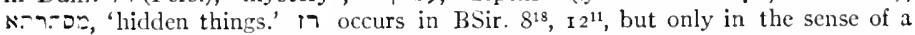
private secret; it looks as if the word only secondarily obtained its technical mng. For similar antique use of גל גל cf. 'having the eyes uncovered' of the seer Nu. $2.4^{4}$, and a revelation 'in the ears of' the prophet Is. $22^{14}$.

${ }^{3}$ Even the element of definite timed prophecies, comparable to the Weeks and Day's in Dan., appears earlier, e.g., not only the disputed yo weeks of Jeremiah, but also the Isaianic oracle, Is. $7^{16} \mathrm{cf}$. $8^{4}$; also Jeremiah's prediction of the death of Hananiah, $28^{16 \mathrm{f}}$.

${ }_{4}^{4}$ Critics have erred in too rigorously adjudging Apocalyptic as late, and Gressmann and Gunkel are right in trying to correct the balance. The antique Blessings of Jacob, Moses and Balaam are true Apocalypses. We should rather say that Apocalyptic is the revival of very ancient oracle-forms, with consequently a domestic history within the Heb. religion. 
his people or his Messiah, upon the earth, as in the elder eschatology, but also an absolute change in the conditions of this world, such as can effect a perfect theatre for the divine Kingdom. And the development of the world's history toward the creation of a single world-wide empire only the more accentuated the contrast between human and divine ideals. Hence Apocalyptic becomes a theological philosophy of history, differing from the elder philosophy of the Historians as well as the Prophets of the O.T. in its far greater sophistication, purchased through bitter experience. It has reached the mental resolution that the empire of man cannot save itself, nor be saved by natural cause and effect, that even the Holy People cannot save themselves by their own heroism, but that God alone can set things right which have gone so far awry. In the elder Prophecy God was conceived as using the units of this world one against the other to effect his sovereign purposes for the world. Isaiah could interpret Assyria as God's chastising instrument and Jeremiah and the Rhapsodist of the Exile regarded Pagan kings as God's Servants and Messiahs. But these were casual explanations that were ever frustrated. That kind of optimism died out after the Exile. There was no Jewish reaction to Alexander's triumphs. Indeed, under Hellenism, and even earlier under the late Persian empire, a new disturbing factor had arisen outside of the sphere of politics, namely in the more crucial field of society and civilization. As Judaism withdrew into itself, realizing that it was not merely one of the many religions of the earth but the True Religion, so much the more it brought upon itself the hatred of its neighbors for its unsociability and 'inhumanity,' the same charges as later made against the Christians. 'The sense of this acute opposition appears in the two stories of persecution for religion's sake, Dan. 3. 6, which are paralleled by the romances of 'anti-Semitic' passion in Esther and Judith, all which stories antedate the Antiochian persecution.

Comparative Jewish literature shows that the development of Apocalyptic, thus defined and described, does not appear until well down in the Hellenistic period. Indeed, there is nothing approaching its definition until we reach Dan. and the primitive parts of Enoch and the Sibylline Oracles in the $2 \mathrm{~d}$ cent. It will be argued in $\S_{2 \mathrm{I}}$ that Dan. $\mathrm{I}-6$ is earlier than cc. $7-\mathrm{I} 2$, i.e., of the $3 \mathrm{~d}$ cent. But for the earlier portion, in c. 2 the theme of the 
ever degenerating series of world monarchies is already worked out, and the moral deduction of their necessary annihilation is presented in the Stone which is to grind them in pieces. But there is absent the bitterness of antagonism that appears in the development of the same theme in cc. $7^{-12}$; the actual Atheist sitting in high places vowing the destruction of the Religion has not yet appeared in the person of Antiochus. Thus it can be observed that Apocalyptic had its slow process, connecting legitimately with elder Prophecy, on the other hand preparing for the crucial issue which the sense of the People of the Religion foreboded. ${ }^{5}$

The characteristics of this later Apocalyptic, in which Dan. leads the way, are closely interknit. They may be presented as follows: The transcendental character of the Deity; his operation through intermediate spiritual agencies, e.g., the 'humanlike' Gabriel who acts as his viceroy and also as medium of inspiration; the transfer of the stage of history to the heavenly places in the archetypal contests between the Princes of the Nations, of Persia and Greece, of Israel in the person of Michael; the limited dualism which allows a long and weary struggle between the cause of God and the evil opposition in heaven as in earth; a theological determinism which regards all history as foreordained, a copy stamped from the drama already enacted above, involving the exact calculation of secular years and days; and then the logical consequence that all this exactly enacted drama could be communicated to a seer living long before the culmination of events, under orders to close and seal the book of revelation which has been given him 'until the time of the end,' then to be opened and read in proof of the divine ordering of events in explanation of the delay of the times and for the assurance of the saints through this guarantee of the divine determinism that the dawn will soon break out of the darkness. ${ }^{6}$

These characteristics have in general their roots in the elder Heb. religion. The transcendentalism of later Judaism was a

\footnotetext{
${ }^{5}$ The writer believes that $A$ pocalyptic is not an ' $A$ bart' but a legitimate development of Prophecy. In this he agrees in general with Charles. The stress of the moral and religious issue of this later age broke down the inadequate reasoning of the Prophets that the right triumphs in this world as it is. The bk. of Job is the earliest protest against the prophetic eudamonism.

${ }^{6}$ On this 'apocryphal' characteristic s. $\$ 19, \mathrm{~g}$.
} 
necessary result of the vast broadening of the Jew's perspective of nature and human society. It is far more difficult, speaking philosophically, to realize the nearness of God in a large world than in a small one. Indeed, every higher religion is a composition, not very static, between notions of transcendentalism and immanence. Transcendentalism had set in in Judaism long before the $2 \mathrm{~d}$ cent., as the contrast of the two Stories of Creation in the opening of the Bible shows. And this view of a more distant God involved logically the postulation of intermediate agencies. God rules the political world as the Pers. monarch did his provinces by almost autonomous satraps, the Princes, and similarly the world of nature, as appears in the late Psalms and in the Benedicite, through the spirits of nature, which are not altogether personifications. Such notions stand simply for what modern theology blandly calls secondary causes. In regard to the Princes of the nations we have an ancient theologumenon going back to the Elîm or Benê Elôhîm who constituted God's court, among whom he distributed his powers as viceroys in the different parts of the world; so in the Song of Moses, Dt. $3^{2^{8 .}}{ }^{9}$, acc. to the doubtless original text of $\mathbb{6}$. These beings he used as spiritual and political agents in the world, e.g., Eze. 9. Io, Zech. I ff., Job I. 2 , etc. One advance appears in Dan. beyond the earlier literature of the Heb. canon, we obtain personal names for two of these celestial personages, Gabriel and Michael; yet the earlier bk. of Tobit knows also of Raphael (the $e l$ of healing), 'one of the seven holy angels who present the prayers of the saints and go in before the glory of the Holy One,' $\mathrm{I} 2^{15}$, i.e., an elaborate doctrine with the notion of angelic mediation.

There is a pronounced moral dualism in the bk., but it is distinctly limited. It presents the conflict between the ingrained evil of the kingdoms of this world and the divine imperium. This has its archetype in the heavens, where a primal conflict is being waged among the divine satraps, wherein the divine viceroy Gabriel can count only upon the loyalty of Michael the Prince of Israel. But this conflict of spiritual powers has its thoroughly Biblical antecedents. The transgression of the Sons of God, Gen. 6, indicates the primitiveness of this notion in Hebrew circles; notions of the conflicts of purpose in the heavenly courts, of the imperfection of the divine courtiers, appear in Job, and had become crystallized in Scripture by the poetical allusions to 
the ancient myths of the Dragon, Rahab, Leviathan, etc. We recall that this explanation of the origin of sin became a dominant one in certain Jewish circles. Our bk. is in line with that development in seeking a transcendental explanation of sin and evil; this belonged to the growing pains of a reasoned moral theology. In any ethical monotheism there comes a stage when the thinker realizes, and truly, that the evil of the world is not attributable to man alone; it is too stupendous a factor to be deduced from man's conscience of sin. The complete step to a principled dualism was made by Zoroastrianism. But in comparison with that the dualism of Dan. is of modest proportions. There is here no speculation on the origin of evil, the Princes are not regarded as fallen angels; the bk. is a pathetic but not hopeless commentary on the ancient discovery that man's thought is altogether evil (Gen. 6, Jer., passim), and that the divine imperium must ultimately crush this rebellious antithesis to its will. And it is significant that no Prince of Evil is devised, a Satan or a Belial, for which notion there were good Scriptural antecedents, and the earlier existence of which is attested by Tobit with its fiend, the Pers. Asmodæus, $3^{8.17}$. The bk is concerned with actual human history, and its arch-fiend is an atheistic king who within a brief space will meet his doom. ${ }^{7}$ Altogether Dan. takes a very sober position in the elaborate dualistic development which was in the air of the Judaism of its day.

Determinism is a far more definite factor in the theology of the bk. than elsewhere in the O.T. But it must not be offhand adjudged a foreign importation. Monotheism easily spells determinism, witness Augustinianism, Calvinism, Muslim fatalism. The prophetical books which the seer consulted, $9^{2}$, gave a Scriptural basis to this idea. The most un-Biblical expression of the notion is found in c. 4, where Neb.'s fate is fixed 'by the decree of the Watchers, by the word of the Holy Ones,' v. ${ }^{14(17)}$. But this exceptional statement, which has its Biblical prototype in the 'we' of the divine council, e.g., Gen. $\mathrm{I}^{26}$, may in part, at least, be attributed to the true dramatic coloring of the story; the Pagan king is addressed in the kind of language his sages

\footnotetext{
${ }^{7}$ It is therefore incorrect to speak of a Danielic Antichrist, except in so far as Antiochus became the Scriptural core of such later speculations. This historical limitation of the theme of evil absolutely distinguishes our bk. from Pers. dualism, the Parsee literature in fact having no historical sense.
} 
might have indulged in. ${ }^{8}$ But this faint trace of fatalism is fugitive: when Neb. comes to himself and recognizes the one God, he is forgiven and restored, whereas repentance has no place in fatalism. Judaism possessed the saving salt of a personal religion rooted in the faith in a Living God, and it never was corrupted by philosophical logic. The prayers of Daniel in cc. 2. 9 are a corrective to any such deductions for the theology of the bk. ${ }^{9}$

There is, finally, one unique contribution to Biblical eschatology, namely the assertion of the resurrection of 'many' from their graves, "some to everlasting life and some to shame, to everlasting abhorrence,' $\mathrm{I} 2^{2}$. There is nothing approximating this clear-cut notion outside of the late apocalyptic document, Is. $24-27$, where we read $\left(26^{19}\right)$ : 'May Thy dead live, may my dead bodies arise! [Response] Awake and sing, ye that dwell in the dust, for Thy dew is as the dew of light [?], and the earth shall bring to life the shades.' What is poetry there has become dogma here, and the resurrection involves a moral judgment, so that some of the wicked are included (with reminiscence of Is. $\left.66^{24}\right)$. But there remains the limitation of the resurrection to some only of either party. And the sphere of this resurrection is evidently this world. Outside of that doctrine the eschatology of the bk. is most meagre. The only other real eschatological feature appears in the vision of the heavenly Assize in c. 7 . There, it is true, a judgment scene in heaven is depicted: but God's people are represented only symbolically by the 'like of a man,' just as the heathen kingdoms are figured by monstrous beasts. And the consummation of the judgment is the donation to the Saints of the Highest 'of the kingdoms under the whole earth,' i.e., God's kingdom is to be established on earth in the hands of his Saints. Here is the usual Biblical nationalistic and secular eschatology without further development; the writer's contribution is literary, not dogmatic. Noticeable is the lack of a Messianic figure, although the figure of the 'Son of Man' in c. 7 promptly lent itself to the formulation of a heavenly Messiah. Finally it is to be observed that this hope of the resurrection is typical of the individualism of later Judaism; salvation

\footnotetext{
${ }^{8}$ This dramatic presentation of the Pagan atmosphere is a notable feature of the Stories.

${ }^{9}$ Jewish scholars have rightly rebelled against such one-sided nisinterpretations. See the fine retort by Montefiore, 'The Spirit of Judaism,' in Foakes Jackson, I, 35 ff.
} 
is no longer for all Israel after the flesh; the Saints compose the ecclesia in ecclesia.

In this review there appears little that is otherwise than genuine development of the older Bible religion. Without doubt there was a quickening of Jewish theology from without, for the religions of the ancient world were passing through identical changes in close contact with one another, and the sympathy of experience must have favored interchanges. The tendency toward monotheism, the problems involved in a moral rule of the universe and in the fate of the individual, even scientific speculations, these factors are found working from Persia to Egypt and Greece in the West. But the bk. of Dan. remains essentially Jewish, and in this respect differs from most of the later apocalyptic literature, which is generally marked by a crass eclecticism. The first six cc. present a background of Babylonian heathenism, which still survived under the Persian, Greek and Parthian dominions. Some would indeed have it that there is a heavy deposit of Bab. myth and lore in Dan., e.g., Gunkel, Schöpfung $u$. Chaos, but such views depend upon many assumptions; s. Comm. to c. 7 . But the bk. is a standing protest against Babylonism. ${ }^{10}$

The influence of Parsism, the religion of Zoroaster, upon the theology and literature of Judaism in this period, with the inclusion of Dan., is stoutly championed by many. The notion was taken up speculatively by scholars of the I 8 th cent., Bertholdt was under its sway, Kohut and others argued for it, and so particularly, Bousset, s. his c. 25 , 'Das religionsgeschichtl. Problem.' Most recently E. Meyer has appeared as a rigorous champion of this influence upon Jewish theology in general and the bk. of Dan. in particular; s. his cc. 4.6 and pp. I74-I99. This position is based upon the major premise of his enthusiastic admiration for the work of Zoroaster as 'the first personality to enter the history of religion with creative worth' (p. 58), while he makes him the real founder of a cosmic monotheism vs. the Jewish particularism of a provincial god ( $f f$. p. 73$)$. But the whole question of that influence in the comparison of religions is sorely complicated and rendered most uncertain by the doubts as to the age of the Parsee documents. In the discussion of the

\footnotetext{
${ }^{10}$ See Meyer's arguments against the postulation of such influence, pp. 5 I ff. Of
} course he is swayed by his pro-Persian penchant. 
Four Monarchies in the Comm. after c. 2 the writer has presented the differences of views of scholars as to the age of the documents and the rise of formulated Parsee orthodoxy. The shaft let down in the discussion of that one theme makes him sceptical; he feels that the sources of the Pers. religion are operated with in as uncritical a way as if in the O.T. a critic should accept $\mathrm{J}$ and $\mathrm{P}$ indifferently for the Mosaic age.

The above presentation of the theology of the bk. shows that it contains no principled dualism. The doctrine of the resurrection breaks forth very naturally in our bk. as born of an emergency, and yet taking its place in a genetic catena of growing belief toward such a necessary dogma. Moreover there is nothing cosmic in the belief there presented; some of the righteous, some of the wicked, of Israel alone, will arise in their bodies for judgment. In the matter of the Four Monarchies Daniel thinks, as has been above remarked, historically, not theologically; four ages may have been given him by some cosmic, numerical scheme (the Greeks had it), but if so he is adapting it to a clear historical order of four actual empires. ${ }^{11}$ The Ancient of Days, remarks Meyer, 'is none other than Ahuramazda' (p. I99). But do not all people think naïvely of the Deity as 'der Alte'-a magnified Sheich? The Greeks so depicted their chief god Zeus on their coins. Whether mythical traits may not, indirectly perhaps, have come in from Persia (where others think of Babylon) may be an open question; e.g., the river of fire under the throne of the Ancient of Days, as Meyer claims (pp. I66, I99), and yet that fire is not represented as a means of purgation as in Parsism, nor is fire a monopoly of the Parsee apparatus, $c f$. Is. $30^{27}$. For the much-discussed 'Son of Man' a Pers. origin is offered, by Bousset in the Parsee 'Urmensch' (p. 407), by Meyer, very cavalierly, in a combination of Sraosha the Genius of religion and the Parsee savior Saoshyant (p. I99). But in Dan. 7 the Son of Man is a symbol which forthwith disappears. There has been noted above, $\S 8, b$, the very slow and small impress that the Pers. language made upon the Semitic idioms; we have to postulate equal delay in the spread of Parsee influence. It is more apparent in the N.T. than in the O.T., still more evident

${ }^{11}$ Meyer thinks, p. I89, that a Median empire were absurd, because there was none; yet the althor deliberately introduces the Median Darius between Belsh. and Cyrus. 
in the Rabbinic literature; that is, its influence was late, not early. ${ }^{12}$

For the Jewish praxis of religion the bk. has its historic value: $n . b$. the punctilious observance of the food laws, $\mathrm{I}^{8 \mathrm{ff}} \cdot$; alms and good works, $4^{24}$; the three times of prayer $6^{11(10)}$, prayer by running water, $8^{2}$, and in general the place of prayer in piety, $2^{17} \mathrm{fr}$. (in contrast to the arts of the magicians). The long prayer in c. 9 is an early liturgical specimen, and there are brief liturgical

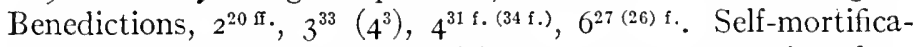
tion is practised in hope of a vision, $\mathrm{IO}^{3}$. Repentance is a characteristic of piety, and is accepted from Pagans, $4^{24(27)}$, of whom the works of the Law are not required. Judaism is not a proselytizing religion; the Pagan confession of the True God is sufficient, as in the cases of Neb. and Darius. Cc. I-6 reflect the life of pious Jews in the heathen environment of Babylonia.

Behrmann holds (p. xxv) that the bk. is a product of the Essene development of the Chasidic type of religion; but too long a lapse exists between the bk. and our first sources for Essenism to pass judgment. On the other hand, cc. 7-12 are an authentic monument of primitive Chasidism, the 'A $\sigma \iota \delta a \hat{\imath} \circ \iota$ of I Mac. $2^{42}, 7^{13}$. Our bk. represents the principled pacifistic wing of the party. In $\mathrm{I}^{34}$ there is a solitary reference to Judas' enterprise, 'when they shall stumble, they shall be helped with a little help'; but there follows immediate criticism of the movement for its worldly complications, 'many shall join themselves unto them in intrigue.' The writer was nearer the primitive type of the party which preferred death to fighting on the Sabbath (I Mac. $\mathrm{I}^{29}$ ff.), and he rejoices in the present martyrdoms in view of the prize that is set before them, $\mathrm{II}^{33.35}$, very much in the spirit of the early Christians. Not by militant means shall the tyrant be overthrown, but 'he shall be broken without hand,' i.e., without visible agency, $8^{25}$, while the Saints shall inherit the Kingdom not by their might but by gift of the Highest, $7^{27}$.

${ }^{12}$ For this distinction s. Scheftelowitz, Die allpers. Religion u. d. Judcntum, 1920. 
§2I. THE PROBLEM OF THE UNITY OF THE BOOK AND OF THE TWO LANGUAGES.

\section{a. The two books, the Stories and the Visions. ${ }^{1}$}

The criticism of the unity of the bk. began in the $I 7$ th cent. with the observation of the distinction of languages, the Aram. and Heb.; Spinoza discovered two documents, cc. I-7 and 8-I 2, referring the latter to the undoubted authorship of Dan., and confessing ignorance as to the origin of the former. The distinction between the Stories and the Visions was first made by Sir Isaac Newton: "The bk. of Dan. is a collection of papers written at several times. The six last chapters contain Prophecies written at several times by Dan. himself; the six first are a collection of historical papers written by other authors"; and cc. I. 5. 6 were written after his death. ${ }^{2}$ Eichhorn in his Einleitung ${ }^{4}, \$ 6$ I 5 , while denying the authenticity of the whole bk., followed the distinction between the Stories and Visions, but aligned the Heb. preface c. I with cc. $7 f f$. J. D. Michaelis first originated a fragmentary hypothesis, holding that Dan. consists of 'several separate pieces,' any one of which may be rejected as historical without prejudice to the others (Or. u. exeg. Bibliothek, I ( I 77I), I90). And Bertholet in his comm., I So6, proceeded to a diagnosis of nine different sources. Thus the possibilities of critical analysis were early sounded.

But a critical distinction on the basis of diversity of language is now generally denied. The extreme positions taken respectively by the defenders and the impugners of the historicity of Dan. have induced the great majority of critics to assign the

${ }^{1}$ Apart from the relevant sections in the comm. and Introductions, there are monographs by Meinhold, Beiträge zur Erklärung d. Buches Daniel, Heft I, Dan. 2-6, I 888 (rev. by Budde, $T L Z$ 1 888, no. 26); von Gall, Die Einheitlichkeit d. Buches Dan., 1895; Barton, 'The Composition of the Bk. of Dan.,' $J B L 1898,62-86$ (cf. Marti, p. x); H. Preiswerk, Der Sprachwechsel im Buche Dan. (Berne Diss.), 1902 (rev. by Mein., TLZ 1904, 353); G. Hölscher, 'Die Entstehung d. B. Dan.', TSK 192I, II3-138. An early defence of the unity of the bk. was made by Bleek, 'Utber Verfasser u. Zweck des B. Dan.', Theol. Zeitsch., 3 (I822), 17 I, noticed in these monographs.

${ }^{2}$ For these reff. s. Mein., pp. I $f$., vGall, pp. I $f$. Spinoza's brief comment is found in his Tractatus theologico-politicus, ed. 1674 , c. I0, p. I89; Newton's in his Observations upon the Prophecies of Dan. and the A pocalypse of St. John, ed. 1732, p. $10=$ Whitla's ed., P. 145. Von Gall also notices Beausobre, Remarques sur le Noureau Testament, 1742, p. 70 , agreeing with Newton and drawing distinction between the 1 st and the $3 \mathrm{~d}$ pers. in the two parts. 
bk. as a whole to either the 6th or the $2 \mathrm{~d}$ cent., with as a rule little or no discussion on part of the comm. of the possibility of composite origin; indeed most ignore the problem. ${ }^{3}$

Before discussing the various views which have been proposed the writer will state his positive opinion. The bk. falls into two obvious literary portions, cc. I-6 the Stories, and cc. 7-I 2 the Visions. C. $\mathrm{I}^{-2^{4 a}}$ is absolutely necessary as introduction to the following Stories, and it is difficult to see how scholars, e.g., Eichhorn, Mein., distinguish it as later. ${ }^{4}$ C. 7 is pure apocalypse, like cc. $8 \mathrm{ff}$., and it is fallacious to appeal to c. 2 as also apocalyptic, for that story tells of a heathen's dream and its interpretation by the hero of the Story, as in the tale of Joseph and Pharaoh. Further, it must be positively denied, as earlier conservative comm., and now Mein., Hölscher, have rightly insisted, that Neb. and Darius are types of the infamous Antiochus, or that the trials of the confessors in the bk. represent the Macc. martyrdoms. ${ }^{5}$ They do stand for the fact that Anti-Semitism (in the modern sense) is much older than the Macc. age, and was not confined to the Syrian empire. Our Stories follow the doubtless true historical theme of underhand efforts of officials and the jealous populace to embroil the Jews with the government on the score of their religion; but these Stories, like Est., correctly show that the imperial administrations refused to take action against the Jews, the instigators of those sporadic, underhand persecutions being represented as 'hoist with their own petard.' Neb. and Darius stand forth as amiable, religious-minded monarchs. The miraculous deliverances of the Confessors portray the truly remarkable fact that the Jews under the successive Pagan empires down to the Roman found their rights providentially maintained by the imperial government. Only in the case

${ }^{3}$ E.g., Dr., in his comm., with only a brief paragraph on the subject in LOT 514 . Von Gall presents an extensive argument for the unity of the bk., rejecting only the Prayer in c. 9 as an interpolation. König, in his Einleit., suggests that cc. $1-7$ were composed in 168, cc. $8-12$ in 165 .

4 But Mein. must be credited for the distinction of the pre-Maccabran (cc. 2-6) and Macc. (cc. $7-8$ ) sections, even if, as vGall insists, some of his argumentation is fallacious. Strack, in his Einleit. ${ }^{3.4}$, proposed the pre-Macc, origin of cc. $1-7$.

${ }^{5}$ Bevan gives up the case for the unity of the bk. on this score in his very frank admission, p. 23: "It is however necessary to guard against a possible misconception. Though the author of Dan. has everywhere the circumstances of his own time in view, we cannot regard Neb. and Belsh., still less Darius the Mede, simply as portraits of Ant. Epiph. The author is contending not against Ant. personally, but against the heathenism of which Ant. was the champion." 
of Belsh. is there condemnation of the monarch, but here the story is following popular Bab. tradition.

There is a further induction from the Stories which has not been drawn by others except those who hold that the whole bk. belongs to the Babylonia of the 6th cent., namely that cc. I- 6 are of Bab. provenance. Corroboration of this position is given by the fact that almost all the Akk. and Pers. words appear in cc. $\mathrm{I}-6 .{ }^{6}$ Nor are we in the position to maintain that the Aram. of the bk. is the Western dialect; s. $\S 7$, n. 5. Further, the historical background of these cc. is Babylonian. Again, their sumptuous barbaric scenery is obviously not that of Palestine; one need only compare the arid scenery of the later cc. And the interest in traditional heroes of the Bab. exile must belong to the Golah in Babylonia. Critics naturally assign the bk. of Tobit to an 'Assyrian' origin, and that of Judith as naturally to a Palestinian, while with equal logic Est. should be located in Persia. Finally, as has been recognized by some, the conflict between $\mathrm{I}^{21}$, 'Dan. continued (i.e., remained where he was) until the first year of king Cyrus,' and the datum of the third year of that king, with the locality given as the Tigris ( $\mathrm{IO}^{1.4}$ ), is cleared up: the implication of the first bk., cc. I-6, is that Dan. and his faithful companions returned home at once upon Cyrus' proclamation of release. And actually in the Chronicler's lists of returned exiles we find a Mishael, Azariah, and Hananiah, Neh. 8. ${ }^{\text {3. }}{ }^{24}$ along with a Daniel, IO ${ }^{7}$.

\section{b. The problem of the two languages.}

This problem may be considered here, as the boundaries of the two languages approximate the distinction between the two bks., cc. $\mathrm{I}-6$ and $7-\mathrm{I} 2$. Dalman's solution, in which he has been followed, evidently independently, by Torrey, is the only one which recommends itself to the present writer. Dalman, after postulating those two bks., proceeds: the redactor must first have turned the preface, c. I, into Heb., and then translated the Heb. c. 7 into Aram., and so have bonded the two into one

'Paton's reasoning for the Palestinian origin of Est. in his comm., p. 64, is not obvious: "It is a plausible suggestion that the author was a Persian who had come to live in Judxa." 
whole; and so exactly Torrey. ${ }^{7}$ This change into the Holy Tongue would have facilitated recognition of the bk. as sacred and eligible for the Canon, while dramatically enough the Aram. could be allowed to stand with the citation of the Chaldæans' response to the king, $2^{4}$, and so on. ${ }^{8}$ A variant suggestion may be made as to the language of c. 7. Granting that it belongs integrally with the following cc., their author, who was deliberately depending upon the elder bk. of Dan., may have continued its language in his first composition, and subsequently have reverted to Heb. as the more suitable tongue for divine revelation, the use of which would have been appropriate to the enthusiasm of the Macc. uprising. ${ }^{9}$ But see sub-sect. (c) for another possible precision of c. 7 .

Other hypotheses advanced for this change in language are most diverse. ${ }^{10}$ The simplest view, on the assumption that we possess the bk. in its original linguistic form, is that the bilingual composer passed easily from his Heb. introduction into the Aram. of the citation $2^{4}$ ff. and then continued in the vernacular; the phenomenon would then be similar to the Aram. section in Ezr., beginning at $4^{8}$ with an official document. But this theory ${ }^{11}$ does not explain why c. 7 continues the Aram., and the change to Heb. is made with c. 8.

A favored theory is one broached first by Lenormant (as cited by Bevan and Haupt) and followed by Bevan (p. 27), vGall (p. I 22), Haupt (at $2^{4 a}$ in Kamp., SBOT), Prince (p. I3) and

${ }^{7}$ Dalman, Worte Jesu, 1898, I1; Torrey, Notes, I, 249. Hölscher, who appears to be ignorant of those scholars' position, and Preiswerk maintain also that the preface is a reversion into Heb. He and Torrey find evidence of an Aram. original, but both admit that this evidence is not conclusive.

${ }^{8}$ This does not involve the absurdity that it was thought even by a late redactor that this vernacular Aram. was the 'language of the Chaldxans,' ${ }^{4}$.

${ }^{9}$ However, Preiswerk (pp. 77-9I) makes a strong argument for c. 7 as translation from Heb., alleging not only Hebraisms, but more convincingly showing that it can be casily reverted into Heb. as its parallel c. 2 hardly can be so treated, while also c. I is an casy subject for reversion into Aram. The authors of the pertinent monographs have noted the dialectic distinctions between this c. and cc. 2-6: the sole use of Ithpeel and Ithpaal vs. Hithp. in the earlier cc. (where however Ithp. $3^{19}, 4^{16}, 6^{8}$ ) and the use of אר (but once 1 v. ${ }^{8}$ ) vs. Hofals is also noticeable.

${ }^{10}$ See Charles' review of the discussion, $\mathrm{pp}$. xix-xxvi.

"So, e.g., Behr., p. ii, Kamp., $E B_{1}$, 1005 , with the indorsement by Dr. as 'relatively best,' p. xxii. Ryssel, TLZ i 895,560 , offered a theory of a progressive composition by one author: cc. $I-7$ in Aram., then cc. 8-I 2 in Heb., upon which he began reverting into Heb., breaking off however with the citation in $2^{4}$. 
Barton (p. 65) that "a portion of the Heb. text having been lost, a scribe filled up the gap by borrowing from the Aram. version" (which already existed), so Bevan, citing Antiochus' systematic attempt to destroy the Law. But this hypothesis stumbles on the fact that Aram. begins neatly at the appropriate point.

The view of a Heb. original for the whole bk. is maintained by Riessler, $\$ \$ 3.4$, and by Jahn at length, the latter reverting the whole of $\mathbb{6}$ into Heb. in order to recover the alleged original. But S. \$II on this perverted appreciation of the text of $\mathfrak{B}$, and the conclusive detailed criticism of Riessler by Preiswerk, pp. 68-77.

Just the opposite view was advanced oy Huet (d. I72I) in his Demonstratio evangelica, 472 (cited by Bert., p. 5I): the whole bk. was composed in Aram. and then translated into Heb.; in the Macc. troubles the Heb. bk. was in large part lost and the lacunx filled up from the orig. Aram. This view has been revived by Buhl ('Daniel,' $P R E^{3} 45 \mathrm{I}$ ) and accepted by Marti and Charles $(l l . c c$.$) , and summarily by Wright, p. 46. But Marti's$ linguistic argument from the 'Aramaisms' in the present Heb. is most meagre.

\section{c. Further divisive theories.}

The suggestion that the bk. is a compilation of so many odd compositions was first made by J. D. Michaelis, who regarded it as compiled of 'abgesonderte Stücke' (Or. u. exeg. Bibliothek, I ( 77 I $)$, I90). Bertholet (pp. 49.ff.) found nine separate pieces by as many different hands. Similarly Lagarde (GGA I $89 \mathrm{I}, 5 \circ 8$ ff.) considered the bk. a compilation of disconnected documents, and most recently Meyer (Ursprung, 2, I 84 ) expresses the opinion that "the bk. is composed of very different parts and has behind it a long history." But such positions, indicating a bankruptcy of criticism, have not found applause. It will be convenient to consider the two parts, $c c$. I-6 and $7-12$, separately in the search for their origins.

I) In the Stories there appear a distinction between those concerning Dan. and that of the Three Confessors c. 3, while the preface, c. I, may be taken as a welding of the Daniel-cycle with that extraneous tale; this is the more obvious in that in c. 3 
Dan. is totally absent, so that commentators have been nonplussed in explaining the absence of the hero of the bk. from that ecumenical scene. This inconcinnity is typical of many others that have been pointed out. But such phenomena can be explained on the hypothesis that the narrator did not invent his theme here or in the other Stories, but was dependent upon existing tales and traditions. C. 3 , which in its form may be regarded as a counterpart to the Story of the Three Pages in I Esd., doubtless has a traditional background, with the motif of an Image that was to be worshipped (for which an historical basis can be found), while the fiery trial of the Confessors may be a popular amplification of the actual penalty inflicted upon rebellious Jews acc. to Jer. $29^{22}$, whom popular tradition turned into saints; s. Comm. In c. 4 we have the otherwise vouched-for madness of Neb., which would have afforded a most likely point d'appui for moralization from the point of view of the True Religion. C. 5 contains particularly definite historical tradition; the fate of the last scion of the Bab. dynasty fitted in well with the expected theodicy upon Babylon, while the theme of Belsh.'s impiety (in contrast with the nobility of his 'father' Neb.) follows the popular Bab. condemnation of the house of Nabonidus. In fact $6^{1}\left(5^{30}\right)$ with its exact datum about Darius can hardly otherwise be explained than as an extract from a written native document. C. 6 may be more particularly a free invention of the author, dependent indeed upon c. 3 and upon current martyrmotifs (likely enough in actual practice), and yet wholly fresh and original in its composition. Still more is the Story of Neb.'s dream, c. 2, the author's own independent work, dependent perhaps upon current themes of the Ages of the World, but worked up into an amazingly dramatic composition. Daniel may already have become hero of current Jewish story (e.g., in the Belsh. episode), and the author of the whole would therefore have possessed some skeletons of narrative to which he would have naturally adhered. Such stories would naturally have been composed and published at different times, and this artle's method of composition, without a purpose of an ultimate integral book, would sufficiently explain the numerous inconsistencies. ${ }^{12}$ tion.

${ }^{12}$ See IIölscher, p. I15, for evidence of unity in cc. I-6 from vocabulary and dic- 
Bert. found no less than five different writers in these Stories (cc. I. 2. 3. 4. 5-6), with most arbitrary assignment of their provenance, geographical as well as historical. Barton (s. note I) is the only recent scholar who has attempted an elaborate reduction of the bk. into a number of distinct sources. Regarding it as practically Macc. in age, he discovers three original contributors (s. table, p. 8I): A cc. 2. 4. 5. 7. 8; B cc. 9.6 (the latter posterior); C CC. IO-I 2 ; and C. 3 as 'possibly from yet another hand,' although related to $\mathrm{A}$; a redactor collected the various writings, prefixed a preface, c. I, and contributed an epilogue, I $2^{5} \mathrm{ff}$, along with verses and phrases intruded through the bk. $\mathrm{A}$ is Babylonian in culture and environment, B similarly Jewish, and C Persian. Barton's position as to the practical unity of time for the components of the bk. disagrees entirely with the view adopted above for the major distinction between cc. I-6 and $7-12$; and it must be claimed that the difference between Story and Vision is far more obvious than any other marks of disparateness. Barton assumes compositions of so many various cultures; he does not go so far as to say that the authors lived in so many different lands (as does Bert.); but if they were so different, even leaving out of question their habitats, how did they all happen on the same theme, and this within the few years of the Macc. uprising, and how were their compositions all collected into one within so short a time? It can hardly be held that the series of Babylonian and Medo-Persian kings offers clews of critical distinction, as the episodes simply follow the sequence of dynasties in the 6th cent. as understood by Jewish historiography, and if we admit composition of the bk. in the Hellenistic age, the background is the later complex of the several civilizations.

2) The question of the unity of cc. $7-12$ is more difficult. For the romances of cc. I- 6 we can attribute contradictions to the varieties of underlying traditions. But $\mathrm{cc} .7^{-\mathrm{I} 2}$ are apocalyptic, hence subjective compositions, and we possess no psychological standards whereby to determine the possibilities of variety in the one composer or to probe how far more than one is required. Barton correctly remarks (p. 78 ) that every one of the important apocalypses known is composite, unless Dan. be an exception. Yet as the actual Daniel-Apocalypse consists of only six chapters and must have arisen within a very few years, we have to 
be chary in pressing a fragmentary hypothesis too far. Barton finds in these cc. three main composers. Quite conservative scholars, Zöckler, Wright, have desired to detach c. I from the original composition. And it has been assumed by many but chiefly from the accident of language, that c. 7 belongs with cc. I-6. Most recently Meyer has expressed the opinion that the 'prophecies' of Dan. offer 'several doublets and parallel treatments of the same subject from quite different historical points of view' (p. I 88). Accordingly, cc. Ix and 9 appear as distinct compositions (l.c.), while cc. 2. 4. 7. 8 constitute a separate corpus with distinct Parsee characteristics (pp. I 89 ff.).

Sellin (Int., $233 f$.) would combine c. 7 with the pre-Macc. cc. $\mathrm{I}-6$, and proposes that $\mathrm{c}$. 7 has been expanded under the later Macc. point of view by the intrusion of direct references to the hateful Antiochus in the judgment scene; he would accordingly delete as unoriginal vv. 8. 20-22. $24 \mathrm{f}$. Hölscher follows suit (pp. I I9 f.), omits as a halting addition 'and it had ten horns,' v. 7, and then deletes vv. ${ }^{8}$. 11a. 20-22. $24 \mathrm{f}$; ; consequently he attributes c. 7 , itself an appendix ('Anhang') to cc. $\mathrm{I}-6$, to the $3 \mathrm{~d}$ cent. Hölscher's arguments from the logic and language of the chap. are not at all conclusive; s. above, n. 9, for Preiswerk's demonstration of its philological difference from the preceding cc. But it must be admitted, as Gunkel has shown, that c. 7 stands out uniquely in the bk. with its mythological background and visional scenery; the Beasts and the Throne appear as quite different conceptions from the historical 'parables' of the Beasts in c. 8 (as also of the Tree in c. 2), and there is certainly a descent in poetic conception from c. 7 in the following cc. ${ }^{13}$ The present writer is therefore inclined to leave it an open question whether c. 7 is a distinct composition, a forcrunner of the apocalypses in the following cc., even without deletion of vv. which would relate it to the Macc. age. Its linguistic distinction from subsequent cc. might then be explained. However, the literary and psychological problem must be weighed, whether one and the same writer may not have developed from the vision in c. 7 and culminated in the veiled historical midrash of c. I I. Almost all

${ }^{13}$ The reaction against the extreme of Pauline criticism should warn against too easily secking explanation of variety in divisive hypotheses for our bk. And for cc. 7 (or 8)-12 we are shut up on any critical theory to a very brief term of years for room for literary accretions. 
students agree that cc. 8-I 2 are from the same hand. Yet in these there is a noticeable variety; c. 8 has its symbolism (which Meyer believes to be the explication of c. 7 by the same author), this disappears in c. 9, an angelic announcement taking its place, while the substance of the final vision is absolutely unpicturesque. Yet the prosaic character of these cc. is broken by the long and fervent prayer in c. 9, and by the vision of the Man in c. Io which is told with psychological verisimilitude. Certainly for cc. 8-1 2 ( $c f$. Hölscher), and it may be added for c. 7 as well ( $c f$. vGall), although here we are dealing with a different language, no clear linguistic arguments can be adduced against their unity. ${ }^{14}$

\section{d. The dating of the two sections.}

I) Cc. I-6, according to the argument above, are pre-Maccabæan, composed in Babylonia: they may be roughly assigned to the $3 \mathrm{~d}$ cent., to an age not earlier than the division of Alexander's empire by the Diadochi. More precisely we may not speak; s. Note at end of c. 2 for the ancient view of Polychronius, followed by Grot., Bert., Torrey, Hölscher, that the 'mingling of the seed of men,' $2^{43}$, refers to the marriage of Berenice, 247 B.C. The collection contains a series of stories based on Jewish and Bab. traditions, which were gradually written and finally compiled in one book. There is no reason to dispute the assumption of one literary hand for the whole.

2) Cc. $7^{-\mathrm{I} 2}$ belong to the first years of the Macc. uprising, I6S-I65 B.C., the four Visions to be regarded as composed seriatim. ${ }^{15}$ In them the temple is pictured as profaned, but its restoration is expected, along with the cataclysmic destruction of the tyrant. This is also the milieu of the last Vision, in which there is a passing reference to the militant and seemingly insig-

1s For extreme views of the origin of the book or of its sections may be noted that of E Havet, Le christianisme et ses origines, vol. 3 ( $\mathrm{I}_{7} 8$ ), 304 .ff., suggesting that the second half belongs to the age of Herod; and that of Lagarde, in his review of Havet (GGA 189 I, 497-520), attributing cc. 7.9-1 2 to 69 A.D. Cf. also Hertlein, $D c r$ Danicl der Römerzeit, 1908, assuming Roman age for final form of cc. 2-7, also his Menschensohnfrage im letsten Stadium, I9 I (rev. by Volz, TLZ 1909, 357 and 19г2, $69)$.

${ }^{15}$ For the possible exception of c. 7 as distinct from what precedes and follows, s. above $[c]$; but this hypothesis depends upon excision of passages which obviously refer to Ant. 
nificant Maccabees ( $\mathrm{I}^{34}$ ), while the climax is expected in a final great battle in the Holy Land, when the tyrant shall be overthrown by divine operation. That is, the Visions were composed well before the retaking of the temple and its purification, which latter event occurred Chislev (about December) 25, I65, according to the record just three years to the day after its profanation. ${ }^{16}$

But the Visions contain what purport to be exact calculations of the time of devastation. In $7^{25}=12^{7}$ this period is to last for $3 \frac{1}{2}$ years. In addition there is a more specific calculation by days, $8^{14}$, '2300 evenings, mornings,' i.e., 2300 matin and vesper sacrifices $=$ I 50 days $\left(v\right.$. ad loc.). ${ }^{17}$ Comm. have naturally attempted to relate these I 50 days to the $3 \frac{1}{2}$ years: but the latter figure, at 360 days, $=1260$, at 365 days, $= \pm 278$. On the other hand the II 50 days would approximate the three years of the actual profanation acc. to I Mac, i.e., at 365 days to a year I I $50=3$ years +55 days; at 360 days i $50=3$ years + 70 days. A way out of attempting any solution is offered by Gunkel, Schöpfung u. Chaos, 266-270, who regards the $3^{1} / 2$ in c. 7 as a mystical, mythological number. But for a people which reckoned both days and years in sevens (in the popular calendar as well, because of the years of Release) there need have been nothing ultra-significant in the figure. We calculate by decades, and so speak of half-decades (decennium, quinquennium), and the comparative import of the latter would be that of brevity. Similarly seven years might imply a long or full period, $3^{1 / 2}$ an $a b-$ breviated one. And the following historical basis for such an expectation may be observed as possible. If the high priest Onias' death be placed at I7 I B.c. (s. Schürer, 3, I95), about half a septennium would have elapsed by 168 ; and as the erroneous chronology, followed by the author, would have terminated Jeremiah's 70 Weeks, understood as 490 years, three years later, it would have been natural to balance one half-septennium

\footnotetext{
${ }^{16}$ Acc. to I Mac. I ${ }^{54}$ the temple was profaned on Chislev 15 (I68), but it is generally recognized that this is error for ' 25 ,' to be corrected in agreement with the statements of $4^{52.54}\left(\right.$ cf. $\left.2 \mathrm{Mac} .10^{5}\right)$ as to the exact three years. There appears now to be general agreement as to the dates 108,$165 ;$ s. Schürer, $G J V$ vol. I, \$., Meyer, Ursprung, 2, 159. 209. Josephus, in stating that the profanation lasted for $31 / 2$ years (B.J. ii, I, I) makes accommodation with Ian. It is noteworthy that I Mac. made no such accommodation, a testimony to its chronological reliability.

${ }_{17}$ The ' 1290 days' and ' $\mathrm{I} 335$ days' of $\mathrm{I}^{11,12}$ ( $\%$. ad loc.) are successive later inser. tions, duc to the retardation of the term of 1150 days.
} 
against the other. Even if we allow that c. 7 is entirely distinct in thought and authorship from c. 8, we have still to regard the author of the latter as interpreting the $3 \frac{1}{2}$-year datum of the former, qualifying it for some reason of his own, but there still remains the question of his I 50 days. It can be equated neither with the $3 \frac{1}{2}$ years nor with the recorded three years of the profanation. The latter fact excludes the hypothesis of a vaticinium post eventum, and indeed the whole bk. is evidently anterior to the Macc. success. If post eventum, then $8^{14}$ must be regarded as a later addition, which no critic has claimed; but even then there would remain the question as to the term of the I 50 days, which in that case must have meant something. ${ }^{18}$

The result of this argumentation is that the $3^{1 / 2}$ years is a round figure, and the II 50 days an exact calculation based on terms wholly obscure to us; neither of the calculations was exactly fulfilled, hence they both must have been devised ante eventum. In the rough the expectation was fulfilled-in briefer time indeed, in three years, shorter than the I 50 days by 55 . This deduction may be satisfactory neither to the theologian nor to the historian. The latter naturally disowns the element of prediction in history, while the modern theologian deprecates it in prophecy (but $\epsilon f . \$ 20$ ) and would admit it still less in our bk. However we may explain the fact, the majority of scholars who maintain the Macc. origin of cc. 7-I 2 regard them as composed before the triumph of the Maccabees in 165 , and hence implicitly, if not explicitly, admit the historical fulfilment of their expectations. So Kuenen, Einleitung, $\$ \$ 88.89$ (as written before Judas' defeat of Lysias); Wellhausen, Isr.u. jiid. Gesch.4, 256, n. 2; Schürer, 3, 256; Kamp., EB I, IOI3. And so almost all recent comm., exc. Behr. at $8^{14}$, who agrees with Cornill for a post eventum date, as does Meyer, p. I86. And some recent comm., following Stuart, Zöckler, al., find here 'genuine prediction' of the Macc. success, e.g., Dr., p. lxvii, Charles, at $8^{14}$. It may be remarked that predictions of seers have often had their

${ }^{18}$ For the history of the interpretation of the 70 Weeks s. Note at end of c. 9 . Cornill, Die Sicbsig Jahmochen Danicls, 21-26, has made a very learned argument based on certain chronological determinations to the end of defining the I 150 days; assuming that the figure must be post erentum, he dates back its starting-point to Tishri (October) I68, when, he argues, Ant. issued his decree for the establishment of one religion. But as subsequent scholars have insisted, the starting-point is obviously the actual profanation in Chislev, and Cornill's position has met with no favor. 
effect on events, as in the case of Jeanne d'Arc; and so these forecasts of our bk. may have nerved the Macc. heroes to their illustrious triumph in $\mathrm{I}_{5}$ at the end of the ' 70 Weeks.'

\section{c. Losses and additions to the original book.}

For the Greek and Latin ecclesiastical tradition which regards the Apocryphal Additions as integral to the bk. and for modern views which would salvage some part of the episode between the prayer of Azarias and the Bencdicite, s. $\$ 4$. For criticism of the position held by a very few scholars that $\mathbf{6}$ offers a fuller and better text and that its actually midrashic expansions should be honored, s. §II.

In regard to supplements, the most extensive addition that has been alleged, namely, by vGall, otherwise a rigorous champion of the unity of the bk., is the Prayer in c. 9; this opinion is rejected in the Comm. On the other hand, the Comm. follows Gunkel in excising $\mathrm{I} 2^{11} \cdot 12$ as later, although very early, attempts at rectifying the number of predicted Days; this criticism removes one of the greatest difficulties.

Otherwise the changes adopted are few, many not being more than glosses of a few words or doublets, the latter an interesting phenomenon of early variation. Certain passages have been objected to as secondary 'joints,' but if the writer of the Stories used various traditional materials, these 'joints' may be attributed to him as well as to another hand. In general the diction of the bk. is what German would call 'spröde' ('splay'), and we may not apply too fine a standard of logic and literature.

The principal excisions from the text adopted or allowed as possible in the Comm., barring occasional single words, are (cf. the list of glosses, etc., accepted by Marti, p. $x$, and Charles, p. xxxi):

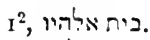

$2^{16}, 1$ ע (?).

$2^{28-29}$, doublet, v. ${ }^{29}$ secondary.

$2^{42-43 a}$, a doublet.

$4^{2}$, 'and visions of my head.'

$4^{20}$, greater part doublet of $\mathrm{v}^{12}$.

$6^{5}, 2,1$, is doublet.

$7^{2}$, a few words.

$7^{25}$, om. after 'I was seeing.'
$8^{2}$, 'and I saw in the vision.'

$8^{9}$, יואר ריאד

$8^{12}$, last two verlos.

$8^{13 b}$, a gloss of items.

$9^{27}$,

I0.0. 21 , a doublet.

I I ${ }^{14}$, a gloss.

$11^{18}$, containing a poss. doublet.

I $2^{11}$, ${ }^{12}$, two successive glosses. 
\$22. AN APPRECIATION OF TIIE LITERARY AND RELIGIOUS CHARACTER OF THE BOOK.

In view of the peculiar genre of Apocalyptic its literary aspect cannot easily be distinguished from its spiritual content. To some extent this is also true of the Stories in Dan., for as in the Visions we find here the elements of intentional art and fiction. But the two must be treated as separate compositions of different authors and times.

\section{a. The Stories.}

These stories have hardly been sufficiently appreciated as literature in the commentaries and the histories of Biblical letters; this in consequence of the devotion of almost all students to the polemic involved in the Higher Criticism of the bk. The writer would briefly express his growing admiration for these religious tales as examples of the story-telling art. Dan. has its ancestry in the classical Heb. literature, and also joins hands with an almost perished story-literature, that of the Aramaic. The latter survives only in the mutilated Ahikar Romance and the Story of the Three Pages in I Esd., but these are testimony to a wellestablished and artistically developed branch of romantic moralizing letters. The latter are Wisdom stories addressed to the more cultured ranks of society; those in Dan. are religious tales composed for the edification of the rank and file of the Jewish faithful. But they are admirable as examples of the short story; each one has its definite theme, and each is composed with notable dramatic art. Also this art is not monotonous in the choice of subjects nor in the development of the plot. The most striking and original of the compositions is the figure of the Image in c. 2, which deserves to be regarded as a notable creation, a veritable Frankenstein monster. The highly colored but sombre scene of Belshazzar's Feast, c. 5, a notable historical romance, comes next in power. Equally dramatic is the story of the discipline of Nebuchadnezzar, c. 4; the fall of human arrogance has never been better sketched in a few strokes. The stories of the Three Confessors, c. 3, and Daniel in the Lions' Den, c. 6, are more strictly hagiological; but they celebrate brave men of faith, and if the deus ex machina appears to solve the impasse of the right, we have to remember that from the 
Greek drama down a Providence has ever been invoked to effect the triumph of the good, for every great drama is a moral theme and so ultimately religious, whether in the background looms a Nemesis or the Living God. Withal the depiction of the characters, the weak point in Oriental romance, is made briefly indeed but with accuracy. Daniel, humble in character but self-possessed and dignified before kings, the Confessors, more shadowy saints but immortal for their defiance to the king, 'If our God can save us . . . but if not'-the several distinct characters of the three kings, all these stand forth as individuals. Even the minor dramatis persona, the royal officers in cc. I. 2, the Queen-Mother in C. 5, the artful conspirators in c. 6, are all appropriately limned. The stories are plainly, simply, compactly told; yet they are not artless, rather inspired by a withal natural and cultivated art, kunstvoll therefore, and it is a misunderstanding of what constitutes religious literature when apologists and critics ignore or depreciate the literary form of these stories.

In $\$ 20$ the Theology of the Book has been treated. Actually of more pertinent importance is the religion of the bk., particularly for cc. $\mathrm{I}-6$. On the historical side we see the Jews of the Golah, no longer hanging their harps on the willows, but bravely taking their place in the world and proving themselves the equals and superiors of their Pagan associates, not by reason of their race or human excellences, but through their constancy of character founded on faith and trust in God. They exercise themselves naturally and dutifully in the rites of their religion, while on the negative side they abstain from 'the forbidden things,' whether these be contaminated foods or false objects of worship. The bk. was written, it is often said, for the encouragement of the community; but it is equally an expression of the life actually lived by Jews who were 'the salt of the earth' at the end of the Old Dispensation, the men who preserved for later ages the illumination of the Lawgivers and Prophets. While they guarded that treasure, often 'cabined, cribbed, confined,' as we may think, they had, like every responsible age of religion, their own contribution to make. They faced a problem far more difficult, complex, apparently hopeless. than confronted an Isaiah or Jeremiah. In the Hellenistic age God's world had become a vast, unified, articulated Cosmos, in the Johannine sense, 
tremendously interesting, intellectual, artistic, beautiful, but also cruel and beastly, religious in the sense of superstitious, or else sceptical and atheistic, godless in sum. Supermen ramped over the stage, self-styled gods whom nations did worship to; the only worldly hope of escape from any one of these was in the usurpation of another like him. To this condition our bk. made answer, but not by a new theology; the bk. is founded foursquare on the centuries-old belief that 'God is king, be the earth never so unquiet.' But its contribution to religion lies in its formulation of faith 'in the Kingdom of God,' that men should 'know that the Highest rules in the kingdom of men,' $4^{22(19)}{ }^{1}$ To this there is added the corollary, arising from the logic of faith rather than of intellect, of God's necessary vindication of his cause in the world. 'This may take place in the way of human catastrophes, as in the judgments upon Nebuchadnezzar and Belshazzar. Or else the godlessness of the world drives the faith and patience of the saints to the breaking-point, and the transcendental action of God is demanded; this theme appears in c. 2, where the successive kingdoms of the world are represented as breaking down in a moment before the 'Stone cut without hands.' In this scene there is the kernel of the Apocalyptic of the later chapters, the reason why an apocalyptic series could be composed as a supplement to the Stories.

\section{b. The Tisions.}

Literary appreciation of this material is more difficult. ${ }^{2}$ The vision in c. 7 rises to a picturesque grandeur, due to the assimilation of ancient mythical elements in part, which however are freely and originally handled. The following visions are prosaic and rather arid, broken only by the more lively personal interludes of the Prayer in c. 9 and the overwhelming vision to the seer in c. Io, along with the concluding word of comfort at the end of c. I2. Indeed the symbolical disappears in the midst of the vision in c. 8, and after that there are only spoken oracles.

${ }^{1} C f$. Driver's excellent review of this theme, pp. $1 \times x x v-x c$. The 'ethical character' of Apocalyptic is presented by Charles, pp. xvi-xix, but Dan. is religious primarily rather than ethical.

${ }^{2}$ For literature s. $\$ 20$, nite I, to which shoull be added Gunkel's treatment of the mythologial clements ir Apocalyptic, and particularly in Dan. 7, Schöpfung u. Choos, $323-335$. 
We feel an increasing 'De profundis' motif in these visions: they are the reflex of the bitter stress of the times and move with a heavy-footed indignation. On the one hand, there is the horror of things as they are, with no hope in the world as it is; on the other, a grim determination of faith that God will interfere. And in this respect the faith was prophetic and the Religion was saved, although not in the terms of the prediction, as is always the case with both Prophecy and Apocalyptic.

There is a problem in these Visions which has concerned all students of Apocalyptic. How far have we in them genuine vision, how much, if not all, is artificial? Answer is obtained largely according to the various attitudes of students toward theological inspiration. C. 7 may be, as claimed by many, a learned composite of mythological motifs; c. II, according to Bousset and others, smacks of the student's study with its correct historical sequence. The present writer acknowledges that there is a predominant element of the intellectual and of the artificial in a certain sense; there is deliberate use of the facts of historical knowledge and of elaborated symbols. But this is art of the same kind as appears in Dante or in Bunyan's Pilgrim's Progre;s; it is primarily literary art. And this includes the artifice of ascribing the visions to an ancient Daniel, in which respect the Visions follow the Stories and an ancient tradition of that kind of literature. ${ }^{3}$ In this characteristic of artistic creation composed for written literature ('the Book,' I $2^{4}$ ), Apocalyptic differs from the elder Prophecy, which was oral and more spontaneous, only subsequently and in part committed to writing. Distinctly literary Prophecy appears first in Ezekiel, himself an apocalyptist; in the Second Isaiah we have a litterateur's composition, and this technically literary characteristic appears in all the subsequent Prophets.

On the other hand, the intensity and gravity of the theme produced a mental exaltation which at least by the composer was interpreted as true ecstasy or vision. He did not distinguish between his own materials and art and the illumination which came to him in the process of absorption in the quest of revela-

\footnotetext{
${ }^{3}$ Charles has again and again insisted that this artifice was necessary in order to procure a hearing after the P'rophetic Canon was closed; and Bousset is inclined to admit this motive (Offenbarung, 14). At the same time the literary mode of anonymity and then pseudonymity had long ago set in. Cf. $\$ 19, g$.
} 
tion. One feels a genuineness, subjectively speaking, in the visions of the Apocalypse and 2 Esdras, even as in Paul's ascent to the third heaven; and the same impression is given by the record of the visionary phenomenon in c. Io. In all these three bks. there is discovered a genuine personal touch which appears to reveal actual spiritual experience. At $10^{3}$ we learn of the practice of prayer and self-mortification in order to obtain illumination even as in 2 Esd.; and this spiritual discipline along with the resultant experiences has ever been native to the mystic's life. Apocalyptic will never be sympathetically appreciated until we bring it under the category of the poet and the seer. Psychologically literary and religious inspiration have very much in common, and the intellectual and artistic elements may not be discounted in religious inspiration. ${ }^{4}$ Our modern rationalism does not easily fancy Apocalyptic, but before casting it aside we should make an honest effort to appreciate it as genuine literature and as genuine religion. To be sure, a criticism that first of all will appreciate, will reserve to itself the right of discrimination; it will distinguish between the higher and the lower, the true and the false, for it must be borne in mind that mystical absorption in seeking the truth and the will of the Divine easily involves illusion. As Prophecy produced its exaggerations until at last the whole order of the Prophets fell into disrepute, so Apocalyptic had its rise and fall. But it is not just to condemn any one book for the faults of all the others. Dan. is the classical apocalypse of the O.T.; with all its peculiar literary art and its mystical practice of religion, it remains true to Judaism, and, more than this, it develops the latter legitimately in translating it into transcendental terms. Similarly the Church adopted only one of the products of its many prophets into its Canon, the Apocalypse of John. One such book in each Canon is sufficient, perhaps, but the two deserve their place in the proportions of the True Religion. Each visualized for its generation, in days of greatest stress for believers, the Kingdom of God as above all and to come on earth, and inspired a faith and comfort that was not disappointed.

\footnotetext{
${ }^{4}$ See the admirable Presidential Address by Prof. C. R. Bowen in $J B L$ 1925, $1 f f$., 'Why Eschatology?' On the literary characteristic of Apocalyptic see the writer's paper, The Education of the Seer of the A pocalypse, to appear in JBL 1926.
} 


\section{\$23. REVIEW OF TIIE LITERATURE ON DANIEL.}

In the Comm. at the end of cc. 2, 9, I I are given sketches of the history of exegesis of certain outstanding themes of the bk.; the reader is directed thither for more explicit statement. The following is a summary review. ${ }^{1}$

For early Jewish interpretation we are thrown back upon the N.T. and Josephus, Philo omitting all ref. to the bk. Jos. speaks of Dan. in the highest terms as one of "the greatest of the Prophets ... for he not only prophesied of future events, as did other prophets, but he also determined the time of their accomplishment" ( $A J \mathrm{x}, \mathrm{II}, 7)$ : and so 'Dan. the prophet,' Mt. $24^{15}$ (but not in the parallel Mk. $3^{4}$ ). Jos. interpreted the Fourth Kingdom as of Rome (although finding Ant. in the little horn of c. 8), but 'thought it not proper to relate the meaning of the Stone,' doubtless fearing offence to Rome, $i b$. and ro, 4. Policy thus kept him from expounding the bk. more fully, to our loss.

In the Talmud Dan. is spoken of as weightier than 'all the wise men of the peoples,' I'oma $77 a$. For Talmudic and other Rabb. references see Hamburger, $R E$ I, 224: in them he is presented in the highest terms as a saint and an example, but the allusions are of personal, not theological interest. The Medixval Jewish opinion appears to have been less favorable to Dan., this on the score of the technical distinction of the bk. from the 'Prophets,' and also probably because of the Messianic interpretation given to it by the Church. Both Maimonides, d. I 204 (Moreh Nebochim, 2, 4I), and Kimhi, d. I 240 (Pref. to the Pss.), ${ }^{2}$ distinguished between Prophecy and the Holy Spirit, valuing the former as far higher because it dispossessed the recipient of his natural faculties, while the latter is but an illumination, and Kimhi notes that Dan. was inferior to Isaiah, Ezekiel, and the other Prophets in that he could not 'maintain strength' $\left(\mathrm{IO}^{8}\right)$ when he awoke from his dreams.

The great Jewish commentators all interpreted the bk.: Saadia, 892-94I; Jephet, c. I000; 'Rashi' (Solomon b. Isaac),

${ }^{1}$ Cf. esp. Bertholdt, pp. I 56-162; Rosenmüller, pp. 38-51; Zöckler, Pref., § $\$ 5$. I 2 , with the fullest bibliography; and the admirable presentation in bried by Behrmann, pp. xliv-xlix. Knabenbauer's survey, pp. 57-6.4, is valuable for its inclusion o: the medixval and later Catholic literature. The Bibliographies in Wilson and Boutflower are useful for presentation of recent archxological discussion.

${ }^{2}$ See C. B. Michaelis, pp. $33 . t$. 
d. Iro5; Aben Ezra (Abraham b. Meir b. Ezra; s. JE s.v. 'Ibn Ezra'), d. Ir67; Isaac Abrabanel, d. I 508 (first printed ed. I497); Joseph b. Yahya, c. I 559. Of these Saadia's comm. has not yet been published. The 'Saadia' who accompanies Rashi and Aben Ezra since the Bomberg and Buxtorf Bibles (the texts followed in this Comm. are those in Mikraoth Gedoloth) has long been recognized as a much later composition and can only be cited as Pseudo-Saadia; but Aben Ezra frequently quotes Saadia's comm. and Jephet polemicizes against it. ${ }^{3}$ In the later Jewish exegesis there appears to have been a reaction toward the Mess. interpretation of Dan. (s. Note, end of c. 9). Of this development Abrabanel is an example in his work on Dan., on which remarks L. Ginzberg, $J E$ I, I 28: "He controverts both the Christian exegesis and the Jewish rationalism. ... In opposition to the Talmud and all later rabbinic tradition he counts Dan. among the prophets-but therein only agreeing with the current Christian interpretation. $\mathrm{He}$ is impelled to this by the fact that Danicl furnishes the foundation for his Mess. theory." Jephet is valuable as representing the Karaite exegesis; his comm. has been published in the Arab. with Eng. tr. by Margoliouth, I889. His observations are often acute and exhibit an ancient line of tradition; but $c f$. Margoliouth's judgment upon him as a commentator, p. viii. In the Comm. constant use has been made of Jephet, Rashi, Aben Ezra, with reference to Pseudo-Saadia. ${ }^{4}$ In addition to the commentators the Jewish lexicographers are valuable: the elemental work of Ibn Janâh, c. I050 (which has been consulted for the Heb. in the Comm.), and the Aruch of Nathan b. Yechiel of the I 2 th cent., which with the labors of Elias Levita lies at the base of subsequent lexicography. ${ }^{5}$ The immense debt of the Prot. commentation and vernacular Bibles to the Jewish commentaries is evident at every step in the exegesis of Dan.

\footnotetext{
${ }^{3}$ On Saadia's comm. on Dan. s. Malter, Saadia Gaon, 192 I, 325 ., and for PseudoSaadia H. Spiegel, Saadia al-Fajjûmi's arab. Daniclversion, 19o6, $13 f$., dating it at end of the I 2 th cent. as of North African origin. For Saadia's Arab. tr. of Dan. s. \$10, $e$.

${ }^{4}$ Rashi was translated by Breithaupt, I7I3, and b. Yahya by l'Empéreur, I 663 (the latter comm. I have not seen). A F. Galle has published selections from the comm. of 'Saadia, Aben-Ezra, Rashi, etc.,' I900, the 'Saadia' being the late commentary. Bibliography of other later Jewish comm. is given by Rosenmüller, pp. 38-40.

'The text of Ibn Janâh's Book of Hcb. Roots followed is that by A. Neubauer, 1875. The Aruch complctum has been published by A. Kohut, 1878 seq.
} 
In the Church the first commentator was Hippolytus of Rome, whose 'On Daniel,' written C. 202 A.D., has been published in full by Bonwetsch and Achelis; s. §Io, $f, \S_{1} 2, a .{ }^{6}$ The work is ardently hortatory, expectant of the Parousia, but its historical exegesis is sane and valuable. Origen's comm. has been lost but for 'a brief extract of his notes' (Salmon, $D C B_{4}$, I I). The Gr. tradition was carried on by Chrysostom (in homiletic manner), Polychronius the brother of Theodore of Mopsuestia, and Theodoret, the two latter representing the Antiochian school of exegesis. Polychronius' work, preserved only fragmentarily, ${ }^{7}$ is, on account of its objective, historical point of view, the most fascinating of all the Patristic literature on Dan. Hipp., Polych. and Theodt. have been particularly consulted for this Comm. The Syriac-speaking Church is represented by its great Father, Aphrem (Ephrem, Ephraim) of the $4^{\text {th }}$ cent., whose comm. on Dan. is a notable work. A commentary by Theodore of Mopsuestia, also translated into Syr., is now lost; s. $D C B$ 4, 940; Baumstark, Gesch. d. syr. Lit., Io3.

The prince of the commentators is Jerome. His work gains in value as it is primarily an apology against the Neo-Platonic Porphyry's attack upon the historicity of Dan., claiming that it was Maccabæan. This polemic purpose appears in the opening words of the Pref. to the comm. ${ }^{8}$ Jerome has done the service of preserving Porphyry's argument in very full form, often in citation, and the polemic has caused him to compose a very careful work. His comm. is intrinsically valuable for its constant dependence upon the tradition of the rabbis under whom he studied, and the work is a monument to the earliest stages of Jewish exegesis, as appears from its frequent agreement with the Mediæval representatives of the latter. Of Porphyry's work we know nothing further. His position as to the date of Dan. has been vindicated by most of modern scholarship.

Of the Mediæval commentaries may be noticed those of Albertus Magnus and Nicolas de Lyra. The In Danielem postillae

- See $\S 12$, n. 2, for monographs on Hipp. as commentator.

'Published by A. Mai in vol. I of his Scriptorum veterum nova collectio, I825. Mai also adds a catena of annotations (Commentarii iuriorum) on Dan. by other Gr. writers, Ammonius, Apollinaris, et al.

- He then notes that Eusebius, Apollinaris, Methodius had written apologies against this attack of Porphyry's, extracts Irom which are preserved only in Mai's catena, s. note above. 
attributed to Thomas Aquinas (Paris, I640) is not recognized as genuine by the editor of the sumptuous Leonine edition, Rome, I 882 seq.; s. vol. I, p. xcii. Of the Roman Catholic commentators after the Reformation many are cited in Pole's Synopsis criticorum, e.g., Pereira, Maldonat; for the I 7 th and 18 th centuries, e.g., Sanctius, Cornelius à Lapide and Calmet; we note also the merits of de Maîtres and Bianchini, s. §ro, $a$ (I). Recent Roman commentators of importance are d'Envieu, I888I89I, and Knabenbauer, I89I. The former work, in three vols., is an extremely apologetic and polemic treatment as against radical criticism.

The Protestant Reformation produced a flood of learned annotations and commentaries upon Dan. as upon all the Scriptures. The writer has depended for his knowledge of these great scholars upon the Critici sacri, London, I660, and Pole's Synopsis criticorum. They include, besides Luther, whose great contribution was his Bible translation, such names as Calvin, who dedicated characteristically brilliant lectures to Dan., S. Münster (whose influence on the English Version was very great), Geier, the illustrious Grotius (in some respects the father of the modern interpretation of Dan., and the first to introduce at length the parallels from Classical letters). For the $\mathrm{i} 8$ th cent. may be particularly noticed C. B. Michaelis, Wm. Lowth and Venema, along with the scholarly apparatus of J. D. Michaelis in his ed. of the Heb. Bible.

Meanwhile a line of radical interpretation had started in the I 7 th and early I 8 th centuries, denying in part or in whole the authenticity of the bk. and its traditional age. The partial criticisms of Spinoza and Sir Isaac Newton (s. \$2I, a) were developed by Marsham, Collins, Corrodi and others in the $\mathrm{r} 8$ th cent. (s. Note at end of c. $9, \$ 5$ ) and precipitated the fully formulated theory of the late, pseudepigraphic character of the whole book, presented by Eichhorn, the father of modern Biblical Introduction, and by Bertholdt (ISo6), the first commentator at length on these lines. Porphyry now came into his own. Bertholdt was followed, but with tempering of his rationalism and extravagances, by Rosenmüller (I 832), von Lengerke (I835), Maurer $(1838)$, Hitzig (1850-indulging in Persian origins), Ewald (I868). This radical position was however warmly contested, with the support of many doughty theologians, as Hengstenberg 
(1831), C. H. Auberlen (I854), Pusey (1864), Hävernick (1832he and von Lengerke are rich in allusions to Classical literature); Stuart of Andover (I 850 -the first American philological commentary on Dan., an exemplary work); Keil (I867-the extreme of the apologetic position); Kliefoth, Kranichfeld (both r $868-$ excellent commentaries); Zöckler (I 870 -a very sound commentary, with full bibliography, and the latest Protestant work with exposition of the elder interpretations).

In the '80's a fresh stimulus was given to the study of Dan. in its philological phase by Kautzsch's Grammar, and especially on the archæological side by the Assyriological discoveries. But most of the formal comm. (exceptions noted $\$$ I9, n. I) accept the radical position: Meinhold (I899); Bevan (I892-admirable for philological acumen and freshness); Behrmann (I 894-with very independent criticism); the American Prince (I 899-stressing the Assyriological point of view); Driver (I900-the fullest of recent commentaries, only limited as based on the Eng. text); Marti (rgor-all too brief); Charles (in the New-Century Bible); also A. Lambert (a brief Heb. comm.). To these should be added the series of select notes on the bk. by Graetz, r $87 \mathrm{r}$; Torrey, I909 and 1923 (s. Bibliography); and Ehrlich in his Randglossen, 19r4. For critical presentation of the text Kamphausen in Haupt's SBOT, r896, and Löhr in Kittel's Bible, I9o6, should be consulted: the former with admirably cautious treatment, the latter far more radical, in general following Marti's criticism.

Archæology has, however, inspired a considerable revival of the defence of the authenticity of the bk., with many extensive monographs, e.g., those of Wright, Wilson and Boutflower, which have been noticed at length in $\$$ I9 (for literature see there, note I); and that Section exhibits the reaction toward recognition of a far greater amount of historical tradition in the bk. than the elder criticism had allowed-a position maintained in this Comm. 

A COMMENTARY ON DANIEL。 



\section{THE HISTORIES.}

\section{CHAPTER 1. THE EDUCATION OF DANIEL AND HIS THREE COMPANIONS.}

(1) 1.2. The deportation to Babylon. (2) 3-7. The education of Daniel and his three companions in the Chaldæan sciences. (3) 8-17. Their piety. (4) 18-21. Their singular wisdom approved by Nebuchadnezzar.

1. 2. With this datum of a reduction of Jerusalem by Neb. in the 3 d year of Jehoiakim and the deportation of the latter and his court to Babylon, the narrator as briefly as possible links up his story with traditional events of the last days of the national life. There is no historical corroboration of such an event in the 3 d year of Jehoiakim, at which date indeed Neb. could only be called ' $\mathrm{K}$ ing' by prolepsis. Our prime authority, 2 Ki. $23^{36}-24^{7}$, assigns an I 1 -year reign to Jeh., recording that 'Neb. king of Bab. came up and Jeh. became his servant three years; then he turned and rebelled against him'; and the LORD sent against him bands of Chaldæans, Syrians, Moabites, Ammonites, to destroy Judah. But Jeh. did not survive the catastrophe; 'he slept with his fathers.' His son Jehoiachin capitulated to Neb. in person after a siege, having reigned three months. There ensued the despoliation of the temple and the deportation of the royal family and upper classes to Babylon. Also Jeremiah informs us with particular fulness about this period. The $4^{\text {th }}$ year of Jeh. is equated with the ist year of Neb., $26^{1}, c f .46^{2}$, acc. to which the latter's defeat of Necho at Karkemish occurred in the $4^{\text {th }}$ year; and c. 36 details the history of the writing and the fate of the first edition of the bk.

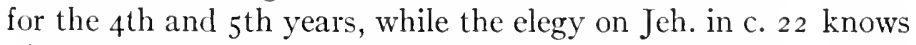
of no such catastrophe happening in that king's reign. But a further development of the history appears in $2 \mathrm{Ch} .36^{5-8}$, viz., that, without definition of date, Neb. came up against Jeh. and bound him in brass fetters 'to bring him to Bab.'; for this the variant and probably earlier text of $\mathrm{I}$ Esd. ${ }^{38}$ reads 'and led him to Bab.,' i.e., להליכi for. As was recognized by 
vLeng. and is maintained by most recent comm., this datum of Ch. has been combined with the 'three years' of Jeh.'s submission to Neb. in $2 \mathrm{Ki} .24^{1}$; ergo his captivity happened at the end of the 3-year term. This gradual midrashic expansion ignores the valuable data of Jer. The close dependence of Dan. upon Ch. appears in the almost exact equivalence of our v. ${ }^{2}$ with 2 Ch. $36^{7}$. 'Neb. also carried some of the vessels of the house of the Lord to Bab., and put them in his temple at Bab.', an identity which has actually affected the subsequent history of the text of Dan. and the Grr. (v. inf.). A rational motive for the shoving back of the date of the captivity to Jeh.'s 3 d year may be found in the probable desire to obtain the fulfilment of the exact 70 years of the Exile, 2 Ch. $36^{21}=$ Jer. $25^{11 \mathrm{f} .}$; so Curtis, Chron., ad loc., cf. Mein. But exact calculations are not to be attributed to our author but to tradition.

Support of this captivity of the $3 \mathrm{~d}$ year has been claimed from Gr. sources; e.g., by Heng., Authentie, 52 ff., and so modern apologists, Wright, Dan. and His Prophecies, c. 3 , §I, Wilson, Studies, c. 4. One unnoticed Jewish legendary parallel is found in Polyhistor, cited by Eus., Praep. ev., xi, 39 (from the Jewish historian Eupolemus, s. Freudenthal, Alex. Polyhistor, I6); after telling that King Jonachim had set up a golden image of Baal, the extract narrates how Neb. made a victorious campaign through Palestine, captured Jerusalem, took Jonachim alive, and carried off to Babylon the gold in the temple along with silver and bronze; this 'Jonachim' appears to be Johoiakim, but there is possible confusion with Jehoiachin. More important is the testimony of Berossus as cited by Jos., $A J$ x, I I, I $=C$. $A p .$, i, I9: Neb. was ordered by his father to chastise the rebellious satraps of Egypt, Syria and Phœnicia, which task he completed, annexing these lands to Babylonia (an anachronism indeed as far as Egypt is concerned). Then hearing of his father's decease, he set out on a forced march across the desert to receive the crown, and ordered the captives, Jews, Phœnicians, Syrians and Egyptians, to be sent on, and these he colonized in Babylonia. This statement is arranged anachronistically by Jos., who makes it follow another extract from Berossus telling of Neb.'s capture of Jerusalem and its destruction by fire, i.e., the event of 586 . But in the former passage there is no reference to a capture of Jerusalem or captivity of Jehoiakim. Operations 
of Neb. in Syria-Palestine in the $4^{\text {th }}$ year may correspond with the datum of Chaldæan and other troops that attacked Judah acc. to $2 \mathrm{Ki} .24^{2}$. Jos. by no means draws the conclusions of modern apologists. Acc. to $A J \times, 6$, I, after the battle of Karkemish Neb. "took all Syria as far as Pelusium except Judæa." In the same chap. Jos. records that later, at the end of Jeh.'s reign, Neb. came against the latter, took Jerusalem, slew Jeh., and had his body cast outside of the walls (itself a perversion of history, dependent upon 'the burial of an ass' that was to be Jeh.'s fate acc. to Jer. 22). As an example of Jos.'s absolute unreliability at times it may be noted that he makes Dan. and his friends captives of the captivity of $586, x$, IO, I, deliberately ignoring the datum of Dan. that they were taken captive in 606; i.e., Jos. is no witness for apologetic on this point.

Commentators have been ever embarrassed over this $3 \mathrm{~d}$ year. Ra. makes the $3 \mathrm{~d}$ year the last of the three years of revolt, Jeh. 'dying under Neb.'s hand'; and so AEz., PsSa., Jeph. The Christian tradition following the unfortunate identification by

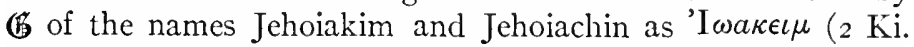
$\left.23^{36}-24\right)$ blundered through the royal succession of this age. Mt. $\mathrm{I}^{10 \mathrm{f}}$. identifies the two under 'I $\epsilon$ ovías, despite Jerome's argument against Porphyry that two kings are required here. Hipp., i, $2, \$ \S_{3} .6$, is in utter confusion as to the series of kings and their names; in $\$ 6$ he identifies the three years with the three months' reign of Jehoiachin. Jer. gives to both kings the one and the same name Ioacim, but is obscure as to his deductions. The early Prot. comm. were equally troubled, proposing many of the exegetical devices since attempted; e.g., Grot. suggested that eight years of Jeh.'s reign were discounted because his captive brother Jehoahaz was still alive for that term. The Cath. Mald. and the Prot. CBMich. fall back upon the Jewish identification of the three years with the term of Jeh.'s revolt. Heng. maintained the unvarnished credibility of the datum, followed by many; their arguments are most completely stated by Klief., pp. $49^{-69}$, and Keil, pp. $4^{6-56}$. Of the points made may be noted: Berossus' statement (made to imply a reduction of Jerusalem); a prolepsis in Neb.'s title as king ( $c f$. Wilson, c. 5); denial that $\leqslant$ means 'arrived at' but rather 'started to go' (so Kran., Keil, Knab., as particularly correct if the writer were in Babylon); insistence that Jeh. was only taken prisoner, 
not removed to Bab. All other recent comm. reject the historicity of the datum, with exception of Behr., who holds to the taking of Jerusalem on Berossus' testimony without further elaboration. All secular historians, Rawlinson, Meyer, Winckler, Rogers, ignore or condemn the datum. For the Winckler theory that Jeh.'s $3 \mathrm{~d}$ and 4 th years may have coincided in part with Neb.'s rst year s. the chronological table given by Dr., p. xlix.

In $\mathrm{v} .^{2}$ the narrator assumes the capture of the city and proceeds to detail its two chief consequences for the subsequent history: the captivity of the Jewish king, which prepares us for the appearance of youths 'of the royal family,' v.4, and the desecration of the sacred vessels by Belshazzar, c. 5 ; however, the $\mathrm{v}$. is but a duplicate of $2 \mathrm{Ch} .3^{6 \mathrm{f}}$. But the clumsy condition of the $\mathrm{v}$. in $=\Theta$ has been recognized by all comm. If the accusative in 'he brought them' refers both to the king and the vessels, there arises the absurdity that the captives were brought into the king's temple; if it refers to the vessels alone (so $\Theta$ $a \dot{v} \tau a$, I $e a$ ), then there follows the repetition that they were 'brought into the treasure-house of his god.' But orig. (5 reveals

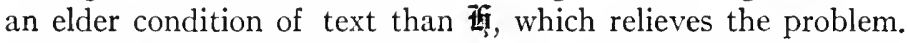
On Hexaplaric testimony 'the house of his god' in v. a was not read by $\mathbb{B}$ (s. Note); the Hexaplaric insertion in $\mathbb{B}$ is taken bodily from $\Theta$, producing an awkwardness in the text as revised. The insertion of 'in the house of his god' in our 得 was prob. due to the interpretation of 'them' as neuter, with the VSS, along with reminiscence of $2 \mathrm{Ch} .36^{7}$, 'and he put them in his temple in Bab.' This induction from $\mathfrak{B}$ agrees with the elision of the phrase by Dr., Mar., Löhr, Ehr., Cha. Pr. (and so Mald.) preserves the text by supposing that the questionable phrase refers to a triumphal presentation in the temple; but this luxurious note is out of place. Behr. without any textual authority בית אלהייו would delete the whole of v. as 'the land of his god,' and cft. Hos. $8^{1}, 9^{15}$. While the Jewish comm. admitted the captivity of Jehoiakim and against the VSS correctly regarded the obj. as including the captives, some of the apologetic school of the igth cent., e.g., Häv., Keil, Zöck. (so also Rosen., vLeng.), confined the obj. to the vessels alone so as to avoid the deportation of Jeh. to Bab. There still remains a certain inconcinnity; 'them' must imply Jeh. and his family 
and entourage; but the implication is so clear that it is not necessary with Ew., Ehr., to suppose that some phrase expressing the large circle has fallen out.

The initial sentence in v. ${ }^{2}$, "the Lord (Adonai, on which s. Note) gave into his hands' is a statement of the divine Providence ordering the tragedy. 'The house of God' stands in the Chronicler $\left(c f\right.$. inf. $\left.5^{3}\right)$ for the earlier 'house of Yнwh.' 'Shinar' is archaizing, despite Mar., as it is in Is. $\mathrm{II}^{11}$, Zech. $5^{11}$; it is well chosen as denoting the land of the arch-rebel Nimrod, Gen. $10^{10}$, and of the Tower of Babel, which is the antithesis of the theme of Dan. In v. b the disposition of the sacred vessels is briefly recorded; they were placed in the treasure-house of Neb.'s god. The sing. mng. of אלהים is to be preferred with $\Theta \mathcal{H}$; but $\mathfrak{B}$ understood it as pl. with the nice word $\epsilon i \delta \omega \lambda \epsilon \hat{\imath} 0 \nu$. The former view is supported by $4^{5}$, where 'Belteshazzar' is interpreted by Neb. as 'according to the name of my god,' obviously, Bel, $c f$. Bel and the Dragon, v. ${ }^{3}$. The later Paganism was henotheistic. בית אלהים means 'god-house,' so Ju. I $7^{5}$, and either 'Gotteshaus' or 'Götterhaus.' Every temple had its treasure-chamber, the sacred things of even a conquered religion being still holy; hence Belsh.'s act in c. 5 was a sacrilege even to Pagan eyes. $C f$. the similar account of the deposit of these vessels in 2 Ch. $36^{7}$, Ezr. $5^{14}$. The plundering of these stores of booty was a constant aim of conquerors. Aph. Syr.'s view, followed by Theodt., Häv., al., that Neb. desired to honor the vessels of God by bringing them into the presence of his gods is a vagary, answered for the Jewish mind by Ra.: he brought them there 'to praise his false gods.'

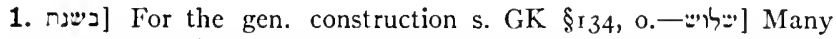
MSS defective.-. מיכור.] A formation of ancient Heb. usage, e.g., Nu. 24,

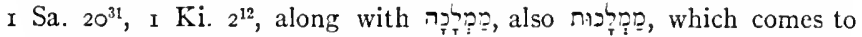
predominate under Aram. influence in the Hagiographa and NHeb. For the vocal swa ? of. מרורות I Sa. 2030. The term is not otiose with the following 'king,' as 6 feels; it refers to the royal era, the first year of which began in Assyria and Babylonia with the first New Year's day after the accession.-K2] As noted above, some comm. insist that this vb. can mean the inception of the action; e.g., Gen. $45^{17}$, Jon. $I^{5}$. But it seems absurd to hold that this very curt passage made a distinction between the moments of starting and arrival.- גבובדניצר]

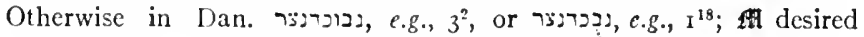
to use the fullest spelling at the first occurrence of the word. The 
correct form, גבוכרראיגר, is found only in Eze. and sections of Jer. (also here in Ken. 245), strangely enough failing here, if Dan. be a contemporary document. For the Gr. forms s. BDB, GB, and Schrader, ZPT I 881, 6I9ff.; the forms with-n-for $-r$-are found only in the Jewish tradition (Berossus in Eus. has - $n$-, but after the Eusebian spelling). For the frequent division of the word into two parts in many MSs, so also here, נבוכר נאצר, see Elias Levita, Masoreth ha-masoreth, ed.

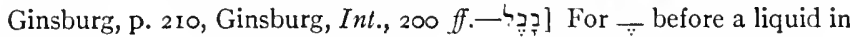

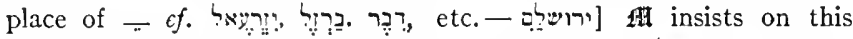
Kre perpetuum except in the Aram. sections, where צור: s. GK \$72, t.-2. ארני] Many Mss יהוה ארני 245 ירוה Jahn Ken. Jahn restores here יהור, but, except in the Prayer, c. 9 and its introduction $v^{3}$, the bk. always uses האילהים, and presumably this was read originally here. But the identification of the deity was required and this was fixed by the Kre אר, which then entered into the text. Similar indifference as between יהוה appears in later Jewish literature, e.g., the Targums, where the abbreviation of יהוה is used for the Bibl. איה: so also in BSira, $c f$. the equivalents for xúpros in

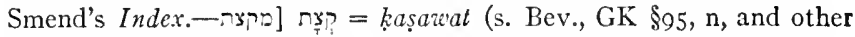

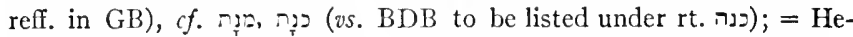
braized word confusion occurs (s. GB s.vv.). The word is partitive here (otherwise at $\mathrm{v}^{5}$ ), as at Neh. $7^{70}$, and like and has the same use in $2^{42}$ (Aram.). The partitive use of nsp is common in the Talmud, s. Jastrow, s.v. The corresponding word in $2 \mathrm{Ch}$.

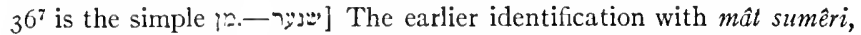
'land of Sumer,' South Babylonia (so e.g., Pr.) is now largely doubted; s. GB s.v. But to the Jews it meant Babylonia, as $\boldsymbol{B}$ reads here and Zech. $5^{\text {11 }}$. The Jewish terms for Babylonia are 'land of Babel,' Jer. $5 \mathrm{I}^{29}$,

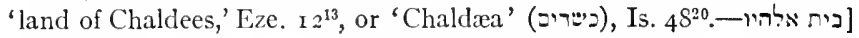
It has been observed above that this phrase was not in orig. $\mathbb{B}$ nor

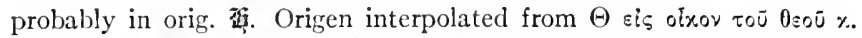
$\tau \grave{\alpha}$ oxeún; in $\mathscr{G}^{\mathrm{G}}$, but not in $\mathcal{G}^{\mathrm{S}}$; there is prefixed to this the doublet gloss

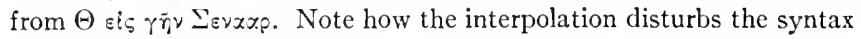
of (5. ואת הכליכ was indeed in 6's Heb. text, but it was omitted as the previous object 'them' was understood by $\mathbb{B}$ to refer to the vessels. As it stands, ביז איהיו is locative. If the rdg. of $B Q^{*}$ otxou be accepted as $\Theta$ 's, then Shinar was regarded by $\Theta$ as the name of the temple; but all other representatives of $\Theta$ have o:xov, expanded in Hexapl. texts into

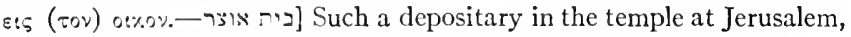
I Ki. $7^{51}$; also read $ר$ אוצ for for 7 at Zech. $13^{7}$. The term = Akk. bit nișirti. For derivations of אוֹ s. GB; but poss. nușâr $>u(n) s ̧ a \hat{r}>\hat{s} s ̧ a ̂ r$. Strangely cnough A $\mathrm{Q}^{*} 23$ om. Oroxupou-by haplog. with 0sou autou?-(6)'s 


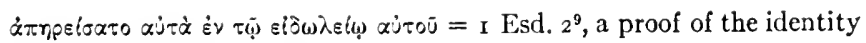
of the translator.

3-7. The education of the youths. 3. The king orders 'his Chief Eunuch' to introduce into the court certain high-born youths of the Jewish captives in order to educate them as royal pages, in line for such promotion as their abilities might deserve. Throughout history this has been the honorable destiny of aristocratic captives; it was doubtless the lot of the family of Jehoiachin, $2 \mathrm{Ki} .25^{27 \mathrm{ff}}$, as evidenced in the favor shown to Zerubbabel, whom I Esd. $3^{4}$ treats as similarly a royal page,

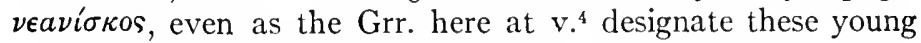
men. The Chief Eunuch is simply the majordomo; it is not necessary to draw the conclusion that the youths were made eunuchs, as Jos. hints: "he made some of them eunuchs," nor to combine the ref., after Theodt., with the alleged fulfilment of Is. $39^{7}$. The Pers. heir apparent was brought up by eunuchs; s. art. by A. V. W. Jackson, cited below at v. ${ }^{5}$. But the notion in Jos.'s mind had its corroboration in many cases, e.g., without doubt, Nehemiah; $c f$. the condition represented by Is. $56^{3}$ ff. Jewish tradition agreed with Jos., as Jer. indicates, and was continued in Targ. Est. $4^{5}$, where the eunuch Hatak is identified with Dan., Iarchi ad loc., Epiph., De vita proph., x (these passages cited by vLeng., p. xcrii). But AEz. denies that the three youths were eunuchs: they were not to stand before women but before the king, while that condition would be a blemish contradicting $v .^{4}$, involving a diminution of mental ability. The understanding of $\mathrm{v} .{ }^{\mathrm{b}}$ depends upon the number and kinds of classes to be distinguished. $\mathbb{6}$ and $\Theta$, each with an exegetical plus making the first class definitely of the Jewish captivity, distinguish three classes: Israelites, members of the royal family, and nobles, the latter two classes being by implication Babylonian. But the objective of the story is the fate of the Jewish captives solely. Jeph., CBMich. find three classes: (I) ' $\mathrm{ex}$ filiis Israel promiscuae sortis'; (2) royalty; (3) nobles; but this arrangement is not orderly. 'Israel' is applied to the laity in contrast to the Levites, as indeed AEz. understands 'Israel' here; but the distinction is not used as between secular classes, with exception of possible appeal to Hos. $5^{1}$. It is best, theretore, acc. to a Sem. usage, and following Jun. and Trem., Bert., 
Behr., Mar., al., to regard the $2 \mathrm{~d}$ and $3 \mathrm{~d}$ conj. as correlative, i.e., 'Israelites, both of the seed royal and of the nobles.' The use of the Pers. word פרתמשים for Jewish gentlemen is not contradictory; it may represent actual courtly use, or be affectation of a high-sounding term, like our 'grandees'; so Ra. capitally interprets, דובטים 'duces,' and Sa. 'patriarchs,' a Syr. Church title. Jos. at once assumes that the youths of the story were of the royal family 'of Zedekiah,' and so Theodt.; so constant later Jewish tradition, s. Hamburger, $R E$ I, 'Daniel,' at end. But this is as much surmise as the notion that Dan. was a priest, $\mathbb{G}$ Bel $^{1}$.

4. The persons to be selected were boys, i.e., of teachable age, of perfect physique and comeliness, with mental powers approved by their primary education, so that they were wholly competent to take their part in the king's court. The stress lies, as naturally in a Jewish story, on the intellectual training. The three phrases used of the youths' mental qualifications are simply accumulative and do not permit analysis into distinct mental functions; it is therefore difficult to give a satisfactory translation of the Sem. rhetorical idiom (s. Note). It is a question whether the three ppls. are to be understood as futuritive ( $c f$. GK $\S I$ I , d) with some comm., or as qualities already acquired, with others. Grot. thinks of their education in the Law, the wisdom of Solomon, etc., but Jeph. properly denies that the king had any use for that sort of wisdom. But it is best with the Jewish comm. (so Sa. very positively in his tr.), to refer the ppls. to the past, of the preliminary humanistic education. The mng. of 'letters and language of (ancient) Chaldæa' has been made clear only since the discoveries in Assyriology, which were only slowly applied by the comm. to the elucidation of the phrase. Keil ( 1869 ) first among the comm. noted the possibility of understanding by it the language of the cuneiform script, and Knab. and Pr. still more positively insisted on the identification, followed by their successors, exc. Mein. There must have existed a wide-spread popular tradition of the ancient hieroglyphic

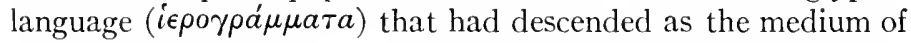
the Chaldæan sages; its monuments with its cabalistic script were still in the public eye. Pliny names three cities famous at a late date for their 'Chaldæan learning,' Hist. nat., vi, 30 , Babylon, Warka, Hipparene; $c f$. Strabo, xvi, I; and for the late sur- 
vival of the cuneiform languages s. Int., $\S \mathrm{I} 9, f$. The parallel to the letters and wisdom of the Chaldæans is found in 'all the wisdom of the Egyptians' in which Moses was educated, Acts $7^{22}$, a common midrashic notion. As in the latter case reference was not to the vulgar Egyptian of the day, but to the hieroglyphic language, so the tradition here concerns not the Bab. vernacular of later times, but the mysterious language of the past surviving only among adepts. Had the writer meant Aramaic he would doubtless have said so; but there would have been no point in his insisting on a culture in that tongue. So Nicolaus of Damascus reports (Müller, Fragm. hist. gr., frag. 67), that "Cyrus was versed in the wisdom of the Magi," as well as trained in the arts of a gentleman. The query concerning the identity of this Chaldæan language is an ancient one. The most ancient interpretation (Jos. speaks only of the wisdom of the Chaldæans, not of the language) identifies it with the Aram. dialect, which is taken up at $2^{4}$; Jer. in his Pref. to Dan. calls this language chaldaicus sermo; and so in Pref. to Kings he identifies the Syrian and Chaldaic tongues. However, in his comm. here he discusses Philo's opinion that Heb. was the same as Chaldee, as Abraham came from Chaldæa; but he inclines to the opinion of others that Abraham knew two languages. This identification was Jewish, appearing prob. in the Talmud (s. Dalm., Gramm., p. 3), and was held by AEz., who interprets the Chaldæan language and the Aram. as the tongue of the king. Until the rise of Assyriology this view remained the prevailing one.

Jeph.'s comment on this assembling of cultured men at the royal court is pertinent: "The king's object was twofold: to gratify his fancy for men of knowledge; and to be able to boast that in his court are the greatest men of the world." Elder comm., e.g., Rosen., Häv., illustrate from a similar practice at the Sublime Porte. The royal court of letters played its part in ancient antiquity as well as in later civilizations; the Epistle of Aristeas represents the Jewish tradition of Ptolemy II's intellectual coterie of scholars; the Story of Ahikar proved how valuable the trained thinker was to the king in his political emergencies. It became a later problem how far Daniel and his friends practised these heathen arts of the Chaldæans. Chrys. argues that no blame lies in learning but only in the use, and Geier similarly holds that we must distinguish between theory 
and practice, that a knowledge of magic is useful in order to counteract it. Calv. more positively decides that Dan. would have made short work with any superstitions just as he did with the unclean foods. But the story stands for the readiness of the Jews to accept secular education, as all through their history, without despite to their religion; $c f$. the story of Joseph.

5. As cadet members of the court the youths were taken on the budget of the royal ménage and given a stated assignment of food and drink from the royal commissariat. A technical Pers. term is used of this gratuity, = 'assignment, appropriation,' and while the elder tr. 'portion' (AV JV) rests primarily on an erroneous Jewish etymology, it is more accurate than 'dainties' (RVV) or 'delicacies' (Dr.), although by implication such fare must have been of superior quality. The Gr. fellow derivative, $\pi \circ \tau i \beta a \zeta_{\iota s}$, was used of honorific gifts from the royal table. Also the gift of the 'royal wine' ( $c f$. Est. $\mathrm{I}^{7}$ ), the indispensable drink of the Persians, is specified. Dr. cft. for these honorary gifts of food, Gen. $43^{34}, 2$ Sa. $11^{8}$, 2 Ki. $25^{30}$. But the Pers. court far exceeded all its predecessors in lavish entertainment, and both Est. and the Gr. writers report the tradition of the opulence of the feast and of the regular support of innumerable guests at the royal table - a proof that the Pers. customs are in mind, not the Bab., as Hengst. argues, p. 335; s. Rawlinson, $S G M$ 'The Fifth Monarchy,' c. 3. The youths were to be given the normal three years of training acc. to the Pers. system. See vLeng. at v. ${ }^{4}$ for the Gr. notices on the education of the Pers. youth; acc. to Plato, Alcibiades $I, \mathrm{I} 2 \mathrm{I}$, the higher education began in the I 4 th year, and Xenophon, Cyrop., i, 2, assigns a limit above this at the 16 th or $\mathrm{I} 7$ th year. This triennium has its origin in the Avesta $\left(S B E^{2} 4\right.$, 3I I ff.): "How long a time of a year's length shall a student go to a master of spiritual learning? For a period of three springtides (years) he shall gird himself with the holy education"; s. A. V. W. Jackson's excellent article on 'Pers. Education' in Enc. of Education, which gathers all the material on the subject and fully illustrates our story. Much later in the old Pers. territory a three years' course was the vogue in the famous Nestorian school at Nisibis; s. Baumstark, Gesch. d. syr. Literatur, II4; Labourt, Le christianisme dans l'empire perse, 297.

6. The four heroes of the following Stories are now introduced. 
They are said to belong to the preferred tribe of Judah; were they of royal blood, as later tradition claimed (s. at $\mathrm{v}^{3}$ ), this would have been noted. A failure in historic verisimilitude appears in the absence of patronymics. The four names occur predominantly or solely in late bks. of the O.T.; all four appear in Neh. On Daniel s. Int., $\S 2$ and Note inf. 7. The Chief Eunuch signifies the adoption of these aliens into the court by giving them native names, which naturally contain elements of the $B a b$. religion. This change of name was a requisite for members of the court, and has its Bibl. precedent, as AEz. notes, in the change of Joseph's name ( $c f$. Dr., $D B$ ii, $773^{b}$ : Erman, Life in Anc. Egypt, p. 5I7). We have so to explain the names of Zerubbabel, Shenassar and Sheshbassar, who were prob. brought up in the royal court. In any case there appears to have been but small objection on the part of Jews to the adoption of heathen names; Esther and Mordecai have their parallels in the papyri and in all Jewish literature. This tendency long preceded the subtle Hellenization of the $2 \mathrm{~d}$ cent. Indeed the Jews, except possibly in periods of reaction (e.g., at present Jews returning to Palestine are adopting Heb. names), have never stickled at foreign names, even those with heathenish implications: see Zunz, 'Die Namen der Juden,' in Gesammelte Abhandlungen, vol. 2. In Dan.'s cognomen Bêlțešaşsar the Akk. word is evident as Balâtsu-ușur, 'Protect-his-life!' (or with some, Balât-šar-uṣur, 'Protect-the-life-of-the-Prince!'). Strangely enough Jewish tradition has vocalized this so as to insert the name 'Bel,' to agree with $4^{5(8)}$, acc. to which Dan. was named after Neb.'s god, i.e., Bel. If the writer meant to include 'Bel,' then he did not know how to analyze Bab. names. But there are other traditions of the vocalization of the name; so with Belittšâșâr, i.e., as compounded with Bêlit, the paredros of Bel (but based on the Gr., not the Sem. spelling, which requires $t$, not $t$ ). The Grr., which $\mathfrak{I}$ followed, identified the name with that of King Bêlšașşar, ren-

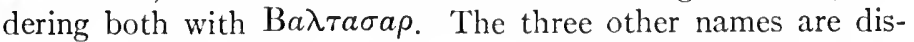
guised. The third doubtless stands for original 'Abed-Nebo,' 'Servant of Nebo'; Šadrak is prob. perversion of Marduk; Mếsak has not been explained. The outlandish heathen names of Babylonia were sardonically played upon by the Jewish tradition. The theophoric elements Marduk and (his father) Nebo are characteristic of the later Bab. religion: s. Jastrow, Rel. Bab. 


\section{u. Ass., I, c. 14. In the Apocryphon in c. 3 these Pagan names} are discarded.

3. ויאפר in the mostly late mng. 'command,' as in Arab.[יש:] Despite Cheyne's gratuitous condemnation of the word, $E B$ s.v., and the comparison or identification with אי איכני Gen $10^{3}$ (Hitz., Cheyne), following unconsciously Jos.'s precedent with his 'A $\sigma$ \&\&nns $A J \mathrm{x}$, 10, 2, the name occurs as $1200 \mathrm{~s}$ in an incantation text from Nippur published by Myhrman in the II ilprecht Anniversary Volume, 345,346 , republished in my Aram. Incant. Texts, 145 . With the name should be compared $A s ̌ p a z a n d a$ in Clay, $B E \mathrm{x}$, p. $4 \mathrm{I}$. For elder views s. Rosen., vLeng., the latter with Rödiger's suggestion of Pers. aspa-nâsâ, 'horse-nose.' Justi, Iran. Namenbuch, 46, connects with Syr. ašpiza, Mand. šapinza, 'post-station,' NPers. siphanj, which can mean 'guest.' See Nestle, Marg., 38, with a possible ancestry from Lat. hospitium (!). Prof. A. V. W. Jackson and Dr. Gehman have kindly examined the word for me and report no satisfactory results. (5's ' $\Lambda \beta \iota \varepsilon \sigma 5 p_{\text {? }}$ is due to identification of this officer with

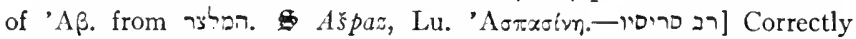
the Grr., 'his chief eunuch,' i.e., chamberlain. For various titles in the Oriental court compounded with rab s. Meissner, Bab.u. Ass., I, 31; these compounds spread in the WSem. world, s. Lidz., $N E$ 366. Aq. pedantically, 'teacher of the eunuchs.' This title appears also $2 \mathrm{Ki}$. I $8^{17}$, Jer. $39^{3.13}$, and in CIS ii, no. 38 (687 B.c.); cf. Phœn. רבסרכרכ ("exalted chief eunuch'?), Lidz., l.c., Cooke, NSI no. 2I. Sarîs appears in Akk., Del., Hwb., 694, and Jastrow has demonstrated the same mng. for $\zeta a r \xi e ̂ n$ in the Ass. Law Code, JAOS 4I, 18. Haupt, $J B L$ i9i6, 32I, explains 10 as a Safel of 0 , 'with the testicles mashed.' But Winckler, Jensen, al., prefer to find in 'o $\xi a$ rȩ̂̌i, 'Vorgesetzter,' s. GB, Manitius, $Z 124,109, \mathrm{n}$. I. The phenomenon of high military officers bearing the title appears to have raised doubts whether it meant primarily 'eunuch.' But it is easier to think of the latter word developing into the mng. of an official title than vice versa. Ancient evidence points to the use of 'eunuch' as of a royal minister, and in Test. Joseph, 7, the eunuch Potiphar is not only married but has children. (On the other hand, Burton records that the actual eunuchs in Mekka have wives.) Further, eunuchs often distinguished themselves both in political and military affairs. Apart from the probable case of Nehemiah, I note what Olmstead says, II ist. of Ass., I 53, of Daiian-Ashur, Shalmaneser's great vizier, remarking that a large proportion of highest officers, many of the military commanders, etc., on the testimony of the reliefs were eunuchs, and that "there is good reason to believe that D.-A. was one of these unfortunates." A general, Bagoas, of Ochus' expedition 
against Syria was a eunuch (Schürer, $G J V$ 3, 233, n. 22). Sevcral such cases may be cited from Byzantine history, e.g., the illustrious commander Narses._- להביא] 'To introduce,' not 'to bring' from Judah, with CBMich.-_מנגי יישראי] The theocratic name of the people is employed (Hitz.) after the prevailing use of the Chronicler, unlike Neh.'s Memoirs and Est., where 'Jews' is used (s. Torrey, Composition, 35, for these terms in Chr.); all the Twelve Tribes are ideally included. At v. ${ }^{6}$ the selected youths are described as of Judah. (\$S inserts '[of the sons] $\tau \bar{\omega} \nu \mu \varepsilon \gamma \_\tau \dot{\alpha} \nu \omega \nu$ [of Israel],' and $\Theta \tau \bar{\eta} \bar{s} \alpha i \chi \mu \alpha \lambda \omega \sigma i \alpha \varsigma$. Blud., p. 51,

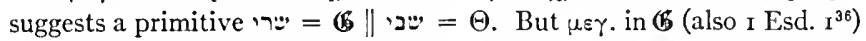
appears to be an attempt to obtain a grading in the three classes. Megistani became the official designation of Parthian grandees (Suetonius, Calig., v, Tacitus, Amm., xv, 27, cf. Mommsen, Röm. Gesch., 5, 343 f.), and possibly $\tau$. $\mu \varepsilon \gamma$. is a doublet to $\dot{\varepsilon} \pi \lambda \varepsilon \kappa \tau \omega \nu=$ Pers. הפרתמ. $\Theta$ 's $\ldots \alpha i \chi$. is an insertion from $2^{25}$, and may be exegetical, as $v .^{2}$ speaks only of the captivity of the king.correlative, 'both . . . and,' with Jun.-Trem., Bert., al.; cf. $7^{20}, 8^{13}$, Gen. $36^{24}, \mathrm{Ju} .6^{4}$ (other cases BDB $253 a, \mathrm{~GB}$ i $89 b$ ). Some mss om. $11^{\circ}$.

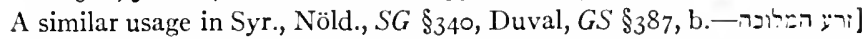
$=2$ Ki. 25 $25^{25}$, etc.- 2 ] Est. $\mathrm{I}^{3}, 6^{9} \dagger$; = OPers. fratama, 'foremost'; the etymology first proposed by Anquetil de Perron and von Bohlen (s. Rosen.), anticipated by Jun., Geier, al., in comparing Gr. words of similar origin. See Lexx. and Paton, also Tisdall, $J Q R$ 4, 97. $\Theta$ transliterates: (G) $\dot{\varepsilon} \pi \dot{\hat{\varepsilon} \times \tau \omega \nu, ~ ' s e l e c t e d . ' ~ A q . ~ i n ~ h i s ~}$ first ed. (s. Field, i, p. xxiv seqq.) had acc. to Jer. Eंx $\varepsilon \varepsilon \tau \bar{\omega} \nu$, but in the second ruparviv, and so 11 tyrannos. Similarly $\Theta$ for ארנריא $3^{2.3}$

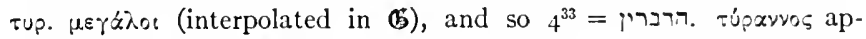
pears elsewhere in $\mathbb{G}$ as tr. of 2 ב $42^{17}, 2$ Mac. $5^{8}$. This is doubtless a Pal. reminiscence of Philistine

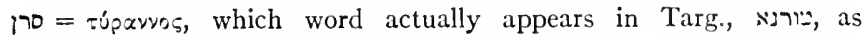
equivalent for 170 , e.g., Ju. $3^{3}$; in Targ. Is. $34^{7}=$ אביר. Also the Syr. Clemens Romanus, p. 24, 1. 24 (ed. Lagarde) uses this word for the Heb. Judges in contrast with kings. Aq. thus interpreted the word with a

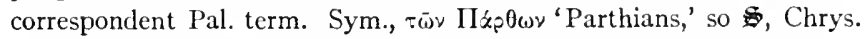

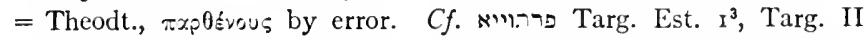
Est. 6', ed. Lagarde, = פרחמיכ. The anonymous 'Hebrew Interpre-

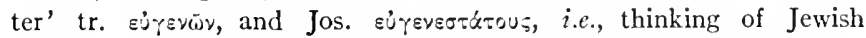
nobles. The word came down from Pers. court language and apparently survived as designation of nobles. Cf. a Pers. title of like origin, ברתברא on Gr. coins of Persia, s. Hill, Gr. Coins of Arabia, Mesopotamia and Persia, p. clxiv seq.; that is, these titles survived to a late date.

4. ירילי] Grr. vexvic\%sus, as of the Three Pages, I Esd. $3^{4}$ f; below 


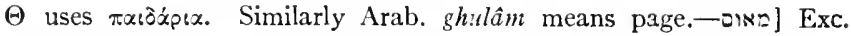
here and Jer. $3 \mathrm{I}^{7} \mathrm{H}^{\mathrm{Oc}}$ always It is best with Torrey, Notes, II, 229,

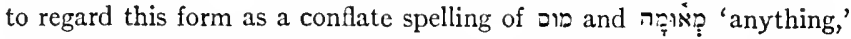
and so to hold them apart. See Lexx. for proposed derivations: the two as identical, מאוס = 'spot' (so most recently $B L 528$, s), or as distinct words, which is far preferable. For מאומה (cf. Akk. indefinites, mamma, mumma, etc.), cf. Arab. mahma, 'whatever' <ma-hu-ma (s. de Sacy, Gram. arabe $2, \mathrm{I}, \mathrm{I} 95)=$ Heb. $m a-(h) i \mathrm{i}-m a$; this derivation avoids the objection on ground of accent lying against Ges.'s derivation (Thes.) as from מה ומה. Jewish lexicography is uncertain, Jastr. s.v. שוכ; but the Jewish comm. here as 'blemish,' and so Sa. in his tr. $(\mathbb{G} \Theta$ imitate

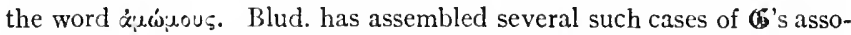

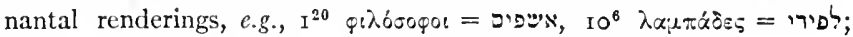
cf. Dr., Text of Sam. ${ }^{2}$, at 54.- טוכי מראה] Not archaistic, 2s. Behr., Dr.;

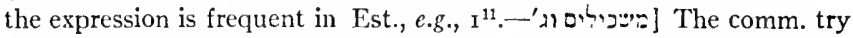
their hand at obtaining exact specifications and a logical order in these three phrases, e.g., Hitz., but many confess it cannot be urged too far (e.g., CBMich., vLeng.). But it is best with Behr. to regard the phrases as superlatives, or rather cumulatives. $C f$. הכבמת כינה v. ${ }^{20}$, and the synonymity of these rts. in $2^{21}$. The terms here are reversed inf. v. ${ }^{17}$. Sem. diction abounds in the heaping of adjectival clauses to produce not an analytic but a single effect; e.g., frequently in the Arab. philo-

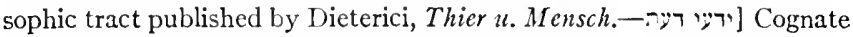

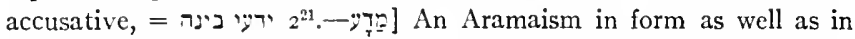
origin, s. Kautzsch, Aramaismen, 5I; = 'knowledge,' e.g., 2 Ch. I10 f.; in Ecc. $10^{20}$ understood by many as 'seat of thought, mind,' but the parallelism here demands an objective gen. Later מנרע = 'Gnosis' in

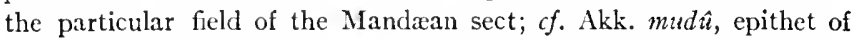
Enmeduranki and a priestly title, s. $K A T 533$, n. 9, p. 59r; Jastrow,

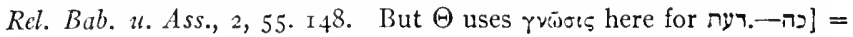
'ability'; summing up the virtues listed, and referring to the youths' ability to carry themselves worthily in the royal presence.—7ay? Technical term for attendance on the royal court; so, more fully, + id המיר, vv. ${ }^{\text {B. } 19}$, cf. I Sa. I6 $6^{22}$, etc.; and so of the servitors of Deity: of the priests, Dt. $\mathrm{IO}^{8}$; of the prophet, I $\mathrm{Ki}$. $\mathrm{I}^{1}$, $c f$. 'standing in the divine council', Jer. $23^{18}$; of the angels, inf. $7^{10}$, Lu. $1^{19}$. Cf. APO pap. 49, 1. 9, and pap. 5I, 1. 13. Cf. Akk. nazâzu ina pân, s. GB s.v. 2, d.—ליכ] In Akk. 'palace,' as here, but in the WSem. field most commonly of the god's temple, and so generally in O.T. So Aq., Sym. here, év vapi, pos-

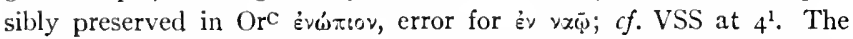
same use as here appears in the Ahikar papp. Later usage reduced the word to the sense of 'mansion': s. Mandaic text in my Aram. Incant. Texts, no. $38,1.2$, and the word survives in the same sense in the 


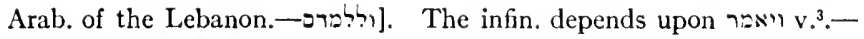

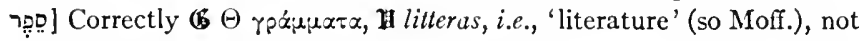
'learning,' EVV. This abstract use of the word appears at ${ }^{17}$, Is. $29^{11 \mathrm{Kr} r}{ }^{13}$. The same use of the word in Syr., e.g., Jn. $7^{15}(=\gamma p \alpha \dot{\alpha} ; \mu \alpha \tau \alpha)$, Acts $7^{25}$; also Ep. Mar Serapion, in Cureton, Spicilegium, 43, 1. 9. Ori-

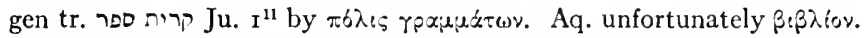

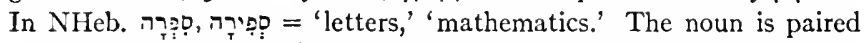
with the following 1 as a const. This construction is not so 'rare' as GK $\S_{128}$, a, n. I, holds, asserting that the present case and רעי Is. $\mathrm{II}^{2}$ can be treated as 'ein absolut stehender Genetiv'-whatever that may mean. Other cases are to be found in Gen. $14^{19}$, Ju. $1^{6}$, and freq. in Est., e.g., $\mathrm{I}^{6 .}{ }^{14}, 9^{17}$, esp. 'script and tongue,' $\mathrm{I}^{22}$, etc. Behr. cites the Jewish coin legend ריאו והבר היהוריט. The same use appears constantly in BAram., e.g., $5^{2 .}{ }^{5}, 6^{19}$, Ezr. $4^{15}, 5^{4}$, etc.; and in Sachau's pap. no. r, l. 23. In Syr. the paired construct is rare, Nöld., $S G \S 209 \mathrm{~A}$, citing but one case; it is occasional in Mand., Nöld., $M G$ p. 309 . In Arab. it is occasional in early poetry, frequent in later prose writers, Wright, Gr., 2, p. 20r. In general the usage is proper where things go in pairs, as here. The accent on 790 is divisive, and so CBMich. argues for the distinction of 'letters and the Chald. tongue'; so apparently $(\mathbb{S}$, but not $\Theta$. But Sa. tr. definitely, 'the script of the Chaldæans and their tongue.'-ליכון כיפדיכ] 'The language of Chaldæa,' so the force of the anarthrous ' 2 ; $c f$. . Gentilic pls. in Gen. $10^{13 t}$. A Chaldæan district and tribe still survived on the Persian Gulf in Strabo's day, xvi, I, 6.

5. Iי [in 'Assigned,' in sense of numerical distribution; as here, v. ${ }^{10}$; in $v^{11}$ of assignment of a command. Cf. Kautzsch, Aramaismen, ro8.

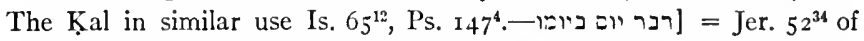
the portion assigned to Jehoiachin by Evil-Merodach; so of the duty of the ministers of the temple, I Ch. $\mathrm{I}^{37}$ - This separation into two words has prevailing Mass. authority and is accepted by Bär, Gin. (s. their notes, the ancient Hilleli Cod. treating it as one word), but not by Mich., Kit. Kamp. notes that as one word ב should not have dageš, cft. $=2 \operatorname{ri}_{2} 3^{16}$. The separation was due to a popular etymology, as though $\mathrm{n}$ = Heb. 'portion,' an etymology not known to the ancients. Ra. says that the word means cooked food in contrast to raw, AEz. interprets 22 from the erroneous ב Eze. $25^{7}$. Sa. also tr. with two words, 'bread and condiment ('udm).' (G paraphrases correctly, 'an allowance ( $\% \times 0 \approx \approx l \zeta, ~ c f$. Blud., p. 35, n. 5) from the king's

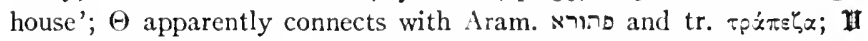
excellently annonam. The word is OPers. patibaga (= Sansk. pratibhaga), 'portion,' taken into Syr. as (so here in 3 ), and into Gr.

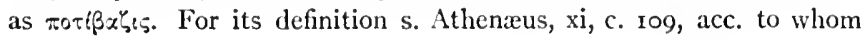


it included certain honorific gifts; in Syr. = 'dainties,' s. PSmith. The identification with $\pi 0 \tau$ $\beta$. was made by Grot. and Castellus.-mere] Sing., $c f$. v. $^{10}$ and s. GK $\$ 93$, ss, $c f$. I Sa. 194; possible other cases GK $\S I 24 \mathrm{k}$. AEz. interprets the pl. of the various wines at the different seasons.-1ולגדיט] For the loose syntax of the infin. $c f$. the exact parallel Gen. $42^{25}$. The infin. may depend by a zeugma of mngs. on

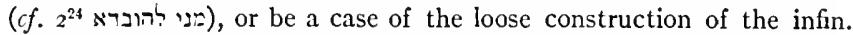
with $h$ equivalent to a finite: e.g., Am. $8^{5}$, and BAram. inf. $2^{16 .}{ }^{18}, 5^{15}$; s. GK §II4, p, Dr., Tenses, §206; cf. Eng., 'and so to.' There is no need with Mar., Löhr, to reverse the two halves of the v., aligning ולג' with ולילברס להביא. Ehr. cancels the first half as superfluous; but the apparently minor point of the cuisine is the hinge of the story. The vb. means, not 'nourish' with $\Theta$ II EVV Dr., al., but 'educate,' with $\mathbb{C} \$$ CBMich., al., Moff. It means 'bring up' physically, e.g., Is. $\mathrm{I}^{2}$, and then intellectually, c.g., 2 Ki. $10^{6}$, and so = Syr. רבא Pael, e.g., Acts

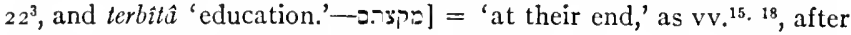
the more common sense, not 'some of them' by reason of the masc. suff., so $\mathfrak{k}$. (AEz. offers both constructions; Sa. definitely $t r$. as here.) Such inconcinnity of agreement appears freq. in Heb., e.g., inf. $8^{9}$, and s. GK §I35, o, Diehl, Das Pronomen pers. suff., Giessen, I895, and for the Aram. dialects, Kau., §53, Anm. a. b, and Nöld., $M G$ §I47.--17מיע] The infin. construction is resolved into the finite with reason as a change of subj. is involved; CBMich. cft. Is. $32^{6}$. Cf. the Arab. subjunct. with $f_{l}$, Wright, Gr., 2, p. 30. Dr., Tenses, P. I39, n. I, cites this as a case 'in inferior prose,' but hardly with justice. For similar usage in Aram. S. at $7^{16}$.

6. וירי Gin. notes a Sebir (s. his Int., p. I87) For sing. vb. with pl. subj. s. GK $\S_{145}$, o. p. In BAram. the present construction appears

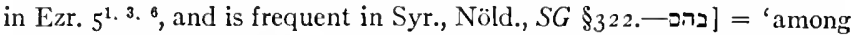
them,' so e.g., Ex. I4 ${ }^{28}$. (G's paraphrase makes the identification of Judah

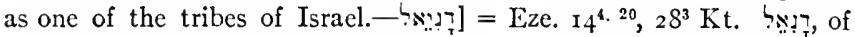
the traditional sage; also a son of David, I Ch. $3^{1}$, and a priest, Ezr. $8^{2}$, Neh. $10^{7}$. The name is also Akk., Dânilu, and Sab., Palm., Nab., s. Lexx.; also of an angel, Enoch $69^{2}$. There is no reason to doubt the mng. 'El has judged'; the name is taken from tradition, not invented for this bk. Geiger, Urschrift, 296, Gin., Int., 397, think of the Mass. pointing as intentionally obscuring the sacred element $\mathrm{el}$; but it is phonetically correct.--הניה] See Lexx.; it appears in Akk. transcription as IIananiyama and on an Aram. docket from Nippur, יחניה; also in Sachau's papp.; in Jewish inscriptions, Lidz., $N E$ 278, Eph. 2, 72 ; in Tobit, $5^{13}$, and in N.T.-Bי Dame of a cousin of Moses, Ex. $6^{22}$, and of a person in Neh. 84. Delitzsch (in Bär, p. xi) interprets, 'who is what God is?'; so BDB and most modern comm.; Hommel, Anc. Heb. 
Tradition, 300 , 'who is a god?' (but Hwb., 'wer ist der der Gott ist?'), and $c f t$. מיכאל as Hitz. had done, deriving element $v$ 'be like.' But Schrader rightly refutes such an etymology, $\operatorname{COT~2,~Io6;~Methusael~}$ is not similar. The name = on with $m=$ 'salvation,' as in the

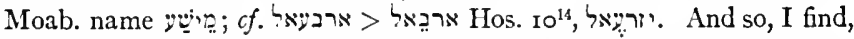
Torrey, Notes, I, 257, decides.--ivi] An ancient name, common in the later age; also in the papp.; s. Lexx. has conj. before this last name, $\Theta$ supplies it to the last three names; $\mathbb{B}$ has asyndeton throughout, and is prob. original; s. at $\mathrm{v}^{20}$. The order of the last three names is alphabetical. Some Gr. Mss, also $\mathfrak{C}^{\mathrm{B}}$, place Azarias before Mishael, probably in consequence of the central position taken by the former in

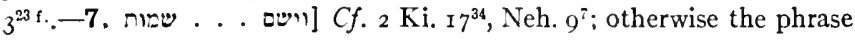
appears only in BAram. $\left(5^{12}\right)$, Syr., NHeb., JAram.; cf. Jastr., s.v. סוס. There is no reason with Scheftelowitz, Arisches im A.T., 64, to hold that the phrase is due to Pers. influence.-D" $\left.2^{\circ}\right](B \Theta \mathcal{H}$ om.; it is superfluous and may have come in from v. ${ }^{8}$ - ass) בלטאישצ. The name prob. = Balâtsu-uşur (with Akk. s > Heb. š), cf. Schrader, COT ad loc., BDB; but GB prefers Balât-šar-uşur, but hardly with reason appealing to the Gr. form; Professor Clay has informed me that this derivation 'is not possible.' Delitzsch, in Bär, p. ix, thinks that the name has been abbreviated from Bêl-balâtsu-ușur, which would then explain $4^{5(8)}$. None of these suggested names actually occurs in Akk. Wilson, p. 30, assumes Bel-lif-sar-ussur, 'Bel protect the hostage of the king,' but without warrant. The testimony of the VSS is against nultimate accentuation (appearing actually in some cursives). The element usur is variously vocalized, e.g., שר The Gr. identified this name with 'Belshazzar,' hence for both $\mathrm{B} \alpha \lambda \tau \alpha \sigma \alpha \rho ; \mathrm{A} B \alpha \rho \tau \alpha \tau \alpha \rho$ is due to

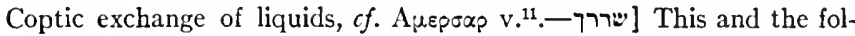
lowing מיטך were analyzed by Del. in Bär, p. xii, as containing the Sumerian element $a k u$, 'moon god,' approved by Schrader (for $\cdots$ alone) and by Kön., Hwb. Lenormant, Jensen suggested identification with the Elamite god Sutruk ( $E B$ 4420). It is most reasonable to conclude with Zimmern, $K A T$ 396, Jahn, that $w$, like 70 , 2 Ki. $19^{37}$ (so for the latter Cheyne earlier), is an intentional perversion of מרדך, 'Marduk.' For such a n. pr. cf. the Aram. docket name מררך in CIS ii, no. 68, and cf. Jehu, Hadad, etc.51, and Winckler, Altor. Forsch., 3, 56 f., suggested a perversion of $7 * 3 \cdot$ cipher for Babel, Jer. $25^{26}$ (Grot. had made the comparison). Again Marduk may be contained in the word. The spelling of these names in Gr. MSS with $-x$ appears to be Origenian.-1ג עבר] Again the elements separated by against the orig. use; at $3^{29}$ ער נגוא. The first element very common in late names, Biblical and epigraphical, s. 
Lexx., Sachau, $A P O$ Index, Lidz., $N E 332 f$. It is pointed here Aramaicwise; so Ms $5 \mathrm{r}$ alone $A \beta \varepsilon \delta \gamma \alpha \gamma \omega=$ Lu. נגו so Sa. (cited by AEz., who holds it to be without proof). Nebo is a common element in late WSem. names; s. Sachau, Lidz., ll.cc. עבנבו is found in Syr., Cureton, Anc. Syr. Doc., text, p. I4. Acc. to Kön., $L g b ., 2,465$, Ruzicka, 'Konsonantische Dissimilation,' BA 6, Heft 4, p. I 26, Bergstr., Gr. $\$ 20$, c, the change is one of phonetic dissimilation. But it is far more likely an intentional perversion to avoid an idolatrous name, as in the preceding names, and $f f$. Timnath-serah, Jos. $19^{50}$ and Sukkoth-benoth, 2 Ki. $17^{30}$ (see my note, $J B L_{3 \mathrm{I}}$, I4I). Winckler, l.c., calls attention to the combination of these names in Jos.'s report of a letter of Darius to the Samaritan officials, $A J \times \mathrm{xi}, 4,9$, in which occur

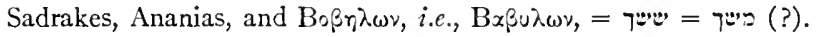

8-17. The test of piety demanded by Daniel. 8. Dan. made up his mind not to defile himself with the heathen foods, and proffered his petition to the Chief Eunuch that he might be excused; the sequel shows that he was also speaking for his companions. VLeng. first exhibited at length the motives for this abstention: the scruples against meats sacrificed 'with the blood' (so PsSa.) and probably $\epsilon i \delta \omega \lambda o^{\prime} \theta v \tau a$, Acts $I 5^{29}$, and against wine as generally graced with a religious libation ( $c f$. I Cor. Io ${ }^{21}$ ), while at least the later law was peculiarly rigorous against the defilement of drinkables and their vessels. Jos. gives a parallel in his anecdote of the pious Jews in whose cause he went to Rome, who lived only on figs and nuts, Life, $\S_{3}$. So Judas and his company preferred to live in the mountains like wild beasts and to eat grasses to escape pollution, 2 Mac. $5^{27}$. The scruple is finer than that exhibited in I Mac. ${ }^{62} \mathrm{ff}$, etc., where Jews resisted the compulsory eating of taboo foods. We may rather compare the pious practice of Tobit, who abstained from eating the food of the Gentiles, Tob. ${ }^{10 \mathrm{f}}$, and of Esther, who acc. to a Gr. addition to Est. 4 ( $\left(3^{28}\right)$ pleaded to God that she had not eaten of Haman's table or honored the king's symposium or drunk wine of oblations. The story of Judith first illustrates the practice of a Jew carrying a wallet $\left(\pi \eta^{\prime} \rho a=\right.$ N.T. cophinus of the satirists) to avoid contamination from unclean foods, Jud. $10^{5}$, etc. The extreme of this principle is summed up in Jub. $22^{16}$, 'Separate thyself from the nations and eat not with them'; with which $c f$. and contrast the story of Peter in Acts Io. For this Jewish regulation of life s. Schürer, $G J V 2,9 \mathrm{I} f f$. It is 
accordingly quite out of question to compare Esther's fasting, Est. $4^{17}$, or to suppose that Dan.'s action was tinged with asceticism (so Whiston to Jos., l.c., Aph. Syr., Albert Magnus, Knab.), or was symptomatic of early Essenism (so Behr., p. xxv), or to rationalize with Jos. and Calv. and to think of a puritanic discipline of body and mind. Issue must be taken with vLeng., al., that this feature implies the Macc. puritanism; cf. Tobit, while the practice was logically based on the Law; cf. Eze. pas$\operatorname{sim}$, Is. $5^{2^{11}}$, Zech. $4^{21}$, etc. 9. 10. Divine grace prompted the official to a sympathetic reply. Jewish romance always represents its heroes as on good terms with officialdom, $c f$. Esther, the story of Joseph the Tobiade in Jos., $A J$ xii, 4, etc., a feature which had its corroboration in actual history, e.g., the cases of Zerubbabel, Ezra, Nehemiah, and the Jews of the Elephantine garrison. But the official deprecated the request on the ground that the physical condition of the youths would suffer, for which the king would hold him responsible. A capital penalty is not involved in the caution he feels; the final phrase means that they would bring the responsibility on him, s. Note. The king's suspicions would be aroused when he 'saw their faces (appearance) out of sorts in comparison with the youths of their own age' (not 'of their sort,' with AV).

11-16. Dan. then appeals privately to a lower official, the 'warden,' as the Heb. word means, who was charged with the care of the youths and their diet. With the exception of 6 and Jos. and of a few moderns who have a penchant for (65's text, the tradition has rightly distinguished between this official and the Chief Eunuch. But the question as to the word hammelsar lies between the interpretations as of a proper name, so $\Theta$ U $\mathrm{AV}$ RVVmg, and of a title, as the article proves; but it is doubtless the latter, and the Akk. or Aram. original can be recovered by help of the vocalizations preserved in $\mathbf{L u}$. $\mathrm{H}$, and the translations of $\mathrm{A}$ and Sa.; s. Note. An underling might grant the boon without fear of discovery. Dan. lays a wager of faith with the warden on the issue of the test to judge of their physical condition. A bit of Oriental color is added by the Grr. in translating, 'he was taking to himself,' àvaıpoú $\mu \epsilon \nu o s$, i.e., enjoying the 'graft' of the arrangement, and this notion is followed by It Sa. and the Jewish comm. The latter are inclined to press the miracle; Jeph. thinks that the Creator must have put something 
extra into the food and water. Mar. rationalizes; better Grot., who while he recalls a $\mathrm{Gr}$. line to the effect that 'a fat belly does not make a fine mind,' insists that here where beauty was concerned the work of God is evident. But the test was above all a miracle of faith with its complement in the divine help; Jer. notes that Dan. even fixed the time; and Theodt. holds that this incident is one of many proving that nothing is stronger than faith. Cf. the story of Joseph in Test. Jos. $3^{4}$, who 'fasted for seven years and appeared to the Egyptians as one living delicately, for they that fast for God's sake receive beauty of face,' and on the other hand deliberately ate of the poisoned food without harm, c. 6 . The 'pulse' of $\mathrm{v}^{12}$ doubtless included grains, e.g., the parched grains so common a food in the Orient; $\mathrm{s}$. Note for variety of specifications of the word. In $v \cdot{ }^{13} \mathrm{tr}$. 'as thou seest fit,' not 'as thou seest [us]' EVV. In V. ${ }^{15}$ not their faces were fatter (AV), but their persons, so RVV JV.

17. In the process of the 3 -years course of education the excellence of the Jewish youths was demonstrated. All four accredited themselves in letters and philosophy ("learning and wisdom,' AV), while Dan. distinguished himself in the 'understanding,' i.e., power of interpretation, of visions and dreams. This faculty may have been exhibited in competition with the other students, for the training of the sages was especially directed toward these recondite mysteries (s. at $2^{2}$ for the several classes of Wise Men). Dan.'s specialty in visions and dreams does not belong to the highest category of revelation, that of prophecy; the Prophets had long since passed away, I Mac. $4^{46}$, and the highest business of the Jewish sage was the interpretation of their oracles, $c f$. Dan. $9^{2}$ and Ecclus. $39^{1}$ : 'He will seek out the wisdom of all the ancients and will be occupied with prophecies.' Dreams and visions belonged to a lower and often deceptive form of revelation, $c f$. Jer. 23, a fact recognized in Ecclus. $34^{1 \text { ff. }}$. But in competition with Pagan interpreters of those phenomena (of whose power in those arts there was no doubt) pious and spiritually cultivated Jews might gain their laurels. Joseph was the classic instance in antiquity; and now 'a Daniel is come to judgment' with the arts of the Chaldæans, who also, acc. to Diodorus Siculus, ii, 29, were adepts in dreams. The color of the story is true to the stress laid by the Bab. culture upon dreams, and is evidence, like the magical papyri and 
the Classical writings on dreams and omens, for the continuance of the 'Chaldæan wisdom' long after the disappearance of the Bab. empire. For the part played by dreams s. Int. to c. 2.

8. ויי: על לבו (similarly Pesh.). The phrase is not identical with שום על לב animadver-

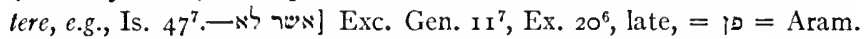

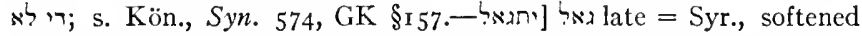

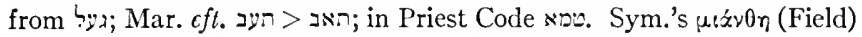
supported by the glosses to 36 233.- נויבקישיש Primarily 'seek demand,' later in weakened sense 'ask'; v. ${ }^{20}$ 'ask a question.' -9. may be understood as a case of waw-consec. where the sequence is not historical but that of order of ideas, $\epsilon f$. Dr., Tenses, $\$ \S 75.76$; and so AV Moff. But rather the sequence is historical; upon the request of the strange youth God inspired the official with favor toward him.The phrase but without I $^{50}$, Ps. I06 ${ }^{46}$, Neh. $\mathrm{r}^{11}$ (ef. 2 Ch. $\left.30^{9}\right)$, and APO I, 1. 2, and Test. Jos. $2^{3}$, sis oixtipuoús; the same with הס alone lies behind Judith $10^{8}$, els $\chi$ kxpev. A similar

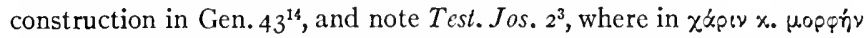
orig. רעו ראי רמו object, $c f$. Hos. $9^{10}$ רחמי-_. The vocalization is abnormal; we expect

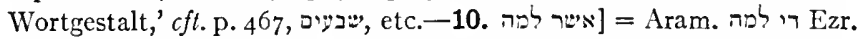

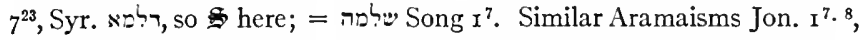
Ecc. $\mathrm{I}^{22}, e f$. Dr., LOT 475, note.$7 \eta_{1}$ as in I Ki. $20^{43}$; but the pointing is corroborated by Gen. $40^{6}$, Pr. $19^{12}$. The rt. = 'disturb,' e.g., of the sea, Jon. $\mathrm{I}^{15}$; then as here and Gen. $40^{6}$ (whence the word is taken) mentally 'disturbed, upset, out of sorts,'

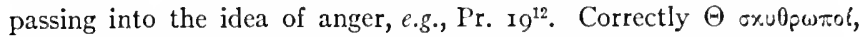
'melancholy,' as $\mathbb{B}$ Gen. $40^{7}$, Lu. $27^{17}$, esp. Mt. $6^{16}$, also as result of fast-

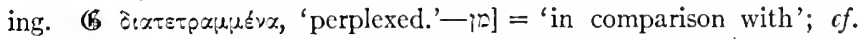

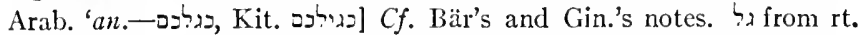

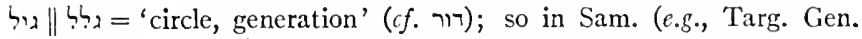
I $7^{7}$ ), NHeb., where ב ב גילו = 'his contemporary,' s. Jastr., and Buxtorf, as of one born under the same star; hence not an Arabism, vs. Jahn. Arab. $j \hat{\imath} l$ is used in the same way; Rosen. cft. Hariri, Assemblies, 4, P. 35, ed. de Sacy, ma'a jîlatika wajîratika, 'with your contemporaries and neighbors.' Cf. Syr., 'sons of one's years,' here and at Gal. $\mathrm{I}^{14}$. $\Theta$ II cor-

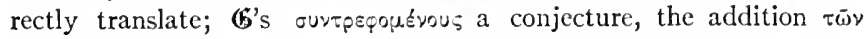
$\dot{\alpha} \lambda \lambda_{\circ} \gamma \varepsilon v \bar{\omega} \nu$ not in $\mathfrak{G}^{\mathrm{s}}$, a gloss to the word. Sa. tr. correctly, and AEz. notes the word as late Heb.- - היכתם] Lit. 'condemn my head to the king.' The rt. is Aram. rather than Heb.; the noun 2 Eze. $18^{7}$ is

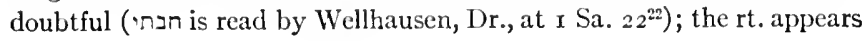


in BSira, Aram. papp., NHeb., s. GB; also in Zad. Fr., p. 3, 1. 10. The phrase is transliterated literally by $\Theta \mathcal{H}$; ( $\mathbb{6}$ ' $\mathrm{I}$ will run the risk of my head'; 'the king will cut off my head.' So in this rigorous sense the comm. generally. But $\epsilon f$. the Syr. mesâm berếs, 'penalty,' not necessarily capital, $e . g$., Acts $4^{21}$; $f f$. the expression to 'put one's way on his head,' r Ki. $8^{32}$, Eze. $9^{10}$. The phrase is curt for 'put (the responsibility) on my

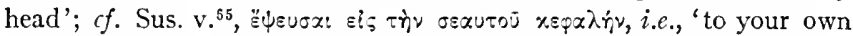
condemnation.' And so Sa. interprets, 'you will bring it down upon my

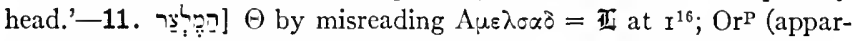
ently orig. Orc, e.g., 106 at $\left.v^{16}\right) A_{\mu \varepsilon \lambda \sigma \alpha \rho}=\mathrm{A} A \mu \varepsilon \rho \sigma \alpha_{\rho}$ by Coptic ex-

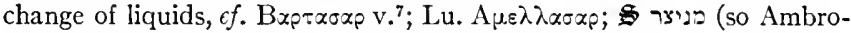
sian and Urmia texts vs. Walton and Lee 7 ר); $A$ ) A has the same tradition munâșir, s. Gehman, p. 339; Malasar. Thus Lu. II A agree in a similar vocalization vs. fft. Schrader, COT, and Delitzsch (in Bär, p. xi) proposed derivation from Akk. mașsar, 'watch,' e.g., mașar bâbi, 'sentry of the gate.' This clew is corroborated by menaișar (Paiel ppl.?) and A munâșir, 'keeper.' As this is supported by the vocalization of $\mathrm{Lu}$. and $\mathrm{H}$, I suggest a Pael ppl., menașşar, with differentiation of $n$ into $l$ in proximity with $m$; שולמית Song המלה Eze. $7^{1}=\pi$ prob. = המון Herodotus' Labynnetos for Nabonidos. The word is then an old Akk. or Aram. term for a 'guard'; the rt. in OAram., Lidz., NE p. 325. The ancients treated the word as a n.pr. But Sa. and Ibn Janâh (p. 355) recognized it as hazân or hâazin, 'treasurer,' and so the Jewish comm.; and the early Prot. comm. mostly followed the Jews. For various attempts at interpretation s. CBMich., Rosen., Hitz., Keil. Lenormant suggested amel-usșur, 'treasurer.' But Mar., Cheyne (EB 3or\&), Jahn, Cha. prefer the rdg. of $\mathbb{G}$ A Ashpenaz of v. ${ }^{3}$. If $(\mathfrak{G}$ be right, then $\Theta$ is to be corrected in both places. But such identification ignores a clever moment in the story, the appeal to a lower servant. In matter of fact the phrase in $\mathfrak{6}$ repre-

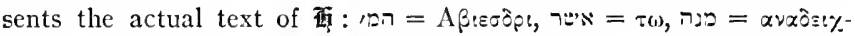
$0 \varepsilon v \pi$, ' viz.: the two final consonants $=\varepsilon \sigma \delta p_{p}$, as normally in such forms (e.g., Eøopxs); the labial $m$ became $b$, the $l$, weak in Coptic, disappeared. The change arose through the oral transmission of the story under Egyptian influence, with the result of evolving a good Heb. name. Josephus also identifies the two officials, but rdg. Ashpenaz (Aschanes) in $\mathrm{v}^{3}$, then substituting this name here for 1 . It is possible that

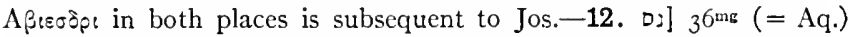

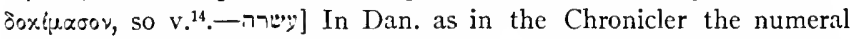
stands as often after as before the noun. The ro-day period, like the week or our fortnight, was a common expression for a few days; like 
the 7-day week it had its own term, רושע, cf. Gen. $24^{55}$ and Acts $25^{6}$, ' 8 days or 10.' There is an allusion to these ro days of trial in Rev. $2^{10}$, and acc. to Jewish tradition Abraham had ro temptations, Jub. $x 9^{8}$ (s. Cha.'s note to $17^{17}$ ), Pirke Aboth 5,4 (s. Taylor, ad loc.), and likewise

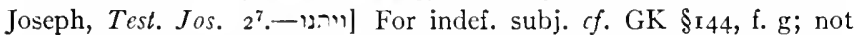
necessarily an 'Aramaism' (Behr.).- - רי:!] Cf. 'what is sown,' i.e., seedling, vegetable, Lev. $\mathrm{I}^{37}$, Is. $6 \mathrm{I}^{11}$; for the forms s. Lexx. In v. ${ }^{16}$

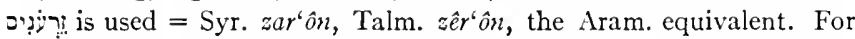
variety of forms of the same word in Dan. s. Behr., p. iii, who ascribes it to carelessness, so Kamp., but per con. Mar. objects. Prob. the common word of later use has intruded itself into the second place (or was it in the Aram. original in both places?). The Soferim have allowed both forms to stand as recognized varieties of reading; $c f$. Boström, Alternative Rdgs. in the Heb. of the Bks. of Samuel, Rock Island, I918,

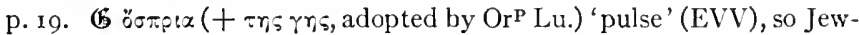
ish comm., who include berries, etc.; Sa. 'grains.' $\Theta \sigma \pi \varepsilon p \nmid \alpha \dot{\alpha} \tau \omega$ ' as from : II I legumina, which Dr. prefers. Jos. has 'pulse and dates'; $c f$. the diet of figs and nuts recorded for certain Jews in his Life, c. 3. Acc. to Krauss, Talm. Archöologie, 1, 115, זריקניכ means beans and the like; but Löw, $J E$ 3, 332, cites Kilaim ii, 3, where the word includes turnips, onions, etc. AEz. has a long discussion of the word at $\mathrm{v}^{16}$, evidently a moot point. G. F. Moore, in Harv. Theol. Rev., 17, 358, n. I 76, remarks: "The reason for the specification of 'pulse' is perhaps that, being dry, it did not contract uncleanness from contact with unclean hands," and gives reff.

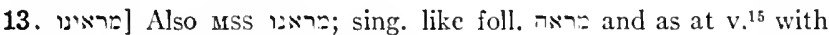
sing. vb.; $\mathbb{6}$ sing. vs. $\Theta \mathfrak{H}, c f$. EVV; the pl. vb. is due to the two subjects.

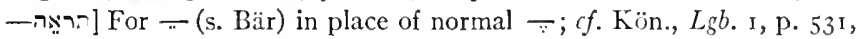
GK $\$ 75$, hh. No explanation can be given of the vowel, exc. poss. as an Aramaism (so BL p. 425). The vb. means 'see fit, have opinion,' and so (6, JHMich., Behr., al., apparently Ra.; so the ppl. Est. $2^{9}$ and freq. in

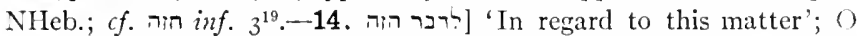

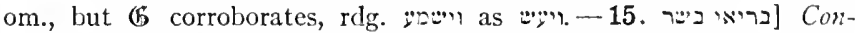
structio ad sensum, Häv.; it depends upon the pl. suff. So Sa., who inscrts 'their bodies [were fatter],' and RVV JV; II makes the phrase adjectival to 'faces' $=A V . \Theta$ tr. correctly but ungrammati-

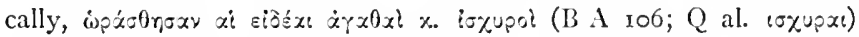

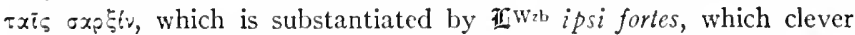
amendment appears also independently in Lu. ajost isupol. (5) $\dot{\eta}$

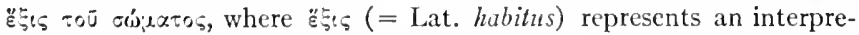
tation as though בריה, which is found in BSir $16^{14}=$ 'creation,' in NHeb. 'creation, constitution.'-D Aram. usage, vs. vLeng.; it appears in Heb., but early only rarely, Dr., 


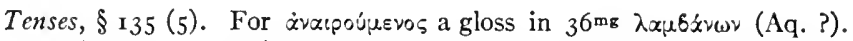
-17. ווהילדיס . The prefixing of the subjects emphasizes them and mutually contrasts them; e.g., $2 \mathrm{Ki}$. $17^{33}$, and $c f$. Dr., Tenses, $\S 160$, Obs.-ארבע:- Eze. ${ }^{10}$; the same form for 7 in 2 Sa. $21^{9}$; a case of this form in BAram., inf. $3^{23}, q . v$. The opening phrase is variously rendered by the Gr. VSS and revisions; illis quattuor pueris agrees closest with Lu._מרץ והישפל] The same phrase as here used adverbially, Jer. $3^{15}$ רעה והישכי Is. For the abs. infin. as noun $3^{17}$; $c f$. the freq. substantival use of Afel infin. in Aram., e.g., Dalman, Gr. \$34.[ספר וחבמה S. at v.4. II bere, not at v.4, follows Aq., in omni libro. N.b. Berossus' note of Oannes' instruction of the Babylonians, rpoxi$\mu \dot{\alpha} \tau \omega \nu$.. $\mu \alpha \theta \eta \mu \alpha \dot{\alpha} \tau \nu$ x. $\tau \varepsilon \chi \nu \bar{\omega} \nu \pi \alpha \nu \tau o \delta \alpha \pi \bar{\omega} \nu \dot{\varepsilon} \mu \pi \varepsilon \iota p(\alpha \nu$ (Eus., Chron. I, ed. Schoene, p. 14).-' הבי[ ב] So $9^{23}$, II ${ }^{11}$, Neh. 812; Sa. as active, 'he (God) distinguished Dan.' - - ח] The word for 'vision' in Dan.; mostly late, cf. תות. The word is used collectively ( Hos. $12^{11} ; c f$. Aram. xin, $2^{19}$, the use of $790 \mathrm{v} .4$, and v. $(6$ has been glossed: by the plus $x$. ppovriol from $\Theta$; at the end by the

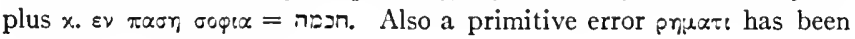
corrected by the plus op $\alpha \mu \alpha \tau$.

18-21. Acc. to vv. ${ }^{18 .} 19$ at the end of the 3 -year term the Chief Eunuch introduced the corps of young alumni to the king, who by personal inquisition found Dan. and his three comrades superior to all the rest. The result was that they were given commissions in the court ('stood before the king'). The practical use of such sages appears in the art of the wise Ahikar in unriddling the riddles of the king's competitors, and a somewhat similar function is that of Dan. in $5^{12}$. In addition to the classical case of Joseph, we find the bk. of Tobit making Ahikar a nephew of the pious Tobit; Ben Sirach expresses the pathetic desire to 'serve among great men and to appear before him who rules,' Ecclus. $39^{4}$. In the cosmopolitan character of those empires a wise Jew might reasonably have adorned the court of a great king, with no questions asked as to his religion. Later Jewish tradition boasted of the cosmopolitan learning of Hillel: "There was no wisdom, no language he knew not," and so of Jochanan b. Zakkai (Bousset, Rel. d. Jud., I90).

20 reinforces the king's findings in $\mathrm{v}^{19}$ by telling how in all subsequent issues he found the answers and advice of these Jewish courtiers 'ten times preferable' to those of their colleagues. Hitz., ignoring this new moment, thinks that the narrator returns to v. ${ }^{19 a}$ in order to detail the degree and the points of their 
superiority. Mar., followed by Jahn, Cha., repeats Hitz., holding that the $\mathrm{v}$. is a disturbing anticipation of $\mathrm{c}$. 2 ; hence it should be elided, along with v. ${ }^{21}$ (v. inf.). But such criticism would wreck any naïvely told story. Kings are forgetful as well as ungrateful, a fact illustrated in the story of Mordecai. A similar inconsequence is found in the compilation of the story of Belsh.'s feast with the earlier cc. The 'magicians and enchanters,' harțummîm, 'ašsâpîm, who are distinguished in comparison with the Jewish youths, are inclusive terms, the one representing the Egyptian magic (so the first word is used in the Egyptian stories, Gen. $4 \mathbf{I}^{8}, \mathrm{Ex} .8^{3}$, etc.), and the other the Bab. magic, where a correct Bab. term is used, $\hat{a}$ šipu. They are not to be treated as having technical mng.; the writer has no special knowledge of the elaborate development of those castes. (5) cleverly rationalizes these two classes into 'sophists and philosophers' (with an alliterative word-play, s. Note at v.4); Jer. makes apology: "discunt ergo ea mente doctrinam Chaldaeorum qua et Moyses omnem sapientiam Aegyptiorum didicerat"; similarly JHMich.: "magos, non qua praestigiis et fascino deditos, sed qua philosophos ac naturae scrutatores et sapientes." $\Theta$ has truer equivalents, émaıoıool ( $=' \sqcap \pi$ also Ex. $7^{11}$, etc.), 'enchanters,' and $\mu a ́$ 'o (outside of Dan. only in Aq., Sym., e.g., Aq. Dt. I $8^{11}=\mathbf{2}$ (א); similarly 11 arioli et magi. Sa. tr. 'wise men and astronomers'; so Ibn Janâh for 'wی゙. Ra. understands the two terms as of necromancers who used the bones of the dead, and astronomers; AEz. explains both as of physicians and dream-interpreters.

21. 'And Daniel continued [when and how he was-colloquial Eng., 'remained on'] until the first year of King Cyrus.' The implication is that he was vouchsafed the joy of the release under Cyrus, and possibly that he like other faithful Jews returned home upon that glorious event. Such a return was understood by one form of Midrashic tradition, s. Hamburger, $R E_{\mathrm{I}}$, 225. The contradiction with IO ${ }^{1}$, acc. to which Dan. had a vision in Cyrus' 3 d year, in the Far Orient, is removed by the critical distinction of cc. I-6 and $7-\mathrm{I} 2$ as distinct books; s. $\S 2 \mathrm{I}, a$. This removes the arguments made by Mar., Jahn, Cha. against the originality of the $\mathrm{v}$. The editor of the whole bk., or composer of cc. 7-12, did not observe the clash between the dates (recognized however by $\mathbf{( 5}$ which reads 'first year' at Io'). 
To overcome the contradiction and for the interpretation of the vb. 'continued' various exegetical expedients have been devised: he remained in honor, AEz.: or, in the king's gate, Hitz.; or, in prophecy, Stu.; or, in Babylon, so Jer. at $6^{8}$, CBMich. holding that he was then removed or exiled to Media. The Heb. vb. היה 'to be,' in the sense as translated here, 'continued,' is fully corroborated, as noted by Häv., al. The tr. of GV Moff. 'lived' has the implication that Dan. died thereupon.

18. אישר ] Not '(the days) which' with RVV JV, but with a general relative sense, as 'at the end of the time that the king ordered them

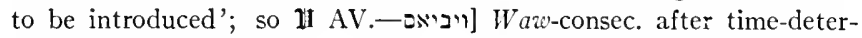
mination, s. Dr., Tenses, $\S_{1} 27 ; c f . v^{20}$. The obj. of the vb. is the whole college of pages, the Sem. syntax being loose in defining antecedents.-

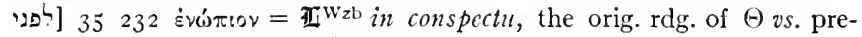

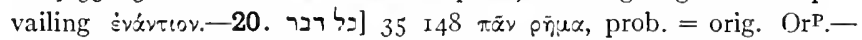
[חכמת בינה The const. relation is broken by the VSS (also Sa.) with 'and,' which Mar., Ehr. demand. The parallelisms presented by Behr., ארמת עפר , I $2^{2}$, etc., are not pertinent. The const. relation may be cumulative, as in the series of constructs Is. $28^{5}$, but that is poetical syntax. JHMich. considers the case 'emphatica constructio

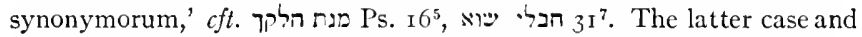
עון חט:מת Ps. $32^{5}$ CBMich. regards along with this as superlatives. Hitz. interprets as '(practical) wisdom of the (higher) intelligence'; Kamp., and Dr. as 'wisdom determined or regulated by understanding.' ביקי" Classical Heb. night prefer the impf., but the aorist is justified by כל; cf. an Arab. example from Tabari, given by Reckendorf, A rab. Syntax,

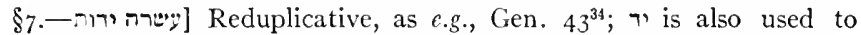
express a fraction, e.g.g., Gen. $47^{24}$; s. GB. BAram. has another expression,

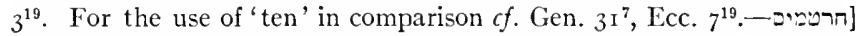

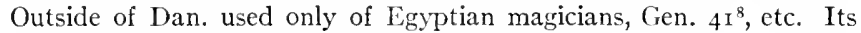
origin is obscure; as from 'inscribe' so BDB, Kön., Hwb.; others cft. Arab. ḩartum, 'snout,' hence 'leader,' e.g., harâtîmu 'l-ḳaumi, 'leaders of the people,' cf. 'anif, 'that which is in front'; or the 'snuffler' (s. GB) who speaks through his nose. Boissier, $P S B A 35$, I89, has attempted a Sumerian derivation.- האיש:] The asyndeton is revised in a few MSS and all VSS, except I $^{\mathrm{W} z \mathrm{~b}}$ incantatores magos; must have followed orig. $\Theta$, which then corroborates is. Asyndeton is common in BAram. and has often to be restored in 7 on authority of Grr. This kattâl form only in the Heb. of Dan.; in the Aram. 论 (âšipu ?) 'exorciser,' for whose functions s. Jastrow, Rel. Bab. u. Ass., Index, s.v., $K A T$ 589. The Akk. ppl. form was retained in BAram., but the secondary nom. opificium was developed in Heb., similar to the 


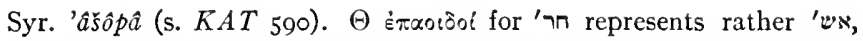
and $\mu \dot{\alpha} \gamma \circ{ }^{\prime}='$ ' ח. For the earliest use of $\mu \dot{\alpha} \gamma \circ \varsigma$ in Gr. s. Meyer, $U r$ sprung, 2, 74, n. 74. (BB 'sophists and philosophers,' and חכמים is used indifferently for one or the other, $2^{12 .}{ }^{14}$, etc., Ex. $7^{11} ; c_{j}^{f}$. Hatch, Influence of Gr. Idcas, IOI; and so Jos. uses 'sophists' of the Pharisees.ל $2^{\circ}$ ] Om. by $\mathbb{I}^{\mathrm{W} z \mathrm{~b}}$ and $\mathrm{Or} \mathrm{C}$, an early variant in $\Theta$. At end of the $v$. $\mathfrak{B}$ has a considerable addition, in part parallel to first part; $c f$. the similar additions in Grr. to $3^{30}$. - 21. Despite the objection of comm., this use of היה, 'remained, continued,' is found elsewhere. The present phrase is exactly duplicated in Jer. $\mathrm{I}^{3} ; c f$. Ruth $\mathrm{I}^{2}$ 'יות ", "they remained there.' Cf. the translation-Greek of Test. Joseph, $11^{8}$, 'we were with him three months'; and with Bert. the use of $\dot{\varepsilon} \sigma \mu \dot{\varepsilon} \nu=\zeta_{\bar{\omega}} \mu \varepsilon \nu$, Acts $17^{28}$, while Ehr. cft. the Talm. use of היה = 'live,' e.g., Baba b. I5a. The

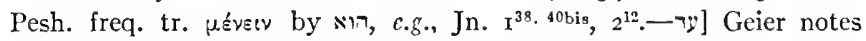
that this prep. does not exclude the remoter future, $c f t$. Ps. $110^{1}$, II $2^{8}$. - כריש Also and so Ezr. I ${ }^{1 f}$.

\section{CHAPTER 2. NEBUCHADNEZZAR'S DREAM AND ITS INTERPRETATION BY DANIEL.}

(I) 1-16. Neb. is disturbed by a dream, and demands of his wise men its interpretation, confounding their artifices in advance by requiring first the statement of the dream, 2-11; on their confession of inability before so extraordinary a request, he issues order for their summary execution, which is respited on Dan.'s plea, 14-16. (2) 17-23. Dan. and his friends pray for illumination, and the desired revelation is vouchsafed to Dan., who offers a confession of praise. (3) 24-45. He asks that he be taken in before Neb. to interpret the dream, 24; after the initial colloquy with the king, 25-28, Dan. relates the dream, 29-35, and then interprets it, 36-45. (4) 46-49. Neb. pays divine honors to Dan. and makes confession of his God; he advances Dan. to great dignity in his realm, in which honors the friends share.

For the notable part played by royal dreams in ancient history reference may be made, for the Mesopotamian field, to Jastrow, Rel. Bab. u. Ass., 2, 954 ff., who cites cases extending from Gudea to Asshurbanapal and Nabonidus. Among these the most similar to the present dream is that of Gudea's; he saw a man whose figure reached from earth to heaven, on his head a crown, etc. (s. Thureau-Dangin, Les inscriptions de Sumer et 
d'Akkad, I4I, Gudea cylinder A, col. iv). Similarly the Pharaoh's dream in the Joseph story, of which the present narrative is reminiscent, has its parallels in the Egyptian literature, e.g., in a dream of Merneptah's in which he "saw a statue of Ptah standing before him .... it was like the height of (?) ..."; also in the dream of Tanutamon. ${ }^{1}$ Comm., e.g. Dr., cft. the symbolical dreams recorded by Herodotus, i, I07 $f$. 209 , iii. 30 . I 24, vii, I9, mostly dreams of or concerning Persian monarchs, Cyrus, Cambyses, Xerxes, for the interpretation of which the

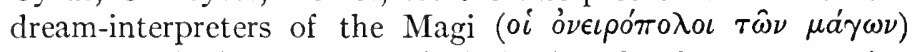
were consulted. More particularly for the Saga concerning Neb.'s visions we may refer to c. 4; as there so also here we may adduce the testimony of the well-informed Abydenos ( $2 \mathrm{~d}$ cent. B.c.?), contained in Eus., Praep. evan. ix, 4I, according to which Neb. had an oracle from an unknown god of the calamity to come upon his people. Neb.'s visions appear to belong to a cycle of legend on which our writer has drawn. Bevan, p. ${ }_{5}$, n. I, cft. a similar royal dream related in Hišâm's Life of Mohammad, which "appears to have been borrowed in part from Daniel, while in other respects it diverges." Our story has a literary parallel in Alexander's dream of the Jewish high priest, in Jos. $A J$ xi, 8, 5. For the spiritually inferior character of dreams, which serve however to exhibit the superior illumination of God's saints, and for the extent of dependence upon the Joseph story, see Note at end of the chap.

1-16. Nebuchadnezzar's dream. 1. The contradiction of the datum of the second year of the reign of Neb. with the three years of schooling that intervened after the deportation of the captives, c. I, has given perennial concern to comm. It was early seen that some other era must be postulated than that based on $\mathrm{I}^{1}$. So Jos., $A J \mathrm{x}$, Io, 3, identifies the year with the second year after the sacking of Egypt; this view is accepted by Jer., on the authority of the Jews and citing Jos.; so Polych., and Jeph., who calculates that it was the $32 \mathrm{~d}$ year of his reign (!). Ra., AEz. make it the second year after the conquest of Jerusalem in 586. Modern apologetic has generally taken refuge in postulating a double reckoning for Neb.'s reign; in $\mathrm{I}^{1}$ he was still coregent with his father Nabopolassar, here he is sole monarch;

\footnotetext{
${ }^{1}$ Breasted, Anc. Records of Egypt, vol. 3, no. 582, vol. 4, no. 922, and $c f$. his History of Egypt, pp. 468, 558; s. also Mallon, Oricntalia, 3 (Rome, I921), pp. $70 \mathrm{f}$.
} 
so comm. from CBMich. to Behr. Knab. and Dr. call attention to the post-dating practice in reckoning royal years in Babylonia, so that the extra year would be the uncounted accession year of Neb.-yielding, to be sure, only 'academic years.' Others have proposed, following Ew., to revise the date, rdg. 'the I 2th year,' and this has been accepted by Lenormant, Kamp., Pr., Mar., Jahn; $c f$. the similar omission in Jos. $24^{12}$. Knab. suggests that numeral letters were used. ב', the 'ten' being lost; but the papyri show that numeral letters were not used. It would be simpler to read שישת 'six' for and the writer sees that Torrey has already made this suggestion, Notes, II, 228. There are, however, cases where 'two' has been used to fill out a lacuna, e.g., I Sa. I $3^{1}$, 'Saul was . . y years old when he began to reign and two years he reigned over Israel'; $c f$. also the datum of 'two years before the earthquake,' Am. I' . First an attempt may have been made to introduce a 'year,' and this was subsequently filled out with 'year two.' In that case the date would be secondary. If it is original and there is intention in it, the point might be that it was in his second year, the year after Karkemish, that Neb. became lord of the world; so AEz., but dating from 586 . Of course there may be simple disagreement with the three years of c. I, that detail with the introductory chap. being on the whole secondary to this story. The writer was not wholly dependent upon Biblical traditions of history, as will appear in the subsequent stories.

In this second year Neb. had a dream-experience (so the pl. תimb); he was agitated in mind (the vb. indicates repeated strokes), and his slecp broke [or, went] from him, with EVV; GV, 'dass er aufwachte.' Comparing $6^{19}$, this tr. appears to be intrinsically correct, and with all varieties of interpretation of the difficult vb. has been followed by most VSS and comm. Aq. and alone of the former express the obvious Heb., 'his sleep was upon him,' i.e., he fell asleep again. This would imply that he forgot the dream, a feature that has been erroneously read into vv. ${ }^{3.5}$. For interpretation of the vb. s. the Note.

1. The initial conj. 1 is corroborated by $\boldsymbol{G}$ Or ${ }^{\mathrm{P}}$, other VSS om.; it is the only case of a story in Dan. beginning with 'and.' Mss 62 I 47 begin the chap. with $\mathrm{I}^{21}$. The repeated 'Neb.' is represented in $\mathbb{6}$ by paraphrase. The first instance is omitted by Ken. II,$\Theta \nsubseteq$, restored by 
OrP.C Lu.; it is required by the date formula.--nמות] Pl. here and v. ${ }^{2}$, sing. $v^{3}$, and so $\mathbf{6}$. The VSS and inner variants in $\Theta$ variously introduce the sing. The simplification from pl. to sing. is more likely than the reverse process, unless we agree with Ehr. that $m$ is dittograph of the following two letters. The pl. is indefinite, of a dream-state, $c f . \mathrm{I}^{17}$, the definition of the single dream appearing in $\mathrm{v}^{3}$; $c f$. "visions of my

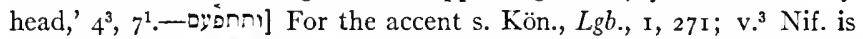
used $=$ Gen. $4 \mathrm{I}^{8}$; 确 has thus included both the earlier and the later use of stems. The Grr. have experimented with various vbs; 1 conterritus $c s t=$ Aq., whose rdg. can be restored from Gen. $4 \mathrm{I}^{8}, x \alpha \tau \varepsilon \pi \tau \dot{p} \eta$.-

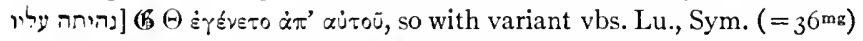
$=11$; Aq. literally $\dot{\varepsilon} \pi$ ' $\alpha \dot{u} \tau \dot{\delta} v=\$$. Hence there is no suspicion of variants to except in the Gr. prep. $\alpha \pi$ which appears to be interpretative. A too simple emendation to suggest is מעy. With the usual mng. of היה the phrase can only mean 'his sleep was upon him'; and so Jun., 'when his sleep was upon him,' and Jeph., Calv., 'and sleep came upon him,' i.e., he fell asleep again. DeDieu, dEnv. treat the prep. as adversative, contra eum, i.e., aduersus ei et molestus. CBMich. appears to have inaugurated a fresh and favorite understanding of the vb., as expressing completion of being and so its termination; he paraphrases, "somnus confectus erat ac esse desierat super eo." VLeng. follows Ges., 'der Schlaf war dahin für ihn,' with נהיה in sense of 'fertig, vorüber sein,' 'was all over with him' = Eng. tr. of Zöck., with על 'ע as dative, as at $6^{19}$; so Dr., defining the vb. by actum est, but insisting, after Keil, that $y$ be taken in its common psychological sense, e.g., Ps. $42^{4}$, 'I pour out my soul upon me.' But parallelisms with Eng. and German idioms are not at all conclusive. Dissatisfaction is expressed by some; Ehr. proposes a vb. בהר (= Arab.) 'forbid,' and Behr., Mar., Jahn, Cha. too easily revise the text by rdg. 'נרדה, cft. $6^{19}$. Grot. tr. 'his dream,' with the implication that it had passed from Neb.'s mind, and Haupt renews this suggestion on the basis of Akk. suttu 'dream' and tr. 'his dream weighed upon him'; objection to which is that then we have two words for 'dream' in the same period. Another way out of the difficulty recommends itself to the writer, following Ra., who $c f t$. Eze. $7^{27}$, and Häv., namely to find the rare vb. הוה 'fall' (identical historically with היה), and so 'sleep fell away for me.' With this $\epsilon f$. the repeated הייר: at $8^{27}$, || with נחימר, 'I was sick,' where the former can mean 'I collapsed'; v. ad loc.

2. 3. Neb. bids the attendance of his wise men 'to tell (i.e., interpret) to him his dream,' not only as Pharaoh did in Gen. $4 \mathrm{I}$, but also as was the universal custom in such royal perplexities. In the Bab. world there were several classes of adepts who 
stood at the service of the king, to obtain for him oracles and to interpret dreams and omens; s. Jastrow, Rel. Bab. u. Ass., c. I9, 'Das Orakelwesen'; KAT 604 ff.; and in detail R. C. Thompson, The Reports of the Magicians and Astrologers of Nineveh and Babylon, I900. For the Persians there existed similarly the Magian dream-interpreters named by Herodotus, $v$. sup. In this passage to the two classes named at $\mathrm{I}^{20}$, the magicians and the enchanters, two others are added, the sorcerers and the Chaldæans. The fourfold listing indicates the levy of the whole fraternity on this occasion. The profession denoted by the sorcerers, פשיטים, is condemned through the O.T. as representing black magic, e.g., Ex. $22^{17}$, or in figurative scenes of immoral seduction, e.g., Is. $47^{9}$. The Akk. has the same vocabulary for the evil sorcerer, esp. the witch, kaššapu, kaššaptu; kišpu, 'bewitchment,' etc.; s. 'Tallqvist, Die ass. Beschwörnngsserie Maqhi, ${ }_{15}, K A T$ l.c. No scruple is felt at relating Dan. with this as well as with the other less obnoxious classes (although the sorcerers do not again appear); cf. $2^{48}, 4^{9}, 5^{11}$, in which passages he appears as dean of the whole fraternity. But it is to be observed that later the rt. $k s p$ was weakened, until in the Syrian Church it came to be used of prayer. For the term 'Chaldæans' s. Int., $\S$ I,$f$. In this passage and elsewhere in the bk. the several classes of diviners are listed with no technical or exact sense, as the variability of the lists shows. Dr. presents the following table of these:

$I^{20}$ magicians, enchanters.

$2^{2}$ magicians, enchanters, sorcerers, Chaldæans.

$2^{10}$ any magician, enchanter, Chaldæan.

$2^{27}$ wise men, enchanters, magicians, diviners.

$4^{4(7)}$ magicians, enchanters, Chaldæans, diviners.

$5^{\dagger}$ enchanters, Chaldæans, diviners.

$5^{11}$ magicians, enchanters, Chaldæans, diviners.

$5^{15}$ wise men, enchanters.

Various classes of Bab. soothsayers are similarly enumerated in Sib. Or., 3, 218 ff.; and so also 'magicians, astrologers and soothsayers' in some VSS of the Ahikar Legend, s. Conybeare, etc., Story of Ahikar, p. Iviii.

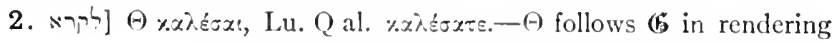

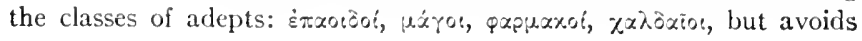


the latter's literal error in construing the last term as gen. to the preceding ones.- להגיר] Classical Heb. would prefer למען with inf.; s. GK

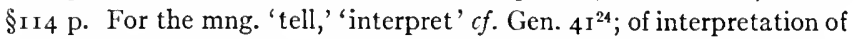
a riddle Ju. $14{ }^{12}$, etc.-3. 3 . חלום הלמתי] We may compare the interesting dream fragment in CIS ii, no. I37, B, 1. I, כ2; this also

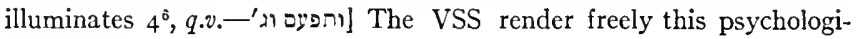
cal phrase.

4. The several classes of wise men are summed up in the comprehensive term 'Chaldæans'; so also below. Both 'magicians,' $4^{6}$, and 'wise men,' e.g., v. ${ }^{48}$, are similarly used. These are said to have responded to the king 'in Aramaic,' so JV correctly; (5 $\sigma u p \iota \sigma \tau i$, 孟 syriace, $=\mathrm{AV}$ 'in Syriack,' $\mathrm{RV}$ 'in the Syrian language.' Through combination of this datum and $I^{\text {t }}$ 'Chaldaic' came into Christian use, first in a gloss to $\mathbb{G}_{2^{26}}$, and then in Jer., e.g., Praef. in Dan., 'chaldaicus sermo'; so GV 'auf Chaldäisch'; and 'Heb. and Chaldee' were the current names for the O.T. languages into the latter half of the roth cent. For the various translation names of the Aramaic dialects s. Dalm., Gr., pp. I ff. Oppert first suggested (Elêments de la grammaire assyrienne, I860-s. Haupt in Kamp. for bibliography, and Nestle, Marg., 39) that ארימית 'in Aramaic' is a gloss, a marginal note indicating the change of language; he has been followed by Knab., Bev., Haupt (vs. Kamp.), Pr., Mar., Cha., and this view appears preferable. For arguments for originality see dEnv., pp. I 27 ff., Behr., Kamp. For the introduction here of Aramaic s. §2I, b. Against Oppert's view, accepted by his followers in this point, that ארמית is equally to be elided in Ezr. $4^{7}$, see Meyer, Entstehung d. Judentums, I 7 ff.-O king, live forever. Cf., along with the same formula in Heb., but in the $3 \mathrm{~d}$ pers., I Ki. ${ }^{31}$; Neh. $2^{3}$, the common Akk. formula, e.g., 'May Nebo and Marduk give long days and everlasting years unto $\mathrm{X}$ my lord' (cited by Pr. from BA I, p. 239). Zöck. cft. similar forms of address to kings and magnates: Judt. I $2^{4}$, 'May thy soul

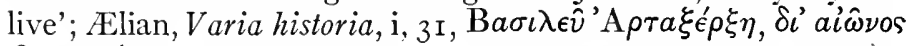

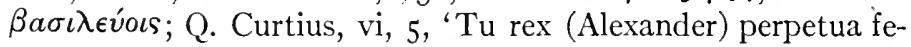
licitate floreas'; and the phrase was current in the later Pers. empires.

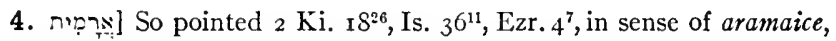
but with gentilic mng. always אִ (so one ms here, Bär). As Nöld. 
remarks, $S G$ p. 8o, note, the second vowel is artificial, formed as though from 'arâm, not the orig. 'aram or 'arm. (On Akk. forms of the name s. Schiffer, Die Aramäer, 14.) The same word occurs in APA pap. K, ll. 4. 6, where it is similarly adverbial, מקרא . . . ארימית. Staerk in his small edition rightly notes this as a case of the Aram. (Syr.) adverbial form, and that it should be pointed 'armâyit; another case of this adverbial

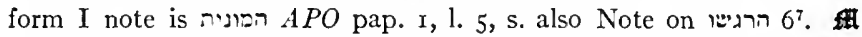
points here Hebrew-wise. Sa. tr. 'in Nabataean.' Haupt thinks that a preceding ויאמדיץ has been suppressed here.e., 'abdaik, for which $\mathrm{K}$ r. here and in similar cases almost universally 'abdâk; s. Kau., $\$ 53$, Anm. $b$, and for similar variations in later Aram., Dalm., Gr., p. Iog,

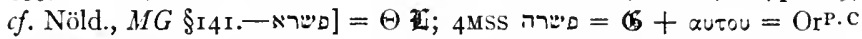
Lu. $\$ \mathfrak{I}$. This uncertainty persists through the chap. and without uniformity in the several authorities. In the papyri the emphatic is always in $\mathrm{k}$, which Jewish scribes often arbitrarily replaced with $\mathrm{n}$; then the reverse process also took place, $\leqslant$ for $ה$. The phenomena are primitive, as the VSS show.without exception by Sachau's papp., s. his statistics, p. 271. Both '-and ${ }^{\prime} \%$ are read (the latter as in pause (?), s. Kau., $\left.\$ 47, g, 3, a\right)$, the latter preferred by Bär, s. his text at vv. ${ }^{7 .}{ }^{24}$. Mar., Gr. $\$ 65$, c, has rightly recognized that the $\mathrm{Pa}$. pointing is erroneous: the Haf. frequently occurs, e.g., v. ${ }^{6}$, and our pointing as Pa. (the usage in Syr.) has arisen in those cases where preform. $n$ was suppressed. Torrey, Notes, I, 253, regards this emendation as preposterous: but $\mathfrak{f i n}$ is wont to distinguish forms arbitrarily after the varieties in $\mathrm{Kt}$.

5. The king responded, The thing is certain with me, so JV; vs. AV RVV, 'The thing is gone from me' (RVVmg, 'The word is gone forth from me'); GV, 'Es ist mir entfallen.' The mng. of the sentence depends upon the debatable $\mathbf{N}$ is, which has been interpreted both as adj. and vb. The eldest interpretation is

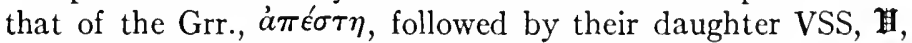
and countenanced by some Jewish comm.; one tradition of enforces it by pointing the word to give it the appearance of a vb. But the explanation of the word as a vb., both as to root and form, is most dubious. The other interpretation, correctly adopted by JV is that of followed by some Jewish comm.: 'The thing, matter, is sure on my part.' The word in question, an adj., is now generally recognized as of Pers. origin. The נכון היבר מעם אלהיהים Gen. $4 \mathrm{I}^{33}$. The king's alternative is that if they do not tell both dream and interpretation, Ye shall be cut in pieces 
and your houses be made ruins (so rather than a dunghill). In such a story as this it is not necessary to debate whether the barbarous order is another proof of the falsity of the history, with Bert., or not, as others hold, citing cases of similar Oriental despotism, so dEnv. at length, with instances stretching down to the English Protestants and the French Terror. In qua romance, the item has true flavor, and we may recall, as possibly the narrator did, the wholesale massacre of the Magi by Darius I, resulting in their almost complete extermination (Her., iii, 79). The king is simply represented as demanding with grim humor that they satisfy his curiosity on his own terms and imposing the common penalty for disobedience to the royal command. The penalty is that of destruction of person and property; $c f$. Ezr. 611. 26. The drastic character of the Assyrian-Babylonian punishments is gruesomely represented in the Assyrian basreliefs, and detailed in the codes of Babylonia and Assyria. For the recently discovered Assyrian Code s. Jastrow, JAOS I92I, pp. I ff., and for a summary p. 7; for the dismemberment of enemies, Beatrice A. Brooks, A Contribution to the Study of the Moral Practices of Certain Social Groups in Ancient Mesopotamia, Lpzg., I92I, pp. I4 ff. The present severity is not, with Heng. (Authentie, 36), a proof of the Babylonian atmosphere of the book. As Häv. rightly holds, the practice of dismemberment was 'wide-spread in the whole Orient,' and he illustrates from the practice of the Hebrews, Persians, Greeks and Romans. For this penalty we have evidence from the age of the Maccabees and the history of Herod (v. inf.). As to the treatment of the criminals' property in this instance, it is a question whether, with the majority opinion, their houses were to be made 'a dunghill,' i.e., ultimately a public privy, or were to be destroyed. For Oriental custom the former interpretation can be abundantly illustrated, as, e.g., in the profanation of the Baal temple, $2 \mathrm{Ki}$. $I^{27}$. Häv. adduces many instances from Oriental history in which a sacred building was thus profaned by edict, e.g., Abu 'l-Fidâ's account of Omar's covering the Holy Places in Jerusalem with dung, whence the current satirical perversion of the Church al-Kiyâmah (the Resurrection) into al-Kumâmah (dung). But this is not the most ancient interpretation nor the sole tradition of Jewish comm. In its form the dubious word obviously Akk., and it is to be related to a common Akk. root, 
'to destroy.' The bodies of the refractory wise men were to be dismembered their houses pulled down.

5. (6 Lu. II pref. 'and,' against usage, $c f$. vv. ${ }^{70}{ }^{10}, 3^{9 .}{ }^{16}$.- $G G A$ I 88 4, p. I021, appears to have been the first to suggest that this should be pointed as perf., ; שו וזארין; five times in cc. 2. 3, only once is followed by Behr., Kamp., Mar., Löhr, Ehr. The same idiom is abundant in early Syr., Curetonian and Peshitto VSS, Bardesanes, Aphraates, etc., but is not particularly noticed in the Syr. grammars; Kau., $\$ 76$, d, is inadequate. However Torrey, Notes, I, $264 f$., puts in a caveat against text emendations, and indeed both constructions appear

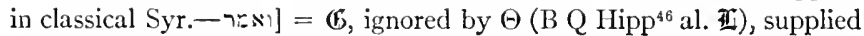

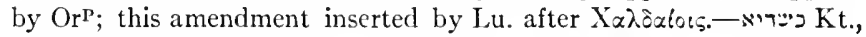

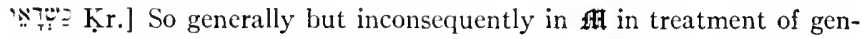
tilics, s. Kau., $\S I$ I, I, b. The weakening of ' to $s$ is EAram. One object in writing the Kr. form may have been to distinguish between the otherwise identical sing. and pl., conveniently distinguished in Syr. by

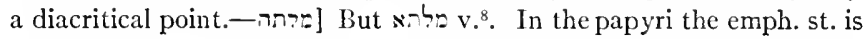
always in N_-; the fem. is in $\mathrm{n}$-, with exception of a very few cases; $\mathrm{s}$. $A P O \quad 264 f$. This evidence would indicate that the confusion of distinction between $\mathrm{s}$ and $\boldsymbol{i}$ in if is not original. For the statistics of $\boldsymbol{N}$ and $\rightarrow$ respectively for the emph. and fem. endings in BAram. s. Powell, $S u p p$. Hebr., pp. 8 ff. These show that the rules of the papyri are predominantly followed. It has not been noticed by Powell and others that equivalence of $x$ and $i$ existed in certain late Jewish writings, and in cases the dominance of $n$ where Aram. use would demand $s$, e.g., the Samaritan Aram. dialect and Jewish magical texts from Babylonia as well as from Palestine. For similar variations of spelling in "'th roots s. at $2^{4.16}$. ing as ppl. (hardly Hebraism for $3 \mathrm{~d}$ sing. fem.) is due to alleged deriva-

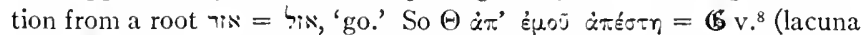
here) II Ra., Jeph. Such a root appears in Talm. (in one case of 'escaping the memory'), but the text of the cases is uncertain, אזי appearing often as a variant (s. Talm. lexx.), so that was probably manufactured from the Bibl. word. Its occurrence in Syr., PSmith, col. 105, would have the same origin. Withal a ppl. (attempted in Bär's pointing) is not pertinent for a preterite. While 7 may be philologically exchangeable with , yet our bk. otherwise knows only his; see Kau., p. 63. For survey of early views s. CBMich. Of later philologists Hitz. compared Arab. waşada, 'be firm'; Fried. Del. suggested an Akk. etymology, which has been generally rejected. But there exists another ancient tradition of interpretation, which goes back to translating the word 
by šarrir, 'sure.' Also it is found in Talm. in sense of 'determined, decreed,' and this mng. is given by AEz. Sa. tr., 'the matter is in earnest with me.' Nöld., in a communication to Schrader, COT ad loc., diagnosed the word as Pers. azdâ (anticipated by Hitz. in his comparison of $a z d \hat{a}$ ). Andreas, in Lidz., Eph., 2, 214, n. 2 (also in Mar.'s Glossary) precises the word as Mid. Pers. azd, 'news.' This is in the way of interpretation of אז as found in Euting's Strassburg Papyrus (repeated in $A P O$ p. $26, A P$ no. 27). In B, 1.3 is read הזר יתער , which Euting translates, 'si certium factum erit [a iudicibus].' As a component it appears in אוזכ, APO pap. 5, 11. 5. 7, where Sachau tr. 'Bekanntmacher.' Torrey, Notes, I, p. 253, objects against Andreas that neither in Dan. nor in the Strassburg Pap. can (א) או mean 'news,' but only 'sure,' in which he is right. His treatment of the present form as adj. fem. is, however, open to objection. The opinion of Scheftelowitz, cited with approval by Kön., $I w w b$., that the word comes from Pers. $a$ ida, 'gegangen,' is now upset by the papyri. Cf. אררגזריא Dan. $3^{2 f .}$. Nobilius, cited by Field, notes a reading 'of the Syrian,' $\dot{\pi} \pi \alpha \tau \bar{\alpha} \mu$ s. The argument of some that is incongruous with Nöld.'s derivation is fallacious; is 'on side of,' is common in spatial relations, s. BDB p. $578 b$, and is so used psychologically Nu. $32^{22}$, Job $4^{17}$; in Mand. and NSyr. עם

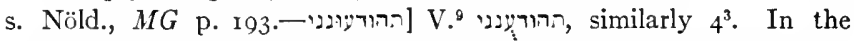
papyri is a case of the spelling plene pris, $A P O$ no. 73,1 . 18, p. 223. For $\hat{u}>u$ in the sharpened syllable $c f$. Arab. Energ. pl. yaktulunna.-

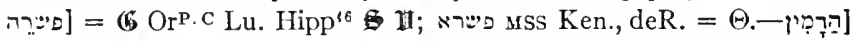
For the Pers. word, early domesticated in Aram. dialects s. Lexx. Of VSS alone understands the phrase, $\Theta \dot{\xi} \iota \varsigma \dot{\alpha} \pi \omega \lambda \iota \alpha \nu$ " $\sigma \varepsilon \sigma \theta \varepsilon$ (so also

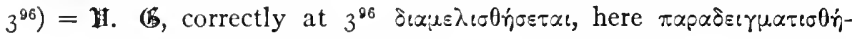
$\sigma \varepsilon \sigma \theta \varepsilon$, 'be made an example of,' as rdg.

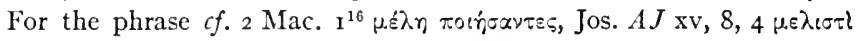

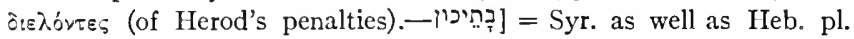
Kau.'s condemnation of the dag. $f$. as a 'Hebraism' is unintelligible. Mar., Gr. $\S 8$, c, and Brock, $V G \S 123$ Anm., prefer to regard the dag. as abnormal lene not forte; cf. Kön., Lgb., 2, 55, BL §19, d.—?ְ] Also $3^{29}=$ נוליו Ezr. $6^{11}$. The common interpretation is 'dunghill,' and for such a penalty $c f .2 \mathrm{Ki}$. $\mathbf{I O}^{27}$; so Ra., R. Joshua in AEz., Eng. VSS, all recent comm. Support for this is the alleged sו נוליח Targum II to Est. $8^{15}$ (cited by Paton $a d$ loc., p. 279), but this is a quotation of our passage and is of no authority. The alleged abstract ending is hardly suitable for such a concrete mng., and the Rabb. mng. of the root, 'be repulsive,' is not conclusive. The eldest interpretation is that of $\mathbb{E}$,

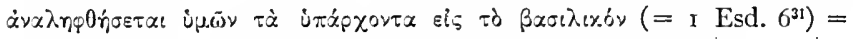

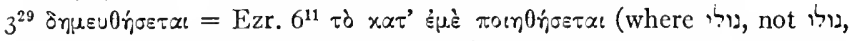
was read, and -t understood as mihi), i.e., confiscation. Jeph. follows this interpretation, 'will be confiscate to the sultan,' evidently 
comparing Arab. nâla 'present gift, possess'; and so Sa., 'booty.' Torrey, $Z A 26,80$, has followed the same clew with similar translation; he discovers the rt. גול in Phœn. in the Tabnit Inscr., 1. 7. The present

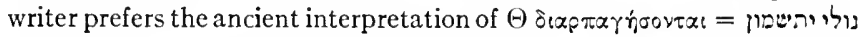
(in place of this Q 228 simply $\varepsilon i_{\zeta} \delta(\alpha p \pi \alpha \gamma \eta \dot{v})=$, and so AEz. This might be supported by Jensen's identification with a supposed Akk. root nawâlu ruin, $K B 6$, I, p. $36_{3}$, accepted by the Lexx. But it is preferable to identify it directly with the common Akk. root nabâlu, 'destroy.' Then the final vowel can be explained as the Akk. case ending and the word is a sheer borrowing; it should accordingly be accented

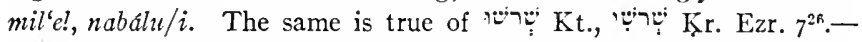

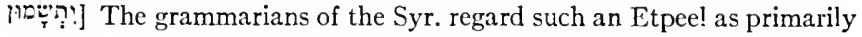
Ettafal. But as BAram. had not acquired the Ettafal, it is best to regard this as a proper Etpeel development. Against the present vocalization the expected $i$-vowel appears in $!: 4^{9}$, and as $A P O$ pap. 53 , I. 2, offers יתשים, it is most probable that here and in ישָ: Ezr. $4^{21}$ the vocali-

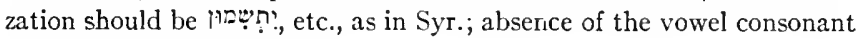
induced the other pointing.

6-9. Neb. balances his threat with the promise of royal largesse and honor if the wise men succeed in telling the dream as well as the interpretation. The latter, $\mathrm{v} .^{7}$, repeat their request in a somewhat more respectful tone, but, vv. ${ }^{8.9}$, the king breaks out in exasperation at them; they are only seeking a respite because they realize the capital danger they are in; they hope for some way out of the dilemma if time be given, either by concocting some false and base reply, or counting on delay to annul their emergency. He repeats his demand; otherwise the one inexorable sentence remains for them all. V. ${ }^{8 b}$ is to be read in the same period with v. ${ }^{9}$ (ignored by most translations, correctly $\mathrm{JV})$ : because ye know that the decree has gone forth that if, etc.

10. 11. The wise men make one more appeal: no monarch, however potent, ever made such a demand on any class of adepts; such knowledge is confined to superhuman beings. $C f$.

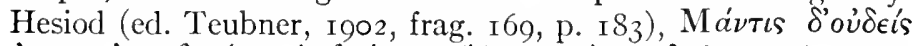

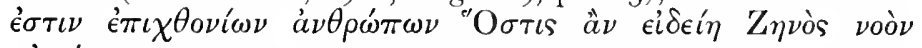

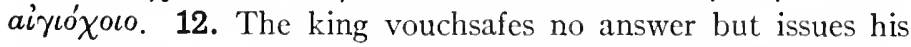
edict, which is put in the hands of the Provost Marshal of the court for execution $\left(c f . v^{14}\right)$. 13. Dan. and his compatriots are equally sought for destruction along with the rest of the fraternity. It was not to be a Sicilian Vespers but a formal execution 
under the proper officials and in the appointed place, hence the first purpose of the officials was to assemble the condemned. Despite one line of interpretation, represented by $\Theta$ and $\mathfrak{H}$, execution of the order had not begun when Dan. received notice of the sentence.

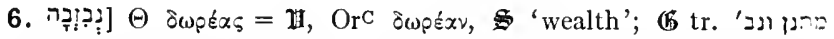

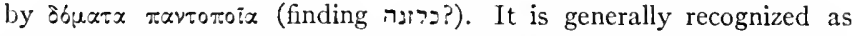
some technical name for gifts. Andreas in Mar., Gr.', compared MPers. nibhẽz (-äz), leaving ב-unexplained; but he is cited by Lidz., Eph., 2,226 , as denying that he can explain it from the Iranian. Tisdall, $J Q R$ 3, 168, claims an error for Pers. nibazna ( $c f$. 6 's rdg.). The word has been taken into the Targums, s. Jastr., s.v. A word נב נב occurs in the Sam. (Targ. Lev. I6 $6^{8 \mathrm{ff}}$ ) = גורל, which Cowley supposes to be taken from Arab. nabada; but it appears frequently in PalSyr. $=x \lambda$ r.pos, and Schulthess's random suggestion (Lex.) of identification with Syr.

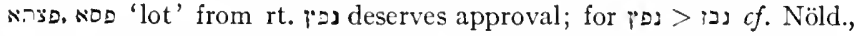
$M G \S \$ 4.48$. It is found in Mand., Euting, Qolasta, no. xliii = Lidz., Mand. Liturgicn, p. 76, in sense of 'pieces' of the liturgy. And finally it has appeared in the papp., $A P A$ pap. L, 1.6 (s. Cowley's note, $A P$ ), but with the apparent sense of 'quittance,' and Perles relates it to our Biblical word, $O L Z_{15}, 219$. But it is strange that the extraordinary form of our word, if in error, should be included in the variant form at

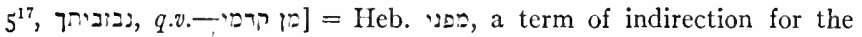
royal person.-[i] The two current interpretations of the word are instanced from antiquity: (I) 'but,' $\Theta \$$ Ra., Jeph., JV; (2) 'therefore,' (6̆s $\mathbb{I}$ Sa., AV RVV. The former = lâ $h c n=$ Syr. 'ellâ, Arab. 'illâ, 'if not'; it appears inf. vv.11. ${ }^{30}, 3^{28}, 6^{6.8 .}{ }^{13}$, Ezr. $5^{12}$, also in the papyri, etc. Meaning (2), which later vanished from Aram., appears in the Teima Inscr., CIS ii, no. I I 3 (Lidz., NE p. 447, Cooke, NSI p. I95) ll. 8. Io and in Heb. in Ru. $\mathrm{I}^{13}$ bis (questioned by some). This meaning is demanded here, $v^{9}, 4^{24}$. For the proposed explanations of lahen, 'therefore,' see the Lexx. and grammars, and especially Torrey's survey and criticism, Notes, I, pp. 255 ff. Nöldeke's and Stade's view that it $=$ la-hinna ( $c f$. Arab., $a b$ hacc) he properly subjects to the condemnation that in Aram. we should expect $l \breve{e}$, not $l \hat{a}$; he holds to the view that the word is the same in both cases and that "the use of this compound covered more shades of meaning in western Aramaic than elsewhere, extending through the whole series: 'unless, except, but, only, however, then, accordingly, therefore.'" But he does not explain how this extraordinary expansion took place. Retaining his principle, we may regard lahen as from lâ 'not,' and hen 'behold,' used interrogatively, 'is it not, lo?' That is, the two uses developed from the two mngs. of hen as 
'behold' and (secondarily) 'if.' 'The compound in the latter sense predominated and ultimately suppressed the other sense 'therefore.'7. [תינות] For the const. fem. used adverbially in Aram. dialects s. Nöld., $M G$ p. 20 I, $S G$ p. 96; similarly 9 $^{18}$.impv. of $v .{ }^{5}$ expresses appropriate humility; $\mathbf{( B}$, followed by Lu., reverts

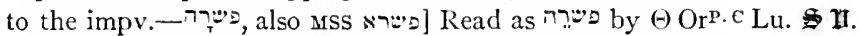

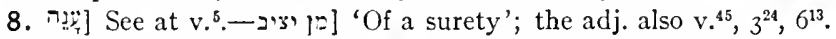

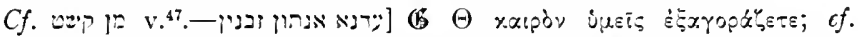

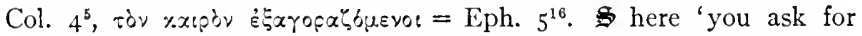
time,' Syr. to the Epp. 'buying your opportunity' (kersa<xapós). Since Geier the distinction between the use in Dan. and in Paul has been observed; in the latter in sense of making the most of time or opportunity ('going into the market and buying up time'), = emere tempus (Cicero, Verres, i, 3, and so here It tempus redimere); in Dan. in sense of 'gaining time,'i.e., respite (dEnv.). Paul's use does not bind the interpretation here, as correctly saw.-. though 'all because,' and so still Kön., Hwb., p. 598, Lgb., ii, 2, \$339 r, 'ganz entsprechend.' Luzzatto, Gr. \$123, first correctly diagnosed the vocable as = lukdam<le + kudam, and lukbal, but with suff. lekubleh. Luzz. $\epsilon f t$. In: $\mathrm{Sccl}$. $5^{15}=\mathrm{JAram}$; the distinction into two words may have been induced by a number of Rabb. phrases, e.g., $127 ?$, quanto magis,

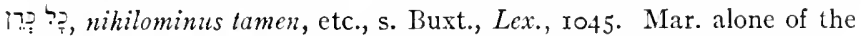
comm. notes the revision but does not revise his text accordingly. Torrey, Notes, I, p. 256, objects to regarding fll's division as 'erroneous'; but there is no evidence of such division in the VSS, and the later tendency was to split up long vocables; see on 'Nebuchadnezzar' $I$ '. For

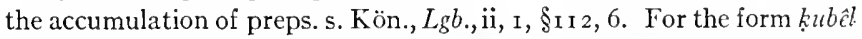
Bev. proposes original diminutive kubail $=$ Arab. k $u b a i l a$, and $c f t$. Syr.

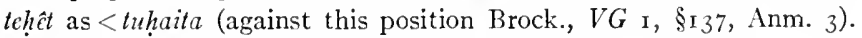
Similar instances are found in Reckendorf, Arab. Syntax, p. 221.-

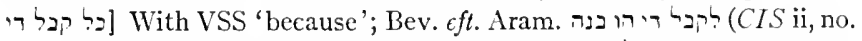
I64, 1. 2); so usual mng. of the phrase, or 'according as,' vv. ${ }^{41.45}$, except $5^{22}$, where $=$ 'despite.'

9. T] The Grr., II understand as introducing a new period: Éx́v

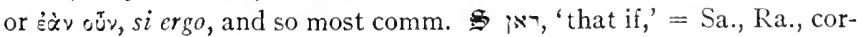
rectly diagnosed the syntax as continuing the period from $v^{8}$; this interpretation was renewed by Klief. and followed by Dr., Mar., Cha., JV.

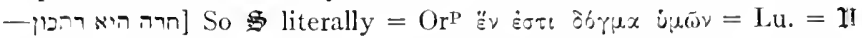
una est de uobis sententia, = Jewish comm. The Grr. fell down here. $(B)$ has apparently a doublet. $\Theta$ has olox (finding ${ }^{\prime}$, in

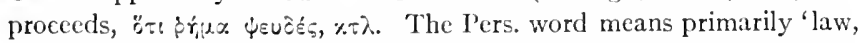
judgment, sentence.' The rival rendering, based on a secondary mng. 
of the word, 'one is your purpose,' is vigorously defended by vLeng., after predecessors. The word has the secondary mng. of 'personal judgment' in Syr., but there is no reason to abandon the constant Bibl. mng., e.5., v. Kau.'s supplementary note, Gr. p. I75, that this word is prob. a noun, is borne out by Targ. "בְר? , 'lie.' Similarly is nominal (fem. =

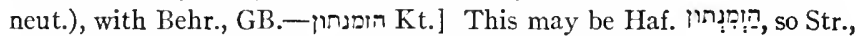

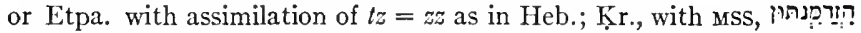
Bär, or הinge Gin. The form without assimilation is correct in Syr. The Aram. corresponds to Nif. of Heb. ואנדעי-ד] For the impf. of result, as in Heb. and Arab., cf. Kau., §Io2.-10. איתי] So Mich., Str., Gin., Kit.; אתי Bär, on Mass. authority; but the papyri have יאי אุ:

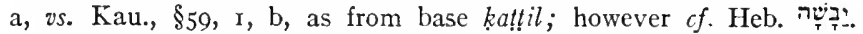
Syr. $y a b \xi \hat{a}$ occurs in the same secondary sense of 'the earth,' e.g., I Mac.

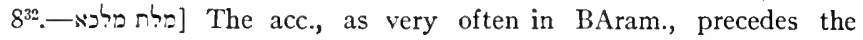
vb. in a relative clause; $c f$. Akk. syntax. The point is not noticed

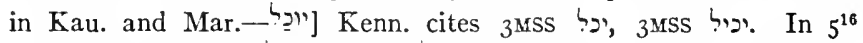

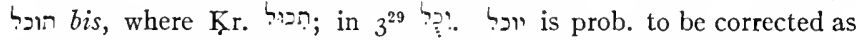
a Hebraism (in papp. only יפל, etc.), to be corrected with Kautzsch, Mar., Löhr. The form is defended by Behr., Powell, Supp. Hebr., $\$ 65$, Torrey, Notes, I, 256. But it is likely that there was meant

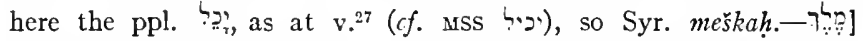
This belongs to a class of nouns which, not consistently, exhibit the Heb. segholate formation. They are: (I) found in abs. not in const.

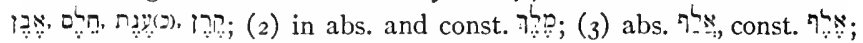
(4) with variant forms in abs. and const., טֵِ abs and const., also

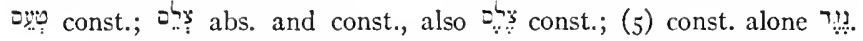

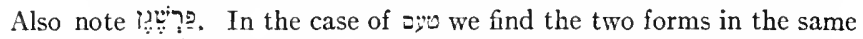

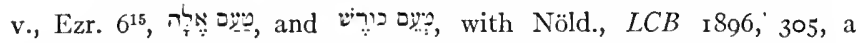
purely scribal distinction; the Heb. form is more appropriate to the divine decree! For $\Delta$ s, const. : in king's face, again apparently an artificial distinction. It may be observed that most of these nouns are also good Hebrew. Kau., $\$ 54$, I, is inclined to the view that these segholate forms are Hebraisms. Nöld. denies this, $Z D M G ~ 22,475$, and so Powell, $\$ 52$. [פל מלך רב ושליט- Read with efl's punctuation and JV the two last words as adjs. to the first, i.e., 'no puissant monarch.' (5 'every king and every dynast'; $\Theta$ 'every great king and ruler.' Sym. finds three classes, 'any king or great one or authoritative,' and is followed by Grot., AV RVV (latter with mg. giving first interpretation).--ואשף

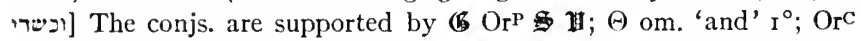
Lu. om. 'and' $\mathrm{I}^{\circ}$ and $2^{\circ}$. For the idiomatic asundeton construction $o f$. 


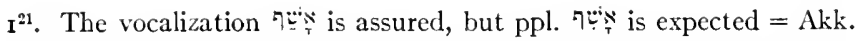
âsipu. The customary listing of it under kâtal is impossible, and comparison with BAram. $7 \stackrel{D}{D}$ is illegitimate. N.b., the Aram. represents the Akk. word, while the Heb. ๆ

11. יקירה [Heavy,' $\mathscr{G} \Theta$ Bxoús $\boldsymbol{W}$ grauis, i.c., 'difficult,' so JV. AEz.

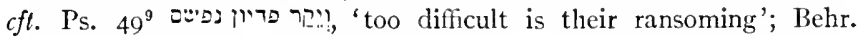
cft. Ps. I39 ${ }^{17}$. AV RVV have 'a rare thing,' a sense found in Syr., not

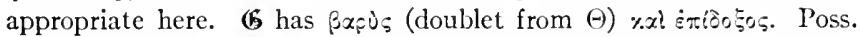
in $A P O$ pap. 54, 1. I, אה לאלהן יקירה הי; we should tr., 'even for God it is too difficult.'-יחונה] The correct Afel form; s. at v.4. - איהין] It is possible that $\mathbf{s}$ is sing. in sense, 'God'; cf. the divine cpithet $7^{18}$, etc.; the pl. pron. suff. following is then due to grammatical attraction, even as Heb. היהיש is often construed with pl. vb. In the papyri the pl. איה is found construed with a sing. vb., c.g., APO pap. 56, l. I, and so in the subsequent text $=$ = 'God'; this point is recognized by Lidz., Eph., 3, 255, Epstcin, $Z A T I V$ 32, 145; the former rightly notes that the history of the use is not of Jewish origin. See further Notes at $3^{12 .}{ }^{25}, 5^{11}$. For the very ancient use of the pl. for the sing., going back to Akk. ilanni, s. Hehn, Die bibl. u. bab. Gottesidcc, r9I3, c. 4, and for the pertinent cases in the papyri his Nachträge, pp. $395 f$. For the translation of $A P O$ pap. 56, 1. I see my note $O L Z$ i9 1 2, 536. Here 6 expresses

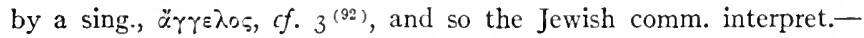
[בדרהון With the original vowel; also מדר $4^{22}$, etc.; cf. Powell, p. 34.] For the contrast of flesh with the divine, spiritual, $c f$. Gen. $6^{3}$, Is. $3 \mathbf{I}^{3}$, etc. The N.T. idea of $\sigma \dot{\alpha} p \xi$ is founded on that of the O.T. in John as well as in Paul.--איהוהי] Acc. to Kau., $\$ 67,8$, the suffix is 'pleonastic,' but it is frequent in Syr. and usual or demanded there in certain combinations, e.g., when subj. precedes; s. Nöld., $S G$ \$303.-12, כל קבל רגה]

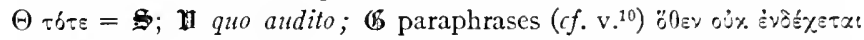

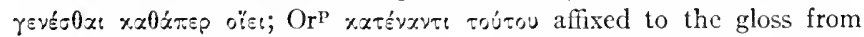
plus of $\mathbb{B}$, which also appcars in Lu. Cf. the VSS at v. ${ }^{24}$.-Dנ] 'Was angry, $=\$$ EVV. The root is found in Targ. Ycr., ctc., with the adj. בניס, and is supported by Sam. סנפ, Targ. to Dt. $32^{16}$ (Hitz., Mar.).

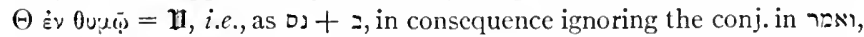
in this following $\mathbf{6}$. This is the interpretation of Ra., AEz. (not of Sa.),

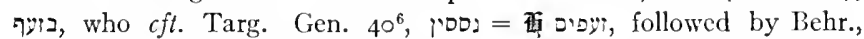
and by Pr. comparing Akk. nasâsu, also a Heb. root. In addition to the support for verbal בנס and the difficulty of treatment of it as nominal, סO: means 'be sick, gricve' in all dialects, never 'be angry.'-להוברה.]

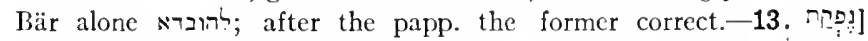

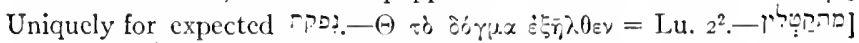
Bär alone rect accordingly the following התקט:ritpa. Cf. the variant forms of מתכניטין $3^{3}$ and $3^{27}$. 'The ppl. is gerundive, 'were to be killed,' $c f$. Kau., 
$\S 76,3$, Mar., Gr. §102, e. $(55$ recognized this; $\Theta$ tr. by impf. The gerundive interpretation is accepted by Sa., EVV Bert., al., and recent comm. For the similar use of ppl. pass. in Syr. s. Duval, GS $\$ 33 \mathrm{I}$, d, Nöld., $S G \S 278$, A. So also in Bibl. Gr., Acts $2^{47} \tau$. $\sigma \omega \zeta$ \%oúvous $=$ saluandos. The ppl. with 'and' replaces the usual Sem. impf.-juss. of purpose; $c f$. Kau., §102, and below at $\mathrm{v}^{17}$ for similar use of inf. Exactly the same construction is found in the Gr. of Acts $15^{27}$.- - I Impersonal $=$ pass. $c f . \mathrm{vv} \cdot .^{18 .}{ }^{30}$, etc., especially $4^{22}$, and Kau., $\$ 96$, I, c. The same use appears in Akk., viz. in the Assyrian Law Code, s. Jastrow, $J_{A O S} 4 \mathrm{I}, \mathrm{I} 4$, n. 27 ; and in N.T., e.g., Jn. $12^{16}$, Lu. $12^{20}$, Rev. $12^{5}$, etc.; also a favorite construction in Mishna, s. Bev. at v. ${ }^{30}$. Behr. cft. the use of this vb. in Targ. Jon. ${ }^{14}$, אלפא בעיא לאיא-ברא, "the ship was going to be broken' (Heb. ה? neusyr. Sprache, p. 295; Ehrl. adds to this argument with passages from Talm., and interpreting כיק, Gen. $43^{30}$ similarly. But the primary mng.

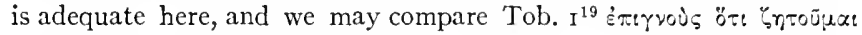
$\dot{\alpha} \pi 00 x v \varepsilon i v$, which corroborates Mar.'s suggestion that the Pêll ?ִּ might be understood here.

14. 15. Dan. displayed his good 'sense and prudence,' a characteristic of the Biblical saints, by taking the matter up directly with the Chief Executioner or Provost-Marshal Arioch, whose name belongs to the Jewish literary tradition. He inquires the cause of the 'peremptory' decree. It is not explained why Dan. was not present in the audience before the king; but a good story does not explain every detail. 16. The difficulty of this v., felt by some translators, $\mathfrak{C}^{\mathrm{B}} \mathrm{Lu}$., and prob. to be corrected acc. to $\Theta$, has been adequately recognized among the comm. by Ehr. alone. How did Dan. enter the king's presence without official intervention ( $c f$. the story in Est.), especially since subsequently, vv. ${ }^{24.25}$, he requires the aid of Arioch to present him to the king? Häv. supposes that Arioch presented him duly on this occasion; but now rather than later the terms of the etiquette are desiderated, while these terms in $\mathrm{v}^{25}$ are much belated. Now $\Theta$ and $\cong$ ignore i ע 'went in and,' and it is plausible that the omission represents the original text; the request for delay could have been transmitted by Arioch. Or with Ehr., making that omission and rdg. Fg' 'of him,' for s' 'of the king,' the respite may have been granted informally by Arioch. Sa. meets the difficulty with a paraphrase: 'D. caused (tasabbaba) that he asked.' However (5 read 倌. The respite is asked by Dan. with the engagement that he would satisfy the 
king with the interpretation of his dream. He exhibits the same calm assurance as in cc. I. 6.

14. [באביו For syncope of $*$ s. Kau., $\S \mathrm{II}, 3, \mathrm{~b}$, and Powell, p. 30. For אריץ cf. Heb. Syr. hâidên, and dên (which through attraction to Gr. $\delta \varepsilon$ became postpositive). ' is is now found in OAram., s. Lidz., Altaram. Urk., I I. For combination with $2 c f$. Heb. הiz, used of time, Est. $2^{13}$. בארין express a new moment or change of

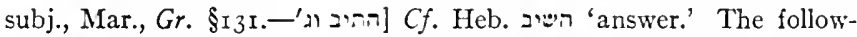

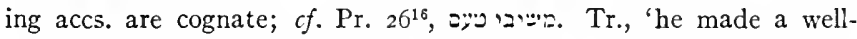
counselled and prudent answer.' The varied use of Lexx.) is due to Akk. usage.-W For the vowel $e$ s. Kau., p. I05, Barth, $N b$., §92, Brock., VG I, §I40, Nöld., $M I G$ §94, Powell, p. 39.אריוך] Also the name of the king of Ellasar, Gen. $4^{1}$; explained by Del., Schr. as Sum. êri-aku, 'servant of Moon'; this derivation is characterized by Zimmern, $K A T{ }_{3} 67$, as 'äusserst unsicher.' In any case the name was not used in Nebuchadnezzar's age (Sayce, $D B$ s.v.) and it was evidently borrowed from ancient literature, even as Arioch appears

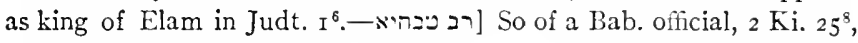
etc. = 'יר רה of an Egyptian, Gen. $37^{36}$. The root means primarily 'slay,' secondarily, in Arab., 'cook,' cf. 를 I Sa. $9^{23}$. Since W. R. Smith, OTJC ${ }^{2}{ }_{262}=$ Religion of the Semites ${ }^{1}$, p. 396, comm. (Dr., Mar., Cha., BDB GB) have accepted his derivation of the term as going back to its sacrificial idea; the 'sacrificers,' as a distinguished class, became the king's bodyguard. But it appears absurd that a priestly caste should have become a civil police. 'Executioners' ('butchers') is simple and appropriate enough here; s. Pr., citing use of the root in Akk. = 'execute,' and so Kön., Hwb. This corps were the lictors (so here dâl $l \hat{s} \hat{e})$, whose frequent enough business was the infliction of capital punishment. The Kapidshi Pasha was the chief executioner of the Porte (Bert.). The official then was the provost-marshal of the court. Such may have been the official named in Gen. $37^{36}$, although there $\mathbb{6}$

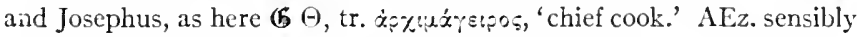
remarks that this mng. was impossible in Pharaoh's court, since the Egyptians did not slaughter. Josephus here, $A J \times$, I0, 3, entitles the

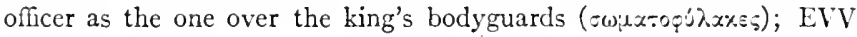

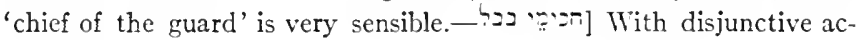
cent, vs. v. ${ }^{18}$, etc.

15. נה ואבר לאריוך]; $\Theta$ om., supplied from (5 by OrC Lu. This may be one of $\Theta$ 's frequent abbreviations avoiding superfluous phrases; but $\$$ also omits it along with the following by orig. (6. Prob. various forms of as appositive to מריר, and so Sym. II EVV, all comm. But the vocative 
construction, as in $\Theta$, is far more in place, the other being otiose.-- ענה] As in Heb. = 'respond to circumstances' as well as to word; $c f . \mathrm{v}^{20}, 7^{2}$. A capital parallel occurs in $A P O$ pap. 49,1 . I5; $c f$. Eng. 'answer' = 'correspond,' of inanimate things. For use in N.T. s. Dalman, Worte

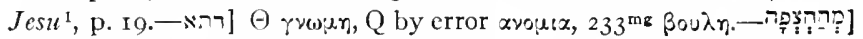

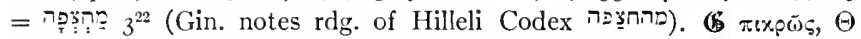

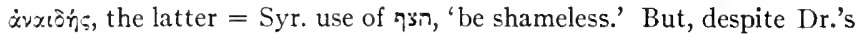
argument for this mng., here ("urgent is not strong enough"), the word in the two passages requires the sense 'hasty, peremptory,' corroborated by the Arab. hassaba, 'festinare' (Freytag) and 'etwas ungestüm beanspruchen' (Wahrmund); and so, more correctly, (B) in $3^{22} \dot{\eta} \pi s t \gamma \varepsilon \nu$, $\Theta$ i $\pi \_$i $\sigma_{\chi} u s v$. In Talm. the root means also 'be energetic.' Criticism from Dan. that the sentence was shameless, or harsh (Bev., Dr.), or cruel (Jer.), would not have helped save his neck. Correctly AEz. מהירית, AV 'hasty,' RVV 'urgent'; best JV 'peremptory.'-16. ו וב] $\Theta(B$ Q 2688 I47) om. The 'critical' texts ignore this important traditional variation of $\Theta$. $\mathbb{C C}^{\mathrm{B}}$ om. 'Daniel.'-איק

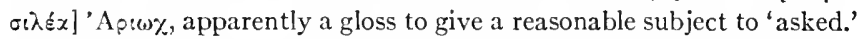

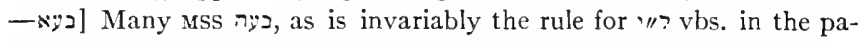
pyri; in this case the spelling with $x$ has by far predominated over

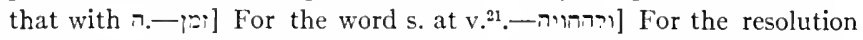
into an infinitival, gerundive clause $c f$. vv. ${ }^{18 .}{ }^{20}, 5^{15}$, and for similar construction in Heb. v. sup. $\mathrm{I}^{5}$; here, 'and the interpretation would be shown.' See Torrey, Notes, I, p. 257 , on the construction; he $c f t$. the same construction in Syr., Nöld., $S G$ p. 2 r6.

17-23. The revelation to Daniel. Dan. summons his friends to supplications before God that they, as well as the other wise men, may not perish. To the simple datum of prayer, v. ${ }^{18}$, for the divine mercy $\mathfrak{b}$ adds the element of fasting ( $c f$. a similar supplement in late texts of $\left.\mathrm{Mk} .9^{29}\right)$. Omission of reference to fasting, which was included in all important acts of devotion (e.g., IO ${ }^{3}$, Est. 4) is due to the shortness of time, the few hours of a night, in which the Jewish saints kept up their vigils. Prejudice accordingly marks Häv.'s criticism of $\mathfrak{G}$. The desired revelation is vouchsafed to Dan., v. ${ }^{18}$, but its contents are dramatically reserved for the climax of the story. It comes by night, as again in c. 7 , but in a 'vision,' not in a dream, the lower means of communication to the Pagan. The intimate scene of the spiritual life of these heroes is concluded, by both natural and liturgical propriety, with a hymn of praise in which Dan. 'blesses God.'

20-23. The hymn of praise put in Dan.'s mouth is a fine ex- 
ample of liturgical construction; it is an original composition, entirely to the point of the story, and is hardly to be characterized, with Mar., as 'aus liturgischen Formeln bestehend.' The four vv. are severally tristich, tetrastich, tristich,' tetrastich (Mar., Cha.). The tristich, $2 \times 2 \times 2$, is a resolution of the double 3 -beat measure $3 \times 3$. On these metrical sections s. Int., §. 20. The saint praises the Name of God, i.e., God in his self-revelation, for his omniscience and omnipotence, attributes revealed in human history, $\mathrm{v}^{21}$. His power is exhibited in his providence over 'times and seasons,' Moff., 'epochs and eras,' and in his sovereign determination of all political changes. In this expression lies a challenge to the fatalism of the Bab. astral religion, a feature which in its influence long survived in the Græco-Roman world. (See C. Fichtner-Jeremias, 'Der Schicksalsglaube bei den Babyloniern,' $M V A G$ I922, pt. 2; Cumont, Les religions orientales dans le paganisme romain, c. 7 , and for a lively impression of its conflict with the Bible religion, Bardesanes' Laws of the Countries, properly a Dialogue on Fate.) The divine knowledge is proved by the occasional revelations God vouchsafes to 'sages and gnostics.' These glimpses of his prescience in human affairs reveal the fact that with him 'the light is lodged,' ${ }^{22}$, for him there is no darkness at all. There is a progress in the crescendo of 'deep things' (problems), 'hidden things' (mysteries), sheer 'darkness,' with their contradiction in the light which has its home with God. The motive of the light belongs to a poetic field common to Semitic religion; $c f$. Ps. IO4 ${ }^{2}$, Is. $10^{17}$, and, quite parallel to our passage, Ps. $36^{10}$, "in thy light do we see light.' Comm. have compared here the somewhat converse idea in I Tim. $6^{16}$ of God 'dwelling in the unapproachable light.' The thought of 'the light' has hardly waxed to the extent of a 'Philosophem' with Bert, yet with Hitz. we may compare Wis. $7^{26}$, where Wisdom is 'the effulgence from everlasting light.' It is not surprising then to find 'the light' of this v. interpreted Messianically. In Midrash Echah, fol. 36, col. 2, Wilna ed., are given several 'names of the Messiah,' concluding with the dictum: "His name is the Light, as it is said (Dan. ${ }^{22}$ ), The light dwelleth with him." An interesting collection of similar Messianic interpretations of 'light' is to be found in Pesikta $R$. at Is. $60^{1}$, ed. Friedmann, pp. I6I ff. The connections with the Johannine theme of the Light are obvious. For this theme 
s. in general Volz, Jiid. Esch., 328. 24. Change occurs to the $2 \mathrm{~d}$ pers. in the language of more personal prayer; it uses the intimate phrase, 'God of my fathers,' a term of ancient origin but especially common in Chron. Dan. praises God for the present particular revelation of his wisdom and might in which he has granted him to share. Yet he credits his associates with the power of prayer, "ut et arrogantiam fugiat, ne solus impetrasse uideatur et agat gratias quod mysterium somnii solus audierit" (Jer.).

18. למבע: For the inf. s. at v.16.- $\tau(\mu \omega) i x v$; Behr. cfl. (BSS's rendering of last term by mesâm berî̌sâ, by which he would understand 'castigatio,' so Mar. 'Kasteiung.' But it must be taken in one of its classical senses, 'vindication, help,' as Häv.

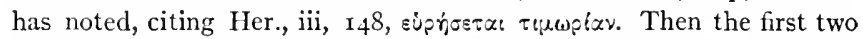
terms appear to have been glossed in from $9^{3}$. - אלה ישמיא Dan., 4 times in Ezr., 6 times in papyri of $A P O,=$ Heb. אלהי הישמים, $1_{3}$ times in Ch., Ezr., Neh., Jon.; $c f$. Tob. $10^{12}$, Judt. $5^{81}, 6^{19}, \mathrm{II}^{17}$. Only post-exilic except Gen. $24^{7}$, where (G) 'God of h. and G. of earth' $=24^{3}$. As an equivalent of בקל ישמין (for whose antiquity s. the writer's remarks, $J B L$ 1909, pp. $67 f$.), the term was disowned in Israel's religion, but was revived after the Exile, when it became the title by which the Pers. government recognized the Jewish God. The correctness of this title in 'Cyrus's edict,' Ezr. I, has been brilliantly demonstrated by the papyri. The title did not arise under the influence of the Pers. religion, but the existent Aram. term became in the use of the Pers. chancellery a remarkable recognition of the essential content of the Jewish religion. It was generally used by the Jews only in external correspondence, and finally fell into disfavor again as too similar to Zeus Ouranios, etc.;

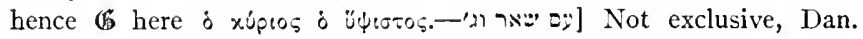
and his friends alone to be excepted from the penalty, but they as well as the other wise men; $c f . \mathrm{v}^{24} .-19$. הis] See Kau., $\$ 56,6$, b, Mar., Gr. $\S_{3}$, c.-win] Pers. word, only in c. 2 and $6^{4}$; also in BSira $8^{18}$, $12^{11}$.

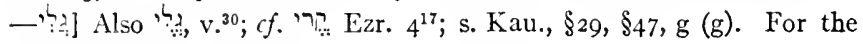
Peîl form s. at $3^{20}$.

20. ילחי So always except $4^{22}$. The change of the doubtlessly orig. form להוא to is an arbitrayy expedient to disguise not merely a spelling but a pronunciation which was that of the Unspeakable Name Yнwн. For arguments for this position s. Mein., Bev., p. 35 (with citation of use in Talm., etc.), Dr., Tenses, $\$ 204$, Obs. I (with extensive bibliography), Mar., Gr. $\$ 65$, Str., Gr. §16, m, Brock., VG I, p. 565. The arguments are: I) The use of pref. $\zeta$, common in EAram. dialects, indifferently as impf. and juss. (Talmud, Mandaic, s. Nöld., 
$M G \S \mathrm{r} 66)$, appears only in this vb. in BAram., and invariably so, not only in juss. 2) The papyri have always יהוה, never להוה; this constitutes a demonstration of fact against the plausible philological theories of the defenders of להוה 3) It is instanced only rarely in late WAram., viz., in jussives, s. Dal., Gr. $\$ 61$, r. The defensive is accepted by Kau.,

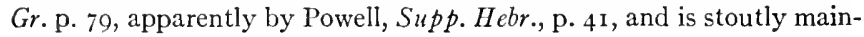
tained by Kön. in his article, 'Das l-Jaqtul im Semitischen,' $Z D M G{ }_{51}$ (1897), pp. 330-337. The one plausible argument for support of the authenticity of the form is derived from a Zenjirli inscription. In the Hadad Inscr. (Lidz., NE p. 440, Cooke, NSI no. 6I) occur apparently four or five impf. and juss. forms with $l$-preformative (cf. Cooke, p. 169). To these cases is now to be added another, in the Aram. ostrakon letter of Asshurbanapal's reign, published by Lidz., Altaram. Urk., 1. 8. The same pref. $l i$ is found in several cases in an Akk. text published by Clay, A Heb. Deluge Story, New Haven, 1922; the cases, summarized by Clay, pp. $19 f$., he regards as further proof of his theory of an underlying 'Amorite' base to the text. But the Zenjirli testimony is wrongly adduced as Aramaic; the early Zenj. monuments are Hebrew, a point not sufficiently recognized, and so with the alleged 'Amoritism' of Clay's document. Even in the ostrakon Lidz. indicates a Canaanism in the same line; he speaks of "eine Koine, die stark durch das Kanaanäische beeinflusst war." As belonging to the Heb. sphere the cases are rather comparable with the 'periphrastic future' of the inf. with ל; s. Dr., Tenses, §204. Accordingly these cases are not WAram. particularly; the most that can be said for the illegitimate להוה is that its introduction was favored by certain formations, even if we may have not to

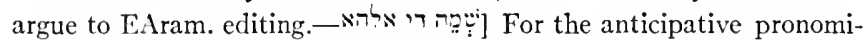
nal suff. s. Kau., §8r, e, and $c f$. Nöld., $S G \$ 205$, C. For the construction in the papyri s. $A P O$ p. 266 . In 'blessed is the Name of God,' 'the Name' has become the surrogate for the actual vocable of the divine name, הישם המפורי (on which s. Arnold, JBL 1905, 107 ff.). For this usage s. the O.T. Theologies, e.g., Schultz, Altt. Theologie $e^{5}, 40 \mathrm{Iff}$., the dictionary articles, especially the bibliography in GB s.v. ovi, at end; also Hommel, Ancient Heb. Tradition, $87 f$., $99 \mathrm{ff}$., and for late usage the writer's Aram. Incantation Texts, 56 ff. JAram. and Mand., where הוכמתמת exists along with Syr. מיכמתא s. Nöld., $M G$ p. 105.-גבורת. For $\hat{u}$ in closed syll. s. Kau., \$9, 4, c, $c f$. Nöld., $S G \S_{42}$. In Gr. tradition of $\Theta \mathrm{Q}$ alone correctly óvauls, all others by

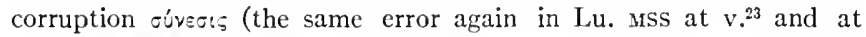
Job $22^{2}(\mathfrak{G})$. TWng sapientia et uirtus et intellectus, i.e., súvaines was read as the second term with $\mathrm{Q}$, later intellectus $=$ oiveors was glossed in to conform with later $\Theta$ text. Orc Lu. revise by doublet gloss, $\dot{\eta}$ oopla $\% \dot{n}$ oúvects \%. $\dot{n}$ ioxús. In a paper in Expositor, Sept., 1921, p. 21.4, 'Anent Dr. Rendel Harris's "Testimonies,", I have noted that 1 Cor. 


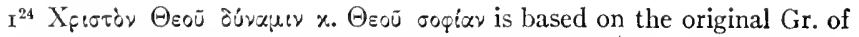
Dan. The same combination appears in Job $12^{13}$. - T? the current grammars (e.g., Kau., §2I), Lexx. and comm. (exc. Mar.) ignore or misinterpret this phrase; e.g., after Zöck., Mein., ר is an emphatic repetition of preceding $'\urcorner$, and so GB, referring to the redundant use of $d e$ in Syr. Or ' ' is taken as = quia with Jer., so EVV 'for.' But CBMich. recognized its true character, as exactly the later Aram. דיליה, etc., possessive pron., suus; s. Dalm., Gr. \$18, 4, and Nöld., $S G$ \$69. The combination is found in the $7^{\text {th }}$ cent. Nerab Inscr., I, 1. I4, in a Cilician inscription published by the writer in $J A O S$ 1907, pp. I64 $f f \cdot ;$ in the Nabataean, and frequently in the papyri, s. $A P O$ p. 263 , where the two words at times appear written as one (so here some Heb. MSs). Translate 'whose are wisdom and power.'

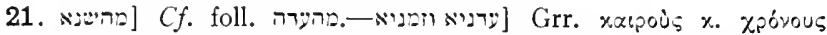
(and so generally the same equivalents elsewhere); IIWng tempora (but Cassiodorus on Ps. Ior gives orig. 珽, tempora et saecula); zabnê we'eddânê (i.e., reversing the terms; the same phrase in Clem. Rom., ed. Lagarde, p. I9, 1. 22 = מוע: Gen. $\mathrm{I}^{14}$ ); II tempora et aetates; EVV 'times and seasons,' which terms Dr., Cha. would reverse. For the same combination, with reverse order, $c f .7^{12}$, Eccl. $3^{1}$. In Acts $1^{7}$ and I Th. $5^{1}$ xpóvol $x$. xatpot is reminiscent of Dan. In the combination the words are synonymous; $c f$. our proverb 'Time and tide wait for no man'; also

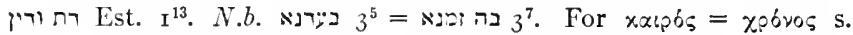
Thayer, Lex. 3 rga. If 1 r be of Pers. origin (s. Scheftelowitz, Arisches im A.T., 8I) from zrvan, which is most questionable (cf. BDB GB KAT $649, \mathrm{n} .5$, arguing for $\mathrm{Akk}$. origin), then it would have meant originally 'time' in the abstract sense.- מהקיה . . מהקיכ] $\Theta$ exchanges, on ground that appointment precedes dismissal; Or $^{\mathrm{P}}$ restores correct order. Against מהיק (all examples given by Kau., p. 74, Powell, p. 40); but $\hat{\imath}$ is demanded in all forms, $v$ s. Powell. Where the vowel-letter was not written $\hat{e}$ was used, and subsequently the spellings

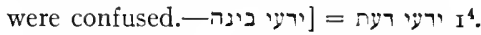

22. עיקהאי] A word of Gnostic connotation; $c f$. Job I $2^{22}$. The related Akk. nîmêk $u=$ 'wisdom'; Ea is bêl nimêkzi, etc. (Del., Hwb., p. Sg). Cf. the 'depths,' $\beta \dot{\alpha} \theta$ r, of God, I Cor. $2^{10}$, I Clem. $40^{1}$; of Satan, Rev. $2^{24}$; and Bathos became a Gnostic figure.- - מתר D Pa. pass. ppl.; $\Theta$ ex-

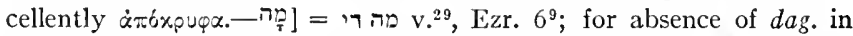
following letter, true to Aram. use, s. note in Bär.-

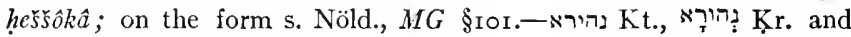

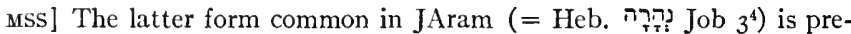
ferred by Nöld., $L C B$ I 896 , 703. Mein., Bev., Behr., Kamp. prefer Kt. which $=$ Syr. and PalSyr. nahhîra, generally adjectival, but also nominal as 'luminary,' also 'light,' e.g., Aphraates, Dem., vi, I. 2, ed. Parisot, col. 249, l. 2I, col. 256, l. I, etc. The form is corroborated by the abstract 
נִ $5^{11.14}$, and the change from Kt. to Kr. is historically more likely. Contrariwise Torrey, Notes, II, 230, who thinks of an artificial com-

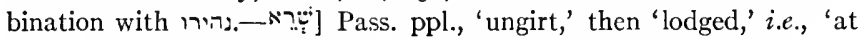
home.' There is no reason with de Goeje, note to Strack's text, to prefer act. ppl. Cf. NHeb. 'שר', and the pass. ppl. similarly often in Syr., e.g., Aphraates, Dem., vi, I I, sub fin., "the sun's light is lodged in the

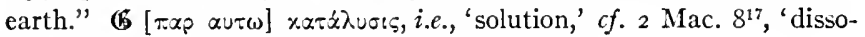
lution,' and inf. $5^{12.16}$ the vb. = 'solve riddles.'

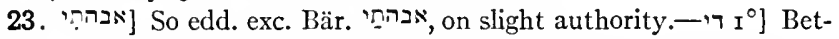
ter personal, 'who,' with EVV than conjunctive, 'because,' with Grr.,

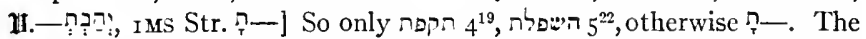
papyri do not indicate the final vowel in $2 \mathrm{~d}$ pers. sing. masc., nor in Nנה 'thou.' It is reasonable to hold that OAram. pronounced the vowel and that the occasional expression of it, e.g., v.41 אנרה חיהת, retains the earlier pronunciation, while our present form is late; so Kamp.,

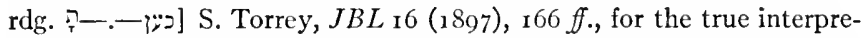
tation of the form, and Lexx.; also in forms ${ }^{2}$ and $n$, the two former in the papyri. Scheftelowitz, Arisches $i m A T$, p. 88, in attempting a Pers. etymology (a caution in this line!) was still ignorant, rgor, of Torrey's derivation.-- הורעפגנ] In Syr. -tân(i); here Heb. influence?

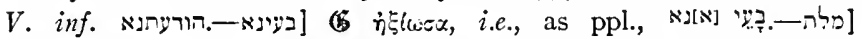
B A Q al. öpa $\mu \alpha$ (= uisum), ancient error for pin $\mu \alpha$, which 33 9I I48

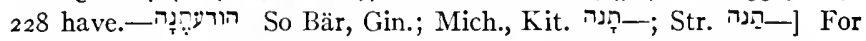
the seghol, sole for this form, s. Kau., $\$ 37,2$, a. Bev. notes that in the Bab. punctuation -ana (or -ena), never -âna, is used, and cft. Merx, Chrestomathia targumica, I 2. $(\mathbb{S} \Theta$ independently took the suff. for the sing., Lot, which Torrey, Notes, II, 230, prefers.

24 45. Dan.'s introduction to the king and the relation of the dream and its interpretation. 24-30. The proffer of the divine revelation.

24. Dan. seeks Arioch, asks him to hold up the order of execution, and requests audience of the king. For the required Oriental etiquette, $c f$. Est. $4^{11}$ (s. Paton ad loc.); Häv. adduces Her., iii, Ir8. I 40 for the Pers. custom, and Meissner illustrates it for Assyria, Bab.u. Ass., I, 70. The present statement is proof that Dan. did not have an earlier audience, vs. v. ${ }^{16}$. 25. Arioch goes to the king, 'in haste,' as at $3^{24}$, so EVV, perhaps more exactly with Behr., in excitcment. There appears to be an inconcinnity in the terms of Arioch's introduction with $\mathrm{I}^{18 \mathrm{ff}}$, yet the formal introduction was obligatory, and royal minds are easily forgetful of 'college professors.' 26. The parenthetical addition 
of Dan.'s surname Belteshazzar, while possibly a gloss ( $c f$. I Esd. $4^{13}$, but per contra the constant 'Simon surnamed Peter' in Jn.), is a proper literary bond with c. I (so vLeng.), giving the name under which the sage was presented. 27. Dan. gives all the glory to God in response to the king's inquiry as to his ability, after Joseph's example, Gen. $4 \mathrm{I}^{8}$, and denies the power of human wisdom in the premises, as equally, $\mathrm{v}^{30}$, any virtue of his own. The humility of Joseph and Dan. is capitally depicted as sprung from reverence before God without fear of man, although courtesy to the latter is not ignored. Paul in I Cor. 2 develops the idea of the heavenly wisdom in a similar way, with indeed a reminiscence of $\mathrm{v} .^{20}$ (q.v.). 28. That there is a God in heaven, as against man-made gods and deified men, is the supreme theme of the book, even as it is the cardinal principle of the Bible, e.g., Ps. $\mathrm{II}^{4}$. For the end of days, so correctly JV, vs. AV RVV the latter days, cf. Dr.'s excellent note: "An expression which occurs fourteen times in the O.T., and which always denotes the closing period of the future so far as it falls within the range of view of the writer using it. The sense expressed by it is thus relative, not absolute, varying with the context. . . . Here, as the sequel shows, it is similarly the period of the establishment of the Divine Kingdom, which is principally denoted by it."

28. 29. There is an extraordinary duplication of thought and phrase as between these vv. In both appears 'the Revealer of mysteries,' and there are the parallelisms: 'what shall be at the end of days,' v. ${ }^{28} \|$ 'what shall be after this,' v. ${ }^{29}$, and 'the visions of thy head upon thy bed,' ${ }^{28}{ }^{28} \|$ 'thy thoughts upon thy bed,' v. ${ }^{29}$. These phenomena are best to be explained-not on a sheer theory of interpolations, so Mar., but as actual ancient duplicates, which may go back to the earliest editions of the book. Probably with the secondary form, v. ${ }^{29}$, should be combined $\mathrm{v}^{30}$, the statement of Dan.'s humility, which overlooked motive may have incited a fresh essay at the passage. Similarly Löhr regards $v^{29}$ as an addition. Jahn (cf. Löhr) argues from a lacuna in $\mathscr{G}^{\mathrm{G}}, \mathrm{v} .^{29}$, to a late interpolation of this passage; but he ignores the witness of $\mathfrak{b}^{\mathrm{s}}$ to the originality of the passage. 30. For the contrast between any possible wisdom in Dan. and the sole ground of the revelation which lies in the purpose of God, Häv. cft. Gal. $I^{11}$; the contrast is rightly ex- 
pressed by Hitz., 'nicht durch eine Weisheit, die in mir wäre,' cf. EVV, 'any wisdom.'

24. בל קבל דנה Best 'accordingly.' The VSS have much trouble with this phrase and tr. most variously. $-72^{\circ}$ ] Idiomatic use of the prep.; $f$. Arab. dahala 'ala fulân, 'he went to one in his house,' Wright,

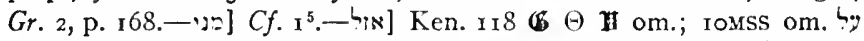
$\mathrm{I}^{\circ}$ supra. Either simplification is possible, so Cha. The vb. לy could have arisen by dittograph of the prep., so Mar. in his comm., Löhr, Torrey, Notes, II, p. 257. But the VSS defend על על as against, and argument cannot be based on superfluity in Aram. diction._in OAram., in the Hadad Inscr., ll. 22, etc., the ZKR Inscr., the papp.

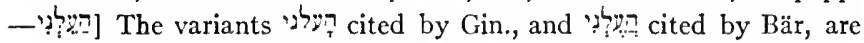

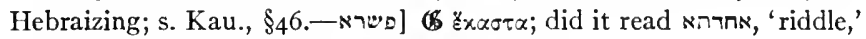
and understand it as the numeral? So also v. ${ }^{26}$.

25. The rt. in Pr., Ch., Est., along with original sense of 'dismay,' has also that of 'hurry,' and so here, $3^{24}, 6^{20}$, and NHeb.-C הניל] For nasal dissimilation in Aram. dialects, s. Kau., §ı I, 4, b; Nöld., $M G$ $\S 68$; Dalm., Gr. §71, 4. The phenomenon is still more pronounced in the papp., s. the nouns listed $A P O{ }_{262}$, and for the forms of this $\mathrm{vb}$.

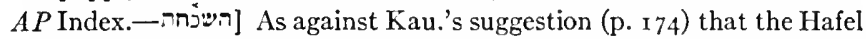
here is properly Peal s. Bev.; the Haf. also in the papp. For the vocalization, which is primitive, s. Kau., $\S_{40}$, 4 ; so the similar fems., ניהור - Also in the papp.; a back formation from the gentilic יהורי, as Hitz. recognized; $c f$. Brock., VG I, 398, Wright, Arab. Gr. I, §251.-26. רי יטמה ]

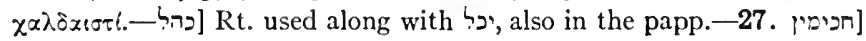
Asyndeton, s. $\mathrm{I}^{20}$; for the classes of wise men, s. $2^{2}$. - 1 ' ג Primary mng. of $7 x=$ 'cut,' e.g., $2^{34}$, then 'decree,' Job $2^{28}$, Est. $2^{1}$, and so = 'fate.' Hence the generally accepted mng., '(fate-)determiners,' i.e., astrologers, so JV, vs. AV RV 'soothsayers.' $\Theta=$ Ir simply transliterate, $\gamma \alpha$ hap nvol (unique to Dan.?). But there is another tradition of the word: Sym. had Outks, 'sacrificers,' II aruspices (Jer. citing in his

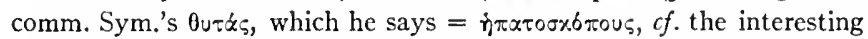
scholium in Field at $4^{4}$ ); and this is supported by W. R. Smith, Journal of Philology, I3 (1885), 28I, citing from Bar Bahlul's dictionary the equivalence of Syr. kâsôm â with Arab. jazzâr, 'slaughterer.' We may then have in this word the Aram. term (also taken over into the Gr.) for the Bab. diviner of liver omens.- יכלי ] $\Theta$ om.-through homoiot. in Sem. copy? Lu. cleverly restores without disturbing construction of $\Theta$ by oúvauıs; also found in Clem. Alex., Strom., i, 4 (ed. Potter, i, 330).

28. אחרית] A borrowing from the Heb.?; otherwise BAram. has 
ๆ10. Cf. Akk. ina aḩrat tumê, s. Del., Hwb., 45.-A considerable passage omitted by $\mathscr{G}^{\mathrm{G}}$ is preserved in $\mathscr{G}^{\mathrm{s}}$; it was known to both Jer. and Lu. It contains the plus, 'O king, live forever.'- ראיאך] For the psychology cf. Franz Delitzsch, System of Biblical Psychology, 300: "It is the only trace of the reference of spiritual-psychical events to the head." But the head is referred to as the seat of vision, so Mar., so also Ehr., who cft. Ecc. $2^{14}$, 'the eyes of a wise man are in his head,' a comparison made long ago by Jer. Häv. well says: "Nach einer poetischer Anschauung des Traumes umschwebt derselbe gleichsam das Haupt," etc., and $c f t$. $I l$., ii. 20, of the dream god standing 'over the head' of Agamemnon; so xxiii, 68, etc.-אנה הוא] Sing. by attraction to following sing. subject-matter; $c f$. Nah. $5^{14}$, Est. $4^{16}$. Incongruence of pron. is exemplified in the papyri, e.g., A PO pap. I5, l. ונה שמהח נישיא 2.

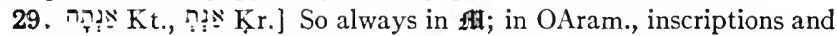
papyri, always אנת, but doubtless = 'anta; s. on יהבת , at v. ${ }^{23}$, and Kau., $\S_{\mathrm{I}} 8$, Anm. For the absolute construction $c f . \mathrm{v}^{32},{ }^{17}{ }^{17}, 5^{6.18}$; similarly in the papyri, e.g., APA pap. B, 1. 8 ביתי אנר ('N as caret), 'my house,' and

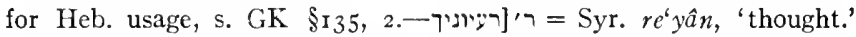
The development of Syr. $\mathrm{s}:$ is from that of 'pleasure,' = Arab. radiya, to 'purpose,' and so to 'thought'; s. Brock., Lex., s.v. The Heb. philologists dispute whether Heb. רב Ps. I39 ${ }^{2}$, ריר: Ecc. I Ecc. $I^{17}$, etc., hail from root $r d y$, so Lagarde, Nöld., BDB (sub III רעה); or from רעה 'shepherd,' so Barth, Kau., Aramaismen, 8I, GB, Kön., $H w b$. Legitimately $r d y=$ Heb. הצר, which actually exists. But the Heb. words in question are late and are to be explained as direct borrowing from Aram. Our word is with to be closely construed with

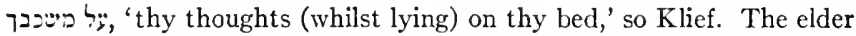
comm. dispute over the exact mng. of ' $ר$, without much necessity in the simple Sem. psychology; it includes the king's cogitations (Pr. 'specu-

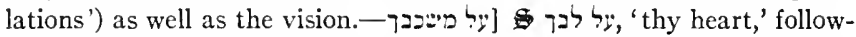
ing a common Heb. phrase, e.g., 2 Ki. I $2^{5}$, frequent in N.T., $\alpha v a \beta x$ ivetv

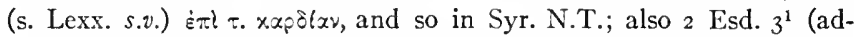
duced by Cha. here), "conturbatus sum super cubili meo recumbens et cogitationes meae ascendebant super cor meum." Bert. argued for the originality of $\mathrm{rdg}$. and is followed by Cha. (without reference to \$). The relative clause ' מה רי וג is epexegetical to similar stative forms s. Kau., $\$ 25$, e. JHMich. properly cites Lat. oboriri; with this idea in mind apparently 1 paraphrases, cogitare coepisti._-] An indefinite relative, = Heb. מה זה often, also Arab. and Aram. mâdâ.-אחרי] This prep. in sing. form appears in OAram. monuments and papyri; it was later replaced by 7 ר, found also v. ${ }^{39}$, etc.-30. 삼] S. at v. ${ }^{19}$. עלדבר, APO pap. II, 1. 3, etc.; also in Heb., ער רבר Ecc. $3^{18}$, etc.יהורעו] For the impersonal use s. at v. ${ }^{13}$; it appropriately here veils 


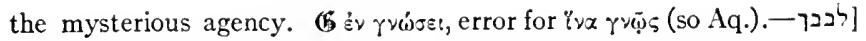
The triradical form in BAram. and the papyri, also in PalSyr.

31-45. The dream and its interpretation. For discussion of the symbolism, s. Note at end of the chap. 31. The v. reads very limpingly as usually translated and interpreted. Both $\Theta$ and have simpler forms; nevertheless, $\mathfrak{G}$ contains all the elements of The almost universal construction of the v., following $\mathfrak{A t}$ 's punctuation, appears thus in JV: 'Thou, O king, sawest, and behold a great image. This image which was mighty, and whose brightness was surpassing, stood before thee; and the appearance thereof was terrible.' But the relatives in the second sentence are not in is $_{\text {, }}$ and that sentence is manifestly circumstantial, parenthetical, as Hitz., Zöck., Torrey alone, apparently, have noted; further, 'lo' ('behold') is generally construed with a ppl. (e.g., $7^{2}$, and cases cited inf.). Tr.: Thou, O king, sawest, and lo, A great image . . standing before thee. For the interior clauses Torrey, Notes, I, pp. 257 f., has best solved the awkward condition of שי (JV as adj., 'great') as adv. (as adj. it means 'much') after the subsequent ר (JV'mighty'). The resultant is: Thou, O king, sawest and lo: an image-that image was very great, and its splendor extraordinary-standing before thee. For a similar lengthy period $c f$. vv. ${ }^{37-38}$.

31. חזה הוית N.b. the genuine Aram. use of the ppl. with vb. 'to be,' expressing continuance of action, also postpositive order of vb.; s. Kau., $\S 76$, f, cf. Nöld., $S G$ §277. For similar Heb. usage s. Dr., Tenses, §I 35, 4; Aram. influence is obvious in iate O.T. use. For 'thou sawest and behold,' $c f .7^{2}$, Gen. $41^{22}$, Zech. $1^{8}, 2^{1}$, Rev. $14^{1}$, etc.; also the frequent

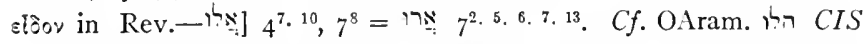
ii, no. 137, A, l. I, B, l. 4 ; on an ostrakon, $A P A$ M, $b=$ Lidz., Eph., 2, 229 ff.; also in Lidzbarski's ostrakon, Altaram. Urk., 1.9. Opinions differ sharply as to origin and relations of the two particles. plained as 'ein verstümmelter Imperativ vom Stamme ראר, 'so Kau., $\$ 67,6$; the prothetic vowel is common in Syr., particularly in impvs., s. Nöld., $S G \S_{5}$; ; but the root early disappeared in Aram., being represented in BAram. only by 17 . For h $\mathrm{N}$ Pr. suggested relation with Akk. lu

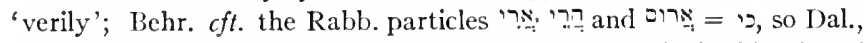
Gr., pp. 221, 234, citing dialectic Aram. forms; Lidz. denies identity of

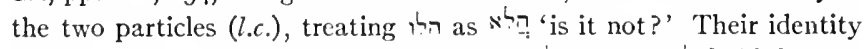

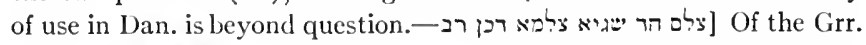

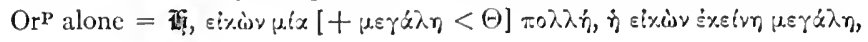


on which Lu. depends for second clause; 1 H $=$; $\mu \varepsilon \gamma \dot{\alpha} \lambda \eta \eta \dot{\eta} \varepsilon i x \omega \dot{0} ; Q^{*} 26$ om. $\eta \varepsilon \varepsilon x . \varepsilon x .=$ Cypr., Test., ii, 17 , ecce imago

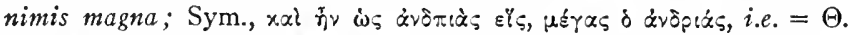

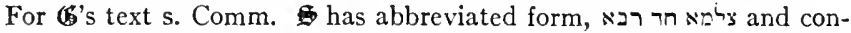

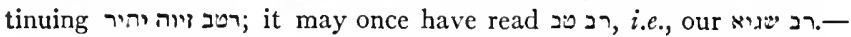
o.s] OAram. in the Nerab Inscr. of a carved design, then of a 'statue,' so in Akk., of a god-image (Pr.); = Arab. şanam 'idol,' as Jeph. tr. it;

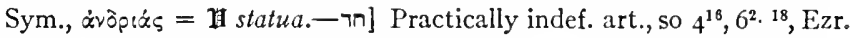
$4^{8}$; so occasionally אחר in Heb., e.g., $8^{3.13}$ (s. Lexx.); similarly $\tau \iota \zeta$ in Hellenistic Gr.-127] $7^{20.21}=i$ ste, rather than with Kau., ille, Lexx. 'this.' For formation, dêk $+n, c f$. Bev.; for $-n$ as in המון , sö, söld., $M G$ p. 86, n. 3. The form is unique in Aram., which developed a great variety of pronominal forms; cf. זכ, APO no. 7I (p. 218) 'to that company.' This form may answer Ehr.'s argument against דכן because of its common gender, he analyzing our pron. into 'י 'י i.e., 'das so beschaffene Bild.' The demon. pron. in BAram. and the papp. can precede or follow the noun, Kau., \$9o, also in Syr., Nöld., $S G$

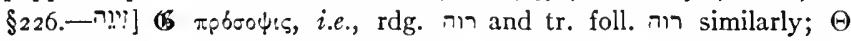
follows $\boldsymbol{B}$ in the first case, but in the second oparts. For $\Theta$ autrs $Q^{*}$ has sixovos autns = Cypr., eius imaginis; Maternus, ipsius im.; i.e., the omission in $\Theta$ has been glossed in. $[$ statura] sublimis, i.e., as from rt. סר. The word in same use $4^{33}$; in pl. of the color of the face, $5^{6}$, etc., $7^{29}$. The word, prob. = Akk. zîmu, 'Erscheinung, Gesichtsausdruck' (Del., $H w b$. s.v., KAT 649), means primarily the light effect of an object, its 'shine, sheen,' secondarily 'glory,' as in Syr. AEz. cft. the month name Ziv. Cf. Haupt on equivalence of Akk. lânu 'aspect' and Arab. laun 'color,' JAOS 37, 253. Nöld. has claimed a Pers. origin, $M G$ p. xxxi, GGA 1884, 1022.--יריר AV RVV 'excellent,' i.e., 'excelling'; s. Dr., and his Add. Note, p. 32, on the use of this old English word in the Bible; better JV 'surpassing,' Behr. 'ausserordentlich,' 'extraordinary.'

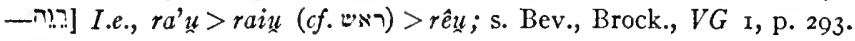

32. 33. The details of the Image. The Image is blocked out in five parts, the last two of which have a common element, hence to be regarded as possessing a certain unity. Each part is composed of a separate substance; these substances are arranged in order of value, gold down to clay, in parallelism with the hierarchy of the members of the body, from the head, the seat of dignity, to the humblest limbs, the legs and feet. The head is of fine gold; the chest (lit. 'breasts') of silver; ${ }^{1}$ the abdo-

'Cf. Herodotus' account of the golden statue of Bel at Babylon; s. Note at end of chap. and Int. to c. 3. Compare the statues of gold and silver recorded by Pliny, Hist. nat., xxxiv, 18. 
men and the hips of brass, more exactly bronze ${ }^{2}$ the legs of iron and the feet 'partly of iron, partly of clay-fabric.' The word for legs is generally used of the upper leg, the thighs (so $(\mathfrak{G} \sigma \kappa \epsilon \lambda \eta)$; if so used here then 'the feet' would include the lower leg, even as the word is used in the description of Goliath's armor, I Sa. $\mathbf{I} 7^{6}$, or euphemistically of the whole leg, e.g., Is. $7^{20}$. But it is preferable to take 'the feet' in the natural sense and the preceding term as meaning the whole leg. $\Theta$ understands by 'the legs' the lower legs, $\kappa \nu \hat{\eta} \mu a \iota$. Only in the interpretation, vv. ${ }^{41}$ f., is mention made of the toes, probably a later addition (v. ad loc.). The one stumbling-block in the description of this fine work of artifice is the word translated 'clay.' The word (-0n hasap), which appears with phonetic modifications in all Sem. stocks exc. Heb., invariably means a formed pottery object, whether a complete vessel or its fragments, i.e., potsherds. And so the ancient

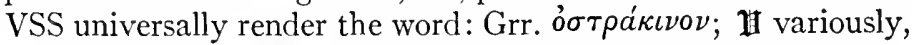
here fictilis (from 7 , also vv. ${ }^{34 .}{ }^{42}$ ), testa (vv. ${ }^{35.41 .}{ }^{43 .}{ }^{45}$ ). And so with the same word, as also Sa. with its Arab. equivalent hazaf. Modern VSS and almost all comm. ignore this mng. and render by 'clay.' But the raw material is denoted in v. ${ }^{41}$ by (EVV 'miry [clay],' RVVmg 'earthenware'), while 5, en is identical with 'potter's ware' (rather 'pottery ware') at v..$^{41}$, where EVV have 'potter's clay.' No more than in the case of the wrought iron can we think of raw clay daubed on the statue, and yet so Behr. defines 'clay,' 'abblätternder 'Thon oder Schiefer,' similarly dEnv. as of raw clay; nor of a conglomeration of potsherds. Menodius (in Pole) thinks of an iron ore with clay admixture. The comm. generally fight shy of an explanation, but correctly CBMich.: ferreos et testaceos, and so vLeng. We have to think of tile work entering into the composition of the figure, applied, as it actually was, in the way of decoration, but then in caricature regarded as shoddy work replacing the essential iron structure; the element was doubtless true to architectural forms of the age. There is no question about the use of tile work in ancient Babylonian architecture; we have the terracotta reliefs in Greek art, the tiling of Saracenic art, while the tile-covered towers of modern Persia are witness to this ancient mode of construction. We might even think of the porcelain

\footnotetext{
2 For the lavish use of bronze in Babylonia of. Her., i, 181 , 'the bronze-gated temple of Bel,' and in general s. Meissner, Bab. u. Ass., 1, $265 . f f$.
} 
towers of China. How far such work may have entered into the composition of statues we do not know. Chryselephantine images were known in late Assyrian as well as in Greek art, while the extremely ancient art of the inlaying of enamels in metal may have induced the similar use of applied tiles. The caricature of the picture lies in the application of this fragile form of art to the weakest section of the statue, enhancing its decoration but replacing the structural elements. ${ }^{3}$

32. הוא צלמא The VSS variously render the pron. Ehr. rightly rejects Behr.'s construction, 'dies ist das Bild,' for which דנה would be used. Nor is Mar. right, 'es, das Bild.' For the indifferent position of

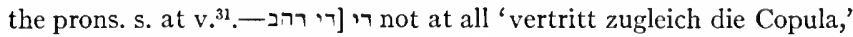
with Behr.; nor does it merely replace the construct. The particle retains its primitive mng. as a demonstrative relative; so frequently in Syr., s. Nöld., $S G \S 209$, where he speaks of 'die grössere Selbständigkeit des $d \breve{e}$, eigentlich eines Demonstrativ-(Relativ-)Pronomens ('der von');' e.g., among his exx. רבית הרורס, 'those of Herod's party.' It corresponds to Arab. $d \hat{u}$, surviving in classical Arab. only in conventional use, s.

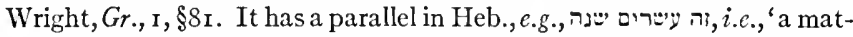
ter of 20 years,' s. my note $J B L$ 1924, 227. In the papyri both this con-

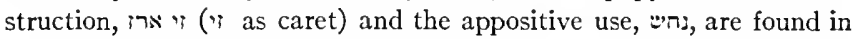
one line, APO pap. I, 1. I 2. Inf. v. 38 is rather in line with the usual Syr. constructions of two definites in const. relation.-20]

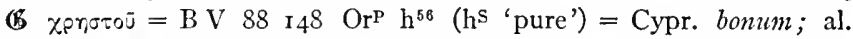

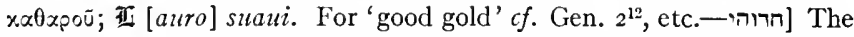
plene writing with $)$ is correct (rarely transgressed, e.g., 56, Ezr. 63. ${ }^{11}$, $\left.7^{14}\right)$, as the papyri show, in which age it was then still pronounced -auhi. חרוהי is dual, so Schulthess, $Z A T W$ 22, I63, and is to be added to

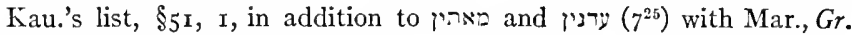

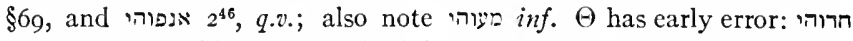
read as ידוה, which was revised by an early doublet, ai $\chi \varepsilon i p \Subset \varsigma$ xal

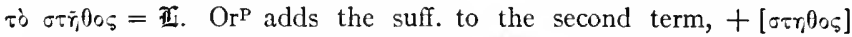
$\alpha^{\dot{j} \tau} \tilde{n} \bar{s}$, and so hereafter consistently with

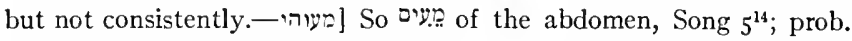
also a dual, and so pointed in NHeb., s. Jastr., s.v.-33. מנהחון Kt., מנהון $\mathrm{Kr}$, and MSs]. So also vv. ${ }^{41 .}{ }^{42}$. OAram. was careless of grammatical agreement, s. Kau., §98, 2 and $A P O$ p. 273 , §10. 3 ; hence Kt. may well

${ }^{3}$ For the Mesopotamian art in tiles s. Koldewey, Das wieder erstehende Babylon, $40 f f$. (with illustrations in color), Meissner, op. cit., $275 . f$. For a terra-cotta relief at Sardes S. Shear, $A J A$ I923, I 3 I $f f$., and for Etruscan terra-cotta 'antefixes' D. M. Robinson, ib., I ff. I note in Bedjan's Syriac text of Mar Jaballaha, p. 137, 1. 6, a 'dome plated with green tiling,' אחצr. 
be original. In the papyri the suff. masc. is in , the suff. fem. is nonexistent but would not be distinguished in spelling; s. further Haupt's note in Kamp. The terms mean that the feet were partly iron, partly clay (not distributive, as among the toes), and the point is to be borne in mind in the interpretation of $\mathrm{v}^{42}$.- Lexx. for philology; add Fränkel, Lehnwörter, r69. Nöld., ZDMG 40, 730 , asserts that here the word is used of the raw clay; this is denied by Schwally, ib., 52, 140.

34. 35. The second and final scene of the drama is the collapse of the Image, smitten on its feet by a Stone quarried without human agency; not a trace is left even of the substances which composed the proud creation, while the Stone expands into a Mountain which fills the whole earth. Only here is given the faintest indication of some background, an origin for the Stone; the detail is filled out subsequently in the explication, $\mathrm{v}^{44}$, that it was quarried out of the mountain, if the item be original there. The item has intruded itself here falsely in most early texts of VSS, but not in $\Theta$. For the Messianic exegesis of these vv. s. Note at end of the chap. More poetical, as more natural, is the prophecy in Is. $\mathrm{I}^{9}$, "The earth shall be full of the knowledge of the LoRD as the waters cover the sea'; the 'hyperbole' (Zöck.) of the rock filling the whole earth is due to that reminiscence.

34. ע ער $C f .7^{4}$. ע here as in Heb. poetry, 'used to mark not an absolute clause, but an epoch or turning-point,' as Ps. Iro' (BDB 725a); cf. the similar use of Arab. hata(y)._- ה. I.e., hitgazârat, retaining

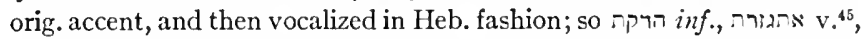
המרת $5^{11}$; s. Kau., \$30, 2, Powell, Supp. Hebr., p. 48.זֶ: 'Rare in Syr.' (Behr.), but frequent in the papp. For the vocalization

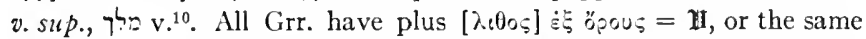
prefixed by Lu., exc. Or ${ }^{\mathrm{P}} \mathrm{V} 233 \mathrm{Hipp}^{56}=\mathbb{I W n g}^{\mathrm{W}}=\mathbf{S}$. This plus in $\Theta$ is an intrusion from $\mathbb{G}$, for $\Theta$ has in $v^{45} \dot{\alpha} \pi \dot{b}$ öpous, and Lu.'s placing of the plus here follows order in $v^{45}$. Kamp rightly refuses to accept the addition, against Houbigant, Jahn, Ehr., Cha. This is a good instance of the fallacy of citing B offhand as 'Theod.,' as do those comm. and Löhr (who accepts the emendation here 'probabiliter'). The witness of Jos., $A J \times, 10,4$, alleged by Cha., is precarious, as he compresses

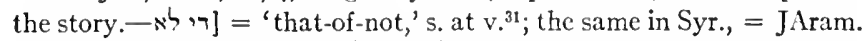

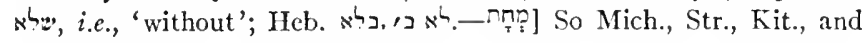
properly, after Syr. vocalization; Bär, Gin. 
$\left.v^{35}\right)$. For the variant traditions of such forms s. Kau., $\$ 47$, p. $78 .-$ ] $C f$. Mi. $4^{13}$, Is. $4 \mathrm{I}^{15} \mathrm{f} ., \mathrm{Mt} .3^{12}$; a frequent figure of the divine judgment.-Cהמון. Only in Dan.; in Ezr. and papyri is, papp. also ה. For -n v. sup. רכ v. ${ }^{31}$; Barth, Die Pronominalbildung in den sem. Sprachen,

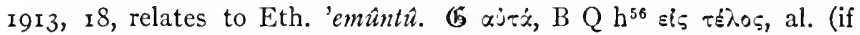

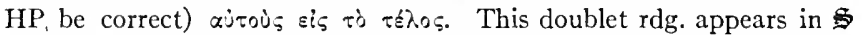
'[ground] them well ( $2 *$ ),' and had entered the Theod. texts before time of 2 , where we have comminuit eos usque ad finem, Iren., or comm. eos minutatim, Cypr., Maternus; cf. A 'very finely.' As $\Theta$ misunderstood המון $v^{35}$ as $=\pi \lambda \bar{r} \theta 05$, we must charge him with a similar lapse

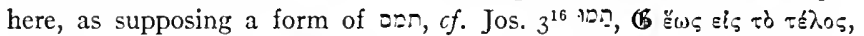
and Dt. $3 \mathrm{I}^{24 .}{ }^{30}$ ב neously restored.

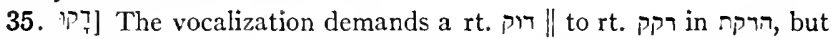
with intrans.-pass. mng., 'broke down'; so Kau., $\$ 46,3$, a, and Kön., $H w b$., giving both rts., which also appear in Rabb., where ppronly in derivative stems. BDB, GB, Mar., Gr. $\$ 66$, c, prefer to find the one root דקי for both, but then abnormal vocalization here; we should expect

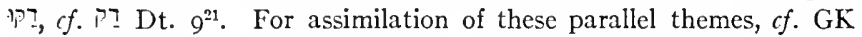

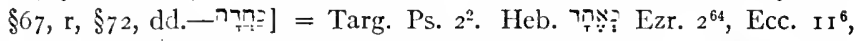

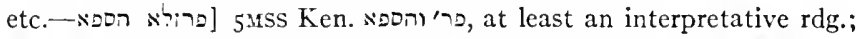

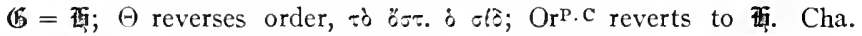
adapts $\Theta$ 's order, but the oldest testimony is against this order, which is due to a rational rearrangement; s. at v.41. Cf. Kamp.'s very sensible note: "Even in passages where the readings of the Versions yield a better sense (as e.g. in vv. ${ }^{35}{ }^{45}$ in the order of the metals), it is hard to decide whether $\mathbb{6} \Theta$ with their smoother reading present the original text, or whether we must rather attribute some slight roughnesses to the author." He cft. $5^{4}$ 'gold, silver,' with $5^{27}$ 'silver, gold.'-inj Aram.

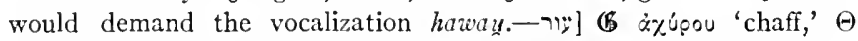
rovooprós 'dust'; Cypr. conflate, palea aut puluis (obvious gloss!). Cf. Hos. 1 $3^{3}$-- 'ר:] For derivation (?) s. Lexx. Lidz., Altaram. Urk., r6, finds a month אררו, 'Tennenmonat' in his ostrakon. I refer to my note

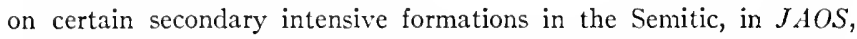
I926, pp. $5^{6-58}$, for a discussion of BAram. ארר , nouns, esp. in the Aram., where doubling has been induced by a foll. liquid; this $v s$. the universal view of them as orig. intensive formations. - רוה ] With masc. vb.; this may be a case of incongruence of gender agreement, $c f$. Kau., 98,2 , a, and s. at $v^{33} ; c f .3^{27}, 4^{9}$ Kt. In Heb. ' $ר$ is predominantly fem. (GB p. $748 \mathrm{~b}$ ), and so in Syr., where even the Holy Spirit was primarily fem. Here for המון רוחא $\Theta\left(B h^{58}\right)$ to $\pi \lambda \bar{r}_{i} \theta \circ \varsigma$ toū

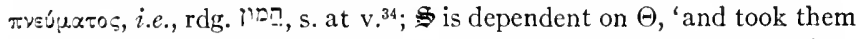

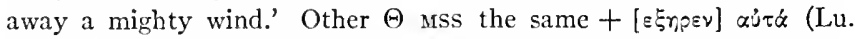

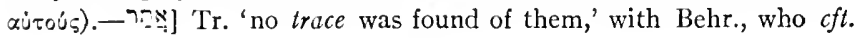


Arab. 'atar; $c f$. also use of איאר as 'monument' in the Panammu Inscr., l. I8 (Lidz., NE p. 442 , Cooke NSI no. 62), and so possibly in SArab., Hommel, Chrestomathie, I 21 . For the phrase of. Ps. $103^{16}$; it is cited in Rev. $20^{11}=\Theta$. $\Theta$ om. prec. 72 , Or ${ }^{P}$ has.—ר] So edd., exc. Str., Kamp.,

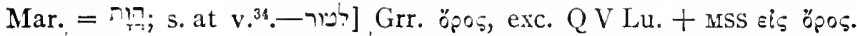

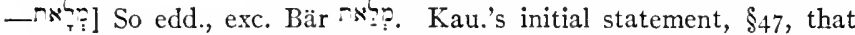
vbs. $\times$ and $1 / 2$ have been fully assimilated, is to be corrected by his subsequent note, $(g)$, that in this vb. and מתני: Ezr. $4^{19}$ the strong formation is intended. The retention of $\mathrm{x}$ is corroborated by the papyri,

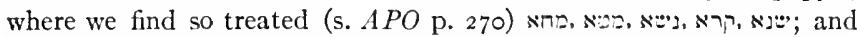
there are traces of this survival in Syr., s. Duval, GS \$2 I4, Nöld., $S G$

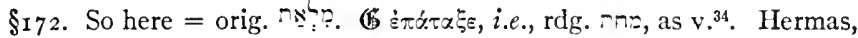

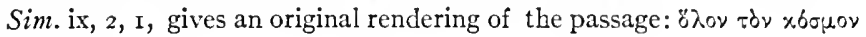
$\chi \omega p \tilde{r} \sigma x t$.

36-45. The interpretation of the dream. 36. Dan.'s pl. we will say has been a moot problem. Ra. interprets, ' $\mathrm{I}$ and His Wisdom' (cf. Acts $15^{28}$ ), supplementing with the remark that "this is the way of good manners," "מפו ego et per me Deus; uel ego cum sociis meis." Acc. to CBMich. the Jews (?) and Socinians, wishing to forestall Trinitarian exegesis, applied the pl. to Dan. himself, 'auctoritatis ac honoris caussa,' cited by Mein., who prefers, with Behr., the reference to Dan.'s colleagues. The pl. approximates the deferential 'we' with $\mathrm{Ra}$. in its impersonality, but is best compared with Paul's 'we' (e.g., I Cor. $\mathbf{I}^{6}$ ), used with a certain humility; the present message was not Dan.'s own. 37. Thou, O king, king of kings: The rhetoric of the passage has been generally overlooked since H, Tu rex regum es, = AV RVV. But 'king of kings' is appositive to ' $k$ ing'; the balance of the $\mathrm{v}$. and $\mathrm{v} \cdot{ }^{38 \mathrm{a}}$ are a parenthesis, the affirmation being made in $\mathrm{v}^{38 \mathrm{~b}}$ : Thou art the head of gold. So rightly the Grr., the rhetoric was ignored by comm. until Hitz., followed by some successors and JV. For Dan.'s courtesy cf. Jer.: "Absque uitio ueritate sociata blanditur ut regi." "King of kings' was, and still remains, the correct Pers. title for the monarch; applied to Neb. in Eze. $26^{7}$, and = Akk. ̌ar šarrâni, but 'not the customary Bab. form of address' (Pr.). It appears in the Achæmenide inscriptions, and so in Ezr. $7^{12}$. The title was also borne by princes of Armenia, the Bosporan kingdom and Palymra, s. Deissmann, New Light from the Ancient East, 368. 'The Seleucides were known as 'lords of kings,' אדן מלכים, 
e.g., inscr. from Umm el-'Awâmîd, CIS i, no. 7; the Aram. equivalent below in $\mathrm{v}^{47}$.

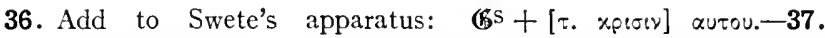
ד [ . . . Not 'for . . . to thee,' e.g., AV RVV, following incorrect syntax of prec. words, but 'to whom,' JV; so $\Theta$. alone objects to the universal treatment of ' $n$ as synonymous with תיקט. His interpretation, ignored subsequently, connects it with Arab. hazana, and derives the idea of 'riches.' For the dubious relations of ' s. GB, p. 248. But a suggestion is to be had from the use of the vb. in $7^{18 .}{ }^{22}$, 'take in possession,' and in particular from the papyri, where, in Peal and Hafel, it has a technical legal mng., possibly of fief-tenancy; s. Sachau's note in $A P O$ to pap. $5,1.6$, where he suggests a likeness between this 'possession' and the later $x \lambda$ npouxix. So in JAram. $\aleph^{\prime}$ ' 'possession,' and Sa., cited here by AEz., tr., מלכות נהליה 'an inherited kingdom.' Syr. confines itself to the mng. 'be strong.' In the present passage then the king holds his fief under God, and we gain a pregnant climax: royalty, possession, might, honor.- - In:] In Nab. 'Vollmacht,' Lidz., $N E$ 387. $\Theta$ treats the last three nouns as adjectives to $\beta x \sigma t \lambda s i \alpha \nu$,

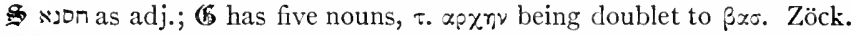
$c f t$. the identical terms in the doxology of the Lord's Prayer, Mt. 6 ${ }^{13}$; $c f$. the similar ascription to the Son of Man below, $7^{14}$.

38. The construction has given trouble since antiquity; e.g., the following varieties of interpretation: JDMich., '(et quae sunt) in omni loco in quo habitant,' etc.; AV RVV 'and wheresoever the children of men dwell, the beasts, etc., he has given into thy hand,' so apparently the punctuation of $\mathfrak{A t}$, accepted without comment by mod. Eng. comm.; Mein., 'alles, was da lebt' (בכל as 'Gesammtbegriff,' not as spatial), but דיארין has not the idea of abstract existence; JV, following the most common interpretation, after $\mathbb{G}$, 'wheresoever the children of men, the beasts, etc., dwell, he hath given them into thy hand,' so Behr., who, after Bert. and with Mar., recognizes an anacoluthon here: "weil dem Verfasser schon am Anfang des V. כהיטיט vorschwebte." The difficulty of [ל] $[3$ was early recognized by H and Heb. Mss, and Bert. suggests its elision. Following the early testimony of $\boldsymbol{B} \Theta$, we may omit initial 'and,' and read, wheresoever dwell the children of men, along with $\Theta$, as continuation of v. 37. The first item then is Neb.'s imperium over men, wherever they are to be found, the second his empire over all living things, the third is the summary, 'over them all has he 
empowered thee.' As an alternative to this slight correction, with some authority and interpretations, there is Torrey's suggestion, Notes, I, 258, that דיארין 'illustrates the use of the indefinite 3 d pers. pl.' with subject unexpressed, and so the

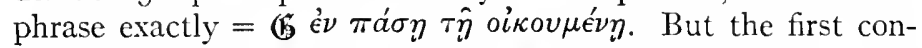
struction gives a better climax. The beasts of the field ( $=$ Heb. חית השרה the equally free fowl of heaven ( $c f$. Gen. $\mathrm{I}^{20 .}{ }^{30}$ ), are reminiscence of Jer. $27^{6}=28^{14}$, where 'the wild beasts' are made to serve Neb. The idea is hyperbolic, not absurd; Neb. as the type and crown of Man has been invested by God with man's charter of dominion over all living creatures, Gen. $\mathrm{I}^{28}$, Ps. 8. An ancient addition to 6 , 'and the fishes of the sea,' glossed into most $\Theta$ Mss (it does not appear in the citation of our v. in Judt. $\mathrm{II}^{7}$ ), is equally not absurd in view of Gen. I, Ps. 8, against Mar. The dominion of man over the wild life was strikingly exhibited in the sports and menageries of the ancient monarchs, who even like Tiglathpileser I evinced their prowess over the monsters of the deep (cf. Haupt, $A J S L$ 23, 253 ff., OLZ I907, 263). Cf. the satire in Bar. $3^{16}$, Where are the rulers of the nations and those who lorded it over the beasts of the earth, those who played with the fowl of heaven?' Also the royal menageries (e.g., the lions' den, c. 6) were symbolical of the monarch's world-power. With pertinence dEnv. cites Ass. inscriptions detailing the tributes of wild and strange beasts and recalls the bas-reliefs depicting them. ${ }^{1}$ In general, it is not necessary to explain away the extravagance of Dan.'s attribution of universal dominion to Neb. DEnv. makes a correct archæological point that the Ass. kings claimed such imperium; he cites the title 'king of the four quarters,' and passages like that in the Taylor Prism, col. I2-I3, 'Asshur has elevated my soldiers over every habitation in the regions.' But it is equally unnecessary to be as serious as dEnv. in his claim that Neb. "could regard himself suzerain of the emperors of China" (ii, I, p. I67), or "of the lands in the north of Europe" (p. I69). It is sufficient to note that this universal sovereignty is attributed to Neb. in Jer. $27^{8}$, and is assumed in Cyrus' edict, Ezr. I $^{2}$.

${ }^{1}$ For the royal hunts and menageries of the Ass. kings s. Meissner, 'Assyrische Jagrten' in D. alte Orient, 13, pt. 2 (I9I I), and, more summarily, in his Bab. u. Ass., I, $73 \mathrm{ff}$.; for the similar amusements of the Pers. monarchs, s. Rawlinson, SGM 'The Fifth Monarchy,' c. 3 , the classical reff. in notes $430 . t$. 


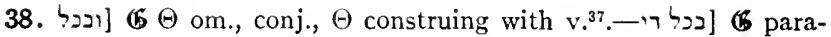
phrases, "in all the world (oi\%oupém) of ( $\alpha \pi 0$, i.e., ננ as ia?) men and wild beasts, etc., he has given under thy hands to rule all'; $\Theta \dot{\varepsilon} v$

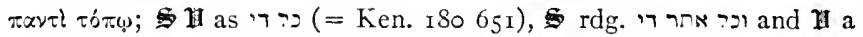
broken construction, et omnia in quibus habitant filii hominum et ( a conj.) bestiae agri uolucres quoque coeli dedit in manu tua. 拴 appar.

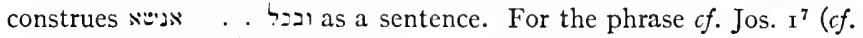
v. $\left.{ }^{16}\right)$, = Targ. בכל אתר, Pr. I $7^{8}$; it may be a Hebraism.-רארין] Kt.,

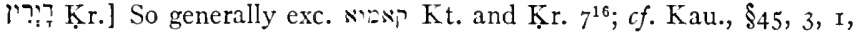
$\S$ I , I, and Kamp. Nöld. in his review of Kau. cft. the Arab. representation of $y$ with hamzah. In Sachau's papp. I find for parallels only [ימי

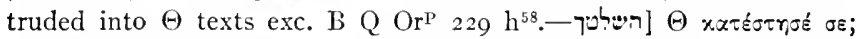

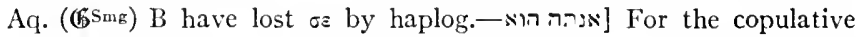

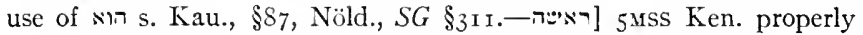

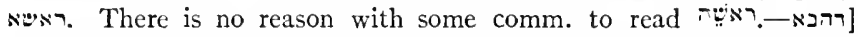
CBMich. $c f t$. the obscure מדהכה used of Babylon Is. I4 4 , by Jewish tradition 'golden city' ( $c f . \mathrm{JV})$, and Jer. $5 \mathrm{I}^{7}$, where Babylon is a golden chalice in the LORD's hand; but the coincidences are accidental.

39. After thee [lit. in thy place] shall stand another kingdom lower than thou. The traditional interpretation, e.g., VSS, EVV, of the vb. is 'shall rise up'; but the same vb. in v.44, used with the eternal Kingdom, is universally translated 'shall stand,' and this mng. is preferable throughout; there is nothing mobile in the scene. The expected designation 'of silver' is added by Orc Lu. and in mss. of $\mathbb{H}$ exc. Cod. Amiatinus; the author instead has used the term 'lower than thou.' The expression 'lower than thou,' EVV 'inferior to thee,' signifies a lower degree of dignity, etc.; but the epithet is not to be confined to the Second Kingdom, for each one of the Kingdoms is equally lower than its predecessor. Hence it is beside the point to argue why this comparison is made here particularly: whether it is a moral inferiority (Zöck.), or lack of unity (Keil), or of ecumenicity (Klief.), all which views are impossible historically on the hypothesis that the Second Kingdom is Persia. Bev.'s explanation that "of the Median empire next to nothing was known in the time of the author" is the most plausible. But the degradation increases with each kingdom one 'below' the other.

39. ברחר So the later Aram. spelling of the prep., $=7 n+2$; in $7^{6.7}$ 2Al is uncertain between באר.ר בתר and The prep. is not found in the 
papyri. For its meaning 'in place (track) of,' so actually here, not 'after,' s. at v. ${ }^{35}$. - W forms $c f$. Nöld., $M G$ § 124 and p. $154 ; S G \S 8_{3}$; and for Arab. nouns in -ay Wright, Gr. I, p. I 79, also 'uhra(y), our very form. In Heb. $=$ • 'Sarah.' $\mathfrak{G}$ om. $\ddot{\alpha} \lambda \lambda \eta$ by hapl. with $\dot{\varepsilon} \lambda \dot{\alpha} \tau \tau \omega \nu$; as a marginal gloss

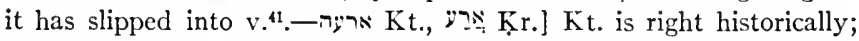
the form is an old acc. in $-a$, to be accented on the penult, used adverbially. Cf. . $^{3}$, and ${ }^{2}$ v. ${ }^{40}(q . v)$. These cases correct Kau.'s denial of such forms in BAram., $\$ 49$. For Heb. s. GK $\$ 90$, 2. The Kr. may be influenced by the later רע. Ra., AEz. take the word as adj., = ire and so Bert., Behr., al. Buxt. appears to have been the first to recognize it as an adv., s. Lex. s.v., 'inferius infra te,' the explanation of

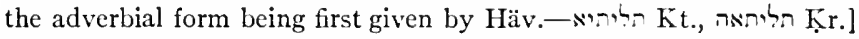
See Kau., §II, I, b. The change of ' to $x$ induced change of $s$ to $\pi$.אהרי $2^{\circ}$ ] Redundant, = 'yet another'; $c f .7^{5} ; \Theta$ om.

40. The v. is difficult with its redundancy, which is surprising in this compact narrative. It may be translated: And a fourth kingdom [so correctly the Grr., EVV erroneously 'the fourth'] there shall be, strong as iron, according as iron crushes and smashes wholly; and like iron which breaks, all these things will it crush and break (so with Torrey, disregarding $\mathfrak{A}$ 's punctuation, followed by EVV). But the VSS all offer shorter forms of text: $\mathbb{G}$, discounting the Hexaplaric plusses, omits 'like iron' $\mathrm{I}^{\circ}$, 'and smashes,' and 'like iron which breaks.' $\Theta$ also om. the last-

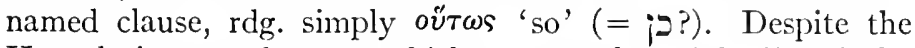
Hexaplaric amendments, which restore the triple 'iron,' the quantum of $\mathbb{G}$ has not been brought up to if. With $\Theta$ agree II, although this agreement does not necessarily add weight. Or $^{\mathrm{P}}$ restores 'the iron' $3^{\circ}$, not the following 'which breaks.' The critical presumption against 'like the iron which breaks' is accordingly strong, and while Torrey, Notes, I, 258, has done the best to save the whole $\mathrm{v}$. by his repunctuation, he has not made its rhetoric much more sensible. It is best with Mar. (text-in comm. he suggests that the orig. ended with 'wholly'), Löhr, Jahn, Cha., to omit these words; read then for the final sentence: and all these things will it crush and break. Kamp. erroneously argues against Mar. that $\mathbb{6}$ read the words omitted. Cha. also would omit 'all these things' (כל אלין) as 'not found

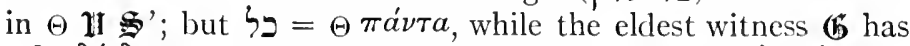
$\pi \hat{a} \nu \delta^{\prime} \nu \delta \rho \nu \nu$, which is simply a misreading of 
40. חשי] Used in later Aram. of the smith's hammer (correct Behr. here !), so JDMich., Supplementum, no. 876; JV 'beateth down,' AV

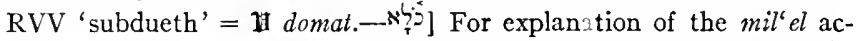
cent as indicating primarily an adverbial form (so always where occurs, $4^{9.18 .25}$, Ezr. $5^{7}$, and frequently in the papyri), s. the writer's article, 'Adverbial killa in Biblical Aramaic and Hebrew,' JAOS 43, 39I.-江资] See Kau., $\$ 39$ for the Mass. principle in the heightened $a$, cf. $27 \mathrm{Z}_{\mathrm{T}} \mathrm{v}{ }^{41}$. The variation of stem is a further proof of the secondary character of this clause.- v. $(\xi+x . \sigma \varepsilon เ \sigma 0 \dot{n} \sigma \varepsilon \tau \alpha t \pi \tilde{\alpha} \sigma x \dot{\eta} \gamma \bar{\eta}$. Cha. accepts 'the whole earth,' rdg., 'so shall it break in pieces and crush the whole earth', and cft. $7^{23}$, וראכל כל ארעא, also of the Fourth Kingdom; similarly Jahn. Blud. suggests, p. 63, that the plus represents original תרק ארק: But actually the clause is composed of two glosses on words ignored by orig.

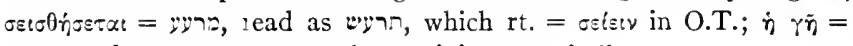
וררע, read as אריץ $\pi \tilde{\alpha} \sigma \alpha$ may be reminiscence of $7^{23}$.

41-44. As in $\mathrm{v}^{40}$, so here is an unnecessary repetition of phrases, and to a greater extent. The idea of the 'mixture' of the two elements is fully insisted on in $\mathrm{v}^{41}$, being reinforced in $\mathrm{v}^{41 \mathrm{~b}}$. It is taken up again in $\mathrm{v}^{42}$ with specific reference to the 'toes of the feet,' while the first sentence of $\mathrm{v} .{ }^{43}$ repeats $\mathrm{v} .{ }^{4 \mathrm{lb}}$. Jahn and Löhr have noticed this insipid repetitiousness. The former recognizes vv..$^{42 .}{ }^{43}$ as a doublet: they "scheinen mir von späterer Ausdeutung des Bildes ausgegangen zu sein. Von Zehen war bei der ursprünglichen Schilderung des Bildes keine Rede; sie sind eingesetzt, um Eisen und Ton besser zu teilen zu können. Von $\mathrm{v} .^{42}$ sind die Zehen auch in $\mathrm{v}^{41}$ eingedrungen." Löhr regards

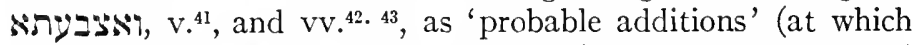
view Torrey, Notes, I, 259, n. 2, exclaims). As to 'and the toes,' $\mathrm{v} .{ }^{41}$, he and Jahn might have claimed the authority of orig. $\mathbf{6}$, which ignores it. With these critics the writer agrees as to $\mathrm{v}^{42}$; it is a thoroughgoing doublet to $v^{41} ; n . b .$, , תקיפה מן נבצבתאי . Tבירה || פליגה The item of the toes suggested itself as an extra satirical touch, and from this v. 'and the toes' intruded into $\mathrm{v}^{41}$. Further, the first sentence in $\mathrm{v} .{ }^{43}$ is identical with the last sentence in $\mathrm{v} .^{41}$, viz., '(because) that thou sawest the iron mixed with the tile-work of clay.' It looks as if after the insertion of $\mathrm{v}^{42}$ the construction of the period was taken up again by the repetition of $\mathrm{v}^{4}{ }^{4 \mathrm{~b}}$. Omit then 'and the toes' in $\mathrm{v}^{41 \mathrm{a}}$ and read on from v. ${ }^{4 \mathrm{~b}}$, According as thou sawest the iron 
mixed with the tile-work of clay, ${ }^{4}{ }^{43 \mathrm{~b}}$, they shall be mingling themselves in human seed, etc. Further, Mar., Löhr regard טינ5 [50ח] EVV 'miry [clay],' vv. ${ }^{41 .}{ }^{43}$ as secondary on basis of its omission by $\Theta$; but $(\mathfrak{G}$ has it in both cases, $\tau \hat{\omega} \pi \eta \lambda \hat{i} \nu \omega$ ó $\sigma \tau \rho a \dot{\alpha} \kappa \omega$, and it is to be observed that $\Theta$ with equal arbitrariness omitted

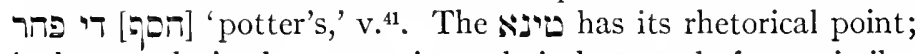
in last analysis that potter's work is but mud; for a similar ironic resolution $c f$. Is. $7^{8.9}$. In the secondary . $^{42}$ a new moment is added to $\mathrm{v}^{41}$, in the distinction of two parts of the kingdom, one strong, the other 'brittle' (so with marg. of AV RVV, rather than the usual 'broken'); these two parts would presumably be the Ptolemaic and Seleucide empires. This interpretation is then reflected back by comm. (e.g., Dr.) to v..$^{41}$, and such a division read into it. But in $v^{41}$ the word usually translated 'divided' (פליגוס, s. Note) means rather 'diverse, composite,' and this is borne out by what follows: it [the whole] will have some [partake] of the strength [stockiness] of iron. Also in $\mathrm{v}^{42}$ the prima facie interpretation of the opening words is: and the toes of the feet-some of them iron, and some of them tiling, a very strained item, hardly agreeing with $\mathrm{v} .^{\mathrm{b}}$, although this distinction among the toes has been accepted by a number of comm., s. Note at end of chap. This fact is obscured in EVV by 'the toes of the feet were part of iron and part of clay.' The same trouble was then introduced into $\mathrm{v} \cdot{ }^{41}$ by the interpolation of 'and the toes,' and indeed Sa. definitely tr. there accordingly: 'some of the members of it shall be clay, some of them iron.' Altogether 'the toes' have complicated both figure and diction.

43. The subject of the participial vbs. in $\mathrm{v}^{\mathrm{b}}$ is attributed by most comm. to 'these kings,' $v .44$, by prolepsis, and the subjectmatter found in the intermarriages of the Seleucides and Ptolemies. For this question reference is made to Note at end of the chap., where, it is argued, after Jewish comm. and Keil, that the mingling of races is intended. The implied subject in such a participial construction is of course impersonal. 44. These kings: hardly a succession of monarchs or kingdoms but a contemporaneous number of régimes. There is no practical difference between a 'kingdom' and its 'king,' for the latter is the symbol and incarnation of the former; the practical identity of the two nouns is obvious in the text and VSS of c. II. We may agree with Dalman, Worte Jesu, $75 \mathrm{ff}$., that in the O.T. (Dalm. adds, 
in the Jewish literature in general) פלכי (' ('Königsregiment'), never 'kingdom' ('Königreich'). However, the Last Kingdom replaces the first Four in the dream, and is, in the idea of the scene, spatially bound as are its predecessors; the Mountain fills the whole earth, is not a spiritual Kingdom of Heaven. Since the early VSS, as well as in the tradition of 4. uncertainty has existed whether there should be read 'the kingdom [to another people shall not be left],' so AV JV; or, 'the sovereignty thereof,' so GV RVV Dr. (AVmg, 'the kingdom thereof') after $\mathfrak{H}$, which is based on the actual Kethîb, but against $\mathrm{ft}$. In the latter case the pron. might refer to 'a kingdom' as antecedent, producing the awkward combination, 'the kingdom's kingdom' (Keil), or better to 'God,' i.e., 'his kingdom'; but is best with the abstract 'the kingdom,' i.e., 'sovereignty.'

41. ' $\left.\mathrm{I}^{\circ}\right]$ For similar construction in Syr. s. Nöld., $S G \$ 366$, C.-

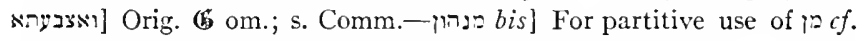
BDB $580 \mathrm{~b}$, and for Syr. Nöld., $S G \$ 249$, C. Here not 'some of them,' etc., as I Ch. $9^{28}$, but 'one part of them . . . another part,' correctly interpreted by vocalization s. Kau., $\$ 59$, I, d. (G for ' $\mathrm{Q}$ י dently $x \equiv p \alpha_{i}<\omega^{\prime} \omega 5$. The word is universally taken as 'potter'; $c f$. Heb.

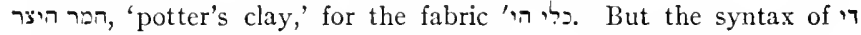
with two indefinite nouns requires th sefer to the stuff, $c f$. v. 32 , else why not הסף פהריא as in Heb.? Accordingly I am inclined to regard 'o as potter's 'clay,' comparing fahhâr, equally 'potter' (acc. to Nöld., $M G$ p. I 20, n. 2 of Aram. formation and origin), and potter's ' lay,' e.g., Koran, 55, I3; and so $\mathbb{6}(5$ under tood the word. - 'clay, iron' is supported by $\mathbb{B} \Theta$, reversed by Lu. = order in $\mathrm{v}^{42}$; $c f$. at v. ${ }^{35}$.- פליגה Following Buxt., citing Rabb. use, Klief., Ehr. correctly remarks: "ס heisst nicht geteilt oder zerstückelt, sondern ... in seinen Teilen verschieden."-תהוה] So only here, v. ${ }^{42}, 4^{24}$, otherwise [נצבתא-, Inהוא In usual Aram. use 'plant, shoot,' and so $\Theta$ pi Aq., Sym. фúrou $=$ II plantario. But rather with comm. the word $=$ 'strength' (e.g., AEz. כ ), or better 'firmness,' Dr., JV. Cf. Eng. 'stick, stock'> 'stocky,' etc. The prec. p is partitive, 'some of the firmness,' Kran., Behr.derivations; n.b. Haupt, $J B L$ 26, 32: "Heb. טיט = Assyr. țițu stands for tîntu with partial assimilation of the fem. $\pi$ as in Syr. sue sarcher

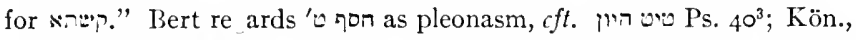
$H w b$. s.v. ףסח, as a superlative expression; Torrey, Notes, I, 259, 
an 'an inferior, miry sort of clay'; for a different interpretation s. Comm.-42. ent partitive mng., 'in part'; Schwally, cited in GB, draws attention to NHeb. תspe, 'partly,' Jastr., p. 832.-רביר] Correctly AV RVV

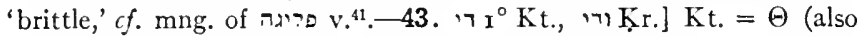

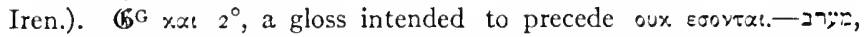
[מר:טרכין Hitz. notes the nice difference between the two stems: "Sie sind durch äuss re Macht zusammengefügt, aber sie selbst verbinden sich nicht mit ein nder"; similarly in Syr., Nöld., $S G \$ 278$, A.一

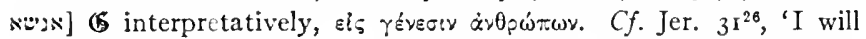
sow : he house of Israel . . . with seed of man and seed of beast,' i.e., by natural generation; here, acc. to Klief., et al., in contrast with divine

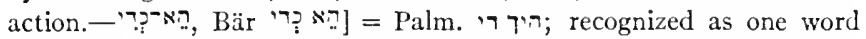

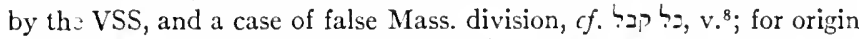

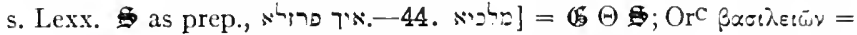

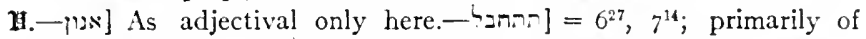
inner corruption.—. read as $\pi-\left(=3\right.$ MSS - $=$ - so Iren., H. Keil prefers $\boldsymbol{H}_{-}-$, and so

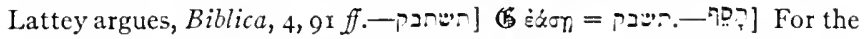
vocalization s. Kau., $\$ 45$, p. 74 ; Powell, p. 40. The rt. in Aram. as in

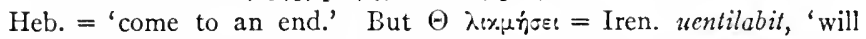
winnow'; correctly Häv., "er dachte wohl an das Heb. derivatum der Sturm." The same vb. appears in Jesus' reminiscence of this pas-

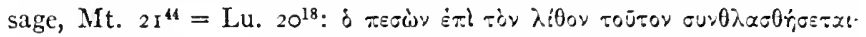

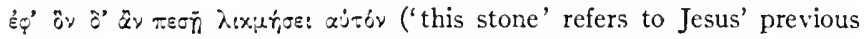
citation of Ps. II $\left.8^{22}\right)$. The doubt concerning the mng. of $\lambda_{(x<\alpha \bar{\alpha} \nu}$ there (s. N.T. Lexx., e.g., Preuschen actually forging a new mng., 'zermalmen,' followed by Deissmann, Bible Studies, 225) collapses; the passage is a verbal citation, and that of a 'Theodotionic' transla-

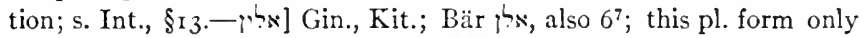
in Dan., not in the papyri. $\Theta$ om. $\mathbb{6}$ om. prec. 2 .

45a. The seer concludes his climax of the Eternal Kingdom which is to destroy 'all these kingdoms' by recurring to its symbol, the Stone: Just as thou sawest that a stone was hewn from the mountain without hands; and he gathers up all the elements of the vision in his miniature of the final catastrophe, how it crushed the iron, the brass, the clay, the silver and the gold. Here the interpretation ends, $\mathrm{v}^{\mathrm{b}}$ being the asseveration of the truth of the whole vision. The relation of $\mathrm{v}^{\mathrm{a}}{ }^{\mathrm{a}}$ with $\mathrm{v} \cdot{ }^{44}$ appears clearly in the Greek translations, but is ignored by the unfortunate Mass. verse-division, followed by the punctuation of the $\mathbb{H}$ edd., and by the EVV. The true relation was recognized by GV, fol- 
lowed by CBMich., et al., and all recent comm. exc. dEnv., Knab., Dr., Cha. In this v. we learn for the first time of the origin of the quarried Stone, it was hewn out of the mountain (generic, mountain mass), an item which is to be taken, with Behr., as 'eine Ausmalung des Bildes,' unless indeed it is to be rejected, with Kamp., as an early intrusion, for the Stone itself becomes a great mountain filling the whole earth.

$45 b$ is the signature to the revelation; Dan. has delivered God's interpretation, not his own; therefore the dream and its explication are true and reliable, in contrast to 'the lying word' the king feared from the mouth of the adepts, v. ${ }^{9}$. For such confirmations of visions $c f$. below $8^{26}, \mathrm{II}^{2}, \mathrm{I} 2^{7}$, and the example was followed by later apocalyptic writings, e.g., Rev. $19^{9}, 21^{5}, 22^{6}$.

45. אתגזרת But v. התג' In the reflexive formations with $t$ in BAram. cases with hit predominate over those with 'it; s. Powell, p. I5, for the statistics. There are almost no exx. in OAram. inscriptions (n.b. התנאבו in the Zenjirli Building Inscr.); in Sachau's papyri only two cases, יאישהוין, Acc. to Kau., §23, r, Anm., 'it, with Arab., is original in Aram., and the cases with hit are to be regarded as Hebraisms; also s. Brock., $V G$ I, p. 531. other VSS 'clay, iron, brass'; $c f$. the orders above, vv. ${ }^{35} \mathrm{ff}$. Was

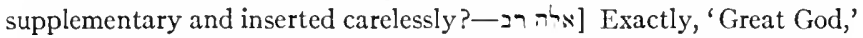
so Grr., $\delta$ $\theta \varepsilon \delta \varsigma ~ \mu \varepsilon \gamma \alpha \varsigma=$ EVV, Kran., Keil, dEnv., Mein., Pr., Jahn;

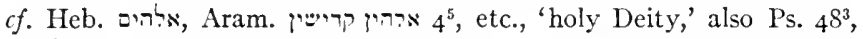

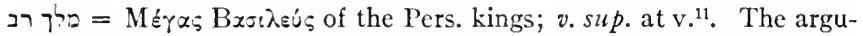
ment of Behr., al., for the indefinite 'a great god,' is hardly seemly to Dan.'s unswerving religion. In Ezr. $5^{8}$ the articulated Pass. ppl. of Haf.; an orig. formation with ha-, which survives in Syr. in this vb.; for other survivals in Aram. dialects s. Brock., $V G$ I, p. 525; it is hardly a borrowing from Heb. (Bev.), as הימנורא appears in the

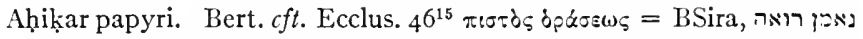

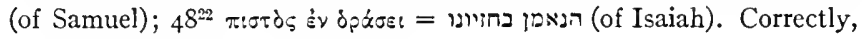
as with gerundive mng., Grr. $\pi \iota \sigma \tau \dot{n}$.

46-49. Neb. honors Dan. and his God, and prefers Dan. and the Three Friends. There can be no question but that Neb. intended divine honors to Dan. in the true spirit of Paganism. The first critic of our book, Porphyry, took exception to this datum, as Jer. cites here; the latter rejoins with reference to the worship done to Paul and Barnabas at Lycaonia. But, at v. ${ }^{47}$, Jer. cites a parallel instance from Jos., $A J$ xi, 8, 5, how when 
Alexander approached Jerusalem and the high priest came out to meet him invested with the pontifical robes and the golden plate on which was engraved the name of God, the conqueror 'worshipped the Name,' and then greeted the high priest. This bit of the Alexander saga may well have been known to our writer, although he is not so careful in distinguishing between the two phases of the monarch's reverence. Bert's view that only civic honors were offered to Dan. (cft. the honors tendered to Alexander on his entry into Babylon), is contradicted by the sacrificial terms in which they are expressed; cf. $(\mathfrak{B}$ and $\Theta$, but Aq. and Sym. avoided the technical mng. of minhah. Comm. generally dismiss this evasion of interpretation. Others suppose that Dan. must have, implicitly, deprecated the divine honors, so CBMich., Knab., after earlier comm. Truer to the story is Klief.'s view of Dan.'s 'das heidnische Verfahren passiv gewähren lassen.' Best Bevan: "We need not stop to inquire whether a strict monotheist would suffer himself to be thus worshipped, for the whole description is ideal-Neb. at the feet of Dan. represents the Gentile power humbled before Israel (cf. Is. $\left.49^{23}, 60^{14}\right)$." Jer. is right in substance: "Non tam Danielem quam in Daniele adorat Deum"; which is inspired by Josephus' report of Alexander's reply to Parmenio, who twitted him for adoring the high priest of the Jews: "I did not adore him but the God who hath honored him with his priesthood." 47. The king's confession of Dan.'s God as God of gods (s. Note) and Lord of kings, is the real climax of the story. Given the story, there is no reason for cavil at the Pagan king's confession, for a polytheist can always take on new gods, the monotheist never.

46. על אנסוהי The noun, also in the papp., is a dual, $c f$. Nöld., GGA I884, ror9, against Kau., \$55, 4. $\mathbb{B}+\chi \alpha \mu \alpha \ell$, an exegetical plus.$720]$ Chap. 3 of worship of gods; in $A P O$ pap. $32,1.3, \times 120=$ the deified place of worship (= Arab. masjid 'mosque'); but ' $D$ is used of prostration before a man in the papyri, viz. of Ahikar before Esarhaddon, pap. 47,1 . I3, so that the contention (e.g., by Dr., who cft. Targ. use) that the vb. does not imply a divine object is correct.- מגנחה] The word is used in the papyri (APO papp. I. 3) of (bloodless) sacrifice at the Jewish temple at Elephantine.-[גיהחי[ As here by itself Ezr. 610;

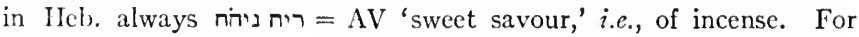

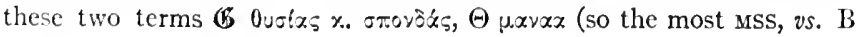




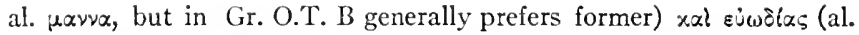

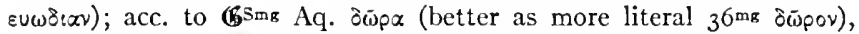

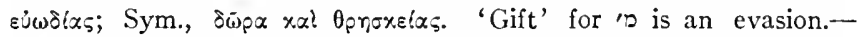

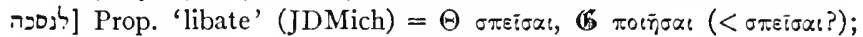
so $\boldsymbol{B}$ Job $42^{8}$ the former $=$ עif. Both liquid and incense offerings were poured or dropped. ' m may be epexegetical to ' $מ$, and the phrase have been current. For the frequency in Bab. rites of bloodless offerings, with terms corresponding to the present ones, s. $K A T 595 f$., $599 f$. For Pers. custom of offering sacrifices to kings as representatives of

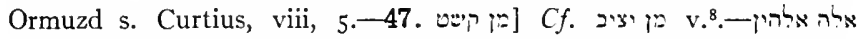
[וברא מלכין Correctly RV JV 'God of gods and Lord of lords,' vs. AV 'a God . . . a Lord,' etc., which is preferred by Cha. Translation must depend upon the idiom of the language. In Sem. such a combination as 'god of gods' is notoriously superlative, = 'most divine'; $c f$. 'age of the ages,' $7^{18}$, i.e., all eternity, and for Heb. the identical expression as here, e.g., $10^{17}$, also 'holy of holies,' etc. The construction can be used without determination, e.g., אל אלים, II I ${ }^{36}$, עבר עבריס 'most slavish,' Gen. $9^{25}$; s. GK §I33, i; anglice, 'God among gods.' N.b., For מרא מלכי הארנים cf. Heb. Dt. I0 $10^{17}$. For the Pers. equivalent ข. sup. at v. ${ }^{36}$. The clause is literally rendered by $\omega^{*} \Theta$; but $\mathrm{Orc}^{\mathrm{C}}(\mathrm{A} Q \mathrm{Q}$ al.)

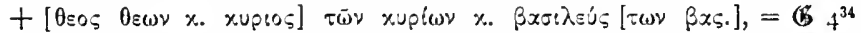
and a reminiscence of the Christ's title, Rev. $19^{16}$. Cf. Enoch $9^{4}$, 'Lord of lords, God of gods, King of kings, and God of the ages,' and a similar phrase in I Tim. 6 ${ }^{15} \cdot-\cdots$ ב ] Gin., Str. (ed. 5), Kit.; Bär, Kamp. (without notice of variant) מרה מרז; the former approved by all Aram. spelling; the latter induced by the parallel גלה (Behr.).

48. 49. There is an historical problem here, as to which Porphyry was the first to inquire, cynically, why the good Jew Dan. did not refuse the Pagan king's honors; Jer. pertinently replies by citing the instances of Joseph and Mordecai. It cannot be denied that in the matter of political preference a stranger might receive the highest honors from an Oriental despot. As to Dan.'s civic position we know of such provinces as Babel, Sippar, etc., governed by a prefect, šakkanaku, s. Meissner, $B a b . u$. Ass., I, I2I; in the Pers. period the term would have meant the whole of Mesopotamia, s. Meyer, GA 3, I, §29; for the Greek period the subdivisions were smaller, the Seleucide cmpire containing 72 provinces acc. to App., De reb. syr., 62, and s. at $6{ }^{2} .{ }^{1}$ The point of Dan.'s primacy over 'all the wise men of

'S. Torrey's interesting discussion, Notes, I, 259, and now at length 'Medina and Polis,' Harv. Theol. Rev., Oct., 1923, on the question when 3 'province' passed into the mng. 'city.' $\Theta$ 's translation here by $\chi \omega \dot{\omega}$ ? $x$ stands correctly for the earlier use, as also $(\mathbb{B}$, , 'over the business of Babylonia.' 
Babylon' has been stressed by those who deny the historical character of Dan., at least since vLeng. (q.v. on $2^{2}$ ). That comm. presents the argument from the closed character of the Magian caste as known from Classical sources ( $c f$. more fully Rawlinson, SGM The Third Monarchy, c. 3), while if the Bab. circumstances are to be insisted upon, the equally sacerdotal and highly technical status of the Bab. religious castes constitutes an equally insurmountable historical objection. See, e.g., Jastrow, Civilization of Bab. and Ass., c. 5, esp. pp. 27 I ff.; KAT 589 ff. Further, Dan. cannot be conceived of as primate over their superstitious rites. The most extensive apology for this feature of the story appears in dEnv., pp. I82-I9I. In controversion of such an argument, $4^{6}$ bluntly entitles Dan. 'chief of the magicians,' . But if the historical truth of the story must be dismissed, the problem that remains is how the Jewish storyteller could conceive of his hero functioning in so ambiguous a position. However, we possess sufficient parallels for this self-stultifying view in contemporary Jewish literature; e.g., the early Jewish midrashists Eupolemus and Artapanus, as well as the exuberant midrashic material presented by Jos., especially in his $C . A p$., in which literature the fathers, Abraham, Moses, etc., not only appear as the first wise men but even as the founders of heathen cults. ${ }^{2}$ The Biblical narrator is by no means guilty of the extravagances of those writers, but innocently accepts a common theme of hagiology without pursuing or even recognizing its ultimate absurdity. The theme has its actual Biblical precedent in the example of Joseph, who married a daughter of the high priest of Heliopolis, and who according to later story became 'an adept in all the wisdom of the Egyptians,' Acts $7^{22}$.

A minor problem is the question of the relation of Dan. and his three friends and their respective offices. This is relieved by recognition of the final sentence as a nominal clause, Dan. being in the King's Gate (s. Note), and of the mng. of the latter phrase as the royal chancellery. He was in the cabinet, while his friends were subordinate officers in their several bailiwicks. More serious is the question whether $\mathrm{v}^{49}$ is redactional to prepare for c. 3 ; so Hitz., Barton (JBL I898, 62 ff.), Jahn, Löhr (dubiously), while the hypothesis is denied by Mar. If the v. be a subse-

\footnotetext{
${ }^{2}$ See Schürer, GJV 3, 468 ff., and for convenient presentation of the less-known texts, Stearns, Fragments from Graco-Jewish I'ritings, Chicago, 1908.
} 
quent redactional joint with a view to c. 3 , it is clumsy enough, for it should have informed us why Dan. was absent from that scene. There is good reason, indeed, to hold that c. 3 is based on an independent story (s. Int., $\S 2 \mathrm{I}, c$ ), but the composer of cc. $I-6$ has cleverly led up to it by introducing the heroes of that scene as Dan.'s comrades and worthy in the development of the present story to share in his honors.

48. [?]? For the reduplicated stem, used only in the pl., s. Kau., $\$ 59,4$; the development into mng. 'magnates,' e.g., $4^{33}$, as in Syr.-

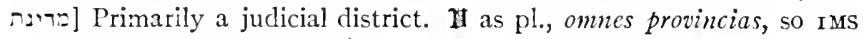

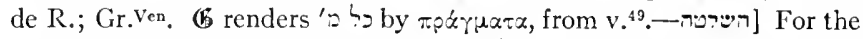

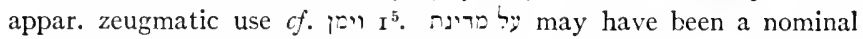

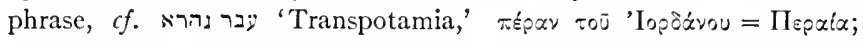
also the Gr. of $\dot{\varepsilon} \pi \dot{\xi} \xi \xi_{0} \sigma t \bar{v} v, 3^{22}$, etc., and $n . b$. the title of Mazdai, appearing in coins of Tarsus (G. F. Hill, Catalogue of Grcek Coins of Ly-

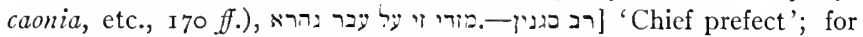
'D s. Lexx.; originally of civil officers, but later of Jewish temple adjutants, e.g., סגן כהני" Jor, s. Buxtorf, Lex. s.v.; also of a novice in the Mandæan clergy. $\Theta$ Sym. have been misled by the usual use of the word and tr. by 'satraps,' 'generals,' and so $-\mathbf{4 9}$.

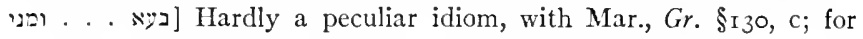

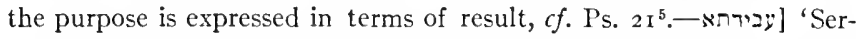
vice,' as in our 'public, civil service,' = 'administration,' = Heb.

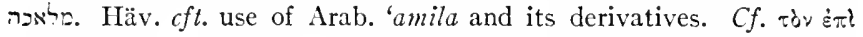

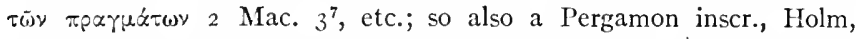
Griech. Gesch., iv, I67.- ובריז מלכה:- Cor-

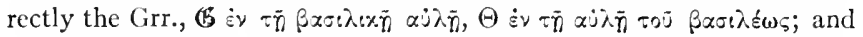
AEz. notes that it was a high position, for there sat the judges, etc., as he had observed in regard to Mordecai's position acc. to Est. $3^{2}$ בישער המיד Accordingly, it is strange indeed that this frequent term in Est. ( 6 times) is abused by the comm., Paton $c t$ al., as though, e.g., the royal gate was M.'s 'favorite haunt,' as 'a man of leisure,' or that he was a money-changer who had placed his table there (Haupt). Bert. and others think of the office of the palace prefect. But as early as one of Pole's authorities, and then by Schultens, Animad., 3I I, and others, it was recognized that 'gate' is a common Oriental term for royal offices, chancellery; $c f$. Arab. bâb, Turkish 'Sublime Porte.' Häv. cft. the identical terminology in Gr. for the Pers. usage, at zúlat (e.g., Her., iii, I 20) and ai Oúpa! (Xen., Cyrop., viii, I, 6); $c f$. also Appian, Syr., I 45,

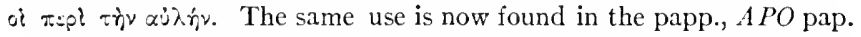
$5^{2}$, 1. I3, of Ahikar, the king's prime minister, 'whom I established in the gate of the palace.' $C f$. 'stand in the royal palace,' $I^{4}$. 


\section{NOTE ON THE SYMBOLISM OF THE IMAGE AND ITS INTERPRETATION.}

For argument for the identification of the Four Kingdoms here and in the Visions with Babylon, Media, Persia, Greece, s. Int., $\S 19, c$. That the Stories were an earlier production than the Visions does not militate against this common identification throughout the present bk. With the Diadochi, especially under the Syrian empire, the essential rottenness of the Fourth Kingdom was evident to spiritual eyesight even in the 3 d century.

Apart from a striking sentence in Dr., p. 17 , commentators and writers on the history of Hebrew literature have in general hardly done justice to the grandly conceived and artistic symbolism of the Image. On the one hand, apologists have been too much concerned to appropriate it as a prophetic chart of the destinies of the world and to seek in every detail revelation and exact fulfilment. On the other hand, the 'higher critics' have been engrossed in countering their opponents, and too often, in their zeal to prove the errors or the inauthenticity of the book, have insisted on its literary characteristic as of bas âge and in so far inferior to the productions of the classical, i.e., Prophetic literature. If lineaments of 'lower age' are evident in this conception, yet its simplicity, its magnificence of proportion, its originality, deserve their right valuation. ${ }^{1}$

The originality of the 'vision' is not diminished by its evident reminiscences of the story of Joseph. ${ }^{2}$ The setting of the stage is indeed the same: the Pagan king's dream which defies the arts of his Pagan wise men; the interpretation vouchsafed by the one God through a sage saint; the result of the interpretation, the royal recognition of the true God and the honoring of his servants who have relieved the royal anxiety. But unless we are to fault every epic and every drama for imitative dependence upon classic predecessors, the writer agrees fully with Behr.'s assertion: "Von einer Nachbildung der Josephgeschichte kann weder hier noch sonst die Rede sein, wenn auch der mit derselben wohlbekannte Verfasser begreiflicher Weise unwillkürlich an dieselbe erinnert." ${ }^{3}$ There is also the identical humanity in both stories: here as there the revelation 'to save much life'; here as there the humility and courtesy of the interpreter, as also the high-minded confession by the royal despot of the truth of the revelation, accompanied with his

\footnotetext{
${ }^{1}$ This against Meyer's opinion, Ursprung, 2, 186, that in the Daniel stories "grösseren poetischen Werth hat nur die Geschichte von Belsazar."

${ }^{2}$ For literary reminiscences $c f$. v. ${ }^{1}$ with Gen. $4^{1}{ }^{8} ; v^{2} .^{2.12}$ with Gen. $v{ }^{8}, c f . v{ }^{28} ; \mathrm{v} .{ }^{30}$ with Gen. $40^{8}, 4 \mathrm{I}^{10}$.

${ }^{3}$ Discussion of this subject is in place when we note vIeng.'s sharply contrasted opinion, p. 35: "Die ganze Erzählung von dem Traum und dessen Deutung [ist] sowohl in Ansehen der ganzen Anlage als in einzelnen Ausdrücken, der Erzählung der Genesis (41) vom Traume des Pharao und dessen Deutung durch den Joseph nachgeahmt."
} 
munificence toward his God-sent benefactors. But such human themes belong to the humanity of the true Israel.

For the apparatus of the Pagan king's dream there is a common Biblical background; not only in the Joseph story but equally elsewhere, in the dreams of heathen magnates, Abimelech and Laban (Gen. $20^{3}, 3 \mathrm{I}^{24}$ ), and of the Midianite soldier ( $\mathrm{Ju} .7^{13}$ ). It was a lower form of revelation, parallel to the divine administration in Balaam's 'enchantments in the wilderness.' This lower and always subsidiary character of the dream appears clearly in the Biblical treatment of the modus operandi of revelation; and criticism of the dream has its classic expression in Jer. $23^{15} \mathrm{ff}$. That this story was influenced by that common, cosmopolitan genre of literature ( $c f$. the dreams of royalty, s. Int. to this chap.) is not to its discredit. The story-telling art included cosmopolitan Jewry among its clients.

In regard to the Image, or with JHMich., the Colossus, we discover, so far as our literary sources go, an entirely original piece of symbolism ${ }^{4}$. It differs from the symbols of the earlier literature, for these like the Lord's parables are taken from nature or human society. For an historically parallel allegory we may compare Ezekiel's symbolism of the great eagle and the cedar of Lebanon, standing for Neb. and Israel, c. I7; but this, as also the overdrawn parables of Oholah and Oholibah, c. 23, are drawn from natural life. We may rather adduce the bizarre symbols of Zechariah, influenced, as is commonly recognized, by the Babylonian culture and art. And equally here is a conception drawn from the monuments of the ancient world. ${ }^{5}$ The fame of the Egyptian Colossi must have spread over the world. Herodotus knew of a golden statue of Bel existing in his day twelve cubits high, and the story must have left its impression on local tradition. ${ }^{6}$ Even the diverse composition of the Image had its parallels in ancient art (v. sup. at $\left.v^{33}\right)$. The effulgence, $z \hat{\imath} w$, of the Image was true to the colorful art of the age.

The Image stands alone without scenery or background. Only subsequently, with more reflection, are we told that it was cut 'out of a mountain' (s. at $v^{45}$ ). But naturalism is obvious in the collapse of the Image when smitten on its shoddy feet. The grim grandeur required no more scenery than did the torture of Prometheus with the solitary crag.

The conception of the figure is composed of two elements, to which the poet-artist hews strictly. It is, first, the artificial figure of a human body;

${ }^{4} \mathrm{I}$ have not been able to find, upon inquiry, any similar figure in the Classical literature. The nearest conception would be the Platonic comparison of the different grades of society with the head, chest, abdomen, etc. The closest approach in literature is the monster created by Mary Wollstonecraft Shelley's Frankenstein.

${ }^{5}$ Bert. notes that this suggestion was made by Herder in his 'Persepolitanische Briefe' (in Zur Philosophie u. Geschichte), no. 7, beginning.

${ }^{6}$ Her., $i, 183$. For this background in fact and fiction, s. Int. to c. 3 bearing on Neb.'s Golden Image. 
and, secondly, it is composed of a series of metals of decreasing value. The metallic character of the Image deliberately stamps it as artificial and but heightens the truth of the symbol. For it is the man-made and hand-made construction of the kingdom of this world that the narrator would portray. The figure stands there stiff and stark, the product of human law and convention at their best and truest, but a lifeless creation. Over against this appears the mobile, supernaturally moving stone, coming how and whence none knows, which, as is true of the cosmic forces, crumples up that proud and complacent work of human art. The stone itself remains within the sphere of the inorganic, and so far is dramatically true. That is a drama of a different picture in c. 7 with the Beasts and the Man; but the stone is as pertinent here as the Man there. ${ }^{7}$

Both these ideas, that of the human figure with its members and that of the series of metals, must be taken in their naturalness and simplicity. It is in offence to true interpretation that most commentators have carried the exegesis off into all kinds of mare's nests. Hence, for instance, we may not make too much of the hierarchy of the succeeding members; for naturally each of the members is successively 'lower,' the corresponding metal then indicating its actual quality. But commentators have pursued the details of the figure to the finest extreme, even lugging in the modern science of anatomy. For example, when we come to the legs, some of the commentators have found in them an added expression of the characteristic 'divided,' $v .{ }^{41}$ (q.v.), of that Kingdom. CBMich. and others have discovered here the division of the Roman empire into East and West, and what-not else; and Cocceius, to bring the figure down to date, finds the distinction between the ecclesiastical and the civil power of the Holy Roman Empire. Zöck. puts it mildly when he says, "The dual number of the legs is evidently not regarded by the composer." For the human body has naturally two legs, and we take it that an image would stand more securely on two legs than on one. Similarly the toes - their number is not given - are counted up, or rather counted in; they have been identified with all kinds of tens in history. But the normal man has ten toes, even if we could work out five Ptolemies and five Seleucides to suit the very uncertain date of the composition of the chapter. The narrative appears to lay more stress on the toes, and this may be due to their representing contemporary history, but here, $\mathrm{v}^{42}$, following $\mathrm{vv}^{33 .}{ }^{41}$, we have to read, not 'some of them' bis, i.e., distinguishing the toes, but 'partly . . . partly.' However, reason has been given above for regarding the repetitious $\mathrm{v} .{ }^{42}$ as a later insertion.

Likewise, it is fallacious to pursue the symbolism of the metals: c.g., the gold as symbolic of the splendor of Babylon, or the iron as peculiarly ap-

\footnotetext{
${ }^{7}$ Knab. falls short of the intrinsic articulation of the drama in his otherwise pertinent comparison: "Compara statwam hanc metallis conflatam quae tandem quasi gluma et puluis tenuis cuanescit cum filio hominis in nubibus coeli."
} 
propriate to Rome. For the mixture of the iron and clay we may sample the pathetic interpretation of Jer., the witness of Rome's collapse: "Pedes eius et digiti ex parte ferrei et ex parte fictiles sunt, quod hoc tempore manifestissime comprobatur. Sicut enim in principio nihil Romano imperio fortius et durius fuit, ita in fine rerum nihil imbecillius, quando et in bellis ciuilibus et aduersum diuersas gentes aliarum gentium barbarum indigemus auxilio" (i.e., the barbarian mercenaries are the clay). ${ }^{8}$

A very different order of treatment of the series of metals is offered by modern students of ancient civilization, by comparison with the antique and wide-spread notion of the succession of four ages, gold, silver, bronze, iron. ${ }^{9}$ In the Classical world this notion goes back in identical terms to Hesiod, Works and Days, ro6 ff. (ef. Ovid, Metam., i, 89 ff.). In point of view of geographical proximity the correspondence of the series of metals in Dan. with the Parsee philosophy of history is still more striking. According to the Dinkart, there were four periods in the 1,000 years beginning with Zoroaster, of gold, silver, steel, and a substance mixed with earth. And in the Bahman-yašt the prophet sees 'the roots of a tree on which were four branches, of gold, silver, steel, clay-mixed stuff.' ${ }^{10}$ But scholars differ contradictorily in their estimation of the parallelism and of historical priority. Böklen, Jïd.-christliche $u$. parsische Eschatologie, 1902, p. 85, Bousset, Rel. des Judentums, 283, 578, n. 3, and most stringently Meyer in his recent work, Ursprung u. Anfänge des Christenthums, 2, I 89 ff., press the Parsee influence. ${ }^{.1}$ On the other hand, for denial or minimizing of the theory of Parsee influence in the Jewish motive, s. Söderblom, La vie future d'après le Mazdéisme, 1901, 248 ff.; Scheftelowitz, Die altpersische Religion u. das Judentum, I920, Conclusion, p. 228. Their objections are primarily based on the chronological uncertainty of the origin of the Parsee notions. ${ }^{12}$ Another point of view is given by Gunkel, Schöpfung it. Chaos, 333, n. 2, pp. 323 ff., for treatment of

${ }^{8}$ Hippolytus' interpretation of the toes (ii, 12) is interesting but vague: $\varepsilon i \tau x$

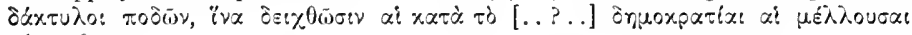

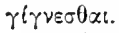

'So far as I can see, Zöck. first among the comm. notes the parallelism.

${ }^{10}$ Dinkart, ix, 7, in West, $S B E$ 37, p. 180; Bahman-yašt, 1, op. cit., 5, p. 191 .

${ }^{11}$ Meyer allows that "die Zertrünmerung durch einen Stein ist natürlich eine Erfindung des jüdischen Schriftstellers," p. I I, n. 2. On p. I 89 he attempts to corroborate his position that the scheme of the Four is borrowed and displays its secondary character, by arguing of Dan. that "wirklich geschichtlich deuten vermag er die Vierzahl nicht, denn er kennt ebenso wie die wirkliche Geschichte nur drei Reiche, das chaldäische, das persische und das griechische"; adding in a note that "historisch wäre eine Mitrechnung des Mederreichs absurd."

${ }^{12}$ The dating of dogmatic Parseeism is not certainly fixed; s. Söderblom, who brings 'orthodox' Parseeism well down into the Achemenide age, and prefers to find Greek rather than directly Persian influence in the Bible; also Lagrange's very sceptical study, 'La religion des Perses,' $R B$ 1904, I ff., who would bring Parsee orthodoxy down into the second century B.c. These disputes among competent scholars caution the laymen in the subject against hasty assumptions of Parsee influence. 
Dan. 7, and his Genesis ${ }^{1}, 241$ ff., finding the four ages in the four Covenants with Adam, Noah, Abraham, Moses; and yet another by Zimmern, $K A T$ 633 , regarding 'four' as the figure of the cardinal points; these scholars stress the Babylonian influence. If we have to carry back the 'four' to the Pentateuchal theory of the Covenants-in which there is the conception of progress, not of degeneration-we approach dangerously near the age when it is a question whether dogmatic Zoroastrianism existed. Since the theme of the 'four' is found in ancient Babylonia and the sequence of the æonian metals in the eldest Greek literature, it looks as if we were confronting a cosmopolitan idea, not with a direct borrowing. ${ }^{23}$ At all events, as far as literary influence is concerned, we find the symbolic four in Zech., in the Four Horses, c. I, and the Four Smiths, c. 2. ${ }^{14}$ At all events, we seem to be dealing with a commonplace scheme, not with an importation.

Keeping strictly to the figure of the Image, the present writer, as indicated above, sees no reason for distinguishing the lower limbs as specifically emblematic. The legs, no more than the arms, are to be interpreted dually. And if the reference to the toes be not spurious, at all events they are not different in character from the feet. The figure of the iron artificially interworked with brittle tiles ( $s$. at $v .^{33}$ ) well fits the thought of the tapering off of the Iron Kingdom into a degenerate and non-consistent polity, whether we would think of the Græcian or the Roman empire. The characteristic of this last stage of the world empire lies in the word 'divided,' פליגה $v{ }^{41}$. Recent comm. still insist here on the division between the Seleucide and Ptolemaic kingdoms, e.g., Behr. (who argues that'o must be defined from $\mathbf{v}^{43}$, where the division between Egypt and Syria is denoted), Dr., Cha., but not Mein., Bev. But, as has been noticed ad loc., 's has also the sense of inner division, composition of heterogeneous substances. That is, each leg, each foot, every toe, are severally composed of non-coherent stuffs, all equally subject to fracture and crumbling. The reference to 'the days of those kings' is simply true to the facts of contemporary history (on the theory of the Greek empire, not of the Roman empire, which had a single head); 'king' or 'kingdom' would have been actually incorrect.

The almost universally accepted interpretation of the 'mingling in human seed,' i.e., by natural intermarriage, $\mathrm{v} .{ }^{43}$, is the application to the state marriages between the Seleucides and Ptolemies with their tragic consequences. The commentary on this history will be found in C. II, S. at vv. ${ }^{6 .}{ }^{17}{ }^{15}$ Such an historical reference would have bearing upon the date of the first part

${ }^{13}$ The four-empire theory appears in Dionysius of Halicarnassus, Ant., prooem. 2: Assyria, Media, Persia, Macedonia, followed by the Romans; and in Claudian, De laudibus Stilichonis, iii, I63 (vLeng., p. 87 ).

${ }^{14} N . b$. the Seven Men in Eze. $9 f$, which have been identified by many since Kohut with the Amesha Spentas of Parsecism-whose original number, however, was six! And how did Parsee influence affect Judaism early in the 6th century?

${ }^{16}$ This comlination is first made by Polychronius, who is summarized by Grotius; cf. Int., $\$ 21, d$. 
of Dan. Keil, however, who holds to the identity of the Fourth Kingdom with Rome, but who cannot agree with any of the innumerable explanations of the royal marriages on assumption of that theory, ${ }^{16}$ would think of the race agglomerations within that empire, denying, very properly, that the plural 'they shall mingle themselves,' $\mathrm{v}^{43}$ (v. ad loc.), refers necessarily by prolepsis to the subsequent 'kings,' and treating it impersonally. This contention of Keil's, ${ }^{17}$ which has good grammatical support, can be as readily accepted by the supporter of the identity of the Fourth Kingdom with Greece, for since the day of Alexander in Babylon, when he took Persian wives and encouraged his generals and soldiers to follow his example, ${ }^{18}$ there never was an age in human history, at least till the time of the population of the New World, in which the fusion of races and cultures took place on so magnificent and determined a scale, the spirit of which was abhorrent to Judaism, fo: it was the revival of the Tower of Babel.

In $v v .44 .453$ the interpretation of the Stone which destroyed the Image is given. There can be no question of the catastrophic and complete character of the ruin wrought by the Stone, and no evasion of the absolute statement of $v v .^{34.35}$, 'not a trace was left.' And this finality belongs to the essence of all apocalyptic prospect of the Last Days. The problem of interpretation has been sorely wrestled with by those exegetes who see the end not yet consummated. For example, 'in the days of those kings' is understood as an historical process, e.g. by CBMich., who finds therein the period of the Church's gradual growth. And Kran. stoutly holds the defensive, pp. I i $2 f$ : "Zu bemerken ist weiter, dass dem Verfasser die Entstchung des messianischen Reiches und die völlige Vernichtung der ganzen feindlichen Weltmacht nicht coincidircn; dass er beide Momente absolut gleichzeitig gedacht habe, geht weder aus C. 2 noch aus C. 7." But the labor he spends is futile against the drastic impression of the immediate collapse of the Colossus and the disappearance of its very elements.

Like the preceding elements, the Stone too is a Kingdom, but one erected by the God of Heaven, to stand forever, in which there will be no change, no shifting to other dynast or people, but which will smash all those other

${ }^{16}$ These range all the way down from the marriages of Casar, Antony, the Constantines (s. Knab., p. 93) to comparison with the marriages of German emperors, etc. A similar view is that of Auberlen (Zöck., p. 85), who discovers the mingling of the German and Slavic races with the Roman empire. It has not been observed that the interpretation accepted here goes back to the Jewish comm., who interpret the item as of racial admixtures: Ra., "they will be joined in affinity with other peoples"; AEz.: "the Persians will marry the Babylonians, the Sabieans the Egyptians"; PsSa.: "Israel intermarried the peoples they dwelt among." Somewhat differently Jeph., who thinks of the difference between the great Religions.

${ }^{17} \mathrm{Cf}$. Knab., p. 92: "regnum illud complectitur uarias nationes et gentes quae inter se quidem commercia atque connubia ineunt."

${ }^{18}$ Some 10,000 followed suit; s. Niese, Griech. Gesch., I, $165 . f$. 
kingdoms and replace them for ever and ever. ${ }^{19}$ The repunctuation for $v .{ }^{45 a}$, attaching it to $\mathrm{v}^{4}$, gives rhetorical character to the period. The story-teller leaves his parable with its most striking point vivid to our eyes; similar is the terse ending of Ps. I 10.

The sphere of that Kingdom is that of its predecessors, only it possesses the everlasting endurance of the natural rock. The supernatural feature is that this Stone becomes a great Mountain. The artifice of men's hands has been replaced by the earthly type of eternity. It is enough to think of 'the mountains of God,' Ps. $36^{7}$, and 'the everlasting hills,' Hab. $3^{6}$; there is no need to postulate a mythical background like that of the Mountain of God, e.g., Is. $14^{13}$, or with Keil to see a reference to Mount Sion, $c f t$. Is. $2^{3}$, Ps. $50^{2}$ (properly denied by Behr.). Only vaguely does the narrator intimate the emblematic content of the Stone; it is by indirection a People. This must be primarily Israel, 'the Saints' of $7^{27}$. Josephus' comment is a good interpretation of Dan.'s vagueness before Neb.: "Dan. did also declare the meaning of the stone to the king, but I do not think proper to relate it,". $A J \mathrm{x}, \mathrm{ro}, 4$.

The interpretation of the Stone, in the history of religious exegesis is, with the exception of one line of rationalistic identification with the Roman empire, ${ }^{20}$ universally Messianic, in the broad sense of the term. Exegesis divides specifically according as the fulfilment is found in the Messiah or the People, i.e., Israel or the Church. Ra. and AEz. tersely state that the final Kingdom is that of King Messiah, מלכוה מלך המשיח. This follows ancient exegesis. Tanhuma, 31, 4, on v. ${ }^{34}$, 'I saw until,' remarks: "Dan. saw King Messiah." On v. ${ }^{35}$ Pirke Elieser, c. 2, notes: "The ninth king is King Messiah, who reigns from one end of the world to the other," and "in their time (of Edom, i.e., Rome) will rise a shoot, the Son of David" (s. Schöttgen for these passages). Jeph. recognizes more varieties of mng.: "It is either the nation or the Messiah who is of them or of David's seed." For the Jewish interpretation of his day Jer. says: "Iudaei et impius Porphyrius male ad populum referunt Israel, quem in fine saeculorum uolunt esse fortissimum et omnia regna conterere et regnare in aeternum." In Tanhuma, Ber. $70 b$ and Bemid. I3 (cited by Dalman, Worte Jesu, 197, n. I) the Stone is interpreted as the Messianic Kingdom. We may also note 2 Esd. 13, in which the Man from the Sea cuts a stone out of a mountain, flies upon it, and finally stands upon it; it is interpreted as Mount Sion.

Similar duality of interpretation appears in the Church, but the strictly Messianic interpretation is earliest and most dominant. There is a direct

${ }^{10}$ Behr., at v.44, rightly denies Schürer's view of the catastrophe that it symbolizes the overthrow of the Gentiles by Jewish arms. The composition comes from early Asidean, not Maccabiean circles.

${ }^{20}$ So Cosmas Indicopleustes, $P G 88$, I 2 , Houbigant (the mountain from which the Stone was cut is the Palatine, Bibt. Hebr., iv, p. 549, cited by Knab.) and Grotius. 
citation of this theme of the Stone understood Messianically in a logion of Jesus, Mt. $2 \mathrm{I}^{44}=\mathrm{Lu} \cdot 2 \mathrm{O}^{18}$, citing verbally a pre-Theodotionic version of $\mathrm{v}_{0}^{44}$ (s. Note above ad loc.). This 'stone' is combined in the logion with 'the stone which the builders rejected,' Ps. iा 8 , the first instance of the accumulation of Messianically interpreted 'stones.' Similar combination of such texts is found in Jewish comm. here, e.g., PsSa., who cft. Gen. $49^{24}$, 'the Shepherd, the Rock of Israel,' and Zech. $4^{7}$, 'Who art thou, O great mountain,' etc. Elsewhere in the N.T. the other 'stones' predominate in exegesis, e.g., 'the spiritual Stone that followed them,' I Cor. IO4, which had similar treatment at the hand of the Rabbis (s. Schöttgen, ad loc.). For the Christian confession of Christ as the Stone of prophecy s. Rendel Harris, Testimonies, particularly vol. I, p. I8, vol. 2, c. I 2. Of the early Fathers, Irenieus, Hippolytus (ii, 13), Tertullian, and for the Oriental Church Aphrem, followed this exegesis.

For the application of the Stone to the Church the earliest instance (overlooked, except in a remark of Ewald's) is in Hermas, Sim., ix. Here, c. 2, we read how the Shepherd "showed me in middle of the plain a great white stone that had come up out of the plain. And the stone was loftier than the mountains, four-square, so that it could fill the whole earth [the Gr. differs from our Grr., s. at v.41]. That rock was ancient, having a gate cut out in it," etc. Later, c. I 2, we learn that the gate is the Son of Man, who builds the Church upon the rock; i.e., the Church is rather identified with the rock.

For more specific ecclesiastical interpretations we may note the view, apparently not held by modern exegetes, that the Stone cut without hands represents the Virgin Birth, so Theodoret, Gregory of Nyssa, Aphrem; or that the history of the Stone represents the humiliation and exaltation of the Lord, so Hilary ( $P L$ 9, 681, cited by Knab.). The problem early arose as to the delay in the consummation of the Eternal Kingdom; Theodoret polemicized against those who held that the prophecy was fulfilled in the moral Kingdom of God already established by Christ; he himself held to the consummation at the future Parousia of the Lord. Then there was the question whether that Kingdom was heavenly or, at least in part, on earth, i.e., Chiliastic. The latter theory came notoriously into the actual political field with the Fifth Monarchy Men of the English Commonwealth, and has had its Millenarian adherents ever since. ${ }^{21}$

${ }^{21}$ For these varieties of view s. CBMich. at v.94; vLeng., pp. $98 f f$; Kran., pp. I 2 ff.; Zöck., p. 88; Knab., pp. 97 ff. 


\section{CHAPTER 3.}

\section{THE GOLDEN IMAGE AND THE THREE CONFESSORS.}

(I) 1-7. Neb. erects a golden idol and requires that all his subjects shall worship it in a great convocation at a given signal on penalty of a horrible death; his orders are pompously carried out. (2) 8-12. Information is laid against the three Jews, Shadrach, Meshach and Abednego, for their refusal to participate in the heathen rite. (3) 13-18. Summoned before the king, the Three persist in the confession of their exclusive religion and in their readiness to meet death, whether or not their God will interfere. (4) 19-23. The king in his rage forthwith commands them to be cast into the fiery furnace prepared for those who disobey, and takes arrogant and absurd precautions that they shall not escape. They are cast into the furnace, when, (5) 24-30, the king beholds a marvel, the Three alive in the fire, accompanied by a godlike personage. He summons them forth; their signal deliverance from all hurt is attested by his court. The king gives acknowledgment of their God and recognizes His religion, and promotes the Three in their civic offices.

"The general purpose of this Chapter is perfectly clear-from beginning to end it is a polemic against the heathen worship and in particular against idolatry. The Israelite who has to choose between idolatry and death, should unhesitatingly prefer the latter" (Bev.). Over against the satirically exaggerated details of the heathen ceremonial and the king's arrogant defiance to their God, the simple and unflinching faith of the Confessors stands in sharp-drawn contrast and at last evokes the homage of the witnesses.

The archæological background of a colossal golden image is found in the Classical authorities. Herodotus reports for the Babylon of his day (i, I 83 ), 'a great golden statue (äya $\mu \mu a)$ of Zeus' in a temple, and also in the same precincts a statue

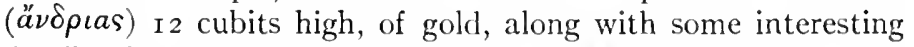
details of its fortunes under Darius and Xerxes. Bert., p. 260, calls attention to the statement of Diodorus Siculus, ii, 9, concerning the three golden images on the top of the Belus temple. 
dedicated to Zeus, Hera and Rhea, the first of which was 40 feet high, weighing I,, $0 \circ$ Babylonian talents. The Rhodian Colossus of 70 cubits' height is sufficient to satisfy the seeker of realism in fiction; and if this was a unique object, we may recall the abundant works of massive proportion which adorned the Græco-Roman world. For these costly and stupendous productions Pliny, Hist. nat., xxxiv, 9 ff., may be consulted; $n . b$. his assertion, §I 8: "Audaciae innumera sunt exempla. Moles quippe excogitatas uidemus statuarum, quas colossos uocant, turribus pares." Also very close to our subject-matter is Nestle's interesting and original note, Marg., 35, on a golden image of Apollo similar to that of the Olympian Zeus, erected by Antiochus Epiphanes at Daphnae, as recorded by Ammianus Marcellinus, xxii, I3, I. Nestle holds that this was the golden image of Jupiter which, acc. to Justin, Hist., xxxix, 2 ('Iouis aureum simulacrum infiniti ponderis') the Seleucide Alexander II (I28-I23) undertook to loot. He concludes: "Ich denke, mit diesen Notizen, ist die Frage nach dem speziellen Anlass, der zur Erzählung vom Kolossalbild Nebukadnezars geführt hat, definitiv beantwortet."

But there is also a vague Jewish tradition, equally to the point, which has not been noticed. Alexander Polyhistor, citing the Jewish historian Eupolemus (s. Freudenthal, Alex. Polyh., I875, p. I6; Schürer, $G J V$ 3, 474 ff.), as excerpted by Eusebius, Praep. evan., ix, 39, records (after Gifford's tr.): "Then Jonachim [i.e., Jehoiakim]; in his time prophesied Jeremiah the prophet. He was sent by God and found the Jews sacrificing to a golden image, the name of which was Bel. And he showed to them the calamity which was to come. Jonachim then attempted to burn him alive; but he said that with that fuel they should cook food for the Babylonians and as prisoners of war should dig the canals of the Tigris and Euphrates." The legend parallels Dan. 3 not only in the item of the worship of a golden idol but also in that of the penalty for recalcitrancy; only, the despot is the Jewish Jehoiakim and the scene Jerusalem. Now as to the date of Eupolemus, Schürer (p. 475) argues that he wrote in I58I 57 , or shortly thereafter, and probably is to be identified with the Eupolemus of I Mac. $8^{17}, 2$ Mac. $4^{11}$. It looks as if he were following some Jewish legend based on the same theme as that used by the Danielic narrator and applied to the Babylonian 
despot. Our narrator has then employed an old hagiological theme, which had its various developments in legend, and accordingly it is very doubtful whether we may attach the idea of the Golden Image to any specific event. ${ }^{1}$

There is also a Pagan tradition, not noted by the comm., which may lie at the basis of our theme. Berossus (Müller, Fragm. hist. graec., 2, 558, frag. I6, from Clem. Alex., Protr., in GCS c. 5, p. 49) is paraphrased as follows: "The Persians did not worship wood and stone with the Greeks, nor the ibis and ichneumon with the Egyptians. But after some ages they introduced human images, Artaxerxes (II) son of Darius introducing the custom, for he erected first the statue of Aphrodite-Anaitis and gave example for its worship to the Susians, Ecbatanians, Persians, Bactrians, Damascus, and Sardis." (See Meyer, $G A$ 3, $\$ 78$, for further reff., also A. V. W. Jackson in ERE, 'Images,' p. I5 I, but ignoring Berossus' datum.) This startling innovation may have motived in popular tradition a story of such an outrageous action as is here attributed to Neb.

Acc. to Hipp., ii, I5, the idea of such an image was induced in Neb.'s mind by the vision of c. 2. As to the impersonation of the image, it has been extensively held, since Hipp., Jer., Chrys., that it represented the deified Neb.; so Dr., 'in all probability,' and dEnv., arguing from the Oriental assimilation of royalty with Deity. But vLeng. rightly points to $\mathrm{v}^{14}$ ( $c f . \mathrm{vv}^{12.18}$ ) against this view, and Jeph. may be followed in regarding the image as a symbol of allegiance to the empire. Its construction of gold has also given rise to extensive argument, with charge of absurdity on one side, e.g., JDMich., with defence based on the fabulous riches of the East on the other. But Herodotus' statements about the golden idols in Babylon afford sufficient background. ( $C f$. Pliny's account of an all-gold image of Anaitis, which was looted by Antony, Hist. nat., xxxiii, 24.) The gold consisted in overlaid plates, for which we possess not only abundant Classical evidence, e.g., the $\chi \rho \dot{v} \sigma \epsilon a$ Góava, but also that of the Bible, e.g., Is. $40^{19}, 4 \mathrm{I}^{7}$, Jer. $\mathrm{IO}^{3 \mathrm{fr}}$, and the practically contemporary statements of Ep. Jer., vv. ${ }^{74}{ }^{56}$, and $\mathrm{Bel}, \mathrm{v} .{ }^{7}$; s.

\footnotetext{
${ }^{1}$ For comparison with the gigantic images of Assyria s. Knab., pp. Io2 ff.; e.g., Ashurnasirapal's statement of his erection of an image to Ninib of 'choice stone and pure gold,' Annals, ii, $133(K B$ I, 95).
} 
Bert., p. 256 , Häv., p. 92. Also the proportions of the 'image,' $60 \times 6$ cubits, have produced extensive treatises, pro and con. There can be little doubt that we are dealing with some sculptured object presenting human lineaments, and hence a monolith or pyramid, with some, is out of the question. The proportions of the human figure are as 5 or 6 to I, and so the present proportions appear grotesque. But the term of the original, salm, can be used of a stele only partly sculptured, e.g., the use of the word in the Nerab Inscription, where the stone is decorated at the top with the relief of the bust of a human body. At all events, it is not necessary to charge the narrator with an obvious absurdity. Of archæological interest is the expression of the mathematics in terms of the Bab. sexagesimal system, for which there is a parallel in the rod of 6 cubits in Eze. $40^{5}$.

Jewish tradition doubtless lies behind the penalty of burning meted out to the recalcitrants. With Bert. we recall the false prophets Zedekiah and Ahab, whom the king of Babylonia 'roasted in the fire,' Jer. $29^{22}$; so also Bev., p. 78 , and Peters' note, $J B L$ I5, I09. The later Haggadic development of the datum of Zedekiah and Ahab is given by Ball in his int. to the Song of the Three Holy Children in Wace's A pocrypha, 2, $305 \mathrm{ff}$; n.b. also his citation, p. 326 , of the passage in Tanhuma, 6, recounting how Joshua the high priest was thrown into the fire along with those false prophets, but was saved unhurt. In the same line of legend lies the extensive midrash about Abraham as saved from a furnace of fire (Ur Kasdim = 'fire of the Chaldæans'); s. reff. in Dr., p. 35 , n. I, and tr. in L. Ginzberg, Legends of the Jewes, $\mathrm{r}, \mathrm{I} 98 \mathrm{ff}$. As to the practice of the penalty of burning, it appears in the Code Hammurabi (e.g., \$\$25. I Io), and is recorded for the treatment of captives in I R I9 (cited by Miss Brooks, Moral Practices, 20). Is. $30^{33}$ is based upon such a practice. It could hardly have been practised by the Persian fire-worshippers. The same penalty is ascribed to the cruelty of Antiochus Epiphanes in his martyrdom of the mother and her seven sons, 2 Mac. 7 .

In fine, Mar. is right (p. I 8) in holding that the author did not invent the story but drew its materials from popular legends. It had assumed its form independently of the Danielic cycle and may well have been incorporated by the compiler or com- 
poser of the latter without much concern as to the whereabouts of Dan. during the episode. As to the historicity of such a tyrannous decree, it is impossible to find place for it in any knowledge we have of the Bab. religion, despite Wilson's arguments, c. 16 , anent this chap. and c. 6 . There may have been a basis for it under the more fanatical régime of Persia.

1-7. Neb. erects a golden image in the province of Babylon; he summons all the officials, from highest to lowest rank, to attend its dedication, and orders that all the various classes of his subjects present shall prostrate themselves and worship before it upon a signal given by the attendant orchestra. The pompous ceremony is forthwith celebrated.

1-3. The valley of Dura in the province of Babylon has not been certainly identified. But the name (Akk. diru, 'circuit $=$ wall $=$ walled place') is common in the geographical nomenclature of Mesopotamia, as has been early recognized by Assyriologists, e.g., Schrader, COT 2, I 27, and Delitzsch, Paradies, $2 \mathrm{I} 6$, who notes that acc. to IV R $38,9^{-\mathrm{II}} b$ there were three localities Dura in Babylonia. Possibly Oppert has identified the name of our place in the river Dûra with the near-by Tulûl Dûra (tells of D.) in the neighborhood; the river flows into the Euphrates some 6 miles S of Babylon, and the tells are 12 miles SE of Hillah. ${ }^{1}$

The completion of the image had consummation in its dedication, after the manner of ancient Bab. rites; s. Jastrow, Rel. Bab. u. Ass., I, $375 \mathrm{ff}$., passim, for specimens of liturgies connected with such rites. ${ }^{2}$ To the festival are summoned all the grandees of the empire, and a list of these classes in order of precedence is given. A similar list appears in I R $45 . f f$, which records that upon the completion of his new residence at Sarrukin (after Meissner, Bab. u. Ass., I, 7I): "Sargon established himself in his palace with the princes of all lands, the regents of his country, the governors, presidents, magnates, honorables

\footnotetext{
1 Oppert, Expédition scientifique en Mésopotamie, I, $238 \mathrm{ff}$., cited at length by dEnv., pp. $228 f$. Oppert, followed by Lenormant, dEnv., believed that a massive square of brick construction found in situ, if metres square by 6 high, is the pedestal of Neb.'s image.

${ }^{2}$ In the matter of local color this dedication ceremony is correct; at the same time such a ceremony was doubtless universal in antiquity, e.g., the dedication of Solomon's temple. The dedication was kept up annually as a 'birthday' festival, as we know for the Jewish usage, and also for the Classical world; s. material on Roman rites collected by the writer in $J B L 29,33 f$., and $c f$. Euseb., Praep. evan., i, ro.
} 
and senators of Assyria, and instituted a feast." Behr. cft. Esarhaddon's Zenjirli Inscr., l. 40, with six titles, ranging from šarru to sâpiru. The unqualifiedly Persian coloring of the story appears in the five Persian terms of the list, the other two, the sagans (2) and pehahs (3) alone being Semitic. The satraps properly lead off, followed by the sagans or lieutenants (to use a term of the old English county administration), and the pehahs, or minor governors. We may compare the satrapy of Abar-nahâra, with its subdivision Palestine, and as a segment of the latter Judah, with its pehah, e.g., Nehemiah, Neh. $5^{14}$, or Bagoi, $A P O$ pap. r, 1. I. $^{3}$ Of the last two terms in the list, the first, that of the databars, bungled by the Mass. pointing, has long been explained from the Pers. as 'judges'; the following and last term, tiftâyê, remains unexplained philologically, but it has been discovered in the Strassburg papyrus associated with daiyânaiyâ, 'judges,' and doubtless is a minor judicial title. The two intermediate terms have not been identified with certainty. We have to depend upon the Iranologists, who are constantly baffled over OPers. terms. If this story was composed in the Greek age, it is interesting, but not strange, that the official titles of the past empires still prevailed. But they witness to Persia, not to Neb.'s empire. VLeng.'s criticism is too arbitrary when he urges that the writer 'heaped together' all sorts of official terms without concern; per contra, an intelligent grading appears in the titles so far as we can define them.

3. $\mathfrak{B}$ avoided the repetition of the official list, summing them up in the phrase 'the aforesaid'; the lacuna was filled in by the Hexapla from $\Theta$. It is possible that original $\Theta$ also avoided the repetition, and that the list was subsequently filled in. Such repetition, with which $c f$. the following fourfold listing of the orchestral instruments, objectionable to the Classical taste, is characteristic of Semitic rhetoric.

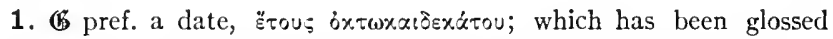
into all $\Theta$ texts, betraying its origin (ignored by Löhr) by the gen. of time peculiar to $\mathbb{G}, \Theta$ using $\dot{\varepsilon} v$ with dat.; s. at $\mathrm{I}^{1}, 2^{1}$. Appeal to $\Theta$ for originality of the datum cannot therefore be made, vs. Jahn, Blud. (p. $5 \mathrm{I}$ ). This datum for the end of Jerusalem is taken from Jer. $52^{29}$, which disagrees with the ' 19 th year' of $2 \mathrm{Ki} .25^{8}$ ( $c f$. Jer. $\left.32^{1}\right)$. It is

'For the organization of the Pers. empire s. Rawlinson, SGM, 'The Fifth Monarchy,' c. 7; Meyer, GA 3, \$ 24 ff.; E. Bevan, House of Seleucus, 1, 325; ff. inf. at 6². 
repeated in $4_{4}^{1}$. The addition is dramatic in identifying the date of Neb.'s impious creation with that of his destruction of the holy city. (6) has also a long plus after $N \alpha \beta$. $\delta \beta \alpha \sigma$., based on Est. $I^{1}$, ascribing to him administration of all the world 'from India to Ethiopia.' (In $\mathbb{6}$ texts of Est. 'to Ethiopia' is lacking, but not in ${ }^{2}$.) The same expression of gcographical extent appears in I Esd. $3^{1}$; also the 'satraps, generals,

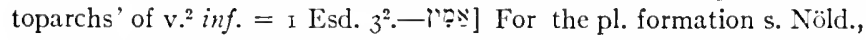
$S G \S 81$, and GK $\$ 87$. - 7 ? ? Syr., e.g., at Eph. $3^{18}$-— $]$ Pause has retained the original vowel, i.c., sidl; s. Behr. vs. Kau., Gr. \$68, I, Anm. I.- ב בקובת Is not found in Heb. and Aram. outside of Bibl. tradition; in Arab. buk'ah has the general sense of 'district.'-רורא]

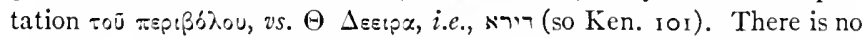
reason to hold with Bert. that $\Theta$ thought of the Susian $\Sigma_{\varepsilon n p \alpha}=$ Ptol, Geog., vi, 3. $\Theta$ 's transliteration is Aramaizing, and appears in the common geographical compositive der. In $S a n h ., 92 b$, is given a more exact

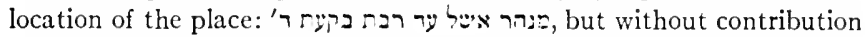
to our information. It is not neccssary to exchange the geographically approved 'Dura' for the theory of Wetzstein (Delitzsch, Jesaia ${ }^{3}, 70 \mathrm{I}$, cited by Mar.) that the word = zor 'depression,' the local designation

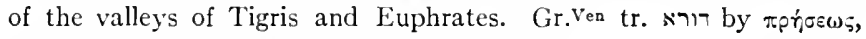
i.e., as = 'pyre'; $c f$. (F's tr. of רור at Eze. $24^{5}$.

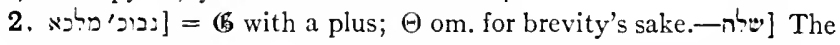
vb. is used frequently as absolute of sending messages, orders, etc.; the Gr. rendering $\dot{\alpha} \pi \circ \sigma \tau \varepsilon \hat{\varepsilon} \lambda \varepsilon \iota \nu$ is similarly used in N.T. The comm. recall

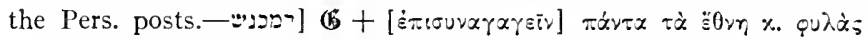

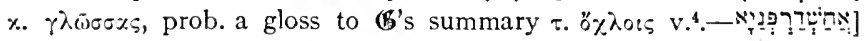
'Satraps'; for origin s. Lexx. and $c f$. Meyer, $G A$ 3, pt. I, pp. 5 I $f$. for its transliterations. In Akk. the word appears first in a list of Sargon's, satarpanu (cf. Offord, QS I919, p. 138), and in texts of later date published by Pognon, $J A$ i I ${ }^{\text {me }}$ Sér., 9, 394, and Clay, Business Documents of Murashu Sons of Nippur (no. 2, 1.6, no. 21, 11. 7. II, s. list of personal names under si-ha, p. 38) as aȟšadar(a)pan; in earlier Gr. = $\varepsilon \xi \varepsilon \tau p<\pi r_{5} s$; in 62 at $6^{3(2)}$ is found $\alpha \sigma \tau p \alpha \pi \alpha 5$ (Aquilanic). (65 exactly 'satraps.' For the variant use of the word in Gr., both exactly and as of high officers in general, s. the elaborate article by Lehmann-Haupt, Pauly's RE, zte Reihe, $3,82-188 ; n . b$. the extensive use in Gr. O.T., e.g., Ju. $5^{3}$; only in Dan., $\mathbb{6}$ and $\Theta$, does $\sigma x \%$. represent the original. $\Theta$ $\tau$. i trisous $=$ consules; the contrast of the two terms is indicative of the different ages of the trr.--No] See at $2^{48}$; properly 'prefects, lieutenants'; $\mathbb{G} \Theta$ orparirous, which is used by Polyb. for consul and practor.-

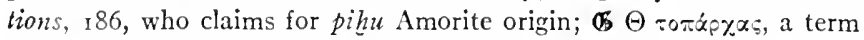
of the Ptolemaic administration.-. 
stood by Nöld., Andreas (in Mar.'s glossary) as 'councillor,' s. Lexx.; Meyer, Entstehung des Judentums, 25, prefers mng. 'Obergeneral.' Sym.

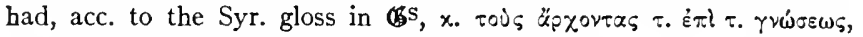
Field recognizing that $\gamma$ vwoเs $=$ 'magic'; i.e., Sym. has interpreted the word from גiר $2^{27}$; this is the basis of RVmg 'chief soothsayers.'

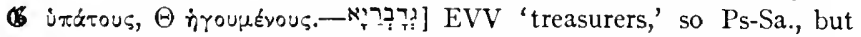
not elder Jewish tradition; accepted by some, e.g., CBMich., Meyer, op. cit. 23 , as perversion of איָז

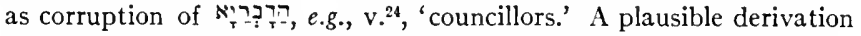
is that offered by Tisdall in $J Q R \mathrm{I}, 337$, equating with a proposed gadhâ-bar, 'mace-bearer,' comparing modern Pers. chûb-dâr and the oxy $\pi \div 0 \bar{x} \% 5$ of the Pers. court, Xenophon, Cyrop., vii, 3, I6, etc. The word may be dittograph of the following רהתכריא, so Lagarde, Agathangelus, 157 (cited by Dr.), who argues from the omission of one of the titles in $\mathscr{B} \Theta$ to the fact of a subsequent dittograph in $\mathbf{T}$. However, haplography, or simple abbreviation on the part of $\mathbf{E}$, followed by $\Theta$,

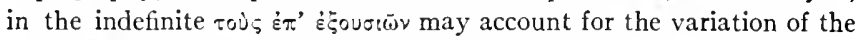
Grr. (5 here sooxri $\tau \alpha \varsigma$, i.e., fiscal administrators, as in Polyb., so

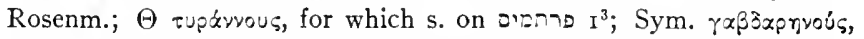

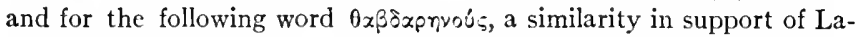

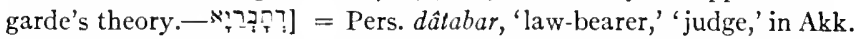
databari, Clay, $B E$ 9, p. 28.- cial titles in Euting's Strasbourg Papyrus (s. $A P O$ p. 26, $A P$ no. 27) B,

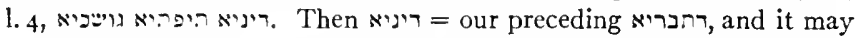

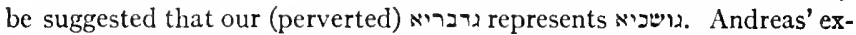
planation of the word in Mar.'s Glossary is renounced by him in $E p h$. 2, 15. Behr., p. ix, and Tisdall, $J Q R 217 \mathrm{ff}$., suggest a possible ati-pati 'overlord,' but the mng. is too grand for the office. An elder derivation, e.g., IEmp., CBMich., connected it with the Arab. root giving

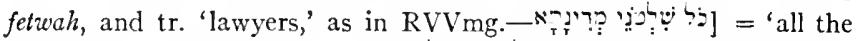
provincial administrators.' For $i_{i}$

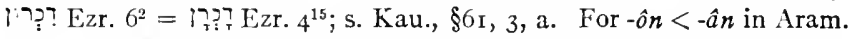

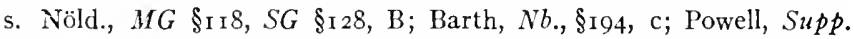
Hebr., p. 35. throws no light on the series of terms. I hopelessly unites nos. 6 and 7 in a phrase. Sym. has all the terms, nos. 5, 6, 7 in (corrupt) transliteration. There is no consistency in the subsequent rendering of these titles; s. Blud., pp. $98 \mathrm{ff}$., for a convenient table of the renderings. (6's list, 'satraps, generals, toparchs,' appears also in

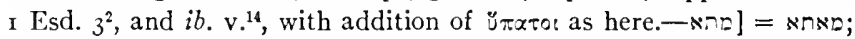
for syncope of $\kappa c f$. s. Sachau, $A P O$ p. 263.- ח The root is not otherwise known in Aram.

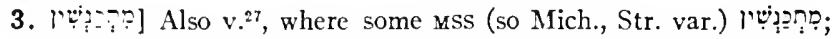
Etpeel is to be expected; s. Note on $r^{2}=2^{13},-\mathbb{B}$ avoided the repeti- 
tion of the list of officers of $v^{2}$, summarizing, as appears from the Hexa-

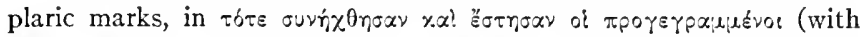

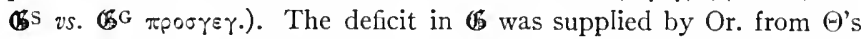
tr., as appears from the use of the latter's terms. Or rather it is probable that $\Theta$ also avoided the repetition in v. ${ }^{3}$, and that the present complement with varying order for the first three terms is due to Hexaplaric

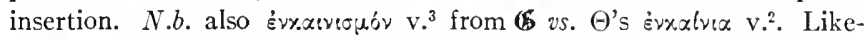

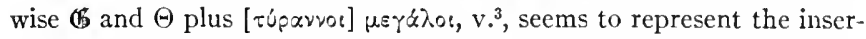
tion of a new rendering of גבריא גרוריא, seven terms being thus achieved. The orig. condition of $\Theta$ may appear in the plus of $A$ ro6,

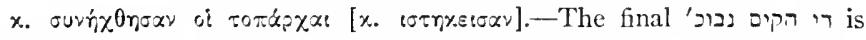
given by $\left(\mathcal{B}\right.$, omitted by $\Theta$, supplied by $\mathrm{OrC}^{\mathrm{C}} ; 62$ I 47 have a double gloss. The threefold occurrence of this phrase within two vv. is objected to by Torrey as 'intolerable,' Notes, I, 26r, similarly Mar.; but with Kamp. it is better to follow the evidence of and $(\mathbb{b}$.

4-7. Proclamation is made by the royal herald that at the fanfare of the orchestra all present,-as expressed in diplomatic language (Ḧ̈v.),-all nations, tribes, tongues shall fall down and worship, while disobedience shall entail death by burning. Unlike the story of Esther, in which likewise universal edicts are given, the application of the universally expressed edict could have had but local effect; tout le monde was there. With great zest the narrator details the instruments of the orchestra, repeating himself in $v v .7 \cdot 10.15$. From his interest in this part of the scene we have an echo of the impression produced by a piece of concerted music upon the ancient mind, just such as the narrator may himself have witnessed at some state pageant. In matter of fact, 搝 and the Grr. slip up in repeating the full list each time. The list begins with two wind instruments, horn and pipe, followed by three stringed instruments with the sixth and last again a wind instrument, over the character of which there has been great dispute. Of the six instruments two names are of Semitic origin, another is doubtful $(=\sigma a \mu \beta u ́ k \eta)$, and three of Gr. derivation, the kithara, psaltery, symphony (as the latter word appears in the Douay VS, following $\mathfrak{i}$ ). The words are of interest as giving the only solid philological evidence for the reflection of Hellenic civilization in Dan.; s. Int., $\$ 8, c$. It is to be noticed that this description is very cosmopolitan as compared with the accounts of the temple music in Chron. ${ }^{1}$

\footnotetext{
'For the music of the ancient Semitic peoples reference may be made, inler al., to
} the articles s.v. 'Music' in $D B$ (by J. Millar) and EB (by Prince), and to Well- 
The burning fiery furnace of v. 6, etc., must have been similar to our common lime-kiln, with a perpendicular shaft from the top and an opening at the bottom for extracting the fused lime; cf. illustration of such an Oriental tannur or țâbun in Benzinger, Hebr. Archäologie ${ }^{2}, 65$, and Haupt's description, AJSL 23, 245. Häv. notes Chardin's remarks on the existence of similar ovens in Persia for the execution of criminals (Voyage en Perse, ed. Langles, 6, c. I8, end, p. 303). The sonorous phrase may have been, as Bert. suggests, the technical name for this gruesome instrument of execution.

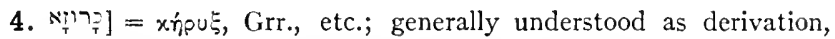
along with denom. vb. in Haf., הכר $5^{29}$, from xnpúvoe?v. The root is common in late Aram. dialects; in Mand. באיווא. Nöld., GGA r884, I019, doubts the alleged Gr. origin, similarly Mar. The n.pr. ברז on an Aram. seal, CIS ii, no. 86, is not to be compared. For the irregular

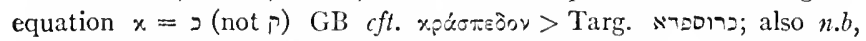

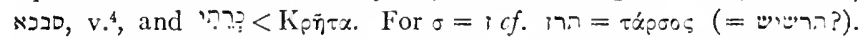
and n.b. Phœn. רבר (Lidz., $N E$ 268). The word must have been an early borrowing. Its form, hâtồl, common for nomen agenlis in

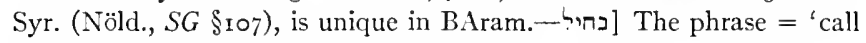
aloud,' also in $4^{11}, 5^{7}, c f$. Rev. 1 $8^{2}$. - Nיע] For the strong form s. Kau., Gr., p. 92, n. I, \$55, 5; in Syr. the same, spn;, along with other cases, s.

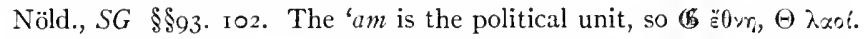

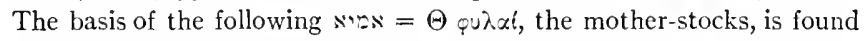
in Heb. and Arab. The 'tongues' were early distinguished for administrative us? of the millat of the Arab empire; besides the well-known use of Aram. in the Ass. chancelleries there was the official recognition of the languages in the Pers. empire, e.g., the Behistûn Inscr. in three tongues, with its papyrus duplicate in a fourth, the Aram. (APO pap.

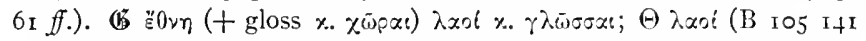

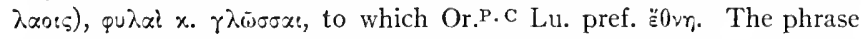
is repeated in vv. ${ }^{7}{ }^{31}, 5^{19}, 6^{26}, 7^{14}$ (cf. Is. $66^{18}$, Judt. $3^{8}$ ), and occurs in various forms in Rev. $5^{9}, 7^{9}, 13^{7}, 14^{6}, 17^{15}$, in several of which cases

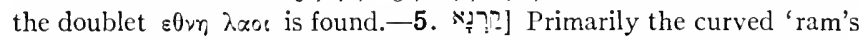
horn,' c.g., Jos. 615._. Tre? and derivatives; Grr. oúp: $\gamma \xi$, with onomatopoetic equivalence; $\mathrm{AV}$

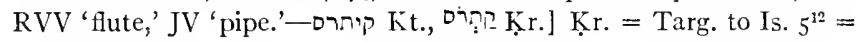
Heb. ๆn! (so here in Heb. tr. in Ken. 240); the vocalization is best

hausen's treatment in the Polychrome Psalms, Eng. tr.; for Babylonia, Meissner, $B a b$. u. Ass., 33 I ff.; for the Rabb. traditions Büchler, 'Tempelmusik,' arts. in $Z A T W$, vols. 19. 20; S. Krauss, Talm. Arch., \$247 ff.; Oesterley, The Psalms in the Jewish Church, cc. 2. 3. 


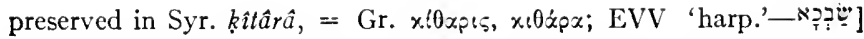

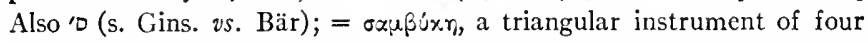
strings with high notes; AV RV 'sackbut,' a sound-equivalent of the original, but erroneously; s. Dr. for reff. and add Hastings in $D B$ s.v. 'Sackbut'; the sackbut was a wind instrument. Dr., JV 'triagon.' As to the word Strabo, Geog., x, 3, I7, notes that it is of 'barbarous' origin

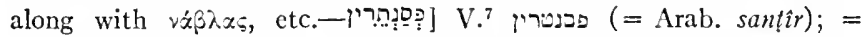
$\psi x \lambda$ tŕp:ov, EVV 'psaltery'; s. Dr. on this 'stringed instrument of triangular shape' with the 'sounding board above the strings.'- ס ס

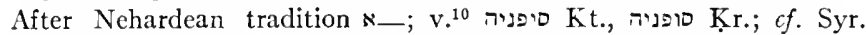

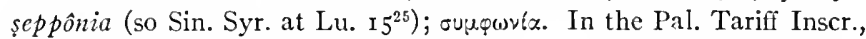
Lidz., $N E$ pp. 463 ff., Cooke, $N S I$ no. 147 , 1100 thrice $=$ oúup̣wos. "The word, which in Plato and Aristotle has the sense of harmony or concord, came in later Greek to denote a bagpipc," so Dr., followed by JV. The first reff. to the symphony as an instrument actually occur in anecdotes of Antiochus Epiphanes' life, Polyb. xxvi, ro, and xxxi, 4, cited at length by Dr., according to which in his mad freaks Ant. would play on or dance to the symphony. But the mng. 'bagpipe' has been strenuously disputed. In $J B L$ 1904, 180-190, P. Barry, under the title 'On Luke xv. 25, ouppovix, Bagpipe,' argued for this mng. G. F. Moore replied, $J B L$ 1905, r66-175, denying the existence of ancient authority for this tradition. Barry countered in $J B L$ I908, 99-1 27. Some have suggested that the Gr. oipov is the original, so a Jewish interpretation, s. Moore, pp. $167 f f$.- Of these musical terms orig. (B) avoided their repetition; om. throughout the sambyke; om. the symphonia v. ${ }^{7}$ (many MSs hab.); (6G.S om. it vv. ${ }^{7}{ }^{10}$, and $\Theta$ vv. ${ }^{5}$. 7. 10; the omissions are doubtless due to carelessness. In $\Theta$ it has been restored by $\mathrm{OrC}^{\mathrm{C}} \mathrm{Lu}$. II has the complete list in v.7.-1; " ein früh recipirtes Wort,' Nöld., SG 89, cf. Lagarde, Armenische Studien, \$749; found in Bibl. Heb., BSira, and now in the papp., APO pap. $4,1.3$.

6. 湿] So Mich., Str., Gin., Kit. (with philological right); Bär., 彷; s. Bär, and per con. Kau., \$22. There may be a Rabb. collusion with P. 1 Ex. $16^{15}$. In JAram., while witten, it is so spelled for distinction from IP, s. Dalm., Gr., p. 7r, top._- ד

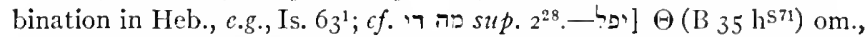

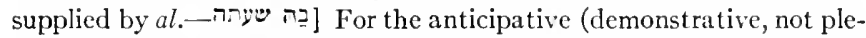
onastic) use of the pron. s. Kau., §88; another use repeats the prep., e.g., $5^{12}$, as is common in Syr., s. Nöld., $S G \S 222$, 2. Similar cases in Heb., Lev. I $3^{18}$, Song $5^{7}$.—א. and Gin. mg. For the moot question of derivation s. Kau., p. 102, Lexx. One development (as here) has a short vowel (Targ., ChrPal., Mand.), but $\mathfrak{A M}^{\mathrm{B}}$ (at $\mathrm{v}^{15}$ ) and $\Lambda \mathrm{rab}$. give $\breve{s} \hat{a}^{4} a t$. It is best derived from rt. העי 'look,' and the form is a fem. ppl., 'the looker,' $c f$. Germ. 'Augenblick.' EVV unfortunately 'in that hour'; correctly among recent comm. 
Mein., Behr., Pr., Mar., 'at that moment,' which mng. is required at $4^{19}$. VLeng., following Buxt., noted the right mng., cft. Targ. Heb. "גר, e.g., Ex. $33^{5}=$ exactly inf. $4^{19}$. The same use is found in Syr., e.s., Mk. $\mathrm{I}^{42}=$ ejoús, and in Arab. The same erroneous view of the Gr. equivalent in the N.T. appears in the EVV, etc.- לג] Also MSs לגו Gin. mg., but s. Bär's note; $7^{15}$ is to be otherwise explained. Cf. the Nab. גוא מנה 'within it,' Lidz., NE 248. Kau., p. 99, and GB suggest 'graphic $N$ '; rather then it would represent the acc. ending, s. on $x^{4} ; 6^{3}$. But it is best, with Nöld., GGA I 884 , 1021, comparing Heb. אי and Arab. jizuâ, to regard $\kappa$ as radical. In the papp. בגו is found, used only adverbially, 'herein, herewith,' s. APA A J. I5, note.-ארון] Akk. word, like the synonyms רנור, בפור; s. Lexx. and Haupt, AJSL 23, 245. The suff. in ${ }^{2}$. T. ${ }^{19}$ vouches for $\mathbf{s}$ as masc.; the agreement here of the fem. adj. קדרה is then with the second component of the const. complex, גור, c.g., a similar case in Heb., Ex. $26^{13}$, and s. in general

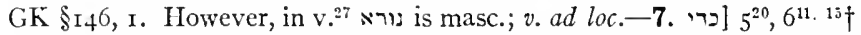

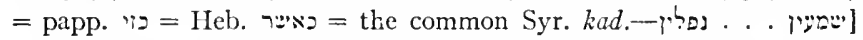
'As soon as they were hearing, they were falling down'; $\Theta$ correctly tr. with impfs.- סגדין] Not a secondary predicate, with $\Theta$, but in asyndeton with poj; cf. jin v. ${ }^{27}$.

8-12. Information is laid before the king against the three Jewish officials, Shadrach, Meshach, and Abednego, for their refusal to participate in the worship at the dedication. The informants are naturally certain Chaldaans, members of the caste which cherished a natural grievance against those obstinate religionists who had yet gained the royal favor. In what way the three Confessors exhibited their recalcitrance is not related; that attitude is dramatically taken for granted.

8. $r า y<g a b r$, ff pum, sum, and for this effect of the labial s. Dalm., Gr. §I4, 2, Nöld., $M G \S$ I9, and in general, Brock., VG I, §76; in Targ. gubra and gabrâ, in Syr., where it is rare, only the latter. Here, also vv. ${ }^{12}$. 20, it has the sense 'certain,' $c f$. אני' Ex. I $6^{20}=$ the common Syr. nâšsinn; also so אu. Ju. $4^{4}$ cases Kt. preserves orig. $y,-y \hat{\imath} n$; s. Kau., \$II, I, b.-_אכלו קרביהון] Also $6{ }^{25}$. The phrase $=$ 'eat the pieces of,' i.e., 'gnaw at'; Behr. cft. Lat. roderc; hence 'calumniate, sycophantize against.' 'This interpretation is far more likely than that offered by Lepsius in Der Christl. Orient, 1897,152 (cited by Mar.) to the effect that the phrase means to eat the table portions assigned to a magnate's client and so to replace him in the great man's favor. The phrase is ancient Akk. and wide-spread through the Sem. languages, s. Lexx., esp. GB. N.b. Syr. אכריקרצה= 


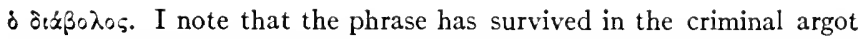
of Paris, acc. to Victor Hugo in his dissertation on that subject in Les Misérables, Part 4, Bk. 7, c. 2; 'manger le morceau' = 'dénoncer.' For the anticipative pron. before the foll. gen. (a usage apparently ignored by Kau., Mar.) s. Nöld., $S G \$ 205$, C. For ${ }^{\prime}$, var.

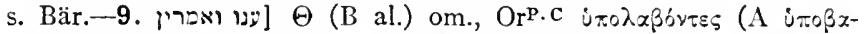

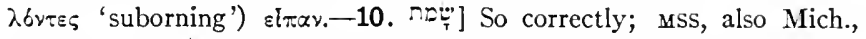
Hebraizing, ת ת.-Denotation otherwise than at $2^{14}$, and with a somewhat diff. nuance, v. ${ }^{12}$ inf.; here it is the 'sense' of the will, correctly $\Theta \delta \delta \gamma \mu \alpha$. The VSS paraphrase here; Aq. tr. with $\gamma \gamma \omega_{i}^{\prime} \lambda$. -

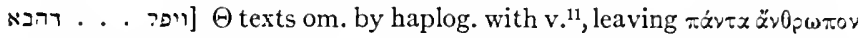

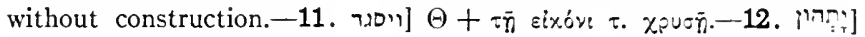
Unique instance in BAram. of this sign of acc. $n$ (not noticed in Kau., Gr. §68). The particle is frequent in Targ., prob. in imitation of Heb. את (so Bev., p. 38), frequent in PalSyr. with pron. suff., rare in Syr., s. Nöld., $S G$ p. 2 r7. It appears as $ת$ in the Hadad Inscr., as $\rightarrow$ in Nab. and Pal., s. Lidz., $N E$ 263. For the particle s. Lexx., s.v. Heb.

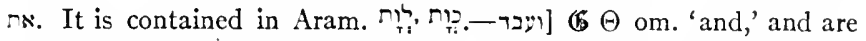
prob. original._- א. $]$ = isti; in the papp., also $C I S$ ii, no. I45 B, 1. 6.

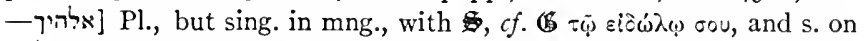
. There is no reason with Mar. to change Kt. to the sing.

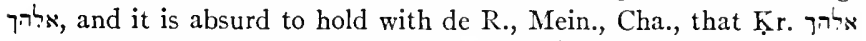
indicates a sing. See Kau., §53, Anm. b. - של In BAram. generally of religious service, so in the Carpentras Inscr. (CIS ii, no. I4r, Lidz., $N E$ p. 448 , Cooke, $N S I$ no. 75 ), but of human service to royalty in APO pap. 50, l. I, 'to serve in the palace,' and so inf. $7^{14.27}$. For the religious significance of the root $c f$. the parallel 2 ; and Lat. colcre; so with Pr., and Haupt., $A J S L$ 26, 209, against Del., Prolegomena, i 76, BDB, Kön., Hwb., who find the original in Akk. palâhu, 'fear'; the Akk. mng. is secondary.

13-18. The king in rage and passion has the recalcitrant Jews haled before him. He demands of them, ${ }^{14}{ }^{14}$, whether it is true (vs. AVmg RV, whether it is of purpose) that they will not serve his god and worship the image. He gives them another chance of compliance, $v_{.}^{15}$, and repeats the statement of the penalty; and concludes with the arrogant demand: What kind of a god can deliver you out of my hand? The response of the Confessors, $\mathrm{v} .^{16}$, is generally translated, We have no need to answer thee, a reply which has been designated by some adverse critics as the height of arrogance; so Bert., vLeng. Martyrs have actually followed various lines of reaction toward their persecutors, and 
an attitude of defiance is at least human. But the term 'make

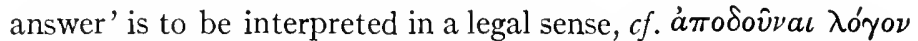
Acts $19^{40}$ and Syr. equivalents of our phrase used in that sense (s. Note), i.e., 'make defence, apology,' and so here: There is no need for us to make defence before thee. The indictment is confessed, there is no apology to make. The defendants throw themselves upon their God; yet with the restraint of faith, for they admit that he may not interfere, but nevertheless they will keep faith and defy the king. Had the story meant that they were sure of deliverance, their reply might have been spiritual arrogance.

17. There has been ancient debate as to the proper translation and reference of the introductory particle, which can only mean 'if.' The implied doubt as to the divine ability in the obvious 'if our God is able,' was an early stumbling-block to the VSS, which agree in rendering the Aram. particle by 'for' [our God is able], or $\boldsymbol{H}$ ecce cnim, 'for behold,' followed by Jewish comm. with 'for' and by many subsequent scholars with 'behold.' Also $\mathbb{B} \mathfrak{H}$ carry their scruple into the interpretation of the correlative 'if not,' $v .^{18}$, disguising or paraphrasing it. With the only correct possible translation of the particle as 'if,' two interpretations are offered. One is that of AV RVV, most recently supported by Torrey, viz.: 'if it be so, our God, whom we serve, is able to deliver us, etc.; and he will deliver us from thy hand, $\mathrm{O}$ king. 18. But even if he shall not do so, be it known unto thee, O king,' etc. 'This, at first sight, appears to avoid the doubt of the divine ability apparently expressed in the other line of interpretation, which is here preferred: If our God whom we serve is able to deliver us from the fiery burning furnace and from thy hand, O king, he will save (us); but if not, etc. So now most comm., SVmg ${ }^{2}$ JV. But to assert with AV, Torrey, that God is able, and then to hedge with the possibility that he may not interfere, amounts to the same result as the expression of uncertainty concerning the divine action at the beginning. 'The 'if not' of $v \cdot{ }^{18}$ would then be adversative to the nearest verb, 'he will deliver,' as Torrey allows. There may not then be the absolute confidence in the divine interference such as possessed Dan. in c. I (but that in a much simpler matter), nevertheless the Confessors are speaking the language of 'natural piety' in asserting, on the one hand, the divine omnip- 
otence, and acknowledging, on the other, its possible restrictions in any given case.

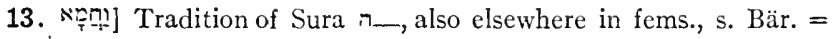

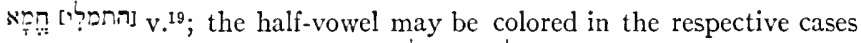
by the preceding vowel; but of. ment s. Kau., §ı3, 4. For the form, from on', s. Kau., $\$ 56$, p. ro3, Nöld., $M G$ p. II I , Barth, $N b$., $\$ 62, e$, and note on הצר v v. ${ }^{14}$. The word appears in the Hadad Inscr., l. 33, with identical spelling, an exceptional in-

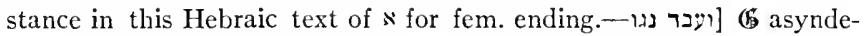

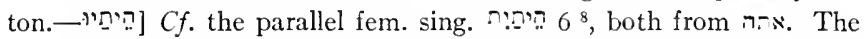
former might be treated as impersonal pl., 'they brought,' with $\Theta$ Ehr., but otherwise the Haf. pointing is must then be arbitrarily revised into a pl. (Ehr. proposes nothing here!), with $\Theta$. In their conjunction the forms must be pass., so $\mathbf{6} \mathbf{H}$ Sa., Ra. But, with Kau., p. 67, n., "eine befriedigende Erklärung dieser Passive ist noch nicht gelungen." An elder view is that it is a Hofal, so Buxt., Lex. col. 247: "Tzere est propter ' sequens," etc.; adopted by Str., §r 7 , b, following M. Lambert and J. Barth. Jahn, Löhr boldly vocalize as Hof. Either method of obtaining a Hof. is possible. Ingenious but farstrained theories are offered by Wellhausen, Deutsche Lit.-stng, I887, 968 (presented by Kamp.), by Behr., and by Powell, Supp. Hebr., p. 43. Torrey, Notes, II, 23I, regards the case as a most interesting example of 'alternative pointings,' i.e., an attempt to combine the Hof. and the Hif.; but it cannot be said that the combination is obvious. 14. הני]

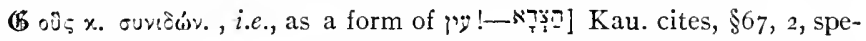
cifically as

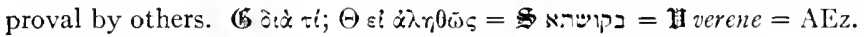

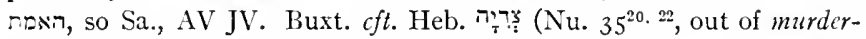
ous intent) and tr., 'is it of purpose?' and so AVmg RVV Mar. (glossary), Kön., $H w b$. But the root is absent in Aram., the form is doubtful, and the mng. is not applicable here. Bev., Behr., suggest $\epsilon f .2^{5}$, corresponding with $\Theta$, etc. But the word has now been found in the

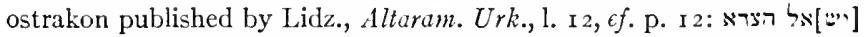
, הני מליא אלה , 'He will ask whether true (ef. pl. pron. as copula) these words.' This early occurrence forthwith pre. cludes the proposed Pers. etymology, connecting with Lidz. ventures an explanation with the brief note, "vielleicht ist es eine erstarrte Kurzbildung vom St. צרק." But Torrey in his Notes, I, 26r, had already derived the Bibl. word from * י cifically as the verbal noun "צִ with shortening of the vowel, as in

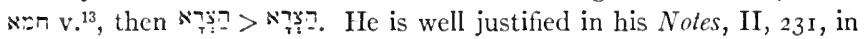
holding that his derivation is corroborated by the new-found text.

15. עבריה For the following aposiopesis of the apodosis, $c f$. exx. in 
Heb., e.g., Ex. $32^{32}$, and s. GK $\S_{167}$ I ; for Syr. Duval, GS $\$ 416$, Nöld., $S G \S_{382}$. Similarly for N.T. grammar cf. Lu. $19^{42}, 22^{47}, 2$ Th. $2^{31}$, etc. $\rightarrow$ הוא [וּן is not here the copula. Actually the pron. here emphasizes the interrogative, 'what (at all) god is there?' A parallel with another demonstrative element is found in the Aramaic boundary inscription published by the writer in JAOS I907, I64 ff., 1. 2, אן וי את 'whosoever' thou art who,' $c f$. Akk. mannu atta sarru, Behistûn Inscr., 1. 105. Similar is the Heb. מה זה די, מה, sup. $2^{28}$, etc. In Targ., Syr. this combination continues in mann $\hat{u}$, etc.; for this emphasizing use of enclitic $h \hat{u}$ attached to various parts of speech, s. Nöld., $S G \S 221$;

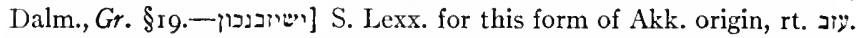
In Heb. עוב = 'leave alone,' and so in Stem I of Akk., but in III, I, ušêsib, it has the sense of 'letting go,' and so 'delivering, saving.' This development explains the difficulty encountered in the law of Ex. $23^{5}$ : 'If thou seest thy enemy's ass crouching under his burden, thou shalt

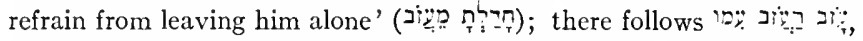
translated usually, e.g., by JV, 'thou shalt surely release it with him,' i.e., the same vb. and stem in opposite mngs. in the one period. Others, e.g., Baentsch, demand a correction of עזב חעזנ into some other vb. But, after the two mngs. of Akk. ezêbu in Stems I and III, we may simply change תעז into the Hif., and, like $u s \hat{e} s i b$, gain the mng. 'deliver.' The abs. inf. is, to be sure, Kal, but the inf. need not agree with the finite vb. in stem. Cf. the Hif. of Heb. רפה, generally 'lassen, ablassen,' but also, e.g., Job $7^{19}$, 'loslassen.' Similarly Eng. 'lose' and 'loose' are from the same rt., as Prof. R. G. Kent kindly informs me.-'T!'] So Bär., Str., Kamp. $=\Theta \mathbb{H}$; Mich., Gin., Kit., Mar. 'ج:;: $=\mathbb{B}$ Or ${ }^{\mathrm{P}} \mathrm{Lu}$. But the sing. belongs to the Sem. idiom and is corroborated by v. ${ }^{17}$.

16. ועבד נגו] OrP $\Theta$ \& alone have conj._._. The discourteous vocative of the Mass. pointing was not only impossible in etiquette but also in the spirit of the writer. Ra. notes the discourtesy and expatiates on it with zest, and Sa. tr. 'O Neb.'; the interpretation is ancient, appearing in Jer., who notes that 'Neb.' is not accompanied in (as in (B) by a following 'king,' Bert. tr. 'to king Neb.,' and Hitz. insists on the necessity of revising the punctuation accordingly. Behr. follows suit, but incorrectly alleging that $\mathscr{B}$ read in sequence $\beta x \sigma i \lambda \varepsilon \bar{u}$ (so Kamp., Mar.), but $\beta \alpha \sigma \lambda \lambda s \tilde{u}$ is sub asterisco and is not original. The general usage is נב' מיכא, but with exceptions, e.g., $2^{46}, 4^{15}, 6^{10}$ (poss. with emphasis on 'king' in some cases, so Hitz.). Torrey, Notes, I, 262, believes that in the original text the two words were transposed, and so indeed they appear in --

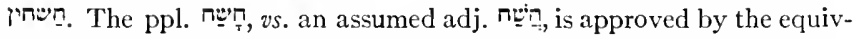
alent in Syr., s. Kau., $\$ 58,2$, e; but Torrey, l.c., argues for $h a-.-$

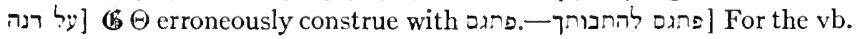


with cognate acc. cf. משוב in in Heb. with double acc., e.g., I Ki. $2^{9}$. For the Indo-European origin of the word s. Lexx., e.g., Armenian patgam. (For the formation cf. פתר סר $\mathrm{I}^{5}$, and idol, appearing in Torrey's Cilician Inscr., JAOS 35, 369; this is also found

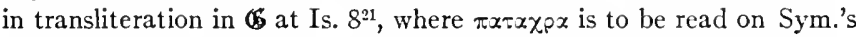
authority in place of corrupt $\pi \alpha \tau p \varsigma x$, s. Nestle, $D B_{4}, 44 \mathrm{r} a$. The word appears also in the 'Targ. and freq. in Aram. magical texts.) For the phrase here the common Syr. equivalent is יהב סרגמא 'give answer, render account,' and also a more exact equivalent is found in Pesh. Mt. I 5 $5^{23}$, 'D. Zirkel, Untersuchungen iiber den Prediger (I792), cited by McNeile, Eccles., 42, followed by Torrey, Ezra Studies, 177, presented the novel theory that $D$ is from $\rho 0 € \gamma \mu \alpha$. But this fairly uncommon Gr. word, while meaning 'voice, utterance, language,' is never used in the sense invariably given by Aram. usage to ' $D$, which always = רבר and ióos, the correspondence being substantiated by the phrase equivalences cited. The objection made by Torrey that no proper IndoEuropean derivation can be found is fairly met by a note by Gehman, $J B L 43,320$. The Gr. ¿̇ooounva $\lambda 6$ yov is rendered in Pesh. at Acts $19^{40}$ by the idiomatic meppak rûhâ, 'make apology, defence.' Our phrase also occurs in Odes of Solomon, $24^{7}$, and can be explained there only by the sense claimed here (Harris ad loc. is unsuccessful in interpretation).

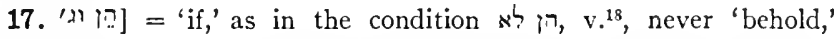
as in Heb. But the VSS unite in ignoring the conditional 'if God is able to save,' and tr. by 'for,' as noted in Comm. Consequently the syntax was recast: 'Behold (or, for) our God is able to save us from the furnace, and from thy hand he will save.' So Sa., AEz., most of the earlier comm., GV, CBMich., Ew., SVmg, Ehr., etc. The correct tr. 'if' was recognized by deDieu, repeated by vLeng., and is accepted by most modern comm. As indicated above, two interpretations of the condition have been proposed. That accepted by AV RVV tr. רן אירת by 'if it be so,' i.e., if the king's order is to be executed, and Torrey defends this by comparing "2 $2 \mathrm{Ki}$. $\mathrm{rO}^{15}$, 'and be it so.' For consideration of this interpretation s. Comm. above. The interpretation accepted there is also that of JV.- אלדָ Anm. a. $\Theta\left(B Q \mathrm{~V} \mathrm{~h}^{76}=\mathrm{CWab}^{\mathrm{W}}\right)$ ignored the suff.; $\boldsymbol{W}$ has a plus. -18 .

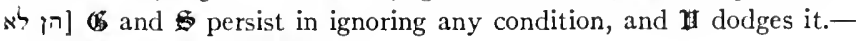
[רהנא $\Theta($ B $89229=\mathbf{I})$ om.

19-23. Naturally enough the despot's features were transformed with rage at the Confessors' pertinacity. He absurdly ordered the flaming-fiery-furnace to be heated seven times hotter than was necessary or was wont, $\mathrm{v}^{19}$. The strongest men of 
the army were ordered to bind the victims and to cast them down into the fiery kiln, v. ${ }^{20}$-all this to forestall any intervention of gods or men. The three Jews were accordingly bound, clad in their full suits of clothes, mantles and trousers and hats; they had attended the ceremony in full court dress. The three terms of dress are variously interpreted in $\mathbb{B}$ and $\Theta$ and so in subsequent VSS, and have induced extraordinary variety of interpretations. The Note substantiates the tr. of GV AV, 'coats, hosen (trousers), hats' against RV JV. The defiance of the king to the Confessors' faith in the excessive heating of the furnace had its retribution; the executioners had taken them up to the top of the furnace (s. Comm. at v. ${ }^{6}$ ) and cast them in, when a lambent flame of fire killed the executioners, v. ${ }^{22}$. The Confessors themselves were fallen down bound into the furnace, v. ${ }^{23}$, when a prodigy attracted the astonishment of the king, vv.24f. - for such is the connection of thought.

At this point is interpolated the great Apocryphon of the Christian VSS; for judgment against its originality s. Int., $\S_{4}, a$. The same opinion is expressed very positively by Torrey, Notes, I, 264, and at length by M. Sprengling, $A J S L$ 37, I32-I35.

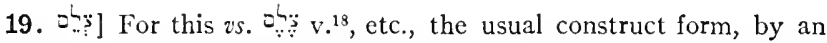
arbitrary distinction, s. on מלר $22^{10}$; 's here = 'fashion, cut,' of the face. In $5^{6}$, etc., $"$ in pl. is so used with Kt., ' $\mathrm{Kr}$.] The pl. of $\mathrm{Kt}$. is to be explained as by attraction to the pl. יה in the construct phrase; s. Kau., $\S_{9} 8, \mathrm{r}, \mathrm{b}$, and for numerous parallels in Heb. GK $\S_{14} 6$, I. The pl. should be pointed 1 - with Bev., Behr., al., vs. נו - with Bär, p. 96, Gin. For the phrase $c f .5^{6}$ and

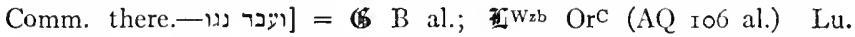
asyndeton; the preceding asterisk in (BSS may refer to the conj.- - הנ:] ] Suss Ken., $[5 \Theta I I$ om. -

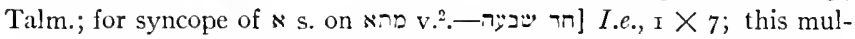
tiplicative expression is found in an $A P O$ pap. $1,1,3,7$, ח ר times.' I find it also in Syr. in to this bk. at $\mathrm{II}^{8}{ }^{13}$, where waven

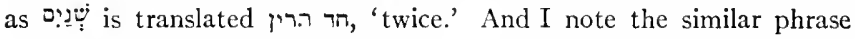
חin Lagarde, Clem. Rom., p. 52, 1. 13. Otherwise the Syr. grammarians note only the use with $د$ prefixed to the second numeral, s. Nöld., $S G$ \$2 (also such a case in Mand., Lidz., Mand. Lit., p. 152 ), as well as 'times,' s. Dalm., Gr. \$23, 2. Kau., \$66, 2, thinks our phrase is an abbreviation of the usual Syr. idiom. But it may have come from reminiscence of recitation of multiplication tables; s. Hilprecht, $B E$ 20, 
pt. I, pp. I 4 ff., for Bab. multiplication tables, which generally employ A-RA 'times,' but one table is given without this symbol. Prob. the obscure ראישונה מיש: Jer. $16^{19}$ represents the same idiom. -

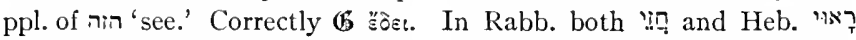
are used in the sense 'seen to' $=$ 'fit'; Sa., 'necessary.' See Lexx. for similar uses of ראה. I Consueuerat is practically equivalent, adopted by

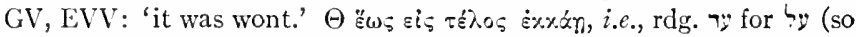
in 7MSs Ken., 3MSs de R). Apparently $\Theta$ regarded הin as from rt. $N$ is and

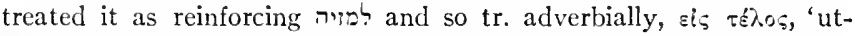
terly.' đWw strangely enough goes its own way, tanto quam solebat. tr. 'over what it was heated.'-20. גנרין] = 'certain,' $c f . v{ }^{8}$.] גְבְרי חַיר ] See Kau., $\$ 59$, r, e. The phrase is Biblical, having in O.T. the sense of 'trained soldiers,' etc., s. Lexx. s.v., as well as of 'strong,

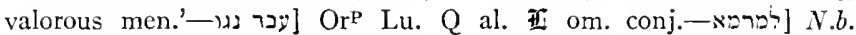

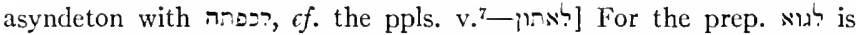
to be expected as $\mathrm{v} .{ }^{21}$, etc., or $\$$, which appears in the papp.; but $c f$.

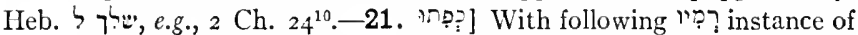
the pass. of the first Stem, so-called Peîl, = Arab. kutila. This was recognized by Nöld., GGA I884, p. Ior6; by Bev. on ג גלי $2^{19}$, Behr., p. vii, Mar., Gr. $\$ 32$, al. This against the elder view that it is a verbal development of the pass. ppl.; so Kau., \$29, 2, Str., \$12, a. Tradition

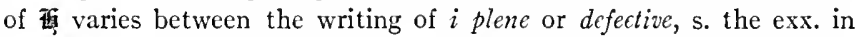
Kau., l.c. The same formation in strong vbs. appears six times in $A P O$, s. p. 270 , all written plene. We have to suppose that the vowel under the accent came early to be stressed and underwent heightening of a sort, $c f$. Heb. hiktill. Similar archaic passive forms have been retained in Heb., s. GK $\S_{53}$, u. The distinction between the Peil and the ppl. appears in vbs. ה', as noted by Luzzatto, p. 32, n; s. Kau., p. 80.

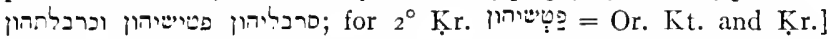
'רo again $\mathrm{v} .^{27}$. On these terms s. Lexx., Andreas in Mar.'s Glossary, Bludau, p. ror, Krauss, Talm. Archäologie, s.vv., and esp. S. A. Cook, 'The Articles of Dress in Dan. iii, 21,' Journal of Philology, 26 (1899), 306-313, with wealth of Classical citation. Since for each of these three terms every category of gear for head, body and !egs has been adduced (e.g., the EVV and margins), the possible permutations are many. Of the three one can now be surely defined, the last, $19=$ Akk. karballatu, 'helmet,' found in the Nakš-i-Rustam Inscr. of Darius I, \$3 (Weissbach, Dic Keilinschriften der Achacmeniden, 89), also in late Akk. texts as prob. 'hats' (Meissner, Supplement, 50). With this agrees the mng. in 'Talm. and Syr., 'cap' and 'cock's comb,' as imitating the pointed Pers cap. Oppert, on Darius' inscr., Records of the Past, Ser. 1, ix, 76, connected the word with xupßxolx $(-a l t>-a 5 t)$, which appears as the pointed cap of the Scythians (IJer., vii, 64) and the Persians (Aristophanes, Birds, $486 f$., with satirical ref. to the strutting, cocklike appear- 
ance of the Persian). With the third term $=$ hat, the first in the series of garments must be the body garment, coat or mantle, and so כר is specified as the principal garment in $\mathrm{v}^{27}$. The vb. is found in $\mathrm{I} \mathrm{Ch}$. $15^{27}$, מכרנל מעיל, 'wrapt in a tunic,' from rt. כנל. Such is the usual mng. of כר in Targ. and Talm., and so here Ra., AEz.; and so Theodt.

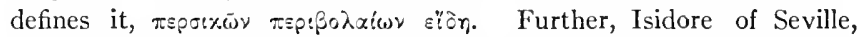
Etymologiae ( $P L \mathrm{lxxx}, 688$ ), explains it as 'fluxa et sinuosa uestimenta de quibus legitur in Daniele,' a definition ignored by Cook, who only notices an alternative given by Isidore that 'some' define it as 'hats.' The rt. is doubtless סבי, 'carry, wear,' in papp., Heb., Syr. (for the $r$

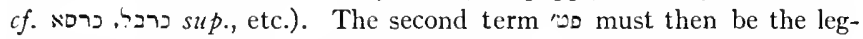
gear. So a tradition of its mng. as 'breeches' in Mfidr. Echa, i, I (but the rdg. is uncertain, s. Buxt., Bev.), and acc. to one mng. given in the Syriac lexicographers = Arab. ranât, 'leggings' (PSmith, col. 30g8). But Sa., AEz., Jeph. tr. it by 'tunics' = RV JV. Its etymology remains obscure. JHMich., CBMich. connected it with $\pi \hat{\varepsilon} \tau \alpha \sigma \circ \varsigma$, and so Hommel, Geog. u. Gesch. I, 2I I, as a gloss to the following term. This order of coat, trousers, hat is corroborated by an appropriate passage in Pollux

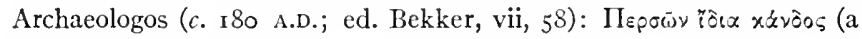

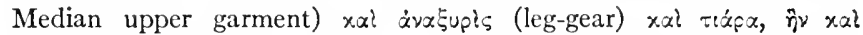
xupßaciav $x \alpha \lambda$ oũot. Pollux, ensuite, cites the poet Antiphanes, who in a verse similarly itemizes $\sigma \tau \sigma \lambda \alpha !, \sigma x \varepsilon \lambda_{\varepsilon x !} \tau$ txpa!. Cook ignores this substantiation of 's order.-But the traditions of the VSS have

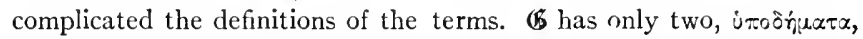

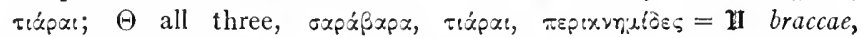
tiarae, calceamenta; also the three, the first two in transliteration, the third infixed after the foll. 'and their clothing,' as קובעיהון = Syr. 'cap' or 'mitre,' so agreeing with the etymology given above. On basis of these discrepancies in the VSS and after Ilommel, Cook argues for the elimination of פט a a gloss (but why was it inserted?), and thinks he can simplify the resultant. But I believe that $\mathbb{B}$ did have but rdg. it as term as $\tau$ ixpat and then shifted the erroneously read second term after it so as to obtain 'hats on their heads.' Unfortunately $\Theta$ followed $\mathbb{B}$ in keeping tiaras in second place, removing the second term to third

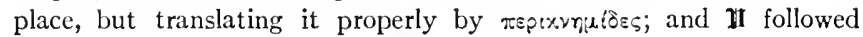
suit. Thus possibly the text of may be vindicated from the VSS and the rdgs. of the latter explained.-The history of interpretation of sarbelah may deserve particular notice. $\Theta$ 's sarabura $=\mathbb{Z W}_{\mathbf{2}} \mathrm{b}$ is explained by Suidas as a Pers. garment, and it was applied in the West to the baggy Oriental trousers; and so Sym. (on Jer.'s authority) d $v a \xi u p(\delta \varepsilon s$, 'leggings' (but (F'smg attributes to Sym. 'shoes'). Interestingly enough Jer. notes that $\Theta$ and Aq. read saraballa and not 'as corruptly sarabara'; if so, our $\Theta$ text has assimilated the former to the latter better knowi 


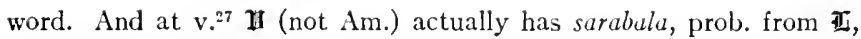
where his mng. 'breeches' would have been out of place. We are not helped out by Krauss's statement, I, I72, that the Talm. knows the word in three senses, 'mantles,' 'breeches,' 'shoes.' Scholars have naturally assimilated the word to the well-known Arab. sirwâl (Pers. salwâr?), 'trousers,' by which Sa., Jeph. tr. here. But Fraenkel, Aram. Fremdwörter im Arab., 47, also knows that word as 'coats.'- וליבוּיהון] For רבוּ pass. katûl-form, rare in Aranı., s. Kau., $\$ 57$, e, and Nöld., $M G$ §IоI, SG §II3; a few exx. are found in the papp., s. Sachau, $A P O$ p. 268. $\Theta$ ignores the word, and Bludau (p. IOI) and Cook (p. 3II) doubt its originality; but $\mathbb{5}$ witnesses to it. By this general term may be meant 'their other garments,' with EVV, or it may be summarizing.

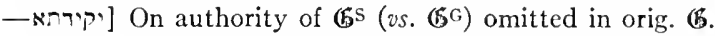

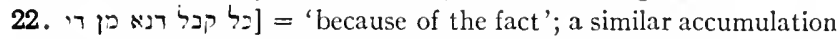
of preps. in Syr., Clemens Rom., ed. de Lagarde, 3I, רמן הרא רבגיל דליא. Sprengling's suggestion to tr. 'at this juncture' makes no improvement. -

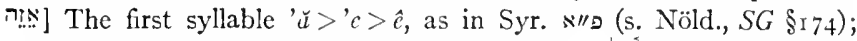
another instance of this phenomenon in BAram., Ezr. $5^{15}$ (but this

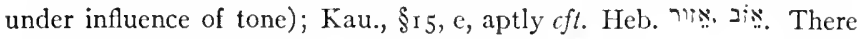

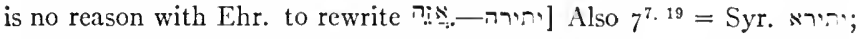
as a fem. form to be compared with the advs. with fem. $-t, e . g .$, ,

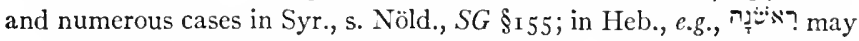
be compared. In papp. $=$ = Syr. appears.-For the Gr. texts of vv. ${ }^{22 b .}{ }^{23}$ v. infra.-B. similation of $l$ with $s$ (which appears in the Aramaizing Ps. I39, v. ${ }^{8}$,

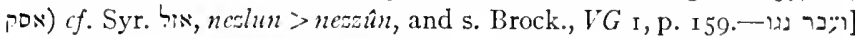

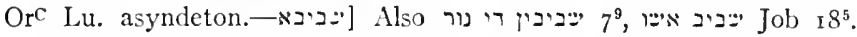
The earlier etymology $\epsilon f t$. Syr. šâb 'burn' as = Arab. šabba. But Arab. should then be sabba, and Bev., followed by Behr., Mar., connects with Arab. sabîb, 'wisp of hair,' etc., and tr. 'streak, tongue' [of flame]. This Arab. rt. has primary mng., 'eut,' hence Talm. ํㅜำ 'chip,' or 'flame-spark.' However, Akk. šabâbu = 'burn,' and the writer has found rt. 'כב 'burn' in a late Aram. text, Aram. Incant. Texts, no. 28, 1. I, and it appears in the Mand., Lidz., Mand. Liturgien,

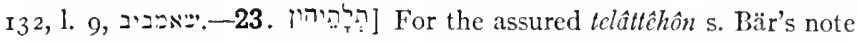
and Kau., p. I 2o. The combination -âttê- is corroborated by the similar Syr. forms for 'three . . t ten of them,' s. Nöld., SG $\S_{149}$. The base of the present numeral is the fem. telatt; the subsequent forms in the Syr., 'arbe'altaihon, etc., are then analogy-formations, even as Ber. suggests that the pl. element $a i-\hat{e}$ is after analogy of teraihôn, 'two of them'; so also Brock., $S G \S$ I7o. This is preferable to an explanati 1.

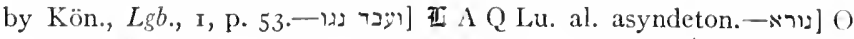

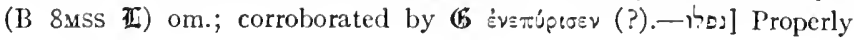


'were fallen down'; for this sense in Heb., common in the act. ppl. s. BDB $657 b$, and $c f$. , with Behr., the similar use in Pesh., e.g., Mt. $3^{10}=$ $\beta$ \& $\lambda \lambda \varepsilon \sigma \theta x$. The $v$. is accordingly circumstantial to $v .{ }^{24}$ and the usual paragraph distinction between them is unnecessary; this against Cha. that "this $\mathrm{v}$. is an otiose repetition of $2 \mathrm{r} b$."

$22 b .23$ in the Grr. These VSS are in corrupt condition before the joint of the Apocryphon. V. ${ }^{22 b}$, 'those men,' etc., is omitted by $\Theta$ (also 玨). The omission is to be explained as a case of haplog., an early scribe having passed over the first of two equal lines, each beginning with 'those men'; so also Torrey, Notes, I, p. 264. The lacuna is supplied

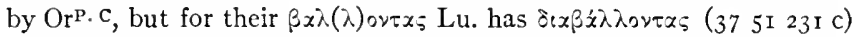

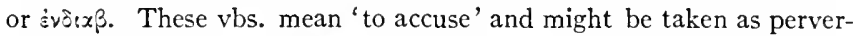
sions of $(\dot{\varepsilon} u) \beta \dot{\alpha} \lambda \lambda \varepsilon เ \nu$. But similarly has We have then to hold that Lu. was following some current Syrian interpretation of הסקו, which does not $=$ or $\beta \dot{\alpha} \lambda \lambda \varepsilon v \%$. $\left(\mathfrak{K}, \mathrm{vv} \cdot{ }^{22 .}{ }^{23}\right.$, is

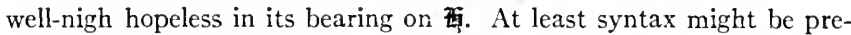
served if at end of $v^{22}$ a comma, not a period, with Swete, were used. $\mathrm{V}{ }^{22 \mathrm{~b}}$ may be a var. of $\mathrm{v}^{23}$. The actual equivalent of $\mathrm{v}^{22 \mathrm{~b}}$ is $\mathbb{6} \mathrm{v} \cdot{ }^{23 \mathrm{a}}$, which is a fair paraphrase of f $_{\text {; }}$ t then $\mathrm{v}^{23}{ }^{23}$, is summed up in $\mathfrak{G}, \mathrm{v} .{ }^{23 \mathrm{~b}}$.

24-30. The miraculous deliverance of the Confessors. The three men were fallen down into the fire when a marvel appears to the king. Dramatically he is made to ask of his courtiers whether it was not three men bound who had been cast into the furnace, and then he states the contradiction of his own eyes: four men loose [ the bonds had been consumed!], walking in the midst of the fire without harm upon them, and the appearance of the fourth like that of a divinity [lit. a son of Deity]. It is not said that the others saw this strange being, and he disappears from the narrative as immediately as he was introduced. Both in this term 'son of Deity,' בר יאלי ב, and in the synonym for it which is later put in the king's mouth, 'his angel,' the latter is given language entirely genuine to Aramaic Paganism; his terms are taken neither from Babylonian mythology, as Heng., pp. $\mathrm{r}^{8} \mathrm{ff}$., and Keil argue, nor from the Greek ideas of the sons of the gods, with Bert., p. 29. As in the Bab., the pl. ilani was used as a singular, so also in the Aram. the pl. 'elâhin, s. Note on $2^{11}$, even as the בעי המאלהים of the O.T. was a common Semitic concept. Also the term 'angel' was appropriate to common WSem. diction as expressing an appearance-form of Deity. It

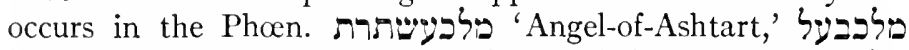
'A.-of-Baal'; and it is now identified by Lidz., Eph., r, 256 (cf. 
Dussaud, Notes de mythologie syrienne, 1903, pp. $24 \mathrm{ff}$. , cited by Cumont, Les religions orientales, n. 23 to c. 5), with the first element in the Palmyrene deity's name hiasho (not malk-, 'king') 'Mal'ak-Bôl,' i.e., 'Angel-of-B.' In these cases the 'angel' is similar to the primitive 'Angel of YнwH,' and is properly a בר איהין. Also the preceding formula in this v., "Blessed (בריך) is the God of,' etc., is typical of good Syrian religion,

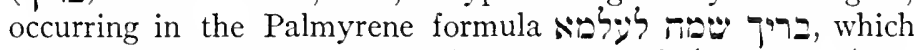
is not necessarily a borrowing from the Jewish ( $c f$. sup. $\left.2^{20}\right)$, as Lidz. holds, Eph. I, 256; and Torrey corroborates the writer's opinion, s. his remarks, $J A O S 43$, r43. As to the theological interpretation of the son of God, the Jewish comm. identify him simply as an angel; Sa. tr. 'like the angels'; acc. to Ra. he was the angel whom Neb. had seen at the calamity to Sennacherib's host, for Neb. had accompanied that expedition, and hence could recognize the celestial being; AEz. identifies with the Angel-ofYHwH appearances. GV RV JV tr. here 'a son of the gods,' with Sym. But $\Theta$ 's vi $\hat{\omega} \theta \epsilon o \hat{v}$ 'einem Gottessohn' is correct. Early Christian exegesis naturally identified the personage with the Second Person of the Trinity, so Hipp., Chrys., al., and AV 'the Son of God,' following Münster; but this view has been generally given up by modern Christian comm. (so among the Roman Catholic interpreters Knab.). And Jer. takes exception to this identification: "sed nescio quomodo rex impius Dei Filium uidere mereatur." Also the epithet in the king's mouth

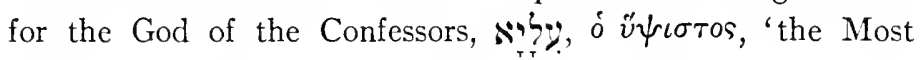
High,' is equally germane to WSem. Pagan language and thought. It has its parallel in Heb. pears generally as a term outside of Hebrew circles, e.g., the God Most High of Melkisedek, while Balaam is 'acquainted with the knowledge of the Most High,' Nu. $24^{16}$, and the term is put in the mouth of the king of Assyria, Is. $14^{14}$. This Elyôn is vouched for in the Phœen. religion by Philo of Byblos ('E $\mathrm{E} \iota$ เovv o $\ddot{\psi} \psi(\sigma \tau o s)$, and as $\ddot{\psi} \psi(\sigma \tau o s$ appears in the later syncretistic Syrian religions, e.g., the inscriptions of Palmyra; s. Bäthgen, Beiträge, $8_{3}$, Cumont, op. cit., $5_{53}$ ff., and especially Hehn, Die bibl. u. babyl. Gottesidee, pp. 258-264, for a comprehensive statement on this theologumenon, inclusive of the Bab. field. In Judaistic Gr. we find it constantly attributed to Pagan speakers, 
e.g., I Esd. $2^{3}$, Acts $16^{17}$, or to demons, Mk. $5^{7}$; it is frequent in Enoch (s. Cha. on 992), Twelve Testaments, etc., and in Syriac Christianity (it is, as meraiyema $\hat{a}$, the constant term for God, e.g., in the Odes of Solomon). This monotheistic term became current in circles more or less influenced by Judaism; s. Schürer, $G J V$ 3, I 74. The epithet is correctly put in the mouth of a Pagan king.

In his summons to the Confessors to come forth (v.26s), the king thus makes his confession of their God as the Highest, summus Deus, in the monotheizing language of the late period. They come forth and the dignitaries in the king's suite assemble and see that the fire had had no power over them (vv. ${ }^{26 \mathrm{~b} .}{ }^{27 \mathrm{a}}$ ); in a well-put climacteric, their bodies were not touched, nor their hair singed, nor their garments a whit changed, and not even a breath of fire was perceptible upon them $\left(v_{\circ}{ }^{27 b}\right)$. The king then utters a praise of the God who had protected his servants in their absolute trust in him, even to the facing of death $\left(\mathrm{v}^{29}\right)$. And he proceeds $\left(\mathrm{v}^{30}\right)$ to utter an edict that whoever should speak the slightest thing amiss against their God should be punished as culprits against the realm $\left(c f .2^{5}\right)$. The edict moves in terms of current polytheism; the Jewish God does not become the king's God, but, as so severe a critic of the book as Bert. admits (p. 255), he merely remains their God. But his religion is formally recognized as a religio licita with its rights to respect from all in the realm. Such a pronunciamento may well have been true to the official protection of religions under the later empires, and in fact this recognition of toleration was all that the Jews desiderated.

30. The Reward of the Three Confessors. It is simply stated that the king promoted (so EVV; lit. prospered) the three Jews in their posts in the civil administration of the province of Babylon. In this there is no contradiction to the sequel of c. 2.

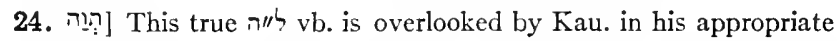

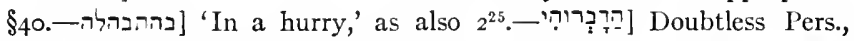
but the etymology is much disputed. A derivation as = simul-iudex was suggested by v. Bohlen, which is denied by Bev., who is again contradicted by Behr. The most recent discussion is by Rashdall, $J Q R$, $338 f$., who argues that the word can be explained from a supposititious khadâbara, 'sword-bearer'; the title might then be purely honorific. Steuernarel, $Z D P V$ 35, 95, would correct ב to 2 and $c f t$. המרכריא $A P O$ 
pap. 8, II. 4. 23; but 2 is supported by (5's interpretation. (5 here and

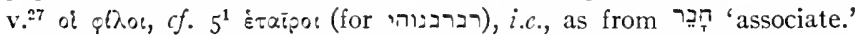
The benai lerutitâ of $\mathscr{G}^{\mathrm{Smg}}$ to $\mathrm{v}^{27}$ expresses the same thought. Blud., p. 100, $c f t$. $\varphi(\lambda \circ s$, as title of the highest officials at the Ptolemaic court, but the title goes back to Pers. usage; s. for various reff. Holm, Gricch. Gesch., I, 162, Cumont, Les religions orientales, I65, Deissmann, Bible Studies, 167 , and Licht vom Osten ${ }^{4}$, 324. (6's's interpretation is satisfactory here as referring to the courtiers in attendance. $\Theta$ varies: here $\mu \varepsilon \gamma t \sigma \tau \bar{\alpha} \nu \varepsilon \varsigma$,

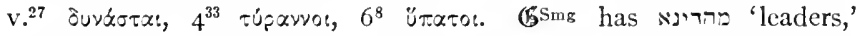
attributed to $\Theta$ (attribution properly questioned), an etymology as though from רבר (so Field); the tr. may be Aq.'s; and so Sa., k.umwând. Similarly the Jewish comm. attempt Heb. etymologies.- [.].] The

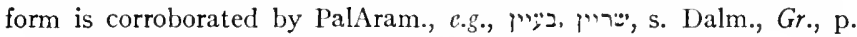
290; for the penultimate accent $c f$. Kau.'s explanation, $\$ 47$, p. 89 , 'an attempt to preserve the consonantal strength of the Yod'; he $\mathrm{cft}$. the pl.

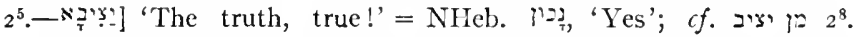
Behr. prefers to regard as fem., or as adv., cft. הירה v. vo , so Mar., but it is masc. emph.-The Grr. supply a joint with the Apocryphon: $(\mathbb{S}$

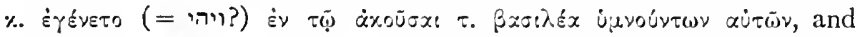
then follows

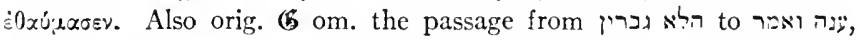
v. ${ }^{25}$, which was supplied by Hex., the complement $=\mathrm{OrC}^{\mathrm{C}}$ in the revision of $\Theta$; the fault arose from haplog. of הלה ve. ${ }^{24}$, and $k \mathrm{v} .{ }^{25}$.

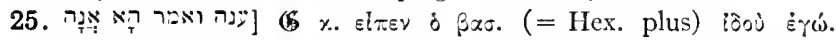

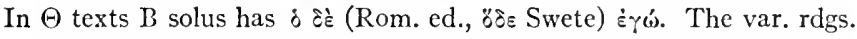

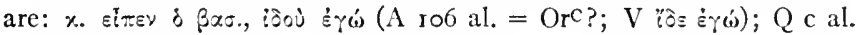

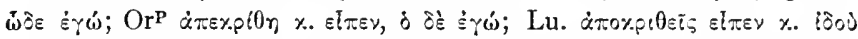
$\dot{\varepsilon} \gamma \dot{\omega}$. Of these $\omega \delta \varepsilon$ is corruption of $0 \delta \varepsilon ;$ i $\delta 00$ was Origen's revision. But B's o $\delta$ is authentic; $\Theta$ om. ענה ואמר, understood an supplying the conj. obtained $\delta \delta$ ' (so prop. vs. Swete), i.c., 'and he [said].' This classicism is prob. unique in the Gr. Bible._p? So with Haf. pointing at $4^{34}$; otherwise Aram. dialects have Pael (= Piel in late Bibl. Heb.). A few mss (s. Bär, Str.) read מִּר which is preferred by Kamp., Löhr, Mar. Is this a Mass. fancy in the two passages, to obtain perhaps a denominative, 'walking after the Halaka'? The

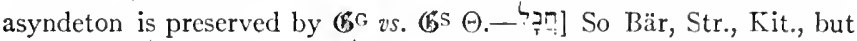

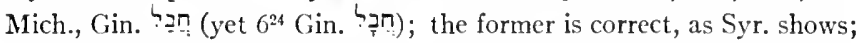

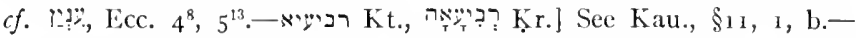

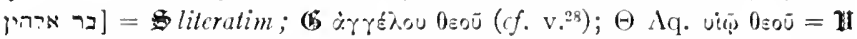

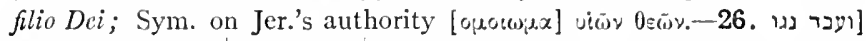

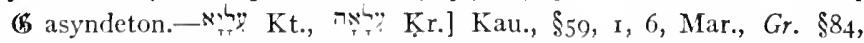
regard as a kittâl or kattâl form, but the doubling is secondary; $f f$. Heb. 
-

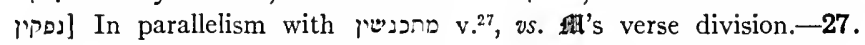
[מתכנשי] For pointing s. at v. ${ }^{3}$ - 'The satraps,' etc.] The first three terms as in $v .^{2}$, the fourth from $v .^{24}$; the latter as brevet title occurs last. $\Theta$ and $\Theta$ vary from their translations in $v .^{2}$. In the third place $(\mathbb{B}$

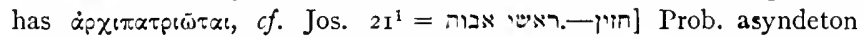
with מתכנשי, rather than secondary predicate, v. sup. v. ${ }^{7}$; $c f$. Mar., Gr. \$1 29, e ('um zu sehen'), who $c f t$. $7^{5}$, etc. Kau.'s note, $\S_{102}$, that asyndeton ordering of nouns and sentences is rare is erroneous; it is a marked feature of BAram., and in the orig. texts was probably still more fully represented, as even the Grr. indicate. For vbs. in asyndeton

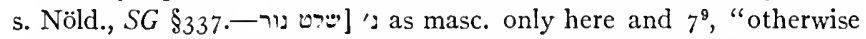
fem., as in Syr. Similarly the Arab. $n \hat{a} r$ is fem. in most cases, rarely masc.," Bev.; cf. Wright, Gr. I, \$292, rem. b: nûr "was 2nciently of both genders." The following ריח is "exceptionally fem., like the Arab. rîh,' Behr. See on these two words Féghali, Du genre grammatical en

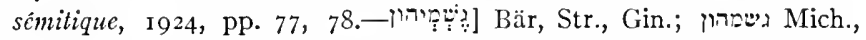
Kit.] The former is the Occidental rdg., the latter the Oriental, acc. to Gin. (cf. his Int., pt. 2, c. 9); the universal Kr. identifies the former with the latter and agrees with the VSS, except $\mathbf{I}=$ pl. (early witness to the pl. Kt. of 7 ). The pl. was induced by the pl. in v. ${ }^{28}$, but here the sing. is quite proper, $c f$. following VSS; Behr., Kamp., Mar. argue in the opposite direction.-ריח נור] Ehr., referring to his notes on Ju. $16^{9}$, Job $14^{9}$, argues that this is not 'Brandgeruch, .... sondern die geringste Wirkung . . . des Feuers'; but 'a smell of fire' is perfectly suitable here. בהון refers to the men, not to the garments.-At end of v. Orc (A Q V Io6 $\mathrm{A}$ al.) a plus, 'and the king worshipped the Lord before them'; similarly Lu.

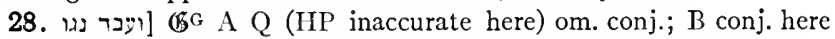

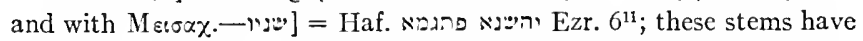
the secondary mng. of 'contradict, disobey,' analogous, as Bert., al., remark, to הלף Is. $24^{5}$; also cf. Arab. halafa in stems III, VI, VIII. In

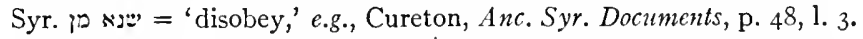

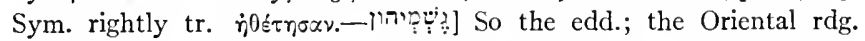
ג'ישמי (Gin.). The Kur. is again identical as in v. ${ }^{27}$; the pl. Kt., however, is here supported by $\mathscr{G}^{\mathrm{G}} \Theta \mathrm{H}$, the sing. by $\mathscr{G}^{\mathrm{S}} \odot$. Read here as pl. Ehr.'s view that ' $\lambda$ is reflexive (he $c f t$. similar Rabb. use of $0 \% ;$ ) is not necessary; he may be right in supposing that the sing. Kr. implied this

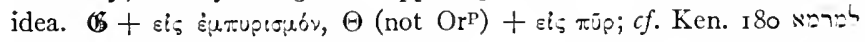
בגו נורא. Paul has reminiscence of this rdg. at I Cor. $13^{3}, x \hat{\nu} \nu \pi \alpha \alpha \delta \bar{\omega}$

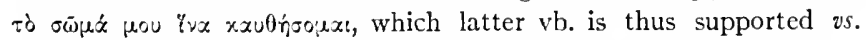

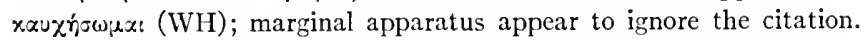

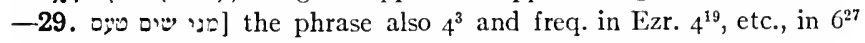

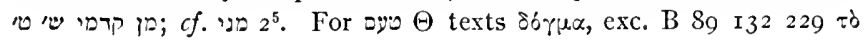




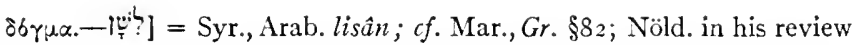
of Kau., Gr., rightly denies the latter's description of this form (\$\$ 2.57 end) as 'eine künstliche Schärfung der Consonante.' The prec. conj. is

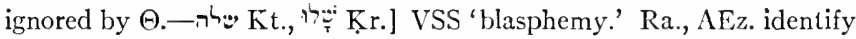
with Heb. rts. גשיש, used of careless, inadvertent error; so Targ. tr. these vbs. by $\times$. '(speak) anything amiss'; Sa., 'an absurdity.' The Kt., if not an error, would be a var. form; Kau., $\$ 6 \mathrm{r}, 4$, b, suggests a pointing after analogy

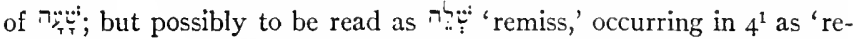
laxed.' The noun it appears in the same sense in $6^{5}$, Ezr. $4^{22}, 6^{9}$ (here Gin. accents bi). For the form s. Kau., l.c., i.e., the participial stem

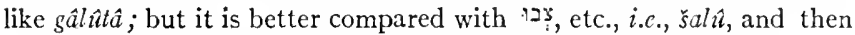
with Heb. heightening of the pretonic vowel. And so the Heb. equivalent

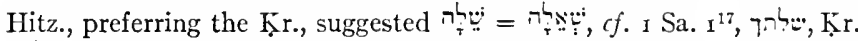

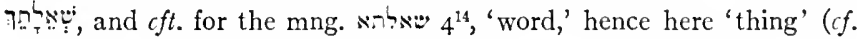
use of Heb. ר27). So Bev., Kamp., Mar.; the latter suggests that $x$ in the unique spelling $\mathrm{s}$ (ג) suite was intended as emendation to our word. A third derivation is offered by Perles, JQR O.S. 18387 , preferred by GB, as from Heb. and Syr. הho, 'despise,' the noun to be

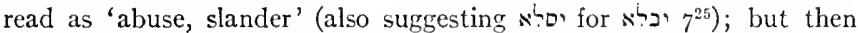
$\because$ is improper. I prefer the traditional interpretation with Behr., Dr., Kön., $H w b$., al. For the danger of a [נגוא Otherwise always 1 , as many mss here; prob. assimilation to

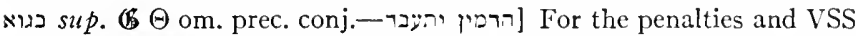

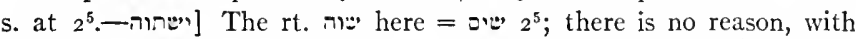

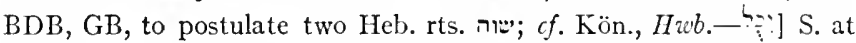

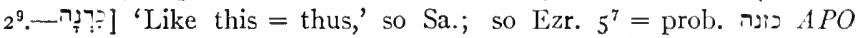
pap. Io, 1. 8; cf. Heb. תאi2, e.g., I Ki. $7^{37}$; erroneously AEz., Hitz., Behr., al., 'like this one,' i.e., their God.-30. ויעבד נגו 1 (5) $\Theta$ asyndeton.-(5

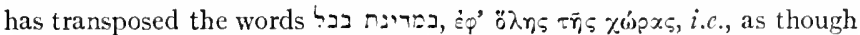

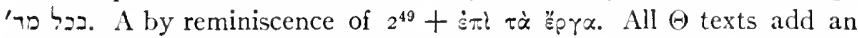
extensive plus at end, most of them with a doublet $\eta_{\xi} \xi \omega \sigma \varepsilon \nu$ aurous $\|$ nu६roev autous; $A$ is in sad confusion. 


\section{CHAPTER 4. NEBUCHADNEZZAR'S MADNESS.}

The story is cast in the form of an encyclical edict emanating from the king, with the salutation c. $3,31-33$ (c. $4,1-3$ ), and the concluding pronouncement, his confession of God, 34 (37). The body of the document contains three acts: (r) 1-24 (4-27) the problem of the king's mysterious dream and Dan.'s interpretation of it; (2) 25-30 (28-33) the story of the king's mania; (3) 31-34 (34-37) his restoration to prosperity. Definite metrical structure is evident for $3^{31}, 4^{1-2}$. $7 \mathrm{~b}-9.11-14$, and the greater part, if not all, of $\mathrm{vv}^{31-34}$. The whole story is composed in a lyric strain. Bert. casts all the spoken parts into verse form.

The amazing malady which possessed Nebuchadnezzar, known scientifically as lycanthropy, is presented in a simple and natural way. There is no idea of his possession by Satan, a view advanced by Origen but denied by Jer. (at the beginning of his comm. on the chap.), no idea of metamorphosis, such as has been advanced by some learned if not scientific students (s. dEnv., p. 319), following in the footsteps of Jer., who insipidly cft. Scylla and Charybdis, Hydra and the Centaurs. The disease is well known in the sad annals of the human mind and attested by scientific examination. With it is associated the primitive werewolf superstition, which may have its rationalistic support in the actual frenzies of the human kind. Reff. for this phenomenon from ancient and modern studies have been assembled by Pusey, pp. 428 ff., and in a popular but well-documented volume by S. Baring-Gould, The Book of Were-Wolves, London, 1865 , in comparison with whose terrible tales Neb.'s madness was a mild case. ${ }^{1}$ Even if the essence of the story were true, that Neb. was so afflicted, after the manner of 'geniuses' and of many royal persons, as George III of England and Otho of Bavaria, corroboration of it can hardly ever be expected from archæology, for royal families do not leave me-

\footnotetext{
${ }^{1}$ See also IV. H. Roscher, 'Das von der Kynanthropie handelnde Fragment des Marcellus von Side,' in Abhandlungen (phil.-hist. Klasse) of the Saxon Academy, vol. I 7, I 896 . Zöck., p. 30, gives an extensive bibliography. Lammens, La Syrie, I 49, notes that Ibn Bațîk records a similar madness of the crazy Hâkim (ii, 2 I 8). Wilson, p. 289 , registers a monograph by D. R. Burrell, 'The Insane Kings of the Bible,' Am. Journ. of Insanity, April, 1894, 493-504.
} 
morials of such frailties. The alleged malady is not an impossibility.

A partly parallel saga of Neb., observed by Grot., has been preserved by Eusebius, Praep. ev., ix, 4I, 6, and in shorter form, in his Chronicle (only preserved in Armenian); s. ed. Schoene, I, 42 (the former text also in Müller, Frag. hist. gr., 4, 282). Eusebius says: "I found also in the book of Abydenus on the Assyrians the following in regard to Neb.: Megasthenes says that Neb. became stronger than Herakles, and made wars upon Lybia and Iberia, and having conquered these countries settled a part of their inhabitants on the right of Pontus. After this, it is said by the Chaldæans, he ascended the roof of his palace, and, being possessed by some god or other, cried aloud: 'O Babylonians, I, Neb., announce to you beforehand the coming misfortune, which Bel my ancestor and the Queen Beltis are alike powerless to persuade the Fates to avert. A Persian mule will come, having your own deities as his allies, and will bring slavery. He who will help him in this undertaking will be the son of Medes [or, by correction, of a Median woman, with ref. to Nabonidus and his Median mother, with Gutschmid and Schrader], the boast of Assyria. Would that before my citizens were betrayed, some Charybdis or sea might receive him, and utterly extinguish him; or else that betaking himself elsewhere, he might be driven through the desert, where is no city nor track of man, where wild beasts have their pasture, and birds do roam, and that among rocks and ravines he might wander alone; and that I, before he imagined this, might meet with some happier end!' Having uttered this prophecy, he forthwith disappeared." For criticism of these passages and their relation to Dan. 4 s. Schrader's notable essay, 'Die Sage vom Wahnsinn Nebukadnezar's,' in Jahrbiicher fiir prot. Theologie, $\mathrm{x} 884$, 6r8629. He would assign only the first part of the statement to Megasthenes, c. 300 , and the story of the oracle to Abydenus, who prob. lived in the $2 \mathrm{~d}$ cent. B.C. He notes the several striking reminiscences of veritable history in the anecdote and $c f t$. with it unfavorably the story in Dan., which certainly lacks any definite historical traces apart from the general coloring, which would better suit a later age than that of Neb. Two plausible similarities between the Greek and the Aramaic story have been observed and variously appreciated by students. One is the 
oracle received on the roof of the palace, the other the wild animal-like existence to which Neb. would condemn the traitor to his land. The apologists for Dan. have made the most of these likenesses, e.g., Heng., Pusey, dEnv.; they hold that Abydenus' version is the younger, a perversion of that in Dan. For the latest lines of defence the pertinent cc. in Wright, Wilson, Boutflower, should be consulted. Others who deny the truth of the story, recognize these features as of a common origin of tradition, e.g., Bert. and Schrader (p. 628); and so Bev., Dr. Others deny in toto any relation, so vLeng., and most recently Torrey, Notes, I, 266. The latter points out that the similarities are in mere commonplaces, and that the wild life desired for the traitor has nothing to do with the king's affliction. This judgment is the simplest. Neb. left but a faint tradition behind him; Her. knows him only under the name Labynetos I, as father of Labynetos II, i.e., Nabonidus, and Jos., $A J$ x, II, I, after summing up a few items of information concerning him, concludes: "These are all the histories I have met with concerning this king." 2

More immediate objects of historical criticism are found in the edict form of the alleged encyclical of Neb. and in its substantial contents of confession by the heathen king of the God of Daniel. As an edict the document is historically absurd; it has no similar in the history of royal conversions nor in ancient imperial edicts. Comparison with the Persian imperial recognition of the God in Jerusalem as 'the God of heaven' in Cyrus' edict, Ezr. I, and the papyrus rescript of Arsames to the Jews at Assouan offers no parallel. Not only is there no trace of the chancellery style of such documents, but the narrative passes fluidly from the first to the third person and back to the first. Calv.'s remark: "haec autem personarum uarietas sensum non

\footnotetext{
${ }^{2}$ There appears to have been a later midrashic expansion of the legend among the Jews, first hinted at in $6 \mathrm{~F}^{2{ }^{28}}$ and then specified in Aphrem Syrus at v. ${ }^{24}$ : "This refers either to Evilmerodach or to Neb.'s wife, who in his absence for those seven years administered the government." This speculation is found in an expanded form in Rashi (cited here by Gallé), who, at Jer. $5^{51}$ and Is. $14^{15}$, tells how Evilmerodach took his father's place in his illness, was thrown into prison upon the latter's restoration, and upon his death refused the crown for fear Neb. might return, but he allayed his fears by casting Neb.'s body out of its tomb. In (6)'s form of the story (s. at end of this chap.) we also have early midrash about Neb.'s successor. The treatment of tradition by S. Bernstein, $K$. Nebucadnezar von Babel in der jül. Tradition, 1907, 72 pp., I have not seen.
} 
reddit ambiguum aut obscurum," indicates that he recognized a difficulty but could not relieve it. Some would hold that the section vv. ${ }^{26-31}$ was interpolated by Dan., so e.g., Calv., Häv., dEnv. (the latter glosses, p. 367: "Dan. ajouta-pour ses lecteurs"). Others, Kran., Zöck., boldly recognizing the incongruity of the document as a first-hand royal edict, because of its theological character, etc., hold that Dan. was the writer, who composed the declaration by order of the king soon after the conclusion of the events. We have still to inquire into the literary phenomenon of the change of person in this story, a change which sets in, from the Ist pers. to the $3 \mathrm{~d}$, in $v .{ }^{16(19)}$, the Ist pers. being resumed in $\mathrm{v}^{31}{ }^{34)}$. Acc. to most modern comm. the change is 'a lapse,' or, with Mar., 'the author forgot himself.' Cha. boldly asserts that this irrational change is an argument for the superiority of $\mathbb{G}$, which assigns a larger portion to the $3 \mathrm{~d}$ person. But it has not been observed by the comm. that the same phenomenon appears in the book of Tobit, which begins with the ego of the hero and passes over into the $3 \mathrm{~d}$ pers. at $3^{7}$. Here $\mathcal{H}$ and the secondary Aramaic version (Neubauer's text) have the $3 \mathrm{~d}$ pers. throughout, but it is well-nigh universally admitted, that the Gr. Tobit is the original form. The change of person in both stories is due to an unconscious dramatic sense. In Tobit the hero speaks in the first act, but when the drama passes to other scenes and characters, the ordinary narrative style of the $3 \mathrm{~d}$ pers. is adopted. And so in our story, in which the alleged edict form sat lightly on the composer's mind, dramatically the account of the king's madness is told in the $3 \mathrm{~d}$ pers., for of that he would not have been a sane witness; the change of person is anticipated somewhat too early in $v \cdot{ }^{16}$. The dramatic propriety involved appears from the fact that probably most readers do not stumble over the incongruity. To the same sense of the dramatic belongs also the shifting from Heb. to Aram. in c. 2.

The text of $\mathbb{5}$ which rarely runs with appendix at the end of the chap. By the fatality of the Mediæval Christian division of chapters, generally attributed to Archbishop Langton of the I 3 th cent., the first three vv. of this story were attached to $\mathrm{c}$. 3. This arrangement of $\mathfrak{H}$ was followed by the printed editions of 1 and also by GV, fortunately not by $\mathrm{EVV}$, except JV, which follows Jewish usage. (See in general 
G. F. Moore, 'The Vulgate Chapters and Numbered Verses in the Hebrew Bible,' JBL I2, 73-78.) The ancient tradition was correct in its division, e.g., the pericope titles of the uncials A and Q; the chapter division in 147 , the Syro-Hexapla, and the Chigi Ms, in Hipp., Jer., A; so Jeph. ('fourth chapter'), and apparently AEz. Also in $\mathfrak{A l}$ a Closed (greater) Paragraph begins at $4^{31}$ of the Heb. edd., while Gin. allows no break between cc. 3. 4 (vs. Bär, who indicates a Closed (lesser) Paragraph at that point). Further, the ancient Seder, or Lection division started at $\mathrm{v}^{30}$. See further $\S 3$.

C. 3, 31-33 (C. 4, 1-3). The encyclical epistle is introduced with a salutation in which Neb. declares how it is my pleasure to declare the signs and wonders that God Most High has wrought for me (31.32), concluding with a metrical pæan of praise:

33. How great are His signs: and how mighty His wonders; $H$ is kingdom is an everlasting kingdom: and His dominion with age and age along.

For Neb.'s confession of God Most High $c f$. Comm. at $3^{26}$, and v. inf.

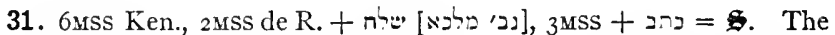

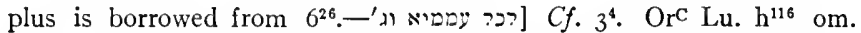

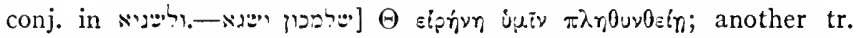

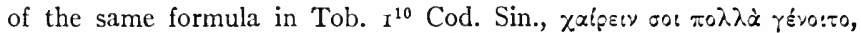

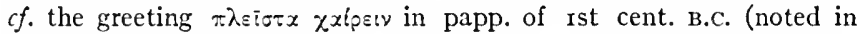
Charles, Apoc., at Tob. l.c.). In the Elephantine papp. the formula is, e.g., 'the God of heaven ask much after the health of $\mathrm{X}$.' For the parallels in Ezr. $5^{7}$ and $7^{12}$ s. the writer's note on kulla in JAOS 43, 391 ff.-

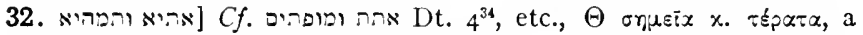
freq. phrase in Gr. Bible, s. Thayer, Lex., s.v. onj.seiov for reff.—כ; בעת As Torrey has observed, Composition and Date of Acts, 38, this idiom occurs in his Cilician Aram. inscription ( $\operatorname{JAOS} 35,370$ ), in Syr., and also is represented in the Gr. of Acts $14^{27}, 15^{4} ;$ N. is similarly used in Heb., e.g., Dt. ${ }^{30}$.- - יטיכר prep. s. $2^{6.9}$. -33. ה洋] The same adv. in Syr., e.g., Pesh. Mt. $7^{11} ; c f$.

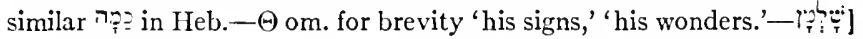

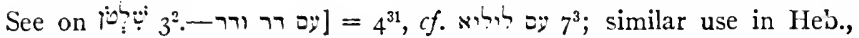
עם שמש Ps. $72^{5}$, with which comm. cft. Ovid, Amor. i, ${ }_{15} f$., "cum sole et luna semper Aratus erit"; $f$. our 'with the morning,' etc.

1-6 (4-9). Neb., frightened by a dream, summons his wise men for the interpretation, but only Dan. is found competent. 
For the theme of royal dreams s. Int. to c. 2. Neb. introduces his tale with a brief idyllic phrase picturing his happiness when the tragic event occurred. (A similar element of pathos appears in the epitaph of Eshmunazar of Sidon, CIS i, 3; Lidz., $N E$ 4I 7 , Cooke, NSI no. 5.) He was enjoying life unconcerned (relaxed, careless) and flourishing in the splendors of his Babylonian palace-like another Rich Man in another story (v.1). His quiet is disturbed by an ominous dream which frightened him (v.2). The two parts of the v. are, like v. ${ }^{1}$, in poetical parallelism, and, as on reasonable grounds (s. Notes), the words and visions of my head are to be regarded as an addition, the $\mathrm{v}$. reads with this omission as a true double trimeter, with the hemistichs rhyming. All the classes of the wise men are summoned to interpret the dream, but they were found incompetent (vv.3. 4 (6. $\left.{ }^{7)}\right)$, until at last Dan. came in (v. $\left.{ }^{5 \mathrm{a}}{ }^{(8 \mathrm{a})}\right)$. The king recognizes him, with pardonable pride recalls his court name Belteshazzar, named after my god, i.e., Bel (acc. to the etymology assumed), and welcomes him as one possessed by the spirit of holy Deity (v. $\left.{ }^{\mathrm{b}}\right)$. The story is deftly told. The seer was Daniel to the Jewish readers, but Belteshazzar to the court. And while the story connects with the sequel of c. 2 in stating Dan.'s pre-eminence among the wise men, actually giving him the title of Master of the Magicians $\left(\mathrm{v}^{6(9)}\right)$, it proudly makes him enter alone and last of all, as though of a different class from the other wise men. In historical verisimilitude the king should have consulted the chief of the wise men first, particularly if he recalled Dan.'s extraordinary faculty in interpreting to him the earlier dream (and so $\mathbb{B}$ transforms the story, s. Note at end of chap.). But a higher dramatic end is gained by having Dan. enter triumphantly at last, when his colleagues again have been nonplussed.

In v. ${ }^{5 \mathrm{~b}(8 \mathrm{~b})}$, repeated in $\mathrm{v} .{ }^{6 \mathrm{a}}$, Neb. speaks of Dan. as one in whom is holy Deity's spirit. The last noun is unarticulated (in the abs. state), and is exactly comparable with, and a literal reminiscence of, Gen. $4 \mathrm{I}^{38}$, where the heathen Pharaoh calls Joseph 'a man in whom there is a spirit of Deity,' or rather 'a divine spirit.' Here, as in Gen., the pl. for God, יאל, is not, against Behr., a polytheistic expression, i.e., 'gods,' and it is, against Behr., Cha., the Aram. equivalent of Jrwir's epithet in Jos. $24^{19}$, ש. $\Theta$ 's $\theta \epsilon o \hat{v}$ is right as against the pl. of H (Jer. takes pains to contradict $\Theta$ ), and against comm. and 15 
modern VSS in general, e.g., Grot., "loquitur ut idolalatra," cited approvingly by Mar. But Ra., CBMich., Ehr. correctly understand it as of singular mng. See further Notes on $2^{11}, 3^{25}$. In addition to the material in the Babylonian field for the use of $i l u, \mathrm{pl}$. ilâni, as generic terms, we may compare the Egyptian distinction between the universal idea of 'God,' neter, e.g., in comparison with 'the god of my city,' in the Book of the Dead, chap. cxxv; s. Budge, Tutankhamen, etc., I923, p. I48, with the accompanying discussion. In $\mathrm{v}^{6\left({ }^{(9)}\right.}$ vast trouble has been given by the statement that the king bids Dan.: the visions of my dream which I have seen and the interpretation thereof tell, yet at once proceeds to tell the dream himself. But the trouble is removed by the suggestion in the Note to read הזו" ('visions-of') as 'lo,' i.e., 'Here is the dream, interpret it!'

1 (4). Jer. $49^{31}$ is 'care-free,' then 'at rest,' with EVV et al. For the moral

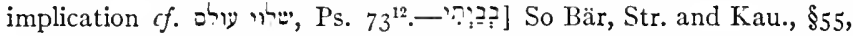
3; בִביָיר, Mich., Gin., Kit., preferred by Mar., $\S 76$, c. But the former is approved by the similar forms in $2^{17}, 3^{29}, 6^{11}$, and the emph. $5^{12}$, Ezr. $5^{3}{ }^{12}$, in all which Gin. so reads without question. For the resp. statistics of ai and $\hat{e}$ s. Powell, Supp. Hebr., p. 53. Bär's rdg. is doubtless the elder form. There are two cases in $A P O$ where with suffix ב- בn written (s. Index), also in a pap, in $A P$, no. $8 \mathrm{I}, 1$. I 5 . All other cases in papp. have - רענ]-_] The green tree is figure of prosperity, for the

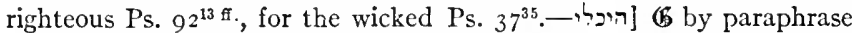

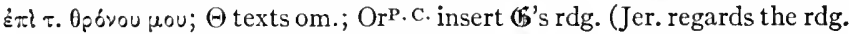
as of $\Theta$ ), followed by Lu., who adds the doublet $\left.x_{0} \pi i \omega \nu \dot{\varepsilon} \nu \tau \tilde{\varphi} \lambda \alpha \bar{\varphi}\right) \mu \circ u$, where $\lambda, \alpha \omega$ is patent error for $v \alpha \omega=$ היכל . Lu.'s rdg. may belong to orig. $\Theta$, having dropped out by haplog., with E் On the impf. following the pf. $c f$. Kau., $\$ 73,4$, Mar., Gr. §ior. Kau. remarks: "Die Ablösung des Perfects durch das Imperf. mit I entspricht hier ganz der Ablösung des hebr. Perfects durch Impf. consecutivum und es ist nicht unwahrscheinlich, dass hier die Gewöhnung an die hebr. consecutio temporum einen Einfluss ausgeübt hat." The first part of this statement is correct, the second is not proved. The alternation of pf. and impf. is one of the picturesque elements in the diction of the dialect.-[?ר? The word is used of dream fantasies, esp. of impure dreams; s. Heb. and Talm. Lexx. It is used in Mand. for 'Täuschung, Blendwerk,' Nöld., $M G$ p. 64 , n. 2, in Syr. of the Fata Morgana, Brock., Lex. s.v.; in Rabb. along with vb. הררה, of concep- 
tions of the mind, and then in particular of impure dreams. Also a magical inscription in my Aram. Incant. Texts (s. p. $8 z$ ) lists the with incubi and 'visions.' $C f$. the denotation of Arab. halama, and this particular mng. in Syr. 'ethelamlam. Buxt., Jast. derive from Heb. הרה 'conceive,' and so Behr., who cft. the Bibl. use for conceiving evil ideas, e.g., Ps. $7^{15}$. But Arab. harhara, 'disturb,' with its derivatives, suggests an independent rt.; $c f$. Arab. harra, 'abhor.' I welcome therefore an oral suggestion from Prof. M. L. Margolis that we connect with our rt. here, har = harhar, the הרוn of Gen. $3^{16}$, universally but with dificulty derived as from ררות and interpreted as mnr. 'pregnancy'; but the form requires our rt. הרר and so means, as Margolis suggests, 'pruriency,' i.e., the sexual metaphysical condition. On account of the unpleasant denotation of the word AEz. takes care to specify, 'a mental harhor without excretion.' Prob. for the same reason om.

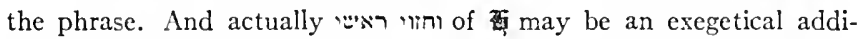
tion, inserted, as similarly in $v .^{7}$, from $v .{ }^{10}$ and $2^{28}$, to avoid that disagreeable denotation; it disturbs the metrical balance of the $v$. and

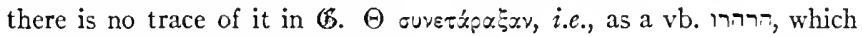
as Bert. recognized = Arab. harra.

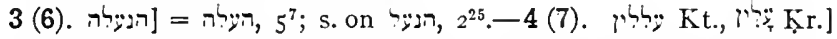
$=5^{8}$, i.e., the Kr. as in Syr.; for the Kt. cf. Dalm., Gr. $\$ 7 \mathrm{I}$, and Nöld.,

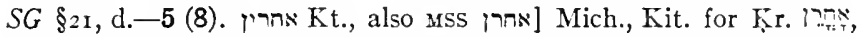

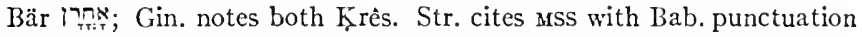
'uhrân and 'aharôn. The equivalent phrase to the present יאר pears in the Ahiksar papp., APO pap. 52, col. 1, 1. 5, י אחרן יi, col. 2, 1. I, שר ז עי על אהרן, also (?) pap. 56, 1. 8 (= AP Ahikar, ll. 53. 64. 133). Häv., approved by vLeng., first determined the true character of the form., namely as pl., ' 'רָ, and so as abstract, i.e., 'at last.' He has been followed afresh by Torrey, Notes, I, 267; and by W. R. Arnold, $J B L_{31}$, 23, upon the basis of the papp. Similar pls. are, e.g., Heb. אחר (e.g., 2 Sa. $2^{23}$ ), and some rare Syr. adverbs cited by Nöld., SG §1 55, A. But it is not necessary with Arnold to replace $¥ ;$ with h $\%$; per con.

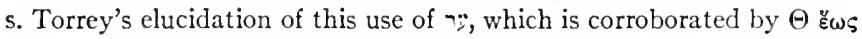
and 'adammâ. Discussions of various attempts at the phrase are given at length by Kamp. The Kr. אחר = Syr. 'another' appears as plus

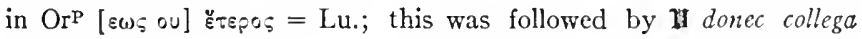
(rdg. Exaipos for हैispos!). The tr. is prob. Aquila's, not of 'the 'Three,' as Jer. states. And so AEz., אחרון; but correctly Ra., ע אישר אחרנה הובא [אההין קריטין Polytheistic is the articulated Phon. phrase in the Eshmunazar Inscr. (CIS i, no. $3=$ Lidz., NE p. 417 , Cooke, VSI no. 5),

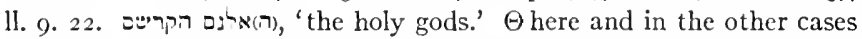

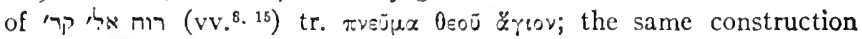

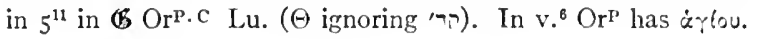


6 (9). (ך) . . . . . . . . for whom, so rightly $\Theta$ and GV ('welchen ich weiss'), but $\mathcal{H}$ tr. ' by quoniam, and so EVV 'because.'-0: ling'; here 'disturbing, incommoding,' EVV 'troubleth.' The vb. is used in Rabb. of 'forcing, outraging' (so Syr.), and also 'taking by force, confiscating,' and with it is to be connected (= Haf.?) in the Nêrab Inscrr. (Lidz., NE, p. 445, Cooke, NSI nos. 64.65) and the ZKR Inscr., col. 2, 1. 20.- $\Theta$ as sing., \& $\Theta$. This sentence in 隹, $=$ H, makes Neb. ask Dan. to tell him the dream as well as the interpretation ( $c f$. c. 2), while acc. to vv. ${ }^{5}{ }^{7}$ Neb. narrated the dream

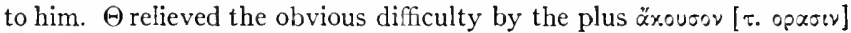
i.e., as $\mathrm{\nu}$, which is accepted by Mar. in his text and by Torrey, Notes, I, p. 267. helped itself out by a forced paraphrase, "in the visions of my dream I was seeing a vision of my head, and do thou its interpretation tell.' Giesebrecht, GGA, I895, p. 598 (s. Kamp.'s exposition),

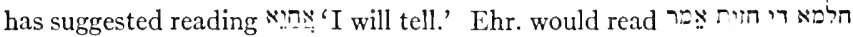
'the dream which I saw I will tell,' and then takes 'and the visions of my head on my bed,' v. ${ }^{7}$, as second object. But the simplest emendation is to read ' 'behold!' This use of 'ח appears in the papp. APO pap. r, 1. 23 , pap. 54, 1. 7 (s. Cowley $A P$ index), the ostrakon in $A P A$ no. M, col. I, I. 4, col. 2, 11. I. 3 (Lidz., Eph., 2, 236 ff.). This was early confused with the word for 'vision,' and $\Theta$ felt bound, exceptionally, to insert 'hear.' The reference of the suffix in able.

7-15 (10-18). The king proceeds to relate his dream. He saw a great and growing tree which appeared to reach the sky and to extend to the horizon. The dream is paralleled by that of the Median Astyages, who dreamed of a vine growing out of the womb of his daughter Mandane, which came to 'extend over all Asia,' the vine being the future Cyrus (Her., i, Io8); and by that of Xerxes, who in preparing for his expedition against Greece saw himself crowned with a shoot of olive, whose branches extended over every land, but afterward the crown about his head disappeared ( $i b$., vii, I9). A similar dream is told of the caliph Othman I (c. I 270$)$; s. Häv., who cites d'Ohsson, Allgem. Schildcrung des ottom. Reiches, 273 ff. But our story-teller is also following good native literary tradition. There is Ezekiel's figure of Israel as a cedar of Lebanon which was cropped by an eagle and planted 'in a city of merchants,' where it grew and became a spreading vine, Eze. $I 7^{1 \mathrm{ff}}$; while the figure is taken up again in vv. ${ }^{22 \mathrm{ff}}$, when the LoRD takes a shoot from the top of 
the cedar and plants it in the mountains of Israel, where 'it

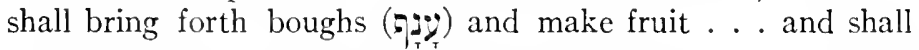

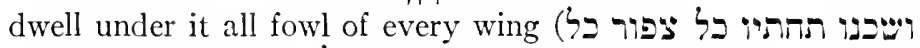
פבי), in the shadow (3) of its branches dwelling.' Still more articulated is the same prophet's symbol of Assyria (the precursor of Egypt) as a cedar in Lebanon, c. 3I: 'Its stature became great ( its branches became long. . . In its boughs nested (p) all the fowl of heaven (aיט), and under its branches brought

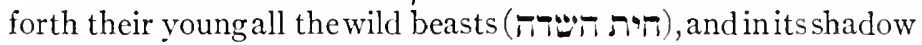
dwelt all (?) great nations' (vv. ${ }^{5.6}$ ). In the judgment upon this cedar we see 'its branches fallen upon the mountains and valleys,' etc., with the beasts and birds feasting on 'the carcass' (vv.12. 13). But our narrator, while reminiscent of the classic figures, is inventive and independent. With him the Tree, symbolic of the Empire of Man, is to be cut down, but not destroyed, that all may know that God is Potentate in that Empire of Man. The Jew here speaks with the universalism of the Second Isaiah; he seeks not his own, nor does he despise humanity, but his sure faith is that God must rule. It may be noted that the trope of the tree for national life is abundant in the O.T.; e.g., the contrast between the cedars of Lebanon which are to be cut down and 'the shoot that shall come forth of the stock of Jesse,' Is. $\mathrm{IO}^{33}-\mathrm{II}^{1}$; and compare the borrowed tropes of the vine and the cedar in 2 Baruch, representing Israel and the Roman empire.

Bert. appears to have been the first to display the poetic structure of the passage, $\mathrm{v}^{7 \mathrm{~b}-14}$ (10b-17), with the exception of the prose interlude in $\mathrm{v} \cdot{ }^{10(13)} \mathrm{a}$, and his example has been followed by Ew., Löhr, Mar., Cha., JV. But there is not sufficient reason, with Mar. followed by Cha., to compress vv. ${ }^{7 b-9}$ (10b-12) to two stanzas of two stichoi apiece by omitting 'and the height thereof was great,' and 'in it was food for all.' Omitting the introductory 'the visions of my head,' which is either simply a title or a gloss (s. the Notes), these vv. may be translated:

7b. Upon my bed I was seeingAnd lo a tree

In the midst of the earth, And its height was great. 
8. The tree grew and waxed strong, And its height reached unto heaven

And the view of it to the whole earth's end;

9. The leafage of it fair And its fruit much, And food in it for all;

Under it the wild life taking shade, And in its branches lodging the birds of the sky, And from it feeding all flesh.

In this arrangement the usual double trimeter is divided at the beginning of each stanza into three dimeter feet, a frequent phenomenon in Heb. poetry. But for the angel's utterance, vv. ${ }^{11 b-14(14 b-17)}$, not more can be said than that the lines are cast in poetic mould; there is no metrical evenness, it is vers libre!

$7(10)$. וחזוי ראישי קל מישכבי The clause is punctuated with athnah, and must have been regarded as title to the following. Orig. (w) (which

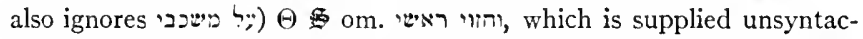

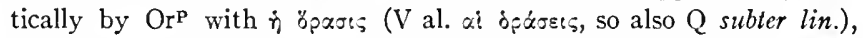
and by Lu., grammatically construing in acc. pl. with v. ${ }^{6}$. I $=1$, uisio capitis mei in cubili meo. The evidence of the first three VSS authorizes us to exclude the unnecessary clause, which would then be similar to the identical gloss in $v .{ }^{2}$ and a reminiscence of $2^{28}, c f .7^{1}$. The comm. either attach it to the prec. v., e.g., Bert., Löhr, Ehr., or predominantly regard it as an absolute clause. (Too freely EVV, 'these were the visions,' etc.). So vLeng., most recent comm., Torrey ('a sort

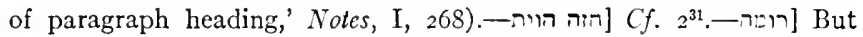

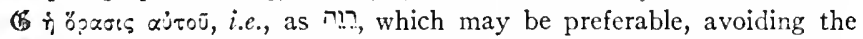
repeated רומה. S. Field on the strange tr. of 65 ; I think the Syr. translator found $\theta_{p \alpha o t s}$ for opasts, took it for $\theta_{p} \alpha \bar{v} \sigma t s$, and hence his rendering.-8 (11). נרכָה אילנא והקר It is debatable whether the vbs. indicate process or state; for the former interpretation CBMich., Hitz., Klief., Bev., Pr., and Keil suggestively: "ihnen (the perfects) entspricht im zweiten Hemistich das Impf. wימ, als die Form des anstrebenden Antriebs." This view is doubtless corroborated by the repetition of the vbs. in $v^{19}$ and adds liveliness to the scene. So EVV. The other interpretation is accepted by, e.g., vLeng., Behr., Dr., Cha., 'was grown.'-

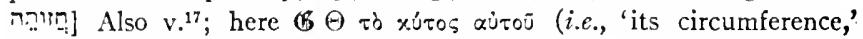
xúros is used of a concave body), and so $\Theta \mathrm{v} \cdot{ }^{17}$, where $\left(\mathbb{B}\right.$ opxoss; in v..$^{19}$ 
(6) xiros, where $\Theta$ correctly xupix. There is no reason to amend the word; 'its appearance,' i.e., as far as eye could see, it reached the horizon. So II EVV and, e.g., Bev., Mein., Torrey. The form (cf. Kau., $\S 55$ end, $\S 6 \mathrm{r}, 4)$ is identical with Syr. mehôtâ, șelôtâ, or, better, it may have been $=$ Heb. ${ }_{\text {n }}$, e.g., $8^{5}$, so Bev. Haupt's revision of the lines (in Kamp.), exchanging העוה and v. v. ${ }^{9}$, has against it the repetition in $v{ }^{17}$. Kamp. gives an extended discussion of the word.-9 (12).

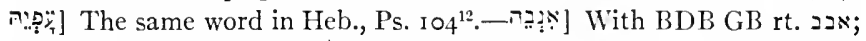
with nasal insertion s. on הניק, v. ${ }^{3}$. But Del., Prolegomena, i I 4, Mein.,

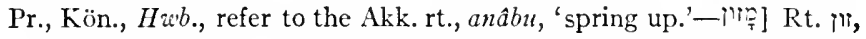

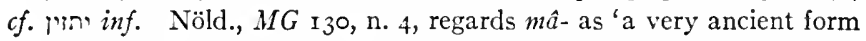
of the prefix,' vs. Kau., p. II 2, who considers $\hat{a}$ a pretonic heightening. Acc. to Powell, Supp. Hebr., 40, "מ and its like are rather Heb. loanwords in Aram., and the Heb. T is retained as stationary." So Bär, s. his note; Gin. om. dagesh; the same variation in v. ${ }^{18}$. For כל s. at $2^{40}$. Bert. rightly notes that (also $\mathfrak{H}$ ) distinctly gives the true interpretation, 'food for all was in it,' with EVV vs. at and some

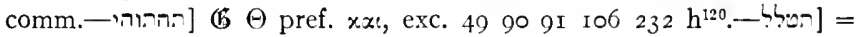
'take shade'; for such operative ('innerlich transitiv') causatives $\epsilon f$. Kau., $\S 33$, I, GK $\$ 53$, d, seq. The strong form of $; " i$ is found only here and in the Peal perf. - - ]

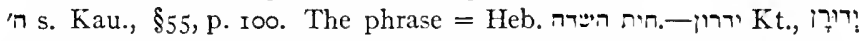
Kr.] Heb. צפ and Syr. șepperâ are predominantly fem. (s. Lexx.), $c f$. inf., v. ${ }^{18}$, where consequence in gender agreement in early Aram. (cf. Sachau, APO 273), the Kt. may be retained with Kamp. vs. Kau., p. I65, n. 3.- - 75 ] S. on $2^{35}$. As against Kau., \$59, c, Brock., $V G_{\mathrm{I}}, \S_{14} 8$, postulating orig. kittal or kuttul, the orig. form is supur, $\epsilon f$. similar words in Barth, $N b ., \S_{\text {I }}$. The hatef vowel here is reminiscent of orig. $u .-$ - Thl] See on

10 (13). The second act of the dream drama is ushered in by the vision of a Vigilant and Holy One descending from heaven calling with a loud voice. We have here the earliest mention of the Wakeful Ones, generally known in our translations as the Watchers, who play so important a rôle in Enoch, Jubilees, the XII Testaments, etc. ( $c f$. the short note of Bousset, Rel. d. Jud.,

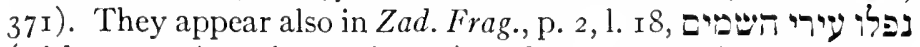
(with correction of actual עידיר). The word Aramaic in form, although it has its Heb. counterpart, and is doubtless an importation from the current syncretistic religion. Hence probably the addition of the epexegetical 'and holy,' to secure the 
identification with the angelic category. The same combination appears in Enoch: $20^{1}$ 'the holy angels who watch,' i.e., the archangels; and I $2^{2}$ 'his (Enoch's) activities had to do with the Vigilants and his days with the Holy Ones,' the parallelism as below, $v .^{14}$. While the Vigilants become predominantly fallen angels, the original implication of the term as of beings nearest to God is preserved in these references. The root of the idea is not un-Biblical. Mein. cft. the eyes of the Cherubs in Eze. I and 'the seven, which are the eyes of the LORD, which run to and fro through the whole earth,' Zech. $4^{10}$. Still closer is Is. $62^{6}$

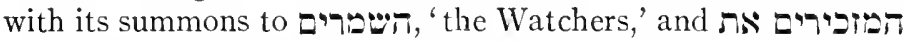
הir ' the Remembrancers of the LORD,' 'to give him no rest' (s. Duhm), suggesting a heavenly caste parallel to our Vigilants. There may indeed be an implied contrast to this notion in Ps. I $2 \mathrm{I}$, acc. to which ' $\mathrm{He}$ that keepeth Israel neither slumbers nor sleeps.' Identification with the many-eyed Amesha Spentas has naturally been attempted, e.g., by Bert. Others, e.g., Heng. (p. I6I), Häv., Keil, would relate these beings to the $\theta \epsilon o i$

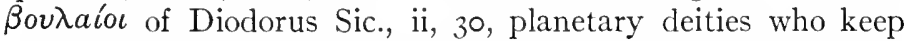
watch over the affairs of the universe; and Häv. cft. the celestial

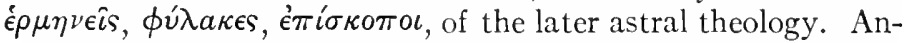
other interesting line of development of the word is that which makes the $y$ a guardian spirit; in Philo it appears to be something like the Egyptian $\mathrm{Ka}$, while in both the Mandaic and the Christian Syriac literature the Vigilants are guardian angels (s. PSmith, s.v.). Note also the corresponding râkib or 'watcher' in the Koran, $50^{17}$, who records the dying man's words. For adequate studies of the word we have still to go back to the comm. mentioned above and to the classical treatise on the subject in the original (anonymous) editio prima of the Chigi text, prefaced to the text of $\Theta$. A fairly modern interpretation, dating from l'Empéreur, and accepted by dEnv., p. 388, is that which would identify the Watcher with the Angel of YHwh, the Son of Man, the Messiah, and so with the Second Person of the Trinity. The question also arises whether Neb. is speaking in terms of revelation or acc. to his own Pagan notions. The former is the view of Klief., who argues from the repetition of 'the Vigilant and Holy,' in Dan.'s words, v. ${ }^{20}$. But it is much more plausible to assume, with Heng., Keil, that Neb.'s description is consciously given a Pagan coloring; Dan. indeed quotes 
the king's terms for the angelic being as a cue, but for him it is, deliberately, 'the decree of the Highest,' v. ${ }^{21}$, not of the Vigilants as in $v{ }^{14}$. The latter $\mathrm{v}$. is an accurate expression of the later astral determinism.

11 (14). And thus the Vigilant made loud proclamation: $C u t$ down the tree: and break off its branches. Strip off its foliage: and scatter its fruit. The beasts wander away from beneath it: and the fowl from its branches. The pl. impvs. have for their subjects the celestial executors of the decree, $c f$. Is. $40^{\prime}$. But v. ${ }^{12(13)}$, the tree is not to be destroyed; its stump with its roots is to be left in the earth, clamped with a bond of iron and brass. The significance of this metal clamp has given rise to many interpretations, the most common one of which since Jer. is that all madmen are bound, and so, e.g., Heng., Klief., Knab. VLeng. proposed the rationalistic idea that the bond was to keep the tree from splitting, which would be satisfactory if there were evidence that such a practice was followed in ancient arboriculture. Pr. thinks that it figures in general Neb.'s confinement. Others find in it an allegorical mng., e.g., Rosen., Hitz., Keil, Bev. It is best to follow Ra., with Mar., Cha., Torrey, to the effect of the symbolism that Neb. should not be removed, with which $f$. v. ${ }^{23}$. The text further reads that he should be left in a bond of iron and brass in the grass of the field, which might then mean, exposed to the elements, in parallelism with the following clause, let him be wet with the dew of heaven. But as we have then two moments in the one sentence, 'Torrey's excellent suggestion is accepted that we supply a vb., let them feed him [with the grass of the field] (s. Notes), which gives the necessary item of his eating grass like oxen, v. ${ }^{29}$. This entails the omission of the last two words of the v., in the grass of the earth, which were subsequently introduced to supply the defective moment. The v. then would end with, and with the beasts shall be his lot. With this item there is a cliange from the metaphor of the tree to the actuality figured; we may compare, with Knab., the similar transition in Eze. $3{ }^{11}$, Mt. $22^{13}$, Lu. $12^{46} ; c f$. also the dramatic development of the parable of the vineyard, Is. $5^{1 \text { r }}$. The uncovered reality is continued in $\mathrm{v}^{13{ }^{136)}} \mathrm{:}$ his intelligence is to be dehumanized, made like that of a beast; the distinctive glory of man is to be taken away from him. And seven times shall pass over (or by) him. The most ancient and common interpretation (e.g., that of $\mathfrak{G}$ Jos., Jer. (at 
v. ${ }^{34}$, Ra., AEz., Jeph., and most moderns) is that seven years is meant; Behr. cft. the corresponding Heb. word for 'time' used as year in פעת היה, Gen. I8 $8^{10}$; and such appears to be the use of the word in the last part of Dan. (s. at $7^{25}$ ). However, other calculations have been propounded. Hipp. tells of a view which identified a 'time' with one of the four seasons. Aph. Syr., Chrys., Theodt. think of a time as one of the two seasons, summer and winter, i.e., after Persian reckoning. See for a long discussion dEnv., pp. 336-34I, also vLeng., and for a good abstract Knab. It is vain to expect to know what was meant. There may have been a tradition of a seven years' madness in Neb.'s case. Or the figure 'seven' is conventional, even as nine years was the term for the were-wolf in Greek folk-lore; s. W. W. Hyde, Greek Religion and Its Survivals, I86 ff. For the use of the number in Bab., Jewish and Pers. lore, s. Scheftelowitz, Die altpers. Religion u. d. Judentum, I34.

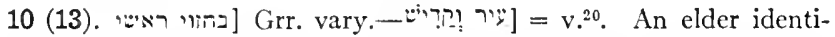
fication (s. Pole, Synopsis) with Heb. רצ, 'messenger' (so Kau., §ı, 2, a, Behr.) is now generally given up, s. the Lexx., Mar. Glossary. רי = 'awake, wakeful,' la zigil, as in Syr., corresponding to the Heb.

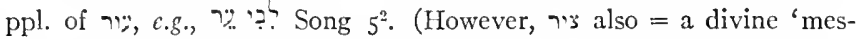
senger,' was in the original of Is. $63^{8}$, where $\pi p \varepsilon \sigma \beta u s$ requires this $v s$.

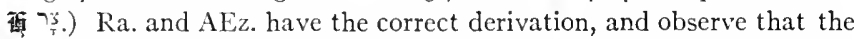
being is an angel. 'Watchers' of the EVV is used in the old English

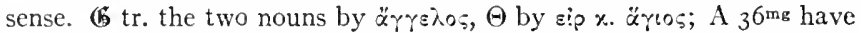
the gloss sंrpriropos attached to the prec. uou, taken doubtless from Aq. and Sym., as a scholion given by Field notes. Jer.'s venture into comparative religion may be observed: "Consuetudo autem graeci et latini sermonis ipev uocat, quae per multicolorem arcum ad terras descendere dicitur," a combination approved by Rosen., Häv. The Slavic version of Hipp.'s comm. actually tr. eip by 'rainbow,' p. I23, l. 2. Ehr. attempts to find our $7 \because$ in Ecc. $10^{15}$, but without success. The Chigi

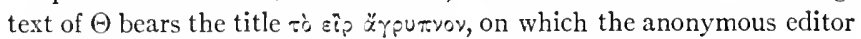
has a learned monograph. The second term קis epexegetical to ריו but not, with Häv., Behr., in order to give it a moral quality, which k.ds never implies; a parallel is For the hendiadys CBMich. $e f t$. 'the roll and the words,' Jer. $36^{27}$, Bev. גר ותויטב, which is a comprehensive legal term. In v.0 קדיטין is is

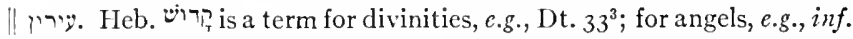
$\mathrm{S}^{13}$, Zech. $\mathrm{I4}^{5}$; and for saints, e.g., inf. $7^{21 .}{ }^{22}$, where pיeי as in v. ${ }^{14}$, along with עירוּ The vivid ppls. of these vv. are 
ignored by the Grr. and $\mathfrak{u}$; but this ppl. is recognized in the reminiscc..ce of the passage in Rev. I 81. ?.

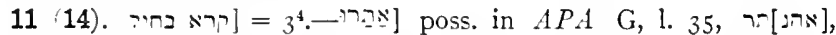

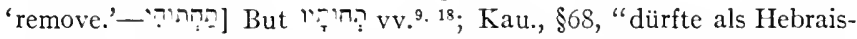
mus zu betrachten sein"; Mar. (Gloss.), Löhr accordingly correct to .תהוריי Nöld. in his review of Kau. notes the discrepancy as an example of the unreliability of rdg. Torrey, Notes, I, 268, defends that the rhythm demands the present pointing here. But it may be an echo of Eze. $_{1} 7^{23} \cdot-12$ (15). error, after the fashion of shortening the vowel of the const.; if. v. ${ }^{33}$, and poss. 27 Ezr. $7^{22}$; s. Kau., p. 103, n. 1. Similar cases are found

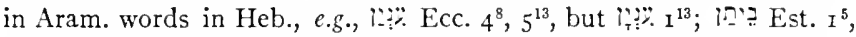
etc.; cf. const. בהדרי Est. $2^{12}$. The doubled $k$ is hardly original (s. on ${ }^{25}$ ), vs. Kau., $\$ 59$, c. Cf.

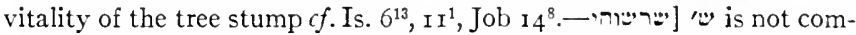

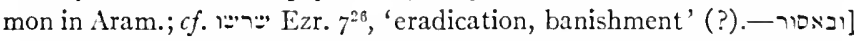
A fresh vb. is expected; however, the hendiadys is supported by v...2,

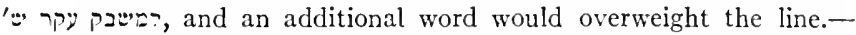
[ברתאא די כרא ירו הehr., followed by Löhr, Ehr., elides as a gloss "welche

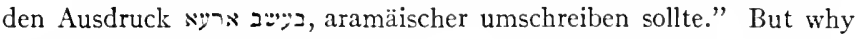
such Aramaic finesse? Those comm. must also elide the phrase in $v .^{20}$, on the rashness of which assumption s. Kamp. On the other hand, Mar., followed by Löhr, om. $N$ בי: on the ground that it is absent in v. ${ }^{20}$. Torrey accepts this elision, p. 269 , noting that v. ${ }^{20 b}$, after is a bald repetition of the present $\mathrm{v}$., and that it is secondary, because the interpretation does not verbally repeat the terms of the dream.

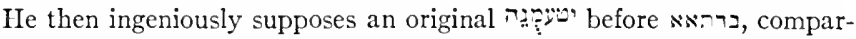
ing vv. ${ }^{22}{ }^{29}, 5^{21}$; this supplied vb. gives the required item of the king's eating grass 'like oxen.' The vb. was early lost before the intrusion of $v^{20 b}$, and the moment was clumsily introduced at end of the v. The

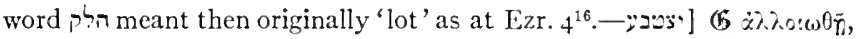

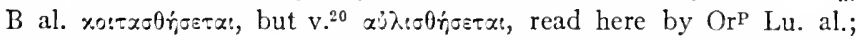
Q notes sup. lin. that rotr. is from Sym. and in mg. that $\alpha u \lambda$. is from $\Theta$. Was rt. רבש understood here (Bert.)? At v. ${ }^{30} \Theta$ correctly ípkpr.-13

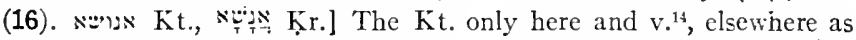
the Kir., e.g., vv. ${ }^{29.30}$. But ${ }^{2}$ is found in Nab., and $c f$. above

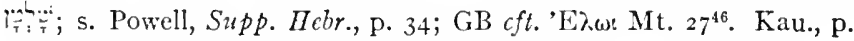
I05, assigns the form to kitâl, but Brock., I'G I, I85, to kututal, with $\partial$ due to influence of $u$ in orig. 'unâšs. For משs 1 Sa. $15^{23}$, ימגו Jer. $48^{2}$, 'from being king, people,' also Is. $52^{14}$, etc. Correctly II cor eius ab humano commutetur.-[ijeי] For the impersonal use s. on I: $2^{13}$; similarly inf. vv. 22. 23. ${ }^{29}$; $f f$. Dalman, Worte Jesu, 183. The rt. 
is used in Syr. of insanity (s. Behr.), and also in Akk., e.g., ušanna tenki

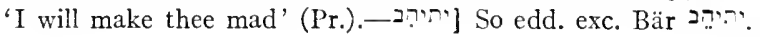

14 (17). The immutability of the divine purpose is stated in a solemn formula like the tolling of a heavy bell: By the decree of the Vigilants is the command: and by the word of the Holy Ones the decision. Hitz. has suggested that we have here a replica of some legal formulism; but prob. it was a formula of the astrologers. It has been discussed whether we are in presence of Persian ideas, so Bert., or Babylonian, so Heng., Klief., al. But rather this is an expression of the later eclectic determinism, with which may be compared the statement of Diodorus Siculus, ii, 30 , concerning the Babylonian fatalism, $\dot{\omega} \rho \sigma \mu \epsilon \dot{\epsilon} \nu \kappa$.

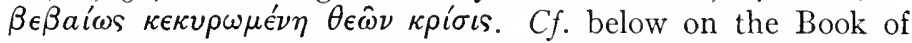
Truth $\mathrm{IO}^{21}$. As noted above, at $\mathrm{v} \cdot{ }^{10}$, the terminology is definitely Pagan, although there is also a Biblical background to this theologumenon of a divine council; $c f$. I Ki. $22^{19 \mathrm{ff}}$, Is. $44^{26}$, Job I-2, and the 'assembly' or 'council of the holy ones,' Ps. $89^{6.8}$. In later Judaism there was a revival of this antique thought; the angelic hierarchy is God's senate, בית דין, or his family, פמליץ, with whom God discusses his decrees; s. Weber, Jïd. Theol., \$35. Dr. cft. Sanh. $38 b$, where it is said, "The Holy One does nothing without first consulting the family above, as it is said (Dan. $\left.4^{14}\right)$ : By the decree of the Watchers, etc." Such terminology is true to color in a Pagan's vision. The decree is issued and its execution ordered not so much for the chastisement of Neb., but that in the fate of him, the type of human pride and glory, all living may learn that the Highest is potentate in the kingdom of man-one of the immortal sentences of the Hebrew Scriptures! Cf. Rev. $\mathrm{II}^{15}$, "the kingdom of the world shall become the kingdom of the Lord.' This principle is further specified, that God gives it to whom he will, and the humblest of men he can raise up over it - a truism in the facts of history, to be exemplified after a few years in Neb.'s own successors. As vLeng. observes, this is a common theme of the Bible; $c f$. I Sa. $2^{7 .}{ }^{8}$, Eze. $17^{24}$, Ps. II $3^{7.8}$, Job $5^{11}, \mathrm{Lu} . \mathrm{I}^{52}$, I Cor. $\mathrm{I}^{26 \text { ff. }}$, etc.

15 (18). The relation of the dream concluded, the king makes his appeal in pathetic accents to Dan. to give the interpretation, for the latter possesses the spirit of holy $\operatorname{God}\left(c f . \mathrm{v}^{5}\right)$, whereas the royal wise men have proved incompetent. As has been re- 
marked by comm., those professionals would hardly have dared to interpret to their royal master the obviously ill-omened sense of the dream.

14 (17). יקרת , $7^{11}$, s. on $2^{14}$; a few cases in Syr., Nöld., SG §ıг. For the technical meaning of 'גas divine 'decree,' hence practically 'fate,' s. on גור $2^{27}$.—

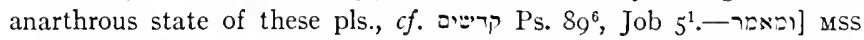
also ' 2 , and so the citations in Talm. (s. Bär's note), followed by Ehr., al.; $\Theta$ confirms if. But vs. Mar., who reads this clause, with $\Theta$, as an independent sentence, the obvious exact parallelism of the two clauses demands the same construction for 'מ גוג so JDMich., al.; for similar cases of implied prepositional government in parallelism in Heb., s. GK $\S 1 \mathrm{~g}$, hh. Il was misled by $\Theta$ and tr. et scrmo sanctorum et petitio.

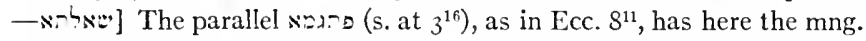
'decree' as the judicial 'response,' so Sa., jaz'âb, and the parallelism must set the mng. of ' $\because$. But the comm. have widely differed. Depending upon the primary mng. of ' $\because$, the Jewish comm. tr. by 'request,' so Ra.: the holy ones are consulted first by God-that is the request $(c f . \Theta \mathfrak{H})$; Klief. tr. 'Beforderung [zu dem Zwecke, dass],' a construction which destroys the unitary character of the couplet; Cha.'s suggestion, 'the word of the holy ones is the matter in question,' is meaningless. Schultens, Animadv., 323, cft. Arab. mas'alat used in the sense of 'thing' (s. also on 1 'י', $3^{29}$ ), and tr. 'ad decretum uigilum res fit' (so also deDieu earlier). But $心$ ' = 'the thing asked about,' and so the 'decision' upon it. In Targ. to Jer. $12^{1}$ מישפטים tr. Heb. Further, form II, $\mathbf{1}$ of Akk. ša'alu is used of mutually asking questions and so of coming to a decision; hence Shamash is muštalum 'decider'; and the derivative situltu = 'Berathung, Entscheidung'; s. Del., $H w b$., p. 633. See in general Jastrow, 'Name of Samuel and the Stem hew', $J B L_{1900,} 8_{2}$ ff., who considers the Heb. and Rabb. testimony on the use of the rt., but does not note the present case. A magical personage, בר מישהאל , 'son of oracle-giver' (?), appears in a bowl text; see my $\mathbf{A r a m}$.

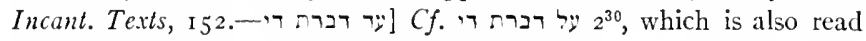
by many mss here, and is accepted by Hitz., Kau., $\S_{11}$, 2, Kamp., Bev., Pr., Mar., Löhr. But 7 is corroborated by (G sense is, 'until they shall know'; $c f$. Behr., al. We find the assimilation of $\zeta$ in $\%$ in late $A$ ram., s. Nöld., $M G \$ 54$, but there is no reason to demand here this later vernacular use.- is The const. has comparative mng., s. Kau., \$85, 4, and for Syr. cf. Duval, GS $\$ 366$, a.

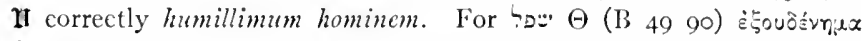

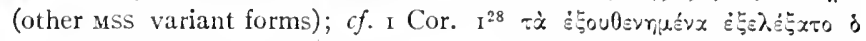

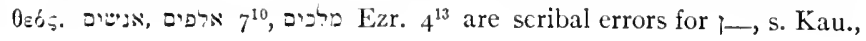


\$5I, 2, Powell, Supp. Hebr., p. 5I (who, however, allows their possibility). Unlike the suffixes ה כס Ezr. $3^{4}, 5^{3}$, there is no support for the variation of $-\hat{\imath} m$ for $-\hat{\imath} n$ in the papp. Mar. would read $N \cdot \dot{w} s$, but the pl. is pertinent here; in Syr. the pl. = $\tau i v \approx \xi$ in general, but also 'people';

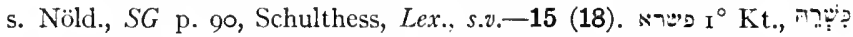

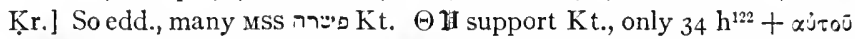

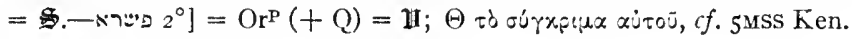
הา

16-24 (19-27). Dan.'s interpretation of the dream. It is introduced by the description of the effect made upon Dan. by the king's narrative. The word used is variously translated: H intra semetipsum tacitus, in which Jer. must have followed a Jewish interpretation, as Ra. gives the same (שטתק); so SV; AV RV 'was astonied,' JV 'was appalled.' But the vb. is not to be taken at its extreme (vs. Dr.), but like other psychological terms of the Sem. be understood from the circumstances. A mng. like 'was perplexed, embarrassed,' is more suitable; $c f$. the same vb. with this sense in $8^{13}$. His embarrassment was due to the necessity of unfolding the ill-omened dream to its subject, and was characteristic of his humanity. The perplexity lasted for a moment (not for an hour with AV!), but long enough to show that his thoughts were troubling him. The king with equal grace and courtesy reassures him, bids him not to be troubled, and the seer in reply expresses the generous wish, 'an expression of civility and courtesy' (Jeph.), that, The dream be for thy enemies: and its interpretation for thy rivals! 17-19 (20-22). He briefly resumes the dream, in variant words from the original narration, and makes interpretation of the tree that, It is thou, $O$ king, thou who grewest great and strong, whose sovereignty reached the end of the earth. 20 . He summarizes the second act of the dream drama, still more briefly than the first telling, if with Torrey (s. Notes) we should excise as secondary the latter part of the v., but the root, etc. 21. He proceeds to its interpretation: This is the interpretation, O king, for $(=a n d)$ the decree of the Highest it is which has befallen my lord the king: 22 (25) that $(=$ and) thee they will drive out from human kind (with impers. use of the 3 d pers. pl.). The seer defines the decree as not of fate, nor ultimately of the Vigilants, but of God himself; s. at $v .^{14}$. In $v .22(25)$ the veiled allusions of $v .^{12(15)}$, which might have defied the skill of any Magians, are definitely interpreted: 
the king is to have his lodging in company with the wild beasts, is to be fed like oxen, to be drenched with the dew of heaven, and seven times shall pass over him, until he shall know that the Highest is sovereign in the kingdom of man; he himself is to learn this and through his experience all 'living beings,' the utterance of v.14 (17) being now precised. But in the philanthropy of the story Neb.'s doom is not to be like that of other arrogant tyrants, for example Antiochus Epiphanes, who too late on his death-bed 'came to recognition' ( $\epsilon$ 's émír $\gamma \nu \omega \sigma \iota \nu$ ) that 'a mortal should not be minded

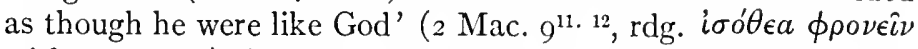
with text. rec.); but the divine power will triumph in him. In accordance with this purpose is the interpretation of the stump left in the ground $\left(\mathrm{v}^{23(26)}\right)$ : thy kingdom is enduring for thee after thou comest to know that Heaven is sovereign. For the first time in Jewish religion (s. Notes) we meet with 'Heaven' as surrogate for 'God'; the word may have been chosen here with tact in contrast to the baseness of all that is of the earth earthy. The term itself is one which like 'the Highest' has entered into the syncretistic vocabulary of the later religion and would have been understood by a cultured Pagan, Persian or Semite or Western. But, v. ${ }^{24(27)}$, with the benevolence characteristic of the Bible religion the doom may be averted by the king 'bringing forth fruits worthy of repentance.' As Jonah preached his rough gospel of repentance to the Ninevites, so Dan. offers his gentle counsel to the king, that thou break off thy sins by right-doing and thy transgressions by showing mercy to the afficted. The long twelve months that intervened before the calamity was respite for the possible repentance. It may be observed that this simple moral code was about all that could be demanded of a Pagan,'to do justice and love mercy,' 'to leave off from evil and to do good' (Ps. 34 ${ }^{15}$ ), for there was no thought of his conversion to the Jewish religion. But Catholics and Protestants have made this a locus classicus for their dispute over 'good works'; e.g., Pole ad loc.: "Pontificii (i.e., Papists) ex hoc loco satisfactiones suas et merita colligunt." See the reviews of the discussion in Häv., dEnv., Knab. In part the strife lies about the word 'righteousness,' בִד it is to be understood in the general sense or in the later Jewish denotation (passing over into the Syr. and Arab.) of 'almsgiving.' This is without doubt the eldest and most constant inter- 
pretation, that of Grr., (eleemosynis), Jewish comm., most Cath. scholars (so Knab.), JV, and also of some Prot. comm., e.g., Grotius, Berth., and of Calvin, with a shading of the word as 'benignity.' The almost equivalence of 'righteousness' and 'almsgiving' appears in Tobit (a book as old at least as our stories), where the two terms are constantly paired, e.g., I $2^{9}$, $\mathrm{I}_{4}{ }^{11}$. In the 'Talm. 'righteousness' = 'almsgiving,' and there are approximations to this mng. in N.T. There is corresponding parallelism elsewhere in O.T., e.g., Ps. $37^{21}$, I $12^{4}$. And indeed why the Protestants should quarrel with the Catholics over the Biblical virtue of charity it is hard to see. A Christian might oppose the Lord's counsel to the Rich Young Man, Mk. Io $^{21}$; also the character of Dorcas, who was 'full of good works (= Rabb. מעיטים טובים) and charities' (Acts $9^{36}$ ), and of Cornelius whose chief virtues were his 'charity to the people' and his prayers $\left(i b ., \mathrm{IO}^{2}\right)$. But it is better not to identify 'righteousness' here too exactly with 'almsgiving'; rather it is the general expression for good works, in which sense it is used in the Sermon

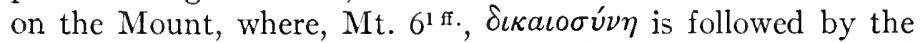
specific terms of alms, prayer and fasting. Similarly here righteousness is particularly specified by charity. A more crucial question is the mng. of פרק translated in EVV by 'break off,' for which, however, the ancient rendering was 'redeem,' so Grr. $\lambda \nu \tau \rho \hat{\omega} \sigma a \iota$, H redime (so prob. which transliterates latter mng. is that held by AEz., Cath. comm. in general, also some Prot. scholars, e.g., Grotius, Bert., Zöck., RVmg; the former by Sa., Ra., Calv. and most Prot. comm., also dEnv. The former interpretation has philological corroboration from the O.T., the other and elder understanding being based upon the later development of the rt. as 'redeem.'

16 (19). אישרומכ] Kau., \$36, regards this and Ezr. $6^{3}$ as Hebraisms. But Nöld., $Z D M G$ I876, p. 326, had claimed such forms as genuine Aramaic; for similar kautal formations in Syr. s. Duval, GS $\S 197$, Nöld., $S G \S 180$, and for their treatment as kautal rather than as

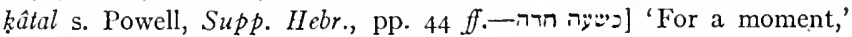
rather than with RV JV, 'for a while,' or the absurd 'for one hour' of AV; s. on $7 ; 03^{6}$. The prep. $\supset=$ time at which, as in Heb., e.g., $8^{5}$

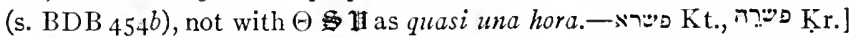

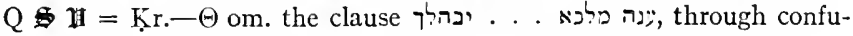
sion with the foll. 'קנה ביט. The lacuna was supplied by OrP.c Lu.- 
יבהיוך יבהלך $5^{10}$ as true juss. forms with omission of the usual energetic element $n$ before the suff. Similar cases are found in the monuments, e.g., Têmâ Inscr. (CIS ii, no. II3) 1. I4, 'נפחוה, and in the papp., but the usage is not consistent, s. Sachau, $A P O$ p. 270 , a ; similarly the impfs. ilu",

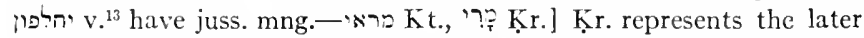
pronunciation; Kt. is supported by the papp., but an ostrakon presents

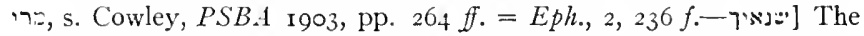
rt. as strong $s "$ h always in the papp., and in some cases in Syr., s. Nöld.,

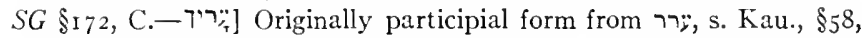
2, h. The ppl. gained the technical sense of 'rival,' s. Lexx. s.v. heb. [אנהה הוא מלכא . 192) 'It is thou, O king'; cf. for a similar

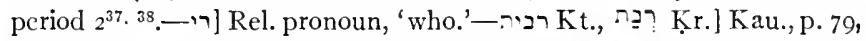
rightly regards the Krr. as 'incomprehensible.' It has carried to the extreme its standardizing process of eliminating $y$ in the diphthong. I cannot follow Torrey's defence of 12 in his Notes, I, 271.—7רור] Bev. notes the form as 'very peculiar': we should expect רבור7 after the analogy of the Syr. But the former, along with the latter, occurs abundantly in the Targ.; it is here a cognate nominative: 'thy growth waxed.'

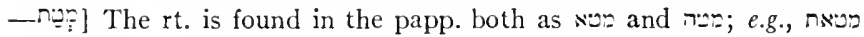
APO pap. I3, 1. 2, but $i$, pap. 28, 1. 6. The pointing here, in place of

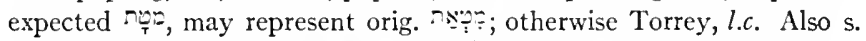

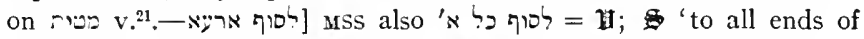

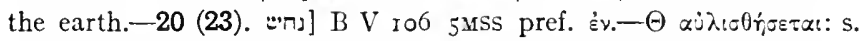

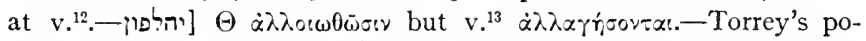
sition that all of $v^{20}$ after הבלוחי is secondary is very reasonable; I will simply cite his argument (p. 269): "The proof of the fact that the passage in vs. 20 is merely a scribe's repetition from vs. 12 is found not only in the remainder of verses 20-23 (where it is evident that the plan of the original writer was to refer in a few words to each of the main features of the dream-divine command; destruction of the tree; the stump left in the ground-and not to repeat the original wording), but also, and especially, in the old Greek translation, in which this part of vs. 20 is lacking."

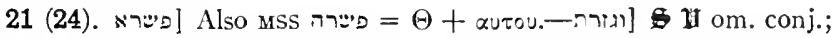
II haec est interpretatio sententiae, etc., attempting to obtain a more satisfactory connection. Here and continuing into $v_{0}^{22}$ with ויך there is a simple alignment of clauses without logical articulation; $f$. Kau., §rO2,

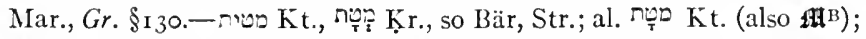
Mich. Rọ] For the rt. s. at v. ${ }^{19}$. Kau., p. 79, Kamp., comm. generally, regard $\mathrm{Kt}$. as error. Torrey's valuable comments correctly illuminate the form; it is survival of the ancient stative, i.e., as Syr., e.g., Jer. $32^{23}, \pi$, מיטיאת, point accordingly in Mand.

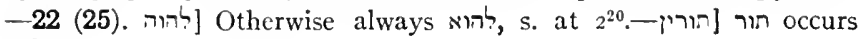
I 6 
in $A P O$ pap. 5, 1. 10 (not recognized by Sachau), s. Cowley, $A P$ no. 33. [ [5בעי[ The most notable case of this impersonal use of the $3 \mathrm{~d}$ pl.; particularly a propos to the present case is Lu. I $2^{20}$, $\tau \alpha \dot{u} \tau n \tau \tilde{n}$ vux $\tau$ ?

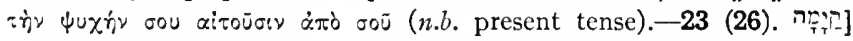
= 'persisting, abiding,' with ref. to Neb.'s life; in $6^{27}$ as epithet of God. mund $u$, 'since'; for the impf. in place of the poss. pf. cf. Nöld., $S G \$ 267$. - יש:] As surrogate for 'God' also I Mac. $3^{18}$, etc., P. Aboth i, 3, etc., Lu. $15^{18 .}{ }^{21}$, and elsewhere in N.T.; $c f$. 'kingdom of Heaven' $=$ 'k. of God'; for the Rabb. use s. Dalman, Worte Jesu, §viii, and for the literature Schürer, $G J V$ ii, 268, n. 47. For corresponding use in the Pagan religions (e.g., Latin Coelus) s. vLeng., and Cumont, Monuments relatifs aux mystères de Mithra, 87 , Les religions orientales, c. $5, \mathrm{n} .64$. The VSS generally avoid the heathen implication.

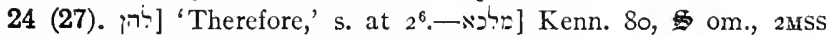

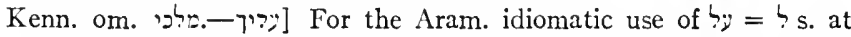
$2^{24}$, and $c f$. שפרה ערי , 615. 19. 24; similar (Aramaizing?) use in Heb., e.g Ps. $16^{6}$, s. BDB $758 a$, GB $588 a$; for Mand., Nöld., $M G \S_{15} 8$, and

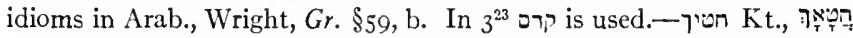
Kr.] If regarded as a sing. the Kt. shows thickening of $\mathrm{N}$ into '; parallel is Syr. haṭahâ. As pl., as is most likely, so VSS, EVV, Kamp., etc., we should expect with Hitz., Bev. But it is possible that the form is equivalent of Heb. Non, with loss of

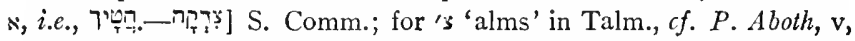
I3 (19) and s. Talm. Lexx. For Jewish and early Christian approximations of $\delta$ :xa10oirn to this mng. S. N.T. Lexx. and GB p. 675b. In Gen. $15^{6}$ 's is a work of religion, a 'merit'; $c f$. its use in the Têmâ Inscr. as 'a religious due' (Bev.). In $9^{16} / y$ otherwise.- D VSS and comm. s. Comm. The vb. is best explained from its use in Heb., e.g., Gen. $27^{40}$, 'and thou shalt break off (פרקר) his yoke from thy neck,' where Targ. Jer. tr. with the same vb.; so Ra. with reminiscence of that passage. Cf. P. Aboth, iii, 9 (8), "whoever casts off (פורק) the yoke of the Law.' Secondarily, ' $D$ was used in the Targg. as = S.ג. y.', 'redeem, save,' e.g., Ju. $\mathrm{II}^{39}$, Is. $45^{17}$, which mng. it has in Syr., e.g., purkânâ = 'salvation.' Hence there was an apparent philological justification for 'redeem' here, as followed by the VSS, but not in the context, as Keil rightly observes: "weil die Sünden kein Gut

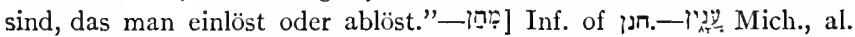
] The form with Mich.'s accentuation (s. on iע, $3^{24}$ ) is pass. ppl. of $\$_{57}$, a, $\beta$, who argues for katâl form, so BDB. The other accentuation is prob. reminiscent of Heb. 'jy und in in den Psalmen. The ppl. form is corroborated by Targ. W. The writer has argued, $J B L$ I909, 59, that the same word ap- 
pears in the ZKR Inscr., 1. 2, where Torrey similarly, JAOS 35 (r9r 7), 356 f., translating 'in distress.' Accordingly the Aram. word is not 'an imitation' of the Heb., vs. Pr., who, after vLeng., regards it in the technical sense of 'the poor' of the Pss., i.e., the LORD's people.-rin] For the indirect question $c f$. the use

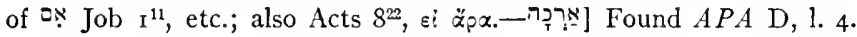
So 5 here and $7^{12}$, s. Bär and Kau., p. 94; cf. מלכרכו

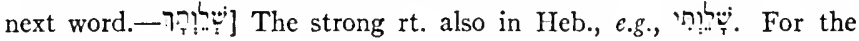
formation s. Barth, $N b$., $\$ 62,2$, c, as katilat, cf. Brock., VG I, §140; treated by Kau., $\$ 57$, c, as katêl. For the mng. cf. "r. v. ${ }^{1}$. The VSS

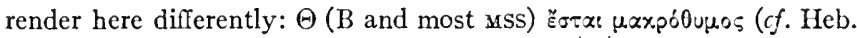

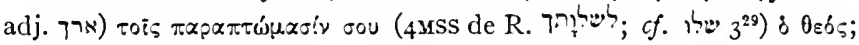
OrP Lu. om. $\delta \theta \varepsilon \delta s$, and Lu. has $\mu \alpha \times p \circ \theta u \mu l \alpha$; prob. $\delta 0 \varepsilon \delta s$ is secondary in $\Theta$ texts. 'until he remove (נרחק) from thee thy transgressions'; $\mathbb{H}$ forsitan ignoscat (Am.) delictis tuis (sc. deus as in orig. $\Theta$ ). Sa., Jeph., $\mathrm{Ra}$. have the interpretation now generally adopted, e.g., EVV, 'a lengthening of thy tranquillity.' But $\mathrm{AEz}$. (so also Grven) understood אריָָ, as in Heb., = 'healing,' and followed the VSS in rendering ' 'error'; so Calv., Münster, hence mg. of AV RVV, 'a healing of thy error.'

25-30 (28-33). It all happened to king Nebuchadnezzar. When at the end of twelve months, the time of the divine respite, he was walking upon the royal palace of Babylon, possibly upon the famous Hanging Gardens, the remains of which Koldewey believes he has discovered, he spake and said: Is not this Babylon the Great, which I have built for a royal residence? While the word was still in the king's mouth, there fell a voice from heaven, which announces the hour of doom. The details of the divine decree, obscurely set forth in the dream, clearly interpreted by Dan., are solemnly rehearsed. At that very moment the word was fulfilled. One new touch only is added to the description of the terrible mania which befell him: His hair grew like eagles' feathers and his nails like those of birds.

The setting of the scene and the king's self-complaisance in his glorious Babylon are strikingly true to history. Every student of Babylonia recalls these proud words in reading Neb.'s own records of his creation of the new Babylon; for instance (Grotefend Cylinder, $K B$ iii, 2, p. 39): "Then built I the palace the seat of my royalty (êkallu mûsâb sarritita), the bond of the race of men, the dwelling of joy and rejoicing"; and (East India 
House Inscr., vii, 34, KB ib., p. 25): "In Babylon, my dear city, which I love was the palace, the house of wonder of the people, the bond of the land, the brilliant place, the abode of majesty in Babylon." The very language of the story is reminiscent of the Akkadian. The glory of Babylon, 'that great city' (Rev. I 8 ), remained long to conjure the imagination of raconteurs. For the city's grandeur as revealed to the eye of the archæologist we may refer to R. Koldewey, Das wieder erstehende Babylon, I9I3 (Eng. tr. Excavations at Babylon, I9I5), with its revelation of Neb.'s palace, the temples, etc. ( $c f$. summary by the same writer in Arch. Anzeiger, I918, coll. 73-8I); further, to L. W. King, $A$ History of Babylon, I9I5 (c. 2 treats the remains and excavations); and for a recent discussion of the size of Babylon and a defence of the reliability of the Classical reff., W. H. Lane, Babylonian Problems, 1923 (esp. c. 7). For the Classical reff. s. the appendices to these last two works, Bochart, Phaleg, lib. iv, cc. I $3^{-1} 5$, and Rawlinson, SGM 'The Fourth Monarchy,' c. 4. Acc. to Pliny, Seleucus Nicator (c. 300) drained the city of its inhabitants, but its decayed magnificence must have remained to that age, enough to keep alive the memory of the ancient glory.

For the bestial appearance of the insane Neb. (a common abnormality) Ball, Daniel, 27, cft. the description of the 'Babylonian Job': 'Like a she-nâkim or a šuk $\hat{\imath} \hat{\imath}$-demon he made my finger-nails grow'; and he finds other points of contact between the Bab. story and Dan. 4, pp. $30 \mathrm{f}$. Also $\mathrm{cf}$. the Ahikar story, 'my nails were grown long like eagles,' Harris's tr., p. 9I, and s. his remarks, p. lviii.

25 (28). כליא See at $2^{40}$; if used nominally here (not adverbially, (altogether'), then the adverbial form has taken rank as a noun.[.] Elsewhere between vv. ${ }^{25}$. ${ }^{26},-26$ (29). ליר ] So v. ${ }^{31}$; otherwise sentence is nominal, dependent on the foll. v.-Dליל See at v. ${ }^{1} ; \Theta v \alpha \bar{\varphi}$,

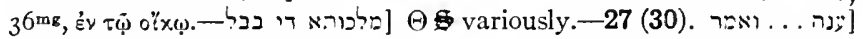
For this 'responding' to circumstances, practically 'beginning' to speak, $c f .2^{20}$, Zech. $3^{4}$, Job $3^{2}$, Song $2^{10}$, Mt. I I ${ }^{25}$, Mk. $9^{5}$. - tive particle; for the equivalent Heb. דִ s. BDB $520 a$, GB 374a.-

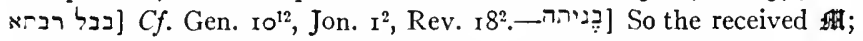
also rss' $^{\prime}$, and ? s. Bär, Str., Gin.; what is intended by the anomalous

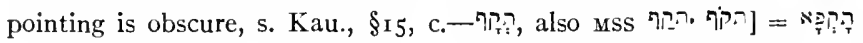
$2^{37}$. Torrey, Notes, I, 273 (also Socin cited in GB) rightly corrects the 
usual assignment of this form to ketâl (e.g., Kau., §57, a), remarking: "The slight variation in pronunciation (o for $u$ ) is a matter of small

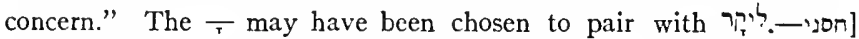
VSS EVV 'of my power,' and so comm., exc. Behr. 'meines Reich-

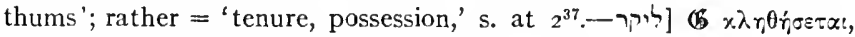
i.e., likkarê. - 28 (31). עו] In the papp. $A P O$, also $A P A$; also in

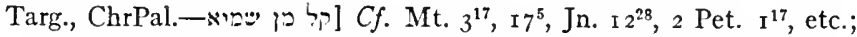
s. Dalman, 'Bath Kol,' PRE ${ }^{3} 443$, Worte Jesu, §viii, I. The same term, ברח קלא , appears in the Pagan Syriac story of Ahikar for the divine response to the hero's prayer for a son at the beginning of the narrative;

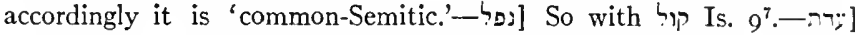

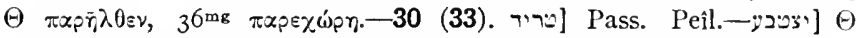
correctly $\dot{\varepsilon} \beta \dot{x} \varphi \eta, v s$. vv. ${ }^{12,22}$.

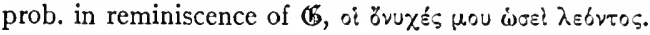

31-34 (34-37). Neb.'s restoration. With simple but profound significance return of reason is said to have come to the king with his recognition of the true God. The statement, remarks Bev., "offers a curious parallel with Euripides, Bacchae, r $265 \mathrm{ff}$., where the same thing happens to the frenzied Agaue." He adds that the likeness is the more remarkable because the Bacchants were in some way assimilated to animals, wearing the skins of beasts, etc. Then follows the content of the king's blessing and praise of God, which represents, stated in the $3 \mathrm{~d}$ person, his meditations upon the irresistible power of God. In v. ${ }^{33(36)}$ the statement that his intelligence returned to him is repeated from $\mathrm{v}^{31}$; Mar. would delete the repetition, which however serves to indicate the two results of the conversion, there in the spiritual, here in the temporal field of restoration to even greater glory.

34 (37). There follows, with the technical particle now, Neb.'s public confession, the climax of the edict. His proclamation of God as King of Heaven, a term unique in the Scriptures (but cf. Jer. $10^{7} \cdot{ }^{10}$, Ps. $48^{3}, 93^{1}$, etc.) is advisedly chosen. Neb. holds his fief from Him who is King in heaven and in the kingdom of man.

31 (34). ניוב Torrey, Notes, I, 273: "This imaginative impf. is com pletely interchangeable with the pf. tense"; s. Kau., §73, 4, Mar., Gr. $\S$ Ior. But vs. Kau. we have here genuine early Aram. diction (lost in Syr.), which is itself characteristic of the 'common-Semitic' use of the

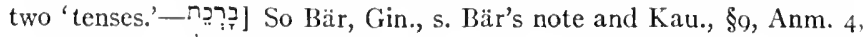

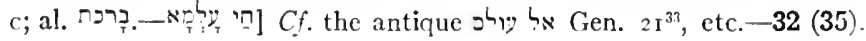




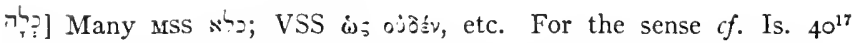

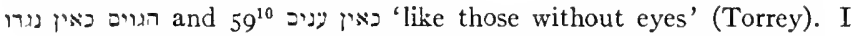
find the same use of ל in Syr., Clem. Rom., ed. de Lagarde, p. 50, 1. 25 ' ליא ובויקיא סבר וג' 'he thought it as naught and cheap to deceive us.' Bev. proposed non respiciendi, but this is 'flat' (Kamp.). Yoma $20 b$ makes הרגא = 'sun motes' (s. Bär, Behr.), repeated by Ra. But Sa. tr. 'like nothing.' Torrey, Notcs, II, 232, thinks of a conflation of פל and all of it,' i.e., the earth. But for the spelling $c f$. Dt. $3^{11}$

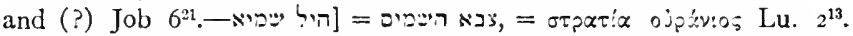
For the thought Behr. cft. Is. $24^{31}$ : "YнwH will punish the host of the height above (המרוס) in the height and the kings of the earth upon the earth.'-יכהז בידה A technical expression in Targ., Talm. for 'reproving, interfering with,' s. Talm. Lexx.; it was prob. based on some symbolic legal action. Schultens, Animadv. 324, cft. the similar Arab. daraba 'ala yadihi, and so Sa. actually tr. here. For אחי', B al. גivt-

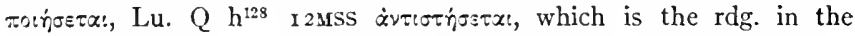
citation Wis. $12^{12}$. H resistat manui eius $=\mathrm{EVV}$, 'stay his hand.'[בה עבדה The same phrase in Is. $45^{9}$, Job $9^{12}$, Ecc. $8^{4}, c f .2$ Sam. $16^{10}$. עיר v. ${ }^{12}$-_.'? understand ' $\mathrm{A}$ as parallel noun with $\cdots$. The most ancient tradition understood it as a vb., $\Theta$ ל by homoiotel.), the reason for which is revealed by Ra., who tr. 'ה by , הררת . 'I returned,' a vb. which also later appears as חדר One, the' was understood as representing the EAram. termination of the rst sing. in '; so ray, $\mathrm{II}^{1}$, was treated by $\Theta$ H. Geier, Behr., al. have followed suit. The error was reasonable on basis of later linguistic premises, and it must be allowed that a vb. here would keep the balance of the consecutive clauses better. Other combinations of the words have been proposed, for which s. Bev.; Mar. suggests that ירוב על וליקר . . וליר ancient gloss to the end of $\mathrm{v}^{33}$; Löhr, Cha. would delete the prec. sentence. But Torrey, p. 275 , rightly remarks that verbal repetitions are eminently characteristic of Dan. It must be admitted that ? makes difficulty; the rdg. יקר, with הדרי זיוי as appositives, would simplify the construction. May the prep. have entered with the construction of

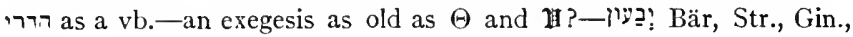
Kit., 'כָ Mich.] Mar. desiderates a Peal, but Torrey, $i b$. .: "the unusual

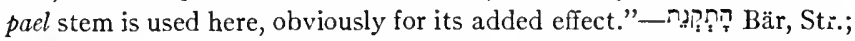

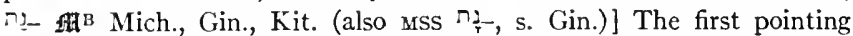
alone is possible here; the other rhymes with תפסD On the genuine Aram. Hof. (so also the following noDi), vs. Kau., $\$ 34$ and others (regarding the phenomenon as a Hebraism), s. Powell, Supp. Hebr., pp. $4 \mathrm{~T}$.f., who gives the literature. Nine instances are found in BAram., 
apart from the questionable forms of מרומם

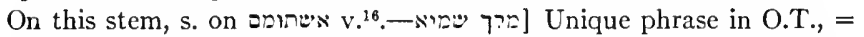
טיא $5^{23}$, found also I Esd. $4^{46 \mathrm{ff}}$; appropriate in a Pagan mouth, but avoided by the Jew; $c f$. 'the Queen of Heaven,' Jer. $7^{18}$-— רי B A al.

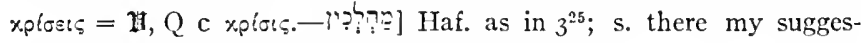
tion that there is implied the denominative idea of walking after the

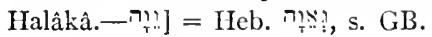

\section{NOTE ON THE TRANSLATION OF $\mathfrak{G}$.}

(5 has a narrative, which despite its omission of much of the material of is is a quarter longer than the latter's text. For detailed criticism and com-

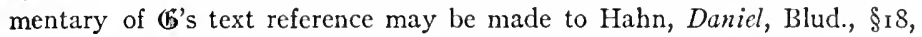

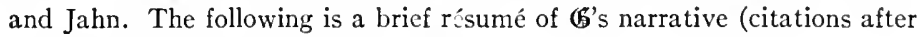
Swete's enumeration of the vv.).

The introductory salutation in $3^{31-33}$, has been omitted, but was reintroduced from $\Theta$, as indicated by the Hexaplaric marks. In place of it are found two parallel proclamations at the end, v. ${ }^{34 b . c}$. But v. ${ }^{34 c}$ contains, with expansion, exactly the contents of salutation, a fact proving that in an earlier form of $\mathbb{B}$ this preface stood in its original place. $A$ date, the ISth year of the king, is given in $v^{1}$ (the same in $\mathbb{F}_{3} 3^{1}$, interpolated also into $\Theta$ at that place), doubtless to make the point of the condemnation of the king for his destruction of Jerusalem at that epoch; the point is specified as indictment against Neb. in $\mathrm{v}^{19}$. $\mathrm{Vv}^{3-6}$ are omitted for the apparent reason of the incongruity of the king's consulting the astrologers first after he had found Dan. preferable to them, as in c. 2. The account of the tree in the dream is sadly confused and absurdly amplified. To v.14 is added a repetitious supplement to the narrative of the dream, and there follows an account of the king's concern, which induced him to call in Dan. The latter's demeanor, v. ${ }^{16}$, is described more at length than in 䱋. In his interpretation of the dream the details are explained one by one, vv. ${ }^{17.23}$, and there are further supplements in those vv. and $v v .^{24}{ }^{25}$. The divine announcement to the king in $v^{28}$ is expanded by a long reference to 'a worthless man in his house,' who shall usurp his place. Finally comes the king's story of his seven years of humiliation and of his recovery and consequent homage to God, to whom he engages to make sacrifice all the days of his life, vv. ${ }^{30-34 a}$. As noticed above, the narrative concludes with the two proclamations, one, $\mathrm{v}^{34 \mathrm{~b}}$, 'an encyclical letter,' in which he commands his people to praise the God of heaven and to offer sacrifice to him, recounting the divine favor to himself; the other, $v .^{34 c}$, representing the original preface at the beginning of the story. At end of $v^{34 c}$ is the statement that he sent letters to all the nations of his kingdoms, this attaching properly to $\mathrm{v}^{34 \mathrm{~b}}$.

For the character in general of the variations of $\mathbf{G}$ from $\mathbf{4}$ s. Int., \$II. In c. 4 , as elsewhere in cc. $3^{-6}$, the variant material has been diagnosed by 
almost all scholars since the publication of the text of $(5$ as purely midrashic; e.g., Bert., p. 125, Blud., p. 148 . It has been left to a few modern scholars to acclaim the superiority of $\mathbf{6}$; so Riessler, p. 33, Jahn, p. 47, and Cha., p. 37. The latter holds that "the older order of the text is preserved in the LXX and not in the Aramaic," and for this decision gives these three chief reasons: (I) We should expect from the analogy of c. 3 that the narrative of Neb.'s experience should be followed by the king's edict. But why? Further, Cha. is in error in remarking that there is nothing in (G corresponding to the first three $\mathrm{vv}$. in ; as observed above, this original introduction has survived, but has been transferred to the end, v. ${ }^{34 c}$, in which the future tense, 'I will show,' indicates its original place.-(2) The uniform 3 d person of $\mathbb{G}$ should be preferred as original. This point has been discussed and answered in the Int. to the Comm. on the chap.-(3) "The LXX shows its superiority in omitting vv. ${ }^{6-9}$, which recounts the king's summons of all the wise men" first, and in "representing the king as at once sending for Daniel in v. ${ }^{18 .}$." This point has been met above in Comm. on vv. ${ }^{1-4}$.-It may further be remarked that if it is true, after Jahn, p. 36 , that "the attempts to prove our piece [c. 4] historical, are particularly weak, even ridiculous," the narrative of $\mathbb{6}$ only heightens the absurdity. What can be thought of the great tree with branches 30 stadia long in which dwelt the sun and moon ( $\left.v^{8} .^{8 .}{ }^{9}\right)$ ? There is the exaggeration of making Neb. undertake to sacrifice to the Jewish God and also command his people to do the same; certainly, as against Riessler, a secondary exaggeration. In v. ${ }^{28}$ appears the earliest stage of the legend in Syriac and Jewish comm. that Neb.'s throne was usurped by his son Evil-Merodach; also an obscure historical reference appears further down in the same v. about 'another king from the East.'

A more serious question pertains to the critical character of $\mathfrak{G}$, which is manifestly composite; even Jahn elides considerable sections. In several passages, for one or more sentences, $\mathbb{G}$ runs parallel with with the usual freedom arrogated by $\mathbb{G}$ in translation. $\Theta$ was evidently acquainted with $\left(\mathfrak{B}\right.$ and followed it when it was usable, e.g., the rare жútos v. ${ }^{8}$. In vv..$^{7 .} 8$ there is obvious conflation of different texts, and otherwise numerous repetitions and doublets exhibit themselves. An earlier stage of $\mathbb{B}$ must have been akin to and that form may have been employed by $\Theta$. Indeed, it may be that, as in the following chapters, original $(\mathbb{5}$ was an abbreviated form. At the same time there is some evidence that the midrashic expansion took place in a Semitic form of text before translation. Bert., p. 130, boldly asserts that the original document was Aramaic; so also Eichhorn, Einl., 4, §6r 7 end, JDMich., Orientalische Bibliothek, 4, 19 $f$. Against this view are arrayed DeWette, Einl., §258, Häv., p. xlvii seq., vLeng., p. cix. I note the following cases which argue to an Aramaic original:

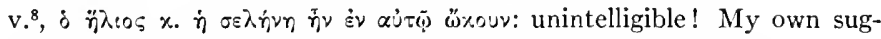
gestion for clearing this up has been anticipated by Bert. as = Aram. שמש וסהר הוו בה מרירין, 'were revolving in it.' 


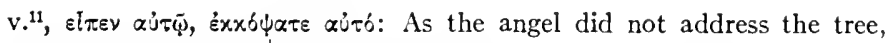
Bert. suggests $\alpha u \tau \omega=\pi$., 'in regard to it.'

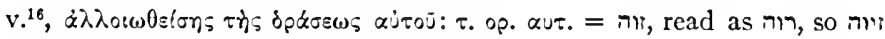
$=\pi$ póołrs $2^{31}$, etc. (Bousset, Rel. d. Jud., 453, thinks of the phenomena of ecstasy developed here.)

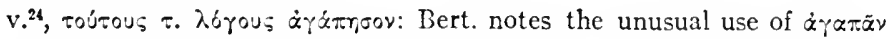
and suggests orig. כר; I would compare similar use of אהז in Heb., e.g., Am. $4^{5}$, Jer. $5^{31}$.

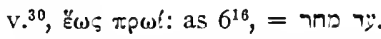

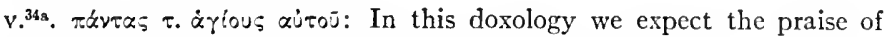
God's mercies; the original may have been 'הסוה, 'his mercies,' which was misread תחסרוה, 'saints' ('ת so occasionally in Pesh.).

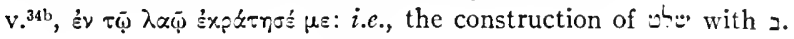

\section{CHAPTER 5. BELSHAZZAR'S FEAST.}

(I) 1-12. King Belshazzar made a great feast for his court. At the wine-drinking he sacrilegiously ordered the holy vessels of the House of God in Jerusalem to be fetched to the banquethall, and while using them the party made their heathen devotions to their gods. A mystical Hand appears and writes on the wall. In his panic the king summons all the wise men for the interpretation of the cryptic legend; they are unable to solve it. The queen then enters and reminds the king of Dan., Neb.'s Master Magian, and of his virtues. (2) 13-28. Dan. is brought in, the king graciously accosts him. Dan. recalls to him Neb.'s experience of exaltation and humiliation, a lesson Belsh. has ignored in his act of sacrilege. He proceeds to interpret the ominous script. (3) 29-c. 6, 1 (29-31). The sequel: Dan. is accorded the promised rewards, while in that very night Belsh. was slain and Darius the Mede succeeded to the throne.

For the historical criticism of this story s. the Int., §I9, $e$. The position there taken is that the story, while unhistorical, nevertheless contains indubitable reminiscences of actual history. Against some comm., e.g., Hitz., Bev., Cha. (Dr. appears uncertain), Belsh. is not the type of the arrogant despot Antiochus Epiphanes; he does not appear as the destroyer of the Jewish religion, only as the typical profligate and frivolous monarch. With Mein., Behr., Mar., al., the story is devoid of reference to Antiochus; it is doubtless far more ancient than the $2 \mathrm{~d}$ cent. B.c. 
1-4. The feast. For the festival which was in progress when Cyrus took Babylon, s. Int., $\S I_{9}, e$. There is nothing surprising in the alleged number of guests. Häv. gives examples: acc. to Ctesias (in Athenæus, Deipn., iv, ro) the Pers. king fed r 5,000 men daily from his table; there was the brilliant international marriage festival celebrated by Alexander, when I0,000 guests were present (s. Niese, Griech. Gesch., I, I6 6 f.); and a similar instance is cited for the last Ptolemy (Pliny, H.N., xxxiii, 47). For such royal feasts as pictured here and the drinking customs of the ancient civilizations the elder comm. have diligently collected the Classical allusions, for which s. especially Brisson, $D e$ regio Persarum principatu, ii, cap. cxxvi. The Bible has the parallel story of Xerxes' splendid feast, Est. I, the crucial point of which is the refusal of the proud Vashti to be presented before the rout. Rawlinson (SGM 'Fifth Monarchy,' c. 3, notes $349 \mathrm{ff}$.) has assembled the reff. from Athenæus (Deipn., iv, 26) on the banqueting habits of the Pers. kings. For the drinking customs of the Persians s. Alian, Varia historia, xii, I, and of the Parthians, Athen. iv, 38. For the lasciviousness and drunkenness of the Babylonians in Alexander's day s. Q. Curtius, v. I: "Babylonii maxime in uinum et quae ebrietatem sequuntur effusi sunt." Whether the royal women were also present on such occasions has been much debated. Acc. to Her., v, I 8, both

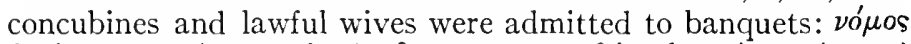

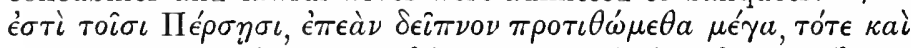

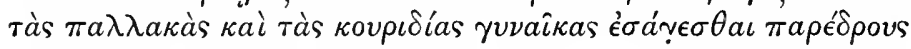
(n.h. the coincidences with terms of our story!); while Plutarch, Symp., i, I, and Macrobius, vii, I, say that concubines, not wives, were so permitted. The undignified manners of royal concubines in public are illustrated from the witty allusion in I Esd. $4^{29 \mathrm{ff}}$. But royal banquets in fin de siècle ages have been much the same the world over, and it is unnecessary to press antiquarian details for or against the historicity of our story.

1. Before the thousand: The expression is technical (cf. Häv., Pr.), and so the king particularly graced the company, facing the guests at his high table. Vice versa, the guests 'ate before' the king, Jer. $5^{2^{33}}$. VLeng. cites Athenæus, iv, Io, who records that the Pers. king generally dined in a separate hall, his magnates in another; but that on festal occasions he dined sitting at a separate table opposite his guests, who then might number 
not more than twelve. Bert.'s opinion that the 'drinking before' them meant pledging them (propinare, zutrinken) has not been accepted. 2. At the tasting of the wine (Eng. VSS ' while he tasted the wine'): The phrase, if it is to be exactly defined, can best be understood as technical of banqueting customs, i.e., when the wine began to circulate after the meal. This Pers. habit is illus-

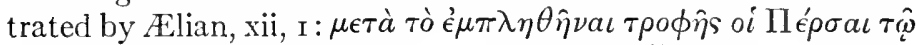

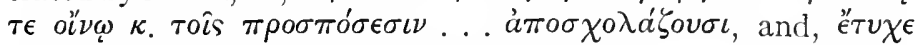

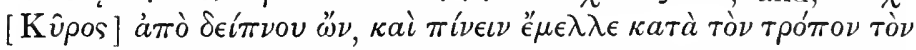

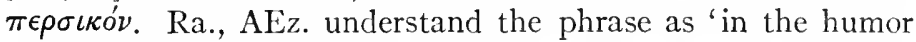
(הצy 'counsel') of the wine'; so Jer., iam temulentus, followed by Pr., and by Dr. as 'under the influence of wine.' CBMich. cft. the Lat. phrases inter pocula, inter wina; Behr. paraphrases: 'als der Wein ihm besonders gut schmeckte.' The vessels of gold and silver... from the temple in Jerusalem, as the only tangible remains of Israel's ancient cult, were uniquely sacred to the Jewish mind; $c f$. Is. $5^{2^{11}}$, Ezr. $\mathrm{I}^{7 \mathrm{ff}}$, Bar. $\mathrm{I}^{1.8}$. The ref. connects with $\mathrm{I}^{2}$. The king must have lost his sense of decency to commit what is to the Oriental view a sacrilege even with the holy things of another religion; $c f$. Amos's allusion to the profligates of his day, 66. His wives (AV RVV, 'consorts' Dr., JV) and concubines: The first term is an honorable one; it is used, e.g., of Artaxerxes' queen, Neh. $2^{6}$; the other denotes the inferior class of harem women, as its etymology may possibly indicate. For the two classes of women in the royal harem $c f$. I Ki. $\mathrm{II}^{3}$, Song $6{ }^{8}$. The usual Sem. word for 'queen' (IDל ) is used in v. ${ }^{10}$ apparently of the queen mother. $\mathscr{G}$ om. all reference to the participation of these women in the sacrilege. JDMich. erroneously brought a lascivious note into the scene, translating by false etymology, 'singers and dancers.' 4. They praised the gods of gold, etc. (cited Rev. $9^{20}, c f$. Bar. $6^{4}$ ). Häv. thinks of some special religious festival and $c f t$. the Pers. Sakae; but with vLeng. it is a common drinking-bout. The customary libations and appropriate snatches of song were in celebration of the gods of wine and joy ( $c f$. dEnv.).

1. ביל which latter spelling is continued in $7^{1}, 8^{1}$ (s. Bär at $5^{30}$ ); = Bêl-šar-ușur. The name appears on a statue of a private man in Egypt 'aus assyrischer Zeit' as במלסראי בph., 3, 117. All VSS identify the name with 
Dan.'s surname, Belteshazzar, as B $\alpha \lambda \tau \alpha \sigma \alpha \rho$, 11 Balthassar, Belittšâsâar. Cod. A, which gave the unique Baprasap in the earlier capp., after this v. reverts to $B \alpha \lambda \tau \alpha \sigma \alpha p$._Aramaic use of ' 2 as 'feast,' for which we might expect מישה as in v. ${ }^{10}$

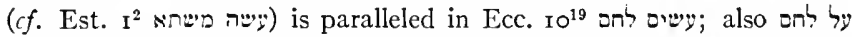
BSir $34^{23}$ 'at a feast.' $-\Theta$ construes vv. ${ }^{1 \mathrm{~b} .}{ }^{2}$ together, and $1 \mathrm{H}$ as though כליקבל, unusquisque secundum suam bibebat aetatem.-2. טעם [י] The physical mng. 'taste' only here in BAram. Mar., Gr. $\$ 48$, notes that the infinitival sense is perceptible.-B oivou autou $\dot{\varepsilon} v \varepsilon \gamma \times \varepsilon i v$, error for

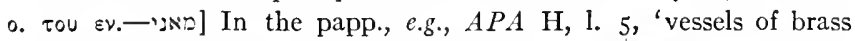

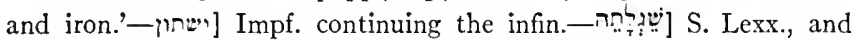
Haupt 'Šegal,' JBL I916,322-324. $\$$ il correctly 'wives' vs. $\Theta \pi \alpha \lambda \lambda \alpha \alpha \alpha$ '.

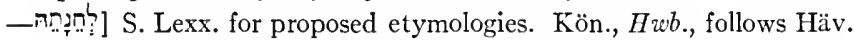
in an etymology from Arab. lahina, 'stink.' Haupt, l.c., 324-326, connects the word, as by interchange of $d$ and $l$, with the theme dak, 'push away,' for which he finds support in $i_{r} \prod_{i}, 6{ }^{19}$, which acc. to many is identical with the present word. In $A P O$ pap. $53,1.5$, appears $n$ nn, but $v s$. Sachau, who suggested identification with our word, it is recog-

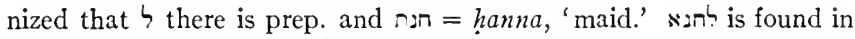
Targ. Onk. for המא and wh, e.g., Gen. $25^{6}, 35^{22}$, and in Mand. in lists of evil spirits, e.g., Qolasta, xv, 5, Ginza R., 279 ff., which Lidz. arbitrarily tr. 'Netzgeister,' Or. Studien Nöldeke gewidmet, I, 54r; rather it

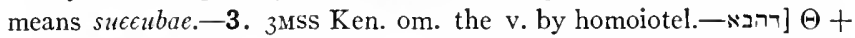

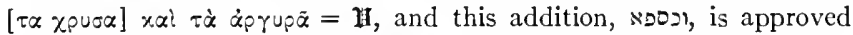

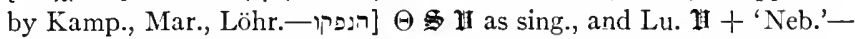
[די ביה This unessential item $\Theta$ om., OrP (62) restores; it introduces the usual term for the temple, e.g., I ${ }^{2}$._and internal $i$ of the stative, as in Syr. ešt end of v. Orc (A ro6 al.) plus from $(\mathfrak{B}$, 'and the eternal God they blessed not who had the power over their spirit,' which was intruded in to 6 from $v^{23}$. That $\mathrm{OrC}^{\mathrm{C}}$ does not represent orig. $\Theta$ is shown by use of $\mathbb{G}$ 's $\pi \nu \varepsilon \tilde{u} \mu \alpha$ vs. $\Theta$ 's $\pi \nu \circ \dot{n}$ at $v^{23}$. Yet Jahn, Cha. accept the addition as authentic.

5-9. The vision of the Hand and the Writing on the Wall; the king's panic. 5. Just then came forth fingers of a human hand and they were writing in front of the candelabrum upon the plaster of the palace wall. The royal table was doubtless set on a dais and against a wall, and that quarter of the hall was lit with a great candelabrum, the light of which was reflected on the plastered wall behind the royal seat. The v. gives details which, if we would understand them historically, may be visualized from the excavations at Babylon. In the Gewolbebau, the 
assumed Hanging Gardens, was found a great hall, for the description of which we may summarize Koldewey (Das wieder erstehende Babylon, c. I5, p. I03; Eng. tr., Excavations at Babylon). In the southern part of the area lies the largest room of the castle, the throne hall of the Babylonian kings. In every respect it is distinguished from all the other halls, and there can be no doubt that it was the chief royal audience chamber. "If one would localize anywhere the ill-fated banquet of Belsh., it could be found with greatest warranty in this enormous room," which is $17 \mathrm{~m}$. wide by $5^{2}$ long. In the centre of one of the long sides, opposite the entrance, is a niche, in which the throne must have stood. And the explorer notes that the walls were covered with white plaster, referring also to an earlier statement, p. 88, where it was remarked that "die Innenräume waren mit einem feinen, auf dickerem Gipsmortel aufgetragenen Putz versehen, der aus reinem Gips bestand." Earlier comm., e.g., dEnv., Pr., Dr., have adduced the evidence for such interior stucco work from the descriptions in Layard and Perrot. The word in $\mathrm{v}^{\mathrm{b}}$ translated by EVV 'palm,' probably means the hand proper below the wrist as opposed to the lower arm, which also is often called 'hand.'

6. Then the king's color changed: The original word for 'color' (EVV 'countenance') is 'sheen, brightness,' s. at $3^{19}$. Cf. the Arab. phrase, taǵayyara launuhu, found in Lammens, Riwâyât al-'Agân $\hat{\imath}, \mathrm{p}$. 100, l. I4. For the 'loosening of the loins' as symptom of panic fear, $c f$. Is. $2 \mathrm{I}^{3}$, Nah. $2^{11}$, Eze. $2 \mathrm{I}^{11}$, Ps. $69^{24}$, and for the 'knocking of the knees one against the other' Nah. $2^{11}$. For corresponding expressions in the Classics s. Bert., Häv. 7. The various classes of wise men (s. at $2^{2}$ ) are summoned to interpret the mystic writing. A royal boon is promised to him who will read it: he shall be invested with the royal Purple and the Golden Necklace and shall have the official rank of 'Third' in the kingdom. Purple (so AVmg RV JV, 'scarlet' AV) was the royal color in antiquity; among the Persians, Est. $8^{15}$, I Esd. $3^{6}$, Xen., Anab., i, 5, 8; the Medes, Xen., Cyrop., i, 3, 2; ii, 4, 6; for the Gr. period $c f$. I Mac. $\mathrm{IO}^{20}, \mathrm{I}^{43}$ (Simon is accorded sole right to the purple), etc. The 'necklace of gold' is more than a 'suggestion' (Pr.) from the story of Joseph, Gen. $4 \mathrm{I}^{42}$. The golden necklace (the word used is of Pers. origin and passed into the

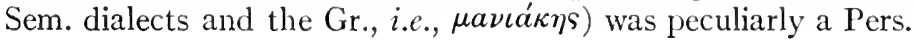


distinction; it was worn by Persians of rank, Anab., i, 5, 8; 8, 29; was presented by the king as a special compliment, ib., i, 2, 27;

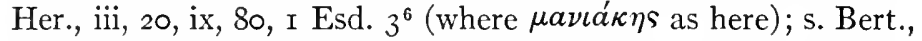
Häv., Dr. Acc. to Cyrop., xiii, 5, I 8, the decoration could be worn only when presented by the king. Rawlinson, SGM 'Fifth Monarchy,' c. 5 , n. 420 , observes that this and other particulars of official insignia are confirmed by the Achæmenidan monuments. As to the title 'Third' (also vv. ${ }^{16 .}{ }^{29}$ ) there is vast variety of opinion. The most common interpretations postulate for the second member of the triumvirate either (so earlier) the queenmother or Nabonidus (for other views s. Note). It has been argued in Int., $\S 19, e$, that the latter is excluded by the whole tenor of the story, which regards Belsh. as absolute monarch; within the scope of the tale only the queen-mother can be accepted, unless we would find in the term a faint reminiscence of the co-regency of Belsh. with his father, who, however, is said to be Neb. (!). But see the extensive Note, which argues that the term is a true reminiscence of old Bab. officialdom, where the Akk. $\check{s} a l s \hat{\imath} \hat{\imath}$ (= our word spelled both talt $\hat{\imath}$ and taltâ) was a high official title, = 'Thirdling' or 'Triumvir,' similar in its use to the Heb. equivalent šâlišs. 8. Then all the king's wise men were coming in, etc.: an apparent conflict with $\mathrm{v}^{7}$, in which the king said to the wise men of Babylon, etc., a statement which supposes the presence of those notables at the banquet. Kran. assumes gratuitously a distinction between the three specified castes of $\mathrm{v.}^{7}$ and 'all the wise men' as here. Behr. supposes that רמא, $\mathrm{v.}^{7}$, means 'commanded,' not 'said,' and so Mar.; but this is forced. Cha., after Jahn, readily falls back on $\boldsymbol{( \boldsymbol { 6 }}$, which he holds gives 'a rational order of events,' as 'also supported by Josephus' (!); but $\mathscr{G}^{\prime}$ 's narrative concludes, $\mathrm{v}^{8}$, with a more emphatic repetition than is found in is: ' $^{-}$and were coming in the enchanters,' etc.; i.e., $(\mathbb{6}$ had the same apparent confusion in his Sem. text as we find. The rather petty inconsequence may be understood as a case of prolepsis in $\mathrm{v}^{7}$, or 'careless diction' (Zöck.). But we may observe the force of the ppl., 'were coming in,' and the comprehensive 'all,' v. ${ }^{8}$; through these ominous hours they were filing in to make essay at the vain enterprise. 9. Their failure cast the king and his magnates as well into the greater perplexity.

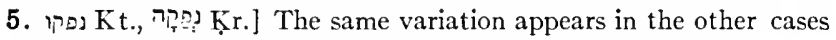
of the 3 d sing. fem.: $7^{8.20}$. Kall., \$23, 2, Bev., Behr. hold that the dis- 
tinction made by $(-\hat{a} v s .-\hat{\imath})$ is secondary and due to assimilation to the Targ. form in $-\hat{a}$. Palm. uses the form in $-\hat{\imath}$ for both genders; there are no pertinent cases in the papp. But $\Theta$ 's rendering of $7^{20}$ as נפל ppl. proves that the latter was once Kt. The fem. in $-\hat{a}$ is found in EAram., WAram., and Eth., and occasionally in Heb. (s. Peters, Hebraica, 3, III ; GK $\S_{44}, \mathrm{~m}$ ). The rdg. of ImS Ken., i i = ppl. is not, with Houbigant, Bert., to be preferred; the frequent order of perf., ppl. is idiomatically followed.—נְּ Acc. to many a foreign, Aryan word, s. Lexx., Behr., Pr., also Tisdall, JQR $2366(=n i+$ Avestan $b a r e j$, 'shine'). Barth, $Z A 2$ II 7 , led the way in regarding it as Sem. by diagnosing $n$ as $=m$ by nasal dissimilation before $b$ ( $c f$. some additional notes on this subject by the writer in JAOS 43, 50). Torrey, Notes, I, 275 (cf. II, 232), argues for composition from (Eth.) גבר and a 'fire-stand,' but with little probability. I have for some time derived the word from ברר 'be clear, bright,' and as from the Safel stem with metathesis of consonants. But, as Dr. W. F. Albright has informed me, Halévy long ago hit upon the same root with a probably better analysis: mabrart > nabrart $>$ nabralt $>$ nabrašt, which fully clears up the derivation. Aq.'s tr. here is cited in Yoma 41a, Heb. I. Is. $27^{9}$. For discussion of origin s. Lexx.; Haupt connects with Akk. kîr 'pitch,' s. Pr., p. 227.-D] tr. by the identical word pastâ, and so ' $D$ is used in Rabb. See Bev.'s note and his explanation that "the king saw the hollow of the hand "; but this were hardly possible. Kön., $H w b$., assuming a rt. 'stretch out,' interprets it as of 'the finger-tips.' But Jastrow, Dict., s.v., defines the word as 'the hand from the wrist to the tips of the fingers,' and so AEz. here interprets, 'a severed hand,' i.e., without a body; so also Hitz. and Torrey. Similarly $\Theta=\dot{\alpha} \tau \tau_{\uparrow} \alpha \gamma \dot{\alpha}-$ $\lambda_{0 u s}=$ articulos. BDB is to be supplemented $(c f . \mathrm{GB})$ by reference to בתגת סטים, Gen. $37^{3}$, where 'o means the hands and feet, sc. a garment reaching to the wrists and ankles; also, with Maurer, cf. $47^{3}$, 'water reaching to the ankles.'-6. 6 .

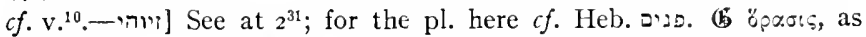

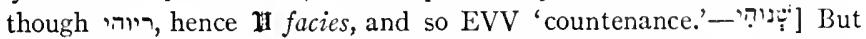
v. ${ }^{9}{ }^{9}$ (the phrase but with Etpaal v. ${ }^{10}, 7^{28}$ ). Accordingly

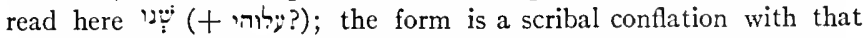
in v. ${ }^{9}$. The suff. for the indirect obj. is hardly possible; for Heb. exx. s. GK $\S_{117}$, x. The use is frequent in SArab., and Pr. cites apparent parallels in Akk. Str., $\S 6, \mathrm{p}$, accepts the text; per contra Nöld. in his review, $L C B$ I896, no. 9.- הריזה, For identity of 'n with Heb. Syr. hașs, s. GB s.v. חל. For similar use of the sing. vs. the pl. of the IIeb. $c f$. Targ. Dt. $33^{12}$, 一

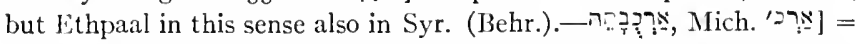
Arab. rukbat; for prothetic vowcl s. Kau., \$60, I. It is preferable with GB, p. II 7 , to postulate two rts., I $b r k=r k b$, 'knee, ride,' and II brk (cf. Akk. and SArab. krb), 'bless,' as against BDB and Kön., Hwb. 


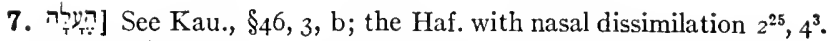

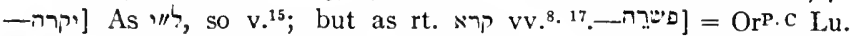
II; $\Theta$ (B + 5 MSS $)$ as $=2$ Ch. $2^{6}$, Palm.,

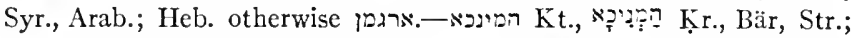
המוניכא Gin., Kit.; המונכא Mich.; these with Kar. as above; the K tîb maintained strictly throughout] Levy, Bev., followed by Andreas in Mar.'s Gloss., as < MPers. *hamyânak, diminutive of hamyân, 'girdle,' with which of. Bär's Kt. Tisdall, $J Q R$ 4, 98 , insists that Pers. hamyân is from Arab. himyân (rt. = 'fall'), mng. 'loin-cloth,' etc., and derives the word from ham + maini, 'necklet,' i.e., 'collection of necklets'; the Targ. form But hemyân is found in Talm. and Mand. The variants in tradition represent different forms of the imported word, with which $c f$. Syr.

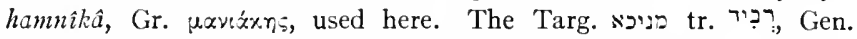
$4 \mathrm{I}^{42}$, of Joseph's necklace.-— - In 1926,58 , the writer has explained the spelling as a development from

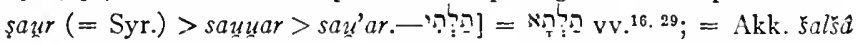
< šalšâi ( $c f$. GB, Kön., $H w b$.), noun of relation from šalšu, 'third,' s. Del., $H w b$., s.v., and $G r$. . p. 207. The word appears in two classes of references. (I) In the one, for citations of which I am indebted to Prof. R. P. Dougherty, we have the term alıu šalsâ, e.g., Streck, Assurbanipal, Rm. III, 48-49 (vol. 2, p. 26), Tammaritu ahuı̌̌ salsa-a. 'T. his brother of third degree'; similarly $K B$, p. 88 of sons; in these cases it is brother or son 'number 3 ' in the family. (2) In the other class the term is official. The reff. have been conveniently collated by Klauber in his 'Assyrisches Beamtentum' in Leipsiger Sem. Studien, 5, r I If. He

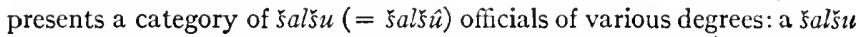
sa కarri, salš dannu mar šarri, etc. The parallel of Heb. observed by Jer.) at once suggests itself, in its mng. of a high royal officer, e.g., Ex. I4 $4^{7}$, I Ki. $9^{22}$, Eze. $15^{15}$, etc., for which Haupt, $B A 4$, $583 . f$., demonstrates the mng. of 'the third' in the chariot, the $\delta \pi \lambda$ opopos, armiger (s. GB s.v. for further reff.). We are dealing here, then, with a customary official title, the numerical denotation of which has been lost. has preserved the two Akk. case-forms of the word, taltâ and talt $\hat{\imath}$, by true

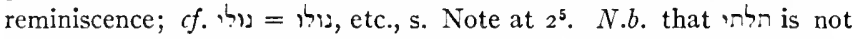
emph. but abs., hence not 'the third ruler,' so AV RVV, but rather 'one of three,' with JV, and we might translate 'Thirdling'; and 'של., v. ${ }^{29}$, is the same although on its surface it might mean 'ruler of the third.' In a word Dan. was appointed a high dignitary in the kingdom, with a title which had lost its original significance, like 'tetrarch,' or 'chamberlain' and 'knight' in English. The recognition of this Akk. origin accordingly antiquates Kau.'s notion ( $\$ 65, \mathrm{x}, \mathrm{Anm} .3$ ) of 'an abnormal stat. emph. to 'r.h', as also the various attempts to rectify the pronunciation, e.g., Behr., Kamp., Mar., Cha. Torrey, 
Notes, II, 232, thinks that the author meant n? in all the three passages, i.e., as 'third' ruler (so $\Theta$ tpiros), with which was combined the notion of the 'ruler of the third part' (as (6 understands the phrase). The above explanation does away with the prevailing interpretation that Dan. was the third ruler after the king, so AV, RV, Hipp., iii, I5 $\varepsilon \pi ! \theta_{p} t \nu(p) \tau_{p}(\tau(\phi)$ and one of Jer.'s alternate views, uel tertius post me;

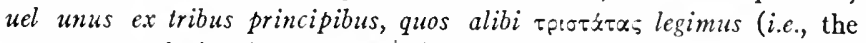
current translation in (of for $\boldsymbol{w}$ ). And accordingly it disposes with speculation as to the person of 'the second' ruler. According to the theories Dan. would have been third to the king and his wife, or his son (Geier, dEnv.); or to the king and his vizier (JDMich., CBMich., Bert.); or to the king and the queen-mother, which to the writer's mind is the only reasonable alternative. For the view that the two in precedence were Nabonidus and 'the crown prince' Belshazzar, s. Int., §19, $e$. The oldest interpretation, that of $\mathbb{6}$, is an erroneous paraphrase, 'there shall be given him authority of the third part'; so practically Sa., Ra., AEz., Jeph. Zöck. cft. the triumvirate appointed by Darius, 61,

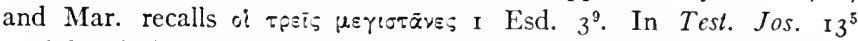
Potiphar is 'third in rank with Pharaoh'; if not dependent upon our passage, the term may corroborate the above interpretation.-

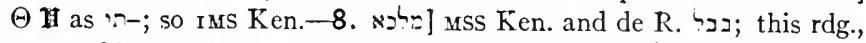
as noted by Bär, was followed by Levi b. Gerson. - - כר? So edd. $(=\$)$

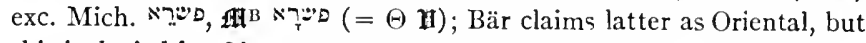
this is denied by Gin., Int., 237.-9. אי] For the adv. before the vb.

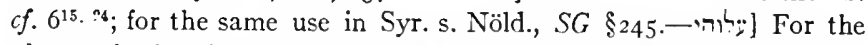
phrase $c f$. Dieterici's text of Thier u. Mensch, p. 5 I ad inf., rakgka kalbuhu 'alaihi.—16 $6^{35}$ (Blud., p. 149).

10-12. The queen's plea that Dan. be summoned. Since Jos. this lady has generally been identified with the queen-mother; some comm., e.g., Origen (acc. to Jer.), Levi b. Gerson, Iacchides, by composition with the Biblical datum in $2 \mathrm{Ki} .25^{27}$, make her Evil-merodach's wife and so mother of Belsh., and similarly the marg. variant in AV 'grandfather' for 'father,' vv. ${ }^{2 .}{ }^{11}$; but most the widow of Neb. (i.e., Nitocris, so Grot.), and so the mother, or grandmother, of Belsh.; so Jos., Jeph., AEz. and most modern comm. The narrator evidently ignores Evil-merodach and regards Neb. and 'the queen' as the parents of Belsh. The bald title 'queen' suggests prima facie Belsh.'s chief consort, and so interpret Bert., p. 367 , Jahn; this position is as old as Porphyry, whom Jer. cites and shrewdly answers: "Euigilet ergo 
Porphyrius, qui eam Balthasaris somniatur uxorem et illudit plus scire quam maritum." Also the lady's masterful appearance on the scene betokens rather the queen-mother than the consort. In the one case where a queen-consort is mentioned in the postexilic history, she is called $\mathrm{v.}^{2}$. In the O.T. the queen-mother bore the title 'Mistress,' I I Ki. I $5^{13}$, etc.; the book of Kings relates several episodes illustrating her prime importance in the administration. Pr., citing Bab. letters from the king to the queen-mother (Del., $B A$ I, I8 $f$.), calls attention to their respectful tone, and for her exalted position s. Meissner, Bab. $u$. Ass., I, 74. We learn still more definitely from Classical reff. of the dominant position of the queen-mother in the Pers. court. Says Rawlinson, SGM 'Fifth Monarchy,' c. 3: "The mother of the reigning prince, if she outlived his father, held a position at the Court of her son beyond that even of his Chief Wife"; and he cites, n. 393, from Arrian, Exp. Alex., ii, I2, a passage indicating that the queenmother might properly hold the title of queen. $C f$. the malign power exercised by Parysatis, the queen-mother in Ochus' reign (ib., c. 7). That the queen came in of her own accord with as against $($, which has her summoned by the king, is historically reasonable, especially if we have here a tradition of Nitocris.

11. There is a man, etc.: Comm. (e.g., Häv., Keil, dEnv.) seek for reasons why Dan. did not officially appear at first. But the story follows dramatic necessity as in c. 4 (s. at $4^{5}$ ), with the additional reason of the frivolity of the new and abandoned régime. In place of the usual translation of the grammatical pl. 'gods,' interpret as sing., 'Deity'; s. at $2^{11}$. For 'light' EVV,

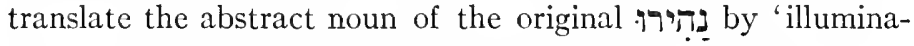

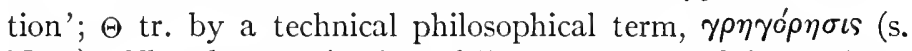
Note). The characterization of Dan. repeats Neb.'s words to him in $4^{5}$. For Dan.'s position under Neb. as Master Magician, s. at $2^{48}$. At the end of the v. appears a superfluous "thy father the king,' an unnecessary repetition, disguised in $\Psi$ and EVV. 12. The first part of the v., punctuated by the edd. of the VSS, EVV, GV, most comm., with a full stop, reads like a superfluous repetition of v. ${ }^{11}$; but if read as protasis to v. ${ }^{\text {, }}$, with dEnv., Bev., it is in place: Since (H quia) that extraordinary illumination was actually exhibited in him, now (כע) let Dan. be called. Of the 
three phases of his art dream-interpretation has been exemplified in c. 2. For the solution (EVV 'showing,' 'declaring') of riddles (so JV, 'hard sentences' $\mathrm{AV}$, 'dark sentences' $\mathrm{RV}$ ) as a skilled specialty of the royal councillor we have the classic example in Ahiḳar, the sage vizier of the Ass. kings, who, acc. to the Syr. version of his story, distinguished himself in riddle contests between his royal master and the king of Egypt; cf. BSira at length, c. 39. The earliest case of such royal jousts of wits is found in the story of the queen of Sheba. As the third specialty is named, literally, the loosing of knots (so JV; AV RV dissolving of doubts). The second noun is common in magic for the knots tied by the sorcerer, which sympathetically bound the victim and which had to be untied by counter-magic; it is in this sense (probably that of $\Theta, \sigma v \nu \delta \delta^{\prime} \sigma \mu o v s=\mathbb{H}$ ligatorum, and accordingly (50m. the item) that Bev., Cha. would interpret the term. But, with Mar., "an Zauberei denkt der Verfasser kaum," and it is preferable with him, Dr., al., to interpret after Talm. and Syr. usage as of 'problems, difficulties.' The repetition of the phrase in $\mathrm{v}^{16}$ indicates that the mystery of the supernatural script fell into this category. At the end of her statement the queen recalls Dan.'s official surname, as it were, in personal reminiscence of $4^{5 t}$.

10. [יבתרא For the emphatic position, denoting change of subject,

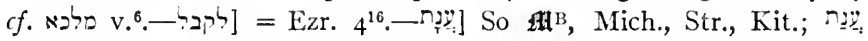

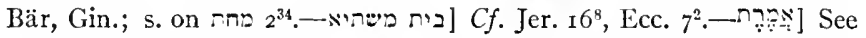
on form similar to form, תמצָ, especially after analogy of fem. ppl., regular in Heb., is otherwise not found in Aram.; however, O $7^{8}$ is so understood by $\operatorname{Or}^{\mathrm{P}}(=\mathrm{Aq} . ?)$, prob. with right, and there

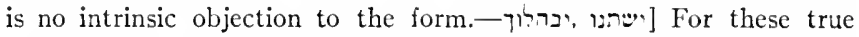
juss. forms s. on יבהלך $4^{16}$. -The $\mathrm{v}$. is abbreviated in $\Theta$. II regina autem pro re quac accideret regi, which Häv. follows, but the pl. opposes (Hitz.). 11. [אלהין קרישין = 'holy Deity,' cf. note on $2^{11}$. Jer. remarks: "praeter Sym., qui chaldaicum ueritatem sequutus est, caeteri spiritum Dei interpretati sunt." $\Theta$ ignored ${ }^{\prime} \cdot{ }^{\prime}$, ק, wh. OrP.c, Lu. supplied, but con-

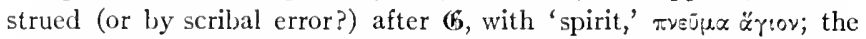

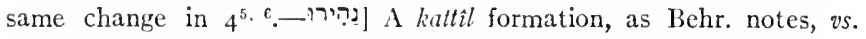
Kau., $\S 16,5$; it is abstract form from the Kt. החירא $2^{22}$, q.v. $\Theta$ tr. by

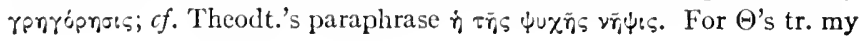


friend Prof. W. R. Newbold has kindly given me an extensive note, which I can only summarize. "This use of rpnyopnors goes back to the Aristotelian tradition," in which غ̇үpŕropors was "exactly equivalent to our "consciousness," " and so it is an attribute of God as "continuously, eternally conscious'; the notion was adopted by Gnosticism, e.g., the divine nature of man is $\ddot{\alpha} \ddot{u} \pi v 0 \varsigma \dot{\varepsilon} \xi \dot{\alpha} \hat{U} \pi$ vou, Poemandres, \$15. He sums up that $\Theta$ "takes נהיר as meaning, not supernatural illumina-

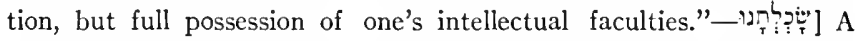
noun form unique in BAram.; for the formation in - $\hat{a} n$ attached to fem. stem cf. .

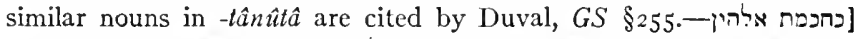

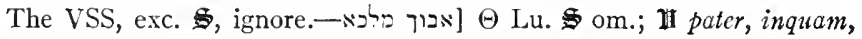
tuus, o rex, which is followed by EVV, throwing the words back so as to follow 'king Neb. thy father.' The repeated subject is unnecessary and is to be elided with Löhr, Mar., Cha. Defence of it can hardly be made as an anacoluthon (Kau., §97, 2), or as emphatic (Pr.); the position of the subject may have floated between the beginning and end of the sentence.-12. ישפלתנו] As Kau., p. 65, n. x, observes, this is absolute and cannot be treated as const. with what follows, vs. some

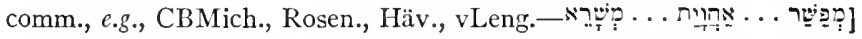
As the second term is an infinitival noun and is used otherwise only in Peal $\left(v^{16}\right)$, $\mathfrak{A l}$ must be wrong in accenting the other two

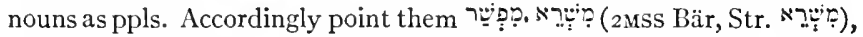
with Bert., Kau. l.c., Kamp., Mar., Löhr, and all recent comm. The three terms constitute a parenthesis, the proper gramm. subjects, רוח etc., being resumed in הישהפת, which is construed in attraction to the leading subject רות. This is the interpretation of II. But en's tradition of the ppls. is very ancient, being found in $\Theta$, followed by $\Theta$ found itself compelled accordingly to manipulate the sentence extensively.-

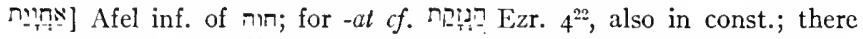
is no reason, with Mar., Gr. $\$ 47$, c, to demand in these two cases the usual ending -ît, which is historically secondary; of. Torrey, Ezra Studies, r $65 f$. The papp. show other varieties of the infs. of derived stems; s. Sachau, $A P O$ p. 270 , col. 2. Similar nouns are found in Heb., GK $\$ 85$, c. tr. by 'âled, 'riddling [riddles].'traditional view of derivation from a rt. חור (so BDB, pp. 295, 1092, also Kön., Hwb.) is to be accepted Lagarde's identification (anticipated, acc. to CBMich., by Cocceius) with Syr. 'uhldâ, rt. אחר; hence Heb. חירד = Aram. אחיר, that which is 'held in' or 'fast.' So Targ. אחירדי 'bolt' (Behr.), and $c f$. use of $\mathrm{m}$ Neh. $7^{3}$ of 'fastening' the gates. See Lagarde, Anmerkungen z. d. griech. Uebersetzung d. Proverbien, 73, Bev., Kau., Aramaismen, p. 30, GB s.v. hebr. חיר . The word, typical of the Aramaic wisdom, was early imported into Heb. (e.g., Ju. $14^{12}$ ), but without identification with the native rt. זמזר אח 'riddles' in APO 
pap. 54, 1. 5, s. OLZ I9r 2, 535, and $c f$. Cowley, $A P$ ad loc.; also $c f$. an

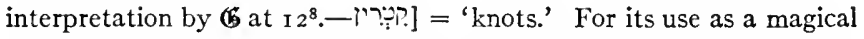
term in Syria and Arabia, s. Bev. and Mar., Gloss. s.v.; the word occurs also in the magical bowls, s. my Aram. Incant. Texts, 88, along with 'ע. B. But preferable (v. sup.) is the mng. 'difficulty' or 'problem'; Dr. cft. Talm., Y cbam. 6ra, Io7b, also the Syr. use, PSmith, col. 359r. Häv. aptly cites Seneca, Ocdip., ror $f$., "Nodosa sortis uerba et im-

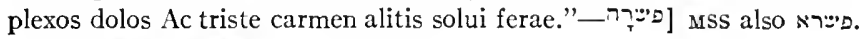
OrP Lu.

13-28. Dan.'s audience with the king. 13-16. The king graciously accosts him as one he had not known (vs. $8^{27}$ ), Thou art Daniel then?-although he had heard of him. His recognition of Dan. as one of the exiles of Judah, $\mathrm{v.}^{13}$, is, as it were, a personal reminiscence of $2^{25}$, and dramatically precedes Dan.'s denunciation of the royal oblivion of the episode of c. 2. The $I$ of $\mathrm{v}^{16}$ is emphatic, of the royal ego. 17-28. Dan.'s response. In 17-21 after refusing the royal gifts but promising to read the Writing, Dan. utters the conclusive indictment of the royal frivolity and sacrilege. It is balanced in two parts: (I) $17 \mathrm{ff}$., Thou, $O$ kingthe Highest God gave thy father kingship, etc., following with the description of Neb.'s acme of glory and its reversal to the depth of beastlike degradation, until he knew that the Highest is potent in the kingdom of man. And (2) 22 ff., And thou his son, didst not humble thy heart, although thou knewest all this. There is no finer example of the preacher's diction in the Bible than this stern and inexorable condemnation. Compare Nathan's indictment of his royal master, I Sam. I2. In this case, unlike that of David or Neb., neither pardon nor respite is offered to the lightminded monarch, for he had known. 23. The realistic picture of the sacrilege in $v^{4}$ is intensified by the spiritual contrast drawn between the gods of earthly material, which see not nor hear nor know ( $c f$. Dt. $4^{28}$, Ps. I I $5^{4 \mathrm{ff}}$, I $35^{15 \mathrm{ff} .}$, Rev. $9^{20}$ ), which were praised in that orgy, and the God in whose hand is thy lifebreath and whose are all thy ways. Bev. well renders the last word by 'destinies'; $c f$. Jer. $\mathrm{IO}^{23}$, 'I know that the way of man is not his own, it is not of man as he walks to direct his steps.'

24. Then is temporal, as vLeng. insists, referring to the moment of $v .{ }^{23}$, rather than causal with $\Theta, \delta i a ̀$ rov̂ro, and some comm. The seer solemnly repeats the details of the vision. It appears that the inscription was left upon the wall. 25. We 
learn at last what the Writing was; it is presented as menê men $\hat{e}$ tekēl hafarsîn. But as earlier Bert. and more recently Peters $(J B L$ I896, I I4-II7) and Torrey (Notes, I, 276-280) have insisted, the actual wording of the original epigraph is the three words which alone are interpreted in the exposition vv. פָּ: menê tekẹl perēs. And that this was the original text in

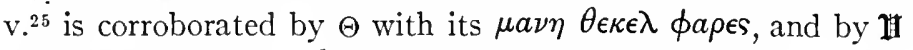
mane thecel phares. The repeated menê and the pl. form with conj., $\hat{u}$-parsin, of the present text are then secondary and do not primarily concern us. Further, as Torrey rightly insists, 1 's tradition of the vocalization of the terms is corroborated by $\Theta$ (the $s w a$ vowel of the first radical being indifferently transliterated by $a$ or $\epsilon$, the second vowel consistently by $\epsilon$ ); this tradition can be carried back to the summary at the head of the chap. in $\mathfrak{G}$, which was known to Jos. $(A J \mathrm{x}, \mathrm{I}, \mathrm{I}, 3)$. The words are nominal forms from the respective roots, and were so understood by Jos., who renders them by ä $\rho \iota \mu \rho \varsigma, \sigma \tau a \theta \mu o ́ s, \kappa \lambda a ́ \sigma \mu a$, in which he is followed by Jer. in his comm. They are interpreted by passive vbs. in vv. ${ }^{26-28}$, and so in 15 and $\Theta$. Acc. to Torrey: "they were vocalized uniformly, after the pattern of the simplest Aram. noun-form qetel ; the most natural form for the narrator to choose, if he wished them to be non-committal"; similarly Peters. The first point in the story is that they were read, and there is preserved the tradition of their vocalization, which vocalization left them abstract, ambiguous. As for their interpretation Torrey's axiom (p. 277) can hardly be disputed: "the man who wrote this tale must be supposed to have known what the solution was." And indeed the tradition of the interpretation is the same in f $_{1}$ and $\mathbb{G} \Theta$. The words are severally translated as pass. ppls., to be translated, numbered, weighed, divided. For the first item numbered there is given the exegesis: God has NUMBERED thy kingdom and transferred it. Involved in the term numbered is the idea of fate and of the destined number of days which have run their course; $c f$. Ps. $90^{12}$, and the mng. of the practically same form in Heb., ?ִ Is. $65^{11}=$ Arab. maniye, 'fate.' Again: Weighed art thou in scales and found wanting. For the divine weighing of human conduct $c f$. Job $3 \mathrm{I}^{6}$, Enoch $4 \mathrm{I}^{1}$ (with reminiscence of this passage), also Ps. $62^{9}$, Prov. $\mathrm{I}^{2}$, $2 \mathrm{I}^{2}, 24^{12}$, etc. And finally: Thy kingdom is DIVIDED (perîsâ) and 
given to the Medes and Persians (pâras). Here a balanced phrase is obtained by finding a double paranomasia in the mystic word, i.e., division and Persia. Were these ominous words first assembled and applied by our narrator; or did he take them from some source and adapt them to his interpretation (so Bev.)? It is to be noted that the play of words gives 'Persia,' not 'Media,' despite the fact that in immediate sequence it is Darius the Mede who destroys the kingdom; the enigma is then based on the correct historical tradition of Cyrus' conquest. (Kran. notes that a play upon מדי 'Media' could have been found in מדד 'measure,' equally ominous with the other words.) The terms may have been actual language of the counting-house or of the law, used of the settling of a bargain, winding up a contract, settling a bankrupt's affairs, or the like.

The above obvious interpretation of the text has been contradicted by an ingenious theory first advanced by ClermontGanneau in $J A$ r886, pp. 36 ff. (= his Recueil d'archéologie, I, 1 36-159), and Hebraica, r887, 87 ff., followed by Nöld., $Z A$ I, 4I4ff. (cf. G. Hoffmann, ib., 2, 45ff.) and generally accepted, e.g., by Bev., Pr. (s. also his dissertation, Mene Mene Tekel Upharsin, Johns Hopkins, I893), Haupt (s. note in Kamp.), Dr., Mar. Cha., who gives a good summary of the different views, is uncertain. Acc. to this view we would have a series of money values:

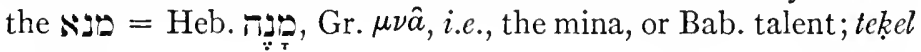
would be the correct Aram. equivalent for šekel; while the discovery of the word 2 on an Ass. weight as equal to a halfmina (s. Clerm.-Gann.), which mng. פר has in the Talmud, appeared to clinch the discovery. Various modifications have been suggested by Haupt, Hoffmann, Mar. (the latter regarding parsin $n$ as a dual). Behr., Peters, Torrey stoutly refused to accept this new interpretation, the latter regarding it as 'untenable and even absurd.' Of Torrey's two arguments against the discovery of money values, that which holds that לpe, not לק, was used in the Aram. world must be modified by the discovery of ${ }^{2} \pi=$ In one case in the papp. (APO pap. 28, 1. 5); as for the other, that the half-mina should be vocalized perâs, entailing correction of the well-authenticated oา: it must be acknowledged we have only Talm. tradition for the vocalization of that word, the corresponding word in Syr. mng. something 


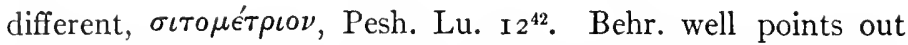
that there is no explanation of the illogical order mina, shekel, half-mina. The phenomenon of the writing Hand is of course meant as a miracle. But the reason why the script could not be forthwith read has naturally puzzled many comm. Heng., p. I22, held that the script was such as could be read only through divine inspiration. Some Jewish comm. have suggested an Athbash method of writing, or supposed that the letters were written in some form of anagram (s. dEnv., p. 4I7) - of course on the theory that the Heb. alphabet is implied. Others, e.g., Grot., Prideaux, have suggested some strange script. At the same time the story may not mean more than that the reading, i.e., intelligent pronunciation $(=k r r e)$ of the consonants forming the inscription $(=k t \hat{b} b)$ was meant, and then with that the interpretation. Similarly ambiguous was Isaiah's proffered enigma, Maher-šalal-haš-baz Is. $8^{1}$.

13. 'אנרה וג' An interrogative exclamation; for omission of particle $\rightarrow \in f$. GK $\$ 150$, a. b. In recognition of the interrogation $Q$ has the unique

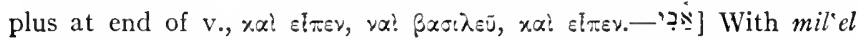
accent. The procession of accent appears which culminates in Syr. in loss of $\hat{\imath}(=\hat{a} b)$; in JAram. this form became GS, p. 88) = N.T. $\dot{\alpha} \beta \beta \alpha$, s. Dalm., Gr. p. 90, n; cf. Behr.-14. אלה ] $]$

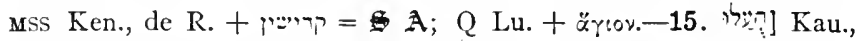
$\S 46,3, c$, understands - here and in but orig. Aram. = hu' alut._-

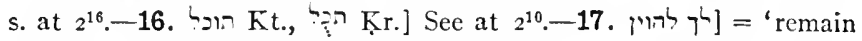
thine'; for this use of הוא in Syr., e.g., Pesh. Jn. ${ }^{40}$; similarly היה in in

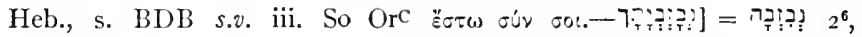

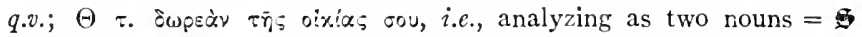

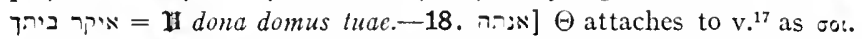

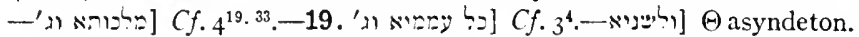

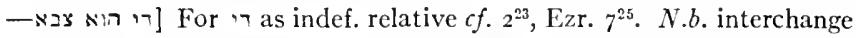

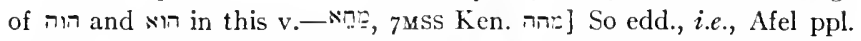
of היה, exc. Mich. $\mathrm{N}_{\mathrm{N}}$ (s. Bär, Gin.) = The latter

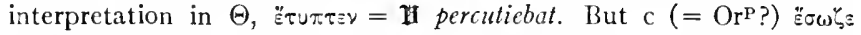
$=$; and so Sa., Ra., Montanus, Grot. and moderns. The vb. is strictly :"», $\in f$. Mar., Gr. $\$ 65$, b, Haupt in Kamp., and for the Syr. s. Nöld., $S G$

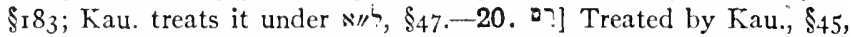
3, I, Torrey, Notes, 276 (cft. . - * 6 64, etc.), as pass. ppl.; but rather with Bev., Str., Mar., GB it is stative form in i, cf. Syr. mît, Heb. תמ, and s.

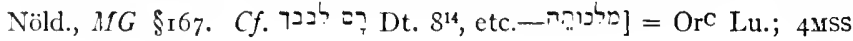




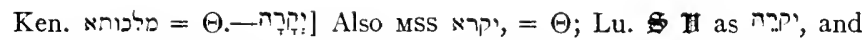

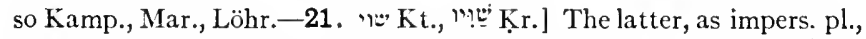
preferred by Kau., $\$ 47$, g, 3, Bev., Kamp., Mar.; the former, !苂, by Behr., Pr., and so Peil ( $\left.c f . \Theta \varepsilon \delta \delta \theta_{r}\right)$. The combination

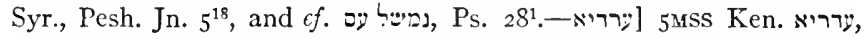
i.e., 'flocks,' preferred by Pr. after JBMich. But the expression is hyperbolic and is consonant with the היות ברה $4^{22}$. For the wild ass $c f$.

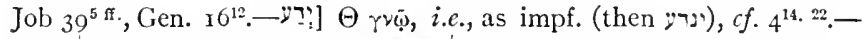

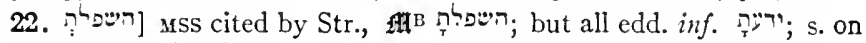
[כל קבל די-_. In the exceptional mng. 'although'; s. at 28.-

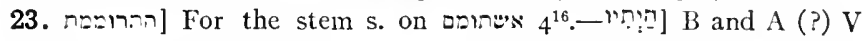

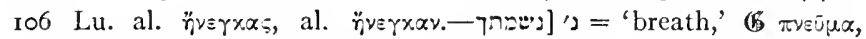
$\Theta \pi v \circ r^{\prime}$; as physical, e.g., Gen. $2^{7}$, Is. $2^{22}$; secondarily of the human spirit, e.g., Pr. $20^{27}$ (parallel to 7 ), Job $32^{8}$. For the context $f f$. "the God of the spirits of all flesh,' Nu. $16^{22}$, and 'the Lord of spirits,' Enoch $47^{4}$ (s. Cha.'s note thereon). N.b. the frequent word attributed to Mohammed in the Traditions, 'by Him in whose hand my spirit (nafs) is.'Construed properly by 2 tl with preceding, = (' implied) 'his.' $\Theta$ treats it, $\alpha \dot{i} \tau \dot{\delta}$, as object of the following vb., and so Kau., $\$ 84$, I, Kamp.

24. 2 ] positively states: "tria tantum uerba in pariete scriptum signauerat: mane, thecel, pharas." The repeated may have arisen from the repetition in $\mathrm{v}^{26}$. S vocalizes here menê mcnâ. The spelling $x y=$ distinguishes the word from $\mathrm{n} j$, the universal spelling of 'talent' in OAram. For פרי 'half-talent,' identified in Clerm.-Ganneau's theory with our סר, s. CIS ii, no. I०. PsSa. notes here one of the mngs. of פ as I/2 mina. Both Sachau's and Sayce-Cowley's papp. present פרס 'in the sense of 'share,' hence probably 'allowance' or 'salary'; in JAram., apart from the sense of $1 / 2$ mina it means a 'portion.' The word also occurs in the Panammu Inscr., 1. 6 (Lidz., $N E$ p. 442), as a grain measure =

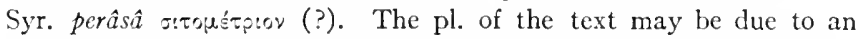
assumed division between the Medes and Persians, as Bert. suggests. It has been constantly interpreted as at once a pl. ppl., diuidentes, and the pl. of מפרס, 'Persians'; in either case the first vowel should be $\hat{a} .-$

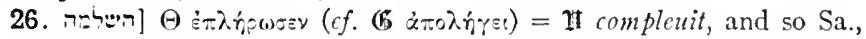
most comm., BD B, Kön., $H$ w b. But in Ezr. $7^{19}$ this Hafel = 'give back,' and deDieu observed that the corresponding Syr. Afel (also appearing here in always = 'hand over, deliver,' i.e., = Heb. רספ?.?. Cf. also IHeb. The Is. $3^{8^{12}}{ }^{13}$; s. (5) and Duhm ad loc. This view is preferred by Behr., Mar., GB, and if there is some legal or commercial lackground to this phrase, as suggested above in the Comm., counting would naturally culminate in paying over.-27. 
2d pers. sing.; the spelling in $\mathrm{k}$ - nicely marks out the form from a possible Peal תקית. $\Theta$, followed by Jer. in his comm., understood this

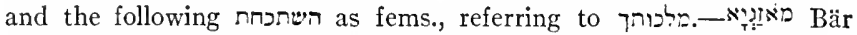
(s. his note), Gin., Str.; משיז Mich., Kit.] The latter form as dual, so also in Mand., would appear more natural; so Kau., \$5I, I, Bev., Kamp., Mar. But the sing. sin is now found in the papp., $A P A \mathrm{G}$,

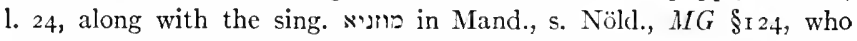
supposes that this is a sing. reduced from the orig. dual in -ayin. For sloughing off of the dual in general s. Kön., Syntax, \$257, e.—Behr. notes, this adjectival form indicates, as against the ppl. Tִ grained characteristic, i.e., 'defective.' -28. ro ra] Sa., Ra., AEz. understood this in sense of ישב 'break'; and so vLeng., followed by Hitz., beld that $\triangle=$ פ 'break down,' on the ground that the Bab. kingdom was not divided but handed over in toto to the Medo-Persians. But the normal sense of פר may be retained, with $\Theta \$ \mathbb{I I}$; when an empire is destroyed its unity is lost, even if it be absorbed as a whole by the conqueror.- - פר?] The $2 \mathrm{~d}-\bar{r}$ is due to Mass. heightening; the orig. form is Pârs. - ' (Behistûn decree), Safaite, Syriac. This form is accommodated to use

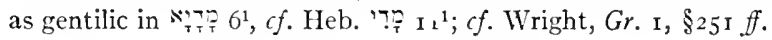

29-c. 6,1 (c. 5, 31). The sequel. 29. Dan. received the promised rewards. 30 . And immediately, in that very night Belsh. the Chaldaan king was slain. C. 6, 1. And Darius the Mede succeeded to [a technical term, lit. received] the royal power, being sixty-two years old. For the historical questions involved s. Int., $\S$ I,$d$. e. The Mass. division concludes the story dramatically with $\mathrm{v}^{30} ; 6^{1}$ follows very lamely, but it belongs as a postscript to c. 5. 'The term 'Chaldæan' is used in its proper ethnic sense (otherwise v.11, etc.). $(\mathfrak{G}$ varies extremely; it om. the note of Belsh.'s death, saying euphemistically that 'the interpretation came upon Belsh.', etc., and revising the succession to Belsh. acc. to some historical theory: 'Artaxerxes the Mede received the kingdom,' while Darius appears in $6^{1}$ without introduction.

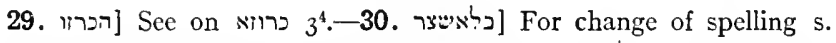
at ${ }^{1}$; ; the change here makes liaison with $7^{1}, 8^{1}$. -

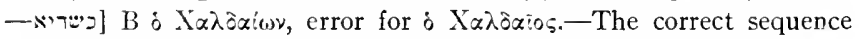
with foll. v. is observed by B Hipp., Jer., etc., and the Western Bibles. Another division appears in A, which begins a new 'Vision' at $\mathrm{v.}^{30}$; this agrees with the chapter division of $\mathfrak{G}_{\mathrm{S}} \mathrm{in}$ the middle of $\mathrm{v} .{ }^{30} .-$ C. 6,1 . T] = Dâriya $(w) u \xi$, the Akk. form of the name; spellings in Aram. 
dockets and papp. (s. GB, p. 168) are closer to the OPers., e.g., דריוהש APO, pap. 1, Dâryawa(h)uš._. ] The phrase 'receive the kingdom' is found $7^{18}$. Here it is used of secular succession, for which use Bev. $f f$. (p. 2o) the same phrase for Julian's succession in the Syr., Hoffmann, Julianos, p. 5, 1. 10. And so II, successit in regnum, and Sa., 'the rule became Darius'.' Hence it is not necessary with Mar., Cha., to read in the mng. that Dan. received it from God, nor with earlier comm. (s. Pole) and modern apologists (e.g., Boutflower, c. I4) to argue that Darius, qua Gobryas, etc., received dominion from Cyrus. Also s. on

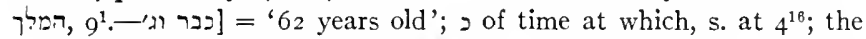

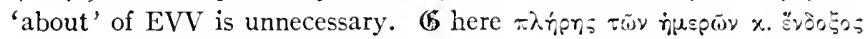

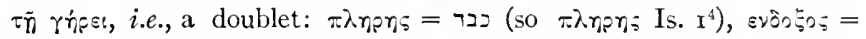
Iב.. Behr. has an impossible solution, working with letter numerals; but s. at $2^{1}$.

\section{NOTE ON THE TRANSLATION OF $\boldsymbol{6}$.}

See Bludau, pp. I49-15r. The text of $\mathbf{6}^{-1}$ is considerably abbreviated. This appears in the curtailment of the king's address to Dan., vv. ${ }^{13 \mathrm{ff}}$, and the total omission of Dan.'s reference to Neb.'s experiences, vv. ${ }^{18-22}$. The omission of both these passages is evidently due to economy; the first of them is a repetition, the second reviews the well-known story in c. 4. For the different order of events in vv. ${ }^{7}{ }^{8}$, and criticism of Jahn and Cha. for their preference of $\mathbf{6}, \mathrm{s}$. Comm. at $\mathrm{v} .{ }^{8}$. In $\mathrm{v} \cdot{ }^{9}$ the king summons the queen for advice, a distinct toning down of the historical color in 谓. We have noted in the sequel of the story the colorless paraphrase and the substitution of 'Artaxerxes' for 'Darius.' In vv. ${ }^{26-28}$ the mysterious words are not given, and the interpretations, except for the first case, $\dot{n}, 0 \mu r \tau \alpha$, are inexact. Those mystic words were probably dropped as unnecessary antiquarian ballast. $V .{ }^{17 b}$ appears to be a later supplement, to give more exactly than is given at vv. ${ }^{25} \mathrm{fr}$. the interpretation of those words; the v. reads: Aürn

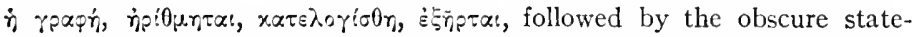

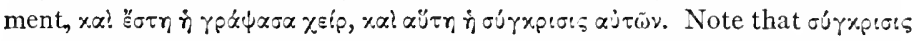
is Theodotionic. It was doubtless in consequence of this failure that a preface was subsequently prefixed to the chap., giving an abstract of the story, concluding with the data of the mystic words and their interpretation. In no respect is $\mathbf{6}$ preferable to 4 ; it appears to be an intentional abstract. There are but slight clews suggesting that $\mathfrak{G}^{\prime}$ 's Semitic text was in like ab-

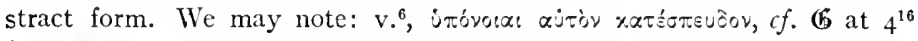
(but $\mathbf{0}$ may simply have repeated from that passage). $V .{ }^{7}, \dot{\varepsilon} \pi$ ? $\theta s \omega$ piav ios:v: possibly a doublet translation. Ibid., $\sigma \tau \sigma \lambda: \varepsilon i \alpha^{j} \tau \delta \nu$, when the origi-

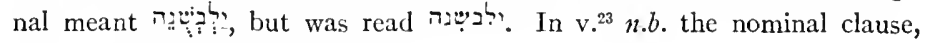

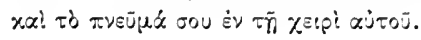




\section{CHAPTER 6. DANIEL IN THE LIONS' DEN.}

(I) 2-10 (1-9). Darius appointed throughout his kingdom I 20 satraps, and over these three presidents, of whom Dan. was one (not 'first' with AV), and the king was minded to make Dan. chief over the whole realm. This purpose aroused the envy of Dan.'s associates, who decided they could find indictment against him only on the score of his religion. Accordingly they conspired to secure from the king a decree, irrevocable according to the law of the Medes and Persians, to the effect that any man who would ask a petition of any god or man for thirty days save of the king, should be cast into the lions' pit. (2) 11-19 (10-18). But Dan. made no change in his public acts of religion, was denounced to the king, and, despite the latter's efforts in behalf of his favorite, was cast to the lions. (3) 20-29 (19-28). Early next morning the king hastened to the lions' den, found Dan. safe, and delivered his accusers to the death they had devised for him. Then the king published a decree confessing Dan.'s God and requiring his people to fear Him.

The story is parallel to that of the Three Confessors, c. 3; Dan. is tested as they were in the supreme article of the Jewish faith. With Bev.: "The main difference is that chap. vi dwells upon the positive side of Judaism." The introduction of a new régime gives dramatic opportunity for this repeated test. There is no inherent impossibility in the escape of a victim thrown to the lions. But the historical character of the story must be judged from the evidently apocryphal character of the whole series of stories in the book. Far more improbable than this material marvel is the alleged edict demanding that no request be made of god or man but of the king for a whole month, an improbability all the greater under the devout Darius. Even the insensate Antiochus Epiphanes, the 'Manifest God,' never made such a claim, and if we desired an historical parallel we should have to come down to the still madder Caligula. The story is based upon the actual solidarity of the Pagan imperialism, in which the king with his despotic power and his formal claims to divine rights was the symbol and summation of the denial of the true God. Hence monarchs like Nebuchadnezzar and Darius, who otherwise are sympathetically treated, appear 
as the incarnation of all the forces arrayed against God. A similar claim of sole deity is attributed to Neb. in Judith $3^{8}$. For defence of this and other edicts in the bk, s. Wilson, c. I6.

2-4 (1-3). Dan.'s preferment. To Darius as the inaugurator of the Medo-Persian empire is ascribed the institution of a new provincial system. The roo satraps (AV 'princes') is an exaggeration, or at least an inaccuracy. Her., iii, 89, records that Darius created 20 satrapies, and that king's inscriptions give their number successively as 2I, 23, 29 (s. Paton at Est. $\mathrm{I}^{1}$ ). Acc. to Est. $I^{1}$ Xerxes had I 27 provinces, which is practically identical with our figure. The same technical inaccuracy is found in the Greek historians, who use 'satrap' of lower officials, e.g., Xenophon; Appian, Syr., 62, speaks of 74 satrapies under Seleucus Nicator. See Comm. and Notes at $3^{2}$. There is no known parallel to the 'three presidents.' The same traditional number appears in I Esd. $3^{9}$. We may possibly compare the triple royal control of the satrapies through the association with the satrap of an independent commandant and secretary; s. Rawlinson, SGM 'The Fifth Monarchy,' c. 7, and Meyer, GA $\S 40$. For the suspicious caution of the whole imperial system against loss of revenue and other damage, $c f$. Ezr. $4^{13 \text { ff. }}$. We have here true reminiscence of the elaborate organization and civil service of Persia. Above all these other officials Dan. was distinguishing himself, not with AV 'was preferred.'

5-10 (4-9). The plot of the rivals against Dan. The story does not tell how Dan. was omitted from the consultation of the conspirators and their presentation to the king-an unnecessary scruple in a good story. 5 (4). The last clause, neither was there any error or fault found against him, is tautologous with the similar phrase in the earlier part of the v., and is apparently a dittograph (so Behr., Cha.). In the account of the conspirators' audience with the king a vb. is used which is translated in AV RVV by 'assembled,' in AVmg RVmg JV by 'came tumultuously.' The same vb. is repeated in vv.12(11). 16 (15). The latter mng., which may be etymologically justified, is impossible both in the court etiquette and in espionage. In the Note the conclusion is reached that it means came in concert, collusion. $8(\mathbf{7})$. The conspirators claim to speak for the entire officialdom. Their ostensibly honorific plea that the king sign a 
decree that none should make request of god or man except of the king for thirty days appears to many commentators as absurd, and probably for this reason $\mathbb{6}$ omits the item. But these stories are generally reasonable; the terms of the request may be meant as a satiric hyperbole, $c f$. Jon. $3^{8}$, where the Ninevite king orders both man and beast to put on sackcloth. Behr.'s position is an entirely sensible one that the implication of the story means a petition of religion (not with Bev. any kind of request), and that this one king was to be regarded for the time being as the only representative of Deity. Such a position was absolutely alien to the religion of the historical Darius, but in the Hellenistic age, when kings vaunted themselves as gods, 'of god or man' was entirely appropriate in the premises. For 'to make a firm decree,' AV, or 'strong interdict,' RVV JV, tr. to put in force an interdict. The terms statute and interdict and writing and interdict, $\mathrm{v}^{10(9)}$, are in the nature of legal pleonasm; cf. Jer. $3^{627}$, 'the roll and the words.' For the alleged irrevocability of the Medo-Persian law, v. ${ }^{9(10)}$, cf. Est. $\mathbf{I}^{19}, 8^{8}$. Bochart, Hierozoicon, I, 748, cites a passage from Diodorus Sic., xvii, 30, ed. Didot, concerning Darius III's attitude toward his sentence of death upon Charidemos: "immediately he repented and blamed himself, as having greatly erred; but it was not possible to undo what was done by royal authority." For the extraordinarily barbarous forms of capital punishment in the power of the Persian king s. Rawlinson, SGM 'Fifth Monarchy,' end of c. 3 ; for the wholesale execution at end of the chap. $c f$. Her., iii, I I 9, Justin, xxi, 4, Amm. Marc., xxiii, 6. For the royal zoological gardens of Assyria s. Meissner, Bab.u. Ass., I, 74, and $c f$. Comm. sup. at $2^{38}$. For the capture of lions for this purpose $c f$. Eze. $19^{8 \mathrm{ff}}$. For the elder material on lions and citation of traditions concerning Dan. in the den, s. Bochart, Hieroz., iii, c. 3; for Rabb. stories, 'Daniel,' $J E$. The earliest apocryphon to the theme is found in the supplement to Bel and the Dragon. The variation of this apocryphon from our story suggests that it is based upon an earlier, popular form of the story.

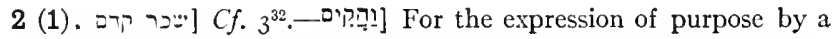

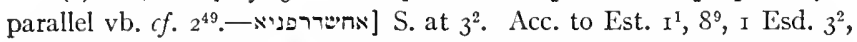
127 provinces, and so $(6)$ reads here. Jos., $A J$ x, II, 4 attributes 360

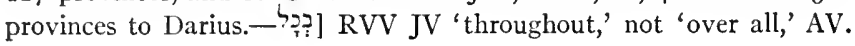




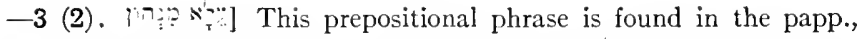
JAram., Syr.; for the acc. form generally accepted, since Ges., Thes., as a Pers. word; s. Bev., Andreas in Mar. Gloss., and Lexx. Behr. proposed a Sem. derivation, = Arab. sarika, 'be associated.' Aq. gives the same etymology in his ouve\%-

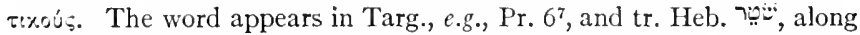

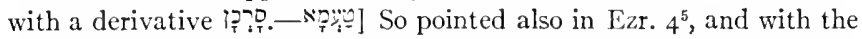
same mng.; the dagesh in $a$ emphasizes the swa with $\ddot{z}$; for other cases of this dag. lene orthophonicum, s. Kau., §9, Anm. 3.—P!̣] For the rt.

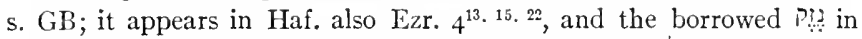
Heb., Est. $7^{4}$. The ppls. of these intrans. vbs., e.g., pointed as katil, not katil, as is to be expected.-4 (3גיהל דנה .4) The pron. may have been intruded here from v. ${ }^{6}, \ldots$ Pars of a presiding officer; the Ethpal appears in the Aram. copy of

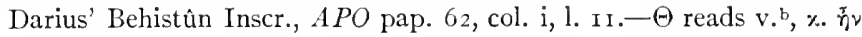

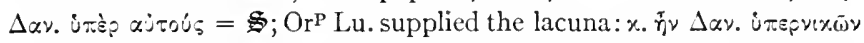

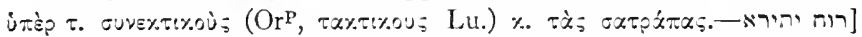

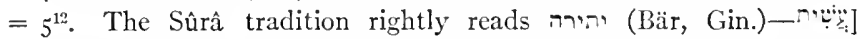
Pass. ppl. with Nöld., GG.1 I884, Ior9, $c f$. his $S G \$ 280$ for similar use of pass. ppl. in Syr.; s. also on $=5^{20}$. Kau., $\$ 38$, I, a, regards $\dddot{\nu}$ as Peal stative with plene-writing, s. $\$ 39$ end. In Sachau's Ahikar papp. עיע appears in the same sense, also the Ethp. F.....; but note that in the papp. the pass. ppl. is always written plene. For the root in Heb. s.

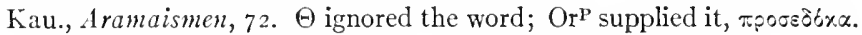

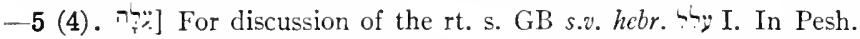
the word is used of a legal indictment, ground of accusation, e.g., Mt. $27^{37}$, as also of a pretext, e.g., Mk. I $2^{40},=\tau_{p} t \rho p \alpha i s$, and so here $\Theta$. [ירהישכהה לרניאר = 'against'; similarly in the Strasbourg Pap., APO

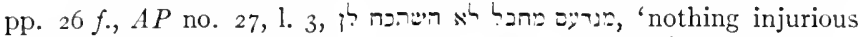

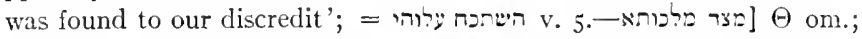

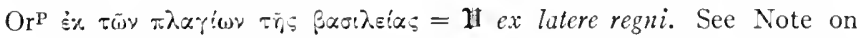
$7 \zeta 7^{24}$. Other cases of the exceptional assimilation of the prep. Ezr.

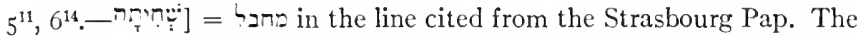

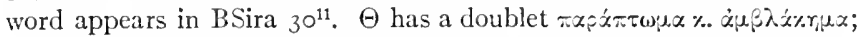
$\alpha \mu \beta$. is an Aquilanic gloss, $c f$. Jer. in Field, appearing again below in Or ${ }^{\mathrm{P}}$._. tion in duty, as above $3^{29} \mathrm{Kr}$. The whole of this last clause of the v. $\Theta$ om., Or ${ }^{P}$ supplies (with $\dot{\alpha} \mu \pi \lambda \dot{\alpha} \% \gamma_{i} \mu x \% \lambda$.). The clause is doublet to

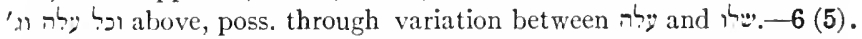

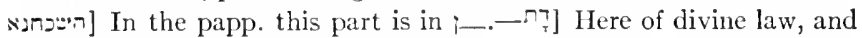
so used of the Thorah Ezr. $7^{12, \text { etc. }}$ inf. $7^{25}=$ 'religion.' The erroneous ר. Dt. $33^{2}$ was so interpreted. It means here as in the Talm. 'religion,' s. Jastr., s.v. 


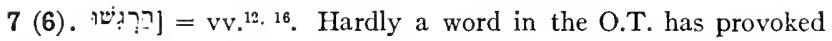
more variety of interpretation than this in its triple occurrence in the chap. The variety begins with the VSS:

\begin{tabular}{|c|c|c|}
\hline v. ${ }^{7}$ & v. ${ }^{12}$ & $v^{16}$ \\
\hline 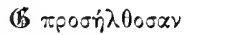 & 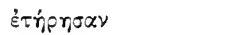 & (vacat) \\
\hline 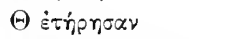 & $\pi \alpha p \in \tau r_{, p \eta} \sigma \alpha \nu$ & (vacat, $\mathrm{Or}^{\mathrm{P}} \pi \alpha \rho \varepsilon \tau \dot{n} \rho \eta \sigma \alpha \nu$ ) \\
\hline קרבו 'drew nigh' & נטרו 'watched' & אריבו 'made outcry' \\
\hline It surripuerunt & curiosius inquirentes & intelligentes \\
\hline
\end{tabular}

II's surripucrunt appears to mean 'they stole away [to the king],' and Prof. R. G. Kent corroborates this with his opinion, although he finds no similar use of the Latin vb. Grot. thinks the orig. rdg. was surrepserunt, 'stole to'; however, the other rdg. is vouched for in Jer.'s comm.: "pulchre dixit, surripuerunt." Similarly the Jewish comm. vary: Ra.

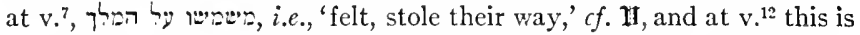

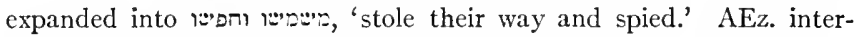

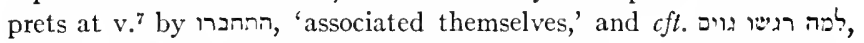
Ps. $2^{1}$, and גהיך ברג', Ps. $55^{15}$. But Sa. tr. by three different vbs.: 'came to'; 'quarrelled with'; 'rushed against.' The comm. of the Reformation followed variously: (I) insidiose aggressi $r \mathrm{cgcm}=\mathbb{H}$; (2) contuenerunt (so Buxt.), congregarunt, or concursum fecerunt $=\mathrm{GV}$ 'drangen,' AV RVV 'assembled'; (3) cum tumultu occurrcrunt (Montanus), tumultuaric conuenerunt (Grot., who however tr. with concursantes at $\mathrm{v} .^{12}$ and conglobati at $\left.\mathrm{v}^{16}\right)$; AVmg RVmg JV 'came tumultuously.' Modern comm. have generally adopted the last mng. It is expressed plausibly by Dr., who tr. by 'came thronging.' But Cha. properly takes exception to 'coming tumultuously' as not suitable to the context here or in vv. ${ }^{7}{ }^{12}$. But Cha.'s remedy lies in textual change; in $v^{7}$ he would read after 'approached,' eliding the word in v. ${ }^{16}$ with $(5)$, and interpreting it in $v^{12}$ after $\$$, 'kept watch, spied,' and so our vb. is used in Aram., e.g., Targ. Jer. Ex. $2^{3}$. But this proceeding is quite too arbitrary. Another line may be ventured upon. It has been observed that in Ps. $55^{15}$ is $\|$ is to and is translated by $\mathbb{G}$

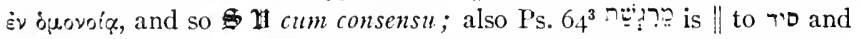
so interprets it. Buxt. also gives the mng. 'fellowship' to רגיא Targ. Pr. $7^{15}$. Further, Briggs in his Comm. insists that רִ Ps. $2^{1}$ means 'consent together.' These instances corroborate AEz.'s התחבר and Ibn Janâh at Ps. $2^{1}$ tr. 'were assembled.' Now in Syr. the Peal and especially the Afel of "' רave the mng. 'to sense, perceive,' etc., gen-

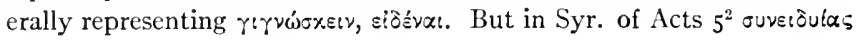




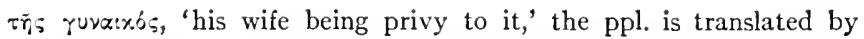
אי.'. The vb. appears then to have developed from the thought of scientia to conscientia, common consciousness, fellow-feeling, and so to common action. A parallel development may be found in the Heb. rt. רהפ, whose occurrence in Ruth $\mathrm{I}^{19}$ the Targ. tr. with רגיו lelism is borne out by the papp. We find the adv. הamônâyit, adverbial form as in Syr.; s. $A P O$ pap. 1, $1.5=A P$ no. 30 , and $A P O$ pp. 26 ff., 1. $4=A P$ no. 27) in the phrase המונית עם וידרנג, which is best translated 'in league with Waidarnag,' so Cowley, following Euting and Sachau 'conspiracy.' There may be noted too המון מעיך Is. $63^{15} \|$ רחוים, where the first phrase = 'sympathy.' Has developed from the sense of 'noise' through 'music' to that of 'harmony'? Compare the figurative use of the latter term. Our vb. הרג' ' then may be taken as mng. 'they acted in concert, harmony,' here practically, 'in conspiracy.'

8 (7). סרכין Here $=$ officials in general; $c f$. the list $3^{2}$, and for the

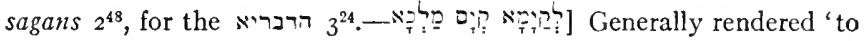
establish a royal decree,' with ignoring of the emph. 'D; מ מ be expected. But with the accents 10 is to be construed as nom. to the inf., so JHMich., Mein., Mar., al., RVmg JV (per con. s. Bev., Dr.). For similar position of subj. of inf. in Heb. s. GK $\$ 115, \mathrm{k}$. Cf. the Heb. Piel Ruth $4^{7}$, Est. $9^{29}$. — ליך] $7 \underset{T}{\mathbb{N}}]=$ = 'confirm, put in force, an interdict'; hardly with most comm., e.g., Bev., 'make a strong interdict' (JV 'strong decree'), Dr., 'make a stringent interdict.' The vb. is || v. ${ }^{9}$. אר אas the Aram. mng. of the rt., 'interdict,' found also in Heb., Nu. $30^{3-15}$, where EVV 'den,' properly 'pit, cistern,' = Arab. jubb, Heb. כור, used of the often bottle-shaped cisterns found in Palestine.s. Kau., §6I, 6, Anm., Nöld., SG $\S \S 79$, I 46. As Bev. notes, the first $\hat{a}$ is EAram., for which of. Nöld., \$49, B; so

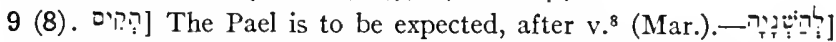
For the act. inf. with pass. implication $c f . A P O$ pap. 54, 1. I4, שפיר

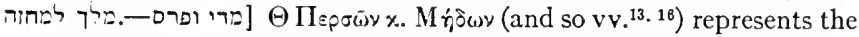
later view of the proportions of Media and Persia. 'Parthians and

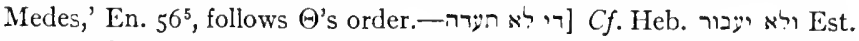
${ }^{19}, 8^{8}$. $\Theta$ om.; the other VSS, followed by Bert., regard the phrase as epexegetical ('so that') to לא להשניה, but the gender of the vb. makes the clause dependent on

11-19 (10-18). The condemnation of Daniel. 11 (10). And when Dan. knew that the document was signed, he went into his house-now he had windows opening in his roof-chamber toward I 8 
Jerusalem-and three times a day he was kneeling upon his knees and praying and confessing before his God, even as he was wont to do before this. The passage is valuable as a picture of the ritual of piety of early Judaism; we note the several items of a special place of devotion, of the direction of prayer toward Jerusalem, of the attitude of kneeling, and of the three times of prayer. For the roof-chamber (EVV, 'upper chamber') cf. Moore on Ju. $3^{20}$ : "an apartment raised above the flat roof of a kouse at one corner, or upon a tower-like annex to the building, with latticed windows giving free circulation to the air," and so used as a place of retirement and spiritual occupation, $c f$. I Ki. I $7^{19}, 2 \mathrm{Ki} . \mathrm{I}^{2}, 4^{10 \mathrm{f}}$. The Gr. equivalent $\dot{v} \pi \epsilon \rho \hat{\omega} 0 \nu$ is found in Acts ${ }^{13}, 9^{37 .}{ }^{39}, 20^{8}$, appearing also in these reff. as a place of prayer. The 'roof-chamber' also appears as a rabbi's apartment in the Talmud, Kethuboth, 50b. He had windows opening out: Ehr. is prob. right in holding the Aram. 'opened,' means windows cut in the wall; $c f$. the identical phrase in the pap. text cited in the Notes and the use of פתח in the Talmud. The window was open at Dan.'s prayers, and this facility of observation and the fronting toward Jerusalem gave the conspirators their opportunity of denunciation. A Rabb. dictum, Berakoth, 34b, cited by Ehr., holds that 'a man is not to pray except in a house with windows,' giving the present v. as prooftext. Toward Jerusalem: This practice is assumed in the (Deuteronomic) prayer of Solomon, I Ki. $8^{35}$ f.; cf. Ps. $5^{8}, 2^{2}$ for the temple as the kiblah; also I Esd. $4^{58}$, cf. Tob. $3^{11} \epsilon \in \eta^{5} \theta \eta$ $\pi \rho o s=\hat{\eta} \theta u \rho i \delta \iota$. The custom is alluded to in the Mishna, Berak., iv, 5. 6. Mohammed borrowed the custom from the Jews, and first made Jerusalem the kiblah, later Mecca; the Christians did not follow this example (against Behr.), although the custom came to prevail of orientating toward the East, s. Bingham, Antiquities, 8, c. $3, \S 2$. Three times a day: $C f$. Ps. $55^{17}$, 'At evening and morning and noon-day will I complain' (but Ps. II $9^{164}$ 'Seven times a day do I praise thee'). Comparing inf. $9^{21}$ (q.v.), where Dan. prays at the time of 'the evening oblation,' the midday prayer in Dan.'s devotions was doubtless that which was later known as the Minllah, 'oblation' ( $c f$. Lev. $6^{12 \mathrm{ff}}$. for the morning and the evening oblation), the evening oblation, offered in the mid-afternoon, having become the chief daily sacrifice and so fixing the most obligatory time of private prayer. For 
the early importance of that sacrifice $c f .2$ Ki. I6 $6^{15}$, Ezr. $9^{5}$, Ps. $\mathrm{I}_{4} \mathrm{I}^{2}$; for the N.T. age Acts $3^{1}, \mathrm{IO}^{3}$; and for the Rabbinic order of the three daily Prayers Berak., iv, I. On the subject of the stated prayers s. Hamburger, $R E$ 2, 'Abendgebet,' 'Minchagebet,' 'Morgengebet'; Zunz, Gottesdienstliche Vorträge, 368 ff.; Schïrer, GJV \$24, n. 40 and \$27, Anhang; Bousset, Rel. d. Jud., 202 ff. This custom of the three daily times of prayer

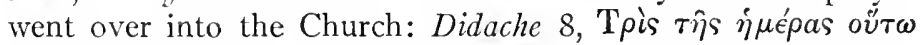
$\pi \rho \circ \sigma \epsilon u ́ \chi \epsilon \sigma \theta \epsilon$ (i.e., with use of the Lord's Prayer); s. Harnack, $T U$ ii, parts $\mathbf{I}-2$, p. 27 . Of the five obligatory prayers in Islam the third, the most important, șalât al-'așr, is at the time of the Minhah. He was kneeling: The attitudes of prayer in the Bible are various (s. Hamburger, $R E_{\mathrm{x}}, 408 ; D B{ }_{3}, 7 f$.); in early Judaism kneeling came to be common, cf. Ezr. $9^{5}$, and the numerous reff. in the N.T. Later Judaism appears to have abandoned it; in the Church it was the rule with definite exceptions at certain seasons and occasions, s. Bingham, l.c., c. 8. Before his God: This circumlocution was common in courtly language, $c f$. 'speak before the king,' v. ${ }^{13}$, etc.; for this usage in Judaism s. Dalman, Worte Jesu, I 7 I.

12-14 (11-13). Then those men came in concert [s. at v. ${ }^{7}$ ] and found Dan. engaged in his customary and well-known devotions. They bring their denunciation to the king, first assuring themselves of his acknowledgment of the irrevocability of his edict. The theme is an early dramatic instance of the outwitting of an innocent ruler by his own laws; Dr. compares the case of Herod, Mt. I4. This legal point clinched, Dan. is denounced. 15 (14). Then the king . . . was sore vexed [not, 'at himself,' with AV], and on Dan. he set his mind to deliver him; and he was striving till sunset to rescue him. 'Striving' is the picture of the animal caught in the toils; he consulted the lawyers, he tried to browbeat the conspirators. 16 (15). The latter resorted again to the king in the evening and impudently demanded their prey. 17 (16). The king had to yield. But his admiration for Dan. made him express the assurance that the latter's God would deliver him-in striking contrast to Neb.'s impiety, $3^{15}$. 18 (17). The execution of the sentence was made sure by closing the mouth of the pit with a stone and sealing it with the seals of the king and his lords. The object of the sealing is well expressed by a plus in $\mathfrak{G}$ : that Dan. might not be taken away by them or 
raised up by the king. As protection against the king, his chancellor was doubtless charged with his signet; $c f$. Ahikar as the king's Great Seal (in the first of the Ahikarar papp., 1. 3). As observed in the Note at $\mathrm{v}^{8}{ }^{8}$, the pit seems to have been conceived as a deep cisternlike cavity, the mouth of which above could be closed with a stone, and so sealed. The writer may never have seen a lions' den. Those who urge the historicity of the story, e.g., dEnv., insist that the mouth, or entrance, may have been on a lower level, as in the case of bear-pits in our zoological gardens. Why, then, a stone and not the regular gate, and why was Dan. hauled up, v. ${ }^{24}$ ? For the royal sealing $c f$. I Ki. $2 \mathrm{I}^{8}$, Est. $3^{12}, 8^{8.10}$. For Persia Her., iii, $\mathrm{I} 28$, refers to Darius' seal, a copy of which is known, s. Rawlinson, $S G M$ 'Fifth Monarchy,' c. 3, n. 456. 19 (18). This second act ends with the king retiring to his palace, where he passed the night fasting and sleepless and without his usual diversions. We may accept the latter non-committal translation (JV) of an obscure word. See the Note for the many essays at interpretation: 'foods,' 'musical instruments' or 'musicians,' 'dancing women,' 'concubines.'

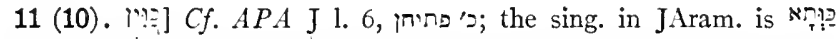

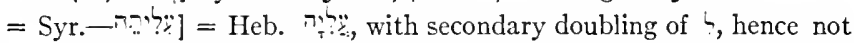

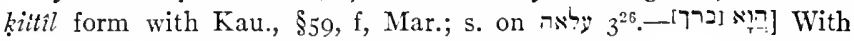
Str., Bür, Löhr, = $\Theta$, vs. Mich., Gin., Kit. הואר; the former rdg. is substantiated by the VSS.- בְרבי Bär, 'Caph raphatum teste Masora';

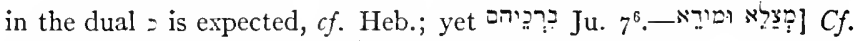

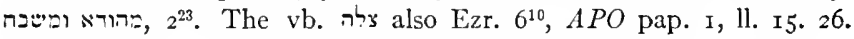

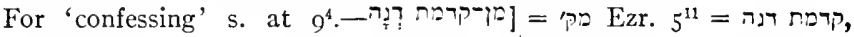

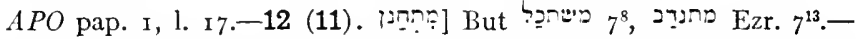

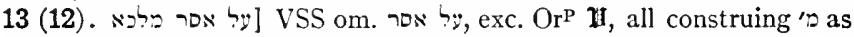

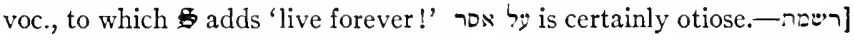

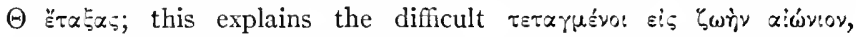

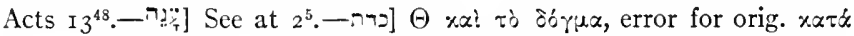
(so V I28), with suppression of the required relative.-14 (13).

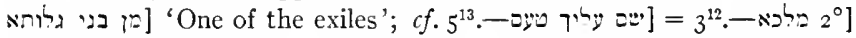

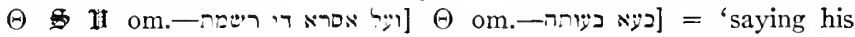
prayers'; it is not necessary, with Cha., to supply ' to his God' after $\mathbb{B} \Theta$. -15 (באיש עלוהי . The vb. is impersonal, with resumption of the

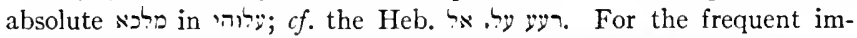

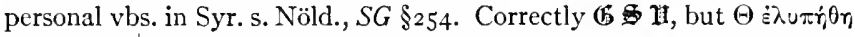

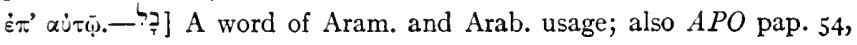


1. 3.- -

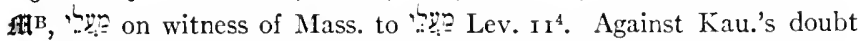
as to the form, $\$ 6 \mathrm{I}, 3, \mathrm{~b}, \mathrm{~s}$. Nöld., GGA I $88_{4}, 1020$, adducing the Syr. construct pl. ma'âlai. For the pl. cf. Syr. madnâhai šemšâ and Heb. בוצאתי The vb. in $A P O$ pap. II, I. 4, of legal action.

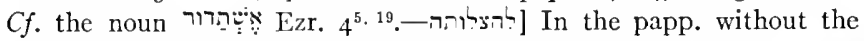
assimilation of $2 .-\mathrm{V}$. $\mathrm{b}$ is omitted by B 106 I48 $22823023 \mathrm{I}$; the lacuna is due to haplography of the double $s \xi \varepsilon \lambda \varepsilon \sigma 0 \alpha$ for the two vbs. of

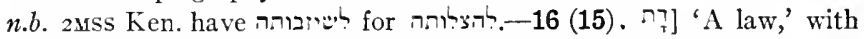
RVV JV, or rather 'law,' not 'the law' with AV; OrP $\delta \delta \gamma \mu \alpha$, al. to $\delta$.

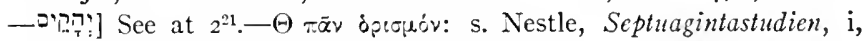
II, who shows that $\pi \bar{\alpha} v$ is used for masc. acc., e.g., I $\mathrm{I}^{38}$, Ex. $\mathrm{I} 2^{44}$. The

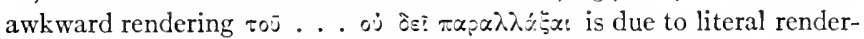
ing of $12^{\circ}=$ ז05.-17 (16), " the noun is used in Targ. = ר, and also as adv. Kau., $\$ 60$, 6, erroneously regards the form as 'Abplattung' of and v. b, on logical grounds (cf.v. $\left.{ }^{25}\right)$. But ' אמר והיתיו וגר = "he commanded to bring,' etc.; cf. $2^{13 .}{ }^{49}$ and s. Mar., Gr. \$r 30 , c.-18 (17).

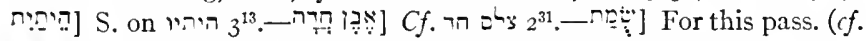
ט $\left.3^{29}, 4^{3}\right)$ is to be expected with Kau., Str., Mar., al. Torrey, Notes II, 233, thinks of a combination of

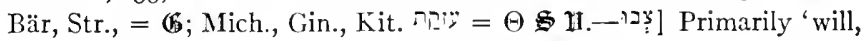

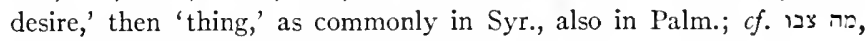
$A P O$ pap. II l. 6. The VSS tr. correctly; Calv., al., 'purpose,' $=\mathrm{AV}$, corrected by RVV JV '(no)thing.'

19 בנבָ (18) The vb. in Akk. and Aram. For relation to noun s. Lexx. and Haupt, SBOT Kings, p. 210.-. Tr?] The fem. as adv., the same form in Syr.; Kau. om. the word in the pertinent \$67._- In:? Gin.

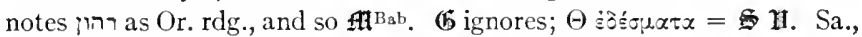
Ra. understood it as of 'table' (i.e., 'boards,' s. Talm. Lexx.); AEz. of 'musical instruments and songs'; similarly PsSa., 'musicians.' Levi b. Gerson, cited by Gallé, plays on the rt. רחה, "they drive away sorrow," or "perhaps they are raconteurs." Similarly Calv., 'instruments of music' = AV RVV, and deDieu etymologizing with 'pulsationes.' (But deDieu prefers combination with Arab. duhân, 'incense.') The Heb.

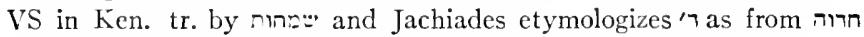
'plcasure'; hence GV 'liess nichts zu Lust vor sich bringen,' and JV 'diversions.' The idea that the word implied women appears in PsSa.; cf. ' ר? 'reveller,' cited by Jastrow, Dict. This line of explanation is followed by Bert., interpreting from Arab. dahâ 'subiccit feminam.' Hence RVVmg, 'dancing girls,' and Mein., Behr., 'concubines.' In agreement with this idea Mar. (Gr.), Pr., Cha. regard the word as corruption of in $5^{2}, q . v$. Haupt, there cited, regards the theme here, dah, as primary, לחנה as secondary development. That the vb. העיל is used 
only of persons, as assumed by Mein., is denied by its use in Targ., e.g., Gen. $6^{19}$. That the king had concubines brought to him would make of his evenings an absurd variety-hall entertainment. The scepticism of Bev., Dr., that the mng. is 'unknown' remains unimpeached, and JV's 'diversions' is good because it is non-committal.—.

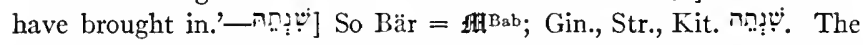
former is the Syr. pronunciation. Kau. explains $\left(\S \mathrm{r} 2, \mathrm{~d} ; \S_{5} 6,2\right.$, b) as a case of dagh. $f$. dirimens, on which Nöld. remarks (GGA I884, гог8): “kein geheimnissvoller 'D.f.d.'; die vereinzelte Bildung schliesst sich ganz den med. gem. an," i.e., as though from iw, not i '

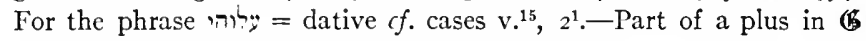

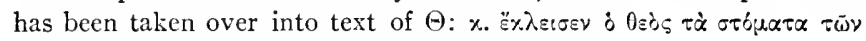

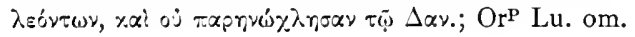

20-25 (19-24). The deliverance of Dan. Then the king arose very early in the morning, so EVV; more exactly the adv. expresses 'the dawn,' and 'in the morning' the time when the sun was visible. When near the den he called to Dan. with a voice full-of-anxiety (AV 'lamentable, JV 'pained'), inquiring if his God had been able to save him. Dan. gives the joyful answer that God had sent his angel and closed the lions' mouths. The king in his joy commanded that Dan. should be lifted up, and then no manner of hurt was found in him because he trusted in his God. (RVV JV, better than 'believed' of AV; the OLat. preserved in Cypr. has confidebat, vs. Il crediderat). The theme is that of Heb. II, which refers to this story at $v .{ }^{33}$. The king thereupon commanded that his accusers with their families should be cast into the den. These became the prey of the ravenous beasts before their bodies reached the bottom; the story depicts them falling into the open mouths of the lions. Exception has been taken (e.g., by Jahn) to this wholesale destruction of some I 30 victims, which it is alleged the text of $\mathbb{B}$ simplifies by making the victims only the two co-presidents. But as is shown in the appended Note on $\mathbb{B}$ this is a secondary simplification. The tragic dénouement is indeed absurd, but the narrator doubtless ignored the large number at the beginning of the chap.

26-29 (25-28). The king publishes an edict requiring of his subjects in all (not 'every' AV) the dominion of my realm to render religious respect to Dan.'s God. The address and the contents of the edict are closely imitated after Neb.'s address, 
$3^{31-33}\left(4^{1-3}\right)$. Especially the end of the story reveals the nature of the theme as borrowed from c. 3. With Bert., Mar., JV the contents of the edict, $\mathrm{vv}^{27}{ }^{276) \mathrm{f}}$, are in poetical form. The appellation of Dan.'s God as the Living and ever-enduring God repeats on the one hand a typical phrase of the Heb. Bible, "the Living God,' also used by the king in v. ${ }^{21}$. The other attribute, an Aram. word, is an epithet of God in the Targ., e.g., Eze. $\mathrm{I}^{24}$, and in the Rabb. literature the same combination is frequent. 'The Enduring One' is a constant epithet of Deity in the Samaritan literature (s. Montgomery, Samaritans, 2I 5), and was a term which acc. to tradition Simon Magus arrogated to himself, $=\dot{\epsilon} \sigma \tau \omega \dot{s}$. The ref. to Cyrus in the final v. loosely connects with $\mathrm{I}^{21} ;$ cf. $\mathrm{ro}^{1}$.

20 (19). ベา

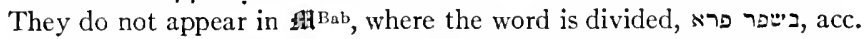
to Gin. the Or. rdg. For the kataltal formation s. Barth, Nb., §I47, Duval, GS $\S 243$, Nöld., $S G \S$ I $24, \mathrm{GK} \S 84$, n. The word appears in the Targ., = Syr. safrâ, sefrâ (also JAram. s's s). The rt. appears in Arab. safara, 'to lighten' (of the dawn). The manipulation of the letters indicates the two possible rdgs.: the reduplicated form and simple שפר; so Torrey, Notes, II, 233. The parallel בנגרה is the time when the sun had risen, $c f$. Pr. $4^{18}$, and marks the exact specification of 'כגר נגור, which means more generally 'at dawn.' For an apparent parallelism in Mt. $28^{\prime}$, s. G. F. Moore, $J A O S$ 26, 323-329. Kamp. is fully right in rejecting the treatment of one or the other term as a gloss, of ' 2 ' by Kau., in his Schriften d. A.T., of '2 2 by Behr., Mar., Löhr, Ehr. $65 \Theta$

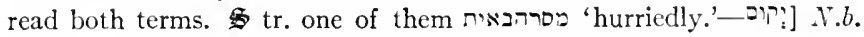
the impf. with יאר, exactly as the Ifeb. construction with $ז$; s. Mar.,

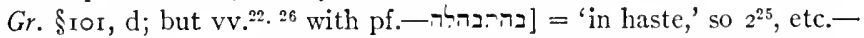

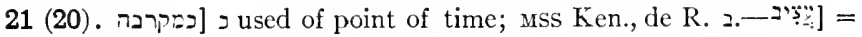
'pained, painful,' cf. Heb. rt.; Bev. cft. Arab. yaumun 'aşîbun, Koran

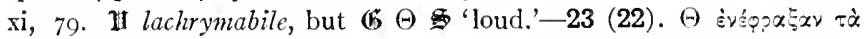

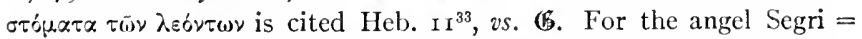

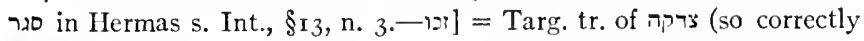

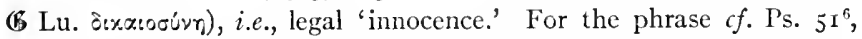
Job $25^{4}$ f. - חנבולה] So edd. correctly as fem., exc. Bär s__-24 (23).

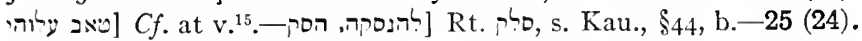

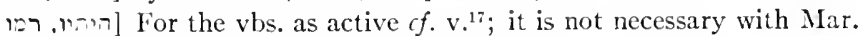
to read them as passives; רנומן was taken by $\Theta$ II as pass.- For abs. use $c f .7^{17}$ - בניהון ונישיהון [1t prefer the logical order, 'wives, sous'; $f f$. a similar reversal of order at $2^{35}$. - ' 


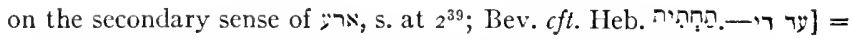
practically 'before,' $c f$. use of Arab. hata(y), Wright, Gr. 2, $\$ 15$, c. Behr. notes that the clause with this conj. in late Heb. and Aram. generally includes a negative, $c f$. Ecc. I $2^{1}$; Syr., Acts $2^{20}$ (but not Mt. ${ }^{25}$ ). - הדקו]

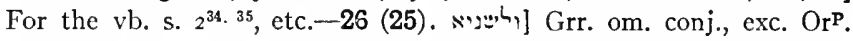

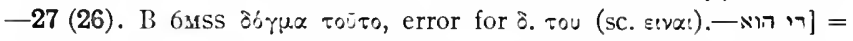
'who' (EVV 'for he').-28 (27). T'] = 'power,' cf. I Sa. $17^{37}$ (where EVV tr. 'paw'); Lu. $\sigma \tau b \mu \alpha \tau \sigma$, ${ }^{\mathrm{Am}}$ manu, but text. rec., Cypr. lacu. $-n_{-3} ;$ ] The intrans. and the trans. use $\left(3^{30}\right)$ of $n^{4} s$ also in Syr. $=$ Heb. Hif.

\section{NOTE ON THE TRANSLATION OF $\mathfrak{( 5}$.}

The variations of $\mathbb{G}$ in this chapter are surveyed by Bludau, $\S 20$, who comes to the conclusion that we have here rather 'a working-over than a translation.' With this judgment the present writer agrees, over against the criticism by Jahn, who offers a running and derisive depreciation of the text of Cha., despite his preference for ignores it in this chap.

(5)'s text is marked with doublets, e.g., v.(3), vv..(3. 4), v. ${ }^{(14)}$, and vv. ${ }^{(19 .}{ }^{23)}$, with the double statement of the presence of the officials with the king at the den (and with reminiscence of $3^{27}$ ). There are several short additions: description of Dan.'s honor, v. ${ }^{(3)}$; the lively word of cheer put in the king's mouth, 'Keep up courage till to-morrow,' v. ${ }^{(16)}$; the statement that 'then the God of Daniel took forethought ( $\pi$ poros $\alpha$, which occurs only in Wis. and the books of Macc., also frequently in Josephus) of him and stopped the mouths of the lions and they did not trouble Dan.,' v. ${ }^{(18)}$, which replaces Dan.'s assertion in $v^{22}$, that 'God sent his angel,' etc. In v. ${ }^{(27)}$ the king is made to say that he will serve Dan.'s God all his days, because hand-made idols cannot save, etc. In v. ${ }^{(28 s)}$ the statement of Darius' death is awkwardly inserted before $v_{0}{ }^{b}=v^{28}$. For other variations we may note the conspirators' 'adjuration' of the king 'by the laws of the Medes and Persians,' v. ${ }^{12 a}$; the sarcastic touch with which the enemies dare to speak of Dan. as the king's 'friend,' $\mathrm{v}^{13}$ (but s. inf.); the placing of the king's word of cheer to Dan. before the latter's being cast to the lions, vv. (16. 17); the query, 'Art thou alive?' v. (20), and Dan.'s response, 'I am still alive,' v. ${ }^{(21)}$.

Apart from some lively touches, which are characteristic of (fos's genius, for the later handlers of the story were themselves good story-tellers, none of these points can be given preference over while the presence of doublets and repetitions is primary proof of the secondary character of $\mathfrak{B}$ as we have it. Only one point can be made for the reliability of $\mathfrak{s}^{3}$ as the simpler

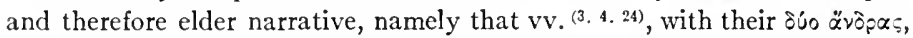

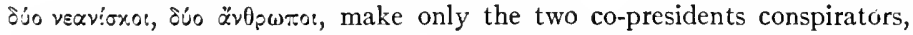
and only these with their families the victims of execution instead of the wholesale slaughter described in wist, which latter we must grant is an ab- 
surdity (but $\mathrm{s}$. Comm. on vv. ${ }^{20 \mathrm{fr}}$ ). The writer has discussed this criticism in a Note in $J A O S{ }_{4} \mathrm{r}, 316$, to which the reader is referred, as also to the reply to it made by Prof. N. Schmidt in his art. 'Dan. and Androcles,' $i b$., $46, \mathrm{r}-7$. The result obtained in that Note is that the Sem. copy before $\mathfrak{B}$ made all the officials conspirators as definitely as The $_{\text {. Thent text }}$ of $\mathfrak{G}$,

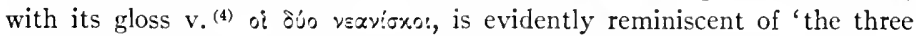
youths' of I Esd. $3^{4}$, and had in mind the rivalry of the two youths with Zerubbabel; so also Nestle, MIarg., 28. (Acc. to Lagarde, Mitth. 4, 3 I $8, c f$. $G G_{A} 1$ I891, 519 , the story of the Three Pages once stood after Dan. $6^{(1)}$.)

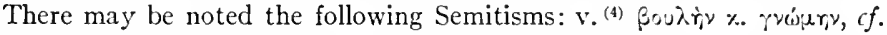

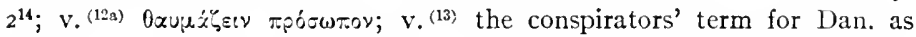

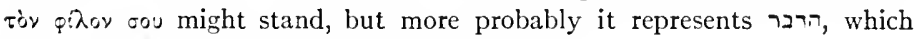

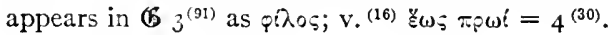




\section{THE VISIONS.}

\section{CHAPTER 7. THE VISION OF THE BEASTS AND THE MAN.}

With c. 7 begin the Visions, a book of independent origin from the Histories; see in general Int., $\$ 2$ r. The view of some recent scholars that the original language of c. 7 was Hebrew is there adopted, Sect. $b$. And for theories of interpolations in c. 7 and for its origin as disparate from the following cc. see Sect. $c$. With regard to the literary form, the chap. is treated as on the whole prose with poetical rhapsodies, at vv. ${ }^{9} .10,13.14$, 23-27; so Mar., Löhr, Cha., while JV expresses poetical form in the first two passages.

Analysis. 1. The circumstances of the Vision. 2-27. The Vision in two parts, 2-14, the phenomenon, and, 15-27, its irterpretation by a celestial attendant. 28 . The sequel, the effect on the seer.

The seer sees the four winds of heaven agitating the Great Sea, from which issue four diverse monstrous beasts: the first like a lion, the second like a bear, the third like a leopard, while the fourth is so horrible that it defies any zoological category. The latter engages his attention; in addition to its ten horns he beholds another of small size coming up, before which three of its predecessors are eradicated; the horn exhibits the spiritual traits of a human being. There follows the vision of a Session of the Divine Court, in sequel of which the fourth beast is destroyed. Then there appears coming with the clouds of heaven one 'like a son of man,' to whom universal dominion is given. The seer appeals for interpretation of the dream to one of the divine bystanders; he interprets it as typifying so many kingdoms, with special explication of the fourth beast and its horns, which are kings, the little horn being the blasphemous opponent of the Highest. But the divine Session typifies that beast's destruction, and the grant of universal dominion to the Saints of the Highest. 
The vision is a reminiscent replica of that of the Image in c. 2. With the four metals there correspond the four beasts here, while the divisive character of the lower part of the Image, which is of iron mixed with tile-work, is paralleled here by the conflict between the horns in the fourth beast. In both the kingdoms of this world are superseded by one of mysterious or celestial origin, there a Stone cut without hands, here a heavenly Man, each representing the divine kingdom that is to be. In both there is the same sequence of acts, representing the progressive degeneration of the kingdoms of this world: from gold to iron, the basest of metals, from the eagle-winged lion, typifying the kings of beasts and birds, down through the meaner bear and leopard to a nameless monster, whose business is destruction. There is explicit reminiscence of the malignant character of the fourth kingdom, $c f$. vv. ${ }^{7}{ }^{19}$ with $2^{40}$.

In simplicity and grandeur of theme this vision falls behind that of c. 2. But in this vision the author allows himself more room for fantasy, as in the details of the first three beasts, which have accordingly offered large room for inventive ingenuity on part of exegetes. On the other hand, the introductory scene of the four winds agitating the Great Sea and eructating the four beasts tastes of ancient mythological poetry, from which the theme takes its start; and the scene of the Divine Session with the coming of the Son of Man is appropriately sublime, one which has no equal among the other apocalypses for simplicity and reserve.

Commentators all agree in giving identical interpretation of cc. 2 and 7 . The present writer agrees with the great majority of modern commentators in understanding by the four successive metals or beasts the several empires of Babylonia, Media, Persia, Greece, for the discussion of which s. Int. $\$$ I $9, c$. There is more diversity of opinion concerning the interpretation of the Son of Man, whether he is to be regarded, like the Stone, as directly Messianic or as symbolical of the people of the saints; the latter view is held here. On this subject see the Note at end of the chap.

1. In the first year of Bclshazzar king of Babylon Daniel saw a dream and visions of his head upon his bed. Then he wrote the dream. [Beginning of the composition.] [He said doublet.] $\mathbf{2} a$. Daniel answered and said. The usual translation of the last 
words of v.' is: 'he told the sum of the matters,' in the sense of 'essence,' 'recapitulation,' as though an abstract were given; so $\mathbb{B} \mathfrak{\mathbb { H }} \boldsymbol{\mathbb { I }}$ Jewish comm. and most. But the phrase is manifestly a title, 'beginning of the story, or book,' and so Aq. (at least $\mathrm{Or}^{\mathrm{P}} \mathrm{Lu}$.) understood it, followed by Theodt., Pagnini, Vatablus, and in modern times by Nestle, Marg., 40, Kön., Hwb. So Torrey, Notes, I, 28I, remarking the similar use of 'head' PalSyr. for chapter headings; he regards it as gloss, with the implication: "Here begin the "personal memoirs' of Dan.," etc. As a gloss it may be appositive to $v^{28 a}$, "Here the end of the matter.' Nestle (cf. Kran., Mein.), comparing 'at the beginning' $9^{21}$, regards it as the original title of the series of cc. and so appositive to $2^{4}$, in which case what precedes would be secondary. We may best suppose early duplicate essays at entitlement, this phrase having in view the whole series of cc. 'Then he wrote the dream' is a summary statement of the subsequent literary composition. For the writing of the vision $c f$. the angelic order, $\mathrm{I} 2^{4}$, and also Is. $8^{16}, 30^{8}$, Hab. $2^{2}$, Rev. $\mathrm{I}^{19}, 2 \mathrm{I}^{5}$, 2 Esd. $14^{37}$ ff.

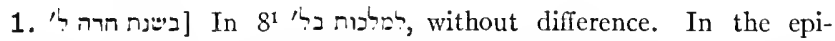
graphic texts the king's name is used absolutely without the prep., e.g., Sachau's pap. I, Clay, Aramaic Indorsements. For $\pi p \omega \epsilon \omega$ B the unique

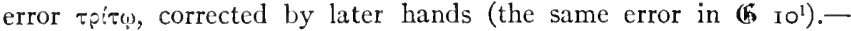

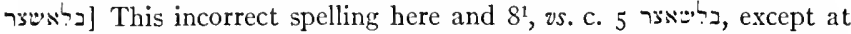
$v^{30}$, where the spelling was accommodated to the present for liaison's sake. The difference of spelling is a proof of diverse origin of the two parts of the book.- בכ2] $\Theta \chi \alpha \lambda \delta \alpha i \omega \nu$, with reminiscence of $5^{30}$.חח bed'] Cf. $2^{28}, 4^{2 .}{ }^{10}$. As the v. is reminiscent of the earlier book, it is not necessary with Torrey to supply יבהילנה, or with Löhr to omit 'and

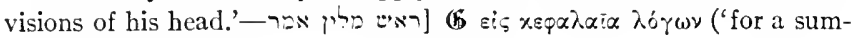

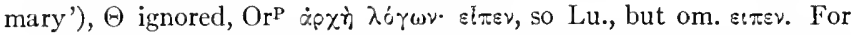
the phrase $\epsilon f$. ר. ראי . Ps. I1 $9^{160}\left(c f .137^{17}\right)$. II has an interesting doublet translation: breui sermone comprehendit summatimque perstrinsens ait. The same phrase occurs in the Syriac Menander, s. Land, Ance. syr., vol. I, f. $\mathrm{I} 63 \mathrm{~V}=$ 'the first business' of a man. As for the

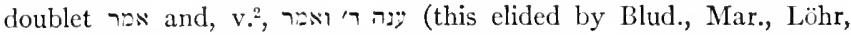
Cha.), (5 om. both, $\Theta$ the former; but $\Theta$ has a trace of the second phrase

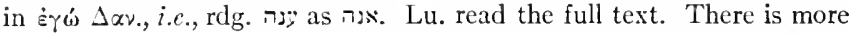
textual authority therefore for the retention of this phrase than of 'he said,' and the former is to be preferred for its genuine Aramaic flavor. 
$2 b-8$. The vision of the four beasts arising out of the sea. $2 b$. I was seeing in my vision by night, and behold,

The four winds of heaven: were stirring up the Great Sea.

For the introductory phrase $c f .4^{7.10}$; it is repeated eight times in this chap. $C f$. the repeated ' $I$ saw' in the vision of doom, Jer. $4^{23 \text { ff. }}$. The Grr. tr. the vb. with $\theta \epsilon \omega \rho \epsilon i \nu$; however, in Aram. the one vb. does for both physical and spiritual vision; in Rev. opâ $\nu$ is used. The four winds are the cardinal winds, 'the south wind, the north wind, the east wind and the west wind' of the Bab. Seven Tablets of Creation, iv, 43 ; cf. Eze. $37^{9}$, etc. They are not the patron angels of the four kingdoms, with Jer., nor angels in general, with early Prot. comm. and Keil; nor is there any particular mythologizing strain, with Gunkel, Schöpfung, 329 , or W. R. Smith, suggesting a connection with Phœnician cosmogony, s. Bev., p. I 20, n. I. Far more apt for the picture of storm at sea are the Classical reff. adduced by Grot., al.; e.g., Verg., Aen., i, 86 ff., naming Eurus, Notus, Africus; Ovid (cited by dEnv.), Tristia, i, eleg. 2, describing Eurus, Zephyr, Boreas, Notus, and remarking pertinently, "Nescit cui domino pareat unda maris." The winds are the product of the sea, and so 'hurricanes and mighty tempests' are the spawn of the evil domain of Chaos, Bab. Seven Tablets, iii, 30 ff. The 'Great Sea' is not the Mediterranean, with Grot., Hitz., al. (also Nestle, Marg., 39, as possible), although the term is so used in Jos. $\mathrm{I}^{4}$, etc., but is the תiת 'Great Abyss' of Am. $7^{14}$, Is. $5 \mathrm{I}^{10}$, and our phrase is properly cited, Rev. I $7^{8}$, as 'Abyss.' It is used symbolically of 'the agitated world of nations' (Dr.), so Hipp., Jer., Theodt. The ocean is an appropriate symbol, ( $\mathrm{I}$ ) because it is a common type of the turbulent world and peoples; $c f$. Is. $I 7^{12 \mathrm{f}}$, Jer. $46^{7 \mathrm{f}}$, Rev. $\mathrm{I} 7^{15}$ ('the waters . . . are peoples and multitudes and nations and tongues'); and (2) following so far Gunkel's lead, because the chaotic ocean is the figure of the domain of all that is opposed to God; hence the beasts are regarded as automatically arising out of their appropriate abode, even as the monsters of the Bab. epic. A breath of this repugnance to the abyss of waters appears in the N.T. seer's vision that 'there was no more sea,' Rev. $2 \mathrm{I}^{1}$. The contrast is given in the heavenly scene, vv. ${ }^{9 f}$. That by the sea is meant the earth is directly declared, $v^{.}{ }^{17}$, and in $v^{4}{ }^{4}$ the figure passes into the 
thing signified, 'from the earth.' Were stirring up: So several recent comm., unconsciously following Calv.'s original suggestion; AV 'strove upon' and RV JV 'brake forth upon' represent the other interpretations.

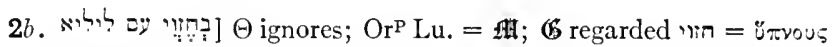
as pl., which as 'In is to be preferred, cf. 'visions of the night' v.?

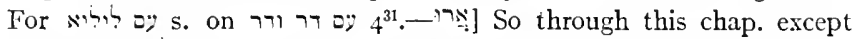
v. ${ }^{8}$, where

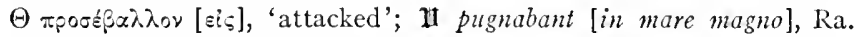
'fought with' (or, 'in midst of,' var. rdg.), AV 'strove (upon)'; the notion of fighting is from the Rabb. use of and $c f$. the Heb. Hif. of a military operation, Ju. 2033. Others, e.g., AEz. (cft. Job $40^{\circ 3}$ ), Junius and Tremellius, Polanus, 'burst, rushed, broke forth upon' (so Dr., RV JV). Best with Calv. commoucbant, Vatablus, agitabant, followed by Kran., Levy, Bev., al.; so the Hif. Eze. $32^{2}$, and similarly in JAram., Syr. This interpretation appears to have been followed in 2 Esd. $13^{2}$, ecce de mari ventus exsurgebat, ut conturbaret omnes futctus cius. This is to be preferred as the far more natural and picturesque term, while $h$ of the following noun is best explained as sign of acc., for which otherwise $y$ would be expected.

3. And four great beasts were coming up out of the sea, diverse one from another. The symbolizing of the heathen powers with rapacious beasts or with mythological monsters, which become then often rationalized into formal types, is common in the O.T.; c.g., Eze. $29^{3 \text { ff. }}$ Is. $27^{1}$, Ps. $68^{31}, 74^{13 \text { f. }} 80^{14}$, PsSol. $2^{29}$, while an elaborate use of this symbolism appears in the vision of Enoch, En. 85-90. They were ascending-n.b. the vivid ppls. denoting the 'moving picture'-out of the sea, the spawningplace of such monsters; $c f$. the reminiscences in Rev. I $3^{1}, 2$ Esd. $\mathrm{II}^{1}$ (the Eagle Vision; in c. I3 the sea is the origin of the Man). They were diverse, not in strength but in worth, so Theodt., vLeng., as similarly in the series of metals, c. 2. Each is successively meaner than its predecessor, although the last, nondescript beast is, like the iron of the Image, the most destructive. 4. The first was like a lion, and had eagle's wings. I was seeing till the wings thereof were plucked off, and it was lifted up from the earth [= ground], and was stood upon a pair of feet like a man, and a man's heart was given it. The winged lion is Babylon, according to almost all who interpret these figures histori- 
cally. The artistic background was first proposed by Herder, who suggested that the wall sculptures of Persepolis were drawn upon. Stuart ( 1850 ) remarks that "on all the ancient monuments of the East are found formae monstrosae, the symbols of dominion and of conquerors." His contemporary Hitzig first adduced the winged lion from Nimrud, with which we can now compare the tile winged lions from Babylon. The combination of the features of the lion and the eagle typifies the lordliest of animal creatures. But it is unnecessary, e.g., with Jer. and the host of earlier comm., to draw out the parallelism in virtues and vices of this and the succeeding beasts. Reference may be made to Pole and especially to Bochart, Hierozoicon, under the appropriate titles, for those who desire to pursue such fantastic details. The succeeding moments in the developing picture are, however, problems. Two quite opposite interpretations have been followed, which also are sometimes combined. Acc. to one view it is all a drama of destruction. But the very evident dependence of 'the heart of a man' upon the 'beast's heart,' $4^{13(16)}$, which was later made human again, $v .^{31}{ }^{(34)}$, compels the exegete to take this as his point d'appui. The prime reference then, really a reminiscent aside, is to the humanization which occurred in Neb.'s case. This is the view of Hipp., Jephet, Stuart, Keil, Zöck., Pusey, al., and most recent comm. Its being raised from the earth (ground) and stood on feet like a man, i.e., in a human posture, would be equivalent. The plucking of its wings, which gives the cue to the other interpretation, might then refer to the removal of the superbia of Babel, so Jer., who cites Is. I $4^{13 \mathrm{ff}}$. and Ob.4, 'Though thou make thy nest as high as the eagle,' etc. Grot. aptly cites a Classical parallel to this figurative plucking of the wings, from Cicero, Ep. ad Attic., iv, 2, "qui mihi pennas inciderant nolunt easdem renasci." The humanization involves the elimination of heaven-vaulting ambition. Possibly the thought is not more than of the return from the monstrous form to the natural beast. The other interpretation is that of humiliation or destruction, which Jer. prefers, although he refers to the other view. Ra. plays on the rt. mng of $\mathbf{w}$ as debilis; Calv. and early Prot. comm. tr. Sלים: 'removed' from the earth, ablata, sublata e terra, so Behr. and Pr. But why should the destruction of the first of the three beasts alone be commemorated here? The Jewish saga took pains to canonize Neb. as a Pagan 
saint! Perhaps we have after all to agree with Cha.: "It must be confessed that the above [the first] explanation is rather forced, but this is owing to the combination of two really incongruous sets of ideas," i.e., with the interpolation of the theme of Neb. The four pass. vbs. in this v., followed by other cases below (of the Peîl peculiar to early Aram.) belong to the later euphemistic language; in c. 4 act. pls. are so used. See on this pass. construction Dalman, Worte Jesu, i $8_{3}$, with exx. from N.T. and Rabb. literature, and Volz, Jiid. Esch., 6, whose judgment, "hier handelt niemand mehr, sondern es geht wie durch eine Maschine," is, however, arbitrary. The euphemistic phraseology was borrowed from the common diction; s. Note at $2^{13}$.

5. And behold, another beast, a second [i.e., number : wo], resembling a bear; and it was raised up on one side, and it had three ribs in its mouth between its teeth, and so it was said [they said] to it, Arise, devour much flesh. The first vb., incorrectly pointed

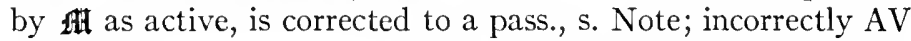
$\mathrm{RV}$ 'raised up itself.' The bear is chosen as ranking next to the lion in size and fierceness. The two are often grouped together as the most dangerous of animals, s. Hos. $13^{8}$, Am. $5^{19}$, Pr. $28^{15}$,

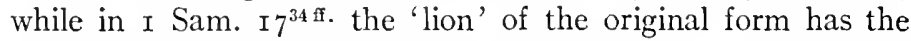
doublet 'or bear,' representing a later age when the lion had largely disappeared. For its carnivorous character $c f$. Is. I I , a fact scientifically recorded by Aristotle, Hist. nat., viii, 5, $\sigma a \rho \kappa о ф а \gamma \hat{\omega} \nu, \zeta \hat{\omega} о \nu \pi a^{\prime} \mu \phi a \gamma o \nu$ (Grot.). The destructive power of the Medes had left its tradition; $c f$. Is. $3^{17}$, Nahum, Jer. $5^{{ }^{11}{ }^{28}}$, etc. The theme is expanded in the final clauses of the v. Comm. have come increasingly to recognize that the last two clauses typify the voracity of the beast; so Junius, 'frendens in omnes partes,' vLeng., Stu., Bev., Mar., Cha.; with Stu. the three ribs "constitute a large mouthful," cf. the two legs which may be rescued out of a lion's mouth, Am. $4^{12}$. This gives the explanation of the much-racked 'raised up on one side.' VLeng. first adduced from the Bab. emblems the figure of a demi-couchant bull, the two legs on the near side being raised as though the animal were rising, and Professor Olmstead notes that the same device appears in Persian art. This representation appears frequently in well-known Bab. seals. The animal then is pausing to devour a mouthful before springing again on its prey, to which feat an oracular voice encourages it. The writer refers to 
the coming overthrow of Belshazzar's kingdom. Thus a singleeyed interpretation of the whole $\mathrm{v}$. is obtained. For attempted detail of the comparison between the bear and its kingdom it may suffice to cite the Tanna R. Joseph that this v. refers to the Persians, "because they eat and drink like bears and are as fat as bears and long-haired like bears, and restless as bears," Kidd. $72 a, A b$. Zara $2 b, M e g$. i $a$. The phrase 'raised up on one side' has provoked most diverse interpretations. Theodt. understands it as of loss of power, Jeph., "as soon as it was raised up it was overthrown." Jer. gives a current Jewish interpretation: "sic Hebraei interpretantur, nihil eos aduersum Israel crudele gessisse," i.e., aside from Israel; Ra., as on one side awaiting the destruction of Babel; others as on one side, or apart, in the scene, e.g., JDMich. The var. in AV RV 'it raised up one dominion,' is due to the Mass. pointing of the vb. as active and a mistaken understanding of the noun. Very naturally for the three ribs historical interpretations have been offered, but their variety fails in conviction. Acc. to Hipp., Jer., they represent Media, Persia, Babel; Bert., Media, Lydia, Babel; etc., etc. Jer. tr. remarkably tres ordines, and gives an extensive discussion; he notes one interpretation that the three represent the successors of Cyrus, a view similar to the one preferred by Ra., that they are the first three Pers. kings. Jeph. holds that they are threequarters of the world, similarly Piscator, $c f t .8^{4}$, and so Kliefoth: it did not attain 'œcumenicity.'

6. After this I was seeing and behold, another like a leopard, which had upon its back four bird's wings, and four heads had the beast; and dominion was given to it: the Persian empire. The Arab. equivalent for leopard is used also of the panther and the tiger. The agility and intelligence of the animal ( $c f$. Hos. $\mathrm{I}^{7}$, Jer. $5^{6}$ ) are stressed by those comm. who see in it the figure of Greece and the rapid conquests of Alexander: Hipp., 'clever,

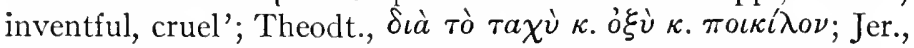
its swiftness; Jeph., "it haunts the gates of cities." However, the velocity of Cyrus' conquests is part of the Bible tradition, Is. $4 \mathrm{r}^{3}$, 'not touching the road with his feet.' Whether the wings were on the back (AV RVV) or the sides (JV) depends upon the understanding of the orig. word. The latter position of wings on an animal is illustrated from the winged lion in tiles from Babylon. The four wings and four heads are variously inter- 
preted acc. to the identification of the empire. The four wings may represent extraordinary velocity (Geier, 'twice as great as Babylon's'), but, better, they and the four heads typify the four quarters of the world, 'œecumenicity' with Klief. We might compare the four-headed beasts in Eze. I, indicating the extension of the divine energy in every quarter. Cyrus in his Cylinder Inscription speaks of himself as monarch of the Four Quarters. Mein.'s objection that acc. to $8^{4}$ the Persian ram pushed west and north and south, i.e. only three-quarters, does not hold, for the east was Persia's original domain. Otherwise vLeng. (following Junius), who interprets from the four kings of Persia implied in $\mathrm{II}^{2}$, so, of recent comm., Bev., Pr., Mar., Cha. But, with Zöck., Mein., horns not heads are type of kings, $c f$. $\mathrm{v.}^{24}$. The traditional interpretation of this beast as Greece, since Hipp.'s day, identified the four heads with the four kingdoms of the Diadochi. For the statement that 'dominion was given to it' $c f .2^{39}$, 'a third kingdom of brass, which shall rule over the whole earth'; aptly Mar., "Hatte das medische Reich hauptsächlich nur zerstört, so war das persische da zum Regieren."

7. After this $I$ was seeing in the night visions, and behold, a fourth beast, dreadful and terrible and strong exceedingly; and it had great iron teeth; it was devouring and crishing, and stamping the residue with its feet; and it was acting diversely from all the beasts that were before it; and it had ten horns. The writer introduces this fourth beast, which is the objective of his parable, with special circumstance. Its identity with the iron of the Image in c. 2 appears explicitly in the verbal reminiscences of 'strong as iron' and 'crushing and breaking in pieces,' $c f .2^{40}$; only here the point of destructiveness is particularly pressed. It is a nameless and peculiarly nondescript beast ("vocabulum tacuit," Jer.). And Professor Olmstead suggests that the monstrous șirušsu beast would have given a prototype from Bab. art. Similarly the monster out of the sea, Rev. $13^{1 \mathrm{f}}$, is based on this apparition with the added features of leopard, bear, and lion. With the theory here accepted that this terrible beast is type of the Hellenistic age, such a judgment of that brilliant. era appears at first sight absurd to modern thought. But this fearful figure meant to the Maccabæan Jew the Seleucide Hellenism which he knew, just as it might be equally applied, although with no better reason, by later interpretation, to the 
Roman empire or its barbarous continuation, to 'Edom' (Rome) or Ishmael (the Saracens) by the Jewish comm., to the Turks at the doors of Vienna by early Prot. exegetes, or to the days before Antichrist, with Millenarians. In $\mathrm{v} .{ }^{\text {b }}$ the 'diverse' of EVV has been translated 'acting diversely,' in justice to the ppl. of the original. In $\mathrm{v}^{19}$ an additional feature appears, the plus 'and claws of brass' after 'teeth of iron'; the plus appears in a few Gr. Mss here and is approved by some (e.g., Ew., Mar.), but the repetitions permit themselves much variation in details: so in cc. 2. 4 .

8. I was contemplating the horns, and behold, there was coming up another horn, a little one, before which three of the first horns were uprooted [i.e., displaced]; and behold, eyes like human eyes in this horn, and a mouth speaking big things. The seer's attention is fascinated by the horns of the beast, among which he observes another, small horn growing up (with correction of An's aorist into a ppl., s. Note) and displacing three of its predecessors. The horn is endowed with eyes like a man and with a mouth. It is universally accepted that these two human traits, the most expressive of the individual person, interpret the little horn as an individual. The attribute of eyes expresses primarily the human personality, so Jer., "ne eum putemus iuxta quorumdam opinionem, uel diabolum esse uel daemonem, sed unum de hominibus," and so vLeng. insists. If with most commentators, who find in the trait perspicacity (Grot.), cleverness, etc., we attempt to discover a moral implication, the best comparison would be with the proud eyes of Is. $2^{11}, 5^{15}$, Ps. IOI ${ }^{5}$. The 'mouth speaking big things' is the king in $\mathrm{I}^{36}$ who 'speaks awful things'; for the phrase $c f$. Ps. $2_{2}^{4}, \mathrm{Ob} .^{12}$, and the behavior of Sennacherib described in Is. $37^{23}$. The phrase has its exegesis in Rev. $13^{5}$,

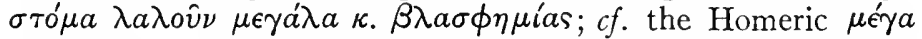
$\epsilon i \pi \epsilon \hat{\imath} \nu, O d .$, xvi, 243 (Behr.). The historical parallel for Antiochus Epiph. is given in I Mac. $\mathrm{I}^{24}$, é $\lambda a^{\prime} \lambda \eta \sigma \epsilon \nu$ í $\pi \epsilon \rho \eta \phi a \nu i^{\prime} \alpha$ $\mu \epsilon \gamma a^{\prime} \lambda \eta \nu, c f$. the description of that tyrant in 3 Mac. $6^{4}, \epsilon \pi a \rho$ -

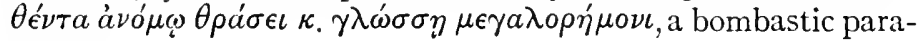
phrase.

There remains the consideration of the 'horns' in vv. ${ }^{7.8}$. The horn is type of aggressive strength in the O.T., e.g., I Ki. $22^{11}$, Am. $6^{13}$. For the horns as symbol of the Seleucide kings s. Babelon, Les rois de Syrie (Paris National Library, Cat. des 
monnaies grecques), pp. xviii seq. In Arab. karn is used both for 'prince' and 'generation.' In this chap. the horns are directly interpreted as kings, and so also in c. 8 are either kings or dynasties. In $8^{9}$ the 'little horn' appears again. In Zech. 2 the four horns are prob. empires. For the former prevailing view that this fourth kingdom is Rome and for the consequent interpretation of the horns, s. Int., $\$ I 9, c$. The earliest interpretation of the ten horns is found in the Sibylline Oracles, $3,38_{I}-400$, which Hilgenfeld, Schürer, al., ascribe to a date not later than I 40 B.C. The passage describes Antiochus Epiphanes and his successors. Lines 385-400 read as follows (from Lanchester's tr. in Charles, $A$ poc., $2,3 S_{5} f$; the Greek original is given in Dr., p. 98, n. 4):

$3 S S$ "One day there shall come unexpectedly to Asia's wealthy land A man clad with a purple cloak upon his shoulders,

390 Savage, a stranger to justice, fiery; for he hath exalted himseli Even against the thunder, a mortal as he is. And all Asia shall have an evil yoke,

And the drenched earth shall drink large draughts of blood, And even so Hades shall attend him utterly destroyed. By the race of those whose family he wishes to destroy

395 By them shall his own family be destroyed.

let after leaving one horn, which the Destroyer shall cut off

From among ten horns, he shall put forth a side shoot.

He shall cut down the warrior parent of the purple race,

And he $\dagger$ he himseli at the hand of his grandsons shall perish in a like fate of wart:

400 And then shall a parasite have dominion."

The 'ten horns' is a manifest citation of Dan. The 'stranger' is without doubt Antiochus. The three horns of Dan. are somewhat illogically represented by the three violent deaths enumerated. Acc. to the interpretation of Hilgenfeld. A pokalyptik, $69 f$., Schürer, $G J V^{*} 3,575 f$., followed by Dr., p. 9 , n. 4, Lanchester, l.c., Cha., pp. $68 f$., the 'one horn,' 1.396 , is Antiochus' son Antiochus V, who was murdered; the 'side shoot,' 1. 397 , is Alexander Balas, who got rid of Demetrius I; he himself, 1. 399, was destroyed by Demetrius' sons; and the 'parasite horn,' l. 400 , is Trypho. There was no question then regarding the application of our prophecy within a few decades of its publication.

The interpretation of the little horn as Antiochus is implicitly 
that of I Mac. (toward end of $2 \mathrm{~d}$ cent.) and 3 Mac, Il.ce. It was also that adopted by Porphyry, Polych. and Aph. Syr. We have then to look for ten kings who preceded him, three of which he displaced. Almost all who accept the fourth beast as Greece agree on this, differing only as to the enumeration of the ten and the three. ${ }^{1}$ Ant. Epiph. had seven predecessors in his dynasty: Seleucus I Nicator, Antiochus I Soter, Antiochus II Theos. Seleucus II Callinicus, Seleucus III Ceraunus, Antiochus III Magnus, Seleucus IV Philopator. The task is then to discover three subsequent kings whom Ant. 'displaced.' Some, Bert., al., make these to be (I) Heliodorus Philopator's prime minister. who assassinated his master and aspired to the throne, but was frustrated by Ant.'s prompt action in returning home from his foreign sojourn and seizing the throne for himself: (2) Demetrius (later king as Soter) son of Philopator. who was hostage in Rome and whose right Ant. usurped: and (3) Ptolemy VII Philometor of Egypt, who made a claim on the Syrian throne. But this brings in a king of another dymasty. Hitz., al., obviate this difficulty by including Alexander in the series, in which case the three whom Ant. 'displaced' are his brother (by natural cause), his rival Heliodorus, whom he got rid of, and the rightful heir Demetrius, whom he displaced during his own life. Another solution, confining itself to the Seleucide dymasty, accepts an historical tradition of another son of Philopator, whom Ant. caused to be put out of the way. So von Gutschmidt, Kleine Schriftch, 2, ISo fi., followed by Ber., Niese. Gesch. 3, 03 (with reff.). In any case it is hardly necessary in a literature which knew only of four kings of Persia to insist on the exact identification of the long Syrian dynasty. Reference may be made, e.g., to Delitzsch, $R E^{\prime}$ 'Daniel,' the excursus to this chap. in Ber, Dr., Cha. For the counter-argument, against identification with the Greeks and the Seleucides, s. Puser, Lect. iii, end. Wright, c. 5. Note may also be made here of the Rabb. interpretation of the little horn as Odenathus, the famous prince of Palmyra,

${ }^{1}$ Bleek, Jbb. $f$. deutsche Theologic, isco, pp. co $\#$.., argued that the ten represents the assumed ten provinces divided among as many generals of Alexander; but s. per conir. Pusey, pp. 155 . If. Dr.. P. 102. Comparison can then be made with the ten toes of the Image in $c$. 2, which interpretation is denied above, in discussion of $2^{31.45}$ (Dr. still wrongly compares the ten toes). Similarly Behr., who interprets the ten horns as a round number, typifying 'die vielgespaltene Diadochenherrschaft.' $\mathrm{He}$ is right in not insisting on the exactness of the number. 
who sacked and destroyed Nehardea, seat of one of the great Jewish schools; s. Genesis R., c. 76, and Graetz's full discussion, Gesch. d. Judent2, 295, and Note 28 at end of vol.

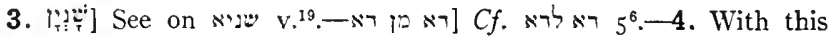
v. introduces historical captions, here 'Kingdom of the Babylonians,' $\mathrm{v} .{ }^{5}$ 'K. of the Medes,' $v .^{6}$ ' $\mathrm{K}$. of the Persians,' $v .{ }^{7}$ ' $\mathrm{K}$. of the Greeks,' v. 'Antiochus' gloss to 'its horns,' repeated v. ${ }^{21}$.- - in ] In the papp.

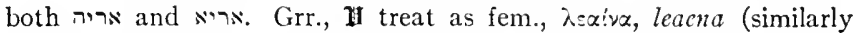
$\pi \dot{\alpha} \delta \delta \lambda_{l 5} v^{6}{ }^{6}$, and Jer. makes a point of the gender in his comm. The noun is masc. in Syr., and the following pronouns can refer to the implied $x, n$ - [ [? Whether dual or pl. was intended is uncertain in view of the vexed tradition about the dual in BAram.; s. on $y v^{8}{ }^{8}$. - די] Similarly $2^{34},=$ 'until at last.'- The vb. in the Ahikar papp. ( $A P O$ pap. $57,1.1 \mathrm{I}=A P, 1$ I69), 'I lifted up my eyes,' similarly the vb. = Heb. $\times$ ' in JAram. and Syr.; hence Behr. should not insist on the sense 'wegschaffen.'-r'?:] fit felt properly that the dual was

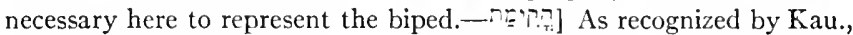
$\S 45,3,5$, Nöld., GGA 1884, Ior 9, al., a survival of the ancient pass. of

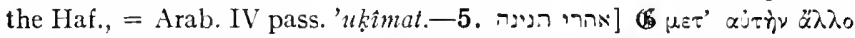

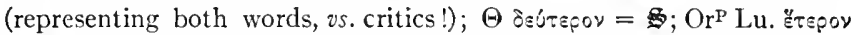

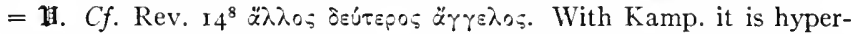
criticism to elide one or the other word, as do Behr., Mar., Löhr, Cha.-

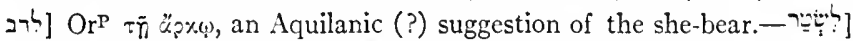
So edd. exc. Mich. ' statement. The spelling רo' 'side,' as in the papp., ' $O$ is later spelling. A Jewish interpretation (s. Buxt., Lex.) of alleged ' $i$ ' tr. 'one dominion,' cf. Heb. '? 'dominion'; this has motived not only AVmg but also the pointing of the following vb. But this involves the use of ? as sign of acc. with an abs. noun, which is impossible, a point ignored by some comm., even Dr. Sa. tr. 'to one side. ally acknowledged that $n$ r.?

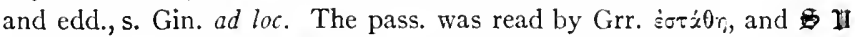

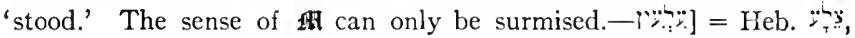
which outside of Gen. $2^{21 t}$. has mng. 'side,' etc.; hence, like Lat. costa, of. Eng. 'coasts,' arose a common interpretation 'provinces,' etc. Bert.'s etymology of 'fangs' depends upon an Arab. lexicographical interpretation of $d a l \hat{\imath}$ ', properly 'robust' as 'endowed with fine teeth,' s. Freytag, s.v.--ספה] For the form s. reff. in GB, also Kön., Lgb., 2, 46 I, Brock., VG I, 333.-6. באירו] So edd., also v. ${ }^{7}$; the variety in spelling is deliberate. See at $2^{39}$ - -

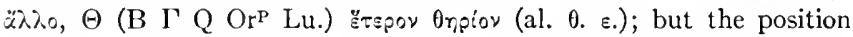

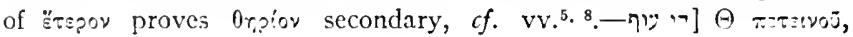




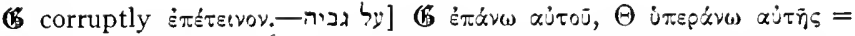
1H. Bev., Behr., Mar., Cha., Kön., Hwb. prefer mng. 'sides,' cft. Syr.

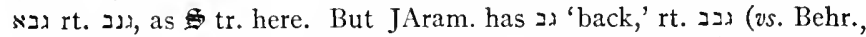
who identifies the two roots), and the common prep. על גבי (also 'upon,' and does not possess the Syr. word.— - י

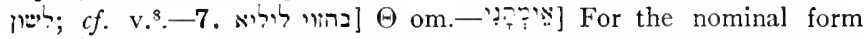
cf. -yâ to nouns in -âan, s. Nöld., $S G$ §71, ז; cf. fem. A var. אחר occurs, s. Gin. RV 'powerful' follows a late, erroneous etymology from Arab. matana 'be strong,' e.g., Rosen.-רירה Adv., s. at $3^{22}$ - -

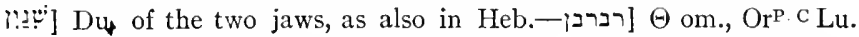

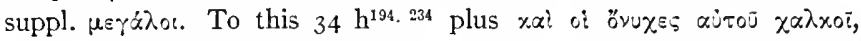

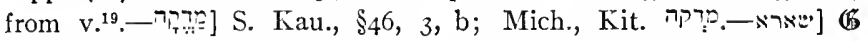
$x^{\prime} \dot{x} \lambda_{\omega}$, , and so $\mathrm{vv}^{12 .}{ }^{19}$, apparently a paraphrase, s. Blud., p. 4r.-

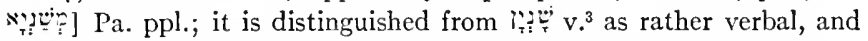

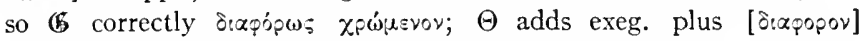
$\pi \approx p \ell \sigma \sigma \omega \tilde{s}$, to mark out the peculiar difference of this beast. Also $\mathrm{Or}^{\mathrm{P}}$

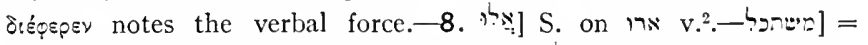
'gaze at for self, contemplate,' cf. Behr., Dr.; as also in Targ., Sam., e.g., Targ. Gen. $3^{6}$. Cf. a similar phrase, Acts $I^{6}{ }^{6}$.

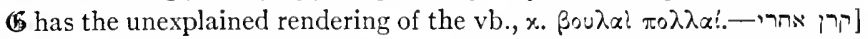

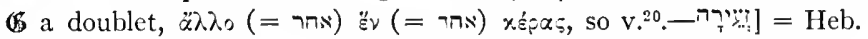
ר.:; prob. diminutive form, knutail, s. Brock., $V G$ I, §1 37 ; this the only instance in BAram., but several cases in Syr., s. Nöld., SG §ıг 2.-

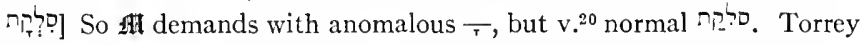
again explains, Notes, II, 233, by his theory of alternative vocalization,

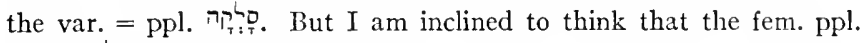
form ס्T was original; s. Note on $5^{10}$. The careful Or ${ }^{\mathrm{P}}$ un-

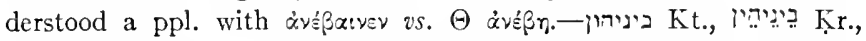

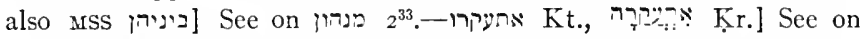
pod $5^{5}$. (G

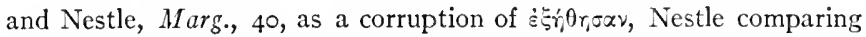

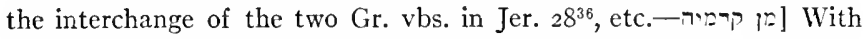

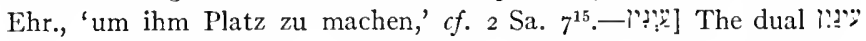

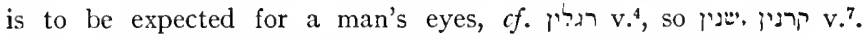
Kau.'s suggestion that the pl. is reasonable because the number of eyes is a reserved question, $\S_{5} \mathrm{I}, \mathrm{I}$, hardly stands; however, 2 may have understood a monstrous number of eyes like the beasts in Eze. I; but they are qualified as 'human eyes,' and $c f . v .{ }^{4}$. In general the dual early became obsolete in Aram. and so exceptional in the tradition of BAram. (e.g., r. v. $^{4}$ ); it was lost in Syr. and appears in the Targ. only in

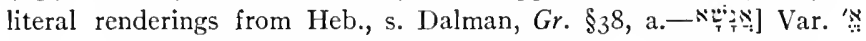
Mich., Gin. mg.-At end of v. $\mathbb{6}$, followed by Lu. and a few MSs, plus 


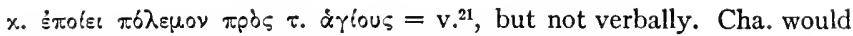
add it here; Ew. regards it as remnant of a lost passage.

9-14. The Great Assize. 9. 10. The Judge and his court. 9. I was seeing

Till thrones were placed : and an Ancient sat; His raiment like white snow : and the hair of His head like pure wool; His throne flames of fire: and its wheels burning fire;

10. A river of fire flowing : and coming forth from His presence;

Thousand thousands serving Him : and myriad myriads standing before $\mathrm{Him}$.

The court sat: and the books were opened.

The first and last lines are dimeters, the others trimeters.

In contrast with the chaos of Great Ocean, its hurricanes and portentous monsters, appears the august vision of God come to judgment. The scenery belongs to the treasury of the O.T., $c f$. I Ki. $22^{19}$ If. Pss. 5 I. 82, Joel 4, etc. But it possesses its own original characteristic, which has become the classical model for all subsequent apocalyptic scenes of like order. Bousset remarks congenially: "In vollkommener Reinheit ist dieses erhabene Bild [of the great judgment] bereits von Dan. gezeichnet $\left(7^{9-12}\right)$. Nicht immer tritt es in der jüdischen Apokalyptik in dieser Kräftigkeit und Klarheit heraus" (Rel. d. Jud., 295). To this section in Bousset and to Volz, Jiid. Esch., I 88 ff., reference may be made for the Apocalyptic parallels, amongst which those in Rev. are particularly dependent upon our passage. It is not so said until v. ${ }^{13}$ - for titles are not necessary to these dramatic pictures-but the scene is in heaven, the calm abode of God ('a sea of glass,' Rev.) in contrast to the chaos. 'Thrones were placed': i.e., sedilia, which constitute, as appears later, the judicial bench. (See Note for the erroneous 'cast down' of AV.) The pl. is not to be stressed, for only One took his seat. Cf. 'thrones for judgment,' Ps. I $22^{5}$. Jewish and Christian comm. have busied themselves to discover who the assessors were. An ancient interpretation is that in the Parables of Enoch (En. 377I), which makes the Elect One, the Son of Man, the assessor of Deity, e.g., $45^{3}$. This doubtless had its influence on the N.T. thought of the judgeship of the Christ, and so Akiba understands 
two thrones, one for God and one for David (Hag. r $4 a$, Sanh. $38 b)$. Or the assessors are the elders of Israel acc. to Tanhuma (Way., 36b, ed. Buber), with which may be compared the promise of Jesus to his apostles that they should sit, along with him on his throne of glory, on twelve thrones judging the twelve tribes of Israel, Mt. I9 $9^{28}$. Acc. to Rev. $20^{4}$ the saints shall sit upon the 'thrones' and judgment be given them. Or they are angels, so Jer., who cft. the 24 thrones in Rev. and the 'thrones, dominions,' etc., of Col. $\mathbf{I}^{16}$ (this personification in Test. Levi $3^{8}$, 2 En. 201); so Calv., and Grot., who likens them to the satraps of the Pers. court. DEnv. thinks of the Faces, the Persons of the Trinity. The angels would be the most likely interpretation, cf. $4^{14}$, "the decree of the Vigilants and the word of the holy ones.' Yet better Maldonatus: "Thronos dicit in plur. quia maior auctoritas sanctiorque maiestas repraesentatur." At the most the assessors would be the recorders who opened the books and inscribed the decisions. Such is the interpretation of the earliest citation of the passage, En. $90^{20}$ (Cha.'s tr.): 'And I saw till a throne was erected in the Pleasant Land, and the Lord of the sheep sat Himself thereon and all [Cha. corrects the text to 'the other,' i.e., Michael] took the sealed books and opened the books before the Lord of the sheep.' For the Jewish reff. s. Schöttgen, Horae, I, I ro4, Weber, Jïd. Theologie, I64, Dalman, Worte Jesu, 201, Volz, p. 260, Bousset, p. 295.

The Deity is represented as an old personage, and similarly the picturing of Zeus in Hellenic art. The usual tr., 'an ancient of days' (erroneously AV 'the Ancient of days') is striking because of its unique sound. Comm. generally take it at once to be a euphemistic term for God, indicating his eternal existence (Stu. as a superlative, 'the most ancient'), and cft. such titles as 'enthroned of old,' Ps. $55^{20}$; or contrast is made to 'new gods,' e.g., Ju. $5^{8}$, and esp. to the new gods of Hellenism (so Mein.). But Dr. appears to be alone in remarking that the orig. term merely means an 'old man'; only the process of the vision reveals who is referred to. The phrase means exactly 'advanced in days,' = Lat. aetate prouectus (Cicero, De senect., iii, Io), English 'advanced in years.' It is identical with the Heb. phrase 'come-on in years,' Gen. $24^{1}$ (EVV erroneously 'stricken in years'); and our phrase appears fairly often in Syr. literature, s. Note. Dalman, Worte Jesu, I94, overworks the 
phrase in comparing it with 'like a son of man,' $v{ }^{13}$, as 'eine ebensowenig prosaische Schreibart.' Cha. desires to amend into 'one like an ancient being' (כעתיק), following similar expressions, but there is no reason to think that the prep. of comparison could easily have dropped or been edited out. The apparition of the Person is in shining white, his hoary hair betokening his venerableness, while the white vesture indicates unsullied majesty, always the dress of notables, and so of the denizens of heaven, e.g., of angels, Mt. $28^{3}$ (an unobserved citation of $\Theta$ here), of the saints in heaven, Rev. $3^{5}$, etc., and frequently in Jewish literature (s. vLeng.'s full note); we may compare the ermine of a modern justiciary. The seer's glance drops down to the more bearable features of the circumstances of the vision, vv. ${ }^{9 \mathrm{~b} .10 \mathrm{a}}$ ( $c f$. Is. 6). The proper element of Deity is fire with its effluence of light, $c f$. Ex. $3^{2}$, Dt. $4^{24}, 33^{2}$, I Tim. $6^{18}$, Heb. I $2^{29}$, etc.; there is no compelling reason, with Bert., Meyer, al., to seek for Parsee

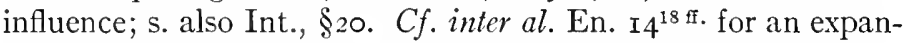
sion of the present scene. The flaming throne and its wheels coursing like a river of fire are to be compared with the vision of the Merkabah in Eze. I. The curule chairs of ancient monarchs and of Roman consuls have been compared with these wheeled thrones (so Grot.), but the figure belongs to a common stock of tradition coming down from Eze. The river of fire which drew forth from the divine presence denotes the irresistibility of the divine energy. Comparing Ps. $50^{3}$, 'a fire devouring before him, $=97^{3}$, this fiery stream also executes the divine herem, and there is a point to the feature in the subsequent destruction of the beast 'in fire,' v. ${ }^{11} .{ }^{1}$ Then the seer observes the myriads ( $c f$. Dt. $33^{2}$, Ps. $68^{18}$ ) of the ministering ones, standing in position as do courtiers before their monarch (s. at $\mathrm{I}^{4}$ ); it is the court of heaven, where, as always in the Bible (e.g., I Ki. $22^{19}$ ), God is never alone.

${ }^{1}$ Meyer, Ursprung, 68, 199, etc., insists on the background to this picture of the Parsee notion of a river of molten metal at the end of the world. The chief passage in question is in the Bundahis, xxx, 19. 20 (West, $S B E$ vol. 5): "The fire and halo melt the metal of Shatvairo . . . it remains on this earth like a river. Then all men will pass into that melted metal and become pure; when one is righteous, then it seems to him just as though he walks continuously in warm milk: when wicked then ... as though . . . in melted metal." And acc. to v. 3 I the serpent (?-the word is uncertain) is burned in the molten metal. The writer does not think that this parallelism, drawn from an actually late document, is very convincing for Parsee influence upon Dan. The Parsee fire, it should be observed, is for purgation, not for destruction; in the end all souls will be purged by fire. 
The seer's eye at last returns from these stupendous circumstances to the opening of the assize: The court sat, for which the original has literally 'the judgment sat'; the abstract passes into the concrete, as is the case with kpıт́npıov (so $\mathbb{B}$ here),

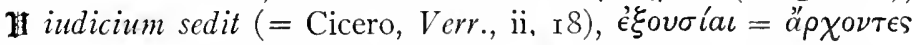
Rom. $13^{1 \mathrm{fff}}$, etc. And books were opened: Current court procedure naturally colors the picture; Medus cft. the process of the Sanhedrin, Grot. the Pers. conclaves; the Pers. monarchs, through their spy system, made note of every petty detail of their provinces (Rawlinson, SGM 'Fifth Mon.', c. 3, notes 334 $f f$.). But the idea of divine books is as old as human writing. It is found in the ancient Egyptian religion, in the Babylonian with the 'tables' of sins and of good works ( $K A T 402)$, and equally in the O.T., Is. $65^{6}$, Jer. I $7^{1}$, Mal. $3^{16}$ (jרפ the N.T., Lu. $10^{20}$, Rev. $20^{12}$ (citing this v.), etc. For this constant theme in Apocalyptic and Rabb. literature s. Volz, Jiid. Esch., 266, Bousset, Rel. d. Jud., 295 ff., Cha. on En. $47^{3} ;$ n.b. Pirke Aboth, ii, I, 'Know what is above thee-a seeing eye and a hearing ear, and all thy deeds written in a book.' Bev. cft. a passage in the Pagan Arab. poet Zuhair: "Hide not from God what ye devise . . . ; it is reserved, laid up in writing, and kept in store against the day of reckoning" (ed. Ahlwardt, xvi, $26 f$.). The Fathers moralize: Theodt., $\beta i \beta \lambda$ ous $\tau$. $\mu \nu \eta^{\prime} \mu a s, \kappa a \lambda \in \hat{\imath}$; Jer., "conscientiae et opera singulorum . . . reuelantur." Mar. observes that not only the past records but also the decisions were entered into these books, $c f \cdot 4^{14}$.

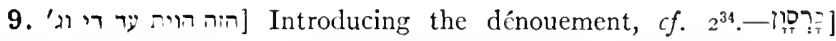
For the internal $-\hat{a}-\mathrm{s}$. on $6^{8}$. The pl. = 'the bench', $c f$. מילן הברסיס 'interpreter of the court' in the Cyprian inscr. CIS i, $44=$

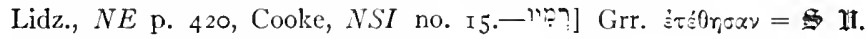

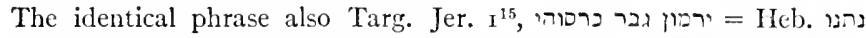

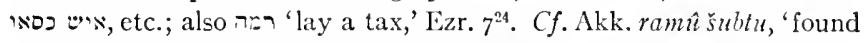
a dwelling,' similarly the freq. Syr. tarmithî, 'foundation,' i.e., 'creation' of the world $=$ Hellenistic $\times \alpha \tau \alpha \beta \supset \lambda \dot{n}$, Polyb., Bibl. Gr., etc. This rt. mng. appears in the name רמירו, s. Cornill at Jer. ${ }^{1}$. Cf. IIeb. רהי, both 'throw,' and 'lay foundation,' Job $38^{6}$; this development appears

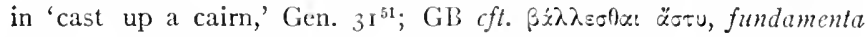
iacere. Sachau's proposed rdg. in $1 P O$ pap. $56,1.8$, , רannot stand, s. Cowley ad loc. The tr. of AV 'were cast down' goes back to the Jewish comm. (also Polanus, Geier, etc.), who interpreted it by 
'were removed,' Ra., AEz.; or הושלמו 'were cast down,' PsSa.; Sa., 'cast away,' so Jeph., the thrones being understood as those of the beasts. Häv. cft. the Koranic name of God, $d u$ l-'arš, xvii, 44, lxxxv, I5.

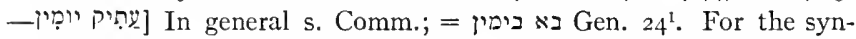
tax cf. GK §г28, 3, Nöld., SG §205, A. The correspondent $\pi \varepsilon \pi \alpha \lambda \alpha$ เ

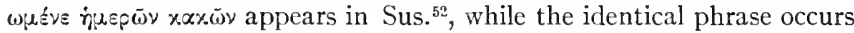
in Syr.; e.g , Wis. $2^{10}$, Ecclus. $25^{5}$ (translating 'old man'); also the pl. freq. in Aphraates, e.g., Dem., xxii, 8, while Torrey adduces a case from John of Ephesus; Sa. tr. by saih, 'old man.' The adj. did not primarily mean 'old,' requiring a specifying addition; but it appears with that mng. in I Ch. $4^{22}$ and also in JAram., Syr. I note Arab. musinnus-samâ' $i$, 'the ancient of heaven,' in the 'Aghân $\mathrm{x}$, I05, 1. 7. The term is cited at times in the Talm., s. Lexx. It becomes 'the head of days,' in Enoch, e.g., 461. While Ra. identifies the Ancient with God, Jeph. finds in him an angel, and AEz. Michael. Hipp. has

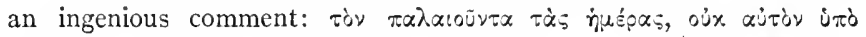

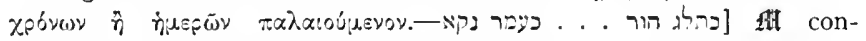
strues the adj. with the prec. noun in each case, but $\Theta$ हैyòul $x$. . .

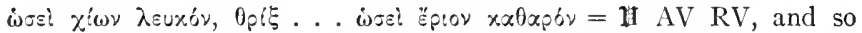
most comm.; this is inconsequent and so Mar., 'weiss wie Schnee,' 'rein wie Wolle.' But there is no reason to abandon fllt's construction, which is followed by Bev., Behr., JV. (G om. 'white,' which appears to have

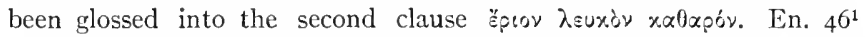
and Rev. ${ }^{14}$, to which Cha. appeals for revision of the text, are inexact and incomplete citations.—...? Kau., $\$ 47$, g, f, as pass. ppl., but

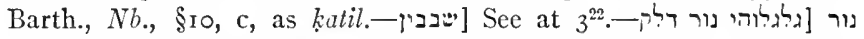
masc. as at $3^{27}$. Orig. $6 \mathfrak{6}$ om. the clause. The Hex. insertion of it was accompanied by a revision of the following clause, $v \cdot{ }^{10}$, plus $\pi \circ \tau \alpha \mu b s$

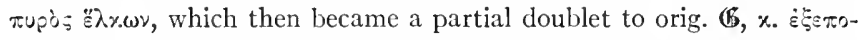

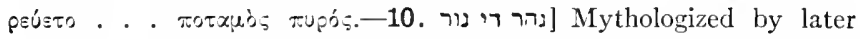
fancy into the river Dînûr, the fiery stream from which issued the ephemeral angels, IIagiga I4a; s. Weber, Jïd. Theologie, I66. Arab. = 'sweat,' Syr., JAram. 'flow,' in Pesh. = Heb. וז (Syr. also with other mngs., e.g., 'draw,' trans. and intrans.). The latter picturesque sense may be retained here.- (מן קרמוהי] vLeng. 'from it,' the throne, and so En. $14^{19}, c f$. Rev. $4^{5}, 22^{1}$; but the prep. = 'from in front of,' 'from his presence' (not 'out of him'!) = Heb. יפנים Kt.]

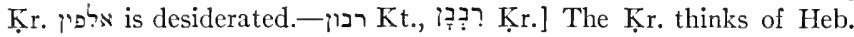

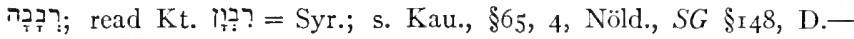

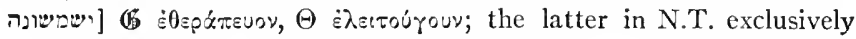
of liturgical service; cf. Test. Levi $3^{5}$, oi $\ddot{\alpha} \gamma \gamma \varepsilon \lambda \lambda \lambda_{0}$. . . oi $\lambda \varepsilon เ \tau o u p \gamma o u ̄ \nu \tau \varepsilon \varsigma$

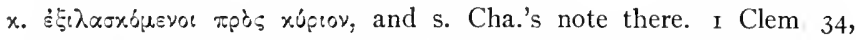
Justin, Tryph., 3 I, Iren., Haer., ii, 6, 2, have $\Theta$ 's rdg. These and later Fathers (s. Lightfoot on Clem.), following Rev. $5^{11}$, transpose the two 
clauses 'thousand thousands' and 'myriad myriads.'-יהובון] Masc.

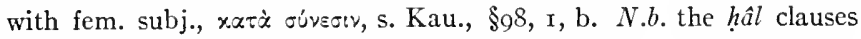
with vb. at end._T? ? סוד for a deliberative body. Grot. cft. the Jewish בית דânâ, 'judge.' Kran.'s 'zum Gericht setzte er sich' is unnecessary, if not impossible in Aram. syntax.

11. 12. The execution of the divine sentence. 11. I was seeing from the time of the utterance of the big words which the horn was speaking, I was seeing even till the beast was slain, and its body destroyed, and it [ the beast] was given to the burning of fire. See Note for revision of the usual tr. of opening of the v., acc. to which the repeated ' $I$ was seeing' gives much debated trouble. The words 'from the time of,' lit. 'then from' (EVV 'at that time because of') are here treated as the starting-point of the seer's observation of the horn's big words, continued even into the scene of judgment, to the point of ('till') its destruction. The tr. is at least less awkward than the current one, for which many comm. help themselves out by the elision of 'I was seeing' $\mathrm{I}^{\circ}$ or $2^{\circ}$. Dramatic indeed is the immediate passage of the great scene into the execution of the sentence; it recalls the katastrophe of the Lord's parable: 'the rich man also died and was buried. And in hell,' etc., Lu. I $6^{22 \mathrm{f} .}$ This observation disposes of Gunkel's categorical criticism (Schöpfung, 324, n. I) that $v^{a}{ }^{a}$ is 'mutilated.' It is held by vLeng., anticipated by PsSa. and followed by Stu., Keil, dEnv., Cha., that the fire is the eternal torment of hell. Comparison is made with the kindred idea in Is. $66^{24}$, and with the hell of fire in Rev. $19^{20}, 20^{10.14}$. Cha. adduces the reff. in Enoch to the place of fire where the fallen angels were cast, $10^{6}, \mathrm{I}^{11}, 2 \mathrm{I}^{7 \mathrm{ff}}$, $90^{24 \mathrm{ff}}$, all but the last of which passages he holds to be older than our text. Even if this point be true, it does not condition the interpretation here; it would be absurd to think of that beast, abstraction of an empire, being cast into hell-fire, while the one reference to future punishment in our book, $\mathrm{II}^{2}$, has no allusion to hell. So in general Dr. It is sufficient, with Mar., to compare Is. $30^{33}$, and to identify 'the fire,' if needs be, with the fiery stream from the divine presence; so Zöck. 12. And the rest of the beasts-their dominion was taken away, and prolongation in life was given them till a time and tide. The natural implication of 'the rest of the beasts' is that of the other three, surviving after the destruction of the fourth beast. 
See the arguments of Stu. and Dr. in support of this view. The destruction of the other beasts had not been narrated; they continue in some condition of survival after the destruction of the fourth beast, which culminated in the little horn; $c f$. the figure of the image in c. 2: "The entire image remains intact until the stone falls upon the feet ..., when the whole of it breaks up together" (Dr.). The v. is then anticipative of $\mathrm{v} .^{13}$. The expected superiority of Israel did not at once imply the destruction of all other political forms in the world; it was a supremacy more like that expected by Ezekiel, with the possibility of the final rise and onslaught of Gog and Magog (so Ra. here), or later of the Antichrist. Calv. held that the vb. = a plupf., the prophet reverting to an omitted detail. Mein. insists properly on the contrast between the fates of the fourth and the other three beasts, the former so terrible, and similarly Mar., who points out that the vision is meant as prophetic, both holding that they had ceased before the fourth beast. But these scholars do not explain the item of 'the prolongation' of their life. Behr., who holds that the ten horns are not the successive Seleucide kings but the various parts of the Hellenistic empire, thinks that the figure has changed, the horns have become beasts. But to the composer the little horn is the climax of the fourth beast, its final expression, and horn with beast is destroyed. In the tr. 'till a time and tide' the latter old English word, = 'time,' has been used to express the identity of the two terms; GV 'Zeit und Stunde,' Behr., 'Zeit und Frist'; cf. Acts I' and v. sup. $2^{21}$. The idea is that of a fixed fate; $c f$. the writer's note on in Ecc. = fate, $J B L$ I924, 243.

11. The repetition of the vb. and the unique use of בארין after its vb. acc. to usual translations (but vs. accents of Am) has induced critical operations. ( $B$ om.

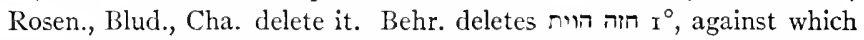
view s. Kamp., Mar. But read: 'I was beholding then from (the time of) the sound .. I I was beholding until, etc., i.e., taking באדין and is as correlative. In this interpretation I have been anticipated by Piscator, Klief. All other comm. understand in as 'because of.' Note

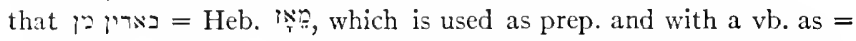
'since.' The sentence is awkward, but is no anacoluthon, as with some.

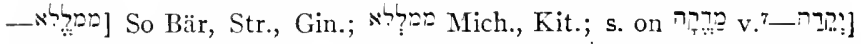

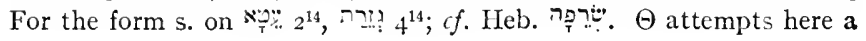


logical sequence: 'and it perished and its body was given.' In (5טילה $=\dot{\alpha} \pi$ rotupravioOn ' was bastinadoed to death' (also 3 Mac. $3^{27}$ ) -a touch of malice?-N] Abs., = $=$ in papp.

13. 14. The vision of the humanlike one and the dominion given to him.

13. I was seeing in the night visions, And behold with the clouds of heaven : one like a man was coming,

And to the Ancient he came : and before him he was presented.

14. And to him was given dominion and gloryand sovereignty : With all peoples, nations and tongues serving him;

$H$ is dominion an everlasting dominion not to pass away: And his sovereignty not to be destroyed.

So for the metre Mar.; . $^{14}$ consists of long stichoi with a short final hemistich.

Again a fresh introduction for this final moment of consummation of the scene; $c f . \mathrm{v}^{7}$. The seer beholds, wafted in the upper atmosphere with a nimbus of cloud, a human figure coming ( $\mathrm{AV}$ ignores the climax of the syntax of the original); he comes to (lit. 'arrives at') the Ancient, he is presented before him, as is the custom in royal courts, and to him is then given universal and everlasting dominion.

There is no reason with some to prefer the tr. of " clouds'; 集 is vouched for by 'pre-Theodotionic' rdgs. of the N.T. and Fathers; s. Note. Behr. cft. Il., v, 867 , where Ares is pictured as ascending to heaven $\delta \mu o \hat{v} \nu \epsilon \phi \epsilon \epsilon \sigma \sigma \nu$. There is a reminiscence of this passage in I Th. $4^{17}$, "with them we shall be snatched up in the clouds to the meeting with the Lord in the air' (in contrast to the usual Messianic interpretation of our v. in the N.T.). The clouds are in contrast to the chaos of waters-the Kingdom of Heaven opposed to the kingdoms of this world. It is a question how far we may press the nuances contained in the clouds; as with Dr., 'superhuman state and majesty,' or possibly swiftness of motion. Position upon the clouds, which the writer avoids, would rather be the attribute of Deity, e.g., Is. I9 ${ }^{1}$, Ps. $104^{3}$, and his enthronement upon the cherubs. The contrast of the human being lies with both the Ancient and the beasts: God, man, beast, $c f$. Ps. 8. The pass. 
'he was presented' (JV 'he was brought near') is the proper rendering of the Aram. idiom of the act. pl.; cf. v. ${ }^{5}$ and Note at $2^{13}$. The idea is that of a royal audience; $c f$. the identical $7 \Omega=p$ מדם סנהואריב, 'I presented thee before Sennacherib,' A PO pap.

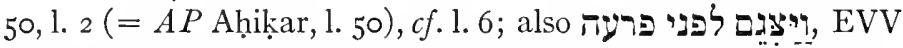
'presented them,' Gen. $47^{2}$. There follows in $v .{ }^{14}$ the description of the viceregal investiture of the humanlike being. For the attribution of dominion and glory and sovereignty, $c f$. the similar terms used of Neb.'s imperial power, $4^{33}, 6^{18}$. The v. depends with its expression of an eternal and incorruptible kingdom upon $2^{44}, q . v$. for discussion of פלכו 'sovereignty,' EVV 'a kingdom.' For the standing phrase 'all peoples,' etc., $c f .3^{4}$, etc. For the vb. 'serve,' used of both human and divine service, s. at $3^{27}$ Note; inf. ${ }^{27}$ ' the people of the saints are the object of this service. Comm., who insist that the vb. implies a divine object, e.g., Keil, are in the wrong, as Zöck. acknowledges. For the interpretation of the 'Son-of-man,'s. Note at end of the chap.

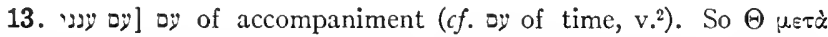

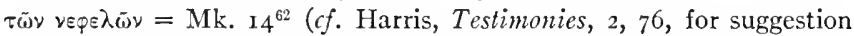
of a basic Targum here), Rev. ${ }^{7}$ (the balance of the v. a non-Septuagintal citation), 2 Esd. $3^{3}$, and so Just. M., Tryph., $3 \mathbf{r}=\mathfrak{H}$. $\quad(6) Q \dot{\varepsilon} \pi t$ $\tau . \nu_{.}=$Mt. $24^{30}, 26^{64}$, Rev. $14^{14} .16=$ Just. M., $A$ pol., $5 \mathrm{I} \dot{\varepsilon} \pi \dot{\alpha} \nu \omega=$ Didache I6, and so Other citations have $\dot{\varepsilon} v, M$. I $3^{26}$ (D $\left.\dot{\varepsilon} \pi i\right)$, Lu. $2^{27}$. The early Lat. texts vary, with cum (so Lucif., prob. OLat.), in, super, all being found in Tert., s. Burkitt, Old Latin, 22. The accumulation of rdgs. by no means justifies Nestle (Marg., 40) and Dalman (Worte Jesu,

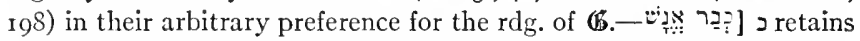
its original nominal character as 'the like of'; s. BDB, GB (otherwise Kön., $L g b$., ii, I, 279). For Heb. cf. the use in Eze. $\mathrm{I}^{27}$, etc.; for Arab.

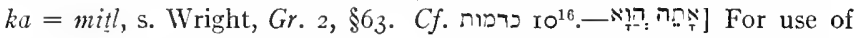
הוה with ppl. s. Kau., $\$ 76,2$, f. After

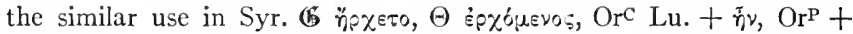

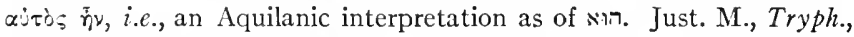

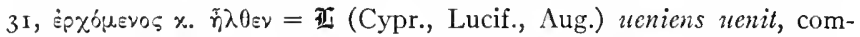

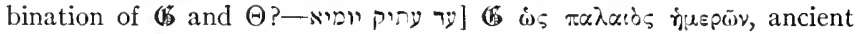
error for $\ddot{\varepsilon} \omega \varsigma \pi . \dot{\eta}$., but pre-Christian, as citation of it in Rev. $1^{14}$ shows; s. the writer's article in Expositor, Sept., 1921, 214. Bousset, Rel. $d$. $J u d$. ., 303, cites this as a Septuagintal notion of a pre-existent Messiah, but it is accidental.-Dקרמוהי הקרבוהי] [ $\alpha \dot{s} \approx \omega$, , the method of which mistranslation is patent. In $\Theta$ texts $B$ 


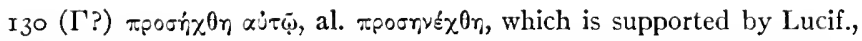
oblatus est $e i$, the vb. being apparently interpreted sacrificially as in Ezr. $6^{10 .}{ }^{17}$, APO pap. I, l. 25 ( $A P$ no. 30 ). Or ${ }^{p} \mathrm{OrC}^{\mathrm{C}}$ (106 A al.) Lu.

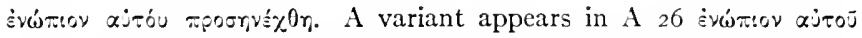

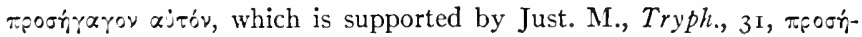
rayov $x ; \tau i v=$ Tert., Idv. Marc., iii, 7 adduxerunt eum (s. Burkitt, Old Latin, 22. 27.ff.). With Burkitt this rdg. appears to be a revision of the faulty $\left(\mathbb{G}\right.$, not a variant of $\Theta$. The same $\mathrm{ddg}$. appears in $\mathbb{6}^{\mathrm{S}} \mathrm{Sm}$, which Swete reverts into $\ddot{\gamma} \gamma \gamma c \xi o v$, but rather $=\pi$ poorirarov. Which was the original one of the $\Theta$ rdgs. it is difficult to decide; either is a possible tr., and either may be a corruption of the other.-14. ? : $\mathbb{H}$ as though

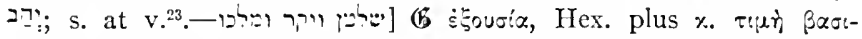

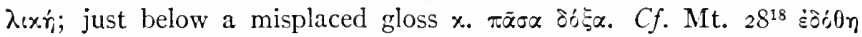

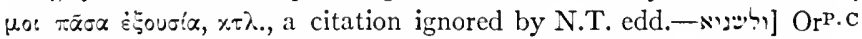

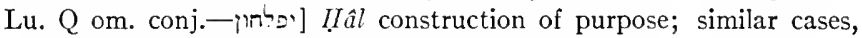
v. ${ }^{16}$ bis; these to be added to cases cited in Kau., $\$ 73,3$, b, Mar., Gr. $\S_{13}$. This use of the impf. appears in Arab., s. Wright, Gr. 2, p. 26,

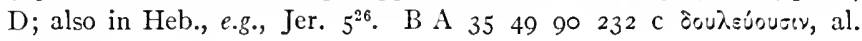

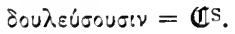

15-27. Daniel's anxiety and the interpretation of the vision. 15. As for me Daniel, my spirit was anxious on account of this, while the visions of my head were troubling me. The emphasis on the first person is not due to the pseudonymous habit, with vLeng.; it marks the break in the vision when the seer comes to himself. The vb. rendered 'was anxious' ( $c f$. a similar phrase, $2^{1}$ ) has been variously interpreted, e.g., 'was horrified,' $\Theta$ II Bert.; 'was grieved,' Aph. Syr. (for the woes threatened to Israel), contristatus, deDieu, or contritus fuit, Calv., and so AV RVV; 'was pained,' Dr., JV. The vb. however has the sense of being 'short' in spirit, and means constraint, impatience, anxiety, and the like. This oppression is the motive which makes the seer bold to accost one of 'the assistants.' $C f$. the similar phrase in 2 Esd. $3^{29}$, excessit cor meum. On the other hand, Rev. $5^{4}$, sometimes adduced as a parallel, implies grief. The tr. 'on account of this,' in place of the traditional 'in the midst of my body' (EVV), is obtained by a slight change and shifting of the Aram. letters, is supported by $(\mathfrak{b}$ and accepted by many moderns; s. Note. For the final clause $c f .4^{2}$, etc. 16. I approached one of the Attendants to ask him the surety concerning all this; and he said to me that he would make me know the interpretation of the things. 'The usual rendering, 'one of them that stood by,' 
ignores the force of the ppl. of the Aram.: 'the standing ones,' i.e., those who were in attendance on the heavenly monarch; the term is taken from court life, s. Note at $\mathrm{I}^{4}$. Cf. Hipp., iv, 8, "the angels who stand before the Glory." The interpreter angel appears in Eze. 40-48, Zech. I-7, the later cc. of this book, I En., Test. XII Patr., Jubilees, 2 Baruch, 2 Esd. (Cha.); in the earlier prophecy God himself spoke, and yet there was from early times the mediation of 'the Angel.' The second part of the v. gives a revision of the usual rendering, which is awkward; s. Note.

15. אהתכרית] S. Kau., p. 8I, $82 ;$ mil $^{6} e l$ accent is to be expected, $c f$.

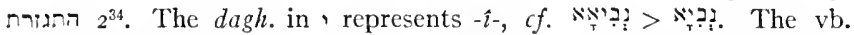

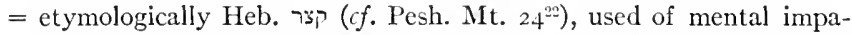

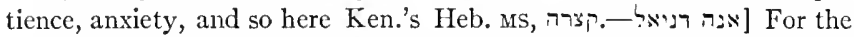
abs. pron. $c f$. Ezr. $7^{21}$; so in the papp. in the pap. in PSBA r907, 260 ff. = ביר יונרן ואנה . ביתי אנה no. 8I, 1. I4; for the same use in Heb. s. GK $\S_{1} 35,2$, e.g., inf. 8. ${ }^{15}$ -

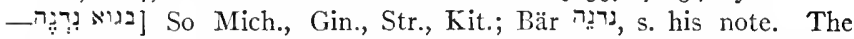
traditional and still dominating explanation connects נרנה with 'sheath,' I Ch. $2 \mathrm{I}^{27}$, also in the Targums, a word of Sanskrit origin ( $c f$. also Tisdall, $J Q R$ 2, 367); so the Jewish and early Prot. comm., Buxtorf, Kau., p. 94, top, Nöld., GGA r884, 1022, Mein., Bev., Behr., Kamp., Pr., Dr., Kön., Hwb. Sa. tr. 'in my body.' This interpretation requires a radical change of punctuation (orig. $=$ nidhâna), while the final vowel is variously treated as a suffix (s. Kau., Kamp.). Two Rabb. passages, e.g., Sanh. 108a, 'lest their soul should return to its sheath' נדנה (s. Rabb. Lexx.), as is often admitted, may merely depend upon the interpretation of the present passage. A parallel is found by some in Job $27^{8}$, and Polanus has compared Pliny, Hist. nat., vii, 53 , "donec cremato eo remeanti animae uelut uaginam ademerint." Preferable is the explanation apparently first advanced by Capellus, followed by Bert. and, of recent comm., dEnv., Jahn, Mar., Ehr., Cha., $\mathrm{BDB}, \mathrm{GB}$, that the phrase is a corruption of בגין בנגין רנָה = 'on account of' in JAram., e.g., 'Targ. Yer. Gen. $12^{13}$. I note Syr. בגן used similarly, Wright, A poc. Acts, 215, 1. I9. Torrey, Notes, I, 282, prefers rdg. בגון (= JAram., s. Dalman, Gr. 221, $226 f ., 239$ ), with origin from Pers. gôn, 'color,' of which gên as here would be a variant. (B) apparently agrees with this modern interpretation in $\dot{\varepsilon} v$ roútols $(=\mathfrak{I}$

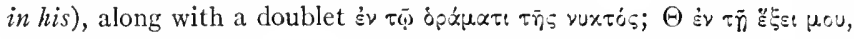
by which noun $\Theta \operatorname{tr} . " 7^{28}$, so supporting Torrey's derivation. This understanding of $\Theta$ is better than that of Bert.'s, who cft. " $\xi$ เ Jud. I ${ }^{9}$. Nestle, Marg., 4I, follows the same line and would read 


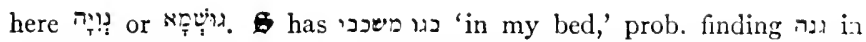

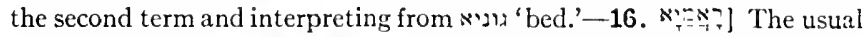

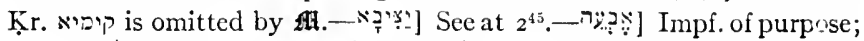
s. on יפלחון] vLeng. has rightly seen that the impf. is one of purpose, and represents the idiom in German by 'er sagte es mir zu und so wollte er mir kund thun.' $C f$. I Ki. I ${ }^{17}$ ל, 'bid [Solomon] that he give me.' The idiom appears exactly in Arabic. I note in 'Usâma ibn Munkịid (ed. Derenbourg), p. Io, l. I9, kultu lahu fa-ta'dina li 'an 'udaiwana, 'I said to him that (and) he should permit me,' etc.; somewhat similar cases in Wright, Gram., 2, pp. $31 \mathrm{f}$. The usual tr. 'told' for רמא makes the vb. entirely parallel to הודענג', is superfluous then, while אמר in that sense should have the obj. expressed, e.g., $4^{6}$. $\Theta$ felt the awkwardness

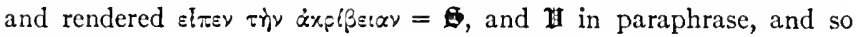
Bert.

17. 18. The interpreter gives a summary explanation of the vision. 17. These great beasts, which [ to be explicit] are four [in number]: four kings shall arise from the earth. The Grr. tr. 'kingdoms' by way of interpretation; but the individual king can stand for his empire, $c f .8^{20}$ and Neb. as the head of gold in c. ${ }^{2}$. The nuance 'from the earth' harks back to 'from the sea,' $\mathrm{v.}^{3}$. Both $\mathbb{G}$ and $\Theta$ introduce at the end of the v. a statement of the destruction of these kingdoms; but that is implied dramatically in the continuation, 18. And the Saints of the Most High shall take over $\left[c f .6^{1}\left(5^{31}\right)\right]$ the sovereignty and shall possess it for-

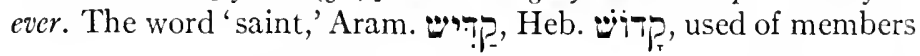
of the Church of Israel, is found only in this chap., $8^{24}$, Ps. $16^{3}$, $34^{10}$; for the thought $c f$. Ex. $19^{6}$, 'Ye shall be to me a kingdom of priests, a whole nation' ( $c f$. inf. I $2^{7}$ ). Its equivalent ä $\gamma \iota 0$ s became the standing name for members of the Christian Church. (See Dr. on the other far more frequent word hasîd, also translated 'saint' in the EVV.) The word translated 'Most High' occurs only in this combination, also vv. ${ }^{22 .}{ }^{25 .}{ }^{27}$. It is a unique,

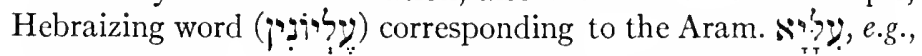
v. ${ }^{24}$ ('against the Most High'), and s. Comm. at $3^{24}$. The term was probably a current one among the Chasidim. It is cited in Schechter's Zad. Fr., 20, 1. 8. As argued in Note at end of the chap., the saints of the Most High are the group typified by the Human, v.13. 
17. רברבתא] (G B Q $26132149 \mathrm{~h}^{208}$ om., al. $\tau \dot{\alpha} \mu \varepsilon \gamma \dot{\alpha} \lambda \alpha$, Lucif. magna.

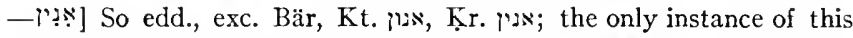
form; it is used as copula. ארבע Jahn, Cha. indorse $\mathbb{G}$, but the argument is weakened by observing that $\mathbb{6}$ syntactically rearranges the broken construction of the Aram.,

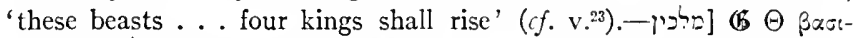
$\lambda_{\varepsilon i \alpha}=M_{2}$, so Ken. $253=\mathbb{I}$ regna; $(\mathfrak{b}$ accepted by Knab., Jahn, Cha., but with Bert., Kamp. the change is needless; $c f$. 'king' for 'kingdom,' $8^{20}$. In c. II the text authorities vary much as between

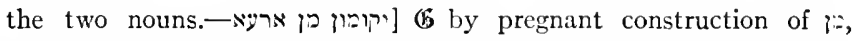
$\dot{\alpha} \pi 0 \lambda_{0} \sigma \nu \tau \alpha: \dot{\alpha} \pi \dot{\delta} \tau \bar{\eta}_{\varsigma} \gamma \bar{n}_{\varsigma}$, which has induced the plus in $\Theta$ texts $\alpha \hat{\imath}$ $\dot{\alpha}_{f} \theta \dot{r j o o v \tau \alpha}$, which fails, however, in Lucif. Jahn, Cha. prefer $\mathfrak{k}$ vs. 括; Ehr. supposes a lacuna.-For $\mathfrak{I}$ cod. Am. gives correct construction

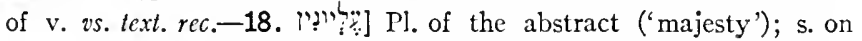
אליה Hos. I $2^{11}$ and Comm. on $4^{5 \mathrm{~b}}$. The similar pl. protects this understanding, against Hitz., Bev., Behr., Mar., who argue for the phenomenon of pluralization of both nouns where the first is the proper pl., exx. in GK \$1 24, q. The case of בני איליט Ps. 291, etc., is no proof, for אליהיכ = אילים. It is remarkable that the Aram. word $y$ otherwise used in the book also occurs v.25, alongside of עיוניון. But in this prob. current term of the day the Saints preferred the Hebraic to the Aram. word. Or the Heb. word may have slipped in from the Heb. orig. of the chap. The word belonged to the common Heb. stock, e.g., Phœe. 'E

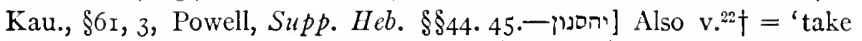
in fief-possession,' s. on $22^{37}$. first nember (supplied in Q V Lu.), and prob. with right Mar., Löhr (but against Kamp.'s judgment) om. it on the ground that the parallelism is improved. A similar plus appears in the Song in c. 3, v. ${ }^{(90)}$. The combination עלים עלמיא is unique; it possesses superlative significance, s. on לים עלמיה אליה $2^{47}$.

19-22. The seer desires more particular information about the fourth beast. 19. Then I desired to ascertain about the fourth beast, which was diverse from them all, exceeding terrible, its teeth of iron and its claws of brass, devouring, crushing, and stamping the residue with its feet; 20 . and about the ten horns which were on its head, and another which came up, and there fell before it three, and that horn, it had eyes and a mouth speaking big things, and its appearance was greater [i.e., it looked bigger] than its fellows. 21. I was beholding, and that horn was making war with the Saints and prevailed over them, 22. Until that the Ancient came, 
and the decision was given for the Saints of the Most High, and the time arrived that the Saints possessed the sovereignty.

The passage follows the description in vv. ${ }^{7 .}{ }^{8}$, with some additional features, which have led many critics to desire to incorporate them in the first instance. On the other hand, Sellin and Hölscher would treat these expansions as secondary; s. Int., §2I, c. 19.20 constitute a long period composed of relative clauses (cf. $\left.2^{37 .}{ }^{38}\right)$. The syntax of $\mathrm{v}^{20}$ is improved by following a suggestion by Torrey (s. Note) so as to read: 'before which three horns fell, which had eyes.' 19. The feature of the 'nails of bronze' is new; the monster is like the Bab. siruššs beast. 21 introduces the fresh item that 'that horn' 'made war with the saints and prevailed over them' ( $c f$. Rev. $\left.\mathrm{I} \mathrm{I}^{7}, \mathrm{I}^{7}\right)$. Some critics have desired to postulate a lacuna between vv. ${ }^{8}$ and ${ }^{9}$ once containing this element, but then the mystery of the vision would have been revealed too early and undramatically. On the other hand, the seer himself is here anticipating the interpretation, and it is probable that this passage is a later addition; s. further Comm. on $v^{25}$. The seer's contemporary interest is revealed by his inquisitiveness concerning the last beast and the judgment, which hitherto have been hid in figures. 22. Read with most comm., RVmg JV 'judgment was given for the saints,' i.e., decision was rendered for them; s. Note. The sentence 'judgment was given,' דיניא יהב, many critics (Ew., Bev., Mar., Kamp., Dr. (?), Löhr, Cha.) desire to amend: 'the court sat

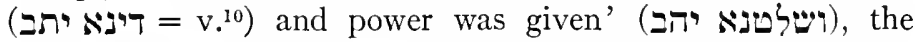
present lacuna having been caused by haplography. But the text of $\mathfrak{T}_{\text {is }}$ is adequate.

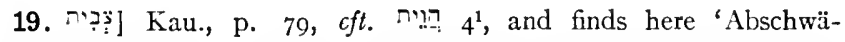
chung des $\hat{e}$ zu $\hat{\imath}^{\prime} ;$ but Nöld. in his review, p. rorg, explains the vowel from the internal $i$ of the root.vulgar texts and MSS Mein., who $c f t$. v. ${ }^{16}$. There is no reason to tamper with the good idiom here $=$ 'make sure, ascertain,' or with Behr. to suppose implicit change

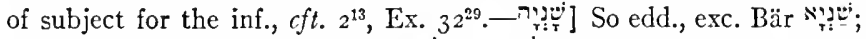

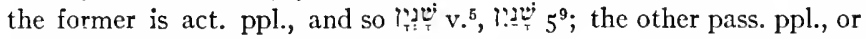
adjectival, and following the Targumic pointing. The latter is more

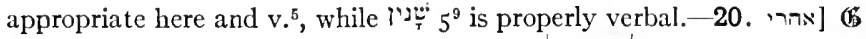

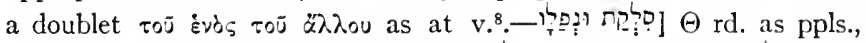

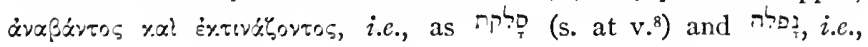




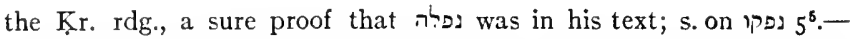

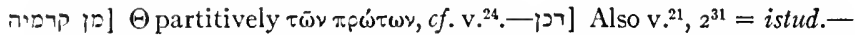
[תלת וקרנא רכן = $\tau p(\alpha \times$ s $p \alpha \tau \alpha)=$ Lucif., and this may have been in orig. $\Theta$. 'That [horn]' would still remain outside of $\Theta$ 's witness, which corroborates Torrey's suggestion, I, 282, that we read וקרנא דכן for, which came in from v. יכל [יכלה להן-1.

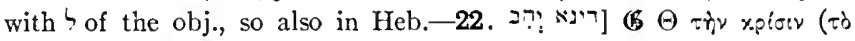
$x_{p}(\mu \alpha) \varepsilon \delta \omega x \varepsilon=1$, i.e., $2.7 ;$; $f$. variants at v. ${ }^{14}$. Two interpretations have been given, both of which were advanced by the early Prot. comm.: (r) 'decision was rendered for,' which has the vote of the majority and of all recent comm., and so the view of AEz., "he gave them

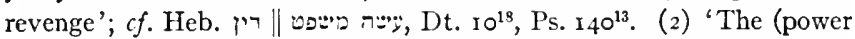
of) judgment was given to,' properly denied on the ground that God is the judge in this chap. Of this interpretation there is reminiscence of the passage in Wis. $3^{8}$, the righteous 'will judge nations and rule peoples,' and in Mt. $19^{28}$, 'when the Son of Man sits on the throne of his glory, ye also shall sit on twelve thrones judging the twelve tribes of Israel,' and I Cor. 62, 'Do ye not know that the saints shall judge the world?', and in a combination of $v^{9}$ and this v. in Rev. $20^{4}$, xpina sosion aurois. It is this 'analogy of Scripture' which has induced some comm. to take the second interpretation.$\mathrm{v.}^{25}$. The following phrase is one of result; cf. $2^{13 .}{ }^{49}$, and s. Mar., Gr.

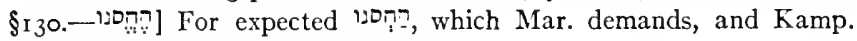

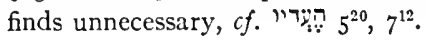

23-27. The interpretation of the fourth beast.

23. Thus he said: The fourth beast-

A fourth kingdom shall be upon earth : which shall be different from all the kingdoms, And it shall devour all the earth: and shall trample it and crush it.

24. And the ten horns-

Out of this kingdom ten kings shall arise : and another shall arise after them, And he shall be different from the first ones: and three kings shall he lay low.

25. And he shall speak words over against the Highest : and shall wear out the Saints of the Most High; And he shall think to change seasons and law: And they (the saints) shall be given into his hand: For a time and times and half a time. 
26. But the court shall sit :

and his dominion shall be taken away :

for utter destruction and annihilation.

27. And the sovereignty and the dominion and the greatness of the kingdonts under the whole heaven :

shall be given to the people of the Saints of the Most High;

Their sovereignty an everlasting sovereignty :

with all dominions serving and obeying them.

The angel speaks in a poetical rhapsody, with free use of metrical forms; $c f$. Mar., Cha.

23. 'All the earth': as was said of the Pers. empire, $2^{39}$. The three vbs. of the beast's activity are picture words: 'devour' (lit. 'eat') = 'destroy,' as Is. $9^{11}$, Jer. Io $^{25}$; 'trample,' of the treading of oxen, and so figuratively as here, Is. $4 \mathrm{I}^{15}, \mathrm{Mi} .4^{13} ; c f$. the accumulation of similar terms in $2^{40}$. 25. "Speak words (over) against the Highest': $c f$. English 'speak against'; speaking words had in itself an evil connotation, $c f$. Hos. Io'. 'Wear out': another picture word, that had come to be equivalent with 'to humble,' I Ch. I $7^{9}$. 'The Highest' and 'the Most High' represent two different words in the original, s. Comm. at v. ${ }^{18}$. 'Think' is a good idiomatic tr. of an Aram. word ( $c f$. the Pesh.) with connotation of 'expect.' 'Seasons and law': the 'seasons' (JV; 'times' AV RVV) are the calendar feasts of the Church;

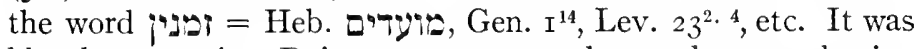
blasphemy against Deity to attempt to change these everlasting ordinances; the book of Jubilees is a commentary on this article of faith. Morgenstern, 'The Three Calendars of Ancient Israel,' Hebrew Union College Annual, i924, p. 75, suggests that the passage refers to an attempt by Antiochus at revision of the calendar. The word 'law' has occurred above in its primary, governmental sense, e.g., $2^{13}, 6^{9}$; then of religious law, 'the law of his God,' $6{ }^{6}$, and so here practically = 'religion.' In Ezr. $7^{12}$, etc., it denotes the Thorah. The historical interpretation of this indictment is found in I Mac. $\mathbf{I}^{41 \mathrm{ff}}$ : "The king [Ant. Epiph.] wrote to his whole kingdom that all should be one people and that each should forsake his own laws. And all the nations agreed according to the word of the king; and many of Israel consented to his worship, and sacrificed to the idols, and profaned the sabbath. And the king sent letters by the hand of messengers unto Jerusalem and the cities of Judah, that they 
should follow laws strange to the land, and should forbid whole burnt offerings and sacrifice and drink offerings in the sanctuary, and should profane the sabbaths and feasts ... that they might forget the Law and change all the ordinances.' There follows the history of the execution of this Nihilistic edict. With the interpretation of the figure here as the type of Antichrist (e.g., in Rev.), this historical ref. came to be entirely ignored, exc. by a few, Aph. Syr., Apollinaris, Polych., and 'times and law' were interpreted of the world's institutes, the two terms referring to divine and human statutes (e.g., Calv., Häv., Keil). Grot. restored the historical interpretation by ref. to Mac. Among curiosities of interpretation may be noted Jeph.'s suggestion of Mohammed's change of the Kiblah, and Geier's of his change of the calendar.

This rather abstract ref. to the terms of Ant.'s persecution raises the question whether the passage in $\mathrm{v.}^{21}$, 'and the same horn made war with the saints and prevailed over them' is original. It is remarkable that this extreme statement should not be repeated in the interpretation, and equally difficult to see how the seer himself could see the thing figured. Either the writer has forgotten himself, or the passage is a later intrusion. Of the comm. Ehr. alone has recognized the inconcinnity of the passage. The omission of the passage would give an earlier date for the composition of the passage than that of the war with the Maccabees.

25 (cont.). 'For a time and times and half a time' עד עד

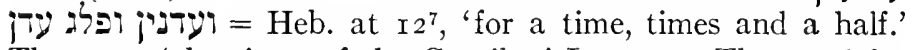
These are 'the times of the Gentiles,' Lu. $2 \mathrm{I}^{24}$. The word for 'time' is another than that for seasons just above (but AV RVV 'times' in both places). The extent of time is expressed, in apocalyptic fashion, indefinitely, and the problem is whether a definite term is meant or an indefinite era is symbolically expressed. Essaying an exact interpretation, 'time' may be interpreted as 'year' after the usual interpretation at $4^{13}$ (q.v.). The traditional and by far the most common understanding of 'times' is as of a dual; the word is pointed as a pl., but the Aram. later having lost the dual, the tendency of is to ignore it in BAram. (s. Note on 'eyes,' v. ${ }^{8}$ ). Accordingly $\mathrm{I}+2+1 / 2=31 / 2$ years. This term is identical with the half-year week of $9^{27}=3^{1 / 2}$ years, and is roughly approximated by the 2,300 evenings and 
mornings of $8^{14}=\mathrm{I}, \mathrm{I} 50$, although this figure falls considerably short of the required number of days, since $3 \frac{1}{2}$ solar years $=$ $\mathrm{I}, 278$ days, and $31 / 2$ years at 360 days $=\mathrm{I}, 260$. (The $\mathrm{I}, 290$ and I,335 days at $12^{11 .}{ }^{12}$ are later additions.) On these data s. $a d$ locc. and Int., $\S 2 \mathrm{I}, d$. This interpretation of our passage was fixed in the Ist cent. A.D., for in connection with the citation of it in Rev. $I 2^{14}$ the apocalyptist interprets it as meaning 42 months, $\mathrm{II}^{2}, \mathrm{I} 3^{5}$, and $\mathrm{I}, 260$ days, $\mathrm{II}^{3}$. So also the contemporary Josephus with his period of $3 \frac{1}{2}$ years for the devastation of the temple by Antiochus in B.J. pref. 7; i, I, 7, which term is a reminiscence of Dan., for in $A J$ xii, 7,5 , he follows I Mac. in making the term exactly three years (v. inf.). The Christian comm. naturally follow suit, e.g., Hipp., Theodt., and Jer. with his grammatical comment, doubtless gained from his Jewish teachers: "tempora, iuxta hebraici sermonis proprietatem, qui et ipsi dualem numerum habent, duos annos praefigurant." Sa. also has the dual (so noted by Ra. here, and AEz. at $I 2^{7}$ ). The Fathers, following the Biblical interpretation, refer the era to the dominion of Antichrist, with a few notable exceptions. Aph. Syr., Polych., Apollinaris see in it the time of the devastation of the temple. This historical interpretation was taken up again by Grot., Junius, Polanus, and is followed, of later scholars, by Bert., Rosen., vLeng., Maurer, Hitz., Stu., dEnv. (with typological reference to Antichrist), Bev., Pr., Dr., Mar., Cha., Curtis (in $D B$ ), Kamp. (in EB), Kön., Mess. Weiss., 3 Io, et al. .

The most natural terminus ad quem is Judas' rededication of the temple in the month Chislev Era Sel. $1_{4} 8=$ December ${ }^{6} 6_{5}$ B.C., I Mac. $4^{52 \text { ff. }}$ The initial attack of Ant. upon Jerusalem was in Era Sel. $\mathbf{I} 43=\mathrm{I} 70$ B.C., but the prohibition of the cult and devastation of the temple did not begin until 'full two years' later, i.e., Era Sel. $145=\mathrm{I} 68$ B.c., s. I Mac. ${ }^{20 .}{ }^{29}$. Acc. to $4^{54}$ the rededication occurred on the anniversary of the profanation of the temple, so the term of the devastation for I Mac. is three exact years. For the dates s. Schürer, GJV I, 200, n. $39 ; 208$, n. 7. (But acc. to 2 Mac. Io $^{3}$ the devastation lasted but two years; this is an item in the disputed question as to the relative value of $\mathrm{I}$ and 2 Mac.) With Bert., al., the extra $1 / 2$ year may include the months preceding the actual profanation of the temple. If the datum is post cventum, there is no reason to dispute what was in the writer's mind as to the facts. But 
if it is prophetic, the question arises why the scrupulous 'half a time,' why not two or three years, or the like? This is a prime argument of those who oppose the historical interpretation. It may however be suggested that $3^{\mathrm{T}} / 2$ years is a current phrase for half a sabbatic lustrum, as we might say 'half a decade,' 'half a century,' etc. The sabbatic years were rigorously observed in agriculture by the Chasids, as we know from I Mac., while the term of seven years was current in law, e.g., Ex. $2 \mathbf{I}^{2}$. With this solution we find the writer using a cryptically expressed but fairly exact definition of time. If the passage is prophetic of the termination of the Antiochian persecution, we must admit it to be a remarkably approximate prediction of a future event. A similar instance of such a short-term prediction, which history shows was fulfilled, is that by Isaiah, Is. $8^{4}$, who prophesied that while his as yet unborn child was still an infant, i.e., within two or three years, Damascus would be vanquished, a prediction that came about within three years, 735-732. For similar exact prophecies of the same prophet $c f$. $16^{14}, 2 \mathrm{I}^{16}, 29^{1 \mathrm{ff}}$; in the case of Jeremiah, the fate of the prophet Hananiah, c. 28. Particularly Dr., pp. lxv seq., and Cha. stress this predictive element.

But the contrary opinion insists that 'time and times and half a time' is indefinite or symbolic. And so some exegetes who would hold to a contemporary, not distant application, but regard the term as altogether vague. For criticism of the 'historical' interpretation, s. esp. Keil, Zöck., Mein., and Behr., denying the definiteness of the $3 \frac{1}{2}$ years. The actual pl. and the indefinite פ פל means constantly 'half') are insisted upon. So Jeph. in as many words; Tirinus paraphrases: "seu longo, seu breui, tempore"; and Behr.: "das gewöhnliche Zeitmaass (ein Jahr), dazu dasselbe mehrfach genommen, dazu dasselbe theilweise genommen." However, the 'half' still militates against the theory of a round number. The early Jewish and general Patristic interpretation was followed by the early Prot. comm. (with a few exceptions noted above), referring the period to the reign of the Antichrist. The most popular interpretation is that which is thus presented by Calv.: "tempus: pro tempore aliquo, cuius finis est in consilio Dei; in tempora: in prorogationem. temporum; usque ad sectionem, uel dinisionem; ut significet ali- 
quem modum fore et finem his malis, adeoque priorem tristitiam mitiget." The latter point is illustrated from the shortening of those days for the sake of the elect in Mt. $24^{22}$. Vatablus holds that 7 is the perfect number, the halving of it gives the inferior number of Antichrist. Similarly Kran., Klief., Keil, who adduce the $3 \frac{1}{2}$ years of the famine in Elijah's day, acc. to Lu. $4^{25}$, Ja. $5^{17}$. (But this Judaistic notion of the time, not in the Elijah story, where only the third-year famine is noted, is perhaps set by our passage; s. the N.T. comm.) This figure is eagerly taken up by the maintainers of the mythological interpretation of the chap. (v. sup. on vv. ${ }^{13 \mathrm{f}}$ ) $; 3^{\mathrm{I} / 2}$ is regarded as an apocalyptic symbol like other multiples of $7, e . g .$, Bousset, Rel.d.Jud., 284 , and his comm. on Rev. $13^{5}$.

26. 27 repeat variantly vv.11. 14. The word 'kingdoms [under the whole heaven]' appears in AV as 'kingdom,' whether through ignoring of the peculiar construct idiom here, or through insistence on the kingdom of Christ; GV abbreviates, prob. for the same reason: 'das Reich, Gewalt und Macht unter dem Himmel.' For 'under the whole heaven' $c f .9^{12}$ and Note there. In $27 \mathrm{~b}$ the pronouns of the Aram. in the phrases translated above 'their kingdom' and 'obeying them' (with JV) are sing., 'its,' 'it,' doubtless referring to 'the people,' to whom in v. ' the sovereignty' is given. From the context the ref. to 'the Most High' as the nearest antecedent is fallacious; but it is accepted by $\Theta$ and AV RVV ('whose' with $\mathfrak{H}$ or 'and his,' 'him') and by a few comm., e.g., Keil. Calv. sees in it the submission to the Christian Church. The Biblical interpretation is of the reign of the Saints, s. Note.

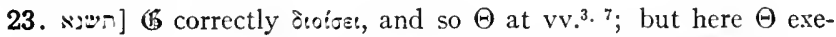

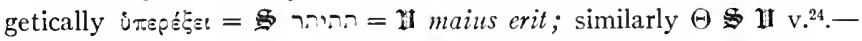
[הרישנה ותדקנה Cf. $2^{40}$. (BS here is in contracted or corrupt form, and

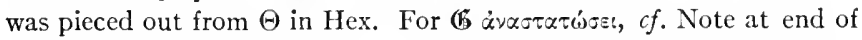

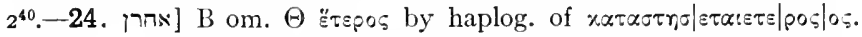
-

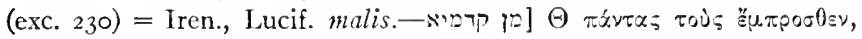
230 plus $\alpha^{j}$ roj (i.e., as in $\mathrm{v}^{20}$ ), indicating a var. tr. = Iren., Lucif., Aug. -25. 7?] $C f .7$. $6^{5}$; with this mng. of. T. $10^{13}$, and by in the parallel passage $\mathrm{I}^{36}$; i.e., uersus > aducrsus (vLeng.); or more exactly with Behr., 'gegenüber'; with Calv., "sedebit quasi ad latus Dei, hoc est, ex opposito: manifestus hostis erit"; and so Häv., "in dem Ausdrucke liegt . . . das sich Gott gleich stellen"; $c f$. Keil. This is Sym.'s 
interpretation (in Jer.), sermoncs quasi Deus loquetur (corr. loquitur), $c f .2$ Thes. $2^{4}$. Tirinus, Kön., Hwb., recognizing a difficulty, tr. 'concerning.' May the word be identified with Arab. d̦add, bid̦addi, 'against,' which would have coalesced in Aram. with șadd?-2??] For origin of the rt. s. Haupt, AJSL 22, 259. Heb. בלה = 'be worn out,' of clothes, then 'perish'; the Piel used actively 'use up'; for the mng. here $c f$. I Ch. I $7^{9}$ ' 2 Sa. $7^{10}$; for the former vb. Curtis suggests that it was supplanting the older

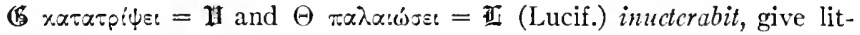

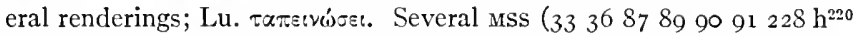
$=$ A) $\pi \lambda \alpha v_{i}^{\prime} \sigma a t$ evidently error (preferred by Bert.) for $\pi \alpha \lambda \alpha t \omega \sigma \varepsilon t, c f$.

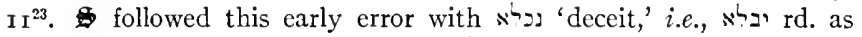
', becoming the Syr. verbal form נכליא, which was then understood

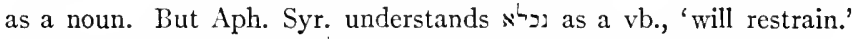

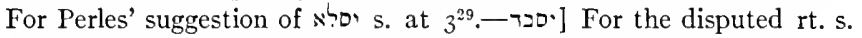
Lexx. Cowley reads the vb. סברת 'I thought,' in $A P O$ pap. Io, $1.7=$

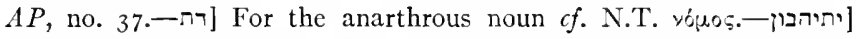
'The saints' are the subject, not 'the times,' with some early Prot. comm., and so evidently $\mathbb{G} \Theta$, which tr. with a sing. vb. עד ערו [יערגין ופלג עדן For s. at $4^{16}$; the Heb. tr. $12^{7}$ uses phrase is cited Rev. $\mathrm{I} 2^{14}$. If a dual was intended originally, it was

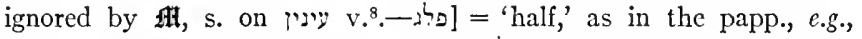
$A P A$ pap. C, 1. Ir. For the conj. with פ $\mathrm{B} 2289$ I30 I32 I49 have xai $\gamma \varepsilon$; elsewhere $\gamma \varepsilon=\eta \aleph ;$ here it appears to represent a glossated

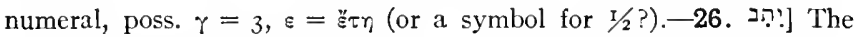
same form in JAram., Syr.; Bär's suggestion, accepted by Behr., that it is an abbreviated Ithpeel is absurd. $\Theta$ read it as perf. $=\mathrm{v} \cdot{ }^{10}$.-

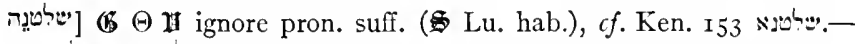

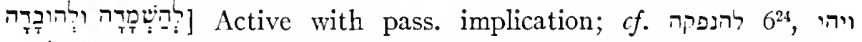
הישער לסגור Jos. $2^{5}$, etc., and cases in Syr. cited by Duval, GS \$332, b. - בד סופאר ה

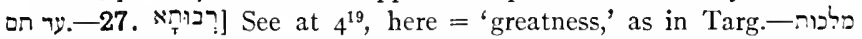
[חהות Unique case of const. before prep. phrase, a usage common in

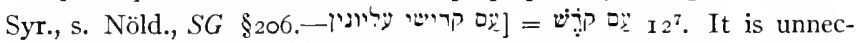
essary to analyze with Mar., Gr. $\S 118$, into 'ein Volk, das aus Heiligen des Höchsten besteht.'-_ה $\left(\mathbb{B}\right.$ stresses this dominion of the saints; and so Wis. $3^{8}$ (cited in Note,

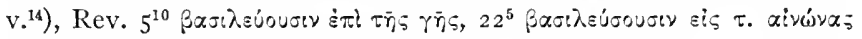
$\tau$. ai $\omega \nu \omega \nu, c f .20^{6}$. $\Theta$ strangely ignores, or avoids this attribution, assigning the dominion to the Highest.

28. At this point the end of the word: so the literal tr. Cf. Jer.

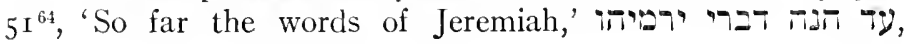


and Ecc. $12^{13}$, 'The end of the word,' term mng. 'book's end' (s. Barton ad loc.) 'The usual tr. 'matter' for מלת is too indefinite here, although proper just below. It includes the subject-matter of the vision, which however is essentially a 'word' of God, $c f$. IO', 'a word was revealed unto Dan.' For the corresponding phrase at the opening of the story, 'beginning of words,' s. at v. ${ }^{1}$. I Daniel-much were my thoughts troubling me: The seer is recalled to himself, as in $\mathrm{v}^{15}$; the phrase, describing his affection of mind, appears above $5^{6.10}$. And my color changed [for the phrase s. at $5^{6.9 .}{ }^{10}$ ], and the matter [a potential word] I kept in my heart. The literary composition of the vision was later, as indeed was the case with the oracles of the great Prophets; a book was finally compiled and concluded, $\mathrm{I} 2^{4}$. The phrase is cited again in Apocrypha and N.T. after similar visions, s. Note.

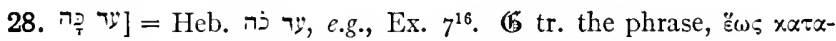

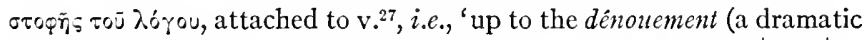
term) of the matter.'-[יווי

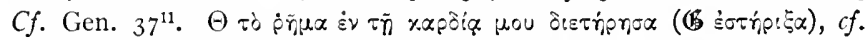

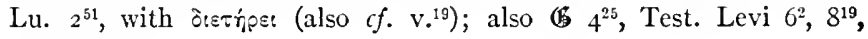
2 Esd. $14^{40}$.

\section{NOTE ON 'SON OF MAN.'}

The term translated above 'like a man' or a 'humanlike one' ( $\left.v_{.}{ }^{13}\right)$, generally rendered verbatim 'one like unto a son of man,' is the most notable crux in this book, the more crucial because with it is involved the Christology of the N.T. However, it is fortunate that the comm. at the present passage have been noticeably free from theological bias, the Messianic and non-Messianic interpretations being found almost indifferently with conservatives and radicals. The present writer will confine himself to the briefest possible discussion of the term in its context.

In the first place, the philology of the term is a matter of dispute. Was it current and commonplace, or is it cryptic, involving a mystery? The many theories fall, on the whole, into three classes, although withal they develop their special nuances. The three classes are as follows: (I) The personal, Messianic interpretation, the eldest and, in past Jewish and Christian exegesis, the prevailing opinion; (2) the symbolical interpretation, the 'son of man' being type of the people of the saints, itself an ancient view; (3) the mythological theory, of recent origin, which finds in the 'Son of Man' a mythical and traditional figure of hoar antiquity-so joining hands in part with the Messianic interpretation. 
To begin with, the prep. 'like' belengs to the agenda of the controversy. Does the prep. indicate essence, identity ( 2 veritatis), or similarity? A vague pursuit of the prep. through the language brings us nowhere. But in this chap. the same prep. is used in exactly parallel circumstances, 'like a lion,' 'like a leopard,' vv.4. ${ }^{4}$, while the same notion is expressed in $\mathrm{v} .^{5}$ by a $\mathrm{ppl}$. ' 'resembling,' with no difference in mng. but for the sake of stylistic alternation. ${ }^{1}$ Analogy requires that the prep. here is equally symbolic; it is exactly identical with 'like the appearance of a man,' $8^{15}=10^{18}$ (with different words for 'man,' uir and homo), 'one like the likeness of sons of men,' ${ }^{10}{ }^{16}$. It is not correct to speak of the prep. as affecting a mystery; it belongs to the expression of visionary phenomena, in which the seer, whether spontaneously or through the use of conventional language, knows that he is seeing only 'the like of' something (so the Sem. use of the prep., s. Note); similarly Volz, Jïd. Esch., I I : "der kbar 'enasch ist ein visionaler Mensch, kein Mensch, wie ihn das gewöhnliche Auge sieht, darum z, aber es ist doch gerade ein Mensch, wie das Wasser, der Löwe doch Wasser und Löwe sind." There is a subtle distinction in $\mathrm{v} \cdot{ }^{9}$, where 'the like of ' an ancient is not said (demanded by Cha.); the reason is that Deity is a person, whereas the beasts and presumably the man are not real living entities but types.

As for the term 'son of man,' בַּ in in Syr. this, often in shortened form barnâs, is the current word for a human being (homo). But Dalman² argues that the term is not found in the PalAram. of early date; the pl. בני אניה appears as a transliteration of the Heb. בני רארס 'sons of man'; in the later Targums the pl. is more frequently found, also occasionally the sing. Fiebig adds a case in a Rabb. tradition of the 2 d cent. A.D., s. Schmidt, col. 4708. Dalman holds that the later usage is due to the influence of the Oriental dialect. He accounts for the term here on his theory of a Heb. original of the chap., the background then being the common Heb. בן ארכ. Dalman's contention is borne out by the subsequently discovered Elephantine papyri, where 2 , wר אי, with also its pl, never appears. There the word dominates by far (some 40 cases vs. Niשs 8 times, the latter only in the Ahikar papp.); it is used of the male, as inclusive of the woman (in legal language), or in the distributive sense-in a word exactly like the Heb. (which word itself also occurs twice). In Dan. the proportion is reversed, ״ג occurs twice as many times as גבר. But this is due to the different sub-

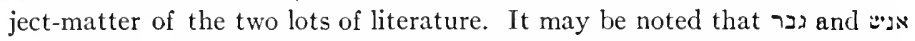
are used in the Ahikar papp. somewhat synonymously-either may be used in an axiom; but if the word is given an attributive adj., then גבר, nנר, is used. That is, גבר meant the individual,

${ }^{1}$ König, Die messianischen Weissagungen, 289, insists on the distinction: the monsters were only like certain beasts, but the figure here is 'menschenartig.'

${ }^{2}$ Worte Jesu, §ix, r, p. I9I; his discussion is elaborated and amended by Fiebig, Der Menschensohn, I901, Schmidt, 'Son of Man,' EB coll. 4705-4740, introd. $\$$, Dr., p. I03, and his article 'Son of Man,' $D B$. 
be asked, with Schmidt, whether the argument ex silentio is to be too much depended upon. The term גבר meant primarily a male and was not always suitable. The abstract $\times$ : $:$ predominates in Dan., but its occurrence in $4^{22}$ is repeated in $5^{21}$ by בגי אגיטא, the one other occurrence of the latter being in $2^{38}$. The idiom of 'son of' a species was common in Heb., and also in Akk. (s. Del., Hwb., p. 390), while we have at least one occurrence of it in the equally unique term בר אה 'a god's son,' $3^{25}$. This case corroborates the idiom for early Aram. The writer might have used here רג, of. $8^{15}$, of the angel; he might have used, like the papp., 2 ; but the expression of both category and individual was best expressed by בר איג' It is not a beast, nor a divinity, 'a-son-of-God,' but a man who is raised to the empire of the world. Accordingly mystery is not to be discovered in the term; it is questionable whether Dr.'s suggestion that it is 'a choice semi-poetical expression' is to be accepted. The writer may have had in mind Ps. 85, 'What is man (Nנוט) that thou mindest him, or a son of man (בי איט) that thou reckonest him?' Curtis, $D B$ I, 556a, aptly cft. Ps. 80, where 'man $\|$ son of man,' $v .^{18}=$ Israel, is contrasted with the wild boar, $v_{\bullet}{ }^{14}=$ the heathen. Unfortunately English gives no satisfactory equivalent, such as German 'Menschensohn.' Exactly, 'son of man' is 'a human.'

However much a student, for one reason or another, may be inclined to find here a Messianic prophecy of a heaven-born Saviour coming to the rescue and rule of his people, nevertheless the strict exegesis of the chap. does not bear this out. The 'accurate' interpretation given later on tells us in so many words what is symbolized by the vision. Acc. to v..$^{18}$ it is 'the saints of the Most High' who 'shall receive the kingdom'; and in $\mathrm{v}^{27}$ ' $s o v$ ereignty and dominion ... are given to the people of the saints of the Most High'; i.e., both statements are intentional replicas of v. ${ }^{14}$. All comm. find the parallel in the Stone in which culminates the great historical drama of c. 2. Early Jewish and Christian exegesis which found in the Stone the Messiah was logical in interpreting c. 2 and c. 7 in parallelism; but it is illogical to understand the Stone of the Kingdom of God and the Son of Man here as the Messiah merely because a personal figure is used.

The writer thus agrees with the majority of recent comm. on Dan., with Mein., Bev., Pr., Dr., Mar., Cha. ${ }^{3}$ For the English reader reference may be made to Dr.'s admirable excursus, pp. 102-110, and to his article, 'Son

${ }^{3}$ Of other scholars who take the same position may be noted: Schürer, $G J V_{2}$, 590: E. L. Curtis, 'Daniel,' DB (s. p. 556a); Hühn, Die mess. Weissagungen, 1899, 1, 78; E. A. Edghill, An Enquiry into the Evidential Value of Prophecy, 1906, p. 371; Lagrange, Le messianisme che les Juifs, rgoo, p. 66 (identifying the Man with the Macc. heroes); König, Die mess. Weissagungen, 286 ff. For the scholarship of the 18 th and early 19th centuries s. vLeng., p. 335. For the 19th-century authorities arrayed for the symbolic and the Messianic interpretation, s. Dr., p. 108, and Schmidt, 'Son of Man,' EB coll. $4709,47 \mathrm{ro}$, notes, and his extensive display of the authorities in his earlier article, "The "Son of Man" in the Book of Daniel,' $J B L 1900$, pp. 22-28. 
of Man,' $D B$. This view also possesses antiquity. Aphrem Syrus notes that the immediate interpretation of the Son of Man is the Jews, as later he interprets the saints of the Most High,.$^{.22}$, as the Maccabees; but even so, he adds, the fulfilment of the prophecy is found in our Lord. This exegesis appears in the historical rubrics in this chap. in Also Theodt. observes that this was the opinion of certain orthodox scholars. So AEz., against the current Jewish Messianic interpretation, held that the Man represents Israel. The notion came up in the early Prot. scholarship, s. Calvin's protestations (in Pole), and Grot.'s notion is of interest, that 'the son of man,' = homo priuatus, indicates the Roman empire (so also he interpreted the Stone in c. 2). Sa. translates, 'a youth,' šâbb. For other views s. Schmidt, col. 4715, $\S 15$.

It must be admitted that the earliest interpretation of 'the Son of Man' is Messianic. The term is frequent in the Parables of Enoch, En. 37-7I, where it occurs 14 times. ${ }^{4}$ The dependence upon Dan. 7 is patent from the first reference, En. $4^{61 \mathrm{ff}}$ : 'And I saw One who had a head of days, and his head was white like wool, and with him was another being whose countenance had the appearance of a man, and his face was full of graciousness, like one of the holy angels. And I asked the angel who went with me and showed me all the hidden things, concerning the Son of Man, who he was, and whence he was, and why he went with the Head of Days. And he answered and said unto me, This is the Son of Man who hath righteousness,' etc. Without doubt this was the primitive Judaistic understanding of the statement of the Lord at his trial, Mk. I $4^{62}$ : 'I am [the Son of the Blessed]; and ye shall see the Son of Man sitting at the right hand of power and coming with the clouds of heaven.' 'The Son-of-Man theme also appears in a vision in 2 Esd., c. 13; the main body of the book belongs to the end of the first cent. A.D., but C. I 3 may be earlier than A.D. $70 .^{5}$ In this vision elements of Dan. have been freely drawn upon to compose an original creation. Vv. 1 ff. read: 'I dreamed a dream by night, and I beheld, and lo! there arose a violent wind from the sea, and stirred all its waves. And I beheld, and lo! the wind caused to come up out of the heart of the seas as it were the form of a man. And I beheld, and lo! this Man flew with the clouds of heaven. ... After this I beheld, and lo! there was gathered together from the four winds of heaven an innumerable multitude of men to make war against the Man that came up out of the sea. And I beheld, and lo! he cut out for himself a great mountain, and flew upon it. But I sought to see the region or place from whence the mountain had been cut out, and I could not.' $N . b$. the combination with the Stone of c. 2. There follows the account of

${ }^{4}$ See Dr., p. I07, n. I. Dr. presents the more important passages at length, pp. Io6 $f$. For criticism of some of the cases s. Schmidt, col. 47 I . The tr. below is from Charles.

${ }^{5} \mathrm{~S}$. Box, The Ezra-A pocalypse, introd. to the chap. Box's tr. is followed in the citation. 
the assault upon the Man by the peoples and their destruction by the breath of his lips. Such a personification of the Son of Man into the Messiah even at an early date-the Parables of Enoch were written within a century after Dan.--is not at all surprising or improbable, as Bousset claims, Rel. d. $J u d$., $305 f$. As noted above, how natural it was for the Servant of YHwh to be personified; of. the naive inquiry of the eunuch, Acts $8^{32} \mathrm{n}$. Similarly the abstract expression of the 3 'the growth' (EVV 'branch') for the Davidic dynasty, Jer. $33^{15}$, was promptly Messianized, Jer. $23^{5}$, Zech. $3^{9}, 6^{12}$, the latter prophet writing within the same century as Jer.

The Messianic interpretation was apparently held by Akiba, first third of $2 \mathrm{~d}$ cent., who held that the thrones of v. ${ }^{10}$ were appointed for God and David (Sanh. $38 b$, cited above ad loc.). Joshua b. Levi, c. 250 , taught that, if Israel deserved it, the Messiah would come with the clouds of heaven, after Dan. 7, or, if otherwise, riding upon an ass, after Zech. $9^{9}$ (Sanh. $98 a$ ). This interpretation was followed by all the Jewish comm., with the exception of AEz., as noted above, including the Karaite Jepheth, e.g., Rashi, 'This is King Messiah.' 6 Finally in the consideration of the Messianic interpretation may be noticed Porphyry's counter-notion that the Son of Man is Judas Maccabee, to whom Jer. triumphantly responds: "docere debet quomodo cum nubibus coeli ueniat," etc.

Of the recent comm. dEnv., Knab., Behr. hold to the Messianic interpretation; so also Kamp., 'Daniel,' EB Io०3, Volz, Jiid. Esch., iof. The strength of the Messianic interpretation arises from the striking impression of the figure of the Son of Man, but those who hold it must admit that that crowning figure disappears at once in its subsequent identification with the kingdom of the saints.

The third class of interpretation, the mythological, is of very recent date. Its precursor is to be found in Schmidt's hypothesis that the Son of Man is the angel Michael; s. his article JBL r900, pp. 22-28, and $c f . E B$ 47 I $a$. His basic argument is that in the subsequent chapters angels are described as 'like the appearance of a man'; he enters the field of Bab. mythology by taking Marduk as the prototype of Michael. See Volz, p. Io, for criticism of this view: Michael is a well-known figure, the Son of Man here a future, non-existent one. And if the beasts are not real, is it logical to demand reality in the Son of Man? Völter in ZTNW I902, I $73 \mathrm{ff}$, would identify the figure with a certain Amesha Spenta, a Persian genius incorporating the Kingdom of God-a view criticised by Schmidt, col. 4710. Bertholet, in Stade, Biblische Theologie, pp. 22 Iff., agrees with Schmidt's opinion, and would incorporate that of Völter: "die Umdeutung wäre dann durch die Gestalt Michaels vermittelt."

- For the Talmudic and Targumic citations s. Dalman. Worte Jesu, $\$ x i, 2$, p. 20I; for the Jewish comm. Schöttgen, Horae hebraicae, 2, 263; CBMich., ad loc.; Kön., p. 299, n. I; and in general Dr., ll.cc. From v. ${ }^{13}$ was derived the Messianic name 'נִy,y, 'cloud-man.' 
But the most representative and wide-spread theory in this class is that which was propounded at length by Gunkel in 1895, followed notably by Zimmern, Bousset, Gressmann, A. Jeremias. ${ }^{7}$ In his Schöpfung und Chaos, 323-335, Gunkel expounds at length the vision in Dan. 7 (cf. Porter's résumé of the theory, $D B_{4}, 26 \mathrm{I}$ ). He seductively adduces the primitive chaos myth with its winds and monsters, finds antique traits in the setting of the divine judgment, and assembles the numerous parallels from Bible and Apocrypha to prove that we have to deal with a common body of primitive mythology. With regard to the Son-of-Man theme he proceeds, p. 33I, to the following induction: "Auch der im Zusammenhange des Dan. so räthselhafte Menschensohn, der auf den Wolken des Himmels kommt, wird zur Tradition gehören; denn es ist schwer zu sagen wie der Verfasser von sich aus auf dies Bild grade für Israel hätte verfallen können; zumal Israel ja in dem Gesichte schon unter dem Namen 'die Heiligen' erwähnt wàr. Im Mythus würde 'der Menschensohn' der Titel des Gottes-Überwinders sein." For proofs of this position Gunkel refers to 'below,' apparently to pp. $367 f f$., where he draws from the elaborations in Rev. and the Adam Kadmon speculations. ${ }^{8}$

This theory was pursued by Zimmern far more exhaustively, as far as the $\mathrm{Bab}$. sources were concerned, in his treatment of Marduk and the 'Christological' myths of that god, in KAT 370-396, esp. 391 ff. From the identity of the four beasts with the four world-ages, Zimmern concludes: "So ist wahrscheinlich, dass ... auch der '(himmlische) Mensch' ursprünglich von einem bestimmten Sternbild am Himmel seinen Ausgang genommen hat. '(Himmlischer) Mensch' wird also ursprünglich so viel bedeuten wie ein bestimmtes Sternbild, das einen Menschen, bezw. einen Gott in Menschengestalt darstellt, im Unterschiede von anderen Sternbildern, die tierische und sonstige Gestalten aufweisen." Farther on, he suggests identifying the Man with one of the constellations in the neighborhood of Marduk's Bull, possibly the Charioteer or Orion. These mythological possibilities, on the basis of later literature, are further pursued by Bousset, Rel. d. Jud., 295, 30I ff. After a criticism of the current symbolical interpretation and the concurrent argument that in Enoch the Son of Man was promptly elevated to Messianic status, he concludes, p. 307: "Somit drängt sich die Vermütung auf, dass in der Gestalt des präexistenten Menschensohnes zwei Gestalten miteinander verschmolzen sind: der judische 'Messias' und eine präexistente himmlische Wesenheit, deren Ursprung und Herkunft noch dunkel ist. . . . Damit ist das Gebiet angesteckt, auf dem wir zu suchen haben." The same writer continues this theme, drawing especially

${ }^{7}$ For a recent criticism of this theory s. König, pp. $295 f$.

${ }^{8}$ For criticism of Gunkel s. Giesebrecht's review in $G G A$ i $895,596 f$., and Wellhausen's critique in his Skizzen $u$. Vorarbeiten, 6 (1899), 215-249. Gunkel responded to Wellhausen in $Z H^{\top} T{ }_{42}$ ( 1899$), 58 \mathrm{I}-6 \mathrm{II}$. 


\section{CHAPTER 7, NOTE ON 'SON OF MAN'}

from Gnostic sources, in his Hauptprobleme der Gnosis, 1907, chap. 4, 'Der Urmensch,' noting the bearing upon Judaistic literature, pp. I96 ff. Gressmann follows in the same tracks in his Ursprung der jiidisch-israelitischen Eschatologie, 1905, \$33, 'Der “Mensch” im Daniel.' Gressmann does so much credit to the more commonplace interpretation as to admit that "die Originalität des Arbeiters besteht allein darin, dass er den Menschen umgedeutet hat auf Israel." But after this aside he continues: "alles Übrige ist, wie die Vision lehrt, zur Rekonstruktion des alten Mythus zu benutzen." Similarly A. Jeremias, in his Das Alte Testament im Lichte des Alten Orients (1906), has surrendered himself completely to the spell of Babylon; s. his Index s.v. 'Menschensohn,' and especially p. 595, note on Dan. 7. He holds, against Zimmern, that if an astral prototype is present, Nebo, not Marduk, is to be thought of. He identifies the term 'son of man' with the epithet zêr amêluti used of the mythological hero Adapa $(=$ Adam $)=$ Marduk, s. pp. 9, 82, r68.

More space has been given to statement of this theory of interpretation because its development is subsequent to the comm. on Dan. The writer subscribes to the acute critique of the Pan-Babylonist school in Prof. Kemper Fullerton's admirable Presidential Address, 'Viewpoints in the Discussion of Isaiah,' $J B L$ r 922 , pp. I-ror, esp. pp. 7 I $f f$. The fault he finds with that school's treatment of Isaiah is not relieved by any demonstrations it can give in the field of Dan., although here the Bab. influence might well be expected to be of far more patent and potent character. That Bab. mythology, current in letters, art and speech, should have influenced apocalyptic literature goes without saying. But it is not convincing to argue back from later literature like Rev., or even Enoch, to what must have been the mental background of Dan. The first principle of interpretation, unless the composition is a crazy patchwork-and that may be said of some later apocalyptic productions, in contrast to the poetic simplicity of this chap.-is to allow the document to speak for itself as the product of the writer's mind, and to subordinate extraneous influences, unless they are required to make his thought intelligible. Not one of those ingenious scholars, working tirelessly over the same field, for which Bab. literature affords an enormous treasure, has been able to identify the Son-of-Man figure.

If we admit that the term 'son of man' is not in itself mysterious, and if we avoid confounding it with the later interpretations, there is nothing strange in its use as the type of Israel. It belongs to the Semitic genius to personify the people, as in the ' $I$ '-Psalms. The Servant of Y11wH is another instance, which easily became personalized and Messianized. (Gressmann is at least logical in insisting that the Servant of Үншн is also a mythological motive, op. cit., \$29.) The present writer submits that the symbolical interpretation of the Son of Man is wholly adequate to the chap. It is terse, but we have not to speculate on sous-entendus. We must allow it its own originality and do justice to the simply but finely limned features of the drama 
without thinking that every detail is a painful borrowing on the part of a second-hand littérateur. ${ }^{9}$

\section{CHAPTER 8. THE VISION OF THE RAM AND THE BUCK.}

1. 2. In the third year of Belshazzar Dan. finds himself in vision as at Susa in Elam by the Ulai. 3-14. He beholds a twohorned ram butting toward three points of the compass; it is attacked and destroyed by a one-horned buck appearing from the west. In the place of its conspicuous horn arise four other horns, and out of these a little horn which exalts itself even against God, desecrates his sanctuary, and interrupts the daily double sacrifice for 2,300 due celebrations. 15-26. The angel Gabriel interprets the vision to the seer: the two-horned ram is the Medo-Persian empire; the buck is Greece, and its horn the first king, its four successors the four subsequent kingdoms, and the little horn a king who is particularly described in his character and doings. 27. As aftermath of the vision the seer falls sick, but returns to the royal business, still without comprehension of the vision. With this chap. the bk. reverts to Hebrew.

With the explicit interpretation of the two beasts as denoting Medo-Persia and Greece (vv. ${ }^{20 .}{ }^{21}$ ) and with the obvious allusion to Alexander, it would seem that there can be no question of the historical explanation of the vision. This interpretation is as old as the Jewish Alexander Saga, s. Jos., $A J$ xi, 8. Commentators like Hippolytus and Jerome, who saw in the little horn of c. 7 the Antichrist, and who, like Jer., contradicted Porphyry's identification of the little horn there with Antiochus, admit without question the identity of the little horn here with that tyrant. This chap. is patently a doublet of c. 7 , and the latter more cryptic chap. must, most reasonably, be interpreted from c. 8. It seems like an amazing obstinacy of opinion when scholars like Hengstenberg, Pusey, Wright, Wilson, refuse to take Yawan-Greece in other than its historical sense and persist in making it include the Roman empire even to the end of the world.

\footnotetext{
${ }^{9}$ The writer has avoided pursuing the theme in the $\mathrm{N} \mathrm{T}$ field. The articles by Dr. and Schmidt in $D B$ and $E B$ present the literature of the discussion; s. also a brief survey in Preuschen, Hwb.d.N.T., 1910, col. 1106 , and for a recent treatment of the problem in the N.T., König, pp. $300 f$.
} 
As a double to c. 7 this vision is notably weaker in poetic force than its predecessor. In c. 7 the cryptic character of Apocalyptic is well preserved; in this chap. the writer shows far more zeal for the concrete, as in vv. ${ }^{10 .}{ }^{11}$, where he abandons the proper elements of vision. If one may allow more than an artificial origin for the scene of c. 7 and find in it the elements of a real psychological state, then this chap. explains itself as not a mere doublet but as a reasoned commentary upon the other; $c f$. Int., $\$ 22, b$. It may be noted that as in c. 7 has the historic rubrics identifying the several symbols with the things signified, Darius, Alexander, his death, Antiochus.

1. 2. Introduction to the vision. 1. In the third year of the rcign of Belshazzar the king a vision appeared to me, me Daniel, after that which appeared to me at the first. 2. And I saw in the vision:-Now it was in my seeing that I was in the burg Shushan, which is in the province of Elam, [and I saw in the vision] and I was by the stream Ulai.

The datum of 'the third year' of Belsh. appears to be gratuitous, unless there was a tradition of a three years' reign of that monarch; s. Int., $\S_{1} 9, e$. For defence of the dating s. Wright, Daniel, I26, Wilson, Studies, II4 ff. For the insistence on the seer's ego $c f .7^{15}{ }^{28}$. $\mathrm{V} .{ }^{2}$ reads very repetitiously and without entire support from the Gir., while its interpretation has been embarrassed from antiquity by the problem whether Dan.'s presence in Elam was in corpore or in spiritu. The eldest interpretation, that Dan. was actually in Elam, appears in Jo3., $A J \mathrm{x}, \mathrm{II}, 7$, who also records in the beginning of the chap. that Dan. built for himself a fine building at Ecbatana in Media, which was still surviving in perfect condition, that in it they were burying the kings of Media, Persia, and Parthia up to the present day, and that a Jewish priest was its custodian. This then would be the first definite instance in Judaism of the canonization of a locality connected with one of the Biblical saints (a process of popular religion of extensive vogue, $c f$. Mt. $23^{29}$ ). For the Tombs of Dan. s. further Int., $\S 4, c$. But that Dan. was in Elam only in uisione was early recognized, e.g., by $\$$, 'I saw in my dream that I was in the city S., which is in the province E., and I saw in my dream that I was standing,' and so Aph. Syr., at least for the last clause, 'and I appeared to myself to stand in a dream'; so also Theodt., and H, uidi autem in uisione 
esse me super portam Ulai (although Jer. does not recognize this point in his comm.). This view was revived by some of the early Prot. comm., e.g., Piscator, Polanus, Calv., and it is followed by most recent comm., including Stu., Keil, Knab., Wright (p. I7 I). This disposes of the question of historicity of the datum that Elam was then a province of Babylonia and not of Media, a criticism raised by Bert., and also of the query how could Dan. have been in Susa on the king's business (v. ${ }^{27}$ ) in the last days of falling Babylon. Winckler, Vorderasiatische Gesch., I905, pp. 54. 85, is disposed to regard Elam, the district of Susa, as still belonging to Babylon, and this point is insisted upon by Wilson, c. I4. If the scene be visionary, then the seer is appropriately transported thither, to the ancient land of Medo-Persia, for the setting of the drama of the symbolical contest between that Oriental empire and Greece.

Textually our passage reads very awkwardly with its repeated 'seeing.' $\Theta$ om. the first clause, 'and I saw in the vision, and it was in my seeing,' but $\Theta$ 's notorious habit of simplification of repetitions does not corroborate his text here. Both $\mathbb{E}$ and $\Theta$ om. the second 'and I saw in the vision'; the tr. above follows this double evidence in bracketing the phrase, which is unnecessary. It is easy to propose more radical changes; Jahn would elide the whole of $\mathrm{v}^{\mathrm{b}}{ }^{\mathrm{b}}$ with its ref. to the Ulai, which he thinks was introduced from $\mathrm{v} .^{16}$ (but $n . b . \mathrm{v}^{3}{ }^{3}$ ). Classical Heb. would have expressed the visionary character of the scene much more exactly (s. Note). This spiritual transportation has its parallel in Ezekiel's removal to Jerusalem, Eze. 8, that of the seer to the desert in Rev. $I 7^{3}$. For the motive of the river $c f$. perhaps Gen. $4 \mathrm{I}^{1}$, Eze. $\mathrm{I}^{1}$ (the Chebar), inf., $9^{4}, \mathrm{I} 2^{5}$. For Shushan, Greek Susa (also Neh. $\mathrm{I}^{4}$ and Est.), the chief capital of the Pers. empire, s. Paton on Est. $I^{2}$ (with full bibliography), also Behr., Dr.,

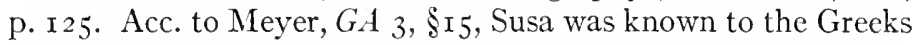
as well as to the Jews as the capital of the Pers. empire. The word translated 'burg' is appositive to 'Shushan,' following a common Aramaism, does not denote a part of the city, the idiom being the same as in the following 'Elam the province' (so literally). The word 'province' need not be taken in a technical political sense, $c f .3^{2}$. The Ulai bears the same name in the Akk., is the Classical Eulaeus; it appears in the Syr. at Judith $I^{6}$ for Gr. Hydaspes (= Choaspes?). Among the three 
streams near Susa the Ulai can best be identified with an artificial canal which connected the rivers Choaspes and Coprates and ran close by Susa; s. Behr., Dr., Cheyne, s.v. in EB, who give full reff.

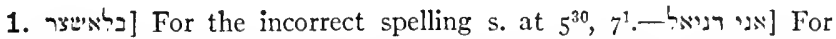
the abs. pron. s. note at $7^{15}$. - אחר ] Ehr. would relieve the apparent redundancy here by supposing that the prep. has qualitative mng.,

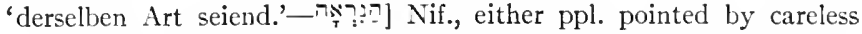
conformation with the pf. נראר sup., or possibly the art. has relative

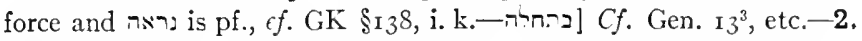
חיוון is evidently part of

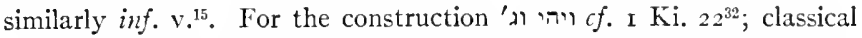
Heb. would prefer הנת, as Gen. $4 \mathrm{I}^{1}$. For the loose syntax of aligned

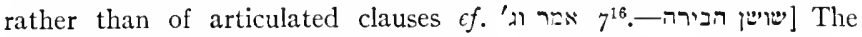
construction of הבירה is by Aram. idiom, universal in Syr., that of a determinative to $\cdots \cdots ;$; it does not mean the citadel as distinguished from the city, as Paton understands the phrase at Est. $\mathrm{I}^{2}$ (with this understanding he is embarrassed at $2^{5}$ ). Cf. בירת ב ב $A P O$ pap. I, 1. I, etc. In Ezr. $6^{2}$ באחמהת בנירתי, the second prep. should be omitted. The same construction, unrecognized by comm., appears in 'Casiphia the place,' Ezr. $8^{17}$. There are similar unrecognized cases in the N.T., s. the writer's Origin of the Gospel acc. to St. John, Philadelphia, I923,

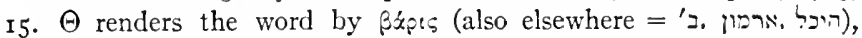
on which s. H. Lewy, Die sem. Fremdwörter im Griechisehen, I895, I82.

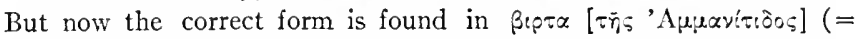
'Arak el-Emîr) in the Zenon papp. of age of Ptolemy II; s. Vincent, 'La Pa'estine dans les papyrus ptolémaĩques de Gerza,' $R B$ I920, I6I

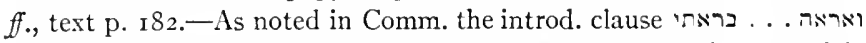
is om. by $\Theta$; it is supplied by $\operatorname{Or}^{P}$ Lu. (G appears to have read it but with paraphrase. The subsequent ואראה בחון was om. by orig. (55 (supplied in Hex.), and by $\Theta$, suppl. by OrP.c Lu.- ואני הייהי] The use of הייח here vs. its absence in the parallel clause above is notice-

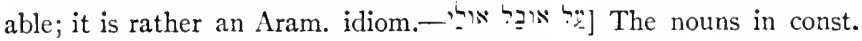

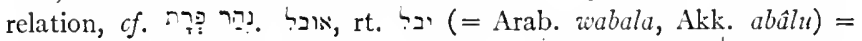

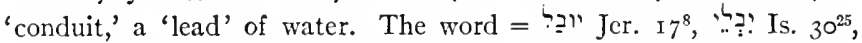
$44^{4}$. The stem wbal $>\hat{u} b a l$ ( $\left.c f . u f a z>\hat{u} f a z 10^{5}\right)$, with loss of initial consonant in the Akk. field, and with this form the more Hebraic y corresponds. Otherwise Kön., $L g b$., ii, I, p. 88, taking אובל, יובל as kutal form. The VSS vary much. $\Theta$ ṡ Sym. alone has above ming., rdg. acc. to Jer., super paludem Oulai. Others transliterated, so Aq. acc. to Jer., supor Oubal Oulai, and Lu.

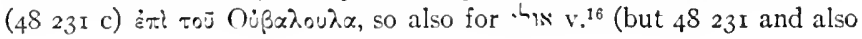


at vv. ${ }^{6.16}{ }_{22} \mathrm{O} \dot{\langle} \lambda \alpha_{t}$ ); and so. Another tradition interprets 'gate':

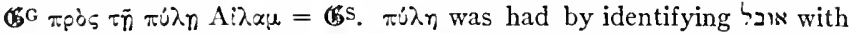
JAram., Syr. abbullâ = Akk. abullu, 'gateway.' So $\mathfrak{H}$, super portam Ulai. For אולי resort was apparently had to the architectural term

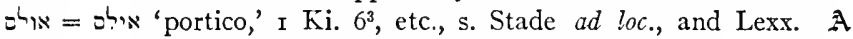

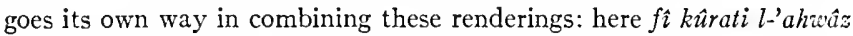

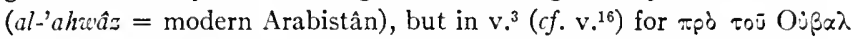
kulddâma d-dahliz, 'before the portico'; s. Gehman, pp. 339, 348. Sa. has here a geographical paraphrase; he agrees with Sym. in under-

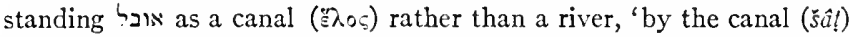
of the river Ulai.' Ra., AEz., Jeph. correctly understand ' $心$ as 'river Ulai'; PsSa. has, "by the gate of the building called Ulai; the Wise call a great gate אבולי אולי."

3. 4. The vision of the two-horned ram, symbol of Media and Persia. 3. And I lifted up my eyes [i.e., I looked], and saw: and, behold, there stood in front of the stream a ram with two horns; and the two horns were high, and one higher than the other, and the higher coming up last. 4. I saw the ram butting [EVV pushing] to the west and the north and the south; no beasts could stand before him and there was none to dcliver from him, and he was doing according to his will and was acting greatly. The ram, like the males of the other domesticated cattle, is a type of power and so of princely leadership, e.g., Eze. $34^{17}$ (' $\mathrm{I}$ will judge between sheep and sheep, between the rams and the bucks'), and the word for ram, $\mathbf{s}$, appears to be used as actual synonym for 'prince'; so GB, Kön., Hwb., with less certainty as to identification BDB I 7 b, I 8a. Häv. has collected similar reff. from the Gr., Arab., and OPers., and Bev. instances Arab. kabs 'ram' = 'warrior'; for a compilation of references on these animals s. Bochart, Hierozoicon, 2, cc. 43. 5I. For the horns as type of strength s. Comm. at $7^{8}$, here they represent the two constituent parts of an empire. The moments of the vision of the horns well represent the relation of Media and Persia in power and time. The other 'beasts' that could not stand up against them presuppose c. 7. Persia was the Far-Oriental empire to the Semitic world, hence the expansion only to three points of the compass is stated, although, against some comm., the far-eastern conquests of Persia were known, $c f$. Est. $\mathrm{I}^{1}$ 'from India to Ethiopia '; accordingly $\mathfrak{B}$ adds 'to the east.' 'Act greatly' is preferable to AV 'become great,' RVV JV 'magnify self'; the 
vb. is used in a good sense, e.g., of God, Ps. 1262. ${ }^{3}$, more often in a bad sense, so below vv. ${ }^{8 .}{ }^{11}{ }^{25}$, Jer. $48^{26 .}{ }^{42}$, Job $19^{5}$, etc., with the attendant muance of affectation = 'act big'; cf. the 'mouth speaking big things,' $7^{20}$.

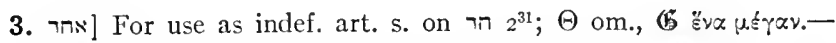

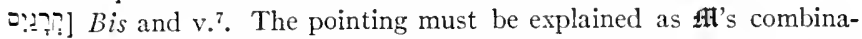
tion of du. and pl.; cf. $0: ? 7 ?$ ? Pr. $28^{6.18}$, and for the other exx. s. Stade, Lehrb., \$339. N.b. the problem of the duals in c. 7, s. at r. ${ }^{8}$.- והקרגיכ)]

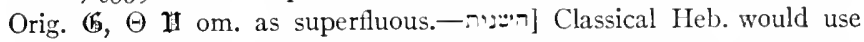
[באהרנה-_האחת.] = 'afterwards,' cf. Dt. I3 $3^{10}$, etc. 6 G attaches to v.44. Exנ So the Pael, of an ox Dt. $33^{17}$, of a sheep Eze. $34^{21}$. For the use of the ppl. as secondary predicate s. other cases inf., e.g., vv. ${ }^{7.13}$. It is rare in early Heb., but note a case in Nu. $\mathrm{II}^{10}$. - For 'west, north and south' of 1 is has 'east, north, west and south,' prob. understanding

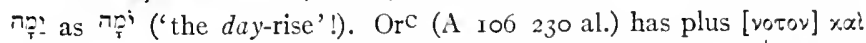
$\lambda \vdots \beta \alpha$, a gloss explaining $x \alpha \tau \dot{\alpha} \theta \dot{\alpha} \lambda \alpha \sigma \sigma \alpha \nu$; so for 2 v. v. - -

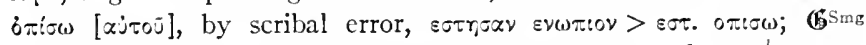
correctly.- - והגריל - Correct pf. with waw-consec., [הגריל For such intrans. (operative) Hifils cf. GK $\$_{53}$, f, and Arab. stem IV, Wright, Gr. I, $\S 45$, Rem. c.

5-7. The vision of the one-horned buck and his contest with the ram. 5. And I was discerning, and behold, a buck coming from the west over the whole earth and not touching the ground [earth]; and the buck had a conspicuous horn between his eyes. 6. And he came to the two-horned ram which I had secn standing in front of the stream, and he ran at him in the fury of his power. 7. And I saw him coming close to the ram, and he was enraged against him, and he smote the ram and broke his two horns; and there was no power in the ram to stand before him, but he cast him down to the ground and trampled him, and there was none to deliver the ram from him. The fresh moment is introduced by a further statement of the seer's continued observation. Cf. the introduction of the little horn $7^{8}$, 'I was contemplating.' The vb. translated 'discern' means 'to distinguish,' 'to make out' objects, and then, as later in the book, e.g., v. ${ }^{27}$, 'to understand,' intellegere. For the buck (or he-goat, Heb. 'goat-buck') as type of power and so a synonym for princes, $c f$. Is. $14^{9}$ ל בירי

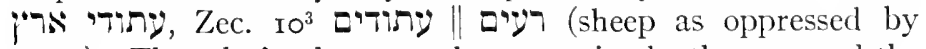
goats). The relation between the two animals, the ram and the 
goat, is not that of worth, as in the descending series in the visions of the metals and the beasts in cc. 2 and 7 , but of power. The goat naturally overcomes the ram, just as in Eze. $34^{7}$ and Zech. $\mathrm{IO}^{3}$ the LORD must intervene between his people, the feeble sheep, and the rough goats. The wild goat, of some species, is a fierce enough animal to be represented in the contests of Gilgamesh, s. W. H. Ward, Cylinders and Other Ancient Oriental Seals, nos. I9 ff. Häv. aptly cites a vision related by Plutarch in his Sulla, c. 28: there was seen a vision of two large goats fighting, attacking and receiving blows, just as is the case with men fighting-which presaged the fall of the younger Marius. The view that the goat was taken to symbolize Alexander's empire because the goat figures in the legends of the Macedonian house and the composition of Macedonian place-names (e.g., the old residence of the dynasty $Æ g x$ and the Macedonian epithet Ageades) was proposed by Medus, and has been accepted by some comm., e.g., Häv., dEnv.; but this habit of finding 'inner (secondary) conformities' (Häv.) between the type and the object has ever been one of the fallacies of interpretation of the book. Had correspondences of this kind been chosen, rather the two-horned ram would have typified Alexander, who, acc. to Clem. Alex., Cohort. ad gentes, iv (ed. Potter, I, p. 4S), had himself represented with two horns to prove himself the son of the ram-headed Libyan Ammon, a trait which appears in the Seleucide coinage and which gave rise to the Arabic epithet for Alexander Du l-kgarnain, 'he-of-the-two-horns' (e.g., Koran, I8. 82 ), the exact equivalent, by the way, of thet for the Pers. ram in v. ${ }^{7}$. See Häv., p. 258, vLeng., p. 369, giving the elder literature, and Babelon, l.c. in Comm. at $7^{8}$. The single horn of the goat, as $v .^{8}$ certainly shows, represents the first of the Greek dynasty, the great Alexander. The unicorn animal has its prototype in the Bab.-Ass. monuments, e.g., the șiruı̌šu, and other representations of one-horned animals, a detail which arose from the artist depicting the animal from one side so that the two horns are merged into one. This feature also appears in the archaic inlaid bulls in the temple discovered at Tell el Obeid, in I923-24; s. Museum Journal (Univ. Penna. Museum), March, I924, cut p. 26. On the Biblical 'unicorn' in general s. Haupt, SBOT Psalms (Eng.), I $72 f$. For the plastic background of this contest of beasts Häv. draws attention to 
the mythological representations in the ruins of Persepolis; and the abundant material, from the art, large and small, of Babylonia corroborates this happy comparison.

Several items are distinguished in the he-goat's progress. He comes 'from the west.' 'He went over the whole earth': comm. have long compared the description of Alex.'s conquests in I Mac. $\mathrm{I}^{3}$ : 'He went through to the ends of the earth and took spoils of a multitude of nations; and the earth was quiet before him,' etc. The rapidity of his progress, 'not touching the ground,' is a reminiscence of the classical description of Cyrus, Is. $4 \mathrm{I}^{2 .}$, who 'pursues and passes on in peace, Not going on the road with his feet.' VLeng. cites a Classical parallel from Verg., Aen., vii, 806 ff., e.g., 'Ferret iter, celeres nec tingeret aequore plantas.' The 'conspicuous horn' is Alexander; for the muchmooted adj. as rendered after the most ancient and most common authority s. Note. 6 . 7 capitally describe the impetuosity of Alex.'s attack upon Persia and the helpless, utter fall of that empire. This and the following v. (with the echoes in $\mathrm{ro}^{20}$, $\mathrm{II}^{3.4}$ ) give us the only memory of the great Alexander definitely preserved by the Jews in their Scriptures.

5. צמיר-ר. [ה For etymology of 's s. Bev., GB; the word is Aram., occurring Ezr. $6^{17}$ in this combination, in Heb. 2 Ch. $29^{21}$, Ezr. $8^{35}$; $f$. the usual

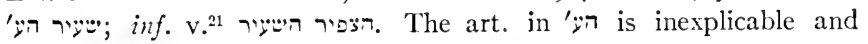
lacks in $(5) \Theta$; either it is conformed to ' 2 ה v. ${ }^{5}$ ( $c f$. a case in Ecc. $10^{20}$, where the Kr. corrects the art. in הפנפיפ), or the whole vocable should be omitted, and so actually $\mathrm{Or}^{\mathrm{P}}$ ignores it; this Aquilanic (?) testimony is noteworthy.—ברו- 1 The word, late in Heb., occurs also in the papp.,

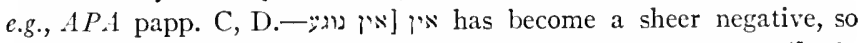

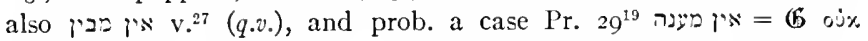

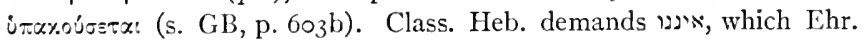

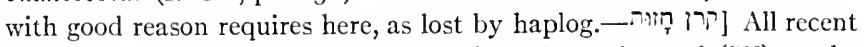
comm. tr. 'n (which recurs at v. ${ }^{8}, q . v$.) by 'conspicuous' (JV) or the like, after the Hex. plus in $\mathbb{C}$ and $\Theta$, (רמחing), I (insigne AV RVV 'notable'), Jeph., Ra., most early Prot. comm. Comparison may be made with חור 2 Sa. $23^{21}$ is a noun from the act. ppl. stem with abstract suffix; $c f$. Heb. גולז $=$ Aram. our word retaining the Aram. - $\hat{a}-; c f$. Barth, $N b$., §98, Brock., VG I, $\$ 126$. G. Hoffmann, $Z A T W W_{1} 883$, pp. $95 f$., would point perhaps that case should be revised to the form here. The noun can mean either the action or the object of the action. But Sa. with mu- 


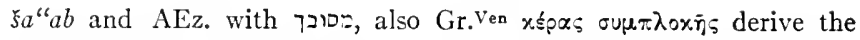
word from in, 'ramify, interlace.' JDMich., Suppl. I, 703, proposed חיור, 'sharpness,' so deWette, Bert. As for the Grr., $\Theta$ om. ' $n$, which OrP.C Lu. suppl., $\theta \varepsilon \omega p r r \delta$ v. Orig. (5 $\ddot{z} v$, i.e., rdg. אח (which Ehr. prefers). Cf. (5 vv. 8.17 favors and the common interpretation.-6. בעיל הקרנים] Cf. בעצל הפנפיב, Ecc. $10^{20}$, and s. GK $\S 128$, u; for the Arab. correspondents s. Wright, Gr. 2, \$8I.-D] $\Theta$ MSs, supported by IIWzb in impetu,

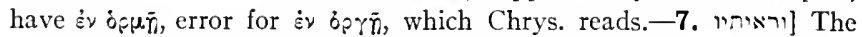
pf. with 'weak,' not consec. waw; for this freq. usage of later Heb. s. Driver, Tenses, §г33. F. T. Kelley, 'The Imperfect with Simple Waw in Hebrew,' $J B L$ I920, I-23, cites, pp. 2I $f$., many of the cases in Dan., and attempts to pursue his thesis that there is some purpose in the variation, but, as this case proves, in vain.-- לצN] Cf. v. ${ }^{17}$ and $2 \mathrm{Ch}$.

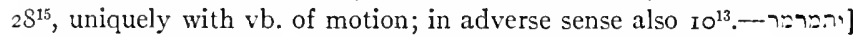
The Hithpalpel also $\mathrm{I}^{11}$, in a variant to BSira $3^{88^{16}}$, and in Syr., e.g., Acts $17^{16}$. - תN bis] As 62 I47 show, Aq. tr. with his customary ouv, and so in subsequent cases. -

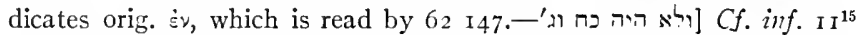

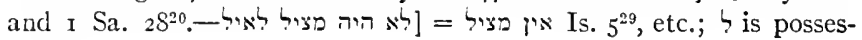
sive.

8-12. The vision of the great horn, continued, of the four horns, and of the little horn that grew up. 8. And the buck was acting exceeding greatly; and when he was strong, the great horn was broken; and there came up [gloss, conspicuousness] four in its place to the four winds of heaven. 9. And out of one of them came forth another horn, a little one, and it waxed exceeding great, toward the south and toward the east [gloss, and toward the Desire]. The buck stands consistently for the Greek empire; its founder Alexander, the great horn, 'was broken.' The four kingdoms, represented by the four horns, are apparently the four kingdoms of the Diadochi, Macedonia (under Cassander), Thrace and Asia Minor (Lysimachus), 'Asia' or Syria (Seleucus), Egypt (Ptolemy). These suitably correspond to the four points of the compass, west, north, east, south. The passage is cited at $\mathrm{rr}^{5}$. Behr.'s criticism upon this view is the query: "What one of the readers of our book knew of this; and if he did how did it concern him?" However, the traditional remains of the ancient proud monarchies must have long survived. This has been the almost constant interpretation of the four, with variations as to the names of the Diadochi, since the beginning: of Hipp., iv, 
26, Jer., Theodt., Aph. Syr., Polych., with the modern exception of those who find here the Roman and post-Roman ages. For the alleged gloss in $\mathrm{v} .{ }^{8} \mathrm{~s}$. Note. In $\mathrm{v} \cdot{ }^{9}$ a slight amendment of the orig. text has been made, following Bev. and most subsequent comm., viz., by the shifting and change of one letter (s to $\Omega$ ), making the orig. 'a horn out of a little' (whatever that may mean) read 'another horn, a little one,' which is the exact Heb. equivalent of the Aram. in $7^{8}$. If Ant. Epiph. be meant there, he must be found here. By the expansion of the horn toward the south are meant Ant.'s campaigns in Egypt, only frustrated by Rome, and by that 'to the east' the prospected campaigns against Parthia, beginning $166-5$, which terminated in his death in Elymais $165-4$. A third point of direction is given in 19, 'to the Delight,' which is commonly interpreted as in the several Eng. VSS, 'the pleasant,' or 'glorious,' or 'beauteous (land),' on the basis of $\mathrm{II}^{16 .}{ }^{11}$, which passages, however, have the desiderated word 'land.' The Note argues for the exclusion of the phrase as a gloss, which cannot have the alleged mng. by itself, which was not so translated by the VSS and early comm., and which is absurd when aligned with two given points of the compass, in which matter the book is remarkably accurate.

10. And it waxed great even to the host of heaven, and it made fall to the earth some of the host, yea of the stars some of them it trampled. With few exceptions, to be noted below, the universal interpretation of 'the host of heaven' and its synonym 'the stars' is that they refer tropically to God's people: Jer., 'the sons of Israel, who are intrenched by the help of angels'; Polych. definitely, 'the Maccabees'; Aph. Syr., 'the sacerdotal order'; and so variously the subsequent views, on which no improvement has been made since Pole's digest: the Church, the saints, etc. For the trope of the stars we are referred to $\mathrm{I} 2^{3}$, "they shall shine ... as the stars,' cf. Mt. I $3^{43}$. (On the Judaistic combination of the saints and the stars s. Volz, Jiid. Esch., 360 ff.) 'This interpretation of 'the host ( from the word in its commonplace sense of 'army,' etc., and hence of the Maccabees, etc.; or as of 'service' and so techni-

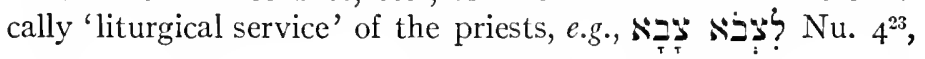
$8^{24}$, etc. (s. Lexx.). But none can easily understand 'the host of heaven' otherwise than of 'the heavenly host,' which is rein- 
forced by the synonymous 'stars' and by the phrase 'Prince of the host,' v. ${ }^{10}=$ 'God of hosts,' etc. Evidently Ant.'s presumption against heaven and its denizens is referred to. The difficulty of the common interpretation is felt by Jer., who tr. in his comm. 'uelut stellas coeli,' and Keil, who insists that this is a vision in which the host and the stars only figure earthly affairs. For the customary interpretation ref. is made to En. $46^{7}$, 'These are they who judge the stars of heaven, And raise their hands against the Most High, And tread upon the earth and dwell upon it,' where the comm. (e.g., Beer, Cha.) interpret 'the stars' from the common understanding of the word here; but rather, the stars and the Most High are grouped together as heavenly ones. (Cha. attempts to rewrite the v. in En. so as to make it agree almost verbatim with that in Dan.) Häv. notes the citation in 2 Mac. $9^{10}$, 'And the man that a little afore supposed himself to touch the stars of heaven (following (5)'s plus 'of heaven'), no one could endure for his stench,' which definitely agrees with the interpretation here followed. There is another passage in the Bible, ignored by the comm. here, which cites and interprets the v., viz., Rev. I $2^{4}$, where, of the great dragon with seven heads and ten horns, it is told that 'his tail sweeps the third of the stars of heaven and casts them to the earth' (with independent $\operatorname{tr} ., \epsilon^{\prime} \beta a \lambda \epsilon \nu \epsilon i s \tau . \gamma \hat{\eta} \nu$ ). Gunkel naturally handled this passage as a mythological trait, Schöpfung, 387 (cf. Bousset, ad loc.): "This can only be understood as an ætiological myth. The Bab. science found in the heaven a vacant space, the origin of which is to be explained by this myth." The present writer's result is that the allusion was to Ant.'s God-defying arrogance, for which the seer had in mind the classical diatribe against Babel in Is. I4, esp. vv..$^{12-15}$. That blasphemous monarch's defiance of the gods in general was part at least of the Jewish tradition, s. I I ${ }^{36-39}$, with which $c f$. the general statement in I Mac. I ${ }^{41}$ of Ant.'s edict against the Religion. This view, independently reached, was more than anticipated by G. F. Moore in his article, 'Daniel viii. 9-14' in $J B L$ I5 (I896), I93-7. It is sufficient to refer to this summary but compelling paper. He notes, inter al., the sacrilegious attempt of Ant. upon the temple of Nanaea in Elymais. As Moore observes, the stars are frequently identified with gods, e.g., Dt. $4^{19}$, Is. $24^{21 \mathrm{ff}}$, En. $80^{1}$. He notes that this interpretation has been maintained by Smend, $Z A T W{ }_{4}$, 20I, 
and Altest. Religionsgeschichte ${ }^{2}, 45^{2}$, and with this view agrees a brief remark by Volz, l.c., 36r. And last but not least, it should be noted that Jephet in the roth cent. gave the same interpretation: "Then it seemed to him as though it had risen to the host of heaven and thrown some of them down. 'The host of heaven' very likely refers to the seven planets, Saturn and šarkâ (?). Then it seemed to him as though it trampled the stars on the ground; and then as though the horn went in to the captain of the host and the mightiest of it; but it does not say that the horn did anything with the captain of the host more than that 'it magnified itself."'

11. 12 constitute crescendo the most difficult short passage of the bk. The early VSS read the same quantum of text; this is true even of the expanded and disfigured text of when it is shorn of its glosses. For the texts of the VSS, which give but little help, s. Note at end of the chap. 11 presents less difficulty of the two: And even up to [i.e., right up to the face of] the Prince of the host he acted greatly [cf. v.4], and by him [or, from him] was removed [so Kr.; Kt. he removed] the Constant (sacrifice), and was rejected the place of his [i.e., the Prince's] sanctuary. 'The Prince of the host' (properly a military term, generalissimo, Gen. $2 \mathrm{I}^{22}$ and often) is the same as 'the Prince of princes' ( $c f$. 'God of gods,' $2^{47}, q . v$.) and can be none other than God, 'the God of Hosts,' as is accepted by almost all comm., even those who take 'the host,' v. ${ }^{10}$, in a contrary sense. Aph. Syr., Grot. are consistent with the prevailing exegesis of that $v$. in finding in the prince of the host the high priest Onias; for this sacerdotal use of 'prince' cf. I Ch. $24^{5}$, etc. Polych. finds here 'the presiding angel of the nation,' and AEz. Michael, following the clew of the use of the word for angels in $10^{13 .}{ }^{20}, c f$. Jos. $5^{14}$; in Targ. to Ps. $137^{7}$ Michael is the prince of Jerusalem. The combination of the vb. with the prep. is very pregnant, 'right up to'; again with reminiscence of Is. I4, e.g., v. ${ }^{14}$. In the pron. 'he,' vs. the fem. ('it') otherwise depending upon the gender of 'horn,' the writer has inadvertently dropped his figure; it is sometimes overlooked by critics that even a writer's autograph may contain errors, vs. vGall, Einheitlichkeit, 5x, and Moore, l.c., 197, who would read the fem. We may take it that the ultimate sense of the variations 'by him . . . was removed' and 'from him (i.e., God) he removed,' is the same. 'From him' is the rendering of 
II $\$ \mathrm{RVV} \mathrm{JV}$; 'by him,' i.e., the horn, of Grr., AV; the former interpretation is more commonly adopted. The conflict of voices between the Kt. and Kr., which is as old as the VSS, is doubtless due to the contrary interpretations of the prep. 'The Constant,' The is the technical abbreviation for the 'constant holocaust' or 'whole burnt-offering of perpetuity,' על מית רמידיד,

which in the late ritual of Judaism was offered in a lamb morning and evening of every day; $c f .9^{21}$ and Ex. $29^{38-42}$; see Nowack, Heb. Arch. 2, 22I f., and Edersheim, The Temple, c. 8. Cf.

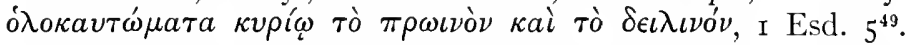
The abbreviated term appears only here and $v v .{ }^{12 .}{ }^{13}, \mathrm{II}^{31}, \mathrm{I} 2^{11}$ in the Bible, but is common in the Talmud. These two daily sacrifices were the basis and expression of the whole cult, and that the two are meant is proved by the ' 2300 evenings, mornings,' $\mathrm{v.}^{14}$, which figure is to be divided by two to obtain the number of days. The word for 'place,' מקום, is rare, implying a construction, a base, e.g., Ezr. $3^{3}$ (the base of the altar), Ps. $89^{15}$, or a dwelling, and so used esp. of God's abode, either on earth, e.g., Is. $4^{5}$, or in heaven, I Ki. $8^{39}$. The vb. here translated 'was rejected' is generally rendered 'was cast down,' as in vv. ${ }^{7}$. ${ }^{12}$. But the vb. implies both 'throw down' and 'throw away,' deiicere and reiicere, e.g., Neh. $9^{26},=$ 'despise,' and this muance is properly proposed here by Ehr. As Dr. remarks, the temple does not seem to have been literally 'cast down'; however, it is described as having been 'laid waste like a wilderness' and 'trampled down,' I Mac. $\mathrm{I}^{39}, 3^{45}$; acc. to $4^{48}$, the Jews '(re)built the holy place.'

12a. And a host shall be given (or, set) upon (or, against) the Constant in iniquity; so 4 literally. The gender agreement between subj. and vb. is most improbable, and the future tense is out of place. Attempts at translation may be exemplified from $\boldsymbol{H}$ : robur autem datum est ei contra iuge sacrificium propter peccata; so practically $=\mathrm{GV} \mathrm{AV}$, but 'a host' for robur; RVV $\mathrm{JV}$, 'and the host was given over to it together with (following the Zürich Bible, also CBMich.) the continual burnt-offering through transgression'; Dr., 'and a host (or, a warfare) was undertaken against the continual burnt-offering with transgression (i.e., wickedly)'; etc. Grot. interprets 'host' of Ant.'s garrison in the Akra. Sa. om. the prep., 'the stars (so $N=3$ throughout) 
laid low the Constant.' Ra., Calv. think of 'a determined time' (?); Häv. of a corps of Jews who had perverted to ("were given to') the innovation, and somewhat similarly vLeng., but 'were surrendered to.' For the first word of the v., the Grr. depart peculiarly from in finding a vb., s. Note at end of the chap.; but no help to the sense is obtained. Emendation has naturally been attempted. VGall, p. 5I, deletes (but hardly on the authority of the Grr., as he and Löhr allege), corrects the vb. into a past, inds., om. the prep. 'in [sin],' and so obtains, 'und es wurde gelegt auf das tägliche Opfer Frevel,' which Mar. follows. Moore, p. I96, following Bert., also om. ו', reads on the daily sacrifice the Iniquity.' He cft. the 'desolating Iniquity,' $\mathrm{v}^{13}=$ 'the Abomination of Desolation,' $9^{27}$, etc. But such an obscure expression as 'putting the Iniquity on the sacrifice' can only be defended by stressing the element of intentional obscurity. Bert., who preceded in this line of emendation, tr. Ty, 'in place of the Constant,' and cft. Gen. 289. But we expect such a phrase as is found in I Mac. $6^{7}$, тò $\beta \delta e^{\prime} \lambda v \gamma \mu a$

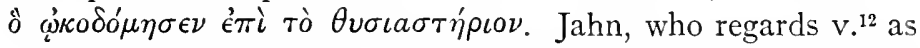
a doublet to $\mathrm{v} .^{11}$, has a similar interpretation, but retaining

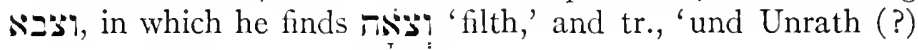
wird freventlich an das beständige Opfer getan.' For another essay might be proposed is (borrowing a noun from the Aram.; a similar opinion given by PsSa., but with ref. to the divine will): 'and his will he set against (or, upon) the Constant.' But emendations are not better than plausible.

12b. And it cast down truth to the ground, and it wrought and prospered: so Eng. VSS. But the sequence of the Heb. tenses, better observed by $\mathfrak{H}$, is difficult. The subj. of the fem. vbs. would be 'the horn.' By rdg. the first vb. as a pass. and with

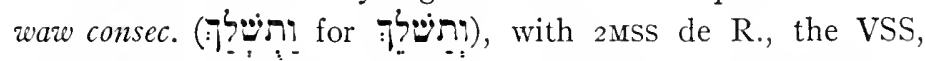
vGall, Kamp., Mar., is obtained, 'and the truth was cast down to the ground.' But 'the horn' must still be understood as the

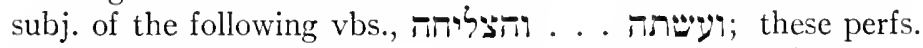
may possibly be regarded as frequentative, 'was doing,' etc. Moore, denying this probability, makes the observation that these vbs. may have been introduced here from v. ${ }^{24}$, a likely sug- 
gestion, relieving the change of subjects. 'The truth,' אמת, is not the abstract truth, as in I Esd. $4^{13}$ ff, but the True Religion as embodied in the Scriptures, esp. the Thorah (cf. the concrete use of (ק), and so Mal. $2^{6} ; c f$. the Pauline $\dot{\eta}$ $\dot{a} \lambda \eta \hat{\theta} \theta \iota a$ év $\tau \hat{\omega} \nu o^{\prime} \mu \omega$ Rom. $2^{20}$. So Ra., AEz., and most recent comm. A concrete historical ref. is found in Ant.'s destruction of the sacred books, I Mac. I $^{54}$ ff. The Gr. paraphrase, $\dot{\eta} \delta \iota \kappa a \iota$ - $_{-}$

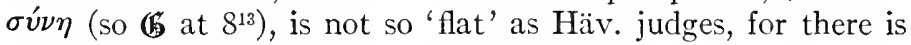
meant 'the righteousness that is in the Law'; sw. For 'wrought and prospered' cf. 2 Ch. $3 \mathrm{I}^{21}$, etc.; for 'do, work' used absolutely $c f$. II ${ }^{28 .}{ }^{30 .}{ }^{32}$, PS. $22^{32}$, etc., mostly of divine activity.

8. 1

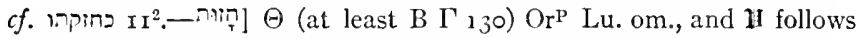

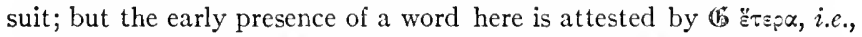
as has been accepted by Grätz, Bev., Kamp., Pr., Dr., Löhr, Cha. But it is to be noted that $\mathscr{G}$ renders testimony may not be accepted too easily here. Ehr. remarks that the order should be ארבז אהרות, $f f$. I $2^{5}$. It is best to regard as an arly gloss, relating the v. to v. ${ }^{5}$. Ra. tr. by מאר and Behr. compares the word with

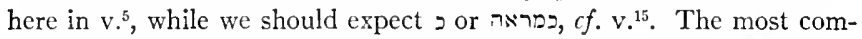
mon interpretation attempts to relate the word with v. the early Prot. comm., AV RVV CBMich., Rosen., vLeng., Hitz., Stu., Keil, Mein., al., with various interpretative essays. Sa. and AEz. repeat their interpretations from v. In] Cf. $7^{2}, 11^{4}$. Behr. notes that $\zeta$ is not necessarily $h x$, and should be translated $x, \alpha=\dot{x}$, as in Is. $32^{1}$, desiring to forestall an exact historical interpretation; but the parallelism of the four horns and the four quarters may be objected to this fine point.

9. מהכ] For lack of agreement in gender with antecedent s. on מינצה $\mathrm{I}^{5}$; also MSS For similar lack of agreement s. GK

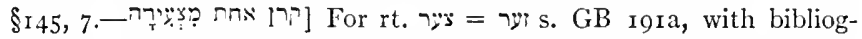
raphy. Bev. suggested the correction קרו אחרי 'י: $7^{8}$, accepted by all subsequent comm. exc. Behr. and adopted here; $n . b$. the similarity of $a$ and $n$ in the papp. Graetz had earlier proposed omitting $\mathrm{r}$. The troublesome word has provoked a large number of conjectures. (I) With 2 regarded as the prep.: Bert. tr. adjectivally, 'kleinwinzig,' so Ges., Thes., 805, i.e., 'of a small character,' cft. '1 Ru. $2^{20}$, on which it may be here remarked that the form unamended (vs. מגיאלינו in Kittel's marg.) has its counterpart in an Arab. idiom of $m i n$, s. Wright, Gr. 2, F. I 38, B-D. Zöck. obtains an adv. phrase, $c f t$. 
בי $2^{8}$, and tr. 'in a small way.' V Leng.proposed a nominal use, 'von Kleinheit,' cft. מאין Is. $4 \mathrm{r}^{24}$, cf. $\mathrm{GB}^{10} \mathrm{e}$ parlis initiis, and Behr., 'von geringerer Würde.' Or, regarding מ as comparative, CBMich. cft. מהבל minus quam uanitas, Ps. $62^{10}$, 1 wa plusquam non, Jer. $10^{6}$; and so Kön., Syntax, $\$ 352$ z, $H_{w} w$., s.v., desiderates minus quam parua. On this vLeng. remarks that 'more than a little' can also mean 'ziemlich gross,' and so he acutely explains the iøxupor of the Grr. Or (2) another

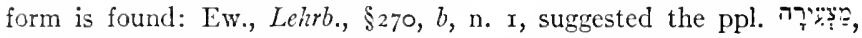
which Behr. criticises, since it must mean 'becoming small' (or 'doing small things'). Others, as cited by CBMich., compared $\mathrm{r}^{20}$, here $s$ with dag. euphonicum, and so Barth., $N b$., §165, finds a unique miktil adj. form, with which he cft. the (dubious) Akk.-Aram. miskên. And (3) the Aram. rt. ' "'s, in act. forms 'despise,' is compared, so Ra., who tr. agreement with Syr. Pael tr. 'blaspheming.' EVV follow II (modicum)

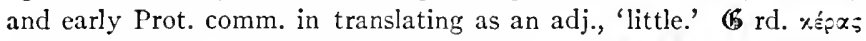

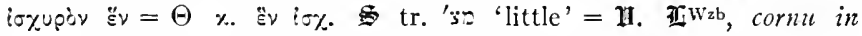
uirtute, i.e., understanding $\dot{\varepsilon} v$ as $\dot{\varepsilon} v$ and manipulating i $\sigma \%$ accordingly.-

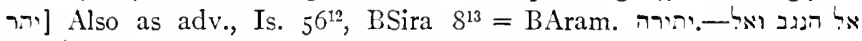

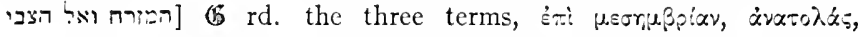

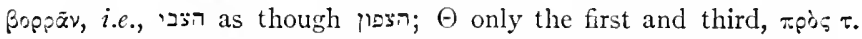

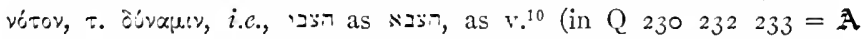

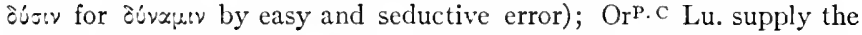
second term, $\dot{\alpha} v a \tau \Delta \gamma_{i} v$ om. the third term. The eldest evidence thus supports the three terms; why $\Theta$ om. the second is not evident. There is no reason with Houbigant (cited by Bert.) and Jahn to accept (6)'s perversion of the text to 'the north'; it is interesting that Sa. has the same interpretation, 'to Syria $(e s ̌ s-s \hat{a} m)$, that is, the north.' The third term is now almost universally interpreted as = ארין ריכי $1 I^{16,41}$, so Prot. comm. generally after the Jewish comm., EVV ('pleasant, beauteous land'), also dEnv., Knab. vs. H. But how can the word in itself stand for that phrase? Hardly so unless that phrase had already occurred and here were a reminiscence. And then why the explicit phrase later? Parallels offered, e.g., ב Eze. $44^{6}$ (Geier), are not forcible for this context. And how absurd is the geography: 'to the south, to the east, and to Palestine'! Note that $\Theta$ is followed by Jer., contra fortitudinem, the latter in his comm. identifying צבא $\mathrm{v}^{10}$ with 'the sons of Israel,' and so Polych. In sum, the oldest exegesis had no suspicion of the modern interpretation. If deliberately omitted the word, this may have been for lack of a suitable understanding. In $I_{1}^{16.41 .45} \Theta$

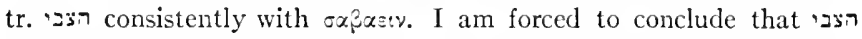
here is not original but an early plus, prob. a gloss to the foll. אבד צבי, and that $\Theta$ actually read sב צמי to the geographical term in in c. II. 
10. יומן הכוכבים With Piscator, CBMich., al., waw explicative, "even of the stars,' $c f$. Zech. $9^{9}$, 'upon an ass and upon a colt the foal of a sheass' (Hitz.); s. on

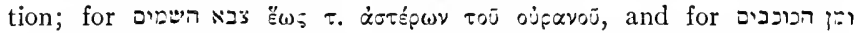
$\dot{\alpha} \pi \circ \tau$. $\dot{\alpha} \sigma \tau \dot{\varepsilon} \rho \omega \nu x$. $\dot{\alpha} \pi \dot{\partial} \alpha \dot{\tau} \tau \tilde{\omega} \nu$ (poss. a doublet). (6) thus identified the host with the stars. The vbs. in $v^{b}$ are put in the pass.,

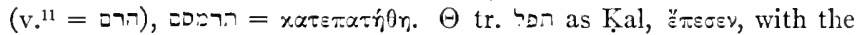

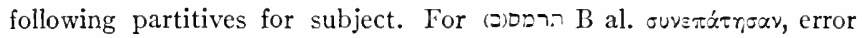

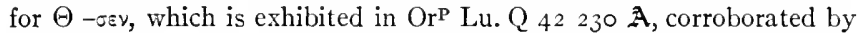

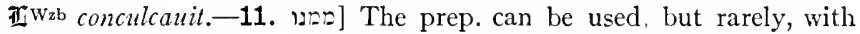
the agent after the pass. Behr. tr. 'seinerseits,' but which 'side' he means is not obvious.- הריש Kt., Kr.] The Hif. has the mng. 'to lift up,' and then 'to remove,' e.g., Is. $57^{14}$, Eze. $2 \mathrm{I}^{31}$, and so constantly of the ritual 'removal' of parts of sacrifice; Behr. finds here a sarcastic allusion to ritual practice. The pass., Hof., was read here with Kr. by

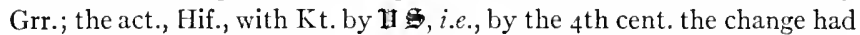
come in. Prob. the change was made so as to define the antecedent of is. The Hof. is preferable in alignment with plained, with Keil, as a conformation to the latter. Ew., Lehrb., \$II5, d, Olshausen, Lehrb., \$259, b, Kön., Lgb., I, 502 f, Behr. regard the Kt.

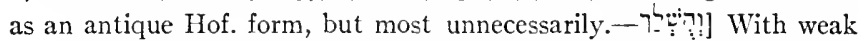
waw. Hitz., Kamp. would read the abs. inf. Hif. 7. supported by $\mathbb{6}$ and prob. by $\Theta$ (which misread the Heb.).

12. 3בי] For the assumed fem. gender in construction with מלאה צכאה Is. $40^{2}$, where, however, as Bev. notes, the vb. can be construed as act., 'accomplished her service'; for discussion of the gender s. reff. in GB. All interpretations of ${ }^{2} \mathbf{s}$ are unsuccessful; s. Comm. If an intrusion-although some word was found here by 6 -it may be a gloss on הצs v. ${ }^{9}$, or a gloss meant to be added to the list of terms in

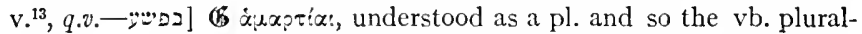
ized in agreement with it, but originally prob. a dative $=\alpha \mu \alpha \rho \tau \alpha$ (s. Note at end of chap.); this contradicts the position of scholars who hold that $\mathbb{B}$ is witness to 20 as nominative._- ועישרה והזיחיחה Schultens, Animadv., 326, cft. the use of Arab. ja'ala with the impf., 'he was doing so-and-so,' and the similar use of $3 *$ in I Ki. $8^{32}$, also below in $\mathrm{II}^{7}$ (q.v.): i.e., 'he did prosperously.'

13. 14. The angelic announcement of the term of the vision. 13a. And I heard one Holy one speaking, and another [Heb., one] IIoly one spoke to so-and-so who was speaking. 'Holy one,' 'Pד, $=$ angel, s. on 'יד $4^{10}$. For the seer's 'hearing in' on an angelic conversation as introduction to a revelation $c f$. Zech. ${ }^{12}{ }^{12} ., 2^{7} ; v^{12}$ of the former passage, 'the angel of the LoRD spoke 
and said, O LoRD of hosts, how long ?' being model to v. ${ }^{\mathbf{b}}$ here. 'So-and-so' (the Heb. word here is a hybrid) may be used where the name is not known, e.g., I Sa. $2 \mathrm{I}^{3}$, Ru. $4^{1}$, or, at least in Arabic narrative, even where the name is known, but it is tedious or unnecessary to repeat it; here the title of the addressee may be implied. As has not been observed, the contents of the first angel's 'speaking' must be the details of vv.10-12. The vision has passed from the visual to the aural, for the moments of that climax could not be seen. 13b. For how long is the vision: the Constant, and the desolating Iniquity, the giving of both sanctuary and host to trampling? I.e., What is the term of this shocking vision? Cf. "P expression of religion, appearing constantly in the Bab. penitentials (adi mati); for example of the repetitious use of this liturgical formula s. the hymn to Ishtar in King, Seven Tablets of Creation, I, $222 \mathrm{ff}$. = Jastrow, Rel. Bab. u. Ass., 2, $66 \mathrm{ff}$.; the same exclamative use in the Bible, e.g., Ps. $6^{4}, 90^{13}$. It became frequent in apocalyptic usage, $c f$. inf. $12^{6}, 2$ Esd. $6^{59}$, etc. (s. Volz, Jiid. Esch., I62). The subsequent items are epexegetical to 'the vision,' detailing its chief contents. The translation followed provisionally above is the one based on the Mass. punctuation, which has been in vogue since the early Prot. comm.; it is followed by GV, the Eng. VSS, and almost all scholars who will not amend the text. It treats the 'and' in "Wri as correlative to the following 'and,' i.e., 'both . . . and,' a usage only occasionally found in Heb. (for the cases s. BDB, p. 253a). It is not, however, the construction known to the ancient VSS, although $\Theta \mathcal{B}$ I had our text at this point. But we might easily overcome the unusual syntax by reading making sanctuary [and host a trampling].' The problem in v. ${ }^{12}$ anent $\mathbf{5}$ ' 'host,' which we gave reason for deleting there, continues here, and all the attempted translations, 'army,' 'cult,' etc., are contrary to the sense of 'host' in $\mathrm{v} .^{10}, q . v$. The Grr. vary from 1 and have given a starting-point for emendations, for which s. Berth., Graetz, Beiträge, 388, Bev., vGall, p. 52, Moore, l.c. (JBL I $\$ 96$, I96). The first two terms inquired of are the Constant and the Iniquity. The former is doubtless improved by following the plus of the Grr., $\dot{\eta}$ a $\rho \theta \epsilon \hat{\imath} \sigma a$ (with Graetz, Bev., vGall, Moore) = מוּר i.e., 'the Constant removed,' cor- 
responding to the Kr., v. ${ }^{11}$ (Moore prefers

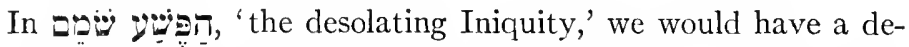
scriptive epithet added to 'the Iniquity' of $v_{0}{ }^{12}$, understanding You there as subject and omitting the prep. $Z$ 'in.' The term is then equivalent, as Berth., Moore note, to ap pap of $9^{27}$, etc., the disguised term for "the abomination which he built on the place of sacrifice,' I Mac. $6^{7}$. And Ra. finds in 'the Iniquity' in both vv. the idol that was set up. For ' But as שט is not an item in the preceding vv., the present writer is inclined to regard it as a gloss from $9^{27}$. Further, on the alleged evidence of $\mathbb{B}$ Berth., Moore delete moving the trouble caused by this word. (S. at v. ${ }^{12}$; again, here as there $\mathbf{6}$ read some word $=\epsilon^{\prime} \rho \eta \mu \omega \theta \dot{\eta} \sigma \epsilon \tau a \iota$ in its place.) For the difficult inf. תח 'giving,' vGall, followed by Mar., proposes to read the Nif. IN. i.e., 'the Iniquity was set up.' Moore, following Hitz., retains תת, regarding it as postpositive to its obj., with the same result as vGall; a parallel for this hard construction is adduced from Jer. $10^{13}$ i $\mathrm{AV}=$ 'when he utters his voice,' but the natural mng. is given by JV, 'at the sound of his giving.' Bev. suggests a considerable amendment. The writer would propose that all the terms after '(desolating) Iniquity' are a series of glosses that have accumulated from terms in vv. ${ }^{10.11 .12}$, terms that provoked inquiry:

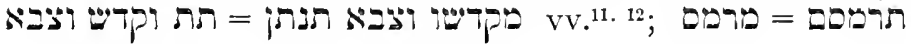
v. ${ }^{10}$. Jeph. has a similar notion: "How long shall this person last who shall do the things mentioned in the v., which are three: giving, the sanctuary, the host?" The primarily abstract 'holiness,' is here used of the concrete 'sanctuary'; so often of holy things, occasionally of the holy place, e.g., Ps.

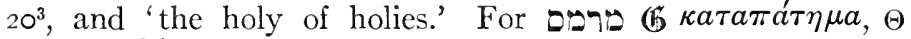
$\sigma v \nu \pi a \tau \eta \theta \dot{\eta} \sigma \epsilon \tau a \iota, c f$. the reminiscences in I Mac. $3^{45.51}, 4^{60}$, 2 Mac. $8^{2}$, Lu. $2 \mathrm{I}^{24}$.

14. And he said unto him [筫 unto me]: Unto evenings (and) mornings two thousand three hundred; and the sanctuary shall be vindicated. All the primary VSS have 'unto him'= "'ssi, adopted by Berth. and recent comm., in place of ss. The problem of the $\mathrm{v}$. lies in the computation of time: Are 2,300 evening-mornings $=2,300$ days meant, or, counting up both 
evenings and mornings, $\mathrm{I}, \mathrm{I} 5 \mathrm{O}$ days? The former is the view of $(\mathfrak{B} \Theta \mathcal{Z}$ ( Jewish comm. follow suit (with various calculations of the time), and such is the predominant opinion of the early Prot. comm.; AV gives 'days' for 'evenings mornings,' putting the latter in the marg.; GV similarly, adding 'vom Abend gegen Morgen zu rechnen.' So Berth., Häv., vLeng., Stu., Keil, Behr.; the last is the latest defendant of this view among the comm. The other view, i.e., I,I50 days, appears first in Aph. Syr.,

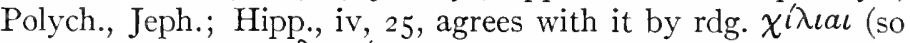
also HP 2635 ) for $\delta \iota \sigma \chi \imath \iota \iota a \iota$, i.e., I,300 days, with identification with the $3 \frac{1}{2}$ years. It was taken up by some of the Prot. comm., and since Zöck. appears to be now the prevailing opinion; and so RVV JV, 'unto 2,300 evenings and mornings.' The decision is to be approved for the reason that the consummate sacrilege consisted in the suspension of the Constant sacrifices, of which there were two a day, hence 2,300 of them $=I, I 50$ days; as we might say, so many Matins and Vespers. The one philological problem lies in the asyndeton, 'evenings mornings' $(\mathfrak{b} \Theta \mathbb{H}$ have 'and'), but what is meant is patent from the fuller statement in $\mathrm{v} .^{26}$, 'the vision of the evening and the morning.' For these words as technical terms of the two Constants $c f$.

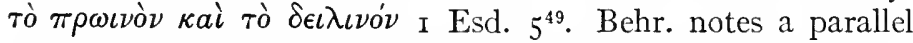
from the Hildebrandslied, 'sixty summers and winters' $=30$ years. The other view cft. 'it was evening and morning, one day,' Gen. $\mathrm{I}^{5}$, and holds that 'evening morning' $=\nu v \chi \theta \eta \mu \epsilon \rho o \nu$ (so Grot., Berth.), but for such a composition of two nouns no exx. are found in the Semitic outside of modern dialects (s. Brock., $V G$ I,$\S 248)$. A period of I, I50 days approximates the $3 \frac{\mathrm{I}}{2}$ years ( $\mathrm{I}, 260-\mathrm{I}, 278$ days) found in our interpretation of 'the time, times and half a time' of $7^{25}$; s. Comm. there. The calculations based on the opinion for 2,300 days, i.e., about $61 / 3$ years, begin quite too early, e.g., with Menelaus' usurpation, I 7 I B.c., or terminate too late, e.g., with Nicanor's defeat, 162 B.c.; s. Pole, who presents a wide range of theories, Pusey, Behr, Dr. The vb. in 'the sanctuary shall be vindicated' is an interesting but perfectly proper use of $p-3$, as Calv. saw: "iustificare Hebraeis est uerbum iuris"; i.e., it will be restored to its

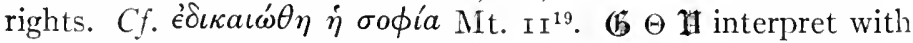
'shall be purified,' and so AV RVV 'be cleansed,' marg. 'be jus- 
tified,' GV 'wieder geweiht werden'; but JV 'shall be victorious.' 'The historical commentary on this vindication is given in I Mac. $4^{43 \mathrm{ff}}$.

13. 1י The Mass. tradition for $\bar{r}$ is certain; for similar cases of apparently arbitrary - , explained in part as due to following guttural, s. Kön., $L g b$., I, p. 74, GK \&1 o, h. N.b. that in the Aram. dialects there was the tendency to replace the expected $a$ stem vowel of the impf. with $u$; s. Nöld., $l i G$ p. 219, $S G \S 170$. For the cohortative form with waw-consec. s. Dr., Tenses, $\$ \$ 69$ ff.: "It occurs only at rare intervals except in two or three of the later writers, some ninety instances of its use being cited altogether." אהרד . . אהר א for similar cases s. BDB s.v. §6. For the prepositive use $f f$. Nu. $3 \mathrm{I}^{28}$ (if the text is correct). It is not here the indef. article, which is always postpositive (s. at $2^{31}$, although cases otherwise in the Mishnah, s. Bev., p. 30), but is in apposition with ישרוי, 'one, a saint' (so GK

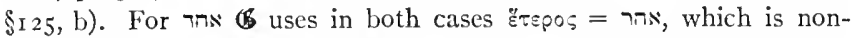

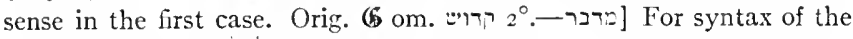
ppl.s. at v.4. noun is always ?ִ. Ew., Lelirb., \$106, c, Brock., VG I, 295, regard the form as contraction of the usual double term; Behr. as erroneous scribal combination of the two; Perles, Analekten, 82, as combination of two rdgs. Probably the ultimately alone current original, and a was inserted artificially to identify with the classical term. The text is ancient, the word being transliterated in $\mathfrak{B} \Theta$

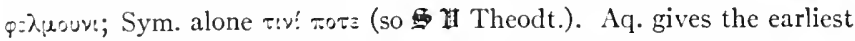
treatment of the word as a proper, angelic name; acc. to Ber.R., $2 \mathrm{I}$, he translated it 'to him who is inside,' identifying with י's, meaning Adam, whose seat is in front of the ministering angels; s. Field, ad loc., Jastrow, s.v. Similarly Polych. regards it as name of an angel, and so Jeph., who finds three angels, Palmoni, Gabriel and an anonymous. N.b. the article in supported prob. by the Grr. With the derivation

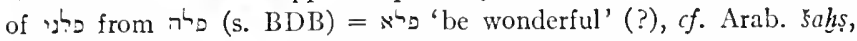
'individual, person,' primarily a 'phenomenon.'reason with Ew., Lehrb., $\$ 290$, e, to regard this as an irregular case of the construct, or with Pr. to read a const. On the VSS at v. ${ }^{13 \mathrm{~b}} \mathrm{~s}$. Note at end of the chap.-14. בקר ] Without depending on the evidence of $\Theta \mathbb{H}$, which prefix conj., we may note that an orig. I may easily have fallen out before the following labial. There may be noticed Knab.'s

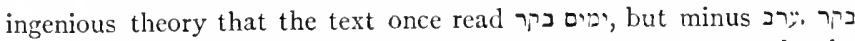
being a numeral, i.e., $2,000+100+200=2,300$; subsequently the numeral was written out, בקר was taken for the noun, and so $\because$ finally dropped. But alphabetic figures for numerals are 
not found in the ancient texts; $c f$. at $2^{1}, 6^{1}$. ב ב ב $]$ The Nif. only here. For $\Theta x \alpha \theta \alpha p t \sigma \theta \dot{n} \sigma \varepsilon \tau \alpha t, h^{252}$, Clem. Al. have the error $\alpha \dot{p} \theta \dot{n} \sigma \varepsilon \tau \alpha t$.

15-27. The interpretation of the vision. 15-18. The interlude of the summons to Gabriel to instruct Daniel. 15. And it came to pass when I Danicl saw the vision, that I sought to understand it. And behold there stood before me as the appearance of a man. 16. And I heard a human voice amidst the Ulai, which called and said: Gabriel, make yon one to understand the vision. 17. And he came near where I stood. And when he came, I was panic-stricken, and fell upon my face. But he said unto me: Understand, son of man; for the vision has to do with the time of the end. 18. And as he was speaking with me I swooned with my face to the ground; and he touched me and made me stand upright. The introduction to the interpretation is similar to that in c. 7 , vv. ${ }^{15} \mathrm{f}$. Here the angels intervene of their own accord. For the phrase 'as the appearance of a man ( 72 , uir),' or 'the like of a man,' $\epsilon f$. similar although not identical phrases, $10^{16 .}{ }^{18}$, and s. Note at end of chap. 7 .

16. For the opening sentence $\epsilon f$. Eze. $\mathrm{I}^{28 \mathrm{~b}}$; 'a human voice,' i.e., אד homo, used in its usual generic sense. The phrase 'amidst the Ulai' is interpreted by the EVV 'between the banks of Ulai'; but the prep. ${ }^{\prime}=$ is sometimes used as here translated. For the scene $\epsilon f$. the angels by the river, $12^{5 \text { f }}$. With Gabriel, here and $9^{21}$, we have the first attribution of a personal name to angels; the one other angel named in the Jewish Scriptures is Michael, ro ${ }^{13 \text { ff. }}$ (q.v.). And these two alone appear in the N.T., Gabriel being there the annunciator as here, Lu. ${ }^{19.26}$. In Tob. $3^{17}$, etc., Raphael is named. In En. the angelic nomenclature is luxuriant; the four or seven archangels there include Michael and Gabriel $\left(9^{1}, 20\right)$. See, inter al., for the Judaistic period Bousset, Rel.d. Jud., c. I6; for the Talmud, etc., Weber, Jiid. Theologie, $\$ 34$; and for later Judaism the great compendium by M. Schwab, Dictionnaire de l'angélologie, I897. Michael and Gabriel retain their pre-eminence in the Talmud. As the writer has observed in his Aram. Incant. Texts, 96, Gabriel is often given precedence over Michael in magical formulas, especially in non-Jewish circles, Michael being the patron of Israel. It became early the vogue to compose angelic names upon the element $-e l$, 'God,' but these were of the type used originally 
for humans, s. Note. The pronoun translated 'yon one', rare in Heb., is reminiscent of Zech. $2^{8}$.

17. 'I was panic-stricken': this tr. of the vb. בעתת is approved by comparing the cognate בפיע: 'terrors of God,' Job 64. The title 'son of man,' i.e., 'human,' is borrowed from Eze., where it occurs about a hundred times, $2^{1}$, etc. 'Falling on the face,' the common attitude of reverence, is a frequent phrase in Eze., e.g., $\mathrm{I}^{28} ;$ cf. Rev. $\mathrm{I}^{17}, 2^{2}$. The causal connection of 'for the vision,' etc., would be that the vision is 'worthy of special attention' (Bev.). But the tr. 'that (כ) the vision' is also possible. The Heb. reads literally 'the vision (is) for time of end,' as we might say 'End-time.' I.e., a fixed term is given for the consummation of the 'age,' which has been counted in days, vv. ${ }^{13 .}{ }^{14}$. The expression recurs in $\mathrm{v} \cdot{ }^{19}, \mathrm{II}^{35 .}{ }^{40}, \mathrm{I} 2^{4.9}{ }^{9}$; and with a change in one word, 'end-term,' inf. v. ${ }^{19}$, it is reminiscent of Hab. $2^{3}$, 'For the vision is yet for the term (Tyis'), and it ... (?) to the end and lies not.' What the 'end' is appears from $9^{26}$, 'his end,' i.e., Antiochus'. For the apocalyptic use of 'end' cf. Am. 82, Eze. $3^{6}, 7^{2}, 21^{25.29}, 35^{5}$. It is the of the prophetic books, commonly translated 'the latter days'; s. Comm. at $2^{29}$. The phrase rings through all subsequent apocalyptic literature; s. Volz, p. I 89 (with numerous citations), Bousset, pp. $278 \mathrm{ff}$. It appears usually in the reverse construction, finis saculi, saeculorum, and so here the text of $\Theta$, $\epsilon$ is

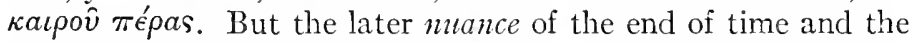
ushering in of eternity ( $c f$. Bousset, p. 2So) is not to be found here, against Cha. 18. The tr. 'I swooned,' 9.רד, is more appropriate for an abnormal unconsciousness than that of EVV, 'I was, or fell into, a deep sleep,' which is correct in, e.g., Jon. $I^{5}$, Gen. $2^{21}($ ก:บภ). The same kind of scene, with the moment of the divine touch, is repeated in $10^{9 \mathrm{f}}$, $c f . \mathrm{vv} \cdot{ }^{16 \mathrm{ff}}$; also En. $60^{3 \mathrm{f}}$, Rev. ${ }^{17},{ }_{2}$ Esd. $5^{14 \mathrm{f}}$. The sentence 'he made me stand upright,' lit. 'on my standing,' follows Eze. $2^{2}$, '(the) spirit made me stand up on my feet.' The parallelism may explain the Koranic identification of Jibrîl with the Holy Spirit.

15. וירי בראמי See at v.2. It is not evident why JV throws the vb. into the pluperf., 'had seen.'-Cאיר] Emphasis on the name to express return of self-consciousness, as in $7^{15}$. 6 simplifies by making the phrase subj. of the following vb.- כיעה] 'Understanding' with ref. 


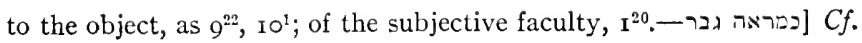

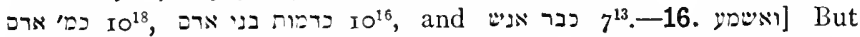

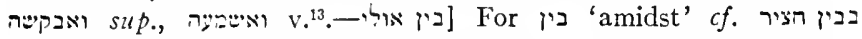
(בבין?) 'amidst the grass,' Is. $44^{4}$; and so in expressions of time,

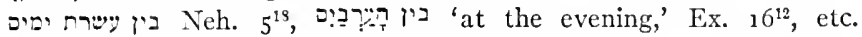
(קיביכ not a dual, s. GK $\$ 88, c, \mathrm{~GB})$; cf. Arab. bainâ, bainamâ, 'while.' [גבריאל- For similar human name $c f$. El-gabri, $B E$ ro, 52, Ilu-gabri, Tallquist, Neubabylon. Namenbuch, 76. Similarly Michael, Uriel were at first human names.- - I For the other few cases, and for found only in Pent., s. GK $\$ 32$, f. - In v. ${ }^{16 b}(\mathfrak{B}$ has a doublet: $x$. $\dot{\varepsilon} \times \dot{\alpha} \lambda \varepsilon \sigma \varepsilon$

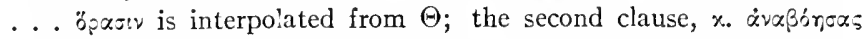

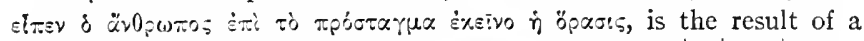
queer but intelligible misreading of

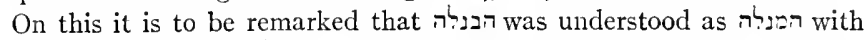

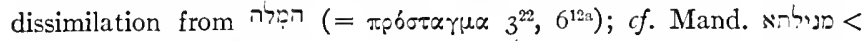
מנלה (s. Nöld., $M G$ p. 54), and cf.

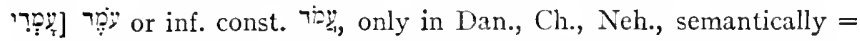

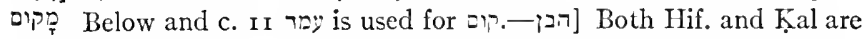

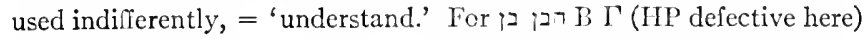

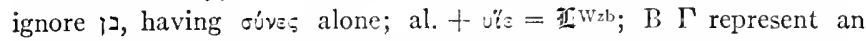
early omission, which was later supplied. - ir.. [.:] $\Theta$ exhibits sis xaspoj $\pi \varepsilon_{p} \alpha s$, but IIWzb in tempus finis correctly, i.e., sis xatpiv $\pi$. (cf. 230 $x \alpha(\rho \omega \nu=x \alpha$ lpov?), and this may have been the orig. rdg. of $\Theta$, with

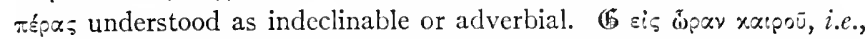
giving $p$ in sense of 'time,' the mng. it probably has in Zad. Frag., I, 5;

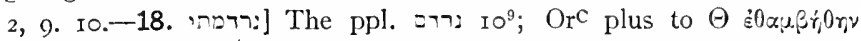

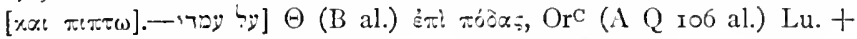
pou, $c f$. II wab supra pedes meos. The phrase is late, else only Io ${ }^{11}$, Ch.,

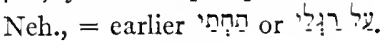

19-26. The angelic interpretation of the vision. 19. And he said: Behold, I will make thee know what shall be in the end of the Wrath; for 'for the term of the end'! The angel repeats his previous announcement, but with greater fulness. The present phrase is enlarged upon in $\mathrm{II}^{36}$, "till the Wrath (without the article) be accomplished, for that which is determined shall be done.' 'The phrases go back to the prophetic books: Is. IO ${ }^{24}$ 'and (the) Wrath shall be accomplished,' $26^{20}$, 'until (the) Wrath pass by.' 'The 'Wrath' is the temper of God at the present epoch, due primarily to Israel's sin, which however is to vent itself upon Israel's enemies, who have taken advantage of her bitter discipline. As Mar. remarks, the whole history of Israel 
since the Exile lies under the Wrath of God, to be terminated by the inauguration of the Kingdom. This interpretation appears in the comment of I Mac. on the persecutions of Antiochus, $I^{64}$, 'there came great Wrath upon Israel' (with actual citation of I Ki. $3^{27}$, a passage of quite different circumstances, but representing the antiquity of the idea). A commentary on the Wrath is given in Dan.'s confession in c. 9. For discussions of this grievous problem of Jewry s. Schultz, Alttest. Religionsgesch., $\$ 54$; Wicks, The Doctrine of God in the Jewish Apocryphal and A pocalyptic Literature, c. 2; Weber, Jiid. Theologie, $\$ 58$. The final clause of the v. repeats the end of $v \cdot{ }^{17}$ with an unessential change in one word and omitting the subject 'the vision.' The latter word is expressed in most $\Theta$ Mss (not in (ㅁ)), and is restored here by Behr., Mar.; but unnecessarily, for the significant words are repeated exclamatively as a clew.

20. The ram which thou sawest, he of the two horns-the kings of Media and Pcrsia; 21. and the buck, the he-goat-the king of Greece; and the great horn which is betwecn his cycs-the first king; 22. and the broken one and there stood up four in its place-four kingdoms shall stand up out of his nation [4i a nation], but not with his power. The items of the vision and their interpretations are given in staccato fashion. It is almost the only case in the book where political allusions are definitely unveiled. 21. In $v .{ }^{17}$ the two horns stand for the two states of Media and Persia, and 'kings' is used for 'kingdoms,' as in $7^{17}$, q.v.; similarly here 'king' is used both of the kingdom of Greece and of King Alexander. The double phrase translated above 'the buck, the he-goat' differs from the corresponding one, vv. ${ }^{5.8}$, 'buck

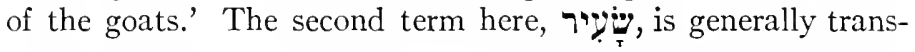
lated as adj., EVV 'rough,' more correctly 'shaggy.' But the word is most often used as a noun, of the he-goat, the usual word in this connection, whereas above an Aramaic word, 'דֶ? 'buck,' was used. Hence comm., e.g., Behr., Dr., have suggested that the classical Heb. word has been here added by way of explanation (Behr., as a gloss). The Grr. read here as above, 'buck of the goats,' but their evidence is not to be taken for the orig. rdg., for the word demon, the 'satyr' of AV, and the Gr. translators would naturally have avoided such a slur on Greece, even as the trans- 
lators of the Pent. avoided $\lambda a \gamma \omega \dot{s}$ for the unclean hare out of respect to the Lagidae. 22. By the addition of one character to the Heb., we obtain the necessary 'his nation,' with the Grr., 11. For the asserted diminution of the power of the Diadochi from that of Alexander $c f$. $\mathrm{II}^{4}$.

23. And at the end of their sovereignty [Heb. kingdom], as it were [Heb. like] the completing of sins [All sinners], there shall stand up a king bold-faced and skilled in enigmas. 24. And his power shall wax mighty [gloss, but not by his power]; and he shall destroy terribly, and shall prosper and do; and he shall destroy mighty ones and the people of the Saints. The climax of the empire of Greece appears in Antiochus (acc. to Oriental notion the Seleucidae were Alexander's legitimate successors, s. Torrey's paper on 'Yawan,' JAOS 25, 302); as in c. 7 all the history of the Successors is focussed in this Atheist who holds the centre of the stage for the pious Jews. The prep. introducing the following gerundive clause may be translated as above, 'as it were,' and so more forcibly, or it may be simply temporal, of time at which, as it is generally understood. This clause in refers to 'the sinners completing (the measure),' i.e., of their sins; and so almost all comm., e.g., JV, 'when the sinners have completed their transgressions.' But all the VSS understood,

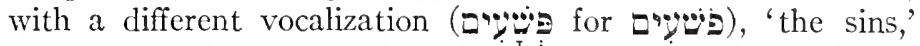
which agrees with 'finishing (so Kr.) transgression,' $9^{24}$, and this amendment is accepted by Berth., Ew., Mein. 'The phrase is then parallel to Gen. I $5^{16}$, 'for not yet is complete ( iniquity of the Amorite,' a theme which recurs in the Scriptures: 2 Mac. $6^{14}, \pi \rho \grave{s} \dot{\epsilon} \kappa \pi \lambda \eta \dot{\eta} \rho \omega \iota \nu$ a $\mu a \rho \tau \iota \hat{\omega} \nu$ (vv. ${ }^{12 \mathrm{ff}}$. an interesting

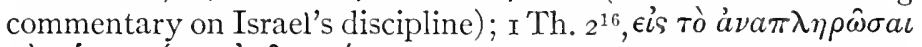

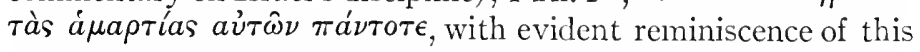
passage, for there follows, 'and the Wrath has come upon them utterly.' 'These reff., adduced by Geier, CBMich., Bert., but ignored by recent comm., give the preference, by 'analogy of Scripture,' to the rdg. 'sins.' The 'sins' are the causes and the object of the 'Wrath,' v. ${ }^{19}$; with Antiochus their measure is brought to the full that the Theodicy may be inaugurated. The description of the 'king,' Antiochus, is a striking miniature in words. He is 'bold-faced,' as close as possible a translation of the Heb., in which the same phrase is used of the harlot's 
effrontery (Pr. $7^{13}$ ); it involves insolence (Bev.), defiancy (Dr.), but we may hold to the concrete, physical expression dear to the Semitic genius. The word rendered 'enigmas' is the 'riddles' of $5^{12}$; the multifariousness of word-meaning in the elder Sem. lexicon is illustrated in the use of the word ( $c f$. the Lord's

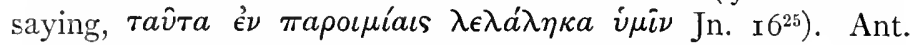
was a master in Machiavellian arts, master-diplomatist, able to deceive 'the very elect.' $C f$. the characteristic of 'deceit' in $\mathrm{V} .{ }^{25}$, which is illustrated from I Mac. $\mathrm{I}^{30}$, 'he spoke to them words of peace in deceit.' Ant.'s character is further depicted at $\mathrm{II}^{21 \mathrm{ft}}$. The clause bracketed above, 'but not by his (EVV plus 'own') power,' repeats the last clause of $\mathrm{v}^{22}$, and by reason of its change of reference has given trouble to the exegetes. Calv., Ew. are logical in making the words refer again to the same antecedent, Alexander; but the antecedent is too distant. Hence a variety of attempts at explanation: Theodt., Aph. Syr., Ra., AEz., Vatablus, by divine permission; or by other human auxiliaries (Bert.), Polanus precising by naming Eumenes and Attalus or the perfidy of the Jewish renegades. Or the contrast is found between strength and deceit $\left(c f . \mathrm{v}^{25}\right)$, so vLeng. and recent comm., Mein., Bev., Behr., Kamp., Dr., Cha.; but we should expect 'by power,' not 'by his power,' as Behr. himself seems to feel. But $\Theta$ om. the clause (it may not be original in $\mathbf{B}, \mathbf{s}$. Note), and so Mar., Löhr, Ehr., cf. Cha. The adv. used in 'he shall destroy terribly' corresponds to the Gr. $\delta \epsilon \iota \nu \hat{\omega} s$, which so often is used like the 'awfully' of Eng. vernacular; indeed, the word may be imitated from the Gr. To the persecuted Jews Ant.'s 'destructiveness' (the vb. is used thrice in this and the following v.) loomed large; the Heb. vb. is commonly used in a moral sense, and its object would include social institutions as well as concrete things. The 'mighty ones' are Ant.'s political foes ([B well 'dynasts'), who are represented through a narrowing of focus by the four 'kings' he displaced; these are in contrast with 'the people of the Saints' (the latter word without the article, and so practically a proper name), i.e., 'the Saints of the Most High,' $7^{25}$. Some comm., e.g., AEz. (not Ra.), Stu., Pr., identify 'mighty ones' with Israel and regard 'the people of the Saints' as epexegetical; but the Maccabees had not yet proved their valor.

25. And after his cunning he shall cause craft to prosper in his 
hand, and in his mind [Heb. heart] he shall act greatly, and unawares he shall destroy many. And against the Prince of princes shall he take stand. And without hand [i.e., natural agency] shall he be broken. As Mar. observes for vv. ${ }^{23 .}{ }^{24}$ the conclusion of the angelic address breaks into metrical form, but it is rather a kind of $s a j^{6}$ than a regulated metre. The syntax of the Heb. in the first sentence is somewhat harsh, although quite possible, and it has been adhered to above. But it has troubled the Grr., $\Theta$ being snarled up in one of its rare absurdities. (5 supplies after the first prep. '\%y, 'the Saints,' obtaining the plausible tr., 'and against the Saints his purpose.' This clew has been seized upon by Graetz, p. 390, followed by Bev., Mar., Blud. (p. 67), Jahn, Löhr, Ehr., Cha. for an emendation: omitting 'and the people of the Saints,' end of $\mathrm{v} .^{24}$ (which $\mathbb{6}$ has!), and then following $\mathbf{G}$, ' and against the Saints shall be his mind [and he shall cause].' Bev. cft. $\mathrm{II}^{28}$, 'his heart against the holy covenant.' But Behr., Kamp., Pr., Dr. rightly stickle at the correction; Behr. regards it as 'flat,' and observes against Bev.'s view that there can be no mention of the saints until v. ${ }^{25}$, that the writer does not avoid repetitions; and Dr. makes the capital point that

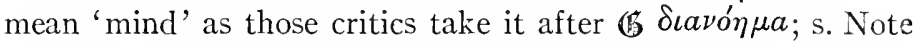
further. 'In his hand' means 'in operation'; for this use of '? s. BDB $390 a$. There is a contrast, perhaps satirical, between it and the following 'in his mind' ('heart' as seat of the mind). For 'act greatly,' 'do big things,' s. Comm. at v.4. 'Unawares' is a tr., now generally adopted after Aram. usage, in place of RVV JV 'in (time of) security,' which amounts to the same meaning (AV 'by peace'). It is generally recognized that here we have a direct historical ref., which can be of use in dating the chap., viz., I Mac. I ${ }^{29 \mathrm{f}}$; this tells how Ant.'s tax-gatherer (Apollonius) came to Jerusalem 'and spoke to them words of peace in guile, and they believed him, and he fell upon the city suddenly ( $\left.\epsilon^{\prime} \xi a^{\prime} \pi \iota \nu a\right)$, and he smote it greatly and destroyed much people of Israel' ( $c f$. below 'deceit' and 'shall destroy many'). The 'Prince of princes' is 'the Prince of the host,' v. "1, q.v., i.e., God. In 'he shall be broken without hand,' the vb. is not used concretely as in $\mathrm{v}^{8}$ of the great horn, but in the secondary sense of destruction, e.g., Jer. $22^{20}$, 'all thy lovers are destroyed.' In 'without hand' the noun is used in one of its many connota- 
tions ( $c f$. manus in Latin), here as the instrument of force, and so force; we may compare Zech. $4^{6}$ : 'not by power and not by force but by my spirit, saith the LoRD.' Not a human or natural agency but the direct visitation of God will destroy the tyrant. We recall the vivid Jewish stories of his miserable death in Persia from some disease accompanied by melancholy: I Mac. 6, 2 Mac. 9, Jos., $A J$ xii, 9, I. However, the vague statement here must not be taken as post eventum or treated too exactly as prophetic. For another similarly vague predictive allusion to Ant.'s death, but one which cannot be post eventum, s. $\mathrm{II}^{45}$.

26. The asseveration of the truth of the vision. And the vision of 'the evenings and mornings' which has been told is true. And thou, close up the vision, for many days yet! 'Evenings and mornings' is a clew from $\mathrm{v}^{.4}$, taken as a summary title of the vision. For this solemn affirmation, "intended here as an encouragement to the persecuted Israelites, who may rest assured that their sufferings will ere long reach the appointed limit" (Dr.), of. $\mathrm{IO}^{1}, \mathrm{II}^{2}$ (in both which cases as here the noun 'truth' is used), Rev. $19^{9}, 21^{5}, 22^{6}$. It is implied that the vision is to be written, $c f .7^{1}$, and then the book is to be 'closed up' (similarly $\mathrm{r}^{4}$ 'closed up and sealed'), because while written in the reign of Belshazzar it relates to the distant age of Antiochus; it is to remain hidden because it would not be intelligible before that epoch, while this charge would explain why none ever heard of the vision until that late day ( $c f$. Dr., Cha.). Cf. En. ${ }^{2}$ (visions seen not for this generation but for a remote one), $\mathrm{rO}_{4}^{12 \mathrm{f}}$, 2 Esd. I4 $4^{45 \mathrm{ff}}$. (distinguishing between the public Scriptures, and the 'apocrypha' which are to be committed to the wise). For the final apocopated clause $c f . v^{19}$. It is a citation of Eze. $12^{27}$ (there a satirical gibe of the people at the prophet's predictions); $c f$. also below $10^{14}$.

19. Ehr. offers the insipid correction of הימים to - - ( 3 has the correct exegetical plus [ $\tau_{r, s}$ opyrs] tois viois $\tau_{0 j} \lambda_{0.05}$ oou, which is adopted by Lu.—T;: $=7 ;$ ] v. ${ }^{17}$; for the equivalence $c f$. the synonymity of $p:$ and $17 \%$, s. at $2^{22}$. - At end of the v. most $\Theta$ MSS $+\dot{\eta} \ddot{\gamma}_{p \alpha \sigma r s}=$ IW 2 b, but Q II Lu. ass omit it, prob. after the earlier rdg. of $\Theta$. 6

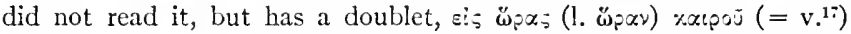

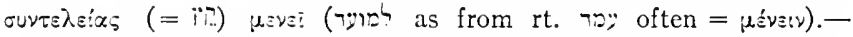
20. מילי [מיד, All VSS as though by the apparent difficulty

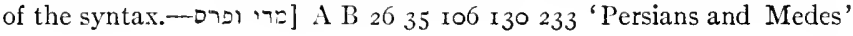




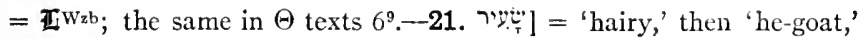
and so the satyr-demon (why BDB, GB distinguish the two nouns is

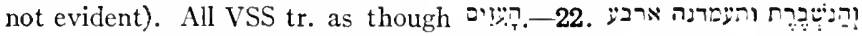
in:-] The whole clause in casus pendens with the waw consec. fol-

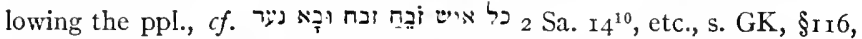
w. The difficult clause is variously rendered by the VSS but without

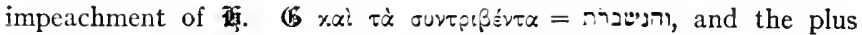

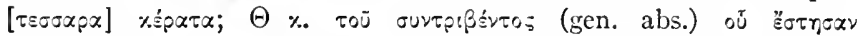

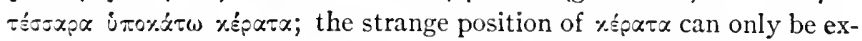
plained as a gloss from $\left(\boldsymbol{B}\right.$, it is not found in II $^{\mathrm{w} z}$. Orc revised the order here, Lu. rendered more elegantly. 更 et contriti ( $=\Theta$ gen. abs.) cornu (an exegetical gloss) in quo steterunt quattuor reges ('four' $2^{\circ}$ lost by haplog.) sunt (?) de gente eius exsurgent.- ת ? noun in abstract $-\hat{u} t$ is unique in classical Heb., to be expected ris? s. GK $\S_{95}$, u. But it is the regular pl. in NHeb., s. K. Albrecht, Neuhcb. Gramm. auf Grund der Mishna, $\$ 84, \mathrm{~h}$. All VSS read 'kings.' It is possible that a double rdg. is implied here, to be read either 10 ry [פגוי_._ All VSS exc. now generally accepted.-

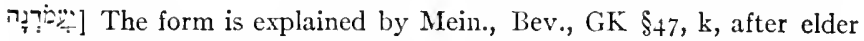
grammarians, as either Aramaizing or survival of an antique Sem. form (with $y$ prefix to the fem. as in other Sem. groups); similar cases in Gen. $30^{38}$, r Sa. 6 ${ }^{12}$. This view is rejected by Kön., Lgb., r, pp. 239. 417 , Behr., Kamp., Mar., Löhr, who read the regular הлמקה. The Jewish grammarians recognized these forms as 'androgynous' (s. Kön.), and Kön. thinks there was intended the double ref. to 'kingdoms' and 'kings'; as such, like מליביור above, it would be an early Rabbinic con-

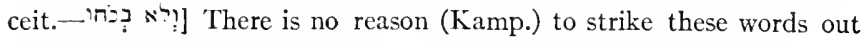
with Behr. as a gloss from v. ${ }^{24}$ (the converse argument is made by some); Behr. arbitrarily holds they must mean 'through Alexander's strength.'

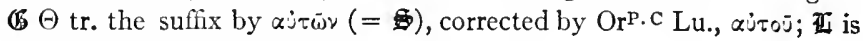
non-committal, in uirtutc sua.

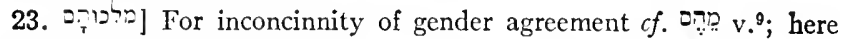
'kings' rather than 'kingdoms' may have dominated.-- Wrb in anno et in nouissimo regni eorum contains a doublet, prob. in anno $=\varepsilon v$ $\varepsilon[\approx \chi \alpha] \tau \omega$.

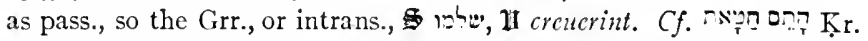
$9^{24}$. For the intrans. use of the Hif. here ( $\mathrm{AV}$ 'come to the full') of.

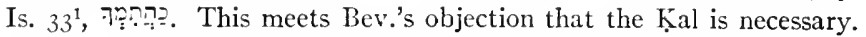

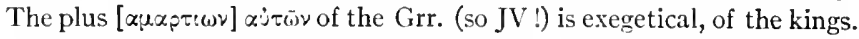

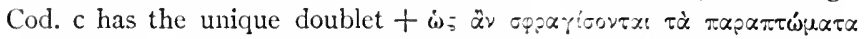

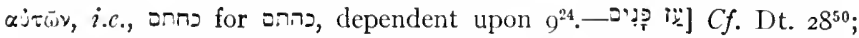
Pr. $7^{13}$ of the harlot; also Ecc. $8^{2}$ (text and mng. ?). Not 'of fierce countenance' with EVV, evidently following $\boldsymbol{H}$ pracdurae faciei, where Jer. 
prob. meant 'impudent,' $c f$. Quintilian praeduri oris; correctly Grr.

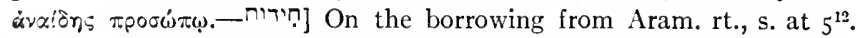

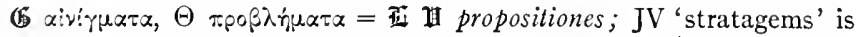

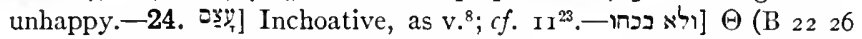
3489 9I I30 229230 I 47) = IWzb Iren., v. 25,3 , om. the clause. (B

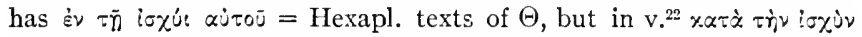

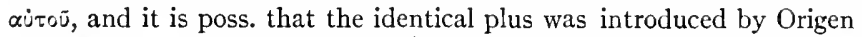

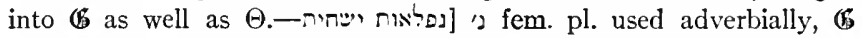

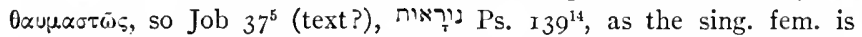
also used; s. GK $\$ 100, d$, and often in Aram. In comparison with

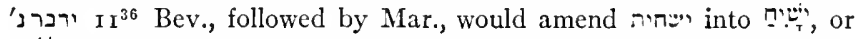
'יז': 'shall utter [monstrous things],' but with Kamp. an unnecessary amendment.-2בומים] There is no reason, in view of the neighboring oצ;; to understand ' $y$ as 'many' with Behr.; for this mng. we find v. ${ }^{25}$.— error, but supported by 西Wab populum sanctum.

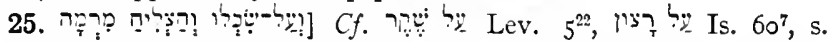
BDB 754b. שכל in malo sensu. The conj. in והצליח resumes the casus pendens contained in the prepositional phrase; s. Dr., Tenses, $\$ \$ 122 f$.: GK $\S$ r 43. Both $\mathbb{B}$ and $\mathbb{H}$ take as subj. to the vb., and possibly an

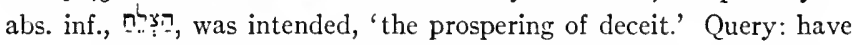
we here a pair of clauses depending on $v .{ }^{24}$ ? - '[will destroy . . . the saints] both by his cunning and the prospering of deceit in his hand'? (F's plus is noted in the Comm. $\Theta$ has the remarkable rendering $x$.

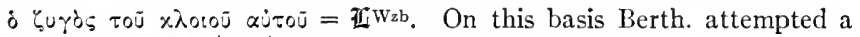

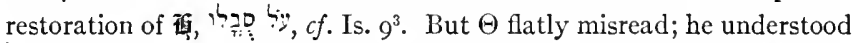

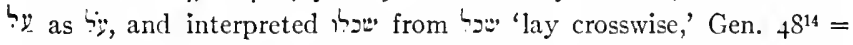
Arab. sakala, 'bind,' which suggested $x$. etc., and so II torquis. has an unexplained misreading, 'in his power,

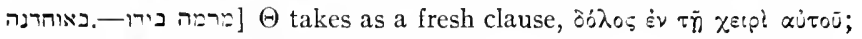

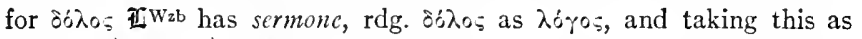

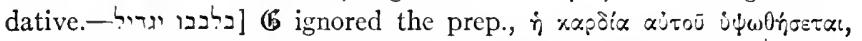

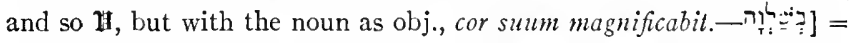
$\mathrm{II}^{21}{ }^{24}$, where $6 \dot{\xi} \xi \dot{\alpha} \pi v \alpha$; for the corresponding Aram. noun s. at $3^{29}$,

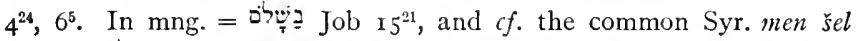

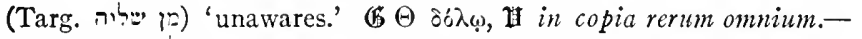

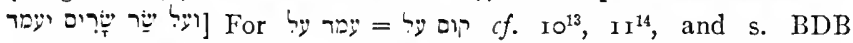

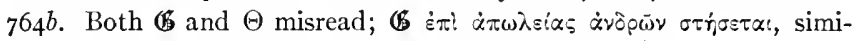

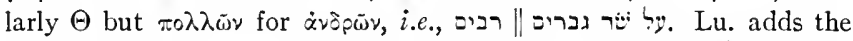

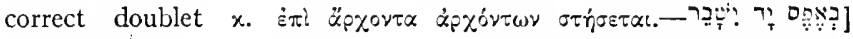

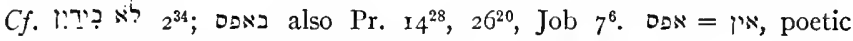
and mostly late; for equivalence with Akk. apsu, s. Hommel cited in

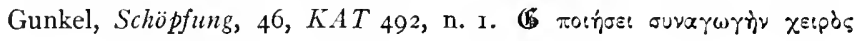




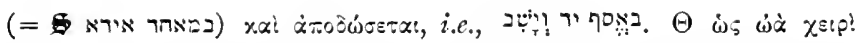

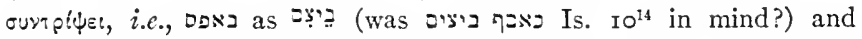
the vb. as Piel.-26. נג] For this use of רas $c f .4^{6}$. As Mar. remarks, the terms for vision, as here, and 'word' can be used promiscuously, so that הזי can be used indifferently with them, e.g., Is. $2^{1}$, Jer.

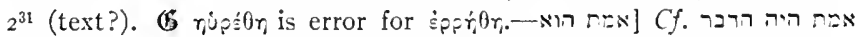
Dt. $22^{20}$, etc. For אמר $\Theta$ (B al.) $\dot{\alpha} \lambda r_{1} 0 \dot{\omega} \zeta$ (after the freq. adv. use of $r a$ א),

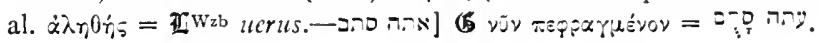

27. The effect of the vision upon Daniel. And for me Daniel, I was befallen [?], and I was sick some days; and then I arose and did the king's business. And I was perplexed at the vision and without understanding. For similar psychological effect $c f$. $7^{28}, 2$ Esd. $5^{14}$. The first vb. 'I was befallen,' i.e., with a stroke of illness, is a translation offered as a possibility; for the various theories s. Note. The reference to the royal business connects with $2^{48}$. For the vb. 'perplexed' $s$. at $4^{16(19)}$. The traditional interpretation of the final clause is 'and there was no one understanding,' so Grr., $\stackrel{S}{S}$, Ra., the early Prot. comm., EVV, most moderns. This is then variously explained: Ra., that none perceived Dan.'s state of mind because he restrained himself before the eunuch; Mein., that none remarked the vision and its effects; Behr. thinks of a lack of sympathetic attention, or suggests a bit of phraseology, cft. Is. $53^{1}$. I tr. 'there was none to interpret,' so Sa., Jeph., AEz. = RVVmg, and this causative mng. of the vb. is entirely possible. But there is no reason why Dan. should have expected attention, sympathy, or an interpreter in his Pagan circle. The tr. given above, which can be justified from the Heb., is that of Maur., Hitz., Mar., Lamb., and is corroborated by $12^{5}$, 'I heard and could not understand.' The moment serves, as Mar. observes, as introduction to the following chap., in which the seer agonizes for further illumination.

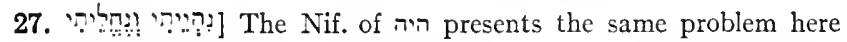
as in ${ }^{2}$, $2^{1}$, tr., e.g., Dr., 'I was done with, exhausted' (= Eng. vernacular 'was done for'!). EVV, 'fainted,' depend upon langui. But it is doubtful if the same vb. could mean, the sleep was done, and the seer was done for. Ra., Kiimhi boldly etymologize from דָ 'ruin,' Job $6^{2}$, followed by Berth., Häv., cft. Arab. haw'a(y), and so cadere factus sum, and cft.

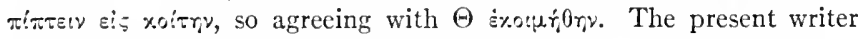
came independently upon this derivation from הוה = היה in its original 
mng. 'fall,' observing its (rare) use in Syr. as an active, 'befall' (e.g., Acts $7^{40}, 28^{5}$, other cases in Wright, A poc. Acts), and so translate, 'I was befallen,' i.e., stricken. The difficulty is too easily overcome by Pr., Mar., Löhr, Ehr. in regarding נהייה as dittograph of נחליהי alleged support of $\mathbb{B}$, which sums up the two vbs. in $\dot{\alpha} \sigma \theta=v \dot{r}_{j} \sigma \alpha 5$. $\Theta \mathrm{tr}$.

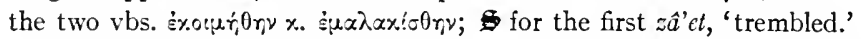

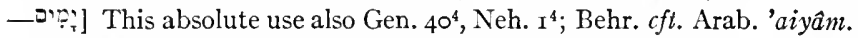

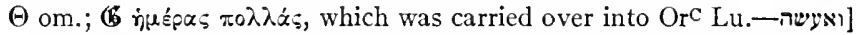
For unapocopated form, frequent especially in ist pers., s. GK $\$ 75, t$; the retention of $ה$ may be due to the expected cohortative mood in $-\hat{a}$.

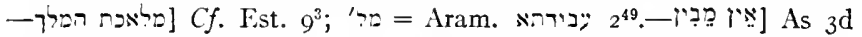
pers. all the VSS and EVV; Grr., take the ppl. as intransitive, 'understanding,' It as causative, non erat qui interpreturetur, and so Sa., Jeph., $A E z$. But $p *$ here $=*$ as pure negative, $c f . v^{5}{ }^{5}$. Dr., Cha. are undecided as to interpretation. prctaretur; Ranke suggests that ouvetich $\omega \nu$ was read for cuvi $\omega \nu$. But this appears to be a contamination from $1 \mathrm{H}$; and Ranke probably gives the actual OLat. in his citation from Auctor de 42 mans. (ap. Ambros.), non erat intel igens.

\section{TEXTUAL NOTE ON gib. $^{12}$.}

The table opposite gives a synoptical critical presentation of the texts of and the Grr. $\Theta$ follows word by word except in two sequences, in one of which he follows $(\mathbf{B}$. The absurd errors of the latter for words (2) (3) are corrected, but הישל is is evidently understood as gloss in $\mathbb{B}$. $\alpha u \tau \omega=0$ is unintelligible except as primitive scribal error for $\tau 0 \pi \omega$. He

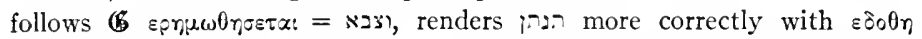
(following (5 with rat prefixed to the clause), and has sing. auaptia. As to variants $B$ alone has $\varepsilon_{p} \alpha \chi \theta r_{1}=\Sigma$ הר, the others $s \tau \alpha \rho \alpha 0 r_{i}=$ conturbatum est. $\Theta \varepsilon \tau x_{p} \alpha \chi \theta \gamma$ represents rdg. of $\sin _{\text {a }}$ as a form of In $2223 \mathrm{I}$ A another variation with $\varepsilon \tau \alpha \chi \theta r_{i}$; Qmg has npon = gloss in 6 . There follows in OrP. C

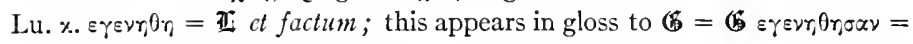
F.r. and is evidently an early gloss from $\mathbb{B}$ in $\Theta$ but out of place. Prefixed to this gloss Lu. has plus $\pi \alpha \rho \alpha \pi \tau \omega \mu \alpha \tau t$, a variant to $\alpha \mu \alpha \rho \tau i \alpha=2 \cdots \cdot$ J, again a gloss out of place.

In col. 3 is given orig. $\mathbb{6}$, which like $\Theta$ follows almost literally. The origin of its evident absurdities is patent. In cols. I, 2 are given two sets of glosses, the place of the words in the present text of $\mathbb{B}$ being exhibited by a consecutive numbering of the words as they stand in the text. Col. 2 contains a consecutive series of glosses intruded solidly into $\mathfrak{G}$; they give valuable independent corrections of the latter's errors. Col. I contains some

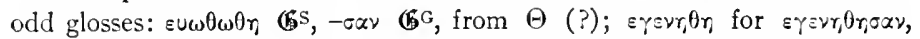
prob. older than the latter, as it is supported by the gloss in $\Theta$ texts; and $\varepsilon \pi t \tau . \gamma r_{i} \| \chi \alpha \mu \alpha t$. 


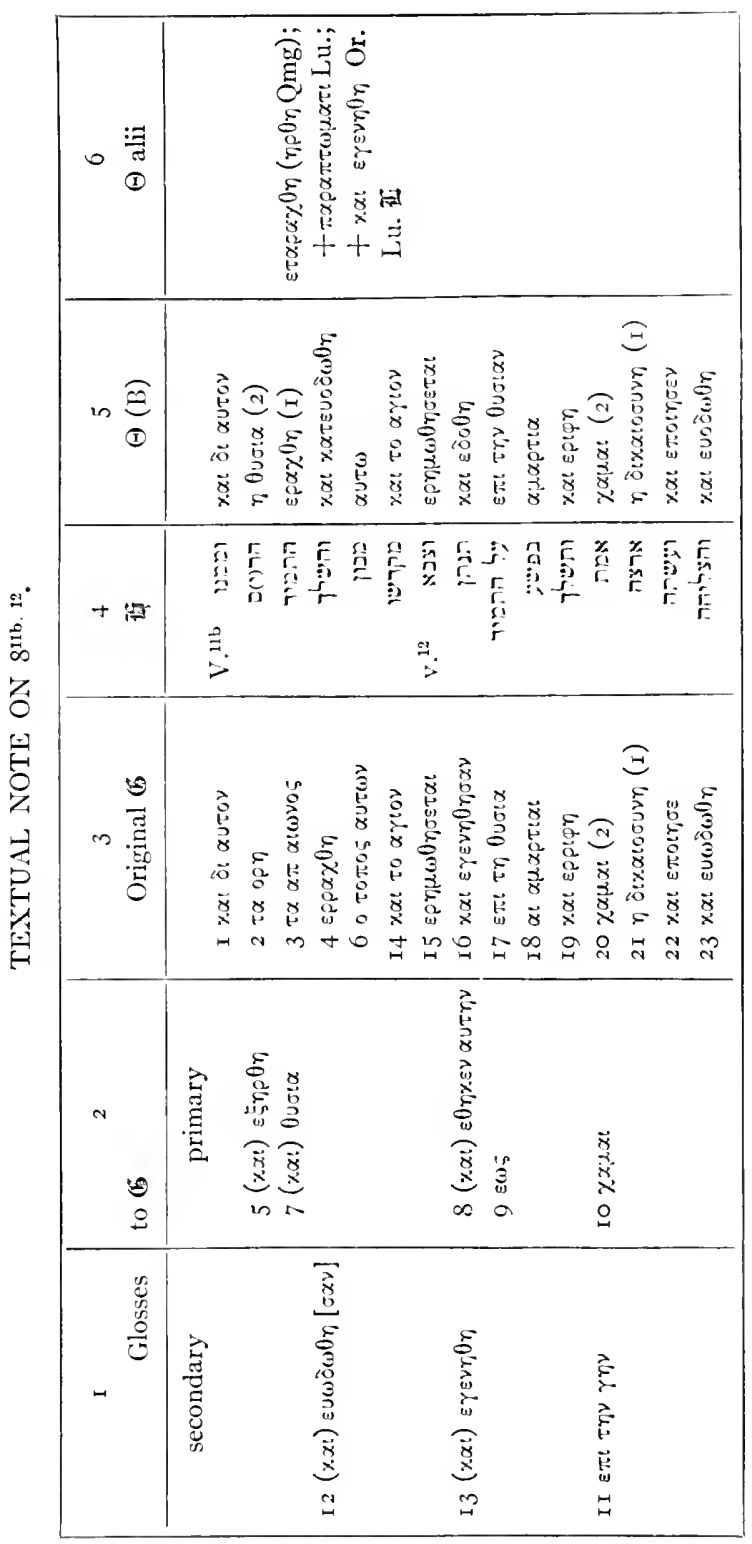


For the VSS the following points are to be observed. OLat. (䢻b corroborated in part by Iren. $v, 25,3)=B$, with exceptions as noted above.

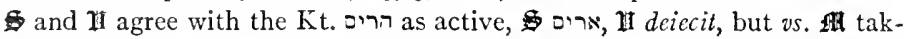
ing רישיר as active. Similar correspondence appears in $v^{12}$ : H robur ( hailâ) datum est ei (not in 称) contra sacrificium propter (in') peccala (also pl. in pointed text of $v s$. The following $\rangle^{2}$. Th is taken as Hof. by all VSS. Thus and $\mathbb{H}$ read our with variations from $\mathbb{A}$.

The above study proves that criticism of the elder VSS, $\mathbb{G}$ as well as $\Theta$, presents after exclusion of patent glosses the same quantum of words. Jahn's servile dependence upon $\mathbb{E}$ is absurd; and quite without proof is Cha.'s assertion that "it is possible by means of the VSS, esp. the LXX and Theod., to recover the criginal for the most part." Only one substantial

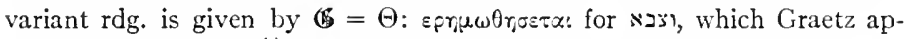
proved, supposing on ; ; but for which Blud. (pp. $6_{5} f f$. ) more reasonably suggests was cast down the place of the sanctuary and it was desolated' (i.c., יביר (ויצרה . But it is questionable how far we may rely upon (E's corrupt text. For other suggested revisions s. Comm. O's $\alpha_{\mu} \alpha_{p} \tau t \alpha=\mathbb{G} \alpha_{l} \alpha_{i} \alpha_{p} \tau t \alpha l$ is claimed by many as proof of orig. rdg. have been original, and this is supported by the gloss $\varepsilon \gamma \varepsilon v \eta_{i} \theta r_{1}$ for $\varepsilon \gamma \varepsilon-$ vr,0r,aav; when it came to be understood as a nom. pl. it entailed a pl. vb.

\section{NOTE ON VSS AT $8^{13 b}$.}

For

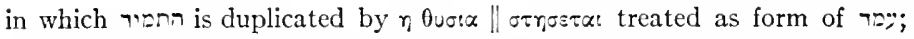
an ancient rdg. in $\Theta$ (interpolated from $(\mathfrak{B})$, corroborated by $\mathbb{I} \mathbf{W z b}^{\mathrm{b}}$, quam diu uisustabit (sic) sacrificium quod sublatum est. The plus $\eta \alpha_{p} 0 \varepsilon เ \sigma \alpha$ is exe-

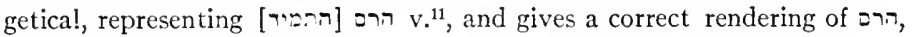

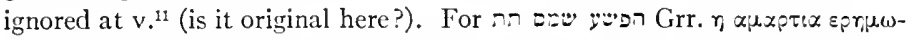
$\sigma \Xi \omega ; \eta \delta_{0} \theta \varepsilon เ \sigma \alpha ; n . b$. the forced rendering of $\Omega \neg$. II tr. תn quae facta est, after

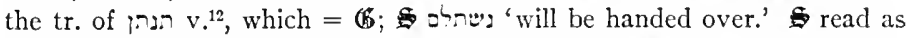

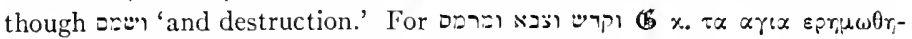

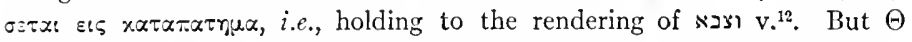

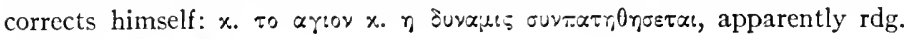

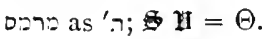

\section{CHAPTER 9. THE REVELATION OF THE SEVENTY WEEKS.}

Dan., having learned from the Sacred Books of Jer.'s prophecy of the doom of seventy years' desolation for the Holy City, a term that was now naturally drawing to an end (1. 2), sets himself to pray for the forgiveness of his people's sin and the promised deliverance (3-19). The angel Gabriel appears to him (20- 
21), and interprets the years as year-weeks, with detail of the distant future and of the crowning epoch of the divine purpose (22-27).

1-3. Introduction. 1. In the first year of Darius the son of Ahasuerus [i.e., Xerxes], of the sced of the Medes, who became king over the realm of the Chaldaans,-2. in the first year of his reign I Daniel observed in the Books the number of the years, as the word of YHWH came to Jercmiah the Prophct, that were to be accomplished for the desolations of Jerusalem, 'seventy years.' 3. And I set my face unto IHWH God to inquire with prayer and supplication in fasting and sackcloth and ashes. For the identity of this Darius, s. Int., $\$ 19, d$. The father's name in the transliteration from the Persian is the 'Xerxes' of the Classics, as $\mathbb{G}$ correctly renders it, although in Est. $\mathbb{G}$ commutes it into Artaxerxes. Jos., following his usual bold treatment of the Persian period in Biblical history, gives the name as Astyages, the well-known royal name of the Median dynasty. The name here may have been simply borrowed from the Biblical onomasticon. In the following relative clause points the vb. as a passive, "was made king'; in the Note is proposed a repointing which, after Aramaic idiom, gives the mng. 'became king,' and this is the tr. of all the VSS. Since the early Prot. comm., Calv., Piscator, Junius, etc., and so still Wright, Wilson, Boutflower, the passive has been explained from the alleged institution by Cyrus of a viceroy, Darius-Astyages-Gobryas, in Babylonia, or, with Stu., from the action of God; cf. the interpretations of Darius, 'receiving the kingdom,' $6^{1}\left(5^{31}\right)$.

2. The repetition of the date, 'in the first year,' found tautologous and omitted by $\Theta$, Bert., has its point. The seer insists upon the date because with the overthrow of the Chaldæan kingdom the hope of the exiles for liberation was awakened afresh, and they naturally took recourse to their 'Books' to judge whether the term of exile had arrived. With the fall of Babylon the seer naturally 'observed' particularly (JV 'meditated upon,' incorrectly AV RVV 'understood') the definite prophecy long ago made by the favorite prophet announcing a term of 70 years of exile, Jer. $25^{11 .}{ }^{12}, 29^{10}$. The result of the seer's prayerful 'seeking' in the matter was a vision which revealed that those 70 years were not to be interpreted by natural mathematics but as year-weeks, a calculation which would bring 
down the objective of the prophet's prophecy into the age of the Maccabæan restoration. The ref. to the prophecies in Jer. is so clear that it is not at all necessary with Nöld., Alttest. Litteratur, 224 , Bev. (int. to chap.) to hold that there is here a midrashic interpretation of Lev. $26^{34 .}{ }^{35}$ ( $c f$. the 'seven times' of $\mathrm{v} .{ }^{28}$ ), and to find there a prophecy of year-weeks. 'The Books' are not the Thorah, with those scholars, but the Canon of the Prophets, which had already obtained authoritative value. The term is the one Biblical ref. to the Canon of the Prophets. 3. The term 'I set my face,' while poetical in quality, $c f$. the freq. 'set the heart,' is probably an old cultic term involving the idea of the kiblah in prayer $\left(c f .6^{11(10)}\right)$, as is also the vb. 'seek' used of inquiring at the oracle, here of divining the interpretation of Scripture. This spiritual inquiry was accompanied with the ancient concomitants of fasting, vesture of sackcloth, and the sprinkling of ashes on the head (the last term is omitted by $\Theta)$. For 'prayer and supplications' $c f .6^{11 \mathrm{f}}$. From primitive times fasting was regarded as the preparative for a revelation, e.g., Ex. $34^{28}$. It is the preliminary to the following vision, $\mathrm{IO}^{2.3}$, and to the visions in 2 Esd., s. $5^{13}$ and Box's note; $c f$. Syr., Apoc. Baruch, 205. 6 , and the Shepherd of IIcrmas, visions 2. 3. For the combination of sackcloth and ashes (more likely the general term 'dust,' s. Note) $c f$. Jon. $3^{6}$, Est. $4^{1-4}$, the latter passage and the present one showing that these rites of humiliation were still practised. Later reff. to the combination, e.g., Mt. I I ${ }^{21}$ and the Talmudic saying, 'Not sackcloth and fasting but repentance and good works effect the divine mercy,' $T a^{\prime} a n$. I $6 a$, are rather reminiscent of ancient practice. For these practices of private piety in Judaism s. Schürer, $G J V$ 2, 566 ff., Stade (Bertholet), Bibl. Theol.d.AT, 2, 422 ff. The divine Name היה occurs only in this chap. In $\mathrm{v}^{2}$ it appears as a citation, in $\mathrm{v} .{ }^{3}$ it anticipates the personal, intimate use of the Name in the following prayer; its occurrence would seem to indicate that the vocable was still in use in the liturgy and private prayer.

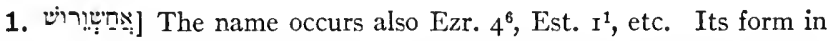
OAram., הישיארש ,חישיריש (CIS ii, no. I22, the papp.), as also correctly אהשיריט, better represent the Pers. Khišayaršâ, s. GB, Gehman, JBL

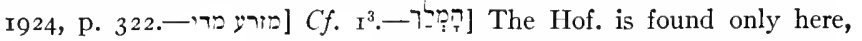
and a pass. is most unlikely. We may point it as Hif., and so 'reigned,' 
after the Syr. use of the Afel. Misunderstanding of the alien idiom pro-

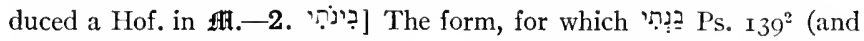

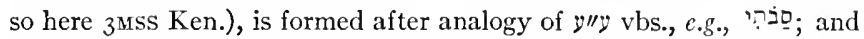
so ריזער Job $33^{13}$. The earlier explanation as Hifil, later upheld by Ewald, is disproved by Nöld., $Z D M G 37,525$.f. It is possible that a Piel, 'בַב, was intended, as in Syr., which (so also the Hif. in NHeb.) has the sense of 'interpret, expound.'-ongo] B solus Búphors (al. $\beta\left(\beta \lambda_{0}(s)\right.$, and so B solus 2 Ch. $\mathrm{I}^{9}$, I Esd. $\mathrm{I}^{33}$, teste Hatch-Redpath, which ignores this case. In the papp. this spelling lasted into the third

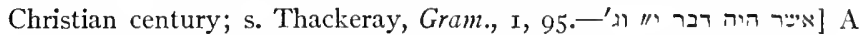
common form of introduction to a prophetic book or oracle, e.g., Jer. $\mathrm{I}^{2}$. In $\mathfrak{G} \tau \bar{n} \gamma \bar{n}$ standing in place of יהוה is survival of the Tetragrammaton carried over, as it once was, into the Gr., in this case, the only survival, misunderstood and read as THCH; see the writer's note in $J B L$

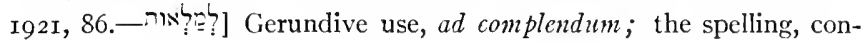

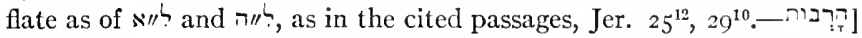
A frequent word in application to the devastated Holy Land, e.g., Lev.

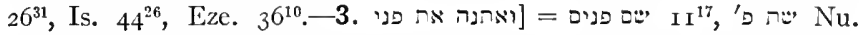

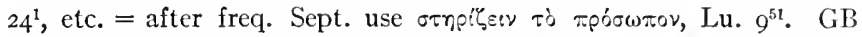
cft. the freq. Amarna gloss nadânu pâna ana.-אדני[ IOMss Ken. יהוה; also the Kr. has entered the text below at times; s. at $\mathrm{I}^{2}$. Mass. edd. vary through the chapter. In the tr. the term is rendered always by 'YHwr.'- בקיש] A common cultic term for approaching the oracle, i.e., 'make inquiry.' The following nouns are cognate accs., cf. Zeph. $2^{3}$ , בקישו צדק ביק"שו ענוה , with Behr., vs. Bev., al. This use of the acc. is good old Sem. idiom, cf. Arab., SArab.- בערה ומתחנן . בהלה ותחנונים Cf. Aram $6^{12}$. 'רה also vv. ${ }^{17 .}{ }^{18 .}{ }^{23}$, Jer. $3^{21}$, and freq. in later books. It refers

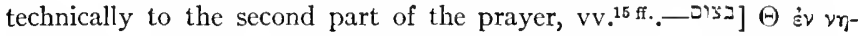

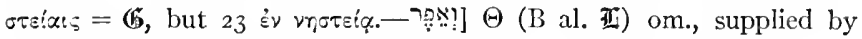
OrP.C Lu. אפר = prob. primarily 'dust' $=$ ר Akk. epirul, so Zimmern in GB.

4-19. Daniel's Prayer. The prayer is of the liturgical type which existed since the Deuteronomic age, represented by Solomon's Prayer, I Ki. 8, the prayers of Jeremiah, Jer. 26. 32. 44, and the prayers in Ezr.-Neh., Ezr. 9, Neh. I. 9. By far the largest part of this prayer consists of language found in those other compositions. Yet it is not slavishly dependent upon them; it is a liturgical gem in form and expression, and excels in literary character the more verbose types found in Ezr. and Neh. (an argument, acc. to many conservative critics, e.g., Keil, and Zündel, Kritische Untersuchungen, I9I, as cited by Zöck., for the priority of our book). The saint prays as the Church 
prays, and this prayer is modelled after customary liturgical forms of the Synagogue. Similar is the prayer of Azarias, $3^{(24-45)}$, and of Baruch, Bar. $\mathrm{I}^{15}-3^{18}$. The latter presents an interesting problem in its relation to Dan. 9, for it appears to be a mosaic of our prayer; it has been discussed at length in Int. $\S$ I3. There was a common genus of Jewish liturgical prayers, of which these canonical ones are the few surviving examples, the later Synagogue losing sight of this ancient treasury of devotion. Dr. K. Kohler has extended our view of the richness of the ancient Jewish liturgy in his demonstration that prayers in the Apostolical Constitutions have been taken over bodily from Jewish (acc. to him Essene) sources; s. his 'Origin and Composition of the Eighteen Benedictions,' etc., in the Hcbrew Union College Annual, I924.

Von Gall, Einheitlichkeit, I23-126, has developed the thesis that Dan.'s prayer is an interpolation, although the rest of his work contends for the practical integrity of the canonical book. $\mathrm{He}$ is followed by Mar., Cha. It is patent, as these scholars argue, that the theme of the prayer does not correspond to the context, which would seem to require a prayer for illumination, $c f .2^{20 \mathrm{ff}}$, and not a liturgical confession bearing on the national catastrophe. Further, Dan.'s prayer for immediate redemption is in contrast to the recognition of the far distance of that event, $8^{26}$ and end of this chap. It is pointed out that $\mathrm{v}^{43}$ repeats $\mathrm{v} .{ }^{3}$ and especially that $\mathrm{v}^{20}$ is a joint with the main narrative, which is resumed in v. ${ }^{21}$; this would explain the repetition: "while I was speaking and praying and confessing' || 'while I was speaking in prayer.' The present writer agrees with Kamp. in finding these arguments inconclusive. The second-century author may well have himself inserted such a prayer in his book for the encouragement of the faithful, even as the calculation of the times was intended for their heartening. The example of the prayers in Ezr.-Neh. would have suggested such a device to him; the inclination to such an expression of piety might have affected him as easily as some interpolator a few years later. Further, the exclusion of the prayer would cut down the length of the chap. to a quantum far below that of the other episodes of the book, and, as remarked at $\mathrm{v} .^{22}$, the prayer is dramatically introduced to fill up the time of the angel's flight. For an elaborate study of the Prayer, defending its authenticity and also 
arguing for its dependence on the Chronicler, s. Bayer, Danielstudien, Part I. In the following tr. the citations from earlier Scriptures are indicated by quotation-marks.

4a. And "I prayed to YHWH my God and made confession"; and I said: Against vGall this need not be a repetition of $\mathrm{v.}^{3}$, as it stresses the Confession which makes the first part of the prayer, vv. ${ }^{4 \mathrm{~b}-14}$, this being followed by the Supplication proper (תחנונים v.33), vv.15-19. The vb. 'pray' has the primary sense of intercession. The Hithp. Tin as here, and its Hif. הTin, are both used similarly to Lat. confiteri in its religious implications: the Hif. generally in the sense of making confession of the Deity, in his names, attributes, etc., properly a creedal use, and so practically equivalent to 'praising,' as it is generally translated; while the Hithp. presents the antithesis of the human subject and so in Jewish piety of his sin, i.e., confession of sin. The vb. has ' $\sin$ ' expressed as its obj. in v. ${ }^{20}, c f$. Lev. I $6^{21}$, etc. 'The same combination 'pray and make confession,' appears in Ezr. $1^{1}$, of. Neh. $1^{4}, 9^{2.3}$; in I Ki. $8^{33}$ i

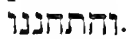

4b-14. The Confession. V."b, "Ah, YHWH, the great and awf $u l$ God, keeper of the covenant and kindness for His lovers and the keepers of His commandments": The citation is almost identical with Neh. $\mathrm{I}^{5}\left(c f .9^{32}\right)$, based ultimately on Dt. $7^{9}$, and, for the epithets 'great, awful,' cf. Dt. $7^{21}$. The text of if in this prayer varies between Yнwн and its $K r \hat{e}$ 'Adonai,' even as $\mathbf{B}$ bears witness to further variant use; in this tr., where 'Adonai' occurs, as in this v., it has been revised so as to read the Tetragrammaton. The Heb. 'in, wrongly translated 'mercy' in AV RV JV, after Grr. ë $\lambda \epsilon o s$, etc., is pietas, personal relationship on its moral side, e.g., Jer. $2^{2}$ 'thy bridal devotion'; better than 'mercy' is Coverdale's coinage, 'lovingkindness,' used capriciously in AV and adopted here by SV; s. Hastings, 'Lovingk.,' DB. 5. "We have sinned and dealt perversely and done wickedly" and rebelled and "turned aside from Thy commandments" and Thy decisions; the first three vbs. = I Ki. 877; 'turn aside,' etc., = Dt. I $7^{20}$. The commandments are legislation, decisions the judicial verdicts given from time to time. 6. "Neither have we hearkened to Thy servants the prophets, who spoke in Thy name" "to our kings, our princes and our fathers, 
and to all the people of the land." As Dr. remarks, a reminiscence of Jer. $26^{5}, c f .7^{25}, 25^{4}, 29^{19}, 35^{15}, 44^{4}$, all containing 'thy servants the prophets' followed by 'ye (they) hearkened not.' The same listing of civic strata in Jer. $44^{21}$, but with 'fathers' first, $c f$. $44^{17}$; in Neh. $9^{32.34}$ 'priests' is added after 'princes'; $c f$. Jer. $\mathrm{r}^{18}$ 'the kings of Judah, its princes, its priests and the people of the land.' By the fathers are probably meant the heads of the 'family houses,' practically elders, so, e.g., Lamb., Ehr., rather than spiritual fathers with Behr., who thinks that the item replaces the priests of the other lists; however, the omission of the latter class has some significance. The 'people of the land' $=$ Landesvolk, commoners, $c f$. Eze. $7^{27}$.

7. "Thine, IHWH, is the right," and "ours is the shame of face, as it is this day," "to the men of Judah and the citizens of Jerusalem" and all Israel, "those near and those far off" "in all the lands whither Thou hast driven them" "for the trachery with which they have betrayed Thee." The word generally translated here and elsewhere as 'righteousness,' legal righteousness; God has been vindicated as right (secondarily as righteous) by the people's experience. $C f$. v. ${ }^{14}$ 'our God is right.' 'Shame of face as it is this day' $=$ Ezr. $9^{7}$; 'shame of face,' also $v^{8}$, is a physical expression for confusion before others, a shame which involves the reproach of others, cf. men (Heb. a sing. collective, Mannschaft) of Judah and the citizens (lit. 'dwellers') of Jerusalem' $=$ Is. $5^{3}$ (with terms reversed), Jer. $4^{4}$, etc., 2 Ki. $23^{2}$. 'Those near,' etc., depends on I Ki. $8^{26}$; the phrase also Jer. $25^{26}$, Is. $57^{19}$. 'For the treachery,' etc. $=$ Lev. $26^{40}$, Eze. $\mathrm{I} 7^{20}$, etc., I Ch. $10^{13}$. The common rt. of the noun and $\mathrm{vb}$. denotes treachery, unfaithfulness, so JV, not the colorless 'trespass' of AV. 8. YHWH, "ours is the shame of face, to our kings, our princes and our fathers," in that we have sinned against Thee. "Haec repetitio ... pondus orationi addit" (Maldonatus). 9. To YHWH our God belong compassion and forgivenesses, for we have rebelled against Him, 10. neither "have we hearkened to the voice of YHWH our God" "to walk in His laws which He set bcfore us" through "His servants the prophets." 'Compassion' is more fitting psychologically than 'mercy' for רחיז: AV unnecessarily insists on the Heb. pl. 
and tr. 'mercies,' and equally unnecessary is JV 'compassions.' 'Forgivenesses,' i.e., acts of forgiveness, $=$ Neh. $9^{17}$, 'thou art a God of forgivenesses' (plus a long series of equivalent attributes). The thought of $\mathrm{v}^{9 \mathrm{a}}$ is motived by $\mathrm{v} \cdot{ }^{\mathrm{b}}$, "for we have rebelled against him'; i.e., we are thrown simply on his mercy. The logic is reminiscent of Dt. $5^{30 \mathrm{f}}$. 'Hearken to the voice of Yнwн' $=$ Ex. $15^{26}, \mathrm{I} 9^{5}$, Dt. $4^{30}$, etc., Jer. $3^{13}$, etc. 'To walk in his laws which he set before us' $=$ Jer. $26^{4}, 44^{10}$; the first clause also $=$ Jer. $32^{23}, 44^{23}$, the second $=$ Dt. $4^{8}$, $\mathrm{II}^{32}$, Jer. $9^{12}$. The antique pl. tôrôt, 'laws,' properly oracle decisions, in place of which 'the Torah' came to be used, is taken from Jer. $32^{23}$, appearing also Ps. IO5 $5^{45}$; 10 it quite naturally understand the word as a sing. The sing. occurs in the next v. 11. Yea [Heb. and], all Israel have transgressed Thy law and "have turned aside" "so as not to hearken to Thy voice," and "there has becn poured out upon us" "the curse and oath that is written in the Law of Moses the servant of God"; for we have simed against Him. "Not to hearken to thy voice' $=$ Jer. $18^{10}, 42^{13}$. 'Poured out upon us,' cf. ' my anger and fury hath been poured out,' Jer. $7^{20}, 42^{18}, 44^{6}$, 2 Ch. $12^{7}, 34^{25}$. The vb. Th has the suggestion of molten metal;

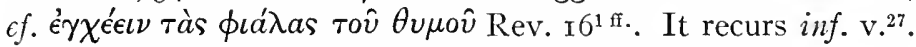
'Curse and oath,' the same zeugmatic expression in Neh. Io ${ }^{30(29)}$ $=$ 'oath of curse' Nu. $5^{21}$. 'The curse written in the Law of Moses' $=$ Dt. $29^{20}$, and refers to the great imprecations of Lev. $26^{14 \mathrm{ff}}$, Dt. $28^{15 \mathrm{ff}}$. 'The Torah of Moses' $=$ Jos. $\mathrm{S}^{31}$, I Ki. $2^{3}$, but found mostly in late books, s. BDB, p. 436, and in N.'T., Lu. $2^{22}+6$ cases. 'Moses the servant of God' $=$ Dt. $34^{5}$, Jos. $\mathrm{I}^{1}$, etc., Neh. IO ${ }^{30}{ }^{(29)}$; $c f$. his title 'man of God,' Dt. $33^{1}$, Ps. $90^{1}$. 12. And "He has confirmed His words [Kr. word]" which He spoke against us and against our judges "that He would bring upon us a great evil," so that theie has not been done "under the whole heaven," as has been done with Jerusalem. "Confirmed his words' $=$ Neh. $9^{8}$, with pl. 'words' as here; $\epsilon f$. Dt. $9^{5}$, etc. 'Judges' is used in the general sense of magistrates, summing up the official classes of vv. ${ }^{6 .}{ }^{8} ;$ Ps. $2^{10}$ 'judges' || 'kings.' Bar. $2^{1}$ understands here the historical Judges. 'Bring upon us a great evil' $=$ Jer. $35^{17}$, $36^{31}$, etc. 'Under the whole heaven' = Dt. $2^{5}, 4^{19}$, Job $28^{24}$, etc., and sup. $7^{27}$. 13. "As it is written in the Law of Moses" "all this evil" has come upon us, and we have not mollified YHWH our God by turning from our iniquities and 
considering Thy truth. This is the first appearance of the term

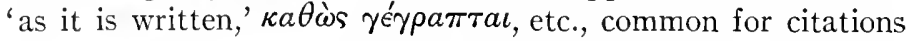
in N.T., Talm., etc. 'Mollify,' the Heb. literally 'soften the face of,' an antique phrase used with God or man as obj., and continuing into late religious usage, Zech. $7^{2}$, Mal. $\mathrm{r}^{9}$, Ps. I I $9^{58}$, 2 Ch. $33^{12}$ (s. Lexx.). Cf. 'cause thy face to shine,' v. ${ }^{17}$. AV 'make prayer to' follows the suit of the VSS, e.g., 1 rogauimus faciem Domini; RVV JV 'entreat the favor of.' The gerunds at the end tr. infs. with $\zeta$ 'to,' and accordingly VSS, EVV, comm. in general, render 'that we might turn,' etc. This evan-

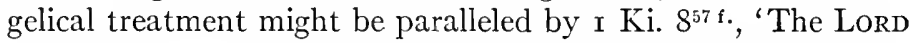
be with us . . . to incline our hearts unto him'; but the sense required in this prayer is that God should be propitiated by right action and thinking; and accordingly the infs. are here translated as acc. to a common use of the inf.; s. Dr., Tenses, $\$_{205}$. In the final clause the VSS take the vb. in the sense of 'to understand, consider,' e.g., $\mathfrak{H}$ cogitare, AV 'understand,' RVV JV 'have discernment in,' and this is the mng. of elsewhere in Dan. $\left(\mathrm{I}^{4}, 9^{25}, \mathrm{II}^{33 .}{ }^{35}, \mathrm{I}^{3} \cdot{ }^{10}\right.$-in $9^{23}$ causative). The object of this consideration is universally translated 'thy truth,' cf. $8^{12}$, where the same word is used of the objective truth, i.e., religion. But the primary ethical sense 'faithfulness' is preferable here. God's promises are absolutely reliable for blessing or bane; the Jews have learned the truth of this in the latter sphere, they can prove it also in the other. 14. And "YHWH has been vigilant over the evil" and brought it upon us ; for "YHWII our God is right in all the works which He has done," and "we have not hearkened to His voice." 'The first vb. is generally translated 'has watched' in the old English sense of 'be wakeful.' The phrase is cited from Jer. $\mathrm{I}^{12}, 3 \mathrm{I}^{28}, 44^{27}$, ' $\mathrm{I}$ am vigilant against

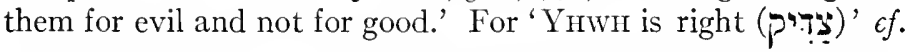
immediately Ezr. 915, Neh. $9^{8.33}$ ("thou art right in all that has come upon us'), also Jer. $2^{1}$ (where JV 'right,' al. 'righteous'), Lam. $x^{18}$, and $v$. sup. at v. ${ }^{7}$.

15-19. The Supplication. 15. YIIWII our God, "who hast brought Thy people forth with a strong hand," and "hast made Thee a name, as it is this day": "We have sinned, have been wicked." The first statement, referring to the Exodus, = Dt. $6^{21}$, etc., Jer. $32^{21}$; the second $=$ Jer. $32^{20}$, Neh. $9^{10}$. For 'to make a name' = 'gain renown,' $c f$. Gen. $\mathrm{II}^{4}$, etc. 'We have 
sinned,' etc., s. at v. ${ }^{5}$; if the distinction of stems is to be observed, here Kal, there Hif., the final vb. here = 'be wicked.' 16. YHWH, "according to all Thy acts of vindication," oh, "may Thy anger and fury turn away from Thy city Jerusalem, Thy holy mount"; because for "our sins and the iniquities of our fathers" Jerusalem and Thy people "are become a reproach to all those

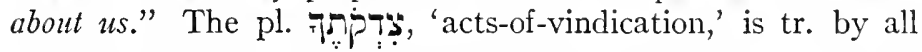
VSS and EVV (even JV) by the sing. 'righteousness.' But the $\mathrm{pl}$. is correct and is a classical reminiscence, being used in the rather antique sense of vindication of a cause; so in the Ode of Deborah, Ju. $5^{11}$, I Sa. $12^{7}$, Mi. $6^{5}$, Ps. $103^{6}$. How far the word developed in another direction appears in $\Theta$ 's tr. $\epsilon \lambda \epsilon \epsilon \mu o \sigma u ́ \nu \eta$ and s. Comm. on the word at $4^{24(27)}$. Cf. Ropes, "Righteousness" and "the Righteousness of God," etc., JBL I903, 21 I-227. Cf. the other shades of the mng. of the word in vv. ${ }^{7}$. 18. "May thy anger turn,' etc. $=\mathrm{Nu} .25^{4}$, Is. $\mathrm{I}^{1}$, Jer. $23^{20}, 3 \mathrm{O}^{24}$. 'Thy city' $=$ v. ${ }^{19}$, 'my city' Is. $45^{13}$. 'Thy holy mount' $=$ Ps. I $5^{1}$, etc., $c f$. 'thy holy city' $v .{ }^{24}$. 'Our sins and the iniquities of our fathers' $=$ Neh. $9^{2}$, cf. the IId Commandment, Jer. II ${ }^{10}$, etc. 'A reproach,' etc. $=$ Ps. $44^{14(13)}$, etc. 17. And now "hearken, our God, to Thy servant's prayer and supplications," and "cause Thy face to shine upon" "Thy desolate sanctuary," "for Thine own [with $\Theta$ ] sake," YHWII. 'Hearken,' etc. = I Ki. 828, Neh. I ${ }^{6.11}$. For 'thy servant's prayer' $c f$. the case of Abraham, Gen. I8, Moses, Ex. 32, etc., and Ja. $5^{16}$, 'the prayer of a righteous man avails much.' This and the similar prayers in the O.T. and Apocrypha are testimony to the sense of the power of prayer in Judaism; it continued with the Pharisees, s. Herford, Pharisaism, c. 6, 'Ph. as a Spiritual Religion,' a very sympathetic study. 'Make thy face shine,' etc. (for the physical expression cf. 'Soften the face,' $\mathrm{v}^{13}$ ), as in the Priestly Benediction, Nu. $6^{25}$, Ps. 804. 8. ${ }^{20}$, a similar prayer, etc. 'The desolate sanctuary' $=$ Lam. $5^{18}$, I Mac. $4^{38}$. For 'desolate' $c f .8^{13}, 9^{27}, \mathrm{II}^{13}$, I $2^{11}$, 'the abomination of desolation,' etc. At the end of the v. If reads 'for the sake of the Lord,' which is most awkward; $\Theta$ 'for thy sake, Lord' $=v \cdot .^{19}$, Bar. $2^{14}$; this is preferable as the orig. text, and so vLeng. (citing Houbigant), Pr., Kamp., Ehr., Lamb. For this phrase $c f$. Is. $48^{11}$, Jer. $14^{7}$, etc. This correction is simpler than $\mathbb{G}^{\prime}$ 's rdg. 'for thy servants' sake,' $=$ Is. $63^{17}$, accepted by Bev., Mar. But the error in if it be one, is ancient. The 
appeal 'for the Lord's sake' is the only possible argument of the sinful people; it is identical with Ezekiel's appeal to the divine 'holiness,' practically God's honor. 18. "Incline, my God, Thine ear and hear, open Thine eyes and see" our desolations and "the city upon which Thy name is called"; for "we present not our supplications before Thee" for our own righteonsness but for "Thy great compassion." 'Incline . . . and see' = I Ki. I9 $9^{16}$ (Is. $37^{17}$ ), Hezekiah's prayer. 'Upon which thy name is called' $=\mathrm{v} .{ }^{19}$, i.e., as proprietary; $c f .2$ Sa. $\mathrm{I} 2^{28}$, 'lest I take the city and my name be called upon it,' i.e., 'I have conquered it.' The expression is often used, esp. in Deut. writers, of Israel, Jerusalem, the temple, as Dt. $28^{10}$, Jer. $7^{10}$, I $4^{9}, 25^{9}$, I Ki. $8^{43}$, Is. $63^{19}$. 'Present supplications,' lit. 'cause to fall s.,' as v. ${ }^{20}$, Jer. $3^{826}$ (before a human potentate), $42^{9}$ (before God); $c f$. the use of intrans. Kal with 'prayer' as subj., Jer. $37^{20}$, etc. Bar. $2^{19}$ lit-

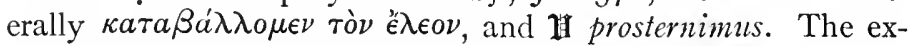
pression arises from the humble prostration of the petitioner. 'Thy great compassion' (s. at ${\left.\mathrm{v} \cdot{ }^{9}\right)}^{9}=$ Neh. $9^{19 .}{ }^{27 .}{ }^{31}, c f .2$ Sa. $24^{14}$, Ps. II $9^{56}$. 19. "YHWH, hear; YHWH, forgive; YHWH, attend and do; defer not for Thy sake, my God, because Thy name is called upon Thy city and Thy people." The Kyrie elcison of the O.T., suggested, as Dr. remarks, by Solomon's prayer, I Ki. 830b. 34. 36. 39. 'Do,' i.e., 'act,' cf. Jer. $14^{7}$, ' do for thy name's sake.' 'Defer not,' i.e., 'procrastinate not' $=$ Ps. $40^{17}$. $\mathfrak{A l}$, followed by RVV JV, puts a stop after this impv., but the balance of the rhetoric and sense rather requires construction as above, and so the punctuation of the VSS, AV. For the final clause s. at vv.17. 18 .

4. ואיאתפלִליה So edd., exc. Bär his note. The Hithp. has mng. of 'interceding for self,' if it is to be combined with the Piel, 'to intervene as judge,' and so BDB, Kön., $H w b$. GB finds two distinct rts. with primary mng. 'pray' for the Hithp.- -

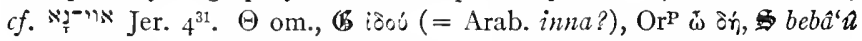
$=$ I obsecro._- ורחסד Neh. $\mathrm{I}^{5}$ in the same combination.-5.

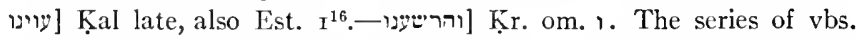
is cited from I Ki. 847, where neve. Hif. of is late, so $\mathrm{I} 2^{10}$, Job $34^{12}$, Neh. $9^{33}$, etc.; inf. v..$^{15}$ the Kal. In the revisions

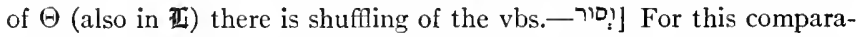
tively late use of the inf. abs., continuing finites, s. GK $\S_{113}$, z; re-

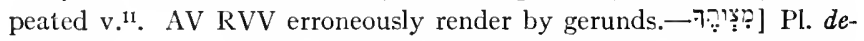
fectivus, so Ps. $119^{98}$ ef. צרקתק v. ${ }^{16}$, and s. GK \$91, n.-6. הנביאים] 


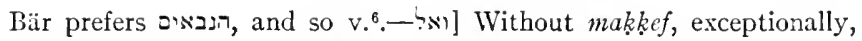
so Jos. $7^{23}$, Is. $36^{12}$. -7. I I $^{\mathrm{Wb}}+[$ nobis autem $=$. nuev $]$ et patribus nostris, a gloss intended for $\mathrm{v}^{6}{ }^{6}$, where the phrase is omitted.-Don] Occ. rdg. (Gin.), Or. rdg. כהיום = Ezr. 97 Löhr carelessly notes that $\Theta$ om.; but $\Theta$ expresses it by है

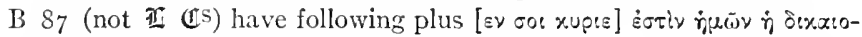
oivn, repeated negligently from beginning of the $\mathrm{v}$. This gloss was

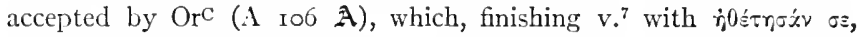

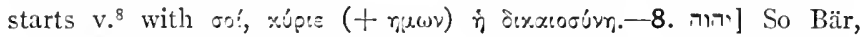
Gin.; Mich., Kit. 'ארנ; s. Bär's note. Here and vv.15. 16. 17bis. 19 (also $3^{37}$, Sus. $\left.{ }^{5}\right)\left(\mathbb{6}\right.$ has $\delta \varepsilon \sigma \pi \delta \tau_{n}$, otherwise жúpros. $\Delta \varepsilon \sigma$. represents the cases where the Tetragrammaton was carried over into the Gr. and proves the orig. Kt. The variant use of $\delta \varepsilon \sigma$. and xup. indicates that there was

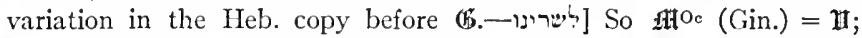

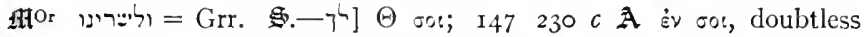
following Aq. in expression of 4 . Some Gr. uss, c.g., OrP 106 and $\mathrm{A}$,

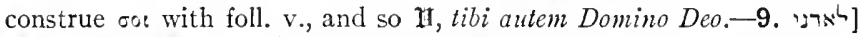

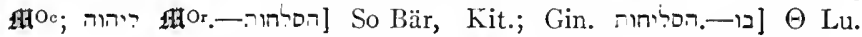

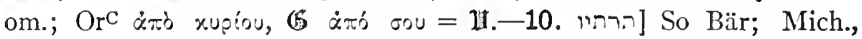

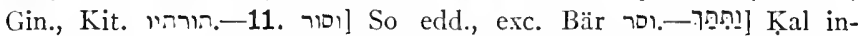
trans. The vb. occurs in similar combination in the Hadad Inscr., 1. 23 (Lidz., NE p. 440, Cooke, NSI no. 61), והרי חרא ליהכה , שרא

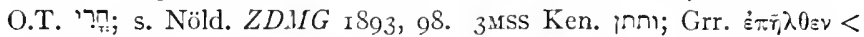

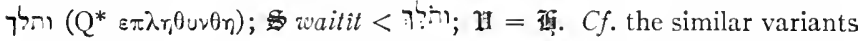

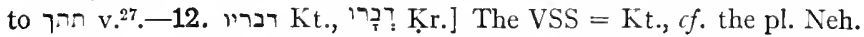

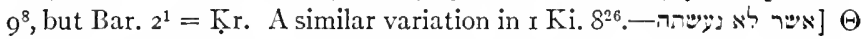

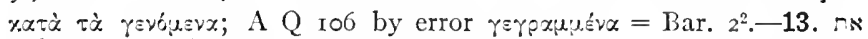

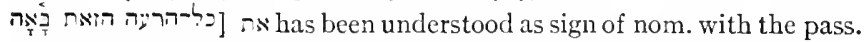
בריוב, so Kran., Bev.; or after later usage as emphasizing a nom., in

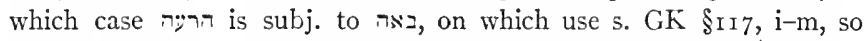
CBMich., Mein., Lamb.; Behr., Mar. find an acc. to אירו" v.12, in which case באה must be a ppl., to be pointed milra', while the absence of the article would be irregular. It appears, however, to be a case of staccato construction; the phrase 'all this evil' is introduced as a quasi-citation from Moses and then continued as nom. to the foll. vb.

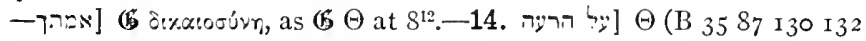
I49 229) on., this corroborated by Aug., Ep. cxi, uigilauit Dominus

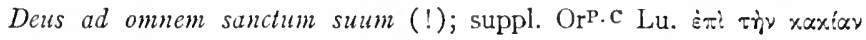

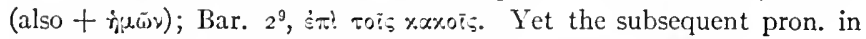
$\Theta$, $\dot{\varepsilon} \pi \dot{r} \gamma \alpha \gamma \varepsilon \nu \alpha \dot{\jmath} \tau \dot{\alpha}$, would indicate that $\dot{\varepsilon} \pi t \tau \dot{\alpha} \times \alpha \times \dot{\alpha}=\mathscr{B}$ once stood in

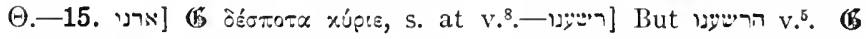

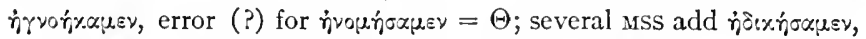

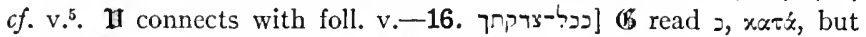
$\Theta$ z, and so uss Ken., de R., lis; similarly Bar. $2^{12}$, attaching to foll.v. 


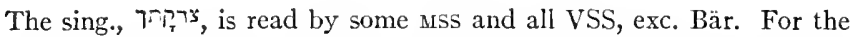
spelling of. מצותך v.

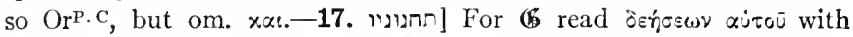

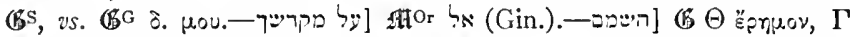

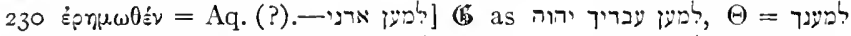

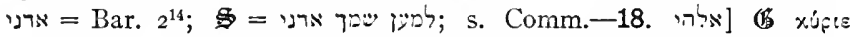

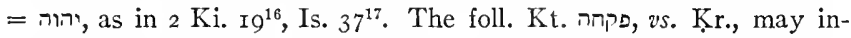
clude reminiscence of הות, as in the cited passage $2 \mathrm{Ki}$. = Is.-

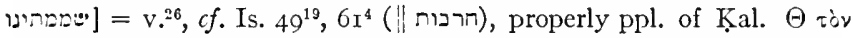

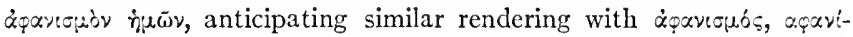

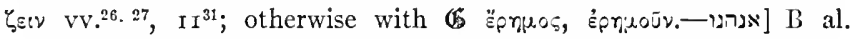
om., OrP.c Lu. suppl.; but $\mathbb{C}$ S read $\dot{\eta}_{i 28 i 5}$, which may have early dropped out after $\dot{\eta} \mu \tilde{\omega} \nu .-19$. For the VSS $\mathbb{0}$ connects

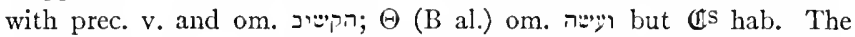
punctuation in MSS has variously affected \%upse in relation to the accompanying impvv. I has domine but twice. The division of the $\mathrm{v}$.

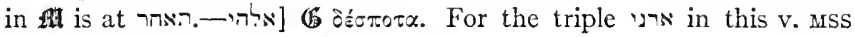
Ken. have יהוה.

20-27. The angelic revelation, 20-23. The coming of Gabriel. 20. And while I was speaking, and was praying and confessing my sin and the sin of my people Israel and presenting my supplication before YHWII my God for the holy mount of my God, -21. while I was speaking in prayer, the man Gabriel, whom I had scen in the vision at the beginning, borne in swift flight, was drawing nigh to me at the time of the Evening Oblation. 22. And he came [so (G) and said: Daniel, now an I come forth to skill thee in understanding. 23. At the beginning of thy supplications a word went forth, and I am come to declare it, for thon art most dear. And so heed the word and give heed to the vision. The repetition of $\mathrm{v}^{21}$ in $\mathrm{v}^{22}$ can be due to the need of resuming the line of discourse after the long parenthesis in $\mathrm{v}^{21}$. Acc. to $\mathrm{v}^{23}$ the angel 'came forth at the beginning' of the prayer, and as it takes time even for an angel to 'fly fast,' $v .^{21}$, to earth, the prayer was dramatically introduced to fill up the interim. 21. It was during this prayer that Gabriel, called 'the man' to identify him with the being in $815 \mathrm{ff}$, was seen rapidly 'approaching' the prophet in swift flight. The vb. has been generally translated, since $\Theta$, by 'touched me,' so It and EVV exc. JV. But the former mng. of the participial vb. is alone possible, and it is supported by $\mathbb{B}$; the vb. itself is used in both senses. The phrase 'borne in swift flight,' literally 'caused to fly swiftly,' is the best rendering of 
an obscure phrase in T $_{\text {; }}$ so the VSS, early Jewish comm. The variant tr. which introduces the idea of weariness (e.g., AV and RVVmg.) as affecting the angel is absurd; s. Note for the various attempts at interpretation. Whether or not the angel's flight involves wings may be an open question; angel wings are first referred to in En. $6 \mathrm{r}^{1}$; both Mesopotamian and Egyptian reliefs present winged genii, and $c f$. the two women with wings of a stork in Zech. 59. A flying angel now appears on a relief from Ur, 2500 B.c., s. Museum Journal (Univ. Penn.), March, I925. 'At (not the literalistic 'about' of EVV) the Evening Oblation': for this the chief time of prayer, about 3-4 p.m., in Judaism and the Muslim Orient, s. Comm. at $6^{11(10)}$. 22. The first vb. in iff, $i=$ ', means 'he made to understand,' which is suspicious for lack of an obj., and this is accordingly supplied by the trr. But (5) with a change in one letter read 'and he came,' which alone is sensible. The change from this to the other text, appearing in $\Theta 1$, prob. came in with the understanding of the angel's 'touching' Dan. in V..$^{21}$ (so $\Theta$ II), which of course rendered further 'coming' unnecessary. 'Now'-i.e., in response to the emergency, cf. Jos. $5^{14}$ (Ehr.) - 'have I come forth,' correctly AEz., 'from the array of the angels or from the heavenly palace.' 'To skill thee in understanding': the two words of the Heb., השיט, בינה, are used accumulatively, not with precision; the paraphrase in AV 'to give thee skill and understanding' depends upon $\mathbb{H}\left(=\right.$. There may be reminiscence of Jer. $23^{20}=30^{24}$ 'at the end of the days ye shall understand it.' 23. 'A word went forth'; the same phrase of a human command, Est. $7^{8}(c f$. 'the decree went forth,' sup. $2^{13}$ ), of the divine word, Is. $55^{11} ; c f$. Is. $9^{7(8)}$. The 'word' is the oracle of revelation in response to Dan.'s study of the Scriptures, v. ${ }^{2}$; till then it was a mystery even to Gabriel, $c f$. Mt. $24^{36}$, 'of that day and hour knoweth no man, no, not the angels of heaven.' 'Dear': AV 'greatly beloved,' RVVmg. 'very precious'; a similar noun of the same rt. is used in lovers' language, Song $5^{16}$. 'Heed the word and give heed to the vision': so with Mar.; the two vbs. differ as stems of the one rt., Kal and Hif.; the second vb. has the more exact mng. of 'understand' as elsewhere. JV's tr. of the first clause, 'look into the word,' is not comprehensible. Mar. interprets here to the point: the two sides of revelation are represented, the word of God and the human vision; he would paraphrase 'vision' with 'revelation.' The word 'vision' here, 
the more usual jm, refers to auditory as well as to ocular vision.

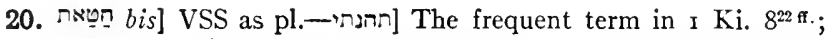
cf. allelism of the two participial sentences in vv. ${ }^{20 .}{ }^{21} \mathrm{cf}$. GK $\$ \mathrm{r}$ 6, u.-

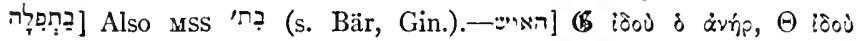

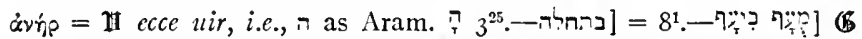

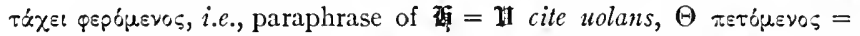
Tert. uolans, Or ${ }^{\mathrm{P}}+\dot{\varepsilon} \nu \pi \varepsilon \tau \alpha \sigma \mu(\bar{\varphi} ;$ פ פרח מפרח (representing by abs. inf. construction) plus 'and he flew and came from heaven.' The ancient and the most general interpretation, followed by Sa., Ra., Jeph., EVV, is that the two words are identical in rt. and mng., i.e., 'fly.' The vb. is then Hof. ppl. of $q ;$; $c f$. the Hif. Pr. $23^{5} \mathrm{Kr}$. (the pass. construction is common in Aram. diction), and ๆ be deduced from a supposed kindred rt. ףי. $\quad \mathbb{B}$ is witness to the early existence of both words. AEz. first explains ๆ -"he was weary from his long flight." This view was accepted by Montanus, et al., and appears in mg. of AV RVV. JDMich. understands' $מ$ as from $\eta$ ' ' and ' $\eta_{r}$ ': as = Arab. waghafa 'hasten,' i.e., 'wearied by haste'; but then better Häv., vLeng., Stu. with the derivation of both words from the Arab. rt. We may at the most admit the possi-

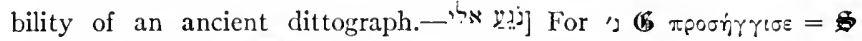

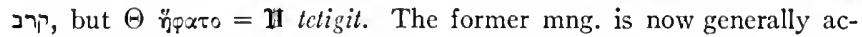
cepted, after vLeng., $c f$. Geier, despite the use of vb. as 'touch' in $10^{16}$;

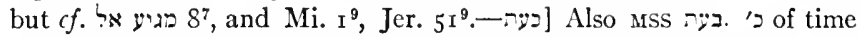

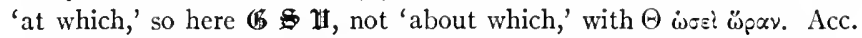
to Kön., IIwb. s.v., the muance is 'as soon as,' e.g., I Sa. $9^{13}$. Luke, in translating his Aram. original at Acts $9^{3}$, has rendered incorrectly as $\Theta$

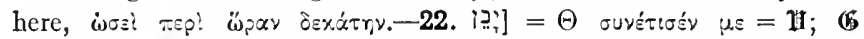
$\pi p o \sigma r_{i} \lambda \theta \varepsilon=$, i.e., $N{ }^{\prime}$; or ' ' $;$; the emendation is accepted, after Berth., by recent comm. exc. Mein., Kamp.-23. תורוa] For the pl. as abstract and unlimited and so superlative, $c f$. Song $5^{16}$ and other exx. S. GK $\S_{14}$ I, c. At I ${ }^{11 .}{ }^{19}$ appears '

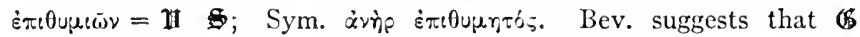

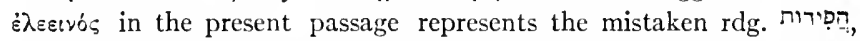

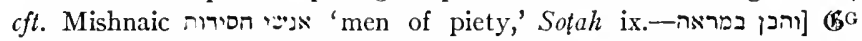

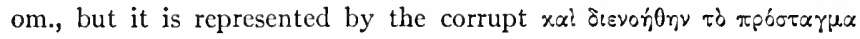
of $\vec{B} \mathrm{~s}$.

24-27. The seventy hebdomads (year-weeks). 24. Revelation of the time that must elapse before the consummation of the several elements involved in the restoration. 
24. Seventy weeks are decreed : against thy people and thy holy city,

For finishing transgression

and completing sin

and absolving iniquity :

And bringing in everlasting rightness

and sealing vision and prophet

and anointing the Most Holy.

The Kr. is followed in two cases, i.e., 'completing' (ニ-rí)

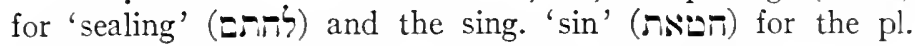

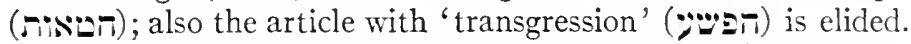
The display of the gerundial clauses above (so Häv.) represents the progress of thought: first the reiterated theme of the filling up of the measure of $\sin , \epsilon f . \delta^{23}$ 'the completing of sins,' and Comm. there; and then the consummation of the divine purpose; Israel is to be everlastingly 'right' with the Lord, past prophecy, particularly that of Jeremiah $\left(\mathrm{v.}^{2}\right)$, is to be ratified, and the holy place is to be reconsecrated with the entailed resumption of the whole cult. Cha. attempts, without resulting benefit, a rearrangement of the gerundial clauses, ordering them in this sequence: $1,4,2,3,6,5$.

For the general discussion of these vv. s. Note at end of the chap. Here, with most recent scholars, it is held that with the Seventy Weeks a definite, not intentionally indefinite, datum of time is meant, for how else would the divine 'word' satisfy Dan.'s inquiry, v. ${ }^{2}$ ? The word usually translated 'week' is primarily 'hebdomad,' a seven of things, esp. of units of time. Inf. IO ${ }^{2}$ we have 'a seven of days,' i.e., a week, while on the other hand the unit may not be expressed where it is evident, e.g., Gen. $29^{27}$, 'fulfil this seven,' i.e., the honeymoon week. The term is not used absolutely of years elsewhere in the Bible, although the seven-year periods culminating in a 'sabbath.' Lev. $25.26^{33}$ ff., would easily suggest such a use; $k f$. the similar usage of hebdomas in Varro et al. (Pole, Bert.). It occurs with this meaning throughout Jubilees, in the Mishna, Sanh., 5, I, etc. Hence the term is 490 years. The mng. of the following rb., 'are decreed' (JV), i.e., judicially (AV 'determined'), is hapax leg. in the O.T., but is found in the Talm., and of its mng. there is no doubt. We may note $\Theta$ 's tr. $\sigma v \nu \epsilon \tau \mu \eta \theta^{\prime} \eta \sigma a \nu$, which went over into as brewiatae sunt, and was rendered 
standard by II abbreuiatae, 'are shortened.' 'Against thy people and against thy holy city': 'Against' in the sense of legal debit, $c f$. Arab. 'ala $(y)$. On the pronouns Jer., after Eus., Dem. ev., viii, 2 , remarks that they are parallel to Dt. $32^{7}$, 'Go down. for thy people has sinned,' i.e., indicating the divine abhorrence; rather, it is a tribute to Dan.'s affection, with Grot., 'tibi adeo amatum,' similarly Calv. 'For finishing transgression': The parallelism requires this mng. of the vb. כלא, but the metaplastic spelling of the rt. כלה induced the early Prot. comm. to follow the form literally, i.e., 'to restrain,' and so mg. of AV RVV, following GV 'wird verwehrt,' after Calv., Grot. For the phrase $c f .8^{23}$, as corrected. 'the completing of the sins.' The three nouns expressing ' $\sin$ ' in this and the following clauses are used quite synonymously. 'Completing sin': As noted above, the tr. follows the Kr., which is supported by Aq. $\mathbb{1}$, and is given in the text of EVV. The parallelism demands the Kr., while Kt. may have been induced by the occurrence of "to seal' in the second following clause. The vb. of the Kr. is that in the passage cited above, $8^{23}$. The Kt. 'to seal' is supported by $\Theta$ and followed by GV, appearing in mg. of AV RVV. Some early Prot. comm., also vLeng., followed the Kt., attempting various interpretations, 'to shut up' and so remove, or following an Arab. use of the rt., 'to complete'; s. Note. But, as Bev. remarks, the identical phrase 'sealed up is my sin,' Job I $4^{17}, c f$. Dt. $32^{34}$, signifies 'to reserve it for punishment,' and indeed the use of the same vb. in quite different mngs. in the one v., $v$. inf., would be intolerable. 'And absolving iniquity': As Bev.

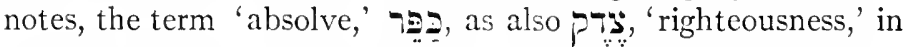
the next clause, are legal terms. See Dr.'s note on the use of kipper. "When, as here, the reference is to $\sin$, or iniquity, the mng. differs, acc. as the subj. is the priest or God; in the former case the mng. is to cover cr screen the sinner by means (usually) of a propitiatory sacrifice, and it is then generally rendered make atoncmcnt or reconciliation for . . .; in the latter case it means to trat as covcrcd, to pardon or cancel," which last word Dr. prefers here. And so in this absolute sense $\mathbb{6} \mathfrak{I I}$ JV ("forGive'); in the other sense 'make propitiation for,' $\Theta \mathrm{GV} A V$ RVV. The tr. 'absolve' adopted here may represent both the religious and the legal implication of the vb. 'Bringing in everlasting rightness': With this begin the three positive elements 
in the restoration of Israel. This 'righteousness, P7: or 'rightness,' to express the legal implication (s. at v. ${ }^{7}$ ), is, as

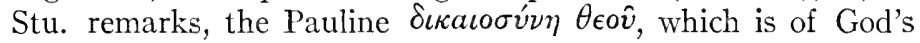
giving. Cf. 'everlasting salvation,' Is. $45^{17}$, 'righteousness' and 'salvation' being synonyms in the Second Isaiah. This rightness on its religious side is holiness, $c f$. Eze. in general, Is. $4^{3 \mathrm{f}}$, etc. 'Sealing vision and prophet': In the sense of 'putting seal to, i.e., ratifying, exactly as $\sigma \phi p a \gamma i \zeta \epsilon \iota \nu$ is used in Jn. $3^{33}, 6^{27}$, and so frequently in Syr. Cf. I Ki. $2 \mathrm{I}^{8}$, Jer. $32^{10}$. So Clem. Alex., Strom., i, 2I, AEz. and most comm. Another interpretation of the vb. is 'to conclude,' so Jeph., PsSa., on the ground that "no prophet has arisen since the second temple." The VSS, also Aq., exc. $\Theta$, appear to have read 2 a ל for the variation between the two vbs. just above, translating 'to finish,' or else they gave this interpretation to לתו- 'Vision and prophet' is taken by Grot., Bert. as hendiadys, = 'prophetic vision,' but the prophet as well as the vision through him calls for justification, $n . b$. the sealing of the Messiah in the Johannine passages cited, $c f$. Is. $8^{18}$, Jer. passim. GV and EVV, exc. JV, have 'prophecy' for 'prophet,' following $\mathbf{H}$, an exegetical makeshift, defined by some comm. as enallage of the concrete for the absolute (s. Pole); the same variation appears sporadically in other VSS and some Gr. Mss. 'Anointing the Most Holy': Literally, 'holy of holies,' i.e., 'the holiest.' The term is used always of sacrosanct things or places: of the tent of meeting, the temple, its debir or adyton, of the territory belonging to the temple, the altars, holy vessels, incense, sacrificial flesh, etc.; s. BDB s.v., the convenient summary in GB and Dr.'s excellent note. Only once is it possibly used of a person, I Ch. $23^{13}$, 'And Aaron was separated to sanctify him as most holy,' which latter clause, however, may mean 'that he should consecrate the most holy.' This well-nigh universal use of 'the holiest' compels us to interpret the term as of either the temple or especially the altar of burnt offerings; s. the narrative of the rededication by Judas, I Mac. 4. For the anointing as the act of consecration ( $c f$. G. B. Gray, 'Anointing,' $E B$ ) $c f$. such passages as $\mathrm{Ex} .29^{36}, 30^{26 \mathrm{ff}}$, $40^{9 \mathrm{ff}}$, where the prescription of anointing always precedes an allusion to a holy of holies. It was natural for the Church to understand the indeterminate

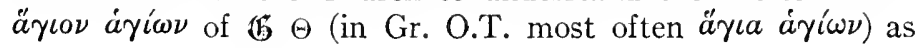




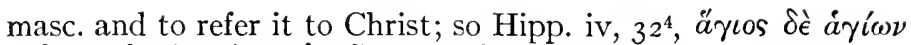

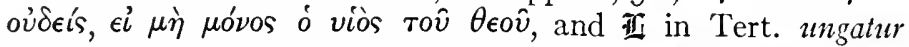
sanctus sanctorum = I1; and so definitely in

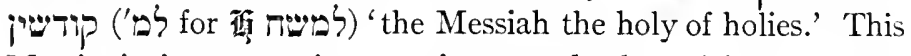
Messianic interpretation was in general adopted by the Prot. comm., so Luther (GV 'der Allerheiligste'), Calv., etc. 'The same interpretation was also at home in the Jewish exe esis.

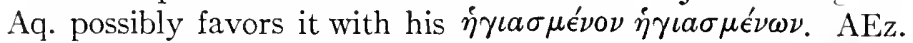
identifies 'holy of holies' with Messiah. Schöttgen, Horae hebr., 2, 264, cites Nachmanides: "The holy of holies is nought else than Messiah, the sanctified one, of the sons of David." With this cf. Ber. R., xiv, I8, "What is the Eternal Righteousness? It is King Messiah" (cited by dEnv., 2, 909). Of the comm. who still refer it directly to Christ there may be named Pusey, p. I82 ff., dEnv., pp. 9I 5 ff., Wright, Dan. and his Prophecies, I99 ff. (these with stress upon the N.T. Messianic title, "the holy one'), Christ being, acc. to Wright, the sacrificial 'holy of holies.' This mediating position is found in some early Prot. comm., referring it to the earthly temple which was to be consummated in Jesus, or to the heavenly temple he was to consecrate, Heb. 8, etc., or to the Church; s. Pole. Stu., Keil, and Zöck. ring various changes on this exegesis. Note that the simple term 'wp, 'holiness,' at $v_{.}{ }^{26}$, refers without question to the sanctuary.

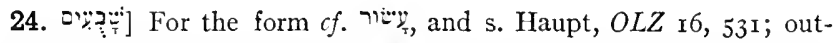
side of Dan. the pl. is always rive, the differentiation in pl. being intentional.—7. Sing. vb. with a pl. subj., which itself represents a single idea, $c f$. GK, $\$ 145, \mathrm{~h}$; or possibly the subj. is to be treated as

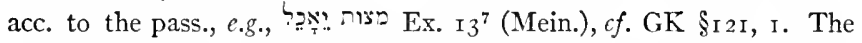
rt., $\uparrow$ in O.T., = 'cut off' and so 'determine'; frequent in both mngs. in Talm., and hence play on n.pr. חרך Est. $4^{5}$ in Meg. ${ }_{15}$ a, "all the

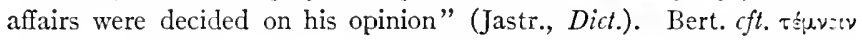

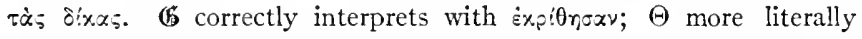

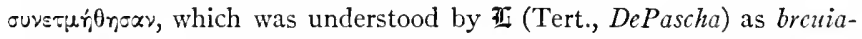
tae sunt and so $\mathbb{H}$ abbreuiatae sunt. It does not appear, against Bert., dEnv., that Jer. interpreted this vb. from the short reckoning as of lunar years, a theory which he presents from a long citation from Jul. Africanus. נתחניחון 'will rest,' which Aph. Syr.

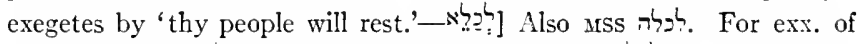

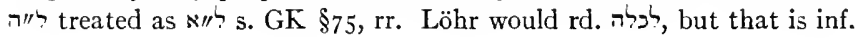




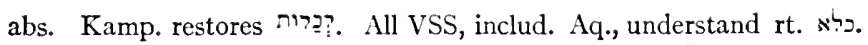

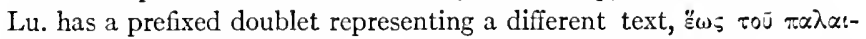

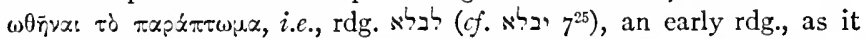
appears in Tert., Adv. Jud. viii, quoadusque inueteratur delictum, of.

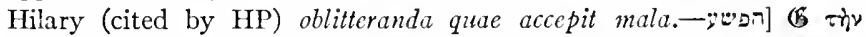
$\dot{\alpha}_{\mu \alpha \rho \tau i} \alpha \nu, \Theta$ om. art. But otherwise the nouns are anarthrous, and the

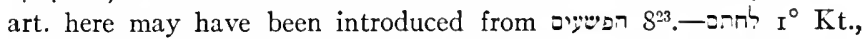

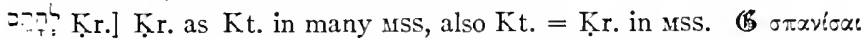
'make rare,' which may speak for the Krr. (unless we suppose error for

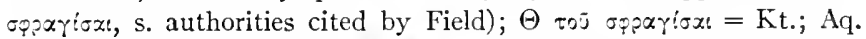
$\tau 0^{\top} \tau \varepsilon \lambda \varepsilon s \omega \sigma \alpha t=$ K.r., and so H. As Bert. notes Arab. hatama has

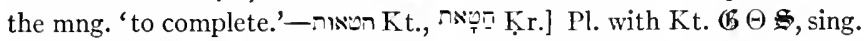
with Kr. Aq. $\mathbb{Z}$, also $42 \mathbb{U}$ s. The parallel nouns here are sing.-

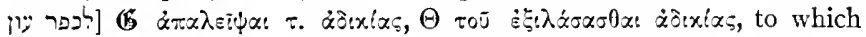

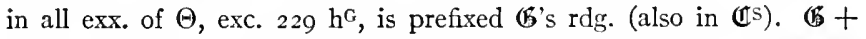

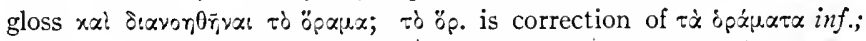

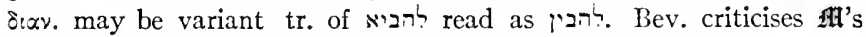
punctuation, but the clause is to be connected with what precedes.-

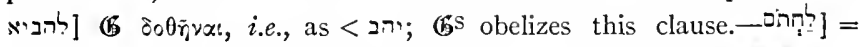

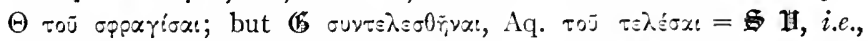

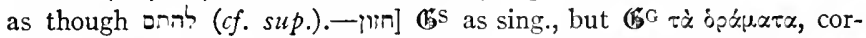

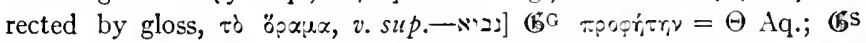

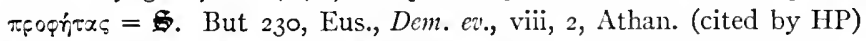

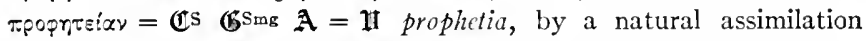
to the parallel 'vision.' The asterisk evidence excludes the word from

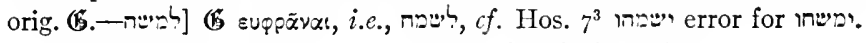
PsSa. understands Aram. rt. = 'measure,' and cft. Zech. $2^{6}$.

25-27. The detailed periods of the Seventy Weeks. The presentation of this most vexed passage aims at interpreting the text of as it stands. For history of the exegesis and for critical analysis of the complicated texts of the Gr. VSS ref. is made to Notes at end of the chap. The writer agrees heartily with Kamp. in his criticism of the critics who light-heartedly 'emend' the text. He approves that scholar's dictum at v. ${ }^{24}$ : "The more the difficulties in understanding an important passage of the Book of Daniel accumulate, the less we are permitted to make an attempt at overcoming them by mere alteration of the text. In such cases the text has been transmitted with especial care." This last remark is fully supported by critical study of the VSS.

Several recent comm. regard these vv. as metrical; s. esp. Marti for his analysis, which depends however upon radical re- 
constructions of the text. But the attempt to pursue and reconstruct a metrical form merely complicates the study of the passage. The passage is essentially prosaic and the best that can be done is to cast it into lines and so obtain the appearance of zers libre.

25a. And thou art to know and understand. This bidding prefaces the following revelation. The two vbs. are practically synonymous; for the accumulation $c f . \mathrm{v}^{22}, \mathrm{I}^{4}$. There follows an analysis of the 70 Weeks into three periods: the first a period of seven weeks. From the issue of the word to build again Jerusalem unto an Anointed-Prince seven wecks. For 'the issue of the word' $c f$. 'word went forth,' v. ${ }^{23}$ (also a similar phrase, $2^{13}$ ), but the 'word' here refers to 'the word of YHwh to Jeremiah,' $\mathrm{v.}^{2}$. We have here a notable early instance of a double interpretation of a prophecy: the one which regards Jer.'s prophecy of restoration as fulfilled in the Return in the Persian period and which calculates this period at $7 \times 7$ years (the 'first' sense of the prophecy); the other which interprets the explicit Jeremianic interpretation of 70 years symbolically (the 'second, or mystical, sense') as 70 year-weeks. The felicity promised by the prophet at the consummation of the 70 years had notoriously failed of consummation; it was necessary to find a secondary, ultimate meaning - a process of interpretative theory which has been abundantly illustrated ever since in the interpretation of this passage. The Heb. vb. $=\mathbf{m}$ is here taken as an auxiliary and translated 'again'; or with EVV, etc., it may be rendered 'to restore [and to build].' 'Unto an Anointed-Prince,' עט

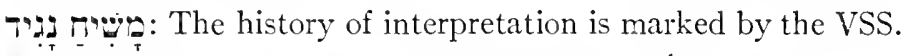

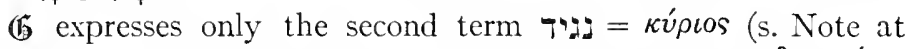

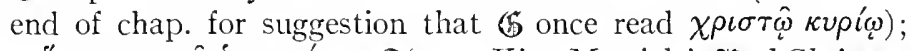

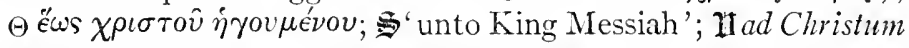
ducem; GV 'auf den Christum, den Fïrsten'; AV 'unto the Messiah, the Prince'; RVV 'unto the anointed one, the prince'; JV 'unto one anointed, a prince.' The nouns, as JV indicates, are anarthrous. 'Messiah' is epithet of king, of priest ( $c f .2$ Mac. $\mathrm{I}^{10}$ ), of prophet; and in a spiritual sense of $\Gamma$ atriarch (PS. $105^{15}$ ), and even of Cyrus, who is 'My Anointed,' Is. $45^{1}$; s. Lexx. and BDD, Kön., Mess. Weissagungen, 5 ff. Unless we interpret such a case as 'my Anointed' in Ps. 2 as directly Messianic, it is 
never an O.T. name of the Messiah. The second term 'prince,' qualifying the first, is used of various officers of rank: as a chief among officials, esp. in the temple personnel, e.g., $\mathrm{II}^{22}$ of the high priest, q.v.; of nobles or princes, e.g., Job $29^{10}, 3 \mathrm{I}^{37}$; then of royalty, appearing as early title for the king in Israel, e.g., I Sa. $9^{16}$, and also of foreign kings. Hence both terms are ambiguous, and their combination does not assist identification, for which three candidates have been proposed: Cyrus, the 'Anointed' of Is. $45^{1}$; Zerubbabel, the acclaimed Messiah of the Restoration; and his contemporary the high priest Joshua b. Josedek. If mašin in $\mathrm{v} .^{26}$ is a later high priest (Onias III), it is reasonable to attribute the title here to one of the priestly line, hence to Joshua, to the exclusion of the secular princes. The interest of the writer lies, not in the legitimate royal line, still less in an accidental figure like Cyrus, but in the maintenance of the cult. The rites were suspended in 586 , at the destruction of the temple, and were resumed 538 upon the Return, i.e., circa 49 years. For another interpretation which disregards the Mass. punctuation and reads 'seren and sixty-two weeks,' perpetuated in $\boldsymbol{Y}$ and some modern VSS, s. Note.

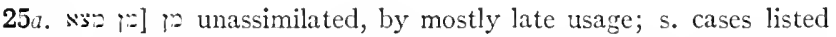

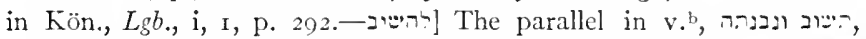
supports the above interpretation of the vb. as auxiliary, and so $\boldsymbol{\text { II }}$. For the mng. 'restore,' adopted, e.g., by vGall, Mar., Lamb., cf. Jer.

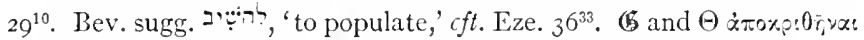
support the pointing of fil.- גיר] S. Lexx. for etymology and use. Graetz, pp. $396 f f$., identifies as the Gr. equivalent of this term $\pi$ pos$\tau \dot{x} \tau=$, used of the high priest in Ecclus. $45^{24}, \pi$. $\dot{\alpha} \dot{y}^{2} \omega \nu$ (not in the Heb.), and $\pi$ poorasi $\alpha$, used of the high-priestly dignity, Jos., $A J$ xii, 4 , 2. More apt is the identification with the third term in the title of Simon Macc. as 'high priest and general and ripoúpevo; 'Touox'wv,' I Mac. $13^{42} ; c f$. the title of the high priest Ananus, slain by the Idumæans in the last days of Jerusalem, $\dot{\alpha}_{p} \%: s p=\dot{j} ; \% . \dot{r} \gamma \varepsilon \mu \dot{\omega} \nu, B . J$. iv, 5,2 (with

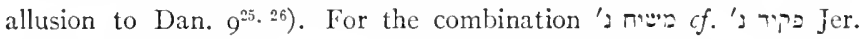
$20^{1}$; the second term refers to the actual functioning of the divinely qualified 'anointed.'-The above interpretation follows the Mass. punctuation, which places athnah with 'seven.' But the VSS, 6 (at v.27a) $\Theta$ II, construe ' 7 ' and ' 62 ' as one numeral, followed by GV AV SV', some comm., e.g., Häv., Boutllower, p. r9o; and then the VSS emphasize this combination by inserting 'and' before the next sentence. But why then the helpless $7+62$ ? It is interesting that the early Christian 
exegetes retained the true syntax of the passage despite the Gr. VSS. Note that $(5$ made a sad mess by confusing the identical appearing

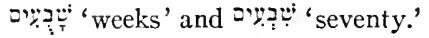

25b. The second period of 62 weeks. And for sixty-two weeks it shall be built again, street and moat, but in distress of the times. A succinctly phrased sentence, i.e., Jerusalem shall be rebuilt and remain so for 62 weeks but in distressful conditions. For this period of year-weeks $=434$ years as covering the age between the Return and the epoch of the Maccabees, s. Note at end of the chap. By 'street' (Ziri), properly 'broadway, plaza,' are meant the broad spaces, generally just inside the city gates, the centre of city life, and by synecdoche standing for the city. The word tr. 'moat' (so Ra., followed by RVV JV), vs. 'wall' of GV AV and other attempts by the VSS, has now been identified with that sense in the mixed Heb.-Aram. Zakar Inscr. of the 8th cent. B.c.; the word is also known from the Talm. As 'street' stands for the interior of the city, so moat for the line of circumvallation, and the two items present a graphic picture of the complete restoration. The great cutting in the natural rock along the northern wall of Jerusalem is a marked feature of the city's defences. For the final clause, literally, 'and in the distress of the times' (EVV 'even,' JV 'but'), we have the illustration in the story of Ezr.-Neh.

25b. רתקררו For the adverbial construction Cf. I Ki. I8

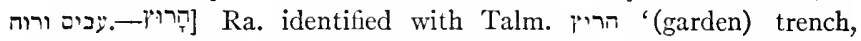
water channel,' and tr. 'moat,' and was followed by some early Prot. comm., and so AVmg. The word is now known also from the ZKR Inscr., i, ll. 9 f.: 'they made a wall higher than Hazrak and dug a trench ( corroborated by Akk. harîșu, 'city moat.' The VSS did not know the

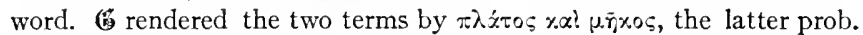
a guess to obtain the two dimensions; some have suggested the rdg. of

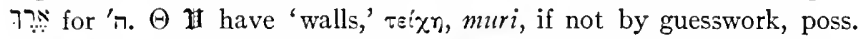
with 1 ' 'partition,' Eze. $13^{10}$, in mind; Graetz proposed this emenda-

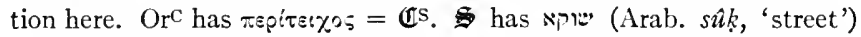
= Heb. חוּ, which constantly pairs with (Jer. $5^{1}$, Pr. $7^{12}$, etc.), and so Bev. would read here, followed by Behr., Mar., Löhr, Cha., Lamb. The obscure oracle cited by Jos., B.J. vi, 5,4 , that the city should

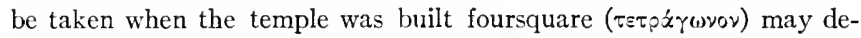
pend upon the 'breadth and length' of $\mathbf{6} ; \mathrm{cf}$. the 'foursquare city in 
length and breadth' of Rev. $21^{16}$. Iיבוק העתים For the explicative , $=$ 'und zwar,' s. BDB, p. 252 b. It is a shallow objection against valid-

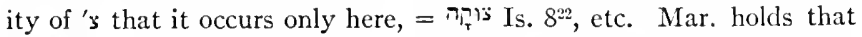
if is is to be kept the two nouns should be reversed, cft.

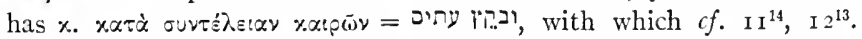
The comm. who adopt the emendation from (G) (Graetz, Bev., vGall, Mar., Cha.) must delete 'and' at beginning of the next v., although it is vouched for by all VSS. supports $\mathfrak{6}$, but $\mathfrak{H}$ in angustia tempormm $=$ is. For $n$ i as of predestined time $c f$. 'the time of the nations,' Eze.

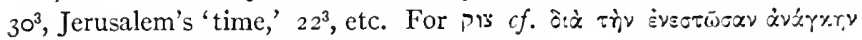

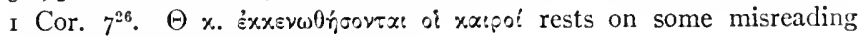

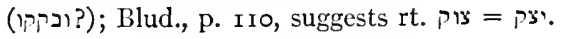

26. 27. The third and last period of one week. 26a. And after the sixty-two weeks shall be cut off an Anointed and [literally] there is naught for him. The vb. 'cut off' (כרת) is used of destruction of persons, e.g., Gen. $9^{11}$, and technically of the death penalty, Lev. $7^{20}$, etc. The subject anarthrous and used titularly. The interpretation here followed interprets it of the martyr high priest Onias III, who was foully assassinated by his Jewish rival at Antioch, 2 Mac. $4^{23-28}$. The next clause, literally translated above, is: may mean 'and have naught,' or 'without anything, any one.' It is an unexplained crux, and many attempts have been made in forcing the Heb. or pressing its natural sense without any sure results. The Heb. is made to produce 'and he is no more,' or 'and not for himself,' i.e., vicariously; or what he has not is found with or without restoring a word to the text in sin, justice, helpers, successors, and what-not. The writer has been inclined to adopt

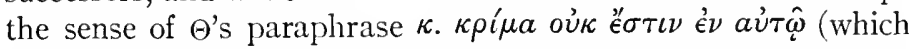
need not represent a different text), meaning 'there is nothing against him,' i.e., judicially, with $\zeta$ to be sure against the expected $2 y$. The most illuminating note on the phrase has been made by Nestle, who finds in it a Biblical allusion. In $Z A T W$

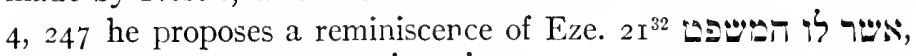

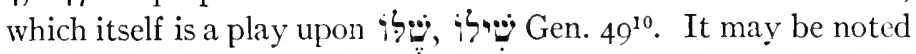

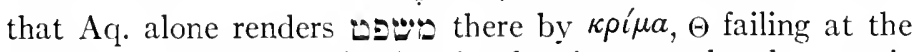
passage. It still hangs in the air what is meant by the cryptic

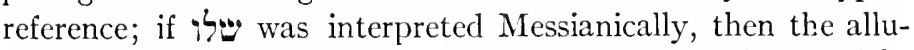
sion implies that the present maši li was found not to be Messiah; 
with which $c f$. the interpretation assigned by Jer. to the Jews that the phrase means that Jesus was not the Messiah. The prevailing interpretation of this passage as of the death of Jesus Christ is actually late and secondary in Christian exegesis, first making its appearance in the Christian translations, the Syriac and the Vulgate, where מיטי is translated 'King Messiah,' 'Christus.'

23a. . 'shall be exterminated'; $=\mathbb{H}$ occidetur, more mildly under Christian interpretation.- continued by the Gr. comm. If we were to accept as the original rdg., then the ritual character of the function is positively meant, not the Messianic. The earliest allusion to the passage finds in $\chi_{p} i \sigma \mu \alpha$ a personal content; Jos., B.J. iv, 5, 2, identifies this event with the death of the last high priest Ananus, when the Jews tò ápxıspé $\alpha$ x.

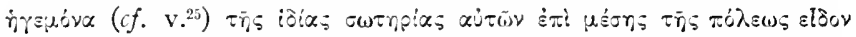
$\dot{\alpha} \pi \varepsilon s p r \gamma$ peśvov. Similarly Eus., Dem. $e v$., viii, 2, identifies it with Herod's

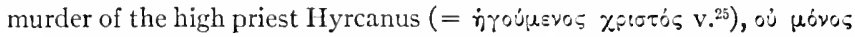

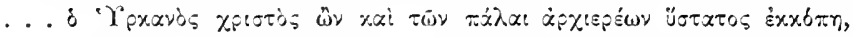

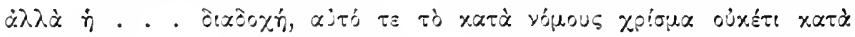

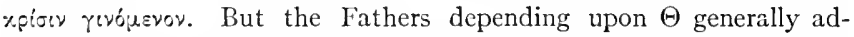
hered to $\chi_{p}$ ic $\mu \alpha$ and referred it to the cessation of the Jewish rites after the advent of Christ. So Tert., Adv. $J u d$., viii: "debellatis Iudaeis postea cessauerunt illic libamina et sacrificia, quae exinde illic celebrari non potuerunt; nam et unctio illic exterminata est post passionem Christi"; acc. to Theodoret, ad loc., the 'chrism' is the 'grace which

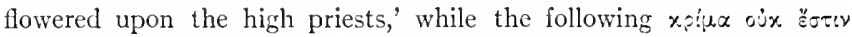
$\dot{\varepsilon} \chi \alpha j \tau \bar{\varphi}$ means that the so-called high priests were functioning illegally and assumed their office against the law. Acc. to Polych. the 'chrism' means 'the anointed high priest,' who would cease with the destruction of Jerusalen. Some comm. pay no attention to the passage, e.g., Hipp.,

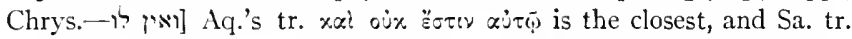

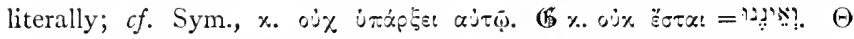

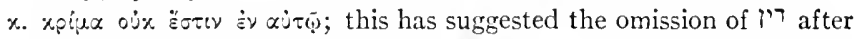
the similar $\aleph$, so Dathe, Thenius. (G's interpretation is followed by many, Ra. (כפו אינט), Hitz., GV JV 'and be no more'; but the two are not equivalent, and if that interpretation be taken, איננו should be read, as by Ehr. A favorite tr. of Prot. comm., e.g., AV, Geier, Häv., is 'and not for himself,' i.e., vicariously; but $r$ is hardly $=\aleph^{4}$. The face value of the words, 'and shall have nothing,' given by AVmg RVV, is interpreted of possessions (Calv., Hofmann, Heng.), or adherents (Auberlen, Wright, p. 224), or 'he has none' as helper or witness 
(Mein.) or as son or successor (Jeph., Behr.). Some early Prot. comm. understood $W_{\text {T }}$ as implied, and similarly Fell's hypothesis (Theol. Quartalschrift, $1892,355 \mathrm{ff}$.) of restoring sin,' so Mar., Löhr, Lamb.; following Jachiades Graetz supplies 'helper,' cft. $\mathbf{I I}^{45}$. U has a remarkable paraphrase, ct non erit eills populus qui eum negaturus est (accepted by dEnv., p. 976, as representing the original text!), followed substantially by Montanus, Grot.: non erit obedicns populus ille quem redempturus uenerat. Some similar interpretation may be represented in welâ 'ît lâh, 'and she (Jerus.) have him not,' which Aph. Syr. interprets, 'and she has no other Christ.' The Grr. comm. following the non-Mess. interpretation of the passage (s. preceding Note) understood the phrase of the illegitimacy of the high priesthood (Theodt.) or of the cessation of the Jewish autonomy (Polych.).

26b. And the city and the sanctuary shall destroy [= be destroyed by] the folk of a prince that is to come, but his end in an overwhelming, and even to the end war determined with desolations. The word translated 'destroy,' הישית', is generally taken in the physical sense, so $8^{24},{ }^{1}{ }^{17}$, but there was little destruction effected by the Greeks in the Holy City; it may then be understood in its moral sense, 'corrupt,' and so Eus., Dcm. $\varepsilon v$., viii, 2. By 'the folk' is to be understood either Ant.'s army (so ע Ju. $5^{2}, 2$ Sa. I $^{13}$, etc.) or the Hellenistic group; $c f$. I Mac. $\mathrm{I}^{34}$, 'and he [Ant.] put there [in Jerusalem] a sinful folk ('é $\theta \nu \circ)$.' 'A prince to come,' following has been identified by Jewish, Patristic (s. Knab., p. 258), Cath. and Prot. comm. with one of the Roman conquerors, by the Jews with Vespasian or Hadrian, by others with Pompey, Herod, Agrippa. A few Fathers found in this person the returning Christ, e.g., Tert., Isidore, Basil (s. Fraidl, Exegese d. Siebsig Wochen, pp. 38, 91, 93); some comm. find the Antichrist, e.g., Klief. Acc. to the modern interpretation he must be Ant. Epiph., so Bert, etc. He is distinguished from the local 'Anointed-Prince' of $\mathrm{v}^{25}$ by the epithet 'to come,' either as some new one or in the sense of invader, as the vb. often implies, e.g., $\mathbf{I}^{1}$, $\mathbf{I I}^{13}$, etc. 'His end in an overwhelming' refers then to the final catastrophe of Ant.'s life, the rt. $5 \cdot \dot{*}$, of an overwhelming flood, being frequently used of the divine wrath, e.g., Nah. $\mathrm{I}^{8}, c f$. Is. Io $^{22}$. But against this line of interpretation it is objected by Graetz, Bev., vGall, Mar., Cha., Lamb., that נגיד, 'prince,' must refer to the same category as that of 
'prince' in $\mathrm{V} .^{25}$, which category reappears in $\mathrm{II}^{22}$ as 'prince of the covenant.' This interpretation adopts the rdg., עם 'with,' with some VSS, and as a subj. is then lacking, it changes the act. ישי into the pass. with the resultant, 'and the city and the sanctuary shall be destroyed along with the Prince,' i.e., the Anointed one of $\mathrm{v} .^{25}$. Then, after $\mathbb{G}$, the following words

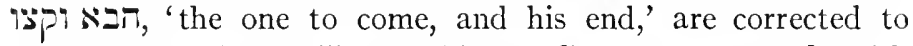
read קצוּ, 'and will come his end [in overwhelming],' with recurrence to the fate of the Anointed already depicted. The initial objection made by these interpreters to the text of 位 that 'prince' cannot be applied to other than the category of the Anointed-Prince is not conclusive; nor is it felt by the Jewish comm.; the distinction is made by the epithet, "the one to come.' Further, it is somewhat de trop to pick up again the thread of the fate of the Anointed, who has disappeared from the stage in $\mathrm{v}^{\mathrm{a}}$; if he were continued as subj. in $\mathrm{v}^{\mathrm{b}}{ }^{\mathrm{b}}$ we should expect 'with him' or 'with the Prince,' a point that Bev., an advocate of the change, admits. Also the expression 'overwhelming' appears little appropriate to the fate of the Anointed, whereas it corresponds to the 'pouring out of a determination' against the sacrile e in $v{ }^{27}$. It is true that $\mathrm{II}^{22}$, which includes both 'overwhelming' and 'prince of the covenant,' supports the emendation theory here; but that passage may be but a literary reminiscence of this. The chief objection to is that it anticipates the ruin of Ant. which is described in $\mathrm{v}^{27}$. It is possible that the ref. of 'his, its end' is to 'the city and the sanctuary' (with attraction of the masc. pron. to the latter antecedent); and so Geier has proposed.

The last clause of the v., while sufficiently clear in its general sense, is troubled by ambiguity of syntax. The VSS, exc. Aq., Sym., and $\mathrm{H}$ construe: 'and to the end of war determined are desolations,' or the like, so AV JV. But Aq., Sym. treat 'war'

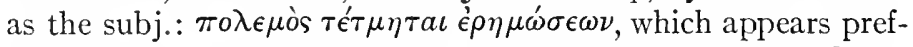
erable, so RVV and as above. The war is 'determined for [Heb. has construct state] desolations'; this is better than devising a new sentence with RVV, 'desolations are determined.' 'Determine' means 'predestinate,' as also in the Midrashim, and $c f$. $\mathrm{II}^{36}$. Mar. may be right in regarding these last two words as a gloss from $\mathrm{v},{ }^{27}$ and may claim support from their absence in $\mathbf{6}$. 


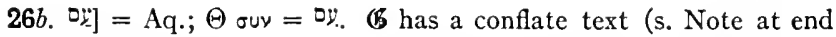
of the chap.) and bears witness to both interpretations, and II is similarly conflate: ciuitatem et sanctuarium dissipabit populus $\left(={ }_{0}\right)$ cum

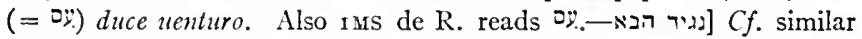
defective use of the art. Gen. ${ }^{31}$, Ps. $104^{18}$, and, as Bev. notes, in CIS

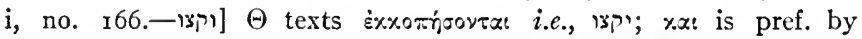
OrP.c, also Clem. Alex., Strom.; i, 21, Eus., l.c., $\mathbb{I}^{\text {Wng }}$ Tert., prob.

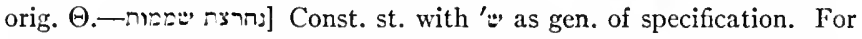
rt. rt. רז, e.g., $4^{14}$. For 'w' s. at v. ${ }^{27}$. The plus $\tau \alpha \xi_{\varepsilon \iota}\left[\alpha \alpha_{\alpha \nu t \sigma \mu \rho t]}\right.$ appearing in $\Theta$ MSS, exc. Or ${ }^{\mathrm{P}}$ Lu. (but Lu. has it bis in v. ${ }^{27}$ ), also absent in If $\mathbb{C r}$

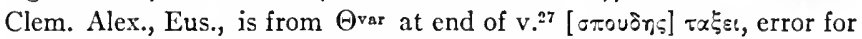

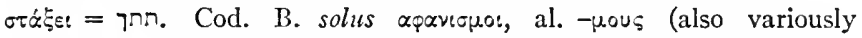
$-\mu \circ u,-\mu \circ \nu,-\mu \omega \nu)$, which latter is supported by the oblique case appearing in 10

27. The final week and the end. And he shall make strong a covenant for the many for one week. And for half of the week he shall cause to cease sacrifice and oblation, and upon the wing [i.e., of the temple] shall be an Abomination-Appalling, even until end and determination shall pour upon the Appaller. $27 a$. If the subject is that of v. ${ }^{26 \mathrm{~b}}$, i.e., Ant., the first sentence is intelligible. There is no intrinsic objection to the tr. of the vb. 'make strong' = 'confirm' 'maintain,' vouched for by almost all the VSS. As with the dispute over 'prince,' v. ${ }^{26}$, the crux lies in the word 'covenant' ברית. It has been urged by many, from Graetz on, that ' 2 is elsewhere used in Dan. of the Covenant Religion ( $\mathrm{II}^{22 .}$ 28. 30. 32), and must be so interpreted here. But the secular sense of ' 2 continued until late; $c f$. Job $5^{23}$, 'a covenant with stones'; Mal. $2^{14}$, Pr. $2^{17}$ of the marriage contract; BSir. $4 \mathrm{I}^{19}$ of a sworn contract. 'The many' are then the majority of the Jews $=$ oi $\pi 0 \lambda \lambda \circ i^{\prime}$; for these renegades $c f$. II ${ }^{30 .}{ }^{32}, \mathrm{I}^{10}$, I Mac. $\mathrm{I}^{10 \mathrm{ff}}$, etc. The historical background of the sentence so interpreted is clear: the clever diplomacy whereby Ant. made his bargain with the worldly majority, at least of the aristocracy, in Jerusalem. It may be noted that the Jewish comm., Ra., AEz., Jeph., do not hesitate to interpret the covenant as of the treaty between the Jews and the Romans. Those who insist that ' $\beth=$ the Religion as also those who do not find Ant. in v. ${ }^{26}$, are compelled to manipulate the mng. of the vb., e.g., "he will abolish the covenant' or to venture upon its emendation, pass. vbs. being speculated in. At least seven emendations have been pro- 
posed; s. Note. The 'half-week' when the tyrant shall cause the cult to cease $=3^{1} / 2$ years, corresponds so closely with the 3 years during which the temple suffered sacrilege under Ant., I68-I65 B.C. ( $c f$. I Mac. $\mathrm{I}^{54 \mathrm{ff}}$. with $4^{52 \mathrm{ff}}$ ), that, whether we regard the present statement as prophetic or post eventum, the identification fits in satisfactorily with the theory of allusion to the Macc. age. The first half of the week then refers to Ant.'s earlier treatment of the Jews, on the chronology of which we are ill informed. In I Mac. $\mathrm{I}^{10 \mathrm{ff}}$. the datum of the accession of Ant. is followed by the statement about renegades of the Jews who received special license from the king, $c$. I 70 B.c. By 'sacrifice and oblation' is meant the totality of the cult, bloody and unbloody sacrifice, $c f$. I Sa. ${ }^{29}$, Ps. 407. In v.21 'oblation' מנהח has a later, more specific denotation.

27b. The next clause contains an obscure word which is fur-

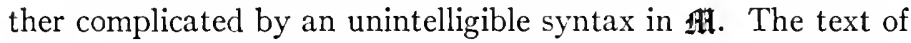
$\mathfrak{A l}$ is thus expressed by RVV: 'and upon the wing of abominations shall come one that maketh desolate' $=\mathrm{JV}$ 'and upon the wing of detestable things shall be that which causeth appalment.' This syntax of 'wing' is found in none of the VSS exc. Sym. (also Aq.?) and the former translating (const.

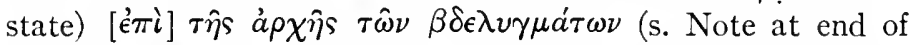
chap.); and 'upon the wings of the abomination'; all the other authorities treat the word as an absolute. Only one other VS correctly renders the word 'wing,' that contained in the variant

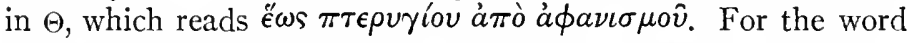
the other VSS make apparent substitutions. $\mathbb{B}$ and the $\Theta$ text found in $\mathrm{B}$ al. have the very plausible tr. émi rò iepóv, which is repeated periphrastically by $\boldsymbol{H}$, in templo. It is easy enough with vGall, et al., to tr. this back into Heb., simplicity of such reversion offers no assurance as to its correctness. It may be partly corroborated by the allusion in the Gos-

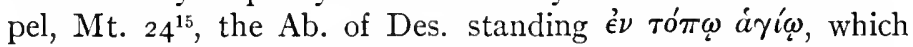
however is doubtless a paraphrase, similar to Jer.'s, who doubtless had our Heb. text. The parallel in Mk. I $3^{14}$, ötrov ov $\delta \in \hat{\imath}$, appears to stand for some cryptic sense of 92 . The rdg. suggested by Kuenen, Historisch-critisch Onderzock, 2, 472, cited

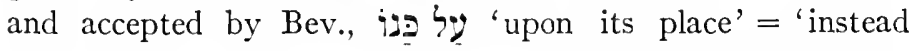
thereof' (c. $\mathrm{II}^{20 .}{ }^{21} \cdot{ }^{38}$ ), is the most plausible of the emendations 
proposed; the pers. pron. then refers to the double antecedent 'sacrifice and oblation.' But there is an interpretation of כנפ which had occurred to the present writer before he discovered that it had already been proposed and maintained with very respectable support, although it has disappeared in comm. subsequent to dEnv. A clew to ' $y=\Theta^{\text {var }} \pi \tau \epsilon \rho u ́ \gamma \iota \nu \nu$ is found in

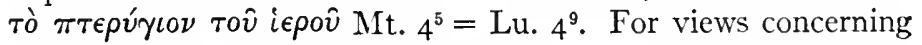
this 'wing' in the Story of the Temptation s. 'Pinnacle' in $D B$; acc. to that review scholars have differed much as to which part of the roof of the temple the 'pinnacle' was. J. Lightfoot, on Mt. $4^{5}$ (ed. Pitman, 1823, 2, 83), suggested the of the Herodian temple, the Royal Portico on the S side, the $\mathrm{E}$ end of which overlooked the giddy abyss which Jos. so grandiloquently describes, $A J \mathrm{xv}$, I I, 5. Others have suggested other parts of the roof, some its topmost point. That article and most, if not all comm., overlook the use of the same term in Hegesippus' story of James the Brother of the Lord, whom

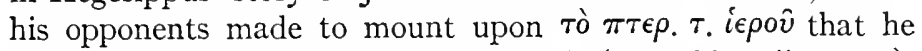
might expound his doctrine to the people (Eus., H. e., ii, 23, I I). Accordingly the place must have been an accessible elevation, like the top of a portico, thus corroborating Lightfoot's explanation. The term means structurally a wing of a building, and this meets the objection of those who argue at our place that 'wing' never means the top, can refer only to extension (e.g., Bleek, Jahrb. f. deutsche Theologie, I 860, pp. 93 ff., cited by Zöck.). We may suppose a heathen image or emblem-an acroterion, to use the architectural term-set up by Ant. upon the pediment or gable of the porch of the temple; the abomination felt by the Jews toward the most trifling of emblems appears in Jos.'s statement that not even the Roman standards might be brought into the holy city, $A J$ xviii, 3 , r. This identification by no means depends upon descriptions of Herod's temple, which would be anachronous, for the temple always had its 'tilam. Indeed, there is reference to this porch, $\pi v \lambda \hat{\omega} \nu$, in the Epistle prefixed to 2 Mac. $\mathbf{I}^{8}$. The first, so far as I can discover, who made this combination, is à Lapide, who $c f t$. Mt. $4^{5}$; he has been followed by Bert., vLeng. (tr. 'Gräuelzinne'), Heng. (Christologie, 3, ro3 f.), Ges. (Thes., Lex., thinking of an image of Zeus placed on the roof), Maur., Pusey, Zöck., dEnv. (who suggests that IEPON of $(\mathfrak{B} \Theta$ is corruption of IITEPON). The N.T. lexica 
ignore this O.T. case of $\pi \tau \epsilon \rho u ́ y \iota o \nu$. For current explanations of if reference may be made to Pole and early Prot. comm.; equally fanciful is Behr.'s attempt. If the above objective interpretaבנפ is an original or secondary crypticism similar to the following 'Ab. of Des.', and that then what it stood for was recognized

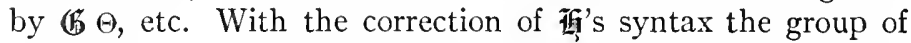
words becomes a predicate statement, 'upon the wing is'; it is not necessary with Mar., after Ruben, to prefix ריפד (?) 'and shall be set,' $c f t$. $8^{12}, \mathrm{II}^{31}$, I $2^{11}$.

'Appalling-Abomination,' for which the classical term, inherited from the VSS, is 'the Abomination of Desolation,' is doubtless a satirical word-play in the Heb. The orig. here is ar, but comparison with $\mathrm{II}^{31}$, I $2^{11}$, where variant forms are given, indicates that we should read here $Z A T W$ r884, p. 248, has given the one adequate explanation of this cryptic term, accepted by Bev., Dr., Mar., Cheyne, but still ignored by some subsequent comm. It is a contemptuous surrogate for the name of the highest Pagan deity, in the Phœnician בעל שיטם, pronounced acc. to the transliterations of Philo of Byblos and others Baal samem, the Lord of Heaven, appearing in the Aram. as Baethgen, Beiträge, $23 \mathrm{ff}$., Montgomery, $J B L$ 28, 66 ff., etc.). Philo of Byblos (Eus., Praep. evang., i, Io, 7) says: "this god they named Lord of Heaven, calling him $\beta \epsilon \epsilon \lambda \sigma a \mu \eta \nu$, which is with the Phœnicians Lord of Heaven, and with the Greeks Zeus." 'Ba'al' was replaced by 'Pיש 'abomination,' a common term of detestation for a Pagan symbol, e.g., I Ki. II ${ }^{5}$, etc.; this term replacing 'Ba'al' here as ב- 'shame' of ten does elsewhere, in proper names, e.g., Mephibosheth, and in such passages as Jer.

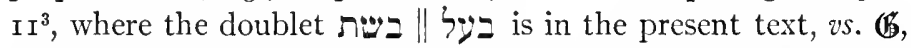
which has the simple 'Baal.' The second word šâmêm by the 'imâle or broadening of $\bar{a}$ became sômem, which is also a ppl. mng. 'appalling, desolating,' etc. The exact equivalent appears

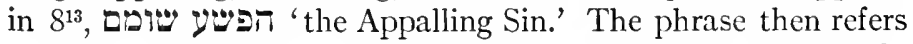
to the installation by Ant. of rites to the Olympian Heavenly Zeus in the temple sanctuary, acc. to $\mathrm{r}$ Mac. $\mathrm{I}^{54 .}{ }^{59}$. And Nestle

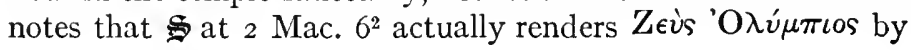


I בעל בימין I Mac. tells only of the heathen altar that was erected; but it is indifferent whether only an altar or also an image were reared, for either was symbol and bore the name of the deity.

'And until end and determination shall pour upon the Appaller': An ambiguous way of stating the fate expected to befall the arch-enemy. For the vb. $c f .{ }^{1} .^{11}$, where it is used of the operation of the divine wrath, like the outpouring of liquid fire. The initial words constitute a hendiadys, 'a determined end,' and are cited from Is. $1 O^{23}, 28^{32}$. The construction of $T y$ as conj. 'until' is preferred by the minority of scholars, e.g., Bert., Dr., Mar., Cha., with GV AV JV; others, including all the VSS and evidently $\mathfrak{A l}$, with RVV, take $i$ as a prep. governing the foll. nouns, or else only the noun 'the end,' with 'determination' construed as subj. of the vb.; but the last construction destroys the unity of the period.

27. On the Gr. VSS for this v. s. Notes at end of chap., esp. for the duplicate in texts of $\Theta ; \mathrm{I}$ argue there that the variant given in the margin of Swete's apparatus is a primitive variant in the text of $\Theta .-$ הגביר] Absence of actual testimony to a trans. Hif. of גבר (Ps. I $12^{5}$ Hif. = 'show strength') does not deny the mng. 'make great,' which is the tr. of all VSS exc. (B) offers var. trr.; in v..$^{a} \delta$ vu $\alpha \sigma \tau \varepsilon \dot{v} \sigma \alpha l$ with 'covenant' as subject; in v. ${ }^{\mathrm{b}}$ the orig. text of the passage prob. read similarly, 'in the prevailing ( $\left.x \alpha \tau: \sigma \chi^{\bar{u}} \odot \alpha \iota\right)$ of the covenant against many one week.' Proposed emendations are: Graetz, העביר 'shall abolish' or 'cause to transgress'; Kraetzschmar, Die Bundesvorstellung, 233 f., הכניר, or better, as Kamp. suggests, הכביד 'make difficult'; Behr. העויב 'cause to abandon'; Ehr.

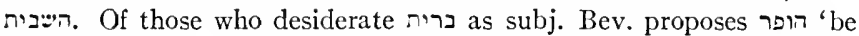

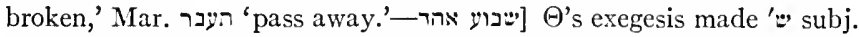

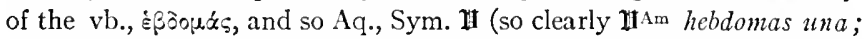
the vulgar text hebdomada una may be nom. or abl.). This construction has been maintained by some moderns, e.g., Heng., Häv., vLeng., Hitz., and naturally the Cath. comm. dEnv., Knab., on the basis of a poetical conceit that the time in which a thing happens can be regarded as the

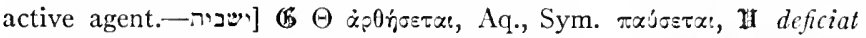

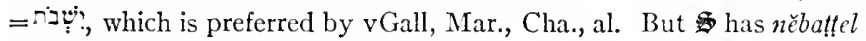

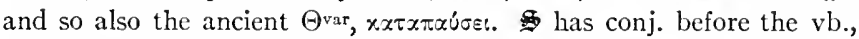
thereby combining 'week' and 'half-week,' and so Aph. Syr. with ref.

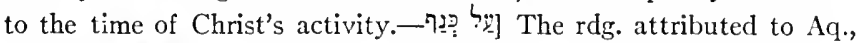

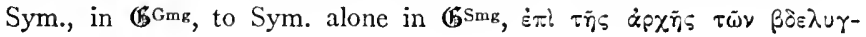




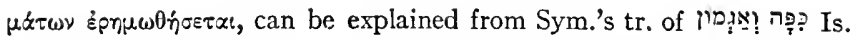

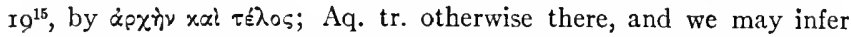

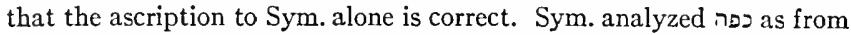
rt. כנת. Heb. cod. Ken. 313 has for על כנף שקוצים the unique rdg. על היכל יהוה שיקוץ. It has been lauded as an original rdg. by Ken., Dissertatio generalis, 95; JDMich., De hebdomade Danielis, 207, and Bibliotheca orientalis, 20,82 ; de R. ad loc. But it appears to be one of the cases where the orig. has been emended after a version. There may be noted finally the Arab. mng. of the rt., 'protect, cover,' with nouns = 'protected, covered place,' a sense agreeable to the proposed mng. 'portico'; cf. the popular use of Solomon's Porch in the N.T.— שיקו

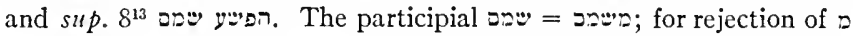
in such ppls. s. GK $\S_{52}$, a. This $n$ may have been desiderated and then have been supplied in duplicate, so causing the pl. שקוצים. The pl. appears in the Grr. only in Sym. acc. to $\boldsymbol{F}^{\mathrm{Smg}}$. But $\mathbb{B}, \Theta$ text in $B$, Lu., I Mac. $\mathbf{I}^{54}$, and N.T. have the sing., $\beta \delta \varepsilon \lambda u \gamma \mu \alpha$. Sym. offers a ver-

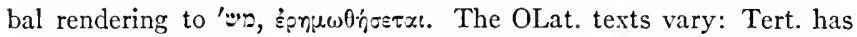
the sing., Chron. pasch., and Iren. the pl., while I.Wng has a conflate text, et supplicatio (?) desolationum interitus et ad sacrificium abominatio, on which depends Aug.'s citation, Ep. 79, of Hesychius of Salona, desolationis interitus; s. further Burkitt, Rnles of Tyconius, p. Ixix. AEz., PsSa. take משמס as ppl., 'desolator,' Ra. as 'desolated,' of the dumb idol, and so Stu. and others. Of modern views we may note that of Bev., who finds a pass. ppl. of שוש = 'set up,' and Winckler's notion, $K A T$ 303, that the phrase $=\theta$ sos Lexx.; the one objection, that exceptionally the vb. does not immediately follow, with Mar., is not a decisive reason. Bev. would read iं, translating 'afterward,' but hardly with improvement.ported by Sym., Aq. (?), $\Theta^{\mathrm{var}}$, $\sigma \tau \dot{x} \xi s$, appearing in $\Theta$ texts erroneously as

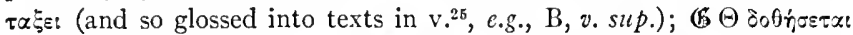
$=$ =n, understood as a pass.; 'until the end it [the Abomination] will rest, תרניח, upon the Desolation'; similarly, perhaps, $\boldsymbol{\eta}$ perseverabit Jesolatio.

\section{NO'TE ON THE INTERPRETATION OF THE SEVENTY WEEKS.}

There has been assumed above the interpretation of the Seventy Weeks, which would bring down that era to the Macc. epoch. Justification of that position will now be given, to be followed with a sketch of the exegesis of the vexed passage.

However the 70 Weeks are to be interpreted, whether historically, apocalyptically or mystically, certain principles must be followed, if the writer meant anything sensible. The total of the 70 should be obtained in the 
addition. The denomination must remain the same: 'week' cannot be a variable quantity, as now a scptennium and now some other quantity of time. We should expect from the circumstances of the chap. a definite terminus ad qucm, because the immediate encouragement of the seer and his readers is demanded. The round number 70 is no contradiction to this demand. The round number of 480 years from the Exodus to Solomon's construction of the temple ( $\mathrm{Ki} . \mathrm{6}^{1}$ ) was also meant as a precise number. And that the present number is to be taken literally appears from its division, not into symbolical aliquot parts, e.g., $7 \times 10$, but into an irregular series, $7+62+\mathrm{r}$, a half-year within the last year also being specified. Otherwise the aliquot division of the 70 Shepherds of Enoch $85-90$ into $12+23+23+12$. And finally we must not expect an exact historical chronology according to the approved data of modern historical investigation; Jewish historiography was affected by a remarkable oblivion as to chronology and sequence of events.

The tcrm. a quo is given explicitly, 'from the issue of the word,' i.e., the Jeremianic word, $c f . \mathrm{v}^{2}$, 'the word of YHwy for completing the ruins of Jerusalem.' The prophecy is that of Jeremiah, specifically the one given in Jer. 25. Entirely out of order, therefore, although enjoying great favor with the interpreters, is the exegesis which would find this terminus either with the chronologically fictitious 'Darius the Mede,' as though the computation was to be taken from the date of the present chap. ( $\left.c f . v_{.}{ }^{1}\right)$; or with year I of Cyrus; or with the reign of Artaxerxes Longimanus. These arbitrary projections of the term. a quo are due to the discovery by the early Christian chronographers that otherwise the desired term. ad quem, the epoch of Jesus Christ, could not be obtained. ${ }^{1}$ When we fall back on a Jeremianic date, we find various dates proposed: 586 , the destruction of Jerusalem; 597, its first capture by Nebuchadnezzar; and 604 (also given as 606), year I of Neb. This latter date has been urged by Behr., now supported by Könis, Die Mess. Wcissagungen, $3 \mathrm{II}$, against the majority of the comm. The date is urged on the ground that 604 ("606") is the date of the prophecy of the 70 weeks of exile, Jer. $25^{1.11}$. This date less I Week, i.e., 49 years, = c. 558, the date of Cyrus' accession; Cyrus would then be the 'AnointedPrince.' Behr. thus obtains a fairly exact perior of 49 years. Cyrus is hailed in the Bible as the LoRD's Messiah, but there is no Biblical datum as to the beginning of his reign, and indecd no room for his historical 30 years' reign is found with the Biblical assumption of a preceding Darius the Medc. ${ }^{2}$

${ }^{1}$ E.g., Clem. Alex. finds the first week, 49 years, from the $2 \mathrm{~d}$ year of Cyrus to the 2d year of Darius Hystaspis; Hipp. from year 1 of Darius the Mede to year 2 of Darius Hyst. Africanus introduced the dating from the year 20 of Artaxerxes, in which case the seven weeks are irnored as a distinct quantum of time, as indeed is the case with the translation of $\Theta$. This became the favorite dating of the Medixval theologians, e.g., Bede, Nicolas of Lyra.

${ }^{2}$ Behr. has been attracted to the date $604(606)$ because by again starting the next datum of 62 Weeks $=434$ years from the same date he obtains the epoch of Ant. 
But if Jeremiah were exactly followed, there should have been a period of 70 , not 49 , years, these 70 years being described as years of service to the king of Babylon. The desolation, as our writer well knew, was less than the 70 years, and, if we may grant him a correct chronology here, he was working between the two striking epochs of Jerusalem's ruin, 586 , and the Return, $c .538$, or circa 49 years. In this case it must be admitted that the dating is not exactly 'from the issue of the word,' i.e., the word of Jer. $25^{2}$ in year I of Neb.; but also the desolations of Jerusalem did not begin in that year, not until 586, which certainly must be the epochal year, not the cursorily mentioned datum of Neb.'s first year in the introduction to the prophecy of Jer. It is from the destruction of Jerusalem in 586 that the Bible itself dates the 70 years, s. 2 Ch. $36^{20}$. If the 7 Weeks terminate at the Return, then of the three candidates proposed for interpretation of the 'Anointed-Prince,' as argued at $\mathrm{v} .^{25 \mathrm{~s}}$, the high priest Joshua is to be decisively preferred. ${ }^{3}$

The Christian interpretation of the chronology in $\mathrm{v}^{25}$ was sadly misled by the original error of $\Theta$ in construing the ' 7 Weeks' with the foilowing ' 62 Weeks,' as though 69 Weeks were the first figure intended. Jerome unfortunately followed $\Theta$ in perpetuating this error in the Western Church, and its traces are still found in the Eng. VSS (s. Notes). This tr. of $\Theta$ and II was agreeable to the Jewish and Christian interpretations which found the fulfilment of the prophecy in events of the ist cent. A.D., and so needed a larger figure than the 62 Weeks $=434$ years to fill up the interim. But taking 538 B.C. as the starting-point for calculating these 434 years we obtain ro5 B.C., an impossible date for anything of prophetic value.' This does not suit at all the early Jewish and Christian identification of the term. ad quem with some epoch in the Ist Christian cent.; nor does the attempt

Epiph., and so claims to justify the Jewish chronology, which is discredited by most scholars. But he is absolutely unjustified by starting afresh at that date for the 62-Weeks period.

${ }^{3}$ The identification with Joshua goes back to the very original treatment of the

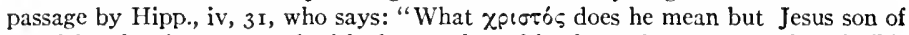
Josedek, who then returned with the people and in the zoth year upon the rebuilding of the temple offered sacrifices according to the law? For all kings and priests are called zprotol," etc. This view was adopted again by Calvin, and taken up in recent years by Graetz, Bev., vGall, Mar., Cha. Rashi understands Cyrus as the Messiah followed by some early Prot. comm., the view still preferred by Mein., Behr., Dr., Schürer $(G J V$ 3, 266), Cornill, König, ct al. Julius Hilarianus, of the end of the $4^{\text {th }}$ cent. ( $v$. inf.), identified the Messiah with Zerubbabel. AEz. found him in Nehemiah. Eusebius, who used Hipp., regarded the 'Anointed-Prince' as the whole list of high priests from the Exile till Christ's advent, Dem. ev., viii, 2, cf. Fraidl, pp. $5^{8} . f f$.

'Eusebius, l.c., in one of his calculations, boldly accepts the consequence of dating 69 Weeks from year I of Cyrus to the death of the Hasmonæan prince Alexander Jannæus, 76 B.c., and understands the prediction of this terminus event as of the prelude of the anarchy which ushered in the Roman dominion. 
fare any better with the shoving down of the term. a quo as far as possible, into Artaxerxes' reign, etc.

To be sure, a similar objection may be made against our identification of the final Week of the Seventy with the period of Ant.'s tyranny, for the 62 Weeks would then take us down some 65 years too far. We can meet this objection only by surmising a chronological miscalculation on part of the writer. For the first 49 years he had exact Scriptural information; he was profoundly conscious of the epochal character of his own age; there was the necessity of extending Jer.'s 70 years into a much larger figure in order to bring it up to date (the natural process of all interpretation of prophecy), and the 70 years became 70 Year-Weeks $=490$ years, too high a figure indeed, but he was not embarrassed, in the absence of a known chronology, in squeezing these 434 years between the Return and the Antiochian persecution. Schürer, $G J V$ 3, p. 266 , has capitally illustrated this chronological fault from the Jewish Hellenistic historians; he cites from so learned a man as Josephus various reckonings of Cyrus' reign, which are too high by $40-50$ years, and notes especially the datum given by the historian Demetrius (in Clem. Alex., Strom., i, 2I, I4I-before 200 B.C.) of 573 years between the Return and the accession of Ptolemy IV in 222 B.C., i.e., 70 years too much. ${ }^{5}$ Cornill, Die Siebzig Jahrwochen Daniels, pp. I5 ff. (cf. Dr., p. 147), has offered the ingenious suggestion of finding twelve high priests (their names drawn from the Bible and Josephus) from the Destruction to Onias III; rating these generations at 40 years we obtain 480 years, which plus the last week of our reckoning $=487$ or almost the 490 years required. But s. Guthe, Gesch. Israels, 276, Mar., p. 73, for criticism of this hypothesis; and indeed it is not necessary to demonstrate any exact basis for the figure. Below, in treating the early Jewish exegesis, is given the ancient chronology preserved in the Seder Olam; according to that scheme the Persian period, from the Return to Alexander, is boiled down to 34 years!

The last Week is introduced by the 'cutting off of an Anointed,' the destruction or depravation of city and temple, accompanied by an unholy 'league with the majority'; for the (last) Half-Week there is to be cessation of the Jewish cult and its replacement by Pagan abominations. This Half-Week equals in round figures the ' 2,300 mornings and evenings' of $8^{14}=\mathrm{I}, \mathrm{I} 50$ days. The whole argument points to the Antiochian persecution and it can be claimed that no period in Jewish history so neatly fits the cryptic allusions of our passage. We may satisfactorily identify the 'Anointed' with the high priest Onias III, who was foully murdered when guest at the court of Antioch (2 Mac. $4^{7.38}$ ), which acc. to Schürer, I, $195 f$.,

- See, however, Behr., p. 65, for criticism of this alleged datum from Demetrius, on basis of uncertainty of Clem.'s text, and with defence of the Jewish chronology; cf. Dr., p. 147, n. 3 . 
happened about $\mathrm{I} 7 \mathrm{I}$ B.c. The Week would then terminate prospectively at about the time when the temple was recovered and purified by the Jews, I65 в.c., and the Half-Week would represent the three years of the profanation of the temple, r68-r65. The Abomination of Desolation is the heathen altar, with its accompaniments, which Ant. reared in the temple ( $\left.\mathrm{I}^{54}\right)$. We may respect the spiritualizing exegesis which can find fulfilments of the striking figure of the Abomination of Desolation in many a subsequent act of sacrilege, the attempted profanation by Caius, the destruction of city and temple by Rome, the erection on the temple site of Hadrian's Pagan shrine, but this natural process of thought should not interfere with our recognizing the primary and most obvious interpretation of the passage as one with a contemporary bearing which was intelligible to its age despite its cryptic phraseology. ${ }^{6}$

For the history of the elder (pre-Reformation) interpretation of the 70 Weeks we can mark out several distinct progressive phases: (I) The interpretation as of a prophecy of the Maccabæan distress, the 'contemporary' interpretation; (2) the apocalyptic interpretation, as in the Gospels, Paul; (3) the application to the destruction of Jerusalem-so by Josephus, and since him the regnant Jewish interpretation; (4) the ultimate 'Christian' exegesis which found in the passage more or less explicit, chronologically verifiable predictions of the advent of Christ. This last exegesis is again variously crossed with the other earlier strains of interpretation. And (5) there is the rationalizing interpretation, instituted by Porphyry and now largely accepted. The writer will content himself with sketching the development of these successive phases; for the detailed history he must refer to the many monographs. ${ }^{7}$

${ }^{6}$ In the application of this last Week to the history of Jesus Christ there has always been embarrassment. In the elder interpretation of the Gospels the Saviour's ministry lasted but one year; the subsequent extension of it to three years entailed comparison with the Half-Week of Daniel $=31 / 2$ years. The middle of the Week was then naturally placed at the termination of the Lord's ministry on earth, but the problem arose what to do with the balance. Without any adequate explanation such authorities as Eusebius, Polychronius, Theodoret, postulate a $31 / 2-$ year period after Christ left the earth. A favorite modern interpretation is to identify the termination of the second Half-Week with the preaching of the Gospel to the Gentiles in the episode of the centurion Cornelius. Similarly the early Jewish interpretation in the time of Jerome found a correspondence for the Half-Week in the three or four years of 66-70 A.D., and for the second Half-Week the three years or so of the Hadrianic war.

${ }^{7}$ I refer primarily to three works which taken together would fairly well summarize the whole history: Fraidl, Die Exegese der Sicbzig Wochen Daniels in der Alten und Mittleren Zeit (through the Middle Ages), i $88_{3}$ - an admirable piece of scholarship, covering equally the Patristic, Oriental, and Western, and Jewish comm.; the invaluable Synopsis of Pole for the early Prot. comm.; and Zöckler's Appendix to his comm. on the chap. (Eng. tr., pp. 205-213). To these may be added for their useful summaries: Bert.'s 'Erklärende Uebersicht' to the chap., pp. 541-626; vLeng., pp. 469-482; Häv., pp. 392-399. For older monographs Zöck. notes those by Calo- 
(I) The 'contemporary' interpretation. The earliest immediate interpretation of this passage is in I Mac. $\Gamma^{54}$ : 'On the 15 th Chislev [read, 25 th], year 145 [Sel. Era $=$ I68 B.c.] they built Abomination of Desolation upon

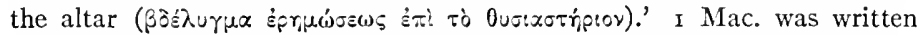
in Hebrew at the end of the $2 \mathrm{~d}$ cent., only two generations removed from the age of Ant. Epiph.; the passage is of prime importance in showing how, as far back as we can go, the earliest tradition interpreted the 70 Weeks.

The second of the Dream Visions of Enoch, i.e., cc. $85-90$, presents, $89^{68}$ $90^{27}$, a series of 70 Shepherds covering the period from the destruction of Jerusalem until the Messianic Kingdom; these Shepherds are evidently distributed as follows: the Captivity I2, the Persian age 23, the AlexandrianPtolemaic age $(\epsilon .200) 23$, the Syrian age I 2 (the arbitrary character of this numerical series is obvious). We have here then an evident replica of our 70 Weeks, with the same lerm. ad quem, i.e., the Macc. age. The Visions are generally regarded as among the earliest portions of Enoch, Cha. dating this Vision before the death of Judas Macc.

Again, the translation of $\mathbb{G}$ may be taken, with Fraidl, pp. 4 ff., as probably definitely precising the end of the period as coinciding with Ant.'s

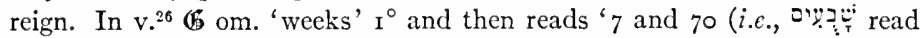
as (6. v. ${ }^{27}$, 'after 7 and 70 and 62 years,' years being specified, i.e., I 39 years. Ant. Epiph. came to the throne ${ }_{137}$ Sel. Era (I Mac. $1^{10}$ ), and the translator may, whether intentionally or accidentally, have hit upon a combination which actually expressed quite accurately Ant.'s date in terms of the current era. Further, the variant in $v_{0}^{27}$, 'and the desolation (sंpin $\mu \omega \sigma: s$ ) will be removed in the enforcing of the Covenant for many weeks,' doubtless refers to Judas' triumph.

To these pre-Christian references should be added Test. Levi $16-17$, if we may regard it, with Charles, as Judaistic and reject obviously Christian material. Acc. to this passage a period of 70 weeks is prophesied when the priesthood and sacrifices shall be polluted and profaned, terminating at the end of the seventh (sic) week with the advent of 'a new priest,' which can then be interpreted of the Hasmonæan dynasty. The Christian interpola-

vius (I663), Wieseler, I839, Baxmann, I 863 , Rösch, I868. Of more recent monographs the following titles should be noted (cf. Marti, p. IOI, Schürer, 3, 267): van Lennep, De zeventig jaarweekcn van Daniel, Utrecht, I8S8; Cornill, Die Siebzig Jahrwochen Danicls, I889; R. Wolf, Die Sicbsig Wochen Daniels, I889; H. Vuilleumier, 'Les septante semaines d'années de Dan. ix,' Rev. de Thêol. et de Philos., I892, 197202; Lagrange, 'La prophétie des semaines,' $R B$ Ig04, 509-5I4; I. Lévy, 'Les soixante-dix semaines de Daniel dans la chronologie juive,' Rev. des étudcs juives, I906, I6I-I90; van Bebber, 'Zur Berechnung der 70 Wochen Daniels,' Bibl. Zeitschr., I906, г 19-I4I; E. Bayer, 'Danielstudien,' Alltest. Abhandlungcn, Münster i. W., I9I 2, pp. I 88, a treatment, literary and theological, of Dan. 9; and König, who in his recent Messianische Wcissagungen, 1923, gives, pp. 302-317, a running critical exegesis of vv, ${ }^{24-27}$. 
tions might, on the other hand, be the earliest direct application of the 70 Weeks to the advent of Jesus Christ. Also in Schechter's Zadokite Frag$m e n t$, text, p. 1, ll. 5. 6, there is reference to a period of 390 years from Nebuchadnezzar to 'the end of the wrath,' which figure Schechter would amend to 490 . But this would be merely a classical allusion. In general, then, the eldest interpretations of the 70 Weeks identify their climax with the Antiochian persecution.

This original historical interpretation of the 70 Weeks passed into oblivion, not to be taken up again until modern times, except for the drastic criticism of Porphyry of the Christian interpretation and for the highly ingenious interpretation offered by a Christian writer of the end of the 4 th Cent., Julius Hilarianus, who in his De mundi duratione libellus ( $P L \mathrm{1} 3,110 \mathrm{ff}$.) finds, with remarkable originality, the term. ad quem of the 70 Weeks in the year 148 Era Sel., and refers the Half-Week of the Abomination to Ant. Epiph.'s sacrilege-“"Abominatio desolationis facta est super altare statua Iouis quem Olympium uocant illic collocata." Following the example of Hipp. he punctuates after the first 7 Weeks (against the syntax of $\Theta$, whose text he follows in the OLat.), discovering Zerubbabel in the 'Christus dux,' for he says, "omnis rex populi Dei in diuina lege Christus appellatus est."

(2) The apocalyptic interpretation of the prophecy appears in the sole direct citation of it in the N.T., Mt. $24^{15}$, 'When ye see the $\mathrm{Abomination}$ of

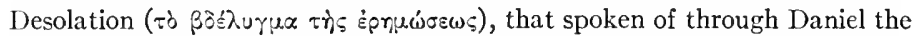
prophet, standing in the holy place ( $\dot{\varepsilon} \gamma \tau \hat{\delta} \pi \omega \dot{\alpha} \gamma^{\prime}(\omega)$ ), let him that readeth understand!' $=\mathrm{Mk}$. $13^{14}$ with the variant, 'standing where it ought not.' Without deciding as to the authenticity of this word, or as to its objective, whether it anticipates Antichrist or the destruction of the state by the Romans, we find in it a patently apocalyptic use of the Danielic prophecy, which could be made to fit the prospect of any great calamity which should strike at the heart of the Jewish religion. The dating down of the longspun-out 70 Weeks into the first century must have been in vogue and have contributed to the inspiration of the various fanatical and transcendental movements of the Judaism of that age. Similarly Paul in his early apocalyptic epistle, 2 Th. $2^{4}$, has the Danielic utterances against Ant. Epiph. in mind, this passage as well as the more specific description in c. II, when he speaks of the Son of Destruction 'sitting in the temple of God, showing himself that he is God' (=epiphanes 1 ).

(3) The first direct application of our passage to the destruction of Jerusalem in A.D. 70 is made by Josephus in his usual cryptic fashion. Fraidl, pp. 18-23, discusses the possible reff. We may note especially $A J$ x, II, 7 , where, after having summarized Dan. 8, the vision of the Ram and the Buck, Jos. proceeds: "and these things, it happened, our nation suffered under Ant. Epiph., and many years in advance he [Dan.] wrote up what was to take place. And in the same manner also he wrote about the empire

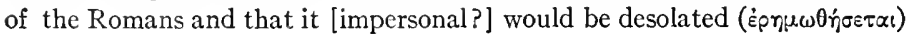


by them." Cf. also the passage cited above (Note to v.26) from B.J.iv, 5, 2, in which he refers to the murder of the high priest Ananus in the last days of Jerusalem as the real beginning of the end, for then they beheld "the

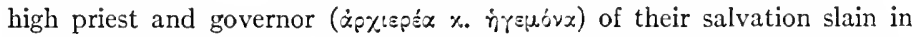
the midst of the city," with evident allusion to our passage. This interpretation became the dominant Jewish exegesis almost without exception; and it passed over into the Christian exegesis, which along with the advent of Christ equally saw the downfall of the Holy City predicted in the prophecy of the 70 Weeks.

The chronology involved in this termination of the 70 Weeks is implied in the ancient Jewish historical work Seder Olam (2d cent.; ed. J. Mayer, Amsterdam, I699) c. $30=$ Aboda Zara, $8^{\mathrm{b}}-9^{\mathrm{a}}$. The 490 years appear to be divided as follows: the Exile $70+$ Persia (after the Return) 34 t the Greeks 180 t the Hasmonæans 103 t the Herods $\mathrm{IO}_{3}=490$. S. Fraidl, p. I22, and particularly by way of elucidation of the chronology, G. F. Moore's note in Jackson and Lake, Beginnings of Christianity, x, 97, n. 2, and also König, p. 3 ז3.

At the end of his interpretation of the passage Jer. gives a summary view of Jewish interpretations, at least professes to do so: "Hebraei quid de hoc loco sentiant breui sermone perstringam, fidem dictorum his a quibus dicta sunt derelinquens." The Jews who were his authority found the fulfilment in the destruction of the city by the Romans, including in the last Week both the $3^{1 / 2}$ years of the war of Vespasian and Titus and the $3^{1 / 2}$ years of Hadrian's war; 'the prince to come' was interpreted: 'cum duce uenturo Uespasiano.' And it appears, if we may trust Jer., that the Jews admitted a reference to Jesus Christ in the death of the Anointed One, but cleverly interpreted the ואין לי by 'but the kingdom of the Jews will not be his' ("non erit illius imperium quod putabant se retenturos"). That the destruction of Jerusalem was the objective of the 70 Weeks is also the opinion of the Clementine Recognitions in an interpretation of the Abomination of Desolation ( $P G$ i, I 242).

The subsequent Jewish interpretation (s. Fraidl, pp. I24-I34) followed the traditional opinion of the term. ad qucm as the destruction of Jerusalem under Titus (or Hadrian). So Rashi, Abn Ezra, PsSaadia, Abarbanel. The Messiah of $\mathrm{v}^{26}$ is Agrippa, acc. to both Ra. and AEz., the latter citing Joseph b. Gorion, vi, c. 30 (s. Schürer, I, I59), who gives the tradition of Agrippa's martyr-death. AEz. goes his own way in making the first Week terminate in Artaxerxes' 20 th year (Neh. $\left.\mathrm{I}^{1}\right)$ and regarding Nehemiah as the Anointed-Prince, whereas the others generally identify this person with Cyrus. In this calculation AEz. was probably influenced by Christian exegesis which had more or less since Julianus Afr. adopted the dating from Artaxerxes. However, it may be noticed that an apocalyptic, Messianic interpretation exhibited itself at times. Acc. to Sanh., 97a, the Weeks were divided into seven parts at the end of which was to come the Messiah; and 
Schöttgen, Horae hebr., 2, 264, gives some instances of similar interpretation among Jewish commentators, $e . g$. ., Moses Nachmanides, "The Holy of holies is naught else than the Messiah, the sanctified one of the sons of David." Another rabbi cited by Schöttgen, Moses Haddarshan, is reported to have said: "The eternal righteousness, that is King Messiah," which interestingly enough agrees with Jer.'s statement that the Jews of his day made the same equation.

(4) The specifically 'Christian' interpretation, which found the terminus of the Weeks in the advent of Jesus Christ, only slowly made its way; it is not found at all in the New Testament, it is not made use of at all in Justin Martyr's Apologies, and outside of a passing allusion in Ep. Barnabas, I6 ('and when the hebdomad is completed, the temple of God will be built gloriously in the name of the Lord'-a spiritualizing interpretation), we have to come to the Fathers at the end of the $2 \mathrm{~d}$ cent. to obtain this exegesis. This development, when it came in, was encouraged by the false translation in $\Theta$, 'unto Christ the chief 7 weeks and 62 weeks,' which made the calculation up to Christ's advent somewhat more plausible.

Of the Fathers Irenæus $(v, 25,4)$ inherits the apocalyptic interpretation of the New Testament; Dan. $9^{27}$, with its $3 \frac{1}{2}$ years, is a prophecy of the Antichrist; he relates with it Paul's prospect of the Antichrist in 2 Th. $2^{3 \mathrm{f}}$, and the Antichrist is to take up his abode in Jerusalem. So far then there is no chronological calculation of the advent of Christ from the 70 Weeks.

Essays at such a calculation set in with the subsequent Fathers: Clem. Alex. (Strom., i, 21, PG viii, 853), Tert. (Adv. Judaeos, 8), Hipp., Julianus Africanus (Routh, Reliquiae sacrae, 2, 297 ff.), Origen (esp. his comm. on MIt. $24, P G$ xiii, $1656 f f$.), Eus. (Dem. ev., viii, 2). Of these it may be noticed that Hipp., to a great extent Irenæus' scholar, includes in his chronological argument also Iren.'s theme of the era of Antichrist (comm. iv, 30-35; De Antichristo, cc. 47,64 , etc.). Also Tert. and Origen, while pursuing chronological interpretations bearing upon the Advent, continue to find prophesied the destruction of the Jewish state. But several of these Fathers were chronologers of highest standing, e.g., Hippolytus and Africanus, and it is not strange that they betook themselves to the task of computing the Weeks so as to find their exact terminus in the advent of Jesus Christ. Accordingly, these masters ushered in a development ominous, although one to be expected, for all subsequent exegesis. From the beginning the masters disagreed, as they have done ever since. For example, the term. a quo was found by Clem. Alex. in year 2 of Cyrus; by Hipp. in year I of Darius the Mede; in Africanus in year 20 of Artaxerxes; by Eusebius acc. to one reckoning in year 6 of Darius Hystaspis (s. Fraidl's Tables, pp. 156 ff.). The climax of the Weeks is generally found in Christ's death, in which there was the cancellation of the Jewish ritual, but with a balance of $3^{1} / 2$ years left over which is treated most vaguely; it is often regarded as representing the period down to the destruction of Jerusalem, or, after ancient precedent, it 
is understood as of the era of Antichrist, or with Polychronius of the teaching of the Apostles.

This specifically 'Christian' exegesis became definitely crystallized in the last great Versions executed for the Christian Church, the Syriac and the Vulgate. The Syriac gave a definite Christian coloring to v. ${ }^{24}$ in paraphrasing the final words, 'to anoint the holy of holies' into 'to Messiah the Holy of Holies'; in v..$^{25}$ it turns 'unto an Anointed-Prince' into 'to the coming of Messiah-King.' And in $v^{.6}$ we have the clear-cut tr. 'the Messiah will be killed' over against the vaguer 'will be destroyed' of and the cryptic 'chrism will be exterminated' of $\Theta$. Jerome has similarly put the Christian stamp upon his great translation. 'Unto Anointed-Prince' becomes 'ad Christum ducem,' and the Syriac is followed in 'occidetur Christus.' Jer. also unfortunately follows the tr. of $\Theta$ in definitely combining the figures ' 7 weeks and 62 weeks' in $v^{25}$ as one numeral, as over against 7 can be read here as agreeing with . It is to be observed, however, that the early Christian exegesis, that of the Greek Fathers and of the early Latins, working with $\chi_{p}: \sigma e \alpha$ of $\mathbb{B} \Theta$ in $v^{26}$, made this crucial passage refer to the abolition of the Jewish cult, not to Christ's death; s. Note ad loc.

While the tendency induced by the Christian chronographers to find the exact terminus of the 70 Weeks in the Advent became universal among Christian exegetes, we have to note the immense variety as to details among the Fathers, a variety which has been in part noticed above. Some of the Fathers honestly enough present more than one calculation of the times, so Africanus three different theories, Eusebius possibly four (Fraidl, pp. $45 f f$., 58 ff.). Variant opinions as to the term. a quo have been noticed above. And there was widest contradiction in other details. Thus the 'Anointed-Prince' of $\mathrm{v}^{.5}$, generally identified with Jesus Christ, is acc. to Eus., the Jewish priestly line down to Alexander, or Hyrcanus, Herod's victim. Tert., following the text of $\Theta$, boldly interprets the 'extermination of anointing' as of the destruction of the Jewish ritual, and so Commodianus (II. $266 f$., CSEL xv). With Tertullian the 'prince to come' is Jesus Christ, and so the usual exegesis, but with Origen Herod or Agrippa, with Eusebius Herod. Against the apocalyptic view of $\mathrm{v} .^{27}$, interpreting it of the Antichrist, Africanus finds reference to the New 'Covenant' in Jesus Christ and the latter's removal of the Jewish cult. This anti-Jewish theme of interpretation is very prominent, and as in Irenæus, Eusebius, Theodoret, the contrast is made between the Jewish cult and the new liturgy of the Eucharist. By the 4 th cent. all possible varieties of interpretation had been reached and it remained for subsequent exegetes to make their arbitrary choice, with actually no room for any novelties.

(5) The rationalizing, critical interpretation. The Prot. Reformers and their immediate successors added nothing to the kaleidoscopic results of the Patristic and Medieval comm. ${ }^{8}$ An entirely fresh direction to scholarship

\footnotetext{
${ }^{8}$ See Pole's Synopsis; and Zöck., p. 208, for a concise survey.
} 
was introduced by the Deists and Rationalists of the $I 7$ th and 18 th centuries, with the premise that the objective of the 70 Weeks is the Macc. age and that the 'prophecy' is accordingly a vaticinium cx evcntu. ${ }^{9}$ But the first credit for this critical position must be given to the Pagan Porphyry, of whom Jer. in the Preface to his Comm. says: "Contra prophetam Danielem duodecimum librum scripsit Porphyrius, nolens eum ab ipso, cuius inscriptus est nomine, esse compositum, sed a quodam qui temporibus Antiochi qui appellatus est Epiphanes fuerit in Iudaea, et non tam Danielem uentura dixisse quam illum narrasse praeterita. Denique quidquid usque ad Antiochum dixerit ueram historiam continere; si quid autem ultra opinatus sit, quia futura nescierit, esse mentitum." In Patristic exegesis a striking exception is found in Julius Hilarianus, s. above at the end of (I). In modern scholarship that trend was first adopted by two Englishmen, John Marsham, Canon chronicus, Frankfurt, i697, pp. 6roff., and A. Collins, Scheme of Literal Prophecy, London, 1726, and also the Catholic scholars Hardouin and Calmet; s. Bert., pp. 596 ff., Pusey, pp. I 97 ff., Knab., p. 270. These were followed, inter al., by Corrodi (Krit. Gesch. d. Chiliasmus, I 794, 3, 253), Eichhorn (Allgem. Bibliothek, 3, 76 I ff.), Bert., Bleek, Rosen., Rösch, vLeng., Maurer, Hitz., Ew., Wieseler, van Lennep. This view-point came to be practically admitted by some conservative theologians, who "regard the events of the era of the Antiochian persecution and the Macc. revolt as types and prefigurations of the founding of Christianity" (Zöck.), with a general assumption of the final Week as of indefinite length, from the Advent to the end of the world; so Hofmann (Die 70 Jahre Jeremias $u$. d. 70 Jahrwochen des Daniel, 1836), Delitzsch $\left(\mathrm{RE}^{2}\right)$, Kranichfeld, Keil. But equally 'conservative' scholars, as Stu., Zöck., adopted the radical theory in a very straightforward way. With them are to be assoriated almost all recent comm., and in general the writers of the several 6.T. Introductions and Theologies, and the Encyclopxdia articles on Dan.

For the directly Messianic interpretation in the past century we have to note Häv., Heng., Auberlen, George Duke of Manchester (The Times of Dan., 1845), Pusey, Kliefoth, and the Cath. comm., dEnv., Knab. For the most recent works we note Wright (Dan. and His Prophecies, c. 7), Wilson (passim in his several monographs), Boutflower (In and Around the Bk. of Dan., cc. 16-I9, 'The Evangelic Prophecy'). We must pass over the exuberant Millennarian interpretations, which have come into great vogue again in England and America. For a critical display of these developments s. S. J. Case, The Millennial Hope, igr8.

To sum up: The history of the exegesis of the 70 Weeks is the Dismal Swamp of O.T. criticism. The difficulties that beset any 'rationalistic' treatment of the figures are great enough, for the critics on this side of the

SSee Bert. in his int. to c. 9 , Zöck., pp. 200 ff., Knab., pp. 262-275 (a digest of the Messianic, Eschatological and Non-Messianic interpretations). 
fence do not agree among themselves; but the trackless wilderness of assumptions and theories in the efforts to obtain an exact chronology fitting into the history of Salvation, after these 2,000 years of infinitely varied interpretations, would seem to preclude any use of the 70 Weeks for the determination of a definite prophetic chronology. As we have seen, the early Jewish and Christian exegesis came to interpret that datum eschatologically and found it fulfilled in the fall of Jerusalem; only slowly did the theme of a prophecy of the Advent of Christ impress itself upon the Church, along with the survival, however, of the other earlier themes. The early Church rested no claims upon the alleged prophecy, but rather remarkably ignored it in a theological atmosphere surcharged with Messianism. The great Catholic chronographers naturally attacked the subject with scientific zeal, but their efforts as well as those of all subsequent chronologers (including the great Scaliger and Sir Isaac Newton) have failed.

\section{NOTE ON THE GREEK TEXTS OF VV. ${ }^{24-27}$.}

(I) $\mathbf{6}$.

For special studies on these texts s. Blud., pp. I04 ff., Behr., pp. xxxiv seq. $\mathrm{Vv}^{24-25 s}$ can be easily equated with and a summary treatment of them is sufficient. The following passage, $\mathrm{vv}^{25 b-27}$, requires detailed analysis.

24. $\tau r \nu \pi \circ \lambda \iota \nu \Sigma i \omega \nu: \Sigma .=\operatorname{\sigma ou}(?)$.

$\tau \alpha \varsigma \alpha \delta: x: \alpha \varsigma \quad I^{\circ}=$ Kt., $\tau$ rq $\alpha \delta ! x: \alpha \nu \mathscr{G}^{\mathrm{S}}=\mathrm{K} \mathrm{r}$.

$\sigma \pi x v i \sigma a t=0$ anל Kt.: s. Note ad loc.

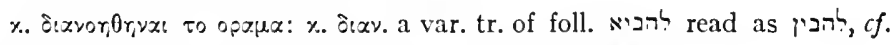

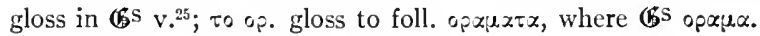

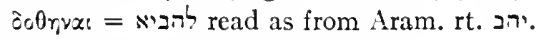

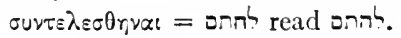

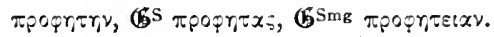

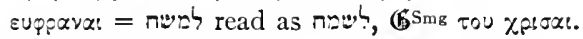

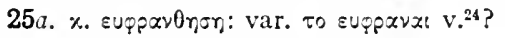

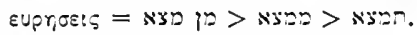

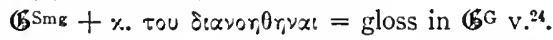

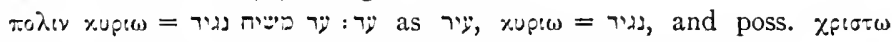
$[x \cup p เ \omega]=\pi$ was once read. An identical loss mav have occurred at $I^{22}$.

In the following comparison for $v v^{25 b-27}$ I have followed the order of ; the equivalents in $\mathbb{B}$ are enlisted in the same order, with a numeral prefixed which indicates the place of the word or phrase in $\mathbb{B}$, and the doublets are arranged in parallelism. The Gr. begins at $\mathrm{v} \cdot{ }^{26}$ of Swete's text.

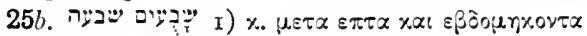

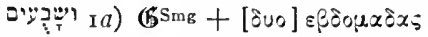

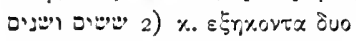

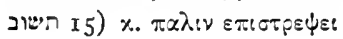




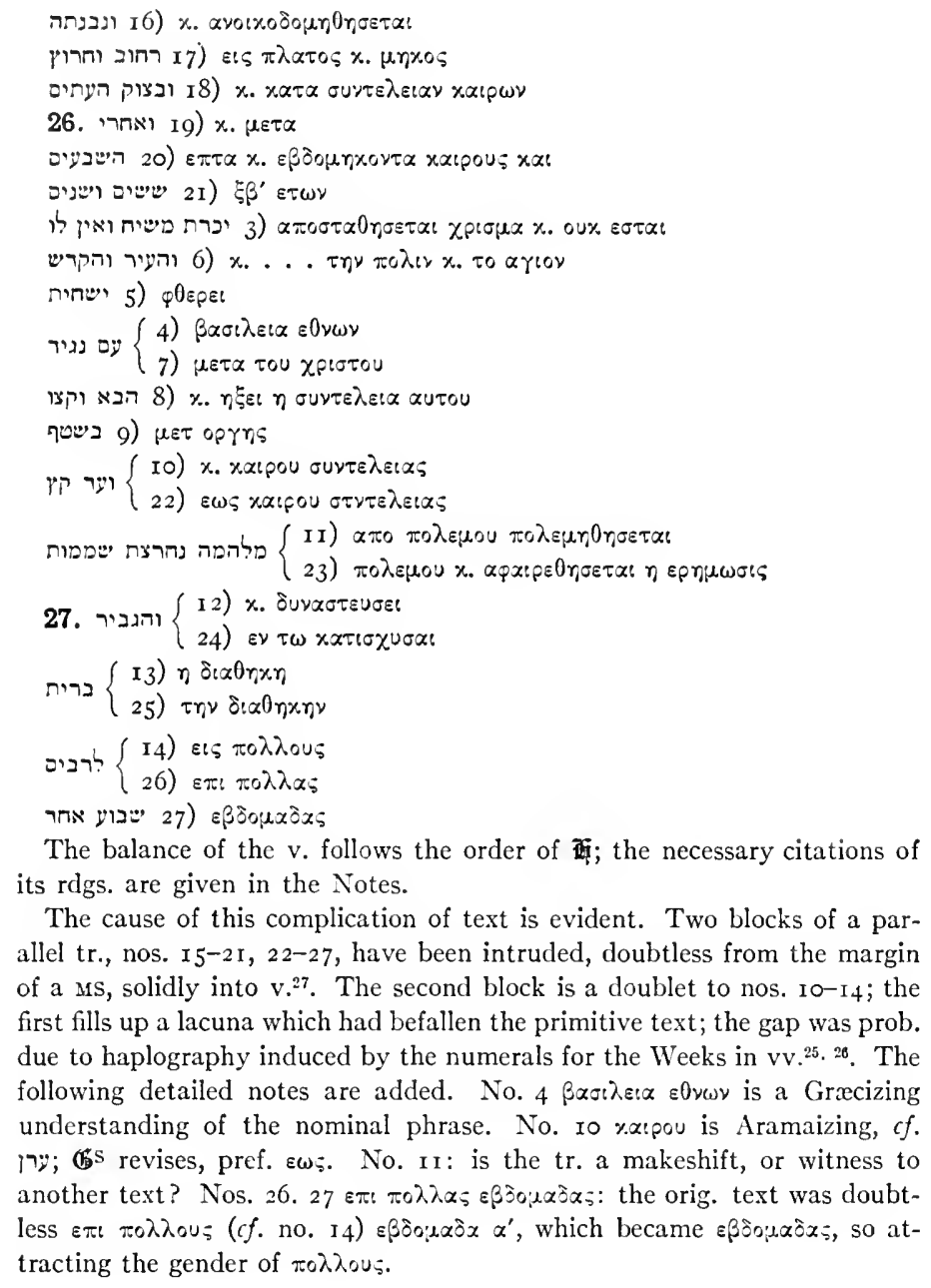

The balance of the v. follows the order of its rdgs. are given in the Notes.

The cause of this complication of text is evident. Two blocks of a parallel tr., nos. $x_{5-21}, 22-27$, have been intruded, doubtless from the margin of a MS, solidly into $\mathrm{v}^{27}$. The second block is a doublet to nos. IO-I 4 ; the first fills up a lacuna which had befallen the primitive text; the gap was prob. due to haplography induced by the numerals for the Weeks in vv. ${ }^{25}{ }^{26}$. The following detailed notes are added. No. $4 \beta \alpha \sigma: \lambda \varepsilon เ \alpha \varepsilon 0 \nu \omega \nu$ is a Græcizing understanding of the nominal phrase. No. Io xappou is Aramaizing, $c f$. 17 ; $\sigma^{5}$ revises, pref. $\varepsilon \omega 5$. No. II: is the tr. a makeshift, or witness to another text? Nos. 26. $27 \varepsilon \pi ! \pi 0 \lambda \lambda \alpha \varsigma \varepsilon \beta \delta 0_{j} \alpha \alpha_{\delta} \alpha_{5}$ : the orig. text was doubt-

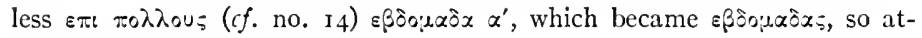
tracting the gender of $\pi 0 \lambda \lambda$ ous.

\section{(2) THE TEXTS OF $\Theta$.}

A doublet of parallel translations appears in $v .{ }^{27}$ in the great majority of Mss, in all but B 42 I 3022923023 I 232 and the text in Eus., Dem. $c v$., viii, 2. The parallelism, which can be followed in Swete's apparatus, may be thus exhibited: 


$$
B=\Theta .
$$

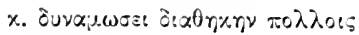

$\varepsilon \beta \delta \circ \mu x \leqslant \mu<\alpha$

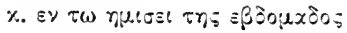

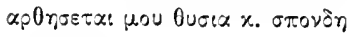

x. $\varepsilon \pi t$ то เеро

$\beta \jmath \approx \lambda \cup \gamma \mu x \tau \omega \nu \varepsilon p r \beta \omega \sigma \varepsilon \omega \nu$

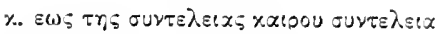

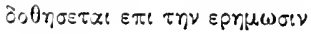

$A(Q$ etc. $)=\Theta^{\text {var }}$.

$$
=
$$

$=$

$=$

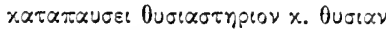

x. $\varepsilon \omega \varsigma \pi \tau \varepsilon p u \gamma t o u$

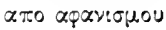

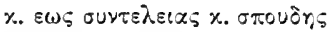

$\tau \alpha \xi_{\varepsilon !} \varepsilon \pi ! \quad \alpha \varphi \alpha \nu ! \sigma \mu \omega$

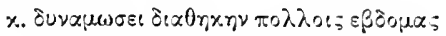

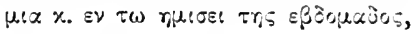

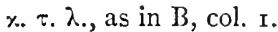

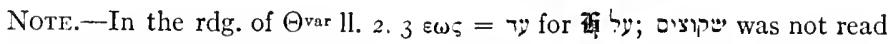

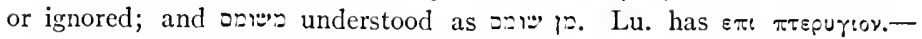
The Constanz fragment published by Dold for vv..$^{25-27}$ agrees with B. But for the passage cited above there is entered a doublet for 'abomination of desolations': 'tolletur sacrificium meum et supplicatio (error for libatio) desolationum interitus et ad sacrificium abominatio et usque,' etc.

The doublet in A, etc., has been clumsily entered into the text with the

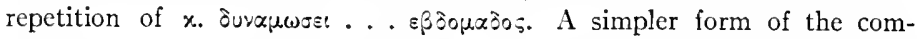
bination appears in Clem. Alex., Strom., i, 21 (ed. Potter, p. 393). He follows

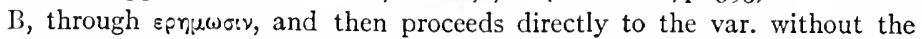
joint. In the double occurrence of 'the half of the week,' with which the parallels begin, Clem. has against $\Theta$ texts, exc. $V+8$ sss, the literal tr.

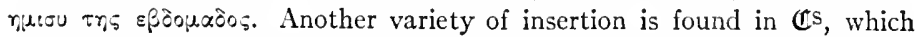

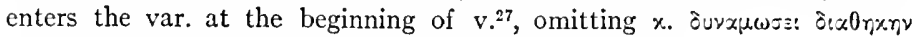
$\pi 0 \lambda \lambda$ oes, thus: 'A week, and the middle of the week,' etc.

These various methods of insertion argue to parallel blocks of translation appearing on the same page, that of the var. being probably on the margin. What is the origin of the var.? The simplest explanation is that it is the Origenian revision. But I was balked in this opinion by the fact that the

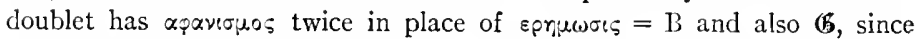
aqxveruos 'evanishment' and its vb. $=$ one are peculiarly Theodotionic, cf. $9^{18 .}{ }^{26}, \mathrm{I}^{31}$, while the common term of $\mathbb{B}$ appears only in $8^{13}, \mathrm{I}^{11}$ (only

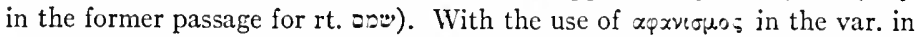
$\mathrm{v} .{ }^{27}$ the section fits in with its occurrence in $v .{ }^{26}$. Further for the var. tr. of

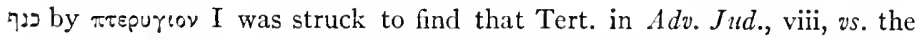
usage of all $\mathbb{T}$ texts, which he also cites in the same chap. (ct in sancto cxsecratio uastationis), twice uses the true tr. destruere pinnaculum usque ad intcritum. But further both Clem. Alex. and the old Coptic know the doublet. These facts make a demonstration of the pre-Origenian existence of the 
doublet, a proof reinforced by the fact that Eus.'s own careful citation of the passage follows $\mathrm{B}$, avoiding the doublet. We are forced to think of an ancient variant in the $\Theta$ tradition giving a more exact tr. of בנף. Whether it is older than the rdg. of the Textus Receptus of B it is impossible to decide. The use in its context of $\dot{x} p x v$ "'sę $y$ argues for the Theodotionic character of the variant, but the more exact tr. for a secondary origin. It is to be observed that the excellent master codex B simplified the doublet by rejecting one of the pairs.

\section{CHAPTERS 10-12. THE FINAL REVELATION.}

These chapters constitute one 'Vision,' the breaks introduced by our chapter divisions being fairly modern (s. Comm. at end of cc. IO. I I). The long narrative falls into three dramatic parts: C. $10-$ c. 11, 2a. Prologue: An angel's appearance to Dan. and the introductory colloquy; C. 11, 2b-c. 12, 4. The Revelation; C. 12,5-13. Epilogue: another dramatic scene and the angel's concluding words to Dan. The length and ponderous detail of the Revelation have properly motived the long introduction in c. IO.

\section{PROLOGUE $10-11^{2 \mathrm{a}}$.}

In the first year of Cyrus Dan. prepares himself by religious exercises for the boon of a revelation (1-3). Beside the Great River, after a three weeks' fast, he is vouchsafed the vision of a brilliant and awful personage, which completely unmans him (4-8). The being's voice casts him into a swoon, from which he is aroused by a celestial hand, and the being announces that he has come, as he was desired, with explanation of his delay (9-14). Still speechless, Dan. is restored by another celestial touch, he apologizes for his failure to respond; a third touch, to enable Dan. for the revelation, is followed by the being's announcement of the duties in which he is engaged, but of his purpose first to make the revelation $(\mathbf{1 5}-\mathrm{c} . \mathbf{1 1}, \mathbf{2} a)$. The scene is dramatically constiucted and with psychological verisimilitude.

1-3. The introduction. 1. In the third year of Cyrus king of Persia a word was revealed unto Danicl, who was called Belteshazzar. And the word was true, but a great task; and he understood the word and there came to him understanding in the vision. For 
the introductory 3 d person in $v \cdot{ }^{1} c f .7^{1}$. The date at first appears to contradict the statement of $I^{21}$ that 'Dan. remained until the first year of Cyrus'; but s. Comm. at $\mathrm{I}^{21}$. ( $\mathbb{6}$ has here 'first year,' which may be a harmonizing change to agree with $\mathrm{I}^{21}$ (acc. to Cha. made after the addition of the latter v., as by his theory), or rather a primitive error, s. Note. We cannot control the datum of the third year any more than the third year of Belshazzar's reign, $8^{1}$; it implies that Dan. did not return to Palestine with the first Return, Ezr. I, while acc. to $v .{ }^{4}$ he was still in Mesopotamia. The designation of Cyrus as 'king of Persia' was not contemporary usage; the Pers. king was entitled 'the king,' 'the great king,' 'king of kings,' or after his conquest of the Babylonian empire 'king of Babel,' 'king of the lands'; s. Dr., Int., $345 f$. Cyrus was 'the Persian king' only later acc. to Hellenistic use. The repetition of the cognomen 'Belteshazzar,' while superfluous, was according to the usage of the day; $c f$. the frequent repetitions of cognomens in the Gospels. For the terms 'word' and 'vision,' cf. $9^{23}$, upon which passage the language here depends. The 'word' is the divine utterance, the 'vision' the revelation; the word is impotent until divine grace unfolds the mystery. And so a progress is prob. implied in the last two sentences of the v., lit. 'and he understood the word and understanding [was] his in the vision,' with the repetition of the rt. $\left\lceil=\right.$; cf. in $9^{23}$ the parallelism of $i=\mathrm{Kal}$ and Hif. with similar mance of progress. The word here translated 'task' has been a notable crux in consequence of its ambiguity. The VSS tr. on

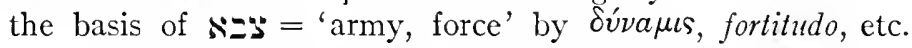
Jewish comm. developed an interpretation as of 'appointed time,' so Ra. here ( $j i \mathbf{i})$, on the basis of Job $7^{1}$, etc., where Kimhi (s. Dr.) similarly tr.; and so most early Prot. comm., e.g., Calv., $\mathrm{AV}$, 'the time (appointed) was long,' like Job $7^{1}$. But GV with originality 'eine grosse Streit,' and so, c.g., Geier, of the militant future of the Church, CBMich., with ref. to the wars human and divine foretold in the foll. prophecy; so Bert., al., Dr. = RVV JV 'a great warfare.' VLeng. offered 'the trouble is great,' rightly substantiating this tr. from Job, and so, e.g., Stu., Zöck., Mein., Behr., Pr., Cha. But most pertinent is Häv.'s tr., making the word refer to the 'Anstrengung' of the prophet as depicted in $\mathrm{v}^{2}$ and implied in the long and exhausting revelation following. And so Bev. suggests that possibly it means an 
'obligation' or 'charge' laid upon Dan. The prophet was commandeered for a great service in behalf of the divine revelation.

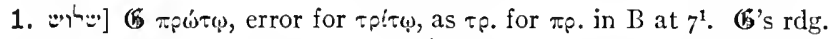

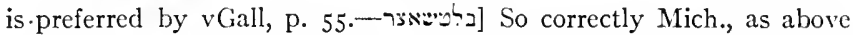

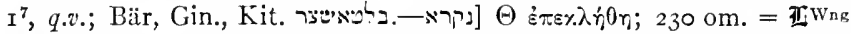
cui nomen Bal.; OrP's order $\mathrm{B} \alpha \lambda \tau$. $\varepsilon \pi \varepsilon x$. indicates latter as secondary.

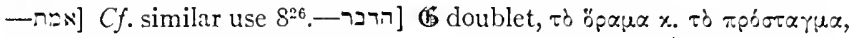

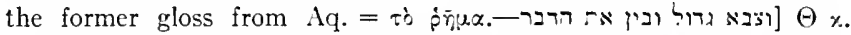

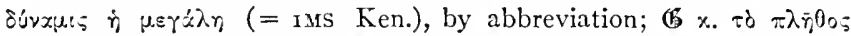

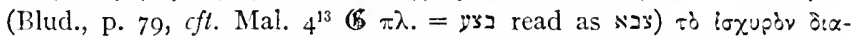

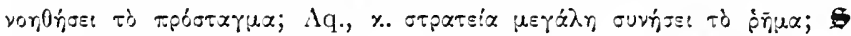
(helping out sense with a prep.); II et fortitudo magna intellexitque sermonem. Thus $\mathbb{B}$. Aq. disagree with in $\mathrm{rdg}$. יבי. In connection with the tr. proposed above of as 'task' it would be plausible to emend to (inf.) or לין לין i.e., 'a great task to understand.' ב as usually interpreted as of a pred. statement gives trouble; Hitz., Mar. take it for an abbreviated Hif., but s. on נינרי $9^{2}$; Kön., $L g b$., I, p. 504, as a variant form of the Kal; Bev., Behr. as an abs. inf., although the comparison with $709^{11}$ is fallacious, as there the inf. follows a series of finites.-W: Lamb. practically agrees with the interpretation suggested in the prev. Note. He understands $\%=$ Aram. Is 'thing,' and paraphrases, 'it was a great, i.e., hard thing for Dan. to understand the vision.' Sa. has a similar etymology for 's, marâd, i.e., a 'great meaning' in the revelation. It may be noted that 's is used of sacred tasks, as those of the Levites. Jer. offers two interpretations, that 'strength,' fortitudo, is either God's or the prophet's,

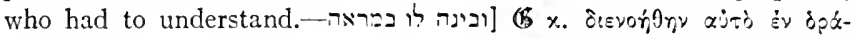
$\mu \alpha \tau t$; error of the Ist pers. maintained by $\$$ 'and I understood.' II paraphrases, intelligentia est cnim opus in uisione.

2. 3. The seer takes up his story. 2. In those days I Daniei was mourning for three whole weeks; 3 . pleasant food I did not eat, nor did flesh and wine come into my mouth, nor did I anoint myself at all, until the fulfilling of three full weeks. Aph. Syr. calls attention to the identity of this 'mourning' with fasting and cites Mt. $9^{14 \mathrm{f}}$, where $\nu \eta \sigma \tau \epsilon \dot{v} \epsilon \iota \nu=\pi \epsilon \nu \theta \epsilon i \nu ; c f$. the Biblical and Jewish terms for fasting, תינעיתית, 'affliction,' on which s. at $v .{ }^{12}$. The 'pleasant food (bread)' is the opposite of 'the

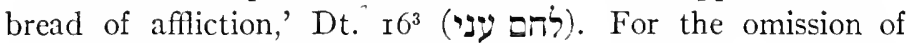
anointing in times of 'affliction' s. $D B$ I, I00, $E B$ I, I 73. There is a reminiscence of this $\mathrm{v}$. in Test. Reuben, $\mathrm{r}$, ro. With this 
act of fasting $c f$. the similar story in $9^{3}$. But that is an act of contrition by the saint for himself and his people; while here, as Hitz. observes, there is a psychical preparation for receiving a revelation. $C f$. the seven days' preparation of the seer in 2 Esd. for his second vision, $5^{13.20}$, also 6 ${ }^{35}$, etc.; Apoc. Baruch $5^{7}$ (s. Cha. ad loc.), $9^{2}$, etc.

2. ישבעים ימים] = calendar weeks, cf. Gen. $4 \mathrm{I}^{1}$, Dt. $2 \mathrm{I}^{13}, 2 \mathrm{Sa} . \mathrm{I}^{23}$, and s. GK $\S_{3} \mathrm{I}$, d. -3. .

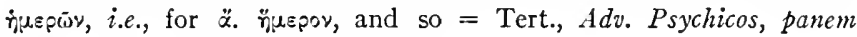
suauem; whence this correspondence?

4-8. The angelic vision. 4. And on the twenty-fourth day of the First Month, as I was beside the Great River [零 which is Tigris], 5. then I lifted up my eyes and saw, and behold, a man clad in linen, with his loins girt with gold and fine-gold, 6. and with his body like beryl, and his face like the appearance of lightning, and his arms and feet like the glance of burnished bronze, and the sound of his words like the sound of a multitude. 7. And I Daniel alone saw the vision, and the men who were with me saw not the vision; but a great trembling fell upon them and they fled hiding themselves. 8. And I was left alone, and I saw this great vision; and there remained no comeliness in me, for my comeliness was turned in me into disfigurement, and I retained no strength.

4. It is not apparent what significance there is in the dating of Dan.'s long fast of three weeks terminating on the 24 th day of the First Month. The period includes the Passover festival and its Mașoth accompaniment. The first month is Nisan, and here the elder, numerical designation is used as against the later use of the Bab. names; s. Morgenstern, 'The Three Calendars of Ancient Israel,' in Hebrew Union College Anmual, I924, p. I9 et passim. For the seer's haunting the riverside $c f .8^{2}$, and inf. $I 2^{5}$. As by 'the Great River' is always meant elsewhere the Euphrates, Gen. $2^{14}$, Josh. $\mathrm{I}^{4}$, it is advisable, with Behr., Mar., Cha., Ehr., to regard the following clause, לחי = 'i.e., Hiddekel,' as an early gloss ( $c f$. a similar gloss in Ju. $5^{5}$, 'this is Sinai'). Otherwise we must attribute a solecism or gross error to the writer. silently corrects to 'Euphrates,' and $\mathrm{HP} 34$, a Ms with many peculiar rdgs., to $\mathrm{X} \omega \beta a \rho$, i.e., the Chebar of Eze. 5. 'Then I looked and saw' cf. $8^{3}$. The word בדיב 'linen' is 
so translated by $\left(\mathfrak{S} \beta \dot{v} \sigma \sigma \imath v a\right.$, as also $12^{6.7}$, I Ch. I $5^{27}$, but $\Theta$ transliterates, and other VSS variously tr. The word represents some distinguished kind of clothing (so Aq. I A). It was the dress of the priests, e.g., Lev. $6^{10}$, and of the angelic man in Eze. $9^{2 .}{ }^{3 .}{ }^{11}$, I0 ${ }^{2 .}{ }^{6.7}{ }^{7}$, distinguishing him from his comrades. $C f$. the angels clad in pure, shining 'linen' ( $\lambda\left(\dot{\prime} \nu \nu \nu\right.$, not $\lambda^{\prime} \theta 0 \nu$ with many MSS) in Rev. 156. T. C. Foote, The Ephod, r902, 47, explains ' 2 as of the antique, ritual loin-cloth. In Eze. 9 it is translated by $\pi \circ \delta \eta \rho \eta s$, a long garment reaching to the feet, which is repeated Rev. $\mathrm{I}^{13}$ in reminiscence of this passage; and this is the prob. mng. of the word here. For the tr. 'gold and fine-gold,' representing two rare words for 'gold' on basis of an emended

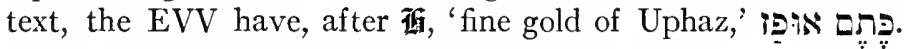

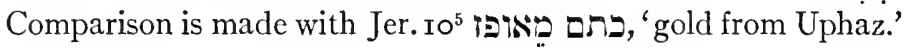
But there is no place Uphaz known. Accordingly the word has been emended by some to "אוֹ 'Ophir,' on basis of Targ. at Jer. ro ${ }^{5}$; so still Mar., Kön., Hwb. But is a term for (some kind or quality of) gold, used in parallelism with 2 if (the common word), corrected to בתם ופם, and similarly in the present form is is a spelling for: S. Lexx. for occurrences of the terms and discussions, Behr., and esp. Haupt, Book of Canticles (= AJSL I8, I93 ff.; I9, I ff.) at $5^{11}$, p. $63, c f$. p. 40 , and his paper, 'Gold and Silver in Hebrew,' $J A O S 43, \mathrm{I} \mathrm{I}_{6-\mathrm{I} 27}$, pp. I $23 f$., for ketem and paz. 6. The passage is reminiscent of the Theophany in Eze. I. The 'beryl,' also Eze. I ${ }^{16}$, as EVV here tr., = shish-stone, has been variously identified: with the chrysolith (as in renderings of $(5$ elsewhere), topaz, etc.; s. $D B$ Petrie, 'Stones, Precious,' and EB Myres, 'Stones, Precious,' and arts. 'Beryl,' 'Chrysolith,' 'Topaz,' 'Tarshish'; also for a recent study of the precious stones and stuffs of the Bible, Schoff, 'The Ship "Tyre", (Macmillan, I920), p. I21, etc. A good review of the elder literature is given by Blud., p. 93. Here Aq. and $\boldsymbol{1}$ alone give a translation, 'chrysolith.' The description continues the reminiscence of Eze. I from v. ${ }^{13}$ : 'their appearance was like coals of fire and burning like the appearance of lamps, . . . and out of the fire went forth lightning'; and, from v.7, '(their feet) sparkled like the glance of polished brass.' And finally our phrase, 'the sound of his voice was like the sound of a multitude,' 
reproduces Eze. $\mathrm{I}^{24}$ : ' $\mathrm{I}$ heard the sound of their wings like the sound of great waters, like the sound of Shaddai, in their going a sound of a multitude ( the vision $c f$. that of the Risen Christ, Rev. $\mathrm{I}^{14 f}$. To the seer's as yet untuned senses the angel's reverberant voice seemed inarticulate. For the terror of Dan.'s companions, v. ${ }^{7}, c f$. the story of St. Paul's vision, Acts $9^{7}, 22^{9}$; they had some sense of the mystical apparition. The word inadequately translated 'comeliness,' $-i-$, means the natural beauty of a living thing, its appropriate strength and grace. The rt. of the word translated 'disfigurement' appears in Is. $5^{2^{14}}$, 'so was his appearance disfigured (AV marred) from human form.'

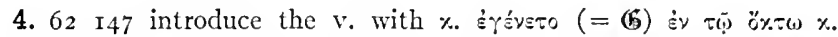

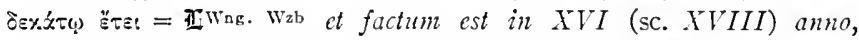
and so $\mathrm{A}$; a primitive gloss, repeated from the gloss in $(\mathfrak{5} \Theta$ at beginning of c. 3 , surviving in widely distributed mss.-חרקי $\Theta$ (exc. Lu.) T:Yp:s

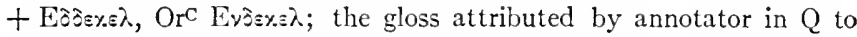

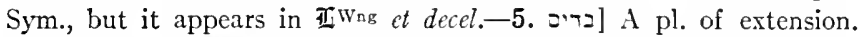
$\Theta \beta x \delta \delta(\varepsilon) \div v(-\mu)$, 还 baddin; Aq.

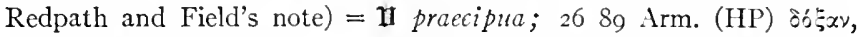

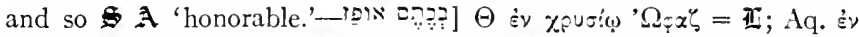

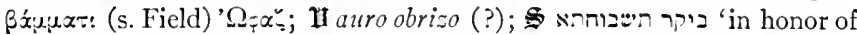

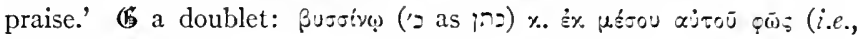

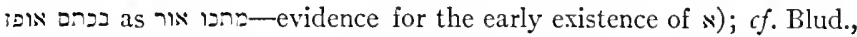

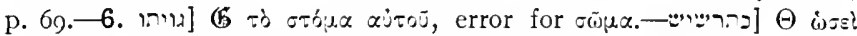
0xposts. has the remarkable paraphrase, 'and his appearance was different ( poss. a phonetic development from a transliteration; Blud., p. 93, notes

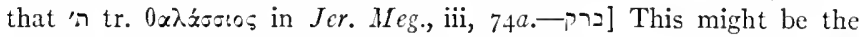

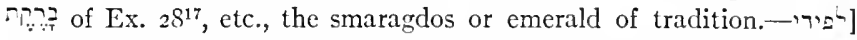
Properly 'torches,' it may well be translated by 'lamps' with Grr., $\mathbf{H}$,

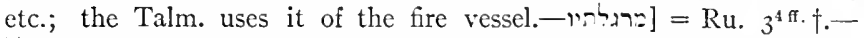
Sh] Eze. $I^{7} \dagger$. The mng. is unknown, the VSS in both places 'shining,' and Targ. to Eze., 'burnished.' This is supported by the inter-

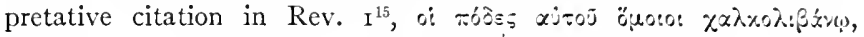

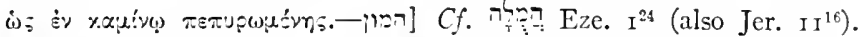
K.b., Dan. supports the text of for those two words, suspected by

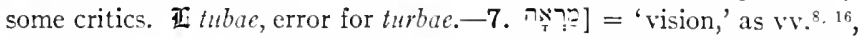
distinguished from בְּר 'sight' $r .{ }^{18}$. $\Theta$ preserves the distinction with

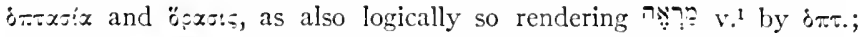

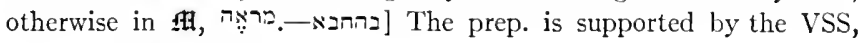




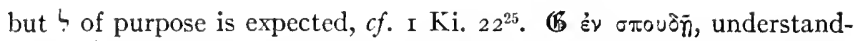

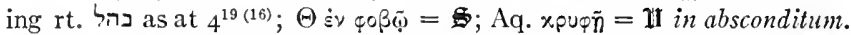

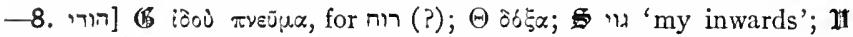
species.—. [. After common Bibl. language psychological experiences come from without upon the subject; $c f .5^{9}, 7^{28}$, and the expression above 'fear fell upon them'; also s. at $2^{1}$.— passing from the idea of the agent or agency to the result effected.

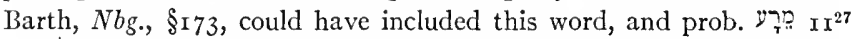

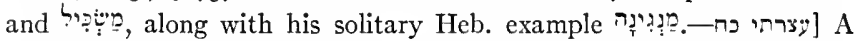
late idiom found else only $v^{16}, \mathrm{II}^{6}$ and in Ch. In the 'Weitschweifigkeit' of the diction there is hardly reason, with Behr., Mar., Cha., to regard it as interpolated from $v{ }^{16}$.

9-14. Daniel's stupor, and the angel's introductory address. 9. And I heard the sound of his words, and when I heard the sound of his words then I fell in a swoon on my face, with my face to the ground. 10. And behold a hand touching me; and it shook me up upon my knees and the palms of my hands. 11. And he said unto me: Daniel, dear man, give heed to the words I am going to speak to thee, and stand upright, for now I have been sent to thee. And upon his speaking to me this word I stood up trembling. 12. And he said to me: Fear not, Daniel, for from the first day that thou didst set thyself to understand and to affict thyself before thy God, thy words were heard, and so I have come because of thy words; 13. but the Prince of the kingdom of Persia was standing against me for twenty-one days, and lo, Michael, one of the Chief Princes, came to help me, and I have left him [i $I$ was left] there with the kings of Persia. 14. And I have come to make thee understand what shall befall thy people at the end of days; for there is a further vision for the days.

9-11 are directly dependent upon $8^{16-18}, 9^{21-23}$. With v. ${ }^{9}$ the seer's attention becomes possessed with 'the sound of his (the angel's) words,' $c f$. v. ${ }^{6}$; and as the voice seemed to become articulate, he swooned, $c f .8^{18}$. The clause 'then I fell' is taken by Bev., Kamp., as circumstantial, 'now I had fallen'; but a new moment, not a circumstance is presented, that of the loss of consciousness, requiring divine recuperation; for the syntax of the clause, s. Dr., Tenses, 10 admirably depicts the return to consciousness; 2 Esd. $5^{14 \mathrm{f}}$. recalls the passage. The Hand 'shook him up' (GB 'aufrütteln') to semi-prostrate position; $c f$. $\mathrm{GV}$ 'rührte mich und half mir.' In the process of the scene this 
tr. is preferable to that adopted by Behr., Dr., Mar., Cha., RVV JV, 'set me tottering.' 'The Grr. do not support Cha.'s proposed elision of 'upon my knees,' etc. The affectionate address in v.11 is from $9^{23}$; for the expression 'stand upright' s. $8^{18}$, and for 'now (i.e., at last) I have been sent' $c f .9^{22}$. The Heb. vb. 'send' involves the notion of a message. 12. Dan.'s quest had been known in heaven from the very beginning of his fastings and prayers, and so the angel has come. For similar responses to pious exercises $c f$. the vision to Zacharias, Lu. $\mathrm{I}^{1 \mathrm{If}}$, and to Cornelius, Acts ro $^{3 \mathrm{ff}}$. 'To understand and to afflict thyself' is practically a hendiadys, with Bert., the self-mortification being a preparation for a desired revelation; this despite the ultraProtestant objections of Häv., who argues that it was Daniel's words that were heard. The vb. translated 'afflict thyself,' igyn, is a technical one, $c f$. Ezr. $8^{21}$, parallel to the phrase 'afflict the soul (self)' in the regulations for the Day of Atonement, Lev. $16^{29}$, etc., $c f$. Ps. $35^{13}$. In Ezr. $9^{5} 5$. term for self-mortifying exercises, and it became later the technical term for fasting. Luth. bravely tr. 'kasteien,' which AV copied with 'chasten,' more weakly RVV JV 'humble.' 'Selfmortification' would be the corresponding term in Christian language. Of course prayer was included in these exercises, and so the angel came 'because of thy words.' 13. For the 'Princes' who are here introduced ( $c f .8^{13}$ 'the Prince of the Host'), s. discussion after $\mathrm{II}^{1}$. The $\mathrm{v}$. explains the delay of the speaker in coming to Dan.; he had been prevented on the way by the Prince of Persia, who desired to impede the divine oracle before it had been irrevocably published. 'There was war in heaven,' the present divine speaker requiring the assistance of Michael, one of the Chief Princes, to assist him in what were else a protracted and indecisive duel; $c f$. Rev. $12^{7}$, where Michael with his angels has become the protagonist against the Dragon. There is a problem in regard to the vb. of the last sentence in the v. If we would follow 'I was left, the various interpretations of the vb. are unexemplified from the use of the rt. יתר. or its more classical equivalent Such interpretations are many and diverse: $\mathfrak{H}$ remansi, 'I remained behind' = AV RVV 'remained'; or 'was left alone,' which Bev. helps out by making the clause circumstantial, 'I having been left alone'; 
or 'was delayed' with for which we should expect the common rt. ה over,' i.c., surviving (generally after a calamity!), as being left alone on the field, so Aq. $\pi \epsilon \rho \iota \epsilon \sigma \sigma \epsilon u \dot{\theta} \eta \nu, \mathrm{GV}$ 'behielt den Sieg' (original for Luther's age) = Geier, the rather banal 'was left over' of Dr., JV, and 'was not needed' of RVVmg = Ehr. 'wurde überfliussig.' The one recourse is to be had in the rdg. of (5) $\Theta$ 'I left him (i.e., Michael) alone,' rdg. הוזרת with most emendators, e.g., Bert., Mein., Behr., Gin., Kamp., Mar., Löhr, Cha. (Lamb. halting between this and Bev.'s syntax); or bet-

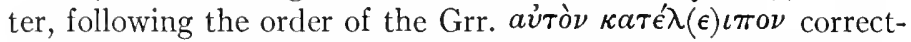
ing 'sis, with Graetz, for there is no reason to emphasize the ego of the speaker. Further, fif reads 'near the kings of Persia,' but (6) Aq. It the sing. 'king'; the evidence of Aq. (if correctly reported in $\left(\mathbb{b}^{\mathrm{mg}}\right.$ ) might favor this change, but the following chap. has too many similar variations on this score (e.g., 'king' vs. 'kingdom'), while the 'three, four kings' of $\mathrm{II}^{2}$ corroborates if here. The king is the 'Inbegriff' of his empire. But it is not necessary, with Bert., Mein., Behr., Dr., Mar., Löhr, Cha., to follow $\mathbb{B} \Theta+[\mu \epsilon \tau a] \tau o \hat{v} \sigma \tau \rho a \tau \eta \gamma o \hat{v}$ If ápxovtos, with their intrusion of 'the Prince [of the kings of Persia]'; we should expect simply 'the Prince of Persia,' as in v. ${ }^{20}$ (Bev.); here a conflation, 'the Prince of Persia.' 14. 'And I have come,' i.e., resuming the end of $\mathrm{v} .^{12}$, after the parenthesis of $\mathrm{v} .^{13}$; ' to make thee understand,' $c f .8^{16}, 9^{22}$, also $9^{23}$; ' what shall befall thy people at the end of days,' cited from Jacob's Blessing, Gen. 491. The final sentence, 'for there is still (a) vision for (pertaining to) the days,' i.e., the times to come, follows

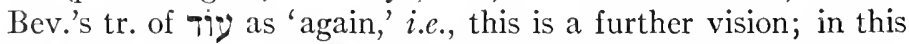
he was anticipated by 'again' (ת), and by Ra., 'to tell thee what has not been told thee, and it is yet to come for the many days which are given for the set time,' and $c f$. Calv. and JV. The usual tr. is with AV RVV, 'for yet the vision (the vision is yet) for many days,' with which $c f$. the end of $8^{17}$, 'for the vision is for a time of end'; but the parallel does not do justice to $7 \%$, unless the sentence is taken pregnantly: "the time covered by the vision is yet (indefinitely) to continue for (sc. many) days,' which requires the loss of the article with the latter word, and this Kamp. accordingly deletes on the basis of $\mathfrak{b} \Theta$. 
9. (5 has the first clause (which it pref. with a gratuitous $x \alpha$ i $0 \dot{u} \chi$ ), om. the second, 'and when I heard the sound of his words,' so also 4 sss Ken., 3 de R., $\Theta$ om. 9 . OrP ignores (= II audiens); OrC supplies the lacuna.-27r?!] The VSS

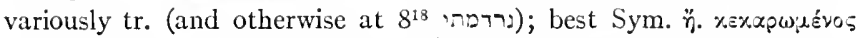

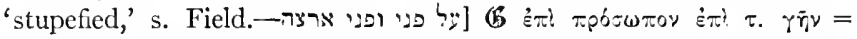

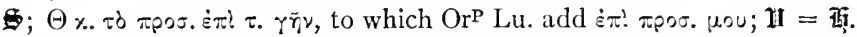

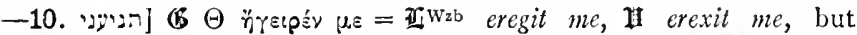
ע.

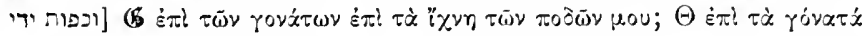

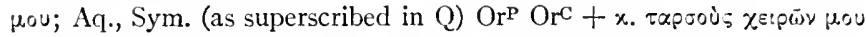

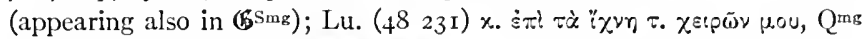

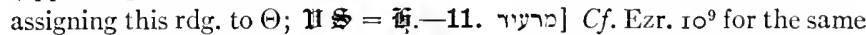
vb. and construction; for this pred. use of the ppl. cf. Dr., Tenses, §I 35, Obs. at end, Kön., Syn., §łI 2, a-f.-12. נרחר את לבך] A late idiom, found

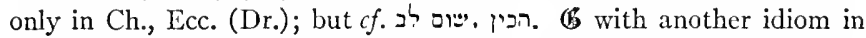

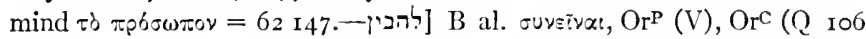
al.), Lu. ouvtévat.-בנדבריך] 3MSs Ken. ברברך, so (5), which Geier, Bert., Behr. prefer, = 'on thy account,' but unnecessarily.-13. מלכות] (5)

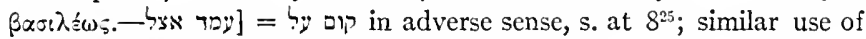

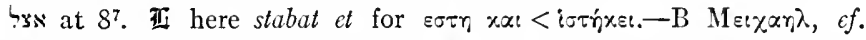

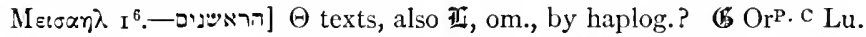

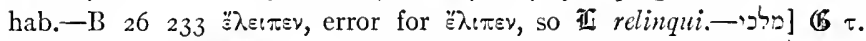

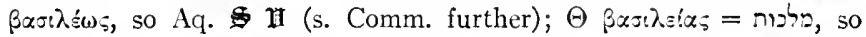
2Mss Ken.; om.-14. להבינך] 梁 has expanded, ut aperirem tibi intellectum ut scient.-רָּ: :] The vocalization may depend on the parallel

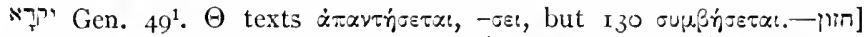

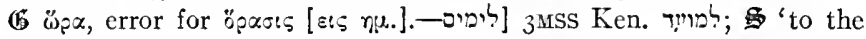
end of the days.'

15-c. 11, 2a. Dan. struck dumb is restored by a divine touch; the angel's colloquy with him. 15. And upon his speaking to me after these words I set my face toward the ground and was dumb. 16. And behold, like the similitude of a son [if sons] of man touching my lips. And I opened my mouth and spake and said unto him who stood before me: My lord, by the vision my pangs are turned upon me, and I retain no strength. 17. And how can my lord's servant here talk with that my lord, when for me now no strength can remain in me, with no spirit left in me? 18. Then there touched me again like the appearance of a man and strengthened me. 19. And he said: Dear man, fear not! Peace to thee! Be strong and stout! And upon his speaking with me I was 
strengthened, and I said: Let my lord speak, for thou hast strengthened me.

15. Despite Dan.'s return to consciousness, the angel's words struck him dumb, of. $8^{17}$. 16. But his consternation is dissipated, as in that earlier vision, $\mathrm{v}^{18}$, by another touch $\left(c f . \mathrm{v} \cdot{ }^{10}\right)$ as of a human-like being; $c f$. 'like the appearance of a man,' $v .18$, and 'the like of a son of man,' $7^{13}$. 'Similitude,' תiv, is frequent in the visions of Eze. ( $\mathrm{I}^{5 \mathrm{etc} .}, 8^{2}, \mathrm{IO}^{1 \mathrm{etc}}$ ), presenting apparitional forms which are not actually substantial; Bert. cft. Raphael's words in Tob. I $2^{19}$, 'In those days did I appear unto you, but I did neither eat nor drink, and ye saw a vision.' In the present instance, as with the hand of $\mathrm{v}^{10}$, the subject of the vision is fearful even of identifying the one who touched him; it simply was, as it were, a human-like touch. With similar indirection he speaks of his visitant as 'the one standing before me.' The divine touch restored Dan.'s speech, even as it gave voice to the prophets, Is. $6^{7}$, Jer. $I^{9}$. The phrase 'my pangs turned upon me' (with the figure of a flood), the language of childbirth, is repeated from the story of Ichabod's birth, I Sa. $4^{9}$; this figure of extreme desperation, frequent in the O.T., appears also in Is. $2 \mathrm{I}^{5}$ in the presence of another 'hard vision,' $\mathrm{v} .^{2}$. The last clause of the v. is repeated from $v .^{8}$. 17. The Eng. of the opening sentence attempts to tr. an idiomatic use of a particle repeated correlatively, like Germ. $d a$, Fr. $\varsigma^{a}$, for contrast; erroneously AV RVV 'this my lord . . . this my lord,' rather with JV 'this servant . . . this my lord.' The tr. of the particle פַערת as argumentative, 'accordingly,' 'now,' follows an ingenious suggestion by Ehr., adducing the frequent dialectic use of the term in the Talm. The usual lit. explanation as 'from now' and on, or 'straightway' with EVV, is properly criticised, e.g., by Bev.; but Ehr.'s explanation removes the difficulty. The foll. vb. is impf., and so tr. here by a potential, the next clause being circumstantial. There is reminiscence here of Ju. ${ }^{11}$; similar is the loss of 'spirit' to the Queen of Sheba through amazement, I Ki. IO ${ }^{5}$. 18. For this third 'touch' $c f$. vv. ${ }^{11 .}{ }^{16}$. 'The 'strengthening' of the Heb. is always primarily psychical or spiritual, after the genius of the ancient psychology. 19. $C f$. vv.11. ${ }^{12}$. 'Peace to thee!': generally the initial salutation in the O.T., e.g., in the address of letters, $3^{31}, 6^{26}$, etc. $=\chi a i \rho \epsilon \iota \nu$ in 
the letters in Mac., Acts $I 5^{23}$, Ja. $I^{1}$. $\mathbb{B}$ does justice to this with its usual tr. of $a b=\dot{v}$ yíaıve. $C f$. with the present passage the angelic salutation at the Annunciation, $\chi a \hat{\imath} \rho \epsilon, \kappa \epsilon \chi a \rho-$ $\tau \omega \mu$ év $\mathrm{Lu} . \mathrm{I}^{28}$. Here 'peace' involves both salutation and its fullest connotation. The foll. vbs., 'be strong and stout!' (with correction of if $_{\text {, }}$ s. Note) are the usual form of farewell, =

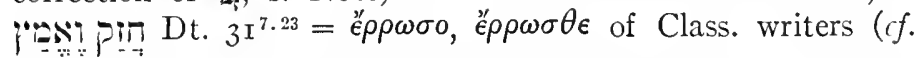

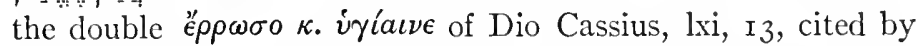
Thayer), of letters in the Gr. Bible, 2 Mac. $I^{21}$, Acts $15^{29}$, Mss $23^{30} ; c f$. the scribe's farewell at end of books of the Mass. Bible, Pin or pirngupin. Thus the Alpha and Omega of friendly greetings are given in these phrases, for the rendering of which modern trr. are inadequate. The seer forthwith is fully emboldened to receive the revelation.

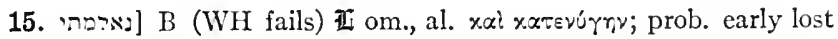

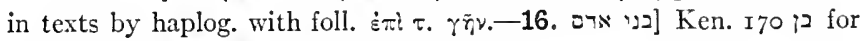

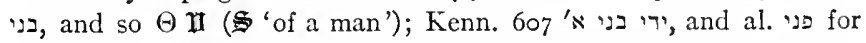
י. (5) Xsipds $\dot{\alpha} \vee \theta \in \dot{\omega} \pi 0 u$, as though ר. This rdg. is preferred by vGall, Mar., Löhr, but the ppl. should correspondingly be made feminine, $c f$.

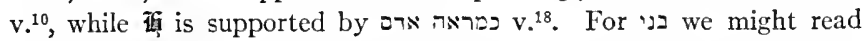
ב with VSS, supposing that, represents an annotated 1 or double

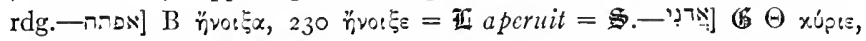

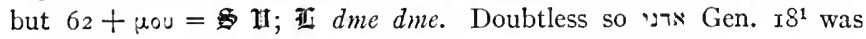

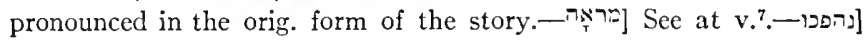
$C f$. the Akk. abâku; the vb. = 'turn upon' adversely, in Akk. = 'destroy,' etc.-'ר? ] The lexx. assume a distinct root, Kön., $H w b$. combining with ציר 'door hinge.' It should be derived from 'bind,' with the development șirr $>$ șîr, cf. Syr. hiirr $>$ hêr, 'noble,' and

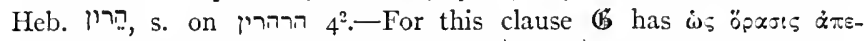

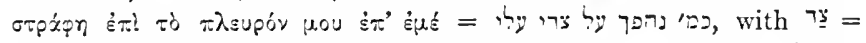

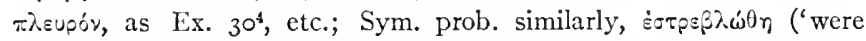

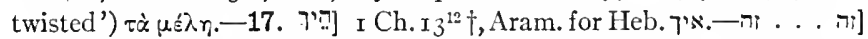
For the enclitic use of $\mathrm{n}$ s. BDB, p. 26I, for its correlative use ibid., 262. (B) II ignore both cases, $\Theta$ renders only the second. For the recession of the accent in ก Cha. prefer; other emendations in Löhr. om. See Comm.-Baw] B $89 \pi v \varepsilon u \tilde{\mu} \alpha$, al. $\pi \nu \circ \dot{\eta}=$ If flatus; $\pi \nu \varepsilon \tilde{u} \mu \alpha$ is contamination from $\mathbb{B}$, as

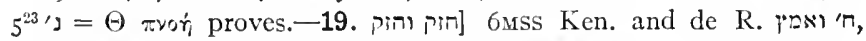

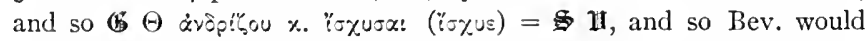
emend here (noting that in other cases of the repeated impv. the conj. 
is not used), followed by most recent critics, or with variations: Behr.

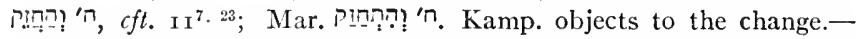
כרברו] So Bär (as on the best authority), Gin., Kit.; Mich. 'כר, the latter above vv.11. ${ }^{15}$; in all cases Grr. év.

20-c. 11, 2a. This passage may be arranged provisionally as follows:

20a. And he said: Knowest thou why I have come unto thee?

21a. But I will announce to thee what is inscribed in the Book of Truth. 20b. And now $I$ have to return to fight with the Prince of Persia; and when I go off, then behold, the Prince of Greece comes on;

21b. and there is none co-operating with me but Michael your Prince,

[c. 11, 1a. gloss: and I in the first year of Darius the Mede] $\mid \begin{aligned} & \text { 1b. standing [i my standing] } \\ & \text { as a helper and as a defence for } \\ & \text { me [i him]. 2a. And now I } \\ & \text { will announce to thee the truth. }\end{aligned}$

By following the lines across and down the page in the above scheme the text of can be read consecutively. It is at once evident that $\mathrm{vv}^{20 \mathrm{a} .}{ }^{21 \mathrm{a}}$ read together, as do similarly vv. ${ }^{20 \mathrm{~b} .}{ }^{21 \mathrm{~b}}$ seq. The present order is certainly chiastic. The conservative Stu. is forced to put $\mathrm{v} .{ }^{21 \mathrm{~b}}$ in parenthesis. One might think that we possess here an actual doublet of primitive origin; both of the parallel passages terminate with the identical promise to 'announce the truth.' Or else we have to agree with Mar. (after suggestions by W. R. Smith, Behr.), followed by Löhr, Lamb., Cha., in rearranging the parts thus: $\mathrm{Vv}^{20.21 \mathrm{~b}}, \mathrm{II}^{1 \mathrm{~b}}, \mathrm{IO}^{21 \mathrm{a}}$, and regarding $\mathrm{II}^{{ }^{\mathrm{In}}}$ as a gloss and $\mathrm{II}^{2 \mathrm{a}}$ as a further gloss that has entered as a doublet after the disarrangement. The difficulty of the passage has been recognized since Jer.; translating II $^{1}$ after if he interprets it as a parenthesis of Dan.'s ego: I was praying that Michael might be strengthened, with the very sensible apology that "it belongs to the habit of the Prophets suddenly to introduce persons without introduction," i.e., he observed the parenthetical nature of the v., differing from the Jewish and the usual exegesis of finding in it a continuation of 
the angel's address. The ' $I$ ' fails in 6 year I of Darius ( $\mathbb{G}$ followed by $\Theta$ has 'Cyrus'-by intentional adaptation to history) is trivial, of course to be referred to Darius' conquest of Babylon, $5^{30}, 6^{1}$, while it is entirely similar to the datings found in the introductions to other chapters. The similarity of this date to the introductory dates in other chapters has caused the unfortunate separation of c. II as a distinct chap. of the book. The distinction is not noted as a separate 'Vision' by the Gr. codices nor by $\mathbb{Z}$ and its ancient divisions (although a subtle change introduced by error in $\mathrm{Lu}$.

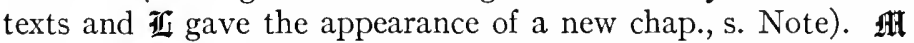
has a pasîk sathim here, so that must have been affected by the date formula. The distinction of a fresh chapter was taken up in the Mediæval Bibles. The above tr. further adopts the change made by Bev., al., changing is 'to him' at end of $\mathrm{v} .^{1}$ to '? 'to me,' with $\mathbb{B}(\Theta$ om., II with dent in one of the angels). Again the syntax of in this v. is

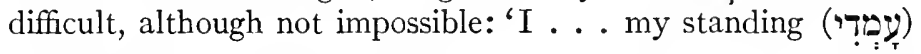
(was) for,' etc. A representative of this gerund was read by all

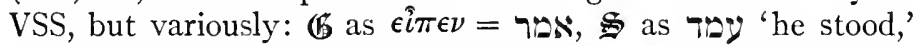
$\Theta$ by interpretation 'I stood.' The difficulty is relieved by Bev.'s reading עפר 'standing,' as adopted above. If we follow 年 we must accept the interpretation of most comm.: There is none helping me now but Michael, who is returning the kind offices I did for him in year I of Darius. But that is a very banal statement of the relations of the angelic vicegerent and Michael the prince of God's people.

The interrogative 'knowest thou why I have come,' v. ${ }^{20}$, is generally taken as equivalent to 'thou dost know,' e.g., Bev., Dr.; but with Stu., it is "rather designed to call attention than to make inquiry." As with the prophet's questions in Zech. I-6, the seer's curiosity is required and stimulated; the colloquy in Rev. $7^{13}$ is exactly similar. The 'fighting' with the Prince of Persia is regarded by Jer. as a legal process before God between the two adversaries, and so similarly many subsequent comm.; but interpretation must be posited on the ancient world's notion that human history is but a reflex of the great drama that is first enacted in heavenly places; for a Biblical mythological background $c f$. Is. $24^{21 \text { ff. }}$. The vb. in 'when I go off' has been 
variously interpreted: as from actual Persia (early Prot. comm.); from God's presence (Jer.); as going out to fight with Persia (after the common military use, so vLeng.); or coming forth out of the contest (Jeph., Bert., Bev., Dr., etc.); or Mar., 'so bald ich los bin,' with the implication that another contest with the Prince of Greece, who is to 'come in,' will begin. The parallel vbs. may best be taken as expressing the exit of the angel after his success over Persia and the introit of the Prince of Greece, for whose coming the angel has prepared (so Ra.); so the apposition of the two vbs., 'go off,' 'come on,' of the shifts of the guard in the palace, $2 \mathrm{Ki}$. $\mathrm{II}^{5-7}$ (Cha.). The adversative 'but' v. ${ }^{21}$ (Heb. ארבְ:) is best explained with the reconstructed position of $\mathrm{v}^{21 \mathrm{a}}$ at the end of the whole passage, as in opposition to the speaker's urgent martial duty: however I will wait to give the revelation. 'I will announce to thee': $c f .8^{19}, 9^{23}$. 'What is inscribed in the Book of Truth': the vb. is formal, of registering decrees, e.g., $5^{24}$, signing a document, 69. This 'True Book' is God's record of the past and the determined future, n.b., the notion of the Book's contents as a ledger of even personal description in Ps. $139^{16}$, and $c f$. Comm. on $4^{14}$ for the Jewish idea of predestination. This Book is the same as the Heavenly Tablets of En. 8I $\mathrm{I}^{\mathrm{l}}$, etc., and $c f$. Charles's note to $47^{3}$, p. 9I ; Bousset, Rel.d. Jud., 295 ff.

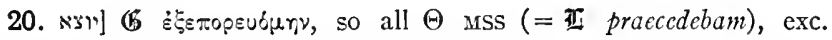

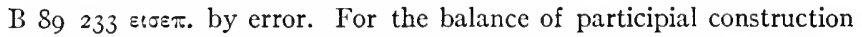

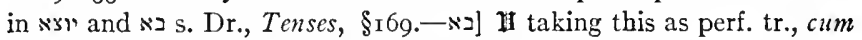
ego egredercr, apparuit princeps Graecorum ueniens, and Jer. in his comm. remarks that the latter Prince had taken the speaker's place in accusing the Prince of Persia.-21. הרישום

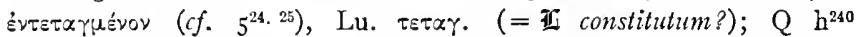

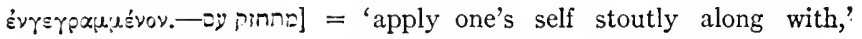
i.e., 'co-operate'; of. cuveprsiv ( $\mathbb{I I}$ at times cooperare), ouveprbs of N.T., also I Esd. $7^{2}$. The same ppl. appears in the 'Ain Dûk Aram. Inscr. of co-operating in the construction of the synagogue.-

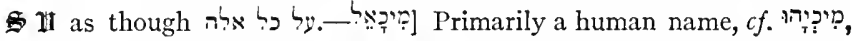

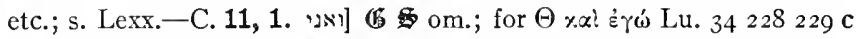

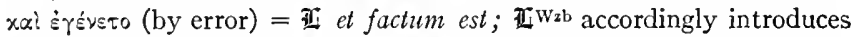

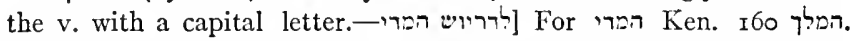

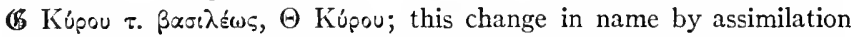
with ${ }^{1}{ }^{1}$, correct historically, but counter to the view of the bk. that 
the Medes overthrew that empire.-C For VSS s. Comm.; there is no more reason to think that $\Theta \mathfrak{H}$ read have changed the text when translating 'I stood.' For construction cf. the very dubious ' with foll. th as '?, 'he stood . . . for me.' We may best follow $\$$ Bev.'s suggestion, rdg. 'i: Assuming a change of orig. b to we may suppose a change of $7 \because$; to 1

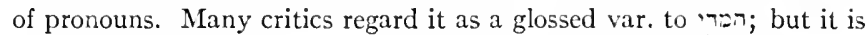

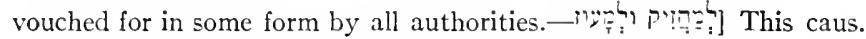
use of Hif. of הin is supported, doubtfully, by v. ${ }^{6}$; the vb. with ב (e.g., Is. $42^{5}$ ) is used in sense of 'support.' As the two nouns are distinguished by the repeated prep., it is not necessary, as GB suggests, to regard the first as an Aram. inf.; at most it might be explained as a

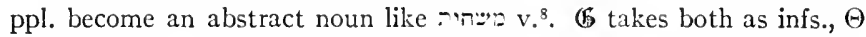
as nouns. "W appears freq. in c. II, e.g., $v^{7}$, in natural sense of 'stronghold,' here in sense of 'help, reinforcement,' and so freq., e.g.,

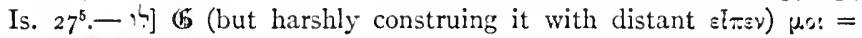
, so so $\Theta$ om.

\section{NOTE ON THE PRINCES AND ANGELS IN C. 10.}

The bk. of Dan. presents a full-fledged doctrine of the Princes of the nations, i.e., their celestial patrons. On the subject s. Dr.'s excellent note at v. ${ }^{13}$, Bousset, op. cit. 373 , and for later Judaism Weber, Jiid. Theologic, I 70. For the term we may compare 'the Prince (i.e., general) of the army of Y'нwh,' Jos. $5^{14}$. Foreign influence is not to be alleged primarily for the rise of this notion of national Patrons. Dt. $32^{18 \mathrm{f}}$. in the text corrected from 6 reads: "He fixed the borders of the pcoples according to the number of the Sons of God (i.e., the divinities); for the portion of YHwir is his people'; repeated by Ecclus. $17^{7}$. The malicious inference is drawn by Jub. $15^{31} \mathrm{f}$. that these spiritual chiefs were appointed to lead the nations astray. The undeniable existence of the $=$ ' 'divinities' of the nations ( $c f$. Ps. 82) was assimilated to the Jewish monotheism under the scheme of an imperial organization in the heavens. After the fashion of the Persian empire God assigned the several peoples to celestial satraps, our Princes, who, much after the fashion of the unwieldy Persian organization, quarrelled and fought with one another, requiring ultimately, tardily enough to the mind of the Saints, the intervention of the divine sovereign, or of his personal vizier, such as the angelic person of this chap. The scheme was a clumsy but inevitable kind of explanation for the mysteries of Providence in history, allowing room for the liberty of the creature in that drama, as Aph. Syr. wisely remarks at $v .^{21}$. In this chap. we learn of a Prince of Israel, of Persia, and of Greece; these were later expanded to Princes of the Seventy Nations (Targ. Jer. I to Gen. $\mathrm{II}^{7}$ ). Of those in Dan. only one is named, Michael the 
Prince of Israel. In Enoch Michael is one of the four or the seven archangels, along with Gabriel. For the vast expansion of theology about Michael, who later becomes identified with Metatron, etc., s. Lueken's monograph, MIichael, Gött., I898. Hipp., iv, 40, identifies Michael with the Angel who was to replace God in leading Israel, Ex. $33^{3}$, etc. He reappears again below, $I 2^{1}$, and in the N.T. in Jude ${ }^{9}$, Rev. $I 2^{7}$, in both cases as a con-

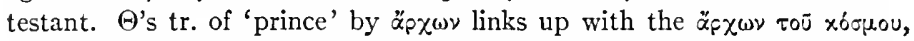
etc., of the N.T. (Jn. I $2^{31}$, Eph. $\mathrm{x}^{2}$, etc.); $c f$. the archons of the Gr. astrology.

The identity of the brilliant being described in vv. ${ }^{4} \mathrm{ff}$. has been much debated. Despite the dependence upon Eze. I he cannot be the Deity, for he was 'sent,' v. ${ }^{11}$. Early Christian exegesis naturally saw in him the Son of God, so Hipp., Aph. Syr. ( $c f$. the citation of our passage in the description of the Risen Jesus in Rev. I); and so dEnv. argues at length, pp. I332 ff. Or he is taken to be some unnamed angel, a third with Gabriel and Michael, e.g., by Jeph., Calv., Zöck. But it is simplest to identify him with Gabriel, who, according to En. $40^{\circ}$, is the angel 'set over all the powers,' and who is given the rôle of divine annunciator, v. sup. at $8^{16}$. The identification is supported by the repetition of the affectionate salutation, $c f$. vv. ${ }^{11.19}$ with $8^{23}$, and by the announcement of 'yet a vision,' v. ${ }^{14}$, as over against the visions in cc. 8. 9 mediated by Gabriel. Why he is here clad with such surpassing glory must be left to the genius of the writer; in Kabbalistic Judaism Michael was identified with the Shekinah (Lueken, p. 42). Gressmann, Israel.-jiid. Eschatologie, 345 ff., may be right in holding that this passage, like that in Eze. ( $c f$. also the King of Tyre, Eze. $28^{11} \mathrm{ff}$ ), has its traditional mythological background; but it is not necessary to follow him in regarding the apparition here as the 'Eschatological Man'; v. sup. on the 'Son of Man,' Note to c. 7. It belongs to the psychology of vision that the 'hand' of $\mathrm{v}^{10}$ and the 'touch' of 'one like a man,' vv. ${ }^{16 .}{ }^{18}$, are not identified as to the agents.

THE REVELATION, $11^{2 \mathrm{~b}}-12^{4}$.

This section presents a survey of history from the age of 'the four Persian kings' down through the Hellenistic age culminating in the reign of Antiochus Epiphanes, concluding with the prospect of his foredoomed ruin and the subsequent transcendental triumph of the Jews. It falls into several distinct episodes:

2b. The Persian age.

3. 4. Alexander and the division of his empire.

5-20. The conflicts of the Lagidae and Seleucidae prior to Antiochus Epiphanes, with these episodes:

5. Ptolemy I Soter and Seleucus I Nicator. 
6-9. The tragedy of Laodice and Berenice and the revenge taken by Ptolemy III Euergetes.

10-19. Antiochus the Great.

20. Seleucus IV Philopator.

21-45. Antiochus IV Epiphanes.

C. 12, 1-3. The final triumph of the Righteous.

4. Injunction as to the Book.

For the age prior to Epiphanes our writer offers several dramatically chosen acts: the passing of Persia; the empire of Alexander and the rise of the two dynasties between which Palestine was to become a shuttlecock; the tragic scandal of Laodice, involving Palestine; the exploits of Antiochus the Great, his rise, including the conquest of Palestine, and his fall. With the latter's sons, Seleucus and Antiochus, the writer enters upon contemporary history, and all that preceded is introduction to the figure who now enters on the stage, the God-defying and man-scorning Epiphanes.

This chapter is the first Jewish attempt at a universal history since the Table of Nations, Gen. Io; accordingly it has been subject of exploitation by profane historians as well as by Bible commentators. The writer gives the historian no new data until he reaches his own age, and even then his history is so veiled that all possible secular help is required for its interpretation; even of the contemporary Antichrist he sketches after all but an impressionistic view, and his 'apocalypse' is chiefly valuable historically for its presentation of inner currents of Judaism in that age. He is the Jewish counterpart of Polybius, who in I66 B.C. was taken as a hostage to Rome and who then doubtless, almost contemporaneously with this apocalyptic review, conceived the bold purpose to relate how it was that almost the whole world within some fifty-three years (220-r68 B.C.) fell under the single empire of the Romans (Hist., i, I, 5). The Romans do indeed appear in this chap. as people of 'the Isles' or 'Kittim,' but only as accessory instruments in the divine drama, which must have its 'catastrophe' $\left(\mathbf{6}^{28(27)}\right)$ in the vindication of God against the ne plus ultra of this world, Antiochus. The seer's view of the future was indeed foreshortened, he had no inkling that at a distant day emperors of that same Rome would fill for Jewish minds the rôle he created for the Antichrist. 
Thanks to the coaching of Jerome by the Pagan philosopher Porphyry a correct historical tradition of exegesis has obtained in the Western Church, both Latin and Protestant; and the same tradition has been at home in the Greek and Oriental Churches. For extensive reff. to the Classical authorities the reader can consult the comm. of the beginning of the last century, esp. Bert., vLeng., Häv., and among the moderns esp. Driver. Several admirable histories of the Hellenistic age have appeared in the last third of a century, and it has been deemed sufficient to refer summarily to them in most cases. The writer makes his acknowledgment to the following: B. Niese, Geschichte der griechischen und makedonischen Staaten, 3 vols., I $893-1903$, and the far briefer but most attractively written Griechische Geschichte, vol. 4, I894, by A. Holm (also in Eng. tr.); for the Syrian empire, Edwyn R. Bevan, The House of Seleucus, 2 vols., 1902, and A. Bouché-Leclercq, Histoire des Sélencides, I9I3; and for Egypt, J. P. Mahaffy, The Empire of the Ptolemies, I895 (paying special and genial attention to the side-lights from Jewish documents), and Bouché-Leclercq, Histoire des Lagides, 4 vols., I $903 \mathrm{seq}$. (cited by title for distinction from the other work). For Antiochus IV we have the invaluable thesaurus of E. Schürer, Geschichte des jiidischen Volkes ${ }^{4}$, the history being given in vol. I, rgor (an earlier ed. also in Eng. tr.); and to this should be added the recent work by E. Meyer, Urspring und Anfünge des Christentums, vol. 2, I92 I, esp. §v.

The commentator must steer cautiously between the Scylla and Charybdis of over-insistence upon the chapter's worth as a historical document and depreciation of it. Many problems of interpretation must therefore be left sub iudice. The inherent difficulty of the diction is increased by the many substantial variations in the authorities for the text; presents five substantial differences as between Kt. and Kr., and the VSS have further served to complicate the tradition.

At the end of the chap. will be given a Note on the history of its interpretation. We may note B. Szold, 'The Eleventh Chapter of the Book of Daniel,' in Semitic Studies in Memory of A. Kohut, pp. $562-572$; the theme is the character of the chap. as an 'epical survey' of the history; the writer attempts an arrangement in poetical lines.

$2 b$. The three remaining kings of Persia. Behold yet threc 
kings are to stand up for Persia; and the fourth shall be rich in riches greater than all; and when he is waxed strong through his riches he shall arouse the whole, the Kingdom of Greece [sic 7i ]. The writer finds himself in a small minority in identifying the four kings of Persia as Cyrus (and the three yet to come), Xerxes, Artaxerxes, Darius III Codomannus, the four Persian kings named in the Bible, the last one denoted as 'the Persian,' Neh. $\mathrm{I} 2^{22}$. For our book distinctly excludes the Median kingdom with its representative Darius (v.1) as preceding the Persian. But that position was taken by Saadia, as cited by AEz., naming Darius the Mede, Cyrus, Xerxes, Darius the Persian, a view known to Jer., who criticises it as 'in vain.' The oldest interpreter, Hipp., iv, 4I, found but four kings, Cyrus, Darius, Artaxerxes, Xerxes (sic). But Jer. interprets the text as of four kings after Cyrus, making 'the fourth' additional to the 'three.' And so Theodt., Jeph., AEz., Häv., Stu., Keil, Del., dEnv., Knab., al. But despite Stu.'s argument that 'the fourth' means 'a fourth,' the patent sense of the passage is supported by the actual four known to our writer. The first to try to equate the four or five kings with the actual sequence of the Persian line was Jer., who names Cyrus, Cambyses, Pseudo-Smerdis, Darius, Xerxes. Most recent comm., agreeing that four kings in toto are meant, obtain various combinations: Cyrus, Darius, Xerxes, Artaxerxes, so Bev., Pr., Mar., Cha., also identifying the four heads and four wings of the Persian leopard in $7^{6}$ as four kings; or Cyrus, Cambyses, Ps.-Smerdis, Darius (so Aph. Syr.) or, as an alternative, excluding the third and adding Xerxes, so Dr.; most comm. have preferred, after Jer., to find the great Xerxes at the culmination, and so Bert., vLeng., Mein. But this is bald interpretation from Western history; that the Jewish tradition had any memory of Xerxes' wars with Greece it is absurd to conceive. The crux of but four kings in Persian history was recognized by Jer., who explains: "non enim curae fuit spiritui prophetali historiae ordinem sequi sed praeclara quaeque praestringere." Behr. interprets the four as 'cyclic,' and Zöck. as 'symbolic.' But we must reject this rationalizing and follow the veritas biblica; Ra., true to the traditional Jewish chronology, notes at $10^{20}$ that there were but 34 years between the rebuilding of the temple and Alexander; on this foreshortening of history s. Note at end of c. 9 . 
'When he is waxed strong' (an ominous reminiscence of two evil kings of Judah, 2 Ch. $\left.\mathrm{r} 2^{1}, 26^{16}\right)$ : It is no foregone conclusion that this description must mean Xerxes, despite Est. and the Greek accounts of his marvellous wealth, e.g., Her., vii, $20 \mathrm{ff}$. It was the wealth of Persia in the possession of its kings that astounded the world and aroused the lust of Alexander. The next clause is obscure in the Heb., and we are not helped by the various interpretations of the VSS, which doubtless possessed our text. The prevailing opinion since Jer. that reference is made to Xerxes' wars against Greece has seemed to corroborate the usual tr., 'and he will stir up all (the nations included in his forces) against the kingdom of Greece.' But there is no 'against' in the text, for which the Heb. has the common acc. particle תي; we must tr. 柋, 'and he will stir up all, namely (?) the kingdom of Greece.' 'But the point is not that he made war against Greece (as far as Asia was concerned, Persia remained mistress, n.b., the Peace of Callias, 449 B.C.), but rather that the world was aroused against the king. It is possible to interpret $\mathrm{fi}$ as of the fourth king 'exciting the whole world' against himself, an implication which may take too much for granted. In that case 'the kingdom of Greece' may well be a gloss ( $c f$. the glosses in the Syriac Bible and s. on 'Egypt,' v. ${ }^{8}$ ), introduced to define the opponent, for through this chap. the kingdoms are referred to only by veiled allusions. 'The whole,' generally translated tout le monde, will then mean 'the whole world'; s. on this phrase W. H. Cobb, 'Note on a Hebrew Conception of the Universe,' $J B L$ 29, 24-28. If this interpretation, with the critical excision involved, may not stand, the only suggestion of value is that proposed by Torrey in his paper "Yawan" and "Hellas" as Designations of the Seleucid Empire,' JAOS 25,

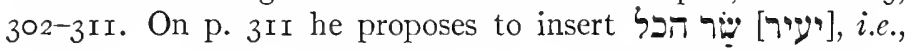
"the Prince of All will raise up [rdg. Tyע"] the kingdom of Yawan [in place of the kingdom of Persia]'; for the vb. in which amendment I would prefer to retain if 'will rouse up,' i.e., hostilely. For the divine title he cft. (q.v.), to which may be added the common Syriac divine title פטריא כל, sontgomery, JBL 3 I, I43 (cf. Acts 10 ${ }^{36}$ ). Torrey also holds that this fourth king can be none other than Darius Codomannus; "the writer derived his information from popular 
legend ... rather than from any authoritative text-book of Persian history." In the paper Torrey demonstrates that Yawan here and in similar reff. is not Hellas but the Greek, i.e., Seleucide empire in Asia.

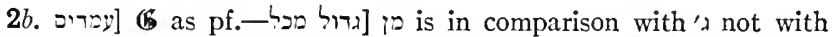
במת understanding יעיריר,

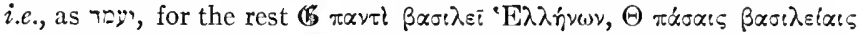

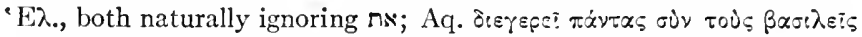

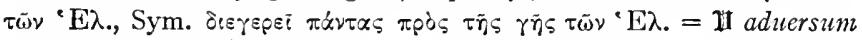
for $\mathrm{N}$ (2MSS Ken. 4 ); $=$ Aq., but 'all the kingdoms.'

3. 4. Alexander the Great and the division of his kingdom. 3. And there shall stand up a valiant king, who shall rule with great rule and shall do after his will. 4. And upon his standing up [or correct to his growing strong] his kingdom shall be broken and be divided to the four winds of heaven-but not for his posterity, nor after his rule as he ruled, for his kingdom shall be plucked up, yea for others apart from these. 3. Alexander is well

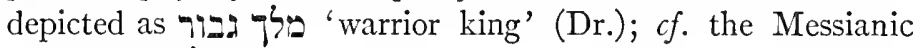

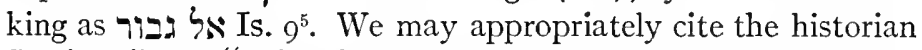
Justin, xii, I6: "When he assumed rule he ordered himself to be called King of All Lands and of the World. . . . He met no enemy he did not conquer, besieged no city he did not take, attacked no people he did not subdue." This king is the "notable horn' of the Buck in $8^{5 \text { ff. } 21}$. His marvellous rise is sketched in this single v., but to the Jewish mind the tragedy of the fall of his empire, $\mathrm{v}^{4}$, is more conspicuous. Are we to charge this difference of perspective to the provincialism of a hillside sect, or rather to a proud consciousness which looked farther than the phenomena of this world? The tragedy is well expressed by E. Bevan, I, 29: "In the spring of 323 before Christ the whole order of things from the Adriatic away to the mountains of Central Asia and the dusty plains of the Panjab rested upon a single will, a single brain, nurtured in Hellenic thought. Then the hand of God, as if trying some fantastic experiment, plucked this man away. Who could predict for a moment what the result would be?" 'He did after his will': Grot. cites Quintus Curtius: "By the favor of this Fortune, as it seemed to the nations, he did whatsoever he pleased." 4. Cf. $8^{8}$, "And when he 
(the Buck) grew strong (כעעצמי), the great horn was broken; and instead of it there came up the appearance of four horns to the four winds of heaven.' In our v. 'upon his standing up, 'כעטיו, must imply the brevity of his power (Mein.), with a possible play between the muances of the rt., 'stand up' and 'stand' ( $c f$. כוק). Graetz proposed to read after 88 כעיכצים, approved by most recent critics, including Kamp., Dr. It must be confessed that, if anything, we might expect contamination from c. 8 , but not a stupid error over against that obvious exemplar. The word 'kingdom' might better be expressed in Eng. by 'empire,' as denoting primarily imperium and only secondarily physical extent of the dominion (s. Comm. at $2^{48}$ ); this was particularly true of $\beta a \sigma \iota \lambda \epsilon u ́ s, \beta a \sigma \imath \lambda \epsilon i a$ in the Hellenistic age, s. Holm, p. 48, Bevan, I, 57. As noted at $8^{8}$, the divisions to the four winds of heaven are Macedonia, Thrace and Asia Minor, Asia-Syria, Egypt; but of these only the latter two are further described in this chap. 'Not for his posterity': Alexander's stupid halfbrother Philip Arrhidaeus, his posthumous son by Roxane, and an illegitimate son Herakles, who had been held as pawns by the would-be ambitious successors to Alexander, were done away with one after the other (in 3I7, 3II, 309 respectively). 'But to others apart from these': the antecedent is generally understood to be 'his posterity'; but Jer. interprets: in addition to the four kingdoms of the Diadochi also to the lesser states, Armenia, Cappadocia, etc., and so AEz., Grot., vLeng., Bev. The latter argues that 2 means always 'in addition to,' not 'to exclusion of,' and that $\boldsymbol{M \pi n}$ is to be expected. But we may have a unique use of the phrase; its Eng. equivalent 'apart from' can mean addition or exclusion.

4. B al. $\omega_{\Sigma} \tilde{Q} \nu \sigma \tau \tilde{n}$, but $Q 34230 \mathrm{~h}^{292} \omega_{\Sigma} \dot{\alpha} \nu \alpha \sigma \tau \tilde{n}, c f$. at v. ${ }^{1}$. $\Theta$ exegetes

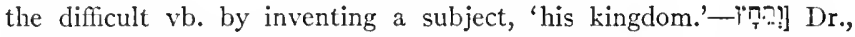
Tenses, $\$ \mathrm{I}_{7 \mathbf{I}} f$., esp. p. $2 \mathrm{I} \mathrm{S}$, Obs., holds that the Juss. mood is here used 'without any recollection of its distinctive significance'; but it is better with Kön., Syn., $\$ 364$, c, to take it as a case of 'consecutive

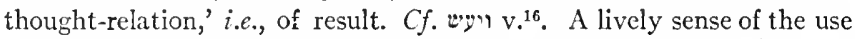
of the impf. survived in early Aram.; s. on ${ }^{16}$.- $7^{16}$ ou

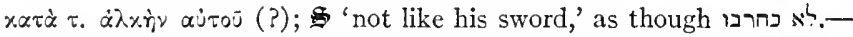

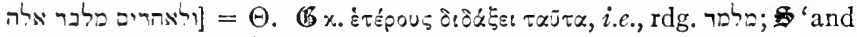
no other (i.e., ולא מלאר (I) apart from these'; paraphrases, exceptis his; 
Orc adds a vb. EoOn்øera!; construes with next v., et aliis extra haec walebit rex.

5-20. The conflicts of the Lagidae and Seleucidae prior to Antiochus Epiphanes.

5. Ptolemy I Soter of Egypt and Seleucus I Nicator of Syria. And the king of the South shall be strong; and one of his princes shall prevail over him and shall rule with a rule greater than his rule [if a great rule is his rule]. The drama quickly passes to those two successors of Alexander who alone attained among the many claimants to his empire and whose dynasties alone concerned Jewish history. The one, Ptolemy, the long-sighted statesman among the Conqueror's lieutenants, early chose Egypt, his wisdom confirmed by the maintenance of his empire for three centuries. The other, Seleucus, inherited his master's grandiose ambition of an Asiatic empire. At Triparadeisos in $32 \mathrm{I}$ he obtained as key position for his dominating purpose the satrapy of Babylonia. Fleeing from it to escape the despotic Antigonus in 316 he attached himself to Ptolemy and assisted the latter in the defeat of Antigonus at Gaza in 312; and hence he is correctly described in our text, from the Egyptian point of view, as 'one of his princes.' In the same year he betook himself by a forced march to Babylon and recovered his position. Before his death by assassination in his homeland of Macedonia in $38 \mathrm{I}$ he had the satisfaction of having obtained his ambition -an empire which stretched from the Panjab to across the Hellespont. 'His rule' was indeed 'a rule greater than his (Ptolemy's) rule,' as our writer says. He was 'the most regal and the ruler of the greatest extent of territory after Alexander,' so Arrian, Exped. Alex., vii, 22. 'The South,' properly 'the Negeb' (e.g., Gen. $\left.12^{9}\right)$, the land south of Palestine, used as a local point of the compass, is in this chap. applied to Egypt, as $\mathbb{6}$ always translates; $c f$. poss. Is. $30^{6}$. The syntax of the middle of the v. is peculiar in the Heb., made more difficult by the pointing of $\mathbb{A l}$, which is followed in EVV, but was not known to the VSS. A correction made by addition of a single letter in the last word of if, anticipated by Lu. and suggested also by Ehr., gives a much better reading than the rather staccato

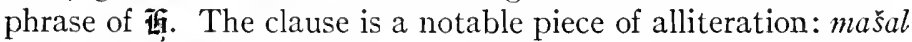
mimšal rab (mim)memšaltô. 
5. The VSS understand יומן שריו ויחזי The, exc. Sym. and his princes, and he will prevail.' Mein., Kamp., Mar., al., are inclined to delete the second conj., but the casus pendens is good Heb. construction, s. Dr., Tenses, $\$ \$ 196$ ff. The partitive use of $p$ to express an individual object is exceptional, poss. so in Ex. $6^{25}$; $c f$. Arab. $b a^{\text {c }}$ ' 'some

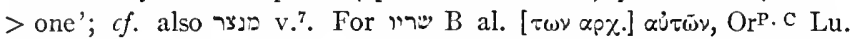

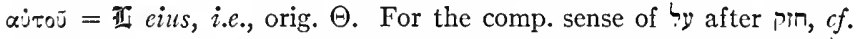
I Ch. $2 \mathrm{I}^{4}$; poss. the writer meant 'to conquer' as in $2 \mathrm{Ch}$. $8^{3}$. For $\Theta$ texts (B A Q V 2649878990$) \varepsilon^{\prime} \pi^{\prime} \alpha^{\prime} \tau \tau \tilde{\omega}^{\prime} \nu=$ Ii $a b(<\alpha \pi)$ his, primi-

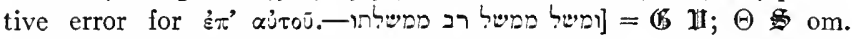

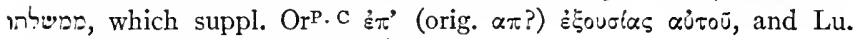

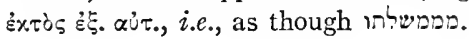

6-9. The tragedy of Laodice and Berenice, wives of Antiochus II Theos, and the revenge taken by Ptolemy III Euergetes against Seleucus II Callinicus (246 B.c.). 6. And at the end of some ycars they shall make alliance, and the daughter of the king of the South shall come to the king of the North to effect the agrcement; but she shall not retain strength [4 + of the arm], nor shall hor seed [7f arm] endurc, and she shall be givon up along with those who brought her and her child [i begetter] and him who obtaincd her. In the events 7 . shall arise a scion of her roots in his [the king of Egypt's] place, and he shall come to the outworks [Al army] and enter into the stronghold of the king of the North and shall do prevailingly with thom; 8. yea, even their gods, with their images, with their precious vessels of silver and gold, shall he bring in captivity to Egypt [?]. And when he shall desist for some years from the king of the North, 9. then he [the latter] shall come into the kingdom of the king of the South, but he shall return to his country.

Of all the high-handed crimes perpetrated by the supermen and superwomen of the Hellenistic age, that charged to Laodice, sister and wife of Antiochus II Theos, grandson of Seleucus I $(262-246$ B.C. $)$, was the most outrageous and the most noisome. For purposes of state Antiochus entered into a marriage alliance with Ptolemy II Philadelphus and took as wife the latter's daughter Berenice, so dispossessing the elder wife Laodice, who retired in high dudgeon to Sardis or Ephesus. The Egyptian princess was brought in great pomp to Antioch; acc. to Jer. she was accompanied by her father as far as Pelusium, bringing a great dower of wealth, which gave her the surname of $\phi \epsilon \rho \nu 0-$ 
фópos, dotalis. A son was born of the new union. Then a reconciliation was effected between the king and Laodice. He died suddenly, by common report through poison administered at Laodice's direction, as the first step in insuring her own children's right to the throne. Forthwith she sent her emissaries to Antioch, murdered the child of Berenice, and while the latter was able to maintain herself for a while she was finally betrayed and killed along with many of her Egyptian entourage. Her straits meanwhile had aroused the power of Egypt, provoking the so-called Third Syrian, or Laodicean, War. Her father appears to have died in the course of the tragedy, but his son and successor, Ptolemy III Euergetes, proceeded with army and fleet to Seleucia and Antioch, into which he successively entered in triumph, but too late to save his sister. The son of Laodice and heir of the dynasty, Seleucus II Callinicus (246-226) could make no resistance, and Ptolemy proceeded on a great campaign into Upper Asia, this vast extent of conquest being corroborated by the inscription of Adulis, copied by Cosmas Indicopleustes (Corp. inscr. graec. 5127, the text given by Mahaffy, p. I99), which boasts of his conquests as far as Bactria. He returned with vast booty $\left(\mathrm{s}\right.$. at $\left.\mathrm{v} .{ }^{8}\right)$, but without clinching his success, historians differing as to the cause, whether prudence or necessity; 'he desisted from the king of the North.' 9 with its obscure reference to a counter-blow of Seleucus against Egypt is faintly corroborated by the Greek historians. The Syrian king appears to have come again into possession of his holdings in Northern Syria, and even ventured an unsuccessful attack upon Egypt (Niese, p. I52, Bouché-Leclercq, p. I04). The rival kings, having their several troubles, then determined upon a ten years' truce. Laodice appears to have fallen into Ptolemy's hands and to have met her well-deserved fate. It may be noted that Jer.'s comm. to this passage is of much historical value.

6. 'And at the end of (some) years': $c f$. 'at the end of days,' Gen. $4^{3}$, I Ki. I $7^{7}$. From the death of Seleucus I to the event described was 35 years $(28 \mathrm{I}-246$ B.c.). 'Shall make alliance': the same vb. in $v .^{23}$, and similarly of an ill-omened alliance in ${ }_{2}$ Ch. $20^{35.37}$. N.b. the absoluteness of 'king,' which means practically dynasty. 'To effect the agreement': i.e., to carry out the terms; the noun means the equitable arrangement of a bargain, etc. (s. also at v. ${ }^{17}$ ). 'Retain strength': the same expression at 


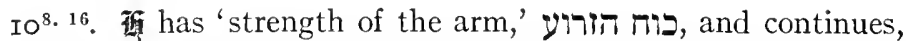
'and not will he (Antiochus) stand and (i.e., with) his arm (i.e., force).' So the passage may be interpreted. But in the first phrase 'strength' always appears absolutely, and so 'of the arm' is suspicious. Bev., Mar., after (5), make 'the arm' subject, i.e., 'this resource shall not retain strength' (i.e., the marriage), and then, after Hitz., 'and not will stand his (other)

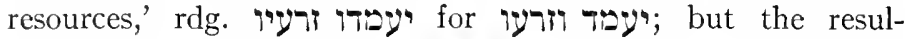

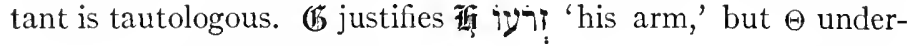
stood it as iִ 'his seed,' and so Sym., H, a most plausible rdg., referring then to the child of the marriage (so Montanus, Houbigant, Bert., dEnv., Knab., Kamp., al.). The present text may have arisen from contamination by מיעמד כה $10^{17}$. "Shall be given (up)': this abs. use of 'נת as 'surrender, betray' (so $\Theta S \mathbb{H}$, (5 understanding the vb. otherwise) is unique, and Is. $5^{12}$, $\delta \iota \delta \delta^{\prime} \mu \nu \nu \nu$ Lu. $22^{19}$, which have been compared, are not parallel; we expect the added תish, as Eze. $3 \mathrm{I}^{14}$. Is influence

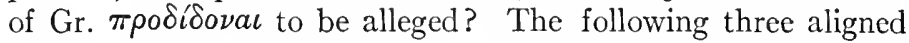
subjects are much disputed as to their mngs. The sequence which tallies best with history is as follows, $x^{\circ}$ 'Those who brought her' to her husband's court, i.e., the accompanying embassy and esp. her attendant ladies, many of whom perished with her, acc. to the stories. $2^{\circ}$ Read

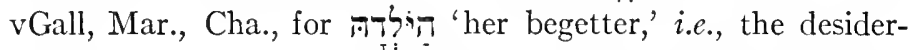
ated item of the murder of the babe; her father died at home at the same time, and it is gratuitous to allege a gross inaccuracy;

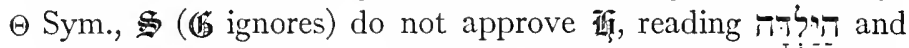
tr. 'maid' ( $\Theta \dot{\eta} \nu \epsilon \hat{a} \nu \iota s)$ or 'maids' (similarly PsSa., 'the maid whose face (person) is concealed'). $3^{\circ}$ 'He who obtained her'

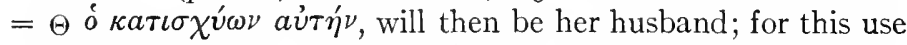
of Prin of. v. ${ }^{21}$; so vLeng., Mein., Zöck., JV. All these perished by Laodice's insane jealousy. $\mathbf{H}$, followed by Prot. comm., AV RVV, understand the third noun as 'him who strengthened her,' i.e., Ptolemy, after the causative use of the Hif. The last word in the v., ביערתי 'in the times,' even if expanded into 'in these (those) times' with EVV, is hopeless. If the word is to be kept and translation attempted, it is best with Mar. to transpose it to beginning of next v., $c f$. 'and in those 
times,' $\mathrm{v}^{20}$, and to understand the noun in the sense of fated events (s. GB, p. 629a). 7. 'A scion of her roots': i.e., her brother and avenger, of her own stock; 'shall stand in his place': i.e., his father's place, $c f$. vv. ${ }^{20 .}{ }^{21 .}{ }^{38}$. 'And shall come to the outworks and enter into the stronghold': The prep. phrase in the first sentence has been most variously interpreted; $\Theta$ 'against the army,' necessarily the opponent's, so Mar., Cha.; or 'to his (own) army,' vLeng., al. ; or 'into power,' Häv., Behr. The in-

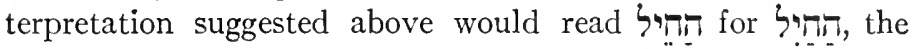
former noun mng. 'outer works,' $\pi \rho \circ \tau \epsilon i \chi \chi \sigma \mu a$, of a fortress; so Is. $26^{1}$, etc. The two sentences would then be complementary in the expression of military success. The following noun 'stronghold' is generally understood of Seleucia; but as Ptolemy after seizing Seleucia proceeded to Antioch (s. Bouché-Leclercq, p. 97), the former may well be 'the outworks,' the latter 'the stronghold.' The v. concludes with, literally, 'he shall deal with them and shall prevail,' a hendiadys. 8. The detailed statement of the booty taken by the king of the South is supported by Jer., doubtless on Porphyry's authority, relating that Ptolemy brought home " 40,000 talents of silver and 2,500 precious vessels and images of the gods, among them those which Cambyses had taken to Persia when he conquered Egypt"; for which benefaction the Egyptians entitled him 'Benefactor.' And this item is now corroborated by the Canopus Decree $(238$ B.C.), lauding as one of the merits of Ptolemy that he "restored the holy images carried out of the country by the Persians, when he made his campaign"; s. Mahaffy, pp. $230 \mathrm{ff}$., for the Gr. text, also p. 205. Acc. to Jos., C. Ap., ii, 5, Ptolemy upon his return from his victories offered thanksgiving sacrifices to God in Jerusalem. 'Precious vessels': the same expression, Hos. $I 3^{15}$, etc. It is only here, until we reach $v^{.42 .43}$, that 'Egypt' instead of 'the South' occurs. Is this an accidental lapse from the writer's masked style, or have we here an early replacement? $8 b$, which is introduced by a prefixed, emphatic 'he' הוא, I have rendered as a circumstantial clause to $\mathrm{v} .{ }^{9}$; it is by such subtle changes of order that the Sem. diction expresses relation of sentences. 'He shall desist from': lit. 'stand off from,' cf. Gen. $29^{35}$, so vLeng., RVV JV; this is preferable to the interpretation of $\Theta$ 'he shall stand above him' with comparative use of $i$, and so paraphrasing, praeualebit aduersum eum, and 
Behr.; and certainly preferable to the banal 'shall continue more years than' of Calv., AV, etc. 9. For the ambiguity of the subject $c f$. Tיע v. ${ }^{6}$ (with text of 解) and freq. below.

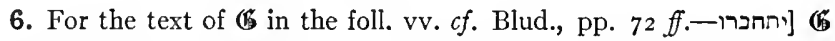

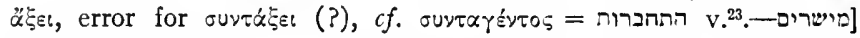

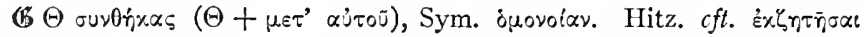

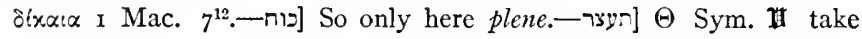

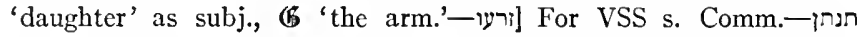

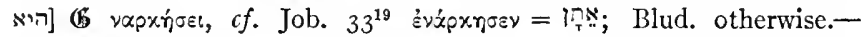
[ביאיה So edd. מביאה S. exc. Bär de R.); the VSS recognize as pl.;

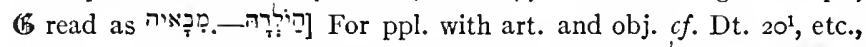
and s. GK $\S 1$ r6, f. As noted above VSS read as

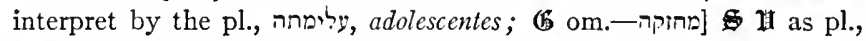

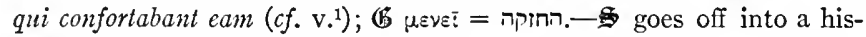
torical midrash in this v. Hipp. 300 , I3 ff., has a paraphrase, $x$. ou

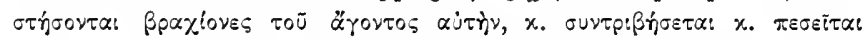

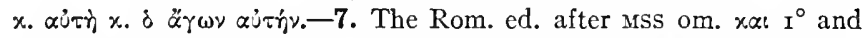

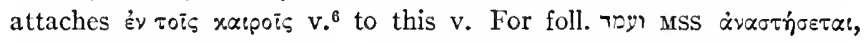

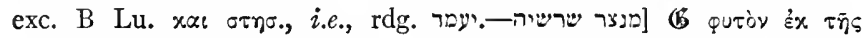

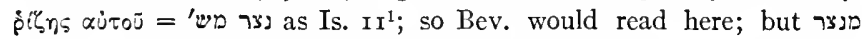

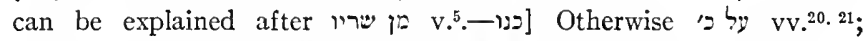

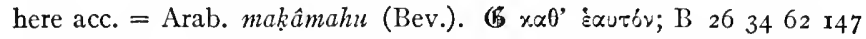

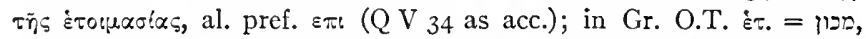
etc.; It plantatio (?), as subj.; at vv. ${ }^{20 .}{ }^{21}$ in loco eius ; 'on his place.'

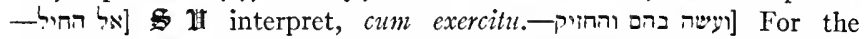
first phrase $c f$. Jer. $18^{23}$, Neh. $9^{24}$ (here if abuttutur eis); the two phrases constitute a hendiadys, s. Schultens, Animadv., 326, who $c f t$. the parallel use of $j a^{6}$ ala in Arab.; s. above at $8^{12}$ and $c f . i n f$. v..$^{32}$ - -6 om. om $2^{\circ}$,

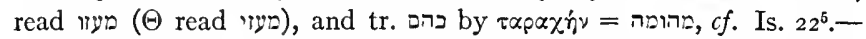

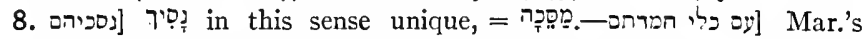
doubt of originality of this item is disposed of by Jer.'s reliable ref. to

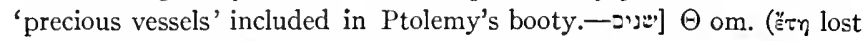

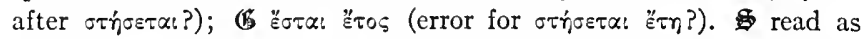
dual, חר הרין 'twofold,' with foll. = 'stand twice as high as'; simi-

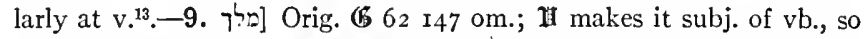
(5) as emended, and also omitting ממות Blud. suggests gloss to šँ

10-19. The exploits of Antiochus III the Great. Seleucus II was followed successively by two sons, Seleucus III Ceraunus, $227-223$ B.c., and Antiochus III the Great, $223-187$ B.c. Our passage opens with a reference to these 'sons' as 'stirring up' 
against Egypt (it is doubtful whether the elder brother was concerned in any operations), and then passes on to a singular subject, who must be the redoubtable Antiochus the Great. He was the one great successor of the first Seleucus; like all the Epigoni he aspired to the rôle of an Alexander, and indeed alone of them all came nigh to achieving it. He was conqueror of Asia and dictator of Egypt, but he met his downfall in Europe when he ventured conflict with the Romans. This third of a century was epochal in the world's history, symbolized by Polybius taking this period to begin his History of the rise of the Roman empire, the worthy complement of Gibbon's Decline and Fall; and where the fragments of his work survive Polybius becomes our main authority for the period. The years 219-20I saw the long course of the Second Punic War with its final triumphant consummation for the Romans; the remaining years found them planted securely in Asia with Egypt become a vassal state. Rome was now mistress of the Mediterranean.

Antiochus' reign was one of unwearied warfare. At first he was obliged to fight with treacherous aspirants to the throne, first Molon in Upper Asia, later Achæus in Asia Minor. Victorious over the former he could proceed to the achievement of the century-old ambition of his house, the conquest of Southern Syria ('Cœle-Syria'). The prospects were the rosier in that 'the contemptible' Ptolemy IV Philopator (22I-203 B.C.) had come to the throne almost synchronously with him, a dilettante voluptuary, ruled by vile ministers. The Syrian operations began in 219 by the retaking of Seleucia, the port of Antioch. In the following years Antiochus proceeded to a methodical conquest of Palestine, waging an extensive campaign in TransJordan (E. Bevan, p. 3I 7; Bouché-Leclercq, p. I46). These successes are summed up in v.10a. But the Egyptian administration had wit enough to pluck itself up for defence, hiring mercenaries and even enlisting Egyptian troops (a bit of fatal politics). In 21 7 Antiochus marched to the Palestinian frontier at Raphia, where he was met by the Egyptian army, commanded in person by Ptolemy and his sister-wife Arsinoe. This is the débâcle described in vv. ${ }^{10 \mathrm{~b}-12}$; the 'myriads' destroyed by the king of the South is true enough literally, the two armies massing toward 70,000 men on each side, and Antiochus' loss being put at $\mathrm{r} 7,000$ (E. Bevan, pp. 3 I 7 ff., Bouché-Leclercq, pp. 150 ff.). There is a $2 \$$ 
lively anecdote told of this battle in the opening vv. of $3 \mathrm{Mac}$. Antiochus lost his Coele-Syria. But the king of Egypt was too supine to follow up his victory; he did not show himself 'strong,' v. ${ }^{12}$. The years 2I 2-204 were spent by the indefatigable Antiochus in recovering his Oriental domains, and he campaigned successfully as far as the Caspian and the borders of India. About 203 B.c. Ptolemy and his queen died in mysterious circumstances, succeeded by their infant son Ptolemy V Epiphanes. The time was ripe for the revenge upon Egypt, and vv. 13-17 tell the story. The 'many who shall stand against the king of Egypt,' v. ${ }^{14 a}$, has been understood, since Jer., of Philip V of Macedon, ally of Antiochus, and native insurrections within Egypt; s. Mahaffy, cc. 7. 8, Bouché-Leclercq, Lagides, 34I ff. In 201 Antiochus invaded Cole-Syria and took Gaza after a long siege (E. Bevan, I, 3I7, Bouché-Leclercq, p. I7I); this is the 'city' taken by 'earthworks,' $v{ }^{15}$. The approaching conflict between Syria and Rome, which was entering the Oriental fray in behalf of its ally Pergamon, tempted Egypt to strike back; the Egyptian condottiere lieutenant Scopas invaded Palestine, was defeated at Banias, then finally blockaded in Sidon, which at last fell to Antiochus, I99-I98 B.C. These are probably the events obscurely described in vv. ${ }^{15 b .}{ }^{16}$, of which there remained a lively memory with the Jews; for the note that he came to 'stand in the Beautiful Land' we have the parallel information from Jos., $A J$ xii, 3, 3, that the gates of Jerusalem were thrown open to him. The threatening interference of Rome induced Antiochus to use his best diplomacy to effect an alliance with subdued Egypt; he married his daughter Cleopatra to the youthful Ptolemy, the marriage being celebrated at Raphia (E. Bevan, 2, 38. 57, Bouché-Leclercq, pp. I 77, I84). The quid pro quo offered by Antiochus was the revenues of Cole-Syria as dower for his daughter, of which, however, he reserved half for himself for administration. 16 presents the datum of this marriage, somewhat in the guise of a means of escape for Egypt from threatened invasion; $\mathrm{v}^{\mathrm{b}}{ }^{\mathrm{i}}$ is obscure.

Had Antiochus willed to remain what he actually was, monarch of Asia and suzerain of Egypt, he would have gone down into history as really 'the Great,' a title prematurely given in his lifetime. But it was his fatal ambition not only to conquer Pergamon, the thorn in the Seleucide flesh, but to take position 
in Greece and so to reincarnate the great Alexander. 18. 19 tersely depict the consequences. He 'set his face to the Isles,' the mysterious lands of the distant Mediterranean. He met his Waterloo twice, first at the pass of Thermopylae, where East once more met West, I9I B.C. Driven back into Asia he again made stand, but was utterly beaten at Magnesia by Lucius Cornelius Scipio (hence 'Asiaticus'), I9o B.C. This is the 'commander' who turned back upon him his own indignities ('his reproach'). Scipio Africanus, the conqueror of Carthage, was present with the Roman army, even as Hannibal accompanied Antiochus' western campaign, their presence a symbol of the world-wide character of the struggle. Its import is well expressed by Plutarch (Comparison of Aristides and M. Cato), in paraphrase: the great victory at Thermopylae cleared Asia out of Greece and so opened the way for Rome into Asia. Antiochus had to retire 'to his own strongholds,' $v_{.}^{19}$, a beaten conqueror. He died $187 / 6$ in trying to loot a temple of Bel in Elymais, according to a story exactly similar to that of the death of his son Epiphanes (s. Bouché-Leclercq, pp. $223 \mathrm{f}$.). 'He was not to be found' is the verdict of our writer, as it is of history.

Our writer was contemporary with at least the latter part of Antiochus' career, and possessed immediate information upon his reign which enabled him to give the succinct and correct résumé of these vv. Jewish historiography in general begins now to operate with clearer light, after a long eclipse. 3 Mac. ( $\left.\mathbf{I}^{1-7}\right)$ opens with a dramatic and genuine account of the battle at Raphia, drawn from some Greek historian. The apocryphal balance of the book deals with the visit of Ptolemy Philopator to Jerusalem. Josephus also has much to say about the high favors granted by Antiochus III to the Jews, $A J$ xii, 3 , and in c. 4 gives the romantic story of Joseph the Tobiade, Ptolemy's (Philopator) tax-gatherer in Palestine, the father of the redoubtable freebooter Hyrcanus, the builder of that remarkable palace-fortress 'Arâk el-Emîr near Heshbon. One may compare Mahaffy, pp. $216 f f ., 267 f f$., for an attempt to make the most of these stories. See also E. Bevan, Jerusalem under the High Priests, pp. 4I ff., for a study of the worldly influences which were bearing down upon the Jews as Palestine became more and more a pawn of the dynasties.

10a. Antiochus' initial successes in Syria (2 I9-2I 8 B.c.). And 
his sons [Seleucus III and Antiochus III] shall be stirred up, and shall assemble a multitude of great forces. And he [Antiochus] shall come on and on and flood and pass beyond. The subj. of vv. ${ }^{10-19}$ is in general a sing., Antiochus; only at the beginning of the present $\mathrm{v}$. have we a pl. subj. with two attendant vbs. It would be convenient to insist on the Kt. בצ (Kr. M tr. 'his son' with the change of the two vbs. to the sing.; so vGall, Mar., Löhr. But the mystifying change of subj. is characteristic of the whole passage, while the VSS support the Kr. The assumption that hostilities with Egypt occurred in Seleucus' reign, although corroborated by Jer., is not proved; s. Bevan, p. 204. 'Be stirred up' is used of passion, e.g., Pr. $28^{4}$, and becomes a technical term for preparation for war, $c f . \mathrm{v}^{25}$, Dt. $2^{9 .}{ }^{24}$, etc.; for the psychology $c f$. Is. $42^{13 \mathrm{f}}$. The figure at the end of the passage is that of a flood $\left(c f . v v{ }^{22.26 .40}\right)$, and is taken literally from Is. $8^{8}$ (symbolically $28^{15}$ ff.),$c f$. Jer. $47^{2}$, in both cases a flood from the North. JV 'as he passeth through' is not adequate.

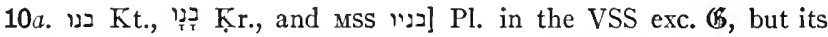

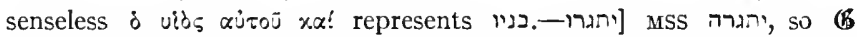

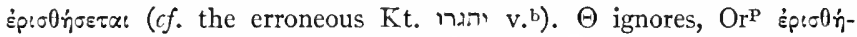

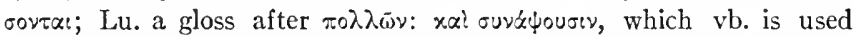
by $\Theta$ for התגר at v. ${ }^{25}$. Orig. cura

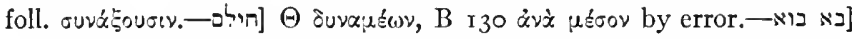
$=v{ }^{13}$. Critical objections against the position of the abs. inf. are not supported, s. GK $\$ \mathrm{rr}_{3}, \mathrm{r}, \mathrm{s}$; the position is indifferent in Aram., and my tr. has in mind the parallel בוא

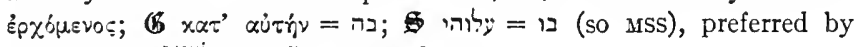
Mar., Ehr.—实 Grr., Ir tr. as ppl.

10b-12. Antiochus' disaster at Raphia. 10b. And he shall again be stirred up, even unto his stronghold. 11. And the king of the South shall be enraged, and shall go forth and war [if + with him] with the king of the North; and he [the latter] shall raise up a great multitude; but the multitude shall be given into his [the former's] hand. 12. And shall be lifted [i + the multitude] and [with Kr.] exalted his heart; and he shall fell myriads, but he shall not be strong. $10 b$ is generally translated: 'and he shall return (home) and be stirred up, even unto his stronghold' (i.e., Ptolemais, Seleucia?). But vLeng. saw correctly that the 
'return' was to the attack, and that the half-verse connects with the foll. vv. The tr. above follows Bev. in taking the vb. 'return' in its common auxiliary sense of 'again,' e.g., v. ${ }^{13}$. The usually alleged 'return' to winter quarters is hardly a notable item. It is disputed whether 'his fortress' is Ptolemy's, e.g., Raphia (so Junius, Geier, vLeng., on the basis of Polybius), or Antiochus', e.g., Gaza (so Dr., proposing a play between מעiז 'fortress' and עr 'Gaza'). But the expression 'be stirred up even unto' would indicate a hostile objective. 11. The same vb. as for the 'rage' of Ptolemy is found in 8 . Tif, "with him with the king of the N.' is absurdly tautologous; the VSS om. 'with him'; Mar. would om. the other half. The sequence indicates that the subj. of 'shall raise up a great multitude' is Antiochus; i.e., the multitude which was 'given into his (Ptole-

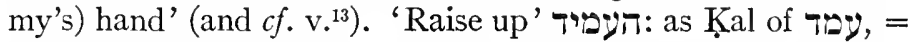
קום , the Hifs. of the two are synonymous. is at end of the v. and beginning of the next has a tautologous doublet in the repetition of 'the multitude'; the vb. נצשא 'lifted up' is usually explained as 'carried off,' $c f$. use of the same vb. at $2^{35}$. One or the other sentence might be regarded as a primitive doublet. The tr. adopted above follows the possibility that jim in' the multitude' has been attached to בשיא 'be lifted up,' by a crossreference gloss to $2^{35}$ נצשיא המטיא. The vb. is then to be paired with the foll. 'be high,' with 'his heart' for subj.; cf. $5^{20}$. The rdg. of Kr. ורים 'and be high' is followed with the VSS vs. Kt. ירום '

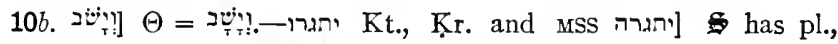
other VSS sing. (A pl.); $\mathbf{n}$ duplicates, concitabitur et congredietur.[ע] So Sym., $\Theta$; abs. fem. noun, which may represent the orig.;

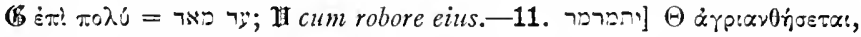

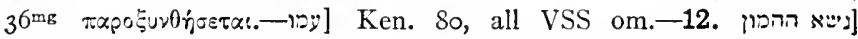
For' ' regarded as gloss from $2^{35}$ (v. sup.), n.b. that there $\Theta$ tr. by $\pi \lambda \bar{r} \theta_{0}$ s.

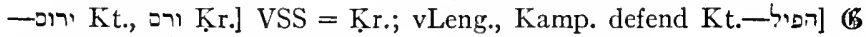
$\tau \alpha \rho \alpha \dot{\xi} \xi \iota=$ rt. בהל as at $7^{15} .-$ -

13-16. Antiochus' victory at Gaza and subsequent successes. 13. And again shall the king of the North raise up a multitude, greater than the first; and at the end of the events [i + years] he shall come on and on with a great force and much equipage.-14. And in those times many shall stand up against the king of the South; and some [ = Tif sons] of the lawbreakers of thy pcople 
shall lift themselves up to confirm vision, but they shall stumble.15. And the king of the North shall come and cast up siege-works and take a fortified city, and the forces [if lit. arms] of the king of the South shall not stand, yea, even for the folk of his picked (soldiers) no strength to stand, 16. so that he who comes against him shall do according to his own will, none standing before him. And he shall stand in the Delightsome Land, and in his hand destruction [?].

13. Tit. 'at the end of the times, years' appears tautologous; the latter noun, representing the 16 years between Raphia and Gaza, may have been intruded from v. ${ }^{6}$ (Bev.), or 'the times' borrowed from v. ${ }^{14}$ (Mar.). For the tr. 'events' s. at v. ${ }^{6}$, and for 'come on and on' Note at v. ${ }^{10}$. The word tr. 'equipage' means 'substance, property,' i.e., the baggage of the army; possibly by assimilation to another word mng. 'horses' it may refer to the horse and baggage animals, especially to the elephants of Antiochus which he fetched from India and which played a large part in his operations, esp. at Gaza; s. Note. 14b. The historical ref. is most obscure. In 'the sons of the robbers (violent) of (among) thy people,' as EVV tr. the phrase, 'sons' cannot mean 'die stürmische Jugend' with Behr., nor need it be taken physically as 'sons' as of some family (so Bev., Schlatter, al.); but rather as members of the category. The second noun, פריצי, meant, first, high-handed criminals, but here the term is one of religious politics, those who 'breach' (rt. $Y$ (פ) the Law. Cf. Ab. Zara Jcr., 4 I $a$, top (cited by Jastrow, Dict., sub rad.), 'thou hast not breached their fence,' i.e., transgressed the law of the rabbis; and this is anticipated by the $Z a d$. Frag., p. 20, 1. 25, 'they breached the bound of the Law,'s. the text in Int., $\$ 2$. Confirmation of this interpretation is obtained from $\Theta$, oi vioi $\tau \hat{\omega} \nu \lambda o \iota \mu \hat{\omega} \nu$ (correct $B \lambda o \iota \pi \omega \nu)$, this being elsewhere (5)'s current tr. of 'cons of Belial,' also = 4 , 2 the hateful epithet applied to St. Paul in Acts $24^{5}$, AV 'pestilent fellow.' And Jer. correctly comments, 'qui dereliquerunt legem Domini.' Jeph. offers as current interpretation that the phrase refers to the Christians, actually naming the four Evangelists. Schlatter, 'Die Bene parisim bei Daniel, rx, r4,' ZATW

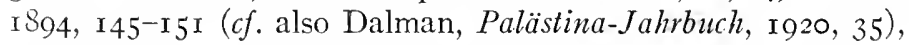
has suggested identification with the notorious family of the Tobiadx, of whom were the notorious tax-gatherer Joseph (Jos.? 
$A J$ xii, 4) and his son the bandit chief Hyrcanus (s. Schürer, I, I95; $2,65 f$.). But as we have seen the sense 'violent' must not be pressed. Jer., perhaps by a Jewish interpretation, applies the passage to the building of the temple at Leontopolis in Egypt by the refugee Onias (modern Tell el-Yehûdîye), which was built ostensibly 'in fulfilment of vision,' i.e., the prophecy in Is. I $9^{19}$. This event took place much later, after I64 (s. Schürer, 3, I 44 ff.), although the tr. of $\mathbb{G}$ here may have been induced by the same interpretation; but Jer.'s parallel is illustrative of the various attempts made by Zealot parties to approve their actions through appeal to prophecy, in the present case bitterly condemned by our writer. The more natural interpretation of 'to cause to stand = confirm, establish, vision' (another instance of many-sided meanings of the rt. Tiv, cf. Ps. $1 \circ 5^{10}$ ) is that the party's apology was the fulfilment of some ancient prophecy. This view is preferable to that of some, e.g., Marti, making it a clause of result, i.e., their failure was foredoomed by a prophecy, for we should expect the clause then to stand after 'they shall stumble.' It has not been observed that the phrase is an exact reminiscence of Eze. $13^{6}$, against the lying prophets, who 'hope to confirm (the) word,' לקים דבר.

15. The parenthesis of $\mathrm{v}^{14}$ has caused the repetition of the subj., 'the king of the N.,' the subject-matter continuing the campaign which ended in the triumph at Gaza, 20I B.C., rather than, as with most comm., that at Sidon over Scopas in I98. In the phrase translated 'folk of his picked (ones),' EVV 'his chosen people,' the second noun 'פברירי 'פ is doubtless a play upon בָחור? 'young men'), and well denotes Scopas and his trained Ætolian mercenaries. 16. The rendering of $\mathrm{v}^{\mathrm{a}}$ as a clause of result follows strictly the Heb. vb. in the Jussive ( $c f$. on v.4). 'The de-

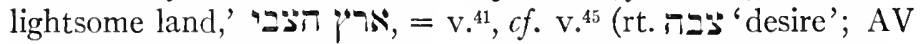
'pleasant,' RVV 'glorious,' Dr., JV 'beauteous'), is based upon

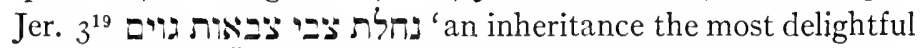
of the nations' || land of delight to all the nations'; the word is similarly used of Babylon, Is. $13^{19}$, etc. Similar epithets for Palestine are

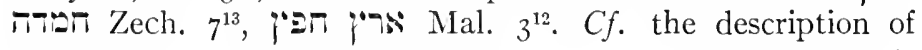
Jerusalem, Ps. $48^{2.3}$, and of Samaria, Is. $28^{1}$. Our phrase is 
cited En. $89^{40}, 90^{20}$. The word argued that the word is not original there. The VSS vary much in their interpretation of 'and in his hand destruction'; the last noun is most obscure, as we are ignorant of the allusion.

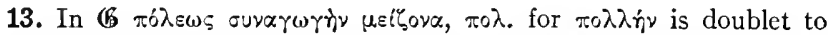
$\mu \varepsilon \zeta_{\text {. }}$ -

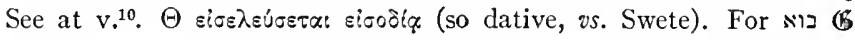

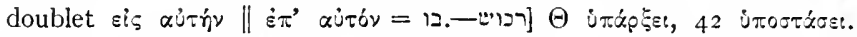
For the phrase here בפרחין תקיפין 'with strong birds,' which Nestle, Marg., 42, rightly corrects to בפרישי בריש, and so 'mit starker Reiterei.'

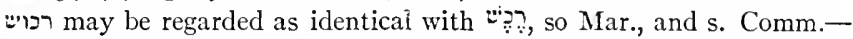
14. Bev. objects to the usual interpretation that such a phrase with the second noun in the pl. cannot mean 'violent persons';

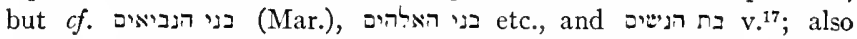

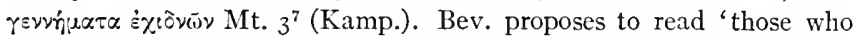
build up the breaches,' etc., $=$ Am. $9^{11}$, for which he might have com-

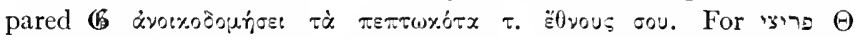

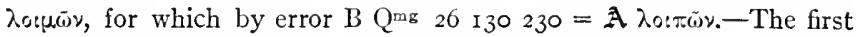

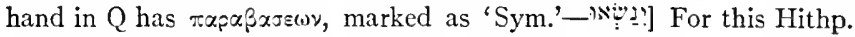
form s. GK $\$ 54$, c. Ehr., who would read Nif., cft. the Nif. weינ\| ניאלי Is. $19^{13}$, and tr., 'sie werden sich falsche Hoffnungen machen,'

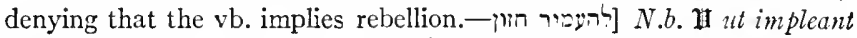
uisionem. Graetz proposes 7ynh, i.e., 'das Gesetz wankend zu machen.'-For רבים Bibliothek, 4, $38 f$., suggests as original 2 'Libyans,' cf. inf. $\mathrm{v}^{43}$. But

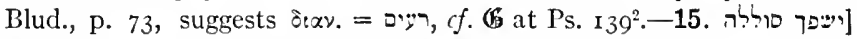

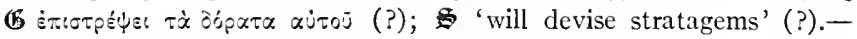

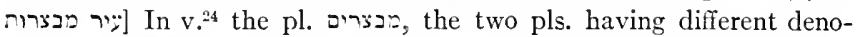
tations. $\Theta$ II tr. 'fortified cities,' and the pl. is quite possible.- הנג] $\mathscr{B} \Theta$ as though 'גיר

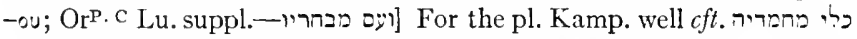
2 Ch. $36^{19}$, in disposing of Mar.'s objections; the sense of the lat-

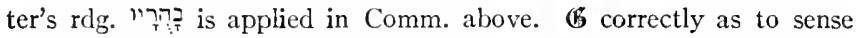

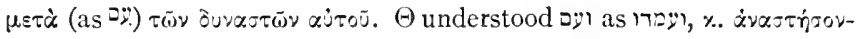

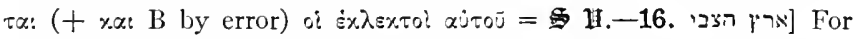
the Jewish and other comm. s. their notes at $8^{9}$; acc. to Ra. this is a mystic name, e.g., 'צב may mean 'Gazelle'; Sa. prosaically, eš- $\breve{S} \hat{a} m$, 'Syria.' The trr., at least their texts, differ much among and within

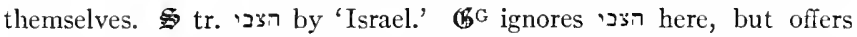
$\theta \equiv \lambda \dot{n} \sigma s \omega s$ at $\mathrm{v}^{45}$, which $\mathfrak{G}^{\mathrm{S}}$ gives here (and Jer. notes at this $\mathrm{v}$. that such is the rdg. of (F). A minority of $\Theta$ texts read here $\sigma \alpha \beta \alpha \varepsilon s \nu$ (or similar forms), also explicitly attributed by Jer. to $\Theta$, as in most texts at 
vv.41. ${ }^{45}$, exc. Lu. $\sigma \alpha \beta \beta \varepsilon เ p$. (A closer form to is found here in 8789 $\sigma \alpha \beta \varepsilon !$, and at $\mathrm{v}^{41} \mathrm{~V}{ }_{3} 6^{\mathrm{mg}} \sigma \alpha \beta \alpha \varepsilon t$.) But here $\mathrm{B} \operatorname{Or}^{\mathrm{P}} \operatorname{Or}^{\mathrm{C}}$ (A Q 106 al.) Lu. have toj $\sigma \alpha \beta(\beta) \varepsilon ! p$ (or similar forms). $\sigma \alpha \beta \beta \varepsilon เ p=$ Aram. ר 'well thought of.' This must represent a current Targum and = Aq.'s

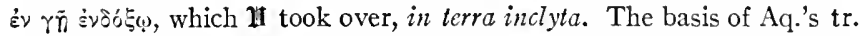
is not evident; he so tr. at Eze. $20^{6}$. Nor is the history of the intrusion of $\sigma \alpha \beta \beta$ stp into $\Theta$ texts (even B) clear. Either it sheerly replaced orig. $\sigma \alpha \beta \alpha s เ \nu$, or $\Theta$ like $\mathbb{G}$ ignored i here, and ultimately $\tau z \beta \alpha s: \nu$ and

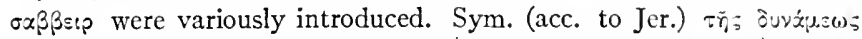

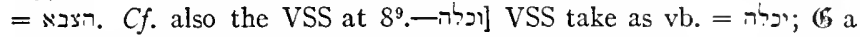
doublet, $\varepsilon \pi \tau \varepsilon \varepsilon \lambda \varepsilon \sigma \theta \dot{n} \sigma \varepsilon \tau \alpha ! \| \pi \dot{\alpha} \nu \tau \alpha$. Sa. tr. by 'sword,' interpreting from Arab. kallat 'short sword.' Ew. tr. adverbially, as at Gen. I $S^{21}$, 'it shall be wholly in his hand'; Bert., Hitz., Kamp., with a change of points, 'it shall all be in his hand'; Stu. 'consummation.' AV 'which by his hand shall be consumed,' after the VSS, is impossible, for the antecedent is fem.

17. The marriage of Antiochus' daughter Cleopatra to Ptolemy V Epiphanes. And he shall set his face to come with the power of all his kingdom; and an agreement with him he shall make [9 and he shall make], and shall give him the Daughter of women to destroy it [or her]; but it [or she] shall not stand nor avail him. 'Come with the power of his whole kingdom': so Grr., Calv., EVV, Bev., Dr., etc. The sense 'enter into the strength of his (Ptolemy's) kingdom' is accepted by jewish comm.; so Häv., vLeng. To the writer all Antiochus' operations were directed primarily against Egypt, and indeed his activities at this period, while directed toward Asia Minor and Greece, nevertheless involved the far-flung colonies of Egypt. 'Shall make' follows the VSS vs. which is represented by AV, 'and upright ones (our 'agreement') with him; thus shall he do.' The betrothal of this royal marriage took place, acc. to Jer., in $198 / 7$, and the consummation 6 years later at Raphia. Ptolemy $\mathrm{V}$ was still young (s. Mahaffy, p. 265). The term 'the daughter of women' (where we would expect 'daughter of man, men,' so $(\mathfrak{G}$ ) is striking. Still, Hitz. cft. תiנis ' early Prot. comm. understood the phrase as superlative, inter mulicres praecellentissima. The term may express the essence of femininity, i.e., the Woman, par excellence. We have to recall Cleopatra's very distinguished position in Egypt, the first by the way to bear this name in that royal family. When her 
husband died in 182 B.C., she became regent of the kingdom during the minority of her children, and had a controlling influence until her death in I 74 B.c. (s. Mahaffy, c. 9, esp. pp. 330-332). The elder of these, Ptolemy VI Philometor, who repaid the memory of his mother in his cognomen, and who was one of the most admirable members of his family, reigned till I46 B.C., while his equally abominable brother Ptolemy VII Physcon succeeded him, continuing till Ir7 B.C. Thus the memory of "the Woman,' as we might say 'the Queen,' was destined to survive for long. The foll. clause of purpose with a fem. obj. has generally been translated 'to destroy her,' the woman, which is absurd. The marriage bargain turned out favorably for the Seleucides. The obj. is then to be taken as referring to Egypt implied, so, e.g., Jer. (ut euertat illud), Geier, Häv., vLeng., Dr., Mar. The $\mathrm{v}$. is further complicated by a fem. subject appearing in the final two vbs. The usual understanding appears in AV, 'but she shall not stand on his side, neither be for him'; this follows Jer., who tells how her husband and his ministers, 'sensing fraud,' took active steps against Antiochus, leading on to the war in which Rome came to be engaged. But it is preferable to take the fem. subj. as impersonal, 'it (his purpose) shall not stand,' etc., cf. Is. $7^{7}$, I4 ${ }^{24}$ (so, e.g., Bert., Bev., Dr., Mar.). Others, e.g., Graetz, find the fem. subj. in the word 'his kingdom.'

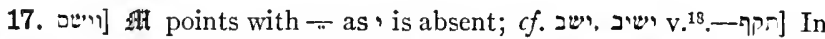
II's tr. of the phrase, ad tenendum uniuersum regnum cius,

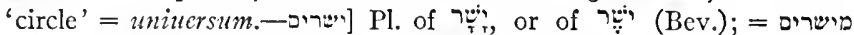
v. ${ }^{6}$, which many prefer to read here; is supported by $\Theta \varepsilon \dot{j} \theta \varepsilon i \alpha \pi \dot{\alpha} \nu \tau \alpha$ ('make all things straight'), יעי = all VSS.

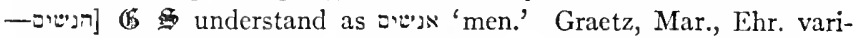

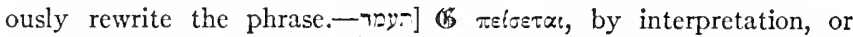

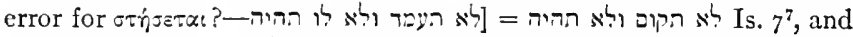
cf. ת ת inf. v. ${ }^{27}$. As it fails in (5 Mar. deletes it and so equates the two passages. For the indef. fem. subj. $c f$. GK $\S 122$, q, end.

18. 19. The utter defeat of Antiochus by the Romans and his miserable end. 18. And he shall turn his face to the Sea-lands, and shall capture many. But a Magistrate shall stop for him his insult, [9 + except that] his insult shall he pay hack to him [doublet?]. 19. And he shall turn his face back to the strongholds 
of his own land. And he shall stumble and fall, and shall not be found. 18. It is preferable to read with $\mathrm{Kt}$., 'he will turn his face' (AV) rather than with Kr. 'set his face' (JV); the former properly introduces a new 'turn' in the campaigns of the North. 'Isles' is an inexpressive term for 'sea-lands,' which appears to mean the indefinite stretches of coast lands; for their magnitude $c f$. Is. $40^{15}$. The word belongs to the Mediterranean geography; it is often defined: coast lands of Kittim, Jer. $2^{10}$ (I Mac. $I^{1}, 8^{5}$ Kittim = Greece-Macedonia); of the Nations, Gen. $10^{5}$, or, as here, absolutely, $c f$. Eze. $26^{15}$. A Sem. derivation is usually accepted for the word (rt. הix); but $c f$. A $\iota-\gamma v \pi \tau o s, \mathrm{~A} \iota$ yacos, etc. 'Will capture many': Antiochus profiting by the misfortunes of Philip of Macedon and the weakness of Ptolemy pursued a victorious campaign through Asia Minor, picking up the Macedonian and Egyptian cities, and reached Thrace as early as I96 B.c., intent on seizing the Macedonian overlordship in Hellas. The 'Magistrate' is doubtless Lucius Cornelius Scipio Asiaticus, the victor at Magnesia, I90 B.C. A somewhat rare word has been nicely selected to denote the Roman Consul, ķașin 'judge' (our Arabic 'Cadi'), parallel in meaning to ט: 'judge.' The 'reproach' offered by Antiochus may denote the high-handed arrogance with which he pursued his Western campaign even to the defiance of Rome; it has been specifically iilustrated by his words to a Roman legation bidding the Romans to abstain from meddling with Asia even as he was not meddling with Italy (Polyb., xviii, 34). Or it may simply mean our 'challenge,' for the Oriental challenge is a shower of abuse. The final sentence of the $\mathrm{v}$. is difficult. It is introduced by an

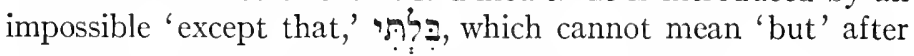
the usual tr. For proposed emendations s. Note. As the content of the sentence is tautologous with the prec. one, the writer must agree with Ehr. in regarding it as a gloss phrasing the former in a more usual way, 'requite his challenge.' 19. Antiochus was thrown back across the Taurus (only Cilicia, always an appanage of Syria, being left to him of his Western domains), 'to his own strongholds.' His 'stumbling and falling' capitally expresses his ignominious death. For 'he was not found,' $c f$. Job $20^{8}$, Ps. $37^{6}$. Bert. cites Appian, Syr., 37 : People came to say, King Antiochus was the Great. 


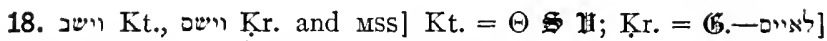

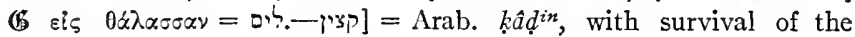
orig. nunation, but the Heb. came to regard p p as the rt.; $\Theta$ as a pl.,

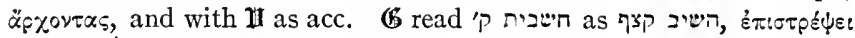
bpynv.--b] This is better understood as ethical dat. than as objective

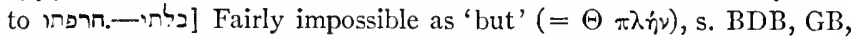

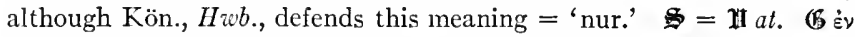
öpxœ has suggested to Bev. שבעתים 'sevenfold,' cft. Ps. 79'12 (accepted by Mar.). But (G read בלחיא Sachau's Pap. I, I. 7, and often in the Ahikarar papp. This rdg. of $\mathbf{6}$ corresponds to Graetz's suggestion of בליחי, '[requite him] on the cheek,' the only objection to which is that this phrase is not otherwise

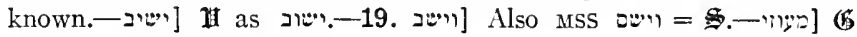
as inf., as at v. ${ }^{1} ; \Theta \mathcal{H}$ as sing.

20. The inglorious reign of Seleucus IV Philopator. And there shall stand in his place one who sends abroad [lit. canses to pass through] an exactor for royal glory; but in a few days he shall be broken, yet not in rage nor in battle. This reign, $\mathbf{I} \delta_{7-\mathbf{I}} 75$ B.C., was of necessity inglorious, whatever the character of the king, whom Appian, $S y$ r., 6o, describes as 'reigning ineffectively and weakly.' Says E. Bevan, 2, I25: "Of the internal administration of Seleucus we know only that the necessities of the time made its first object the replenishing of the empty treasuries." Appian, Syr., 45, tells how a 'certain courtier,' Heliodorus, plotted against and did away with his royal master and seized the power, ostensibly in the name of an infant child of the king (of which more anon). In 2 Mac. 3 we read the following story. An officer of the temple in Jerusalem gave information to Apollonius, governor of Cœle-Syria and Phœnicia, of the wealth in the temple treasury, which included not only alleged trusts for widows and orphans but also banking funds of the notorious Hyrcanus the Tobiade. Seleucus sent Heliodorus tò $\nu$ $\dot{\epsilon} \pi i \tau \hat{\omega} \nu \pi \rho a \gamma \mu a \dot{\tau} \omega \nu$ (v. sup. at $2^{48}$ ) to seize these funds, from which sacrilege he was frustrated by a divine apparition. He was revived from a lifeless state only by a sacrifice offered not for charity's sake, as it is explicitly remarked, but lest the king's anger might be incurred. This Apocryphal item about Heliodorus' position, which stood unique, is now corroborated by two inscriptions on bases of statues erected in his honor at Delos; for which see at length Deissmann, Bibelstudien, I 7 I ff., 
Eng. tr., pp. $303 \mathrm{ff}$. In these inscriptions he is called a foster-

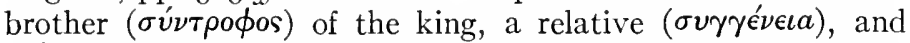

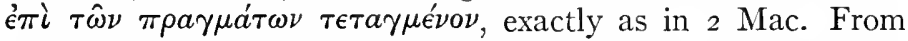
these few facts we learn that Heliodorus was prime minister; he then is the 'exactor' of our v., whom his sovereign 'made to go abroad' through his domains to raise the funds, or as the writer satirically puts it, 'for royal glory.'

The participial phrase describing the king is most variously disputed. The one chosen above was proposed by some early Prot. comm. (s. Geier, Pole). The rendering 'cause an exactor to pass through' is supported by Zech. $9^{8}$. Understanding 'glory of royalty' (without the article, not 'the kingdom') as secondary object (so RVV JV) is indefensible; the abstract character of the phrase is confirmed by the parallel 'royal majesty,' v. ${ }^{21}$. The 'exactor' is he 'of' or 'for, royal glory.' 'In a few days' ( $c f$. Gen. $27^{44}, 29^{20}$ ) prob. refers to Seleucus' short reign of twelve years as compared with his father's reign of forty; those who press the reference to Heliodorus' mission suppose a brief time between it and the king's murder; others interpret it as 'suddenly,' which would rather be 'in one day.' 'Shall be broken': cf. vv. ${ }^{22}{ }^{26}, 8^{25}, \operatorname{Pr} .6^{15}, 29^{1}$. 'Not in rage' is a favorite subject of exegesis and emendation. The interpretation adopted means that he did not die in brawl or battle; he was killed, but not 'with his boots on,' a disgrace to a king; cf. Saul's death.

20. At the beginning $\mathbb{G}$ has been conflated from v. ${ }^{7}, \beta \alpha \sigma: \lambda \varepsilon i \alpha s$ is a gloss correction to subsequent $\beta \alpha \sigma: \lambda \varepsilon$ ş. $\Theta$ text has been interpolated

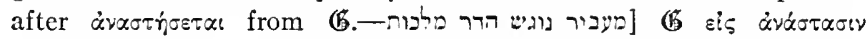

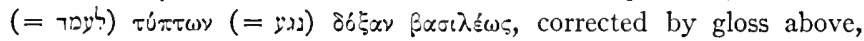

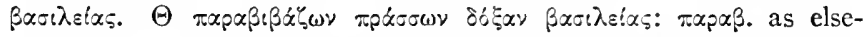

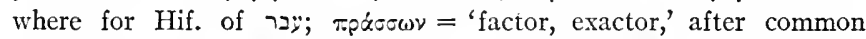
use of $\pi p \dot{\alpha} \sigma \sigma \varepsilon t \nu$. and It are wide of the mark: a remover of power (eט, n.b. approximation to Eth. use of the rt.) and of glory of the kingdoms'; If uilissimus et indignus decore regni. For attempted revisions see Kamp.'s note. For רֶ? (so Kön., $H w b$.)

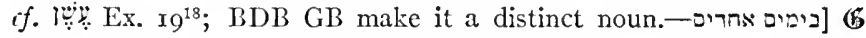

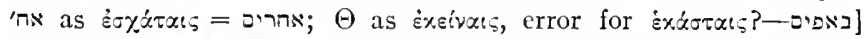

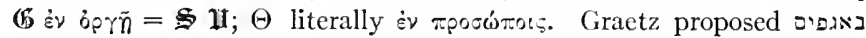
'in battle array,' cf. Eze. $12^{14}$, $17^{21}$, etc. Behr. thinks it means 'openly,' cft. 'face to face,' Dt. $5^{4}$, etc., and Dr. notes the Syr. usage, $c f t$. PSmith, col. 278 . 
21-45. Antiochus IV Epiphanes, I75-165 B.C. Antiochus, the younger son of Antiochus the Great, was disporting himself like a true Hellene in Athens when word came to him of the murder of his brother Seleucus by Heliodorus (s. at v. ${ }^{20}$ ). He had been a hostage at Rome since I89, but at the close of his father's reign exchange had been made whereby his elder brother Demetrius had been taken in his place and he released. He made his way at once to Antioch; Heliodorus disappears from the scene, and the new king does away with the puppet king, the infant son of Seleucus. The Romans had their troubles in Greece with Macedon and the Leagues, and Pergamon, and desirous of keeping a balance of power in the Orient actually helped Antiochus to the throne. But the Romans could bide their turn to play, nothing loath doubtless of the faction in the Syrian house which gave them the lawful heir to play as a trump at the right time (the latter ultimately came to the throne, in 162 , by murdering his brother's son and successor). Accordingly the reign falls into two parts, divided by the Roman victory over Perseus of Macedon at Pydna, I69 B.C., when Rome came in position to lay down the law to Antiochus and force him out of Egypt (s. at $\left.v^{30}\right)$. The history of the first period is taken up with the Syrian wars against Egypt, the second half, after I69, finds Antiochus confined to the rôle of an Asiatic monarch, the history of which years we know chiefly from the documents of the Jewish people, with whom he became engaged in petty warfare. In the last year of his life he pursued obscure campaigns against Armenia and the Parthians, and was killed ingloriously when attempting to loot a temple of 'Anaitis' in the Elymais. But these wars and the king's end are beyond the purview of our chapter, which makes only vague allusion to the Maccabees (vv. ${ }^{33}$ ff.), while the inevitable catastrophe of his career is left to divination of the future, $v v .40 \mathrm{ff}$.

The death, I 82 B.C., of his sister Cleopatra, the wise regent of Egypt in the minority of her sons Philometor and Physcon (s. at $v^{17}$ ), gave Antiochus free hand to interfere in Egypt. The first Egyptian War was actually provoked by the young Philometor's foolish counsellors, and resulted in Antiochus' triumphal entrance into the land ( 170 or I 69 B.C.- -for the question of the exact date $c f$. Schürer, pp. I69, I96, and Meyer, Ursprung, p. I50). Philometor, attempting to escape, fell into the invader's 
hands (s. at $\mathrm{v} \cdot{ }^{26}$ ). But Alexandria held out, proclaimed the younger brother Euergetes II Physcon as king, the upshot being that after an attempt to take the city Antiochus evacuated the land. The two Ptolemies now became reconciled and were to reign conjointly. Antiochus made another attempt at conquest and the invasion ensued in I68. But near Alexandria he was met by the Roman consul Gaius Popilius Laenas and given Rome's effective orders to leave the country. There followed, in his ill condition of temper, his supreme desecration of the temple in Jerusalem, which brought on the Maccabæan uprising ( $v{ }^{30}{ }^{30}$. $){ }^{1}$

For Antiochus' relations with the Jews we have two Jewish histories, I and 2 Mac., which give narratives difficult to harmonize. Niese in his classical monograph, 'Kritik der beiden Makkabäerbücher,' Hermes, 35, pp. 268-307, 453-527, came forth in outspoken preference for the Second Book. In this he stands fairly alone; s. Schürer's judgment, p. 202, n. 42, and Moffatt in the Int. to his Commentary on that book in Charles, $A$ poc. The second book, which properly begins at $2^{19}$, after a preface, $2^{19-32}$, proceeds to the story of Heliodorus' attempted sacrilege, c. 3 (s. sup. at $v^{20}$ ). The sequences of subsequent events may be conveniently presented in the following comparative table, with an attempt to show the possible agreements:

I MAC.

${ }^{10}$ Accession of Antiochus, Era
2 MAC.

$4^{1 \text { ff. The unabashed machinations }}$ of Simon $\left(c f .3^{4}\right)$, which cause the high priest Onias to betake himself to Antioch to use his good offices for his people with King Seleucus.

$4^{7}$ Accession of Antiochus. Sel. $147=\mathrm{r}_{7} 6$ B.C.

1 The present almost consensus of opinion is that there were but two Egyptian Wars, although as many as four have been alleged (Bouché-Leclercq, p. 255; for the earlier literature s. Niese, 3,168 , n. 2). All the authorities named in the introduction to this chap. agree in this; s. Mahaffy, p. 494; Bevan, p. 297, App. G; Schürer, p. I69; and Meyer, p. 15 I, most positively. The elder comm. followed Jer.'s lead in finding a distinct campaign in vv. ${ }^{21-24}$, but doubtless only on the strength of his own deductions. This section is probably only a general introduction to the following history, as Rosen. first observed, for war against the king of the South is not mentioned until v.25; that and the war of $v^{29}$ are the two Egyptian Wars of history. The claim of an additional war at the beginning has been supported from 2 Mac. $5^{1}$, 'his second campaign'; but as Bev. suggests, pp. 297.67 ., this may count in the abortive campaign as far as Joppa, mentioned in $4^{21}$. 
${ }^{11-16}$ Rise of 'transgressors of the Law,' who introduce a gymnasium in Jerusalem and forsake the Law.

Vv. ${ }^{16-19}$ Antiochus? campaign into Egypt.

Vv. ${ }^{20-38}$ Upon his return, E. Sel. I43, he comes to Jerusalem, despoils the temple, massacres the citizens.

Vv. ${ }^{29-40}$ 'After two full years' the king sends a chief collector of tribute, who wastes the city and builds an acropolis on the site of the ancient City of David.

Vv. ${ }^{41 \mathrm{ff}}$. Edict of the king to his whole kingdom that 'all should be one people and each should forsake his own laws,' with specific rescripts against the Jews; and, vv. ${ }^{54}$ ff., there is set up the Abomination of Desola-

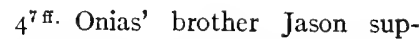
plants him as high priest by promises of lavish donations to the king, asking the boon of introducing Greek fashions, gymnasium, etc., among the Jews.

$\mathrm{Vv}^{21-22}$ The king visits Jerusalem, where he is magnificently entertained.

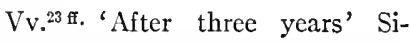
mon's brother Menelaus outbids Jason with the king and is given the priesthood.

$\mathrm{Vv}^{30}{ }^{30}$ fi. Menelaus, coming to Antioch, effects the assassination of Onias, who was lured from sanctuary at Daphnae; the king upon his return home condemns the actual assassin to shameful death.

Vv ${ }^{39-50}$ The outrages committed by Menelaus and his brother Lysimachus in Jerusalem.

$5^{1-10}$ When 'Antiochus made his second campaign into Egypt' (v. ${ }^{1}$ ), a rumor arose of his death, and the fugitive Jason makes an unsuccessful attempt to recover Jerusalem.

Vv. ${ }^{11-20}$ The king, thinking that Judæa is in revolt, sets out against Jerusalem 'in furious mind' (v. ${ }^{11}$, assaults it, massacres the citizens, and loots the sacred vessels and enormous sums of money in the temple.

$\mathrm{Vv}^{21-27}$ Departing he leaves various governors to afflict the people; one Judas Macc. and a few others seek refuge in the mountains.

$6^{1-11}$ 'Not long after this' ensues the supreme desecration of the temple by the governor Geron, its dedication to Zeus Olympios, etc., and the stern repression of the Religion. 
tion on the altar, heathen sacrifices are offered, and a rigorous persecution instituted of all who 'will not profane the Holy Covenant' ( $v .^{63}$ ).

C. 2 The heroic story of Mattathias. Macc.

C. 3 The beginnings of Judas
$6^{12}-9$ The martyr-stories of Eleazar and the Mother and her Seven Sons.

C. 8 Ditto.

It is to be observed that our chap. alone of the three authorities cites the two campaigns against Egypt and alone refers to the part of the Romans in blocking Antiochus' purpose in the second $\left(v^{30}\right)$. Each of those books relates but one campaign (as does Josephus), except for the obscure reference at 2 Mac. $5^{1}$. Apart from an earlier honorary visit of the king to Jerusalem noted by 2 Mac. $4^{21 \mathrm{f}}$, only one visit of his to the city is noted in either book, the final sacrilege of I 68 being ascribed to his governors. Hence our $v .^{30}$, speaking of his actions in the city in the same terms as in $\mathrm{v}^{28}$, which corresponds to his actual visit, must be understood in the general sense of his royal responsibility for the final outrages.

Every historian pauses over the enigmatic character of Epiphanes, 'the Manifest God,' whose character has been indelibly stamped by the Bible as the arch-fiend. There is no occasion here to add to the innumerable attempts at characterization. ${ }^{2}$ At the end of his description E. Bevan offers a useful summary of some of the various opinions advanced by historians (pp. I 28-I32). These opinions draw diametrically apart, according as the student holds to the Hellenic or the Biblical point of view. Antiochus is indeed 'a man of riddles' $\left(8^{23}\right)$, possessing 'the fascination of enigma,' as Bevan remarks. A Græco-Roman Levantine at home, he had the Hellenic polish and 'ideals' (he was elective chief magistrate of Athens at the time he rushed home), and for fourteen years he had lived a hostage in Rome, absorbing Rome's Realpolitik. Somewhat of a reincarnation of his ancestor Demetrius Poliorcetes, he was the first cosmopolite of the new era of the Roman dominion. If he outraged the temple at Jerusalem, Classical art owes a debt to his memory for his

2 The classical character sketch is that by Polybius, xxvi, ro; Phillips Barry presents the ancient authorities in a study in $J B L$ 1910, $126 \mathrm{ff}$. 
temple to Zeus Olympios at Athens, the few remaining columns of which are one of the glories of that ruined city. And if he perpetrated the edict that all his subjects should be one people, one religion-un-Greek enough!-he was but anticipating the Roman imperial policy on which the Church ran foul.

The references to his character in Dan. are monotonously drastic, but true. He is a "little horn . . . with a mouth speaking great things,' $7^{8}$; the same little horn which challenged the host of heaven, $8^{10}, c f$. inf. ${ }^{36} \mathrm{ff}$; ' 'a king of fierce countenance,' clever in plots with a cunning that made deceit succeed in his hand, $8^{23} \mathrm{ff}$. And these brief descriptions are capped by the running description in the following vv. of this chap., in which is revealed the writer's fascination not so much for what he did as for his diabolical character. He was the first precipitant of the conflict between the World and the Bible Religion.

The passage may be analyzed as follows: 21-24. Introduction, Antiochus' accession and early years. 25-28. The first Egyptian War. 29-35. The second Egyptian War, vv. ${ }^{29 .}{ }^{30 a}$, and the consequent trials of the Jewish Religion. 36-39. A description of Antiochus' arrogance toward God and man. 40-45. An apocalyptic account of his end.

21-24. The becrinnings of Antiochus Epiphanes. 21. And there shall arise in his place a contemptible person upon whom had not been conferred royal majesty; but he shall come in unawares and shall seize royalty by intrigues. 22. And forces shall be utterly [if forces of the flood] flooded away before him, and shall be broken [1 + and] even the Prince of the Covenant. 23. And by confederacy (of others) with him he shall work deceit, and he shall come up and grow strong, with a little nation. 24. And

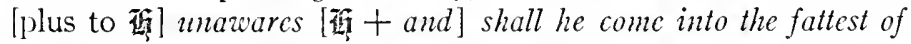
provinces, and he shall do what his fatincrs did not nor his fathers' fathers, lavishing on them spoil and booty and property; and against fortresses shall he devise his devices-but until a Time!

21 depicts Antiochus' character-'a despicable man,' no' a 'manifest god'-and his clever usurpation of the throne. In the foll. relative clause (as EVV correctly tr. the Heb. sentence aigned with 'and') the pl. may imply 'men,' or as equal a passive, ultimately of divine cause; $c f$. I Ch. $29^{25}$, 'YIrwH conferred upon him (Solomon) royal majesty,' which is cited here. 'Unawares': as at v. ${ }^{24}, 8^{25}$ (q.v.). 'By intrigues' $=\mathrm{v} \cdot{ }^{34}, c f . \mathrm{v}^{32}$ : 
lit. 'smoothness(es),' AV 'flatteries,' JV 'blandishments'; concretely the word means 'slippery places,' Jer. $23^{12}$, Ps. $35^{6}$.

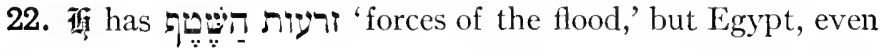
if referred to, presented no such obstacle; the tr. follows Bev., rdg. an inf. abs. 'arms' of the Heb., generally military 'forces' in this chap., can mean 'resources' in general. In $\mathrm{v} .{ }^{\mathrm{b}}$ if has the $\mathrm{vb}$. in the pl., agreeing with the first subject, leaving the final clause, 'yea, also the Prince of the Covenant,' as a 'bedeutungsschwere A posiopese' (Behr.). One must hesitate at correcting the often amazing diction of the chap., but the correction, proposed by Mar. (omission of the two waw's), is plausible. 'The Prince of the Covenant' (a title, lit. 'Covenant-Prince') has been most variously identified in the sense of 'an allied prince' (s. at $9^{25}, c f$. Gen. $I 4^{31}$, etc.); Pole registers four such princes as discovered here, the favorite identification being Ptolemy Philometor, but we should expect 'the king of the South.' But Theodt. identified the person as Onias III, who was assassinated at Antiochus' court, and this view, revived by Rosenm., is accepted by all recent comm. That high priest was removed from office $c$. I 75 and assassinated $c .17 \mathrm{r}$. If these vv. give a general view of the reign, no anachronism is involved, the usual argument against the identification. This person is then the 'Anointed' of $9^{26}$. For 'prince' as high-priestly title s. at $9^{25}$. The word 'covenant' ברית, also vv.30.32 (equally anarthrous), is used almost concretely, as of the Covenant Church; cf. ברית עם Is. $42^{6}, 49^{8},=$ 'a covenant institution of a people,' and s. Duhm, ad loc. With this v. Jer. finds the beginning of the description of the Antichrist, honestly parting company with his guide Porphyry.

23. The initial prep., $i v$, is ambiguous. The most usual interpretation follows Jer., post amicitias, = EVV' after the league made with him'; but preferable is the causative mng. as above, with Geier, and so prob. $\Theta$. Ra., AEz. understand the phrase partitively. Explicit historical ref. need not be sought, beyond the Jews' experience of the king's arts in playing off the local parties against one another, e.g., Jason against Onias, Menelaus against Jason. The figurative mng. of $\boldsymbol{B}$ - $; y$ ' go up' = 'grow up' is most suitable in this general sketch of the king's rise to power; for the vb. $f f ., e . g .$, Gen. $40^{10}$, and of. the Tree sup. $4^{\text {sf. }}$, where 


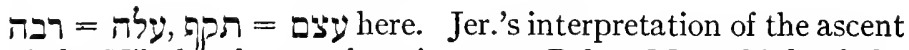
of the Nile has been a favorite one. Behr., Mar. think of the military use of the vb., as, e.g., Is. $7^{1}$. 'With a small nation' is taken here as referring to the actual reduced Syrian kingdom, or the actual domain at first controlled by Antiochus; so Grot. Others understand the small band of his partisans (so Bev.), or, in connection with the military interpretation of the vb., of his few troops, so Behr., Mar., the former however acknowledging that such a use of 1 is unique.

24 sums up the opposite sides of Antiocnus' mixed character; his high-handed avarice and his squandering of the ill-gotten gains on his friends (so we must understand here the ambiguous 'on them'), and on public works of munificence which gained for him the applause of the Greek world. For his prodigality cf. I Mac. $3^{30}$ ('in expenses and buildings'), Jos., $A J$ xii, 7, 2 ('being magnanimous and generous'), and for his cultivation of the gods Livy, xli, 20; $c f$. the same chap. for a list of his public works, and s. Dr.'s note, and the modern historians, e.g., E. Bevan, 2, I4 8 ff. By this excess over 'his fathers' appears to be meant his character as an ignoble looter and senseless spender; $c f$. vv. ${ }^{37 .}{ }^{38}$ for a similar reflection on his religious innovations. In the tr. the first 'and' of thas been transferred to the beginning of the v., with Bev., Cha., and so practically EVV; others, e.g., vLeng., Behr., Kamp., Ehr., attach 'unawares' to end of $\mathrm{v} \cdot{ }^{23}$, and $c f t .8^{25}$. 'The fattest of provinces' (so also Stu., Ew.): by translation of a good Sem. idiom, s. Note; so practically $\mathrm{H}$, ubcres urbes ingredietur. The usual tr. sticks to the sing. 'province,' then generally made articulate, 'the province,' which is forthwith identified with Egypt. But the whole passage is of general import, and ref. to the particular attack upon Egypt seems premature. The point of the v. appears to be Antiochus' ability in seizing by hook and crook the wealth of the provinces, in advance of the attack upon Egypt. For this, followed up in $\mathrm{v}^{25}$, the item of his 'devices against fortresses' makes introduction. 'But until a time': not indefinite, for some years, with Grot. and most; but ad terminum, 'the time fixed in the counsels of God,' $c f$. vv. ${ }^{27}{ }^{35}$, so Dr. after Geier. 
21. נגבוה $\Theta$ as pf., $\dot{\varepsilon} \xi_{0} 0 \delta \varepsilon \vee \omega \dot{\theta} \theta \eta$, obviously construed with v. ${ }^{20}, c f$. In consequence of this Porphyry found the description of Ant. Epiph. beginning at this v., for which Jer. corrects him. Against Dr. the ppl.

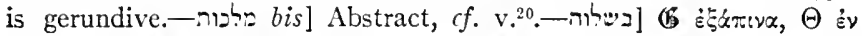

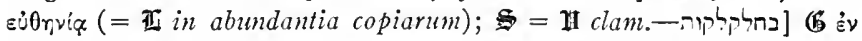

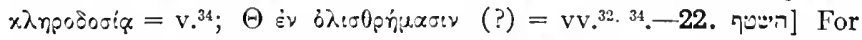
Bev.'s suggestion of abs. inf. s. Comm. $\Theta$ It read as ppl. (G read the two cognate words as though from rt. 20 , and so came to ignore or

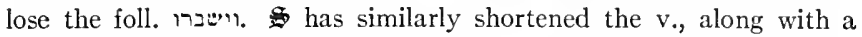

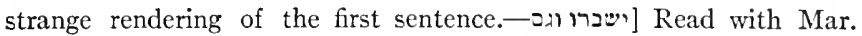

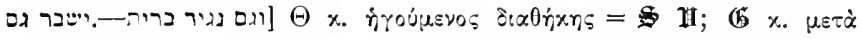

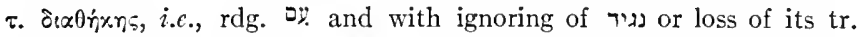
xupiou; $f f$. Note on text of $\mathbb{G}$ at end of c. 9 at $\mathrm{v}^{25}$; $\mathbb{B}$ construes the phrase with opening of v. ${ }^{23}$.-23. Anח' Aramaizing form

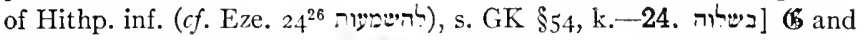
$\Theta$ as at v. ${ }^{21}$; Sym. riouxiqu, $\mathfrak{H}^{\mathrm{Am}}$ om.; $\mathfrak{H}$ text. rec. ct abundantes [et uberes], gloss from ili in abundantia copiarum.-במשמני מרינה] $\Theta(\mathrm{B} \mathrm{V}$

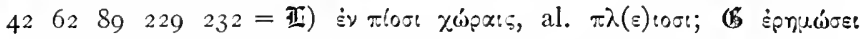

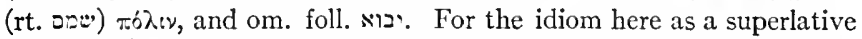
cf. פריקו אבניץ חיות , I Sa. Is. $37^{40}$, equally with polarization of genders; for superlative use of מיט the gen. sing. $c f$. בני נבנר, etc., and s. Kön., Syn., $\$ 256$, a. This polarization between genders and numbers is well known in Arab. in the elative idiom, s. Wright, Gr. \$§86. 93, e.g., șâlihu (masc.) nisâ'i Kururaišin, 'the best of the women of K.'; 'afdalu rajulin, 'a most excellent man.'

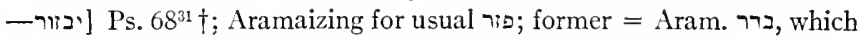
actually saw or heard here, for his tr. נרבר 'shall lead' is a corruption of יבדר

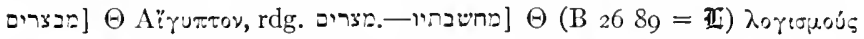

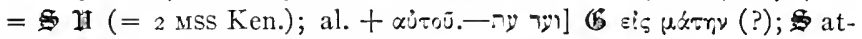
taches to $\mathrm{v}^{25}$, omitting 'and' $\mathrm{I}^{\circ}$ there.

25-28. Antiochus' first war against Egypt and his action against the Holy Covenant. 25. And he shall arouse his power and courage against the king of the South with a great army. And the king of the South shall stir himself up to battle with an exceedingly great army; but he shall not stand, for they shall devise devices against him, 26. and they that eat of his provision shall break him, and his army shall be flooded away [i active, shall overflow] and many shall fall slain. 27. And as for the two kings, their heart shall be for mischief, and at one table they shall speak lies; but it shall not succeed, for (there remains) yet an end for the appointed time. 28. And he shall return to his own land with 
great property. And with his heart against the Holy Covenant he shall do; and he shall return to his own land.

25. 'His power and courage' (lit. 'heart'): power in spiritual sense, $c f$. Mal. $3^{8}$, Job $36^{5}$; for this self-excitation to passion $\mathrm{s}$. at $v^{10}$. For 'with a great army' $c f$. the citation at $\mathrm{I}$ Mac. $\mathrm{I}^{17}$,

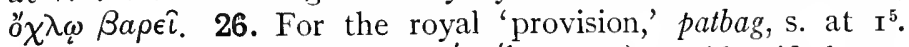
These men of his table ( $\sigma \nu \nu \tau \rho a ́ \pi \epsilon \zeta o \iota$, Mar.) are identified particularly with Eulaeus and Lenaeus, Philometor's unwise counsellors who foolishly took the offensive against Antiochus; the end of the prec. v. suspects them of treachery. 'Shall be flooded away': as at vv. ${ }^{10 .}{ }^{22}$; in has intrans. 'shall overflow,'AV RVV; but the pass. is required, $=\mathbb{I}$, read by Bev., Dr., Mar., Cha., and so JV tr. The final clause is cited for the same event in I Mac. ${ }^{18}$, the Gr. = Grr. here. 27. 'The two kings,' etc.: when Philometor fell into the conqueror's hands he was entertained with elegance, dined and wined, but with his uncle's intention to 'deceive him'; s. Bouché-Leclercq, p. 254, citing Diodorus, $\mathbf{x x x}, 2 \mathbf{I}$. The reciprocal 'speaking of lies' is what was to be expected, but a treachery the grosser for Oriental ethics in that it was carried on at a hospitable table; $c f$. the deceit of 'the familiar friend, who ate of my bread,' Ps. $4 \mathrm{I}^{10}$. 'There is yet an end for the appointed-time': $c f . \mathrm{v}^{24}{ }^{24}$ ' but until a Time!" and the parallelism makes this phrase refer to the ultimate doom in the counsels of God (so Cha.). Most recent comm. interpret as that the subjugation of Egypt was not yet complete, $c f . \mathrm{v}^{30}{ }^{30}$. But the combination of the two terms points the fact that the king's triumph was short-lived. 28. For Antiochus' return home with great spoil $c f$. I Mac. $\mathrm{I}^{19}$, 'he took the spoils of Egypt.' His consequent actions against the Jews are expressed in two brief sentences. For 'the Holy Covenant' (the same term I Mac. $\left.\mathrm{I}^{15}{ }^{63}\right) \mathrm{s}$. at $\mathrm{V} .{ }^{22}$. 'He shall do': a reminiscence of $8^{24}$, also inf. $\mathrm{v} \cdot{ }^{30}$; not so much as 'do his pleasure' with EVV, but cryptically 'do what he shall do' ( $c f$. the Arabic idiom).

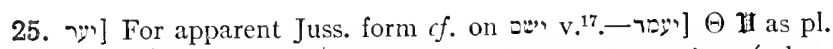

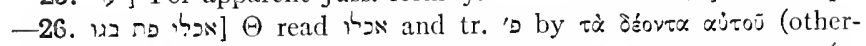

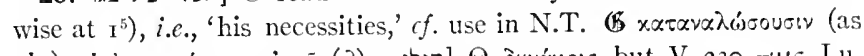

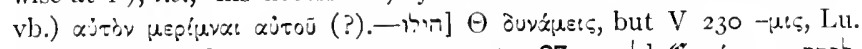

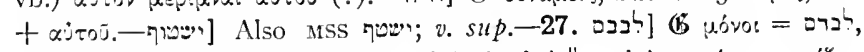

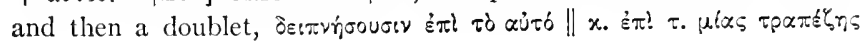


çrrovta..-—va] Prob. Hif. ppl. (cf. the same Pr. $17^{4}$, Is. $9^{16}$ ), in which

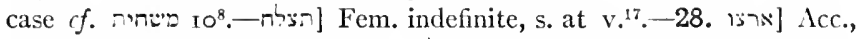
cf. Is. $52^{8}$ after ישוב; but $n . b$. inf., whence the term may have been glossed here.

29. 30a. The second Egyptian war and its estoppage by Rome. 29. At the appointed time he shall return and come into the South, but it shall not be at the last as at the first. 30a. For 'ships of Kittim' shall come at him and he shall be disheartened. At the 'term' Antiochus launched on his second campaign, in which he was halted by Rome and sent home a broken-spirited man. For 'Kittim' as general designation for the lands and peoples of the Mediterranean (primarily for Cyprus, which is visible from the Lebanon) s. Lexx. and BDD. In I Mac. $\mathrm{I}^{8}, 8^{5}$ the word is used for Macedon. $C f$. Jos., $A J \mathrm{i}, 6$, I, "from it (Cyprus) all the islands and most of the parts beyond seas are called Kittim by the Hebrews." Here the Romans are meant, even as 'the Isles' is used of Greece at v. ${ }^{18}$. But further, 'ships of $\mathrm{K}$.' is a citation of 'ships from the quarter of K.,' Nu. $24^{24}$, which explains the use of both words here. The allusion is pregnant, for we read on in Balaam: 'they shall humble Ashur (i.e., Syria), and shall humble Eber (Abar-naharaim), and he (Antiochus!) shall be unto destruction.' 'The striking scene of the arrogant Greek's personal meeting with Rome's representative is told at length by Polybius, xxix, 27, transcribed by Livy, xlv, I 2 ; a tr. by Mahaffy, p. 339. Popilius presented to him the written letter from the Senate peremptorily forbidding his war against Philometor. The king tried to hedge. Whereupon "Popilius did a thing which was looked upon as exceedingly overbearing and insolent. Having a vine-stick in his hand, he drew a circle around Antiochus with it, and ordered him to give his answer to the letter before he stepped out of it. [Appian, Syr.

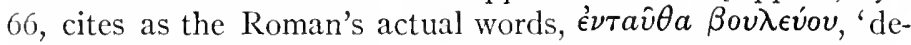
cide there.'] The king was taken aback by the haughty proceeding. After a brief interval of embarrassed silence, he replied that he would do whatever the Romans demanded. . . . He withdrew his army into Syria, in high dudgeon indeed and

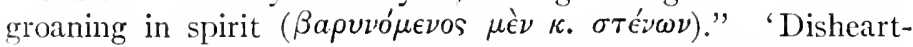
ened' (Bev., JV 'cowed') is the usual Heb. mng. of במז; Behr., Mar., Cha. prefer, with (6, the Syr. mng. 'threaten.' 


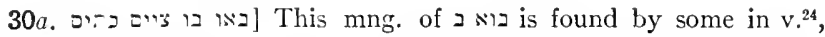
and correcting the text, in $v^{10}$; the phrase is prob. a forced correspondence with בא בנגב v.29. כ' כת is adjectival; also Mss There is no need with JDMich., Orient. Bibliothek, 4, 39, Winckler, Altor. Forsch. 2, 422, to emend to צירים 'ambassadors.' (6) й

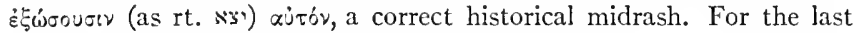

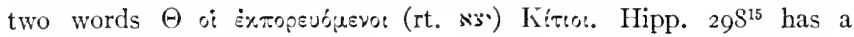

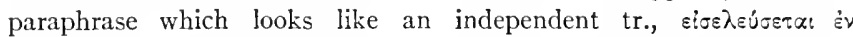

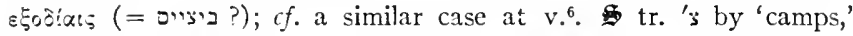

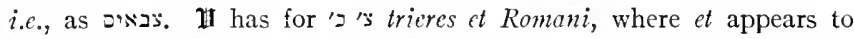
be secondary, having come in from misunderstanding of Jer.'s comm.; edd. print Trieres; equally $\mathbf{H}$ at Nu. $24^{24}$, uenient trieribus de Italia.-

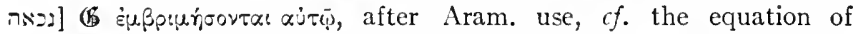

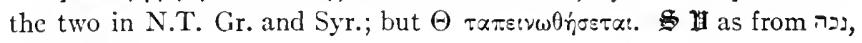
percutictur.

$30 b-35$. The persecution of the Religion and the resistance. 30b. And he shall (re)turn and rage against the Holy Covenant, and he shall do; and he shall turn and have regard to those who abandon the Holy Covenant. 31. And helpers [Heb. arms] from him shall take stand, and they shall profane the Citadel-Sanctuary and remove the Constant (sacrifice) and set up the Abomination Appalling. 32. And those who act wickedly toward the Covenant shall play the hypocrite [if he shall make profane, or, pervert] in intrigue, but the people that know their God shall be stout and do. 33. And the Learned of the people shall teach the many. And they shall fall [lit. stumble, as so inf.] by sword and by flame, by captivity and by despoilment, for (some) days. 34. And upon their falling they shall be helped with a little help; and many shall join themselves to them in intrigue. 35. And some of the wise shall fall, for refining among them and purifying and cleansing-until the time, for the term is yet to come.

The passage, despite its prosaic diction, is weighted with tragic feeling, and its sentences fall into phrases of ponderous measure. $30 \mathrm{~b}$. The two vbs. 'turn' are troublesome. Offhand the first appears to be parallel to the use in v. ${ }^{28}$, 'return,' but the second cannot have this mng.; the tr. of AV RVV 'shall even return' (Dr. 'home to Antioch') as a repetition, is flat. $C f$. efforts of vLeng. and Ehr. It is not necessary to require the identical sense in a repeated Sem. rt., which may be polysemantic within a breath; $c f$. the play in Jer. $4^{1}$, 'if thou wilt turn 
. . . then turn unto me.' Or the vb. may suggest the king's volatile turning hither and thither. For the king's 'rage' $c f$. Polybius' account of his indignation upon Popilius' demand, and the report in 2 Mac. $5^{11}$ of his attack upon the city, $\tau \epsilon \theta \eta$ $\rho \iota \omega \mu$ évos $\tau \hat{\eta} \psi \psi \chi \chi \hat{\eta}$, a passion however attributed to another cause than the Romans. There is no evidence that he came to Jerusalem after the second war. 'Have regard for': the same $\mathrm{vb}$. in favorable sense at $\mathrm{v} \cdot{ }^{37}$. "Those who abandon the Holy Covenant' are the $\pi a \rho a$ a $\nu$ po of I Mac. $\mathrm{I}^{11}$, who 'removed from the Holy Covenant,' v. ${ }^{8}$; $c f$. Jub. $23^{16}$, etc. 31 . The word translated 'helpers,' lit. 'arms,' is the same as 'forces' at vv. ${ }^{15 .}{ }^{22}$, but a change in the gender form (here masc.) suggests an intentional shift of denotation to individuals ( $c f$. Is. $9^{19}$, Eze. $3 \mathrm{I}^{17}$, but in both cases the text is doubtful). The ref. then is to the lieutenants who executed the desecration. 'Take stand': עמ ע = aip, a many-sided word of our writer ( $c f$. at vv. $\left.{ }^{8.14}\right)$. "The Citadel-Sanctuary': lit. 'the c., the s.'; the latter word = 'stronghold' above, e.g., $\mathrm{v}^{10}$, and the construction the same as at $8^{1}$, 'Shushan the fortress.' The temple was itself a fortress with its citadel within its holy area, $c f$. Neh. $2^{8}$, 'the gates of the citadel (הבירה) of the house' (cf. Neh. $7^{2}$ ), and in I Ch. $29^{1.19}$ the temple is simply called the Birah, also a frequent designation in the Talmud (s. Torrey, Comp. and Hist. Value of Ezra-Neh., 36). We have explicit ref. to the destruction of the fortifications of the city in I Mac. $\mathrm{I}^{31}$, upon which follows the account of the building of a new and lofty Akra in the City of David (i.e., the Ophel to the south of the temple), which dominated the temple and remained in possession of a Syrian garrison until I42 B.C. (s. Schürer, p. I98). For 'the Constant' s. at $8^{11}$, and for 'the Abomination Appalling (Ab. of Desolation),' s. at $9^{27}$. For this desecration S. I Mac. $\mathrm{I}^{54 \mathrm{ff}}, 2$ Mac. $6^{1 \mathrm{ff}}$. Acc. to the former it took place on Chislev 25 (in December), E. Sel. $\mathrm{I} 45=\mathrm{I} 68$ B.C.

32. 'Those who act wickedly toward (in re) the Covenant,' : מרשיטיעי ברית: the second word is gen. of specification (cf. a case at $v .{ }^{20}$ ), and the Hif. intrans. as at $9^{5}$. Junius took the ppl. as active, damnantes foedus, then Geier, condemnantes foedus, Hitz., 'die Verdammer' ('Anklager'); and Bev., 'those who bring guilt upon the Covenant,' cft. the opposite in I $2^{3}$, מצדיקי הרבים יחדים; and so Behr., Mar., Cha. On the other hand cf. מרשיעי ידיהי הרים 
'the evil-doers of Judah,' Zad. Frag., p. 20, 1. 26. The received interpretation of the sing. vb. '9' ' ' is 'he shall make profane,' i.e., 'make hanef,' although otherwise the Hif. = simply 'to profane.' 'The tr. 'make wicked men profane' is somewhat absurd, alleviated however by Bev.'s suggestion to tr. "חיחני' 'make apostates of,' RVV 'pervert,' after a Syr. use of the rt. The renegades proceeded from technical wickedness to apostasy. But the tr. adopted above follows a clew of $\mathbf{H}$, impii in legem simulabunt, with a pertinent comment in Jer.'s comm. This mng. of simulare Jer. must have obtained directly from Jewish usage, in the late Jewish sense of is the word used by Delitzsch in his Heb. tr. of the N.T. for iтокріт $\eta$ s). Along with $\mathbb{H}$ the other VSS, exc. rb., which is followed here, and so JV 'shall be corrupt' (!). If the sing. of $\mathrm{ft}_{\mathrm{f}}$ be retained we can obtain an equally good sense with 'he shall flatter them with blandishments'; but the Jewish use is to be followed as against the Syriac. Those who take the king as subj. compare the promises held out for perversion, e.g., to Mattathias, I Mac. $2^{18}$. "Shall be stout and do' ( $c f$. the hendiadys at $v .{ }^{7}$ ) is a faithful description of the faithful Asidæans; $c f$. I Mac. $I^{60}$.

33. 'The learned' $=\mathrm{I} 2^{3}$ : AEz.: 'the Men of the Mishna'; $\Theta \sigma \nu \nu \epsilon \tau o i$, II docti; $c f$. the use of $\sigma v \nu \epsilon \tau o$ 's in the N.T., parallel with $\sigma o \phi o ́ s$, and as technical term, Acts $13^{7}$. Dereser, Hitz. prefer the act. sense of the ppl., as at $9^{22}$; but the sentence then becomes tautologous. The term doubtless represents the Asidæans, 'the Pious,' which party are said to have attached themselves to Judas after his early successes, I Mac. $2^{42}$, although not permanently. 'The many': as at $\mathrm{I} 2^{3}, q . v$. The element of education was already deeply impressed in the Jewish religion. 'Stumble': a synonym for 'fall,' 'be destroyed'; $c f . \mathrm{v} .{ }^{19}$, Jer. $6^{15}$, etc.; it has not here the moral sense of $\sigma \kappa a \nu a-$ $\lambda i \zeta_{\epsilon \sigma} \theta a \iota$, and the subj. is prob. indefinite (Hitz.), not particularly 'the Learned' or 'the many.' For these persecutions $c f$. I Mac. ${ }^{60 \mathrm{ff}}, 2^{29 \mathrm{ff}}, 2$ Mac. $6^{5 \mathrm{ff}}$, and the following martyr-stories, $6^{18 \pi f}, 7$. 'For (some) days': not 'many days' with EVV; $c f$. 827. 34. 'A little help': as recognized since Porphyry, the heroic defence made by Judas. The passage is the only direct ref. to that contest in the Heb. O.T., barring of course whatever passages, Pss., etc., may be critically assigned to this age. The 
writer is not a Maccabæan but an Asidæan, for he looks for help to God alone; $c f$. the challenge of the three Confessors, $3^{17 \mathrm{f}}$. The ref. is valuable for dating these cc. Judas evidently has gained sufficient success to win over many adherents of doubtful character, who 'attached themselves' to him 'in intrigue' (i.e., 'smoothly, speciously,' the same word as at vv.21. 32). But no signal victory has been achieved. As every revolution must learn, popular following depends upon success, and the drastic punishments inflicted by Judas upon renegade Jews forced a time-serving adhesion of many; indeed, the honest problems of religious politics produced a bitter factionalism, so that there were many traitors, true and alleged. Cf. I Mac. ${ }^{14 \mathrm{ff}}, 3^{5.8}, 6^{21 \mathrm{ff}}$.

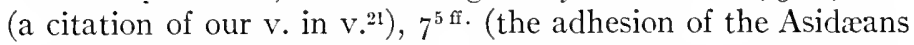
to the high priest Alcimus, who is condemned by the historian), $8^{24}$ (Judas takes vengeance on deserters). 35 reverts to the martyrdom of the Learned, and the plan and result of it in the divine economy; their death is not a judgment upon them, as in the earlier theology, but a means of testing and purification for the mass of the people. $C f . \mathrm{I} 2^{3}$, where these same maskillim 'shall justify the many,' with reminiscence of Is. $53^{11}$. Their death will be the testing-stone of their fellows, for elimination of the faithless, for heartening of the faithful. The $v$. is the earliest expression of the thought that 'the blood of the martyrs is the seed of the Church.' Three metaphors are used for this purging process: 'to refine,' or 'test,' as of the smelting of metals; 'to sift' ( $c f$. Am. $9^{9}$ ), as of wheat; 'to scour,' or 'whiten,' the word used in NHeb. for cleansing and polishing vessels, instruments, etc., also of clothing (e.g., $\lambda \epsilon v \kappa a i ́ v \epsilon \iota \nu$ Rev. $7^{14}$ ). The three vbs. recur $I 2^{10}$. Cff. Rev. $3^{18}$, 'I counsel thee to buy gold purified in the fire and white clothing.' For the final clauses $c f$. vv. ${ }^{24 .}{ }^{27}$.

30b. יבן וג' The clause was rendered by Aq. acc. to Jer., cogitabit ut deseratur pactum sanctuarii, i.e. (s. Field), Aq. read $2 \%$ infin. - 31.

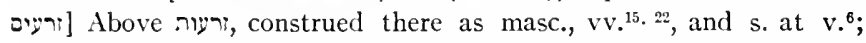
for the gender s. Albrecht, 'Das Geschlecht d. hebr. Wörter,' ZATW 1896, 74, and Kön., Syn., p. 165. For a poss. difference in signification of gender forms $c f$. עיר מבצרות v. v. $^{15}$ 'a fortified city,' and ${ }^{24}$

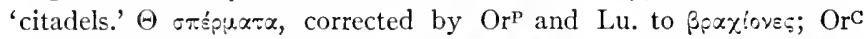

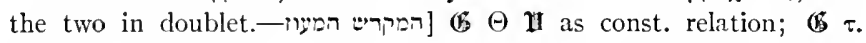

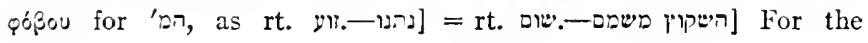




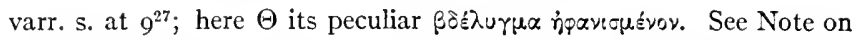
Text of $\Theta$ at end of c. 9.-32. מרישיע] The Hif. in this operative sense

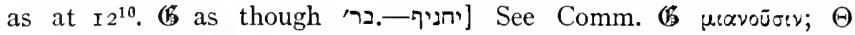

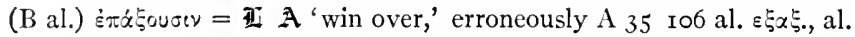
$\alpha \pi \alpha$. For notes on Arab. hanîf, 'pious,' s. Wellhausen, Arab. Heidentum, $207 \mathrm{ff}$., and for the Jewish sense as 'hypocrite,' etc., Grünbaum,

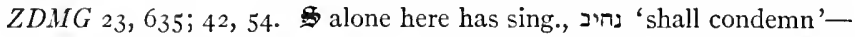

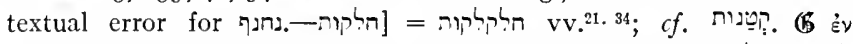

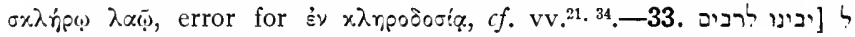

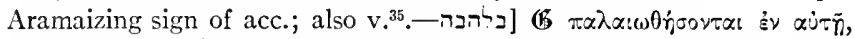
as though בבזה ימיכ-_. Onלה בה, One ed so as rel. const. (G) $\Theta$ II; uss and many edd. + רניש (s. de R.); + 'I000.' $\mathfrak{B}+$ + at end

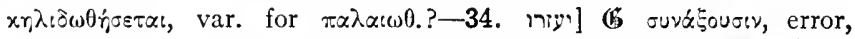

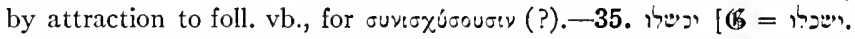
- בהפי] Comm. differ as to ref.: whether to indef. 'people,' 'among them' (Dr.), or as obj. 'them' (Bev., Behr.); or with ref. to 'the learned,' 'unter ihnen' (?), so Mar. Cha. prefers the passives of

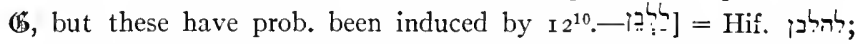
Hitz., al. correct to Piel, but LHeb. uses both stems with this mng.;

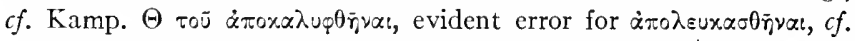

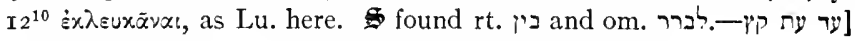

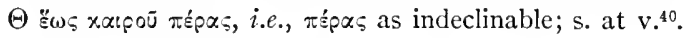

36-39. The king's consummate arrogance toward God, the gods and men. 36. And the king shall do according to his own will; and he shall exalt and magnify himself against every god, and shall speak monstrous things against the God of gods. And he shall prosper until the Wrath is accomplished, for the determination is made. 37. And the gods of his fathers he shall not regard, nor the Darling of women, yea, no god shall he regard, for against all shall he magnify himself; 38 . but the God of Fortresses shall he honor in place thereof, yea, a god whom his fathers knew not shall he honor with gold and silver and precious stones and costly things. 39. And he shall make for defenders [An fortifications] of fortresses a-people-of [All with] a foreign god; whom he will recognize, he shall increase his honor, and he shall make them rule over the many, and the land he shall divide in fief [lit. for a price].

This obscure passage throws novel side-lights upon Antiochus' religious history. To be a god was no new claim for the Orientalized Hellenes, from Alexander down. Antiochus II was posthumously entitled 'Theos'; and compare the earlier story of the 
deified Darius, c. 6. But Epiphanes took his godhead very seriously. He was the first to assume 'Theos' on his coins, and the addition of 'Manifest' (practically 'incarnate') indicated his self-identification with Deity, he was not merely a god like his forebears. The ever-increasing obsession of godhead appears from the sequence of his coins. See Babelon, Les rois de Syrie (Catalogue of coins in the Paris National Library, I89r), pp. xcii seq. (cited by Dr.). The portrait is finally approximated to the features of Zeus Olympios. For light on the god 'his fathers knew not,' Nestle (Marg., 42) has called attention to the same work of Babelon, p. xlviii, who notes (as Nestle says, 'ohne Ahnung unserer Danielstelle') that Apollo (the historic deity of the dynasty) seated upon the Cyprian omphalos disappeared almost entirely from the Seleucide coinage after the reign of Epiphanes, being replaced by Zeus. This replacement of gods, so contrary to antique sentiment $\left(c f\right.$. Jer. $\left.2^{11}\right)$, may suffice to explain our writer's bitterness. We must bear in mind that our document was not inspired by first-hand news from Antioch but by provincial reports, and it is primarily valuable for this reflex of popular opinion. Yet we may find in it a possible allusion to the alleged edict of Antiochus in I Mac. $I^{41 \text { ff. }}$, that all his kingdom should be one people, one religion, otherwise unsupported except for Jos.'s datum that he introduced the cult of Zeus Xenios on Mount Gerizim. See E. Bevan, 'A Note on Ant. Epiph.', Journ. of Hell. Studies, 20 (I900), 27 ff., and his chap. xxiv, 'Antiochus the God Manifest.'

The epithet 'God of Fortresses,' v. ${ }^{38}$, apparently title of the new god the king came to worship, is entirely obscure. $\Theta$ II transliterated the second noun, Maozin, i.e., as n.pr., and this may be implied by the disjunctive accent in 1 (but the prep. $\}$ for the acc. implies a definite obj., 'the-god-of-M.'). Jeph., etymologizing מים, thought of el-'Uzza, and so Aph. Syr., with the epithet $\mathbf{N} r y$, prob. of the Syrian 'Azîz; and so $\mathbf{A}$ and Sa. the same adj. Grot. suggested Mars, the war god; and so forth. The identification with Jupiter Capitolinus (a citadel god) to whom Antiochus erected a great image at Antioch (Livy, xli, 20), has been maintained by Dereser, Häv., vLeng. E. Bevan suggests, P. I50, n. I, the goddess Roma, "the goddess having, of course, as her emblem, a mural crown."

Also 'the Darling (desire) of women,' $v .{ }^{37}$, has been variously 
interpreted (s. Pole, Häv.). JDMich., followed by Gesenius, Häv., al., came on the right track in the identification with Nanai-Anaitis-Astarte-Mylitta, goddess of women and their passions. And Häv. has ingeniously corrected a word in Aph. Syr. (rdg. NNI for $K N I$ ), showing that he found here the goddess Nanai. But Ew.'s identification with Tammuz-Adonis has now, since Bev., come to be generally adopted. $C f$. Eze. $\delta^{14}$ for a description of this passionate cult of women. The actual phrase may be illustrated from Hipp., Refut. haer., v, 9, who cites as Syrian epithet for Adonis $\tau \rho \iota \pi o^{\prime} \theta \eta \tau o s$ 'thrice-desired' (Dr.). May we think of some attempt of the king to control or suppress that lascivious cult, in line with his unification of religion? For often æsthetes, such as he was, join forces with the religious against the absurd and barbarous. We may compare the attempt to abolish the worship of Isis from Rome in the next century.

In general 'the lack of regard for any god' may be summarily explained from the king's many despoliations of temples; $c f$. Polyb. xxxi, 4, 10, "he robbed most of the temples." E. Bevan would find in this objective the practical reason for his assumption of divinity, that he might enjoy the profits of religion.

36. 'The king,' the fascination of the writer, now stands alone upon the stage. 'According to his will': so of the other 'Greats,' $8^{4}$ and I I $^{3}$ (Alexander), II ${ }^{16}$ (Antiochus III). For 'exalt himself' $c f .5^{23}$, of Belshazzar, 'against the Lord of Heaven'; and for 'magnify himself,' Is. $10^{15}$, a description of Assyria. For 'the God of gods' s. at $2^{47}$; the One God of the Jews, but there is latent sympathy for 'the Unknown God' of Paganism, the Lord of Heaven. In general $c f$. the elegy over the king of Babylon, Is. I4 (of which city Antiochus was sovereign). 'Monstrous things' (Bev.): the same adj.-noun as adv. at $8^{24}$ (also of Antiochus), where also 'he shall prosper'; and for the divine 'Wrath' s. at $8^{19}$. The final clause is repeated from $9^{26.27}$; the Heb. pf. is that of certainty. 37. The word for 'darling $=$ desire' appears at vv. ${ }^{8 .}{ }^{38}$, the 'costly' things or vessels, i.e., the sumptuous works of art donated to the gods, and a cognate word in the address to Dan. as 'dear man,' $9^{23}$, $10^{11 .}{ }^{19}$. 38. 'In his place' (lit.): indefinite relation, prob. referring to 'all,' ${ }^{37}$; in view of the same phrase vv. ${ }^{71}{ }^{11}{ }^{21}$ not super basi sua (as, e.g., Ex. $30^{18}$ of the laver), with some early Prot. comm. 
(cf. AVmg), and vLeng., 'on its pedestal,' thinking of Jupiter Capitolinus.

39. Hitz.'s emendation of $\mathfrak{A t}$, reading $\mathbf{z y}$ 'people' for $\square$; 'with,' has been adopted above, in company with Mein., Bev., Behr., Mar., Löhr, Cha., Lamb., Ehr. Further clarification can be obtained by repointing the word 'fortifications' in 鼓 for 9 , following a gratuitous suggestion by Kamp., cft. Is. $22^{10}$ ), and so = 'those who block up,' i.c., 'defenders' (Mar. offhand, 'Besatzungen'). The ref. is then to that prime scandal to Jewish feelings, the heathen garrison, 'people of a strange god' ('a sinful people,' I Mac. ${ }^{34}$ ) in the new Akra (s. at $v^{31}$ ). This was a deliberate and effective insult to their religion; $c f$., c.g., I Mac. $\mathrm{I}^{36}$, the "citadel out of which they issued and polluted all things round about the sanctuary and did great hurt to its purity.' Porphyry is the first to have made this identification: faciet hace omnia ut muniat arcem Ierusalcm. The text of $\mathfrak{A l}$ may best be represented by JV, but the allusions are totally obscure. There follows a statement of the honors and possessions that accrued to the king's mercenaries and favorites; $c f$. I Mac. $3^{36}$, of Antiochus' plans at the sending of Lysias, 'that he should make strangers (prob. orig. בעי בער) dwell in all their coasts, and should divide their land to them by lot,' $c f$. Am. $7^{17}$. At the end 'in fief,' lit. 'for a price,' i.e., by $\kappa \lambda \eta \rho o v \chi \chi^{\prime} a$ : the land was not so much sold as given in return for services or rental. Erroneously $\mathbb{Z}$ gratuito $=\mathbb{B} \epsilon i s \delta \omega \rho \epsilon \dot{\alpha} \nu, \Theta \dot{b}^{\prime} \nu \delta \omega^{\prime} \rho \circ \iota$, except so far as these terms may be technical for the royal bounty. We are in general in the dark how the Sem. rendered customary Gr. legal terminology.

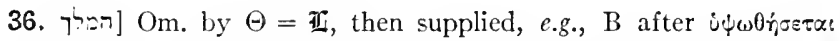
(al. in other positions); entered in duplicate here by Lu.—כבר.

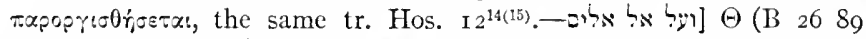

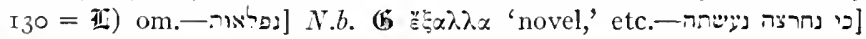

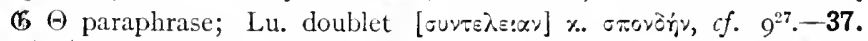

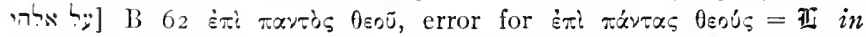

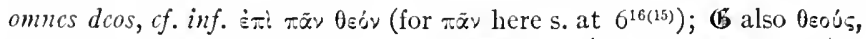

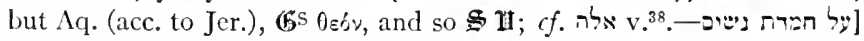

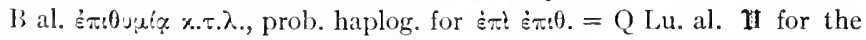
sentence, ct erit in concupiscentiis feminarum, i.e., avoiding continuance of the negation; Jer. deliberately contrasts $\mathbf{6}$ 's $\mathrm{tr}$., and proceeds to paint 
a highly colored picture of Ant.'s concupiscence.--1ישל כל אלוה 3MSS Ken., (5 Lu. om.-38. אלה מעזים (5 here inexplicable; $\Theta$ transliterates,

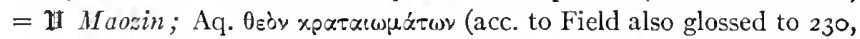
not in HP). Jer. does not further commit himself as to the mng., but ridicules Porphyry for identifying it with Modin, the home of the Maccabees. The transliteration in $\Theta$ If caused the word to be generally taken as n.pr. of a god, and in general provoked interminable discussion, of. Pole; dEnv. makes it surrogate for 'P'́s $\mu \eta=$ 'force' (!).-

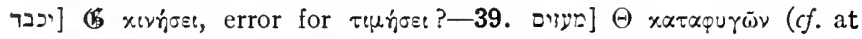
$\mathrm{vv}^{10,21,38)}=$ Sym. confugiorum, as with primary mng. of cites $\Theta$ as aget haec ut muniat praesidiis cum deo alieno (?), and so ren-

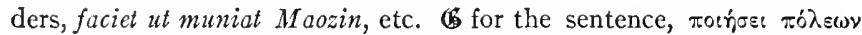

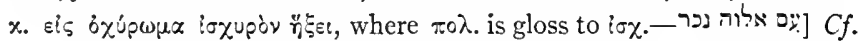

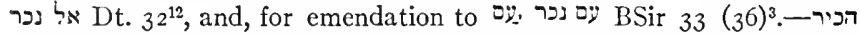
Kt., יכיר Kr., Mss.; Mich. הכיר Kt. and Kִr.] There is no substantial difference between $\mathrm{Kt}$. and K.r. The syntax of the clauses . . . איר כבוד is variously analyzed, $c f$. EVV; best with Ehr. to keep the same subj. in both vbs. and with is implied in the apodosis. B A $106 \mathrm{om}$. איֵּר הכיר relates איוה, and adds $e t$ [multiplicauit] with $\Theta$. goes its own way in the $\mathrm{v}$.

40-45. The last great effort of Antiochus, then his end. 40 . And at the time of the end shall the king of the South butt with him; and the king of the North shall storm against him with chariots and horsemen and many ships, and he shall come into lands and shall overflow and pass on. 41. And he shall come into the Delightsome Land and myriads [Af many] shall fall. But there shall be delivered from his hand Edom and Moab and the remnant [if chief] of the Bnê-Ammon. 42. And he shall lay his hand on lands, and the land of Egypt shall not escape. 43. And he shall master the deposits of gold and silver and all the costly things of Egypt; and Libya and Ethiopia shall be at his heel. 44. But tidings shall alarm him from the East and the North, and he shall go out in great fury, to destroy and annihilate many. 45. And he shall plant the tents of his pavilion between the Sea and the Holy Mount of Delight. And he shall come at last to his end, and none to help him.

For the varieties of interpretation of this passage we may aptly quote Bev. (p. 198): "With regard to these verses there are, as we have seen [p. I62], three rival hypotheses, viz., (I) that they relate historical facts which took place after those al- 
ready mentioned, i.e., after the year I68 B.C., (2) that they give a general sketch of the course of events from about I 7 I B.C. to the death of Antiochus, (3) that they describe, not real facts, but merely the expectation of the author." To these should be added (4) the view maintained since Jer., that the end of Antichrist is portrayed here. The second theory is based on the allegation of a fourth Egyptian war attributed by Jer. to Porphyry; as we have seen above (note to int. to $\mathrm{vv}^{21-45}$ ), this view is now wholly discountenanced by historians, however we may explain Porphyry's datum or the way in which Jer. came to make the attribution (s. Dr.'s excellent note introductory to this passage). The present writer agrees with the great majority of recent comm.--many of them of most conservative tendency, e.g., Häv., dEnv., who would find in the passage an accurate forecast of Antiochus' death-in regarding the passage as a prophecy of the king's catastrophic end. But it cannot, with those conservative theologians, be taken in any way as an exact prophecy of the actual events of his ruin. The alleged final victorious war with Egypt, including the conquest of the Cyrenaica and Ethiopia, in face of the power of Rome and the silence of secular history, is absolutely imaginary. All attempts to place the scene of the king's actual death as accurately foretold in $\mathrm{v} .{ }^{45}$ are based on misunderstandings, of long inheritance. The boastful threats of the fearful man after his expulsion from Egypt in 168 B.C. laid the basis of expectation of his return thither, but with little understanding of the new factor Rome, which had entered the stage of the Orient; he is to have his heartful of triumph over Egypt and many lands, but God's vindication against him is to be made by his overthrow 'between the Sea and Jerusalem,' v. ${ }^{45}$, i.e., in the Holy Land, as he prepares to march against the Holy City. For it was on this holy stage that apocalypse ever depicted the breaking down of all Antitheistic power; so of Gog, Eze. $39^{4}$; also Joel $4(3)^{2}$, Zech. $14^{2}$, En. $56^{6 \mathrm{ff}}$, $90^{13 \mathrm{ff}}$, Rev. $20^{9}{ }^{1}$ However, this inaccuracy

\footnotetext{
${ }^{1}$ The location 'between the Sea and the Holy Mount' for the final progress against the latter might best be taken for the route up from Ptolemais (not Joppa) inland; this would have passed by the commanding fortress of Megiddo ("the plain of Megiddo' acc. to 2 Ch. $35^{22}$, and and A tr. אפרנו ve by 'plain'), and the combination of our prophecy with the many historic crucial events at Megiddo may have produced the theme of Armageddon, Rev. $16^{16}$. Is there any association of ideas in the name of Campus legionis, the modern Lejjûn, hard by Megiddo?
} 
of the prophetic forecast is of extreme value to the critic; our bonk must have been composed well before the tyrant's death. On the other land, the essence of the prophecy was strangely justified by Antiochus' miserable death.

40. 'At the time of the end': $c f . v .^{27} \cdot{ }^{35}$, and inf. v..$^{45}$, 'his end.' 'Butt with him' (reciprocal vb.): the figure as in $8^{4}$; and for 'storm' $c f$. Jon. I ${ }^{11}, \mathrm{Hab} .3^{14}$. Has 'many' been dislodged from orig. 'many [lands]'? The figure of overflowing is as at v. ${ }^{10}$. 41. For 'the Delightsome Land' s. at v. ${ }^{16}$. 'Myriads' is a correction of one vowel point in $\mathfrak{A H}$, which reads 'many,' fem., sc. 'lands' (?). The exemption of the lands to the east and south of Judæa is entirely obscure, not satisfactorily cleared up by the usual appeal to the fact that those peoples were hostile to the nationalistic revival under Judas ( $n . b$. his wars against Edom and Ammon, I Mac. $5^{1 \mathrm{ff}}$ ), and so, ipso facto, exempt. It must be some local allusion whose significance escapes us, unless we regard it as a later insertion. Jer.'s comment, "illuc sancti ad deserta confugiunt," has in mind prob. the flight of the Jerusalem Church to Pella. For here שיארית 'remnant,' with and so GB Mar., Löhr, Cha., Ehr., Lamb.; the former cannot be explained by appeal to $\mathrm{Nu}$. $24^{20}$, Am. 6 , etc.; cf. 'the remnant of Edom,' Am. $9^{12}$, etc. 42. 'Lay his hand upon': as at Ex. $22^{10(8)}$, Est. $8^{7}$. The mask is thrown off with the naming of Egypt; for its earlier occurrence s. at v. ${ }^{8}$. 43. 'Deposits' פעב (Aram. rt.), lit. 'hidden things,' i.e., 'treasures.' As treasures were always 'hidden' in the ground (e.g., Mt. I $3^{44}$, or in safe places like temples, we may render the word technically by 'deposits.' 'Libya and Ethiopia': the nouns are grammatically pls., but such pls. are designations of the peoples as a whole, $c f$. פלישתים = 'Philistia.' The two lands, the Cyrenaica, a possession of the Ptolemies, and Ethiopia, represent the extremes of the traditional ernpire of Egypt, the whole of which shall be conquered. 'At his heel': lit. 'steps'; cf. 'at his feet,' e.g., Ju. $4^{10}$, i.e., 'in his train,' as subjects. 44. 'Tidings' or 'rumors,' i.e., news, 'from the East and the North': i.e., in contrast to Egypt, the South. Antiochus' last year was actually spent in campaigning against the kingdom of Armenia and the Parthians; these were the three strategic points of the compass for his empire. 'Alarm': the same vb. in the Aram., $4^{2(5)}$, etc. The two infins. at the end are found 
paired, but in reverse order, at 2 Ch. $2 \mathrm{O}^{23}$; in both passages the rt. haram, primarily of religious 'ban' and so destruction, is used in an entirely secular sense. 45. "The tents of his pavilion': the last word, appéden, is of Pers. origin, apadana, and came in through the Akkad.; s. literature in GB, and add Scheftelowitz, Arisches im AT, I90I, 79, Tisdall, $J Q R$ 2, 370. Acc. to Maspero, Passing of the Empires, 74I, it meant the hall of honor. The word taken along with 'tents' must signify here the royal pavilion, a mng. supported by Targ. to Jer. $43^{10}$ (Dr.), where it tr. the obscure Heb. שבריר, generally recognized as 'baldachin,' s. Lexx., esp. Kön., Hwb. Of the VSS Aq. and Sym. alone approximated the mng., the others transliterated and then their texts fell into error. Häv. cites Polyaenus' description (Straiegica, iv, 3, 24) of Alexander's great audience pavilion in India. 'Sea' (so RVV): Heb. 'seas' (AV JV), i.e., pl. of extension, so in poetry, e.g., Ju. $5^{17}, \mathrm{Dt} .33^{19}$. The word in all these places anarthrous, = 'the Sea.' 'The Holy Mount of Delight,' Heb., 'mount of delight of holiness': combination of the name for the land as above, e.g., v. ${ }^{41}$, and the freq. 'mount of holiness,' e.g., Ps. $2^{6}$; for such a series of constructs $c f$. Is. 281 . One of the usual Heb. expressions for 'between' is used here, lit. 'between the sea $(\mathrm{s})$ to the mountain,' rightly rendered by $\mathbb{B}$; but $\Theta$ tr., 'between the seas, at ( $\epsilon$ ' following prob. the suggestion of a Gr. rdg. $\epsilon \pi i$, tr., inter maria, super montem; this tradition was followed by GV, 'zwischen zwei Meeren, um den ... Berg,' and AV, 'between the seas in the . . . mountain.' This current 'between the seas' has originated many curiosities of interpretation: the Mediterranean and the Dead Sea (Jer.); the two rivers of Mesopotamia (Porphyry); the Euxine and Persian Gulf (Calv.); the Caspian and Persian Gulf (Häv.); etc.; dEnv, explains from the Bab. terminology of 'the Upper and the Lower Sea,' and understands the centre of the Oriental empire. These latter interpretations, of course, seek identification with the actual scene of Antiochus' death at Tabae in Persia, and then generate the absurdity of a Jew calling a heathen temple 'Holy Mount of Delight,' as Bev. observes. 'At last to $(\boldsymbol{y})$ his end' = 'bis zu seinem Ende': c $f$. the catastrophic end foreseen for Antiochus at $8^{25}$.

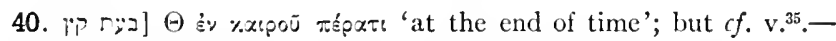

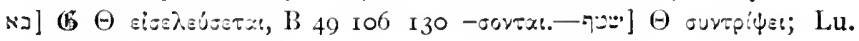




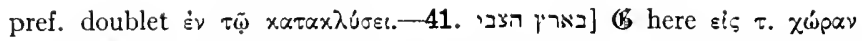
pou._-_ ברות = Neh. $7^{10}$, with Sym., de Wette, al., $c f$. רבאות v. ${ }^{12}$. $\Theta$ as masc., $\pi 0 \lambda \lambda$ oi, (6) correctly fem. $\pi 0 \lambda \lambda \alpha$ !. But the passage $x . \pi 0 \lambda \lambda \alpha t^{\prime} . .\left(v^{42}\right)$ yatats is a Hexaplaric insertion; the omission is due to homoiotel. of בארצות בארץ הצכי and This insertion is not from $\Theta$, and in view of Jer.'s note, "multas autem corruere, iuxta Aquilam, uel urbes, uel regiones, uel provincias intellige," we may assume that the inset was taken from Aq.; $n . b$. the archaizing raiats. 'many' = 1 multae, also edd. multi.-42. ארצות] $\Theta$ as sing.; i.e., the subj. as Antichrist?-43. 'מכמנ] Rt. $\dagger$; mng. 'hidden' is supported from later Jewish use $=\Theta \tau$. ¿̇ंoxpúpoıs. II properly interpret as thesauri, s. Comm.; there is no reason, on basis of Syr. mng. 'lie in ambush,' to

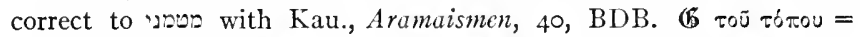

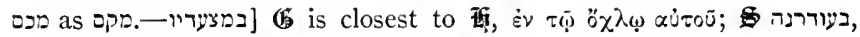

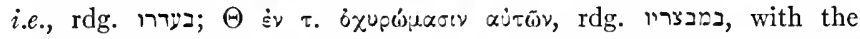
pron. pluralized after syntactical alignment of 'Libyans and Ethiopians' with 'Egypt'; $\boldsymbol{H}$ paraphrases with another interpretation, per Libyam quouue et Ethiopiam transibit.-44. יפהיהו] All $\Theta$ mss exc. V

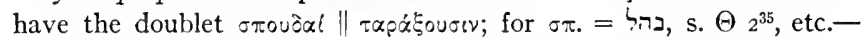

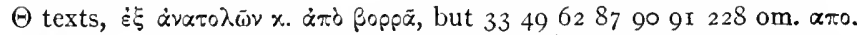

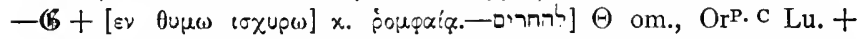

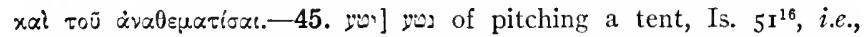
the 'implanting' of tent-stakes, $c f$. Ecc. $12^{11}$ of driving a nail; otherwise

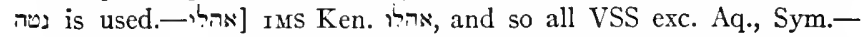

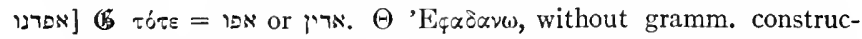

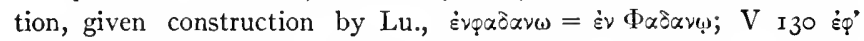
'A $\delta \alpha \omega$, etc. Jer. gives as Aq.'s tr., et plantabit tabernaculum prae-

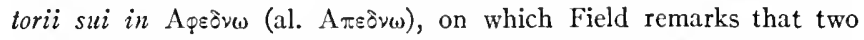
versions of Aq. appear to have been compounded. If follows Aq.,

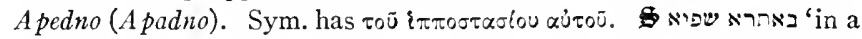
level country'; i.e., as בפדן, 'in a field,' and so A; on this correspon-

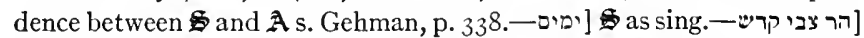
1 super montem inclytum et sanctum follows Aq.; for 'and will keep (ינ) his sanctuary,' which Aph. Syr. naturally interprets,

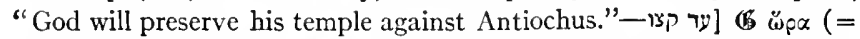

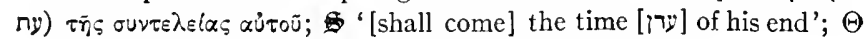

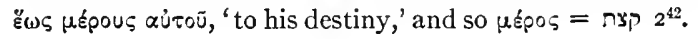

\section{NOTE ON THE INTERPRETATION OF C. 11.}

There appears to be an utter lack of allusion to this chap. in early Jewish and Christian literature. And subsequently the Jewish comm. with their characteristic lack of historical sense make the chap. a phantasmagoria of fanciful allusions, among which appear pell-mell Rome, Ishmael, the Hasmo- 
næans, the Queen of Sheba, etc. Jephet alone exhibits somewhat of an historic continuity, concluding with the theme of God's overthrow of Islam. ${ }^{1}$ The comm. of the Eastern Churches go early astray in the historical ribwork of the chap. Hipp. takes up his exegesis of it at iv, $4 \mathrm{I}$; in c. 42 he interprets vv. ${ }^{3 \text { ff. }}$ of Antiochus Epiphanes, and then comes the story of the Maccabees. By c. 46 he has reached the death of Alexander Balas, with citation of I Mac. I I ${ }^{11 \mathrm{ff}}$. With c. $48=$ our vv. ${ }^{36} \mathrm{ff}$. enters Antichrist.

But two early commentators, unlike Hipp. and Jer. and most of their successors, pursue an entirely historical exegesis of the whole chapter, both interpreting it from the Macc. history. Aphrem (his rubrics are carried over into only as far as v. ${ }^{12}$ ) finds in $v^{6}$ the marriage of Cleopatra daughter of Antiochus III. The rest of the chap. is assigned to the reign of Antiochus IV, and the conclusion is interpreted of the latter's death. Polychronius pushes the history still farther forward. At vv. ${ }^{5}$. he sees the victory of Alexander Balas over Demetrius I, I50 B.C., and his marriage with Philometor's daughter (yet noting here Porphyry's view that Berenice's marriage is meant). The history is continued with the wars of Trypho against the Jews, and his master Antiochus VI is identified with the tyrant of the rest of the chap.

Western scholarship has been delivered from the vagaries of apocalyptic exegesis through the mediation of Jerome. Porphyry, the heathen commentator of Dan., in his argument against the Christian interpretation of Dan. as a Messianic prophecy, had given a detailed historical interpretation of c. II, proving step by step that it is veiled history culminating with the Macc. period, and hence logically the earlier cc. must be similarly interpreted. He has many characteristics of an ingenious modern scholar, as when he identifies Maomin with Modin the home of Maccabees, or Ephedano with a place between Euphrates and Tigris as the scene of Antiochus' actual death. Jer. honestly allowed himself to follow his reprobated opponent's excellent historical criticism, only parting company with him at v. ${ }^{21}$, when for him the Antichrist appears. But he continues what is one of the greatest services contributed by any Patristic comm. in still presenting in parallel Porphyry's adverse views, so that Western scholarship has been in general committed to a sane exegesis of the chap. Cath. theologians themselves have divided in part as between Jer. and Porphyry, some treating the whole of vv.21 f. as referring to Antichrist, others introducing this figure only at $v .{ }^{36}$, in this respect following Theodt. (s. Knab., p. 320). Chrysostom, however, found the Antichrist throughout the chap. (Adv. Jud., v, $7=P G$ $48,894)$.

${ }^{1} \mathrm{Jeph}$. possesses the same tradition for the location of the appeden, $\mathrm{v} .{ }^{45}$, as we find in Jer. The latter remarks: "nostri . . . sic exponunt . . . ut figat tabernaculum suum in Apedno iuxta Nicopolim. . . . Deinde se erigens usque ad montem Oliueti Ierosolymarum regio ascenditur" (hence the "seas' are the Mediterranean and the Dead Sea). And so Jeph., "it is thought that he will pitch his tents at "Amwas four parasangs from Jerusalem." 
The early Prot. comm. followed the leads offered by Jer., some finding the Antichrist at v. ${ }^{21}$, others accepting Porphyry's historical exegesis to a later point in the chap. A subdivision appears in this class, of those who find the Antichrist introduced first at $\mathrm{v}^{36}$, e.g., Geier, CBMich.; much later Klief. proposed that his first appearance is at $v^{40}$.

Later the historical, as against the apocalyptic, interpretation of this final section, $v{ }^{40}{ }^{4}$, advanced more and more to the fore, both with the conservatives and the radical theologians. The latter, e.g, Bert., found a vaticinium ex eventu and generally the Fourth (or Third) Egyptian War; vLeng. was the first to reject this hypothesis, descended from Jer.'s presentation of Porphyry, and he regarded the passage as a general summary of events, such as occurs in $v^{22}$ fi. Of the conservative theologians some found a true and exact prediction of Antiochus' end, including a Fourth war, so Häv. (e.g., v. sup. at v.45), Stu., dEnv., Knab.; but Kran., denying this war and confessing the vagueness of detail in prophecy, insisted only on the truth of the chief objective of the prediction. Withal the ancient theme of Antiochus as type of Antichrist was still woven in by some without prejudice to an historical exegesis, e.g., Knab., p. 3 I 5 .

On the other hand, the more theologically minded, who recognized that their interpretations of cc. 2. 7-9 were logically involved, found still in this chap. a symbolic prophecy of the conflict of the kingdoms of the World, with only occasional and indistinct prefigurations of secular events, the whole culminating in the prospect of the Antichrist; so, e.g., Keil, and apparently Pusey, who however does not particularly treat this chap. One conservative scholar, Zöck., bravely found his way out by the unique position that exact historical data in the chap. are due to interpolations by 'a revision in the time of Ant. Epiph., by a pious apocalyptic investigator' (Int., §I, p. 4, n. 2). Zöck.'s theory has been continued by Wright in his Daniel, cc. 8-1o. Wright's position is heartily indorsed by Boutflower, In and Around the Book of Daniel, $5 \mathrm{ff}$.

The current view of recent comm. is that with $v .^{40}$ begins a prediction of the future, the Maccabæan author leaving the ground of past history at the point where he stands and forecasting the end of the tyrant. This is the position of Mein., Bev., Behr., Pr., Dr., Mar., Cha., Lamb. The modern consensus is theretore a continuation of the ancient historical exegesis of the chap. as introduced by Porphyry, with the exception that vv. ${ }^{40} \mathrm{ff}$. are a necessarily vague prediction of events subsequent to I68 B.C., after the manner of much of O.T. prophecy and apocalyptic.

C. 12, 1-3. The final triumph of the Righteous. 1. And at that time shall Michael stand up, the Great Prince who stands by the sons of thy people. And it shall be a time of distress, such as has not been brought to pass since there was a nation until that time. But at that time thy people shall be delivered, every one 
found written in the Book. 2. And many of those who sleep in the ground of dust shall awake, some to everlasting life, and some to reproach. to everlasting abhorrence.

3. And the Wise shall shine like the sheen of the sky:

And they who set the many right like the stars for ever and ever.

The end of the godless tyrant must have its positive foil in the bliss of the righteous; so the elder apocalypses concluded, c.g., Eze. $3^{8}-39$, Joel 4(3). Those prospected the future redeemed Israel of earth living free of enemies and of the curses of earth (e.g., Is. 4); death was generally accepted in a commonsense spirit as inevitable, at the best a long life might be expected (c. Is. $65^{20 \mathrm{f}}$ ). But a new factor had entered now. The righteous had been martyred for the Religion of the One God, and what was their meed? The growing individualism of the age, marked in the piety of saints and the heroism of the Macc. minority, stung by the sense of lack of equity in the laws of nature, demanded the personal vindication of the martyrs and confessors of the Religion. The doctrine of the resurrection of the dead was the precipitate of the problem; and these vv. are "the earliest passage where the belief is unambiguously set forth" (Bev.). From the time of the Maccabæan struggle that belief entered to become one of the few chief dogmas of Judaism.

The doctrine as expressed here has its marked features and limitations. Acc. to v. ${ }^{1}$ the living who are entered in the divine Register of those whose 'citizenship is in heaven' shall be delivered from the present distress. As for those who sleep the sleep of death $\left(\mathrm{v}^{2}\right)$ some, only, will be raised up, and of them two classes: these, the rightcous, to everlasting life (the first occurrence of the term in the Bible), and those, eridently the arch-sinners, to everlasting reproach, i.e., for their own shame and the moral satisfaction of the righteous. The rest, who were neither good nor bad, with whom divine justice had satisfied itself, are ignored, left in the shades. And, v. ${ }^{3}$, from the righteous a higher order is distinguished, 'the Wise,' who knew and practised the doctrine of the Religion and who by their instruction and discipline were able to 'set right' or 'make rightcous' the mass of the community, 'the many'; these are to shine with brilliance like the stars. Further, whether the conditions of these blest ones is secular or celestial, we are not told. The boon of 
this bliss is given to the seer himself as the climax of the bk., $\mathrm{V} \cdot{ }^{13}$.

For the doctrine of the resurrection in general s. above, Int., $\S 20$, and such authorities as Volz, Jiid. Esch., \$\$26 ff., Bousset, Rel. d. Jud., 308 ff., Charles, Critical History of the Future Life, cc. $3-5$, the O.T. and N.T. Theologies, etc. Volz, p. I2, without any convincing reason regards these vv. as constituting by themselves 'a little apocalypse.' V. ${ }^{2}$ is cited Pss. of Solomon $3^{16}$, and Test. Levi $10^{8}$ with the development that 'all men shall rise.'

1. For Michael s. c. Io; here with the title 'great prince,' i.e., later 'archangel.' 'Stand by' or 'over': as in Eng. idiom of protection, $c f$. Est. $8^{11}, 9^{16}$. 'Time of distress' is cited from Jer. $30^{7}$. 'Such as never was,' etc.: cf. Ex. $9^{18}$, Joel $2^{2}$ (דיה as here), cited Mt. $24^{31}=M k$. I $3^{19}$. 'In the Book': i.e., the register of citizens enrolled for the eternal life. It is an extension of the idea of the book God keeps of the names of Israel in this world; cf. Ps. $69^{29(28)}$ and Ex. $32^{32}$. The present idea is anticipated by Is. $4^{2}$, 'those who are written unto life' in the glorified Jerusalem. So in En. $47^{3}$ (where s. Cha.'s note), etc., and freq. in the N.T., e.g., Phil. $4^{3}$, Rev. $3^{5}$; s. note on the heavenly 'books' at $7^{10}$ and Bousset, pp. $295 \mathrm{ff}$. 2. 'Those who sleep': this tender term is continued in the N.T., Jn. II ${ }^{11}$, Acts $7^{60}$, I Th. $5^{10}$ (a reminiscence of our passage). 'Dust' is the element of the grave, $c f$. Job. $20^{11}$, Ps. $22^{29}$, the natural place of man's ultimate return, 'for dust thou art and unto dust thou shalt return,' Gen. $3^{20}$. The collocation of the words 'ground of dust' has troubled translators since $(\mathfrak{G}$; it may be noted that $9 \boldsymbol{y}$ has in later Heb. the sense of hyle, matter. The otherwise unused word for 'abhorrence' is cited from Is. $66^{24}$, where there is the first glimpse of the eternal pains of the damned in a Gehenna. 3. 'The wise': as at $\mathrm{II}^{35} ; B a b a b$. 8b cites the term here as applying to the teachers of Israel. For the 'sheen' of the sky $c f$. its 'clarity,' Ex. $24^{10}$. There is the incipient idea of the transcendent conditions of the blest, 'a new heaven and a new earth.' 'Who set the many right,' EVV 'that turn (the) many to righteousness': with the Hif. of pTy, but not in its customary legal sense of 'declaring innocent'; the present text of Is. $53^{11}$ may be compared, 'by his knowledge shall my righteous Servant (?) make the many righteous,' of which our v. is reminiscent. Bev. aptly quotes $P$. Aboth, v. 26. 27, which depends upon our pas- 
sage: "Whosoever makes the many righteous (Jewish Bibl. Pירו) sin prevails not over him; and whosoever makes the many to sin, he is deprived of the power of repentance $[n . b$. many parallels in the N.T.]. Moses was righteous and made the many righteous, and the righteousness of the many depended upon him." 'The many' (= II $\left.{ }^{33}\right)$, as Taylor remarks ad loc., are practically the community, the public; $c f$. Rom. $5^{15}$

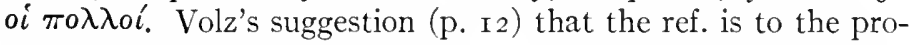
pitiatory value of the sufferings of martyrs is not impossible. The theme of these glorified saints shining like the stars is taken up in En. $39^{7}, 43$, 104 ${ }^{2}$, Wis. $3^{7}$, Mt. $13^{43}$ ('the righteous shall shine as the sun'), etc.

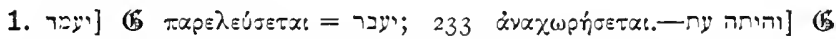

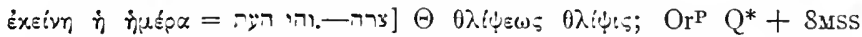
om. $\theta \lambda$ f 4 !5. Is this a back-reading from Mt. $24^{21}=\mathrm{Mk}$. I $3^{19}$ ? $C f$. also the citation in I Mac. $9^{27}$. - נהירה] For the same Nif. s. $2^{1}, 8^{27}$.

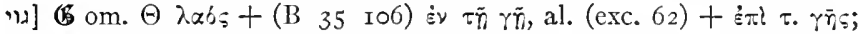
the latter form of plus in the citation Rev. $16^{18}$; is our plus a back-

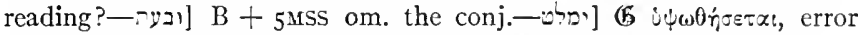

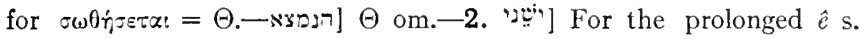

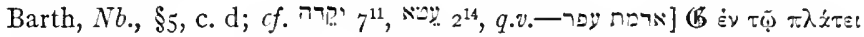

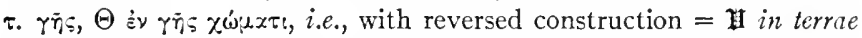
pulluere $=$ EVV. S. note by Bev. for a possible הרמה 'cairns,' cft. Ps.

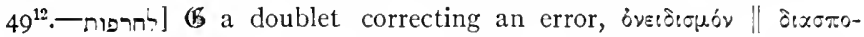

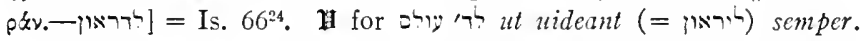

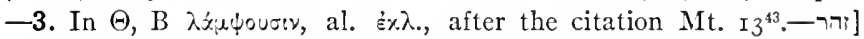
(B)

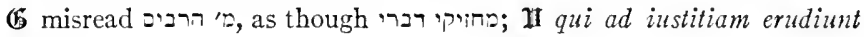
multos.

4. Final injunction to seal the Book. And thou, Danicl, shut up the words, and seal the book, even to the time of the end, (while) many shall run to and fro that knowledge may increase. For 'closing up the words' $c f$. 'closing up the vision,' $8^{26}$. For the inviolability of 'sealing' cf. Is. $29^{11}$. The opposite injunction is given, Rev. $22^{10}$, but there the consummation is immediate. By 'the book' is evidently meant the whole book. 'The time of the end': as at $8^{27}, \mathrm{II}^{35}$; i.c., the climax of the Antiochian crisis. 'Run to and fro,' etc.: the passage is best explained as an allusion to a well-known Scripture, Am. $8^{12}$ : 'they shall wander from sea to sea and from the north to the east; they shall run 
to and fro (the same vb. as here) to seek the word of Yilwh, but shall not find it'; so Ra. interprets by simply citing Am. The parallel interprets the clause 'that knowledge may increase'; it is all a vain search until the Book is published. This sense of 'wandering' has been accepted by some early Prot. comm., vLeng., al., but with the sense that 'knowledge' must be interpreted in a depreciatory sense, as vain or false opinions (Montanus). The most common interpretation is that given by Jer., who tr. the vb. by pertransibunt, and comments, "id est, percurrent; solemus enim dicere, percurri librum, pertransiui historiam." So indeed Jeph., also Geier, et al., and still a prevalent view, e.g., dEnv., Knab., Mein., Pr., Mar. ('durchforschen'). But there is no support for this meaning of the vb., the parallel adduced, Zech. $4^{10},=2 \mathrm{Ch}$. I6 $6^{9}$, of YHwr's eyes 'going to and fro through the earth,' having the sense fixed by the subject. Häv., after and Calv., explains: only to those who seek is the grace given to look into God's mysteries; but again the vb. does not mean 'seek.' Behr. and Bev. have suggested emendations. V. ${ }^{\mathrm{b}}$ is best understood as dependent, as in the tr.

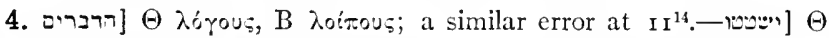

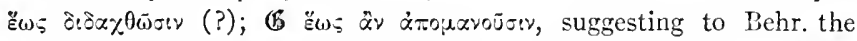

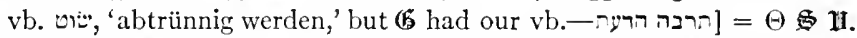

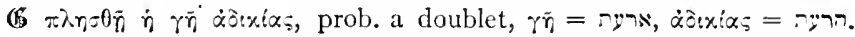
The latter is accepted by Bev. in place of הריז, 'many shall be the

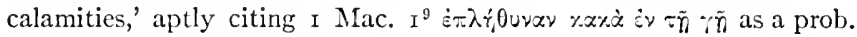
quotation of the oris. IIeb.

\section{EPILOGUE $12^{5-13}$.}

The Vision was properly finished by the command to 'seal the Book' v.4. This epilogue is therefore a supplement, a condition which has induced Barton to regard it as a later addition to the bk.; on this criticism s. Mar. here. Two motifs give authentication to this appendix: ( $I$ ) The anxious inquiry of the seer as to the time of the end, on which the Vision had given no information; (2) the personal promise to the seer of his own fortunate lot in the future ( $c f$. a similar promise to Baruch, Jer. 45); with this personal touch the bk. quietly but dramatically ends.

5-7. The celestial colloquy as to the end. 5. And I Daniel looked, and lo, two others standing, the one at this side of the bank 
of the stream, and the other at that side of the bank of the stream. 6. And one (of them) said to the man clothed in linen, who was beside the waters of the stream: How long until the end of the marvels? 7. And I heard the man clothed in linen, who was beside the waters of the stream, as he lifted up his right hand and his left unto heaven and swore: By II im who liveth forever, it is for a time, times, and a half; and when an end is made to breaking in pieces the power of the Holy People, all these things shall have end.

5. Two angelic persons are introduced in the final solemn scene. One of them puts the question as to the end, the query in the seer's heart which he dares not to utter. It is addressed to the man in linen, the personage in $10^{5}$ fr., i.e., Gabriel. Similarly in $8^{13}$ two persons appear on the scene, and likewise in Zech. $\mathrm{I}^{7 \mathrm{ff}}, 2^{5(1)} \mathrm{ff}$. there is a duplication of such men. Bev. ingeniously explains the two as witnesses to the oath in v. ${ }^{7}$. 6 . The subj. of 'said' is unexpressed, it must be one of the two;

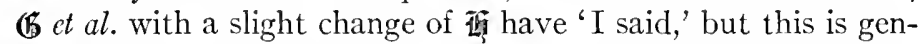
erally disowned by critics. The locality is still that of the riverside, as at $10^{4}$. The word 'stream' is the word which elsewhere denotes the Nile, or in the pl. its arms, except at Is. $33^{21}$ (a Mesopotamian scene) and Job $28^{10}$, where, if correct, it must mean the galleries of a mine; it poss. appears in the Talmud as 'canal.' 'Marvels': a cognate form of the rt. is used of the 'awful' actions and language of Antiochus at $8^{24}, \mathrm{II}^{36}$. The query 'how long' is the same as at $8^{13}$, where however the answer is in terms of the 2,300 matin and vesper oblations (= I,I $5^{\circ}$ days); here, $\mathrm{v.}^{7}$, it is in the terms of $7^{27}$, with the Heb. equivalent of the Aram. there; i.e., three and a half years. For 'raising the hand' at the oath $c f$. Gen. I $4^{22}$, Dt. $32^{40}$; the two hands give fullest asseveration. The oath 'by him who liveth forever' reappears in Rev. $10^{6}$, in citation after $\Theta$. It corresponds to the usual 'as Yнwh liveth.' 7. The final sentence is difficult. Bev., followed by Mar., Löhr, Cha., Ehr., proposes to follow the order of $(\mathfrak{b}$, exchanging 'power' (lit. 'hand') with the preceding word Jinf.), which is then read as a ppl. (j), and so, 'the power of the smasher of the Holy People,' i.c., Antiochus. But the transposition of nouns in st. const. is a common exegetical device in the Grr. Behr. accepts the simpler change of $"$ ' 3 to the ppl., 'him who breaks the power.' It is best to remain by the text of 1 , which is intentionally obscure diction. For 'hand' 
$=$ 'power' cf. Dt. $32^{36}$, Jos. $8^{20}$, Is. $28^{2}$, etc.; so here Ra. Some take it as mng. 'part' (cf. Gen. $47^{24}$ ), so Bert., Mein., al., following Grot. in seeing a ref. to the dispersion ( $9 j)$ of the Jews out of Judæa at this time (I Mac. $5^{23}$, etc.). But the end remains out until almost the destruction of the whole, not of a part.

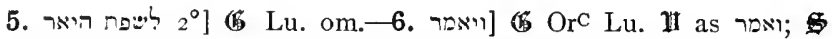

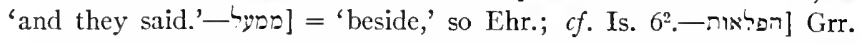

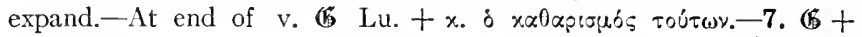

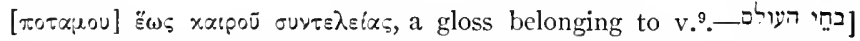
This pointing is insisted upon (s. Bär), but $ᄁ$ is expected; the former should mean 'by eternity.'- למוער מועדים ורצי] Cf. the Aram. $7^{25}$. For the first two words $\Theta$ (B 222662 ) हi of בנה

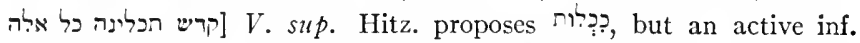

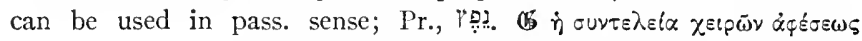

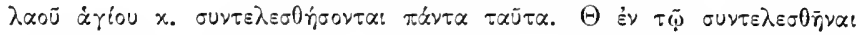

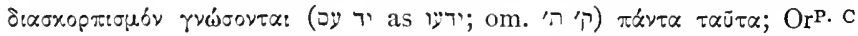

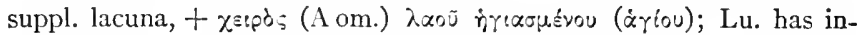

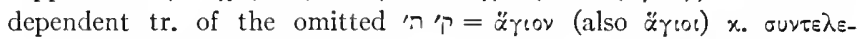
$\sigma \theta \dot{n} \sigma o v \tau \alpha \iota$, and Lu. texts conflate this with Or.'s rdg.

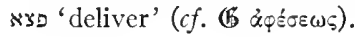

8-13. The seer inquires as to the conclusion of the age; he is given an answer prospecting a time of purification and the personal assurance of bliss in the resurrection. 8. And I heard, but I could not understand. Then said I: My lord, what shall be the conclusion of these things? 9. And he said: Go, Daniel, for the words are shut up and sealed till the time of the end. 10. Many shall become purified and eleansed and refined; and the wicked shall do wickedly. And none of the wicked shall understand; but the Wise shall understand. [Interpolation. 11. And from the time that the Constant (sacrifice) is taken away and the Abomination-A ppalling set up are a thousand two hundred and ninety days. 12. Happy is he that watth that he may attain to the thousand three hundred and thirty-five days.] 13. But do thou go [得 + to the end.], and thou shalt rest, and shalt rise for thy lot at the end of the days.

8. 'The conclusion': EVV 'the latter end,' distinguishing אהרית ' 'after part' from 'p 'end,' which has been used through the vision. It is the word in the technical phrase 'the latter 
days,' e.g., $2^{28}$, ro ${ }^{14}$, also of 'posterity' $\mathrm{II}^{4}$. The phrase signifies 'the closing stage' of the present trial (Dr.). For the seer's anxiety $c f . \mathbf{I}$ Pe. $\mathbf{I}^{10}$. 9. The sense is that the revelation is now closed, nothing can be added to it. But, v. ${ }^{10}$, there follows a practical intimation which the angel is justified in giving. The last act in the drama is to be marked by the purification of the saints through trial and temptation, while the wicked still persist in their wickedness; $c f$. Rev. $22^{11}$. But the key of the solution is possessed by the 'intelligence' of the Wise $\left(c f . \mathrm{II}^{35}, \mathrm{I}^{3}\right)$. 'Here is the patience and the faith of the saints' Rev. $13^{10}$. The three vbs. are the same as those in $\mathrm{II}^{35}$, but in different order. Despite the Hithp. stem of the first two, all are to be treated like the third (Nif.) as passives (so AV) rather than reflexives (RVV JV).

11-12. Cf. $8^{11}$ f.. Gunkel's suggestion (Schöpfung u. Chaos, 269), accepted by Mar., Löhr, Cha., Lamb., is here followed, that the two vv. are successive glosses intended to prolong the term of I, I 50 days announced at $8^{14}$; that term was not fulfilled and these glosses, which must be very early, successively extend the time to I,290 and I,335 days. For the difficulties in the way of assimilation of the three contradictory figures one need only glance at the labors of comm. at this point. Gunkel's remarks give pregnant exegesis of these supplements: "In diesen Glossen ist eine ganze Geschichte niedergelegt: Die Zeit der Erfüllung verzog; aber der Glaube wankte nicht. . . . Diese beiden Glossen sind also ein Denkmal der Enttäuschung und des unwandelbaren Glaubens der maccabäischen Zeit." 12. The term of I,335 days appears in Ascension of Isaiah $4^{12}$, s. Charles ad loc. 'Happy (with JV = N.T. $\mu$ aкápıos, not 'blessed' with AV RVV) is he that waiteth': a reminiscence of Is. $30^{18}$, and cited Ja. I ${ }^{12}$. 'Attaineth to': i.e., experiences the consummation.

13 is a final word of assurance to the seer; $c f .2$ Esd. $13^{6}, \mathrm{I}_{4}^{8}$. if 'to the end' is of doubtful import. It has been interpreted 'to await the end' of life (e.g., Dr.); but this periphrasis for death is rather a modernism; or eschatologically (Behr.), which is preferable. A suggestion from W. Robertson Smith, accepted by Bev., Mar., is followed above: that $p$ ל has been inadvertently copied in here after $\boldsymbol{T}$ from the similar combination just

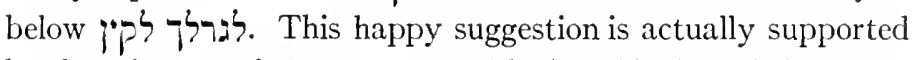
by the orig. text of $\mathbb{6} \Theta$; s. Note. The 'rest' is that of the grave, 
as Is. $57^{2}$, and as of the saints $c f$. Wis. $4^{7}$, Rev. Io ${ }^{13}$, etc. 'Rise,' rt. קום = עמד: we may at once assume this technical mng. here, even as ip is used in Syr. and Arab. Briggs also insists on this mng. in Ps. $\mathrm{I}^{5}$. For 'lot, assignment' in the spiritual sense cf. Jer. $13^{25}=$ 'destiny'; Mi. $2^{5}$, 'lot in the congregation of Yнwн'; Ps. $125^{3}$, contrast of 'the lot of the righteous' with the wicked; Col. $\mathrm{I}^{12}$, 'the lot of the saints in the light.'

Finale: "So the best end is given to the book by the announcement of the death of Daniel in the way which alone is possible in this second half where Daniel appears in the first person" (Behr.). And Stu.: "An assurance full of comfort to him, who was now very far advanced in life; and full of comfort to all who walk in his steps, and are animated by his spirit."

8. $]$ [ $\mathrm{B}^{\mathrm{ab}} \mathrm{Q}+$ guss om. The nuance of the impf. should be

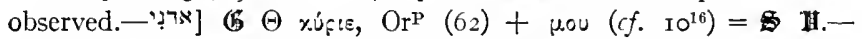
אמחדות, s. at $5^{12}$.9. 9. $7=\tilde{\varepsilon} \omega \varsigma$ construed as conj. with the vbs. in v..$^{10}$; it appears as a gloss

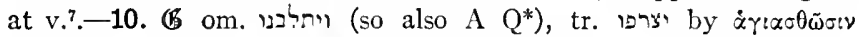
(as though rt. קרs?); $\Theta$ Mss, exc. B Q $2362 \mathrm{c}$ Lu., add $\dot{\alpha} \gamma(\alpha \sigma \theta$. as a fourth vb. from $B$ B. $\Theta$ treats the vbs. as subjunctives, following the

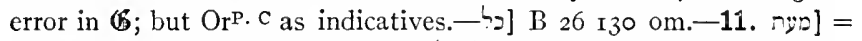
'from the time that,' as Ps. $4^{8}$. -

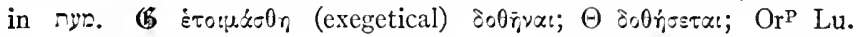

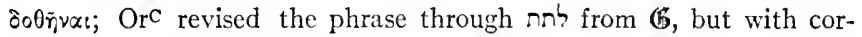
ruption of $\dot{\alpha} \pi \circ \sigma \tau \alpha \theta \tilde{n}$ to $\dot{\alpha} \nu \alpha \tau \tau \alpha 0 \tilde{n}$, etc. If follow $\Theta \delta \delta 0 \dot{y} \sigma \varepsilon \tau \alpha$, II dabunt abominationem in desolationem, of. $\left.\mathrm{II}^{31},-13 . \mathrm{pp}^{3} \mathrm{I}^{\circ}\right]$ For $\zeta$ Behr. eft.

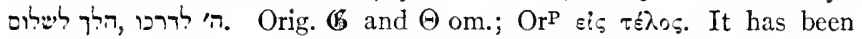
introduced supplementarily with a paraphrase (doubtless in $\mathbb{6}$ first,

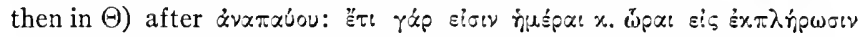
ouvre $\lambda_{\varepsilon} i \alpha_{s}$; this has induced the repetition after it of the impv. in $x$. ¿ $2 \alpha \pi \alpha u^{\circ} \sigma n$ in $\mathbb{B}$ and $\Theta$ texts exc. B. (The plus was known to Rev., $n . b$. $6^{11}$, $\left.{ }^{2} \nu \alpha \pi \lambda r_{\text {p }} \omega \theta \bar{\omega} \sigma \mathrm{t}.\right)$ The actual simple text of orig. $\Theta$ is vouched for by Jer., who cites it as, tu autem uade et requiesee, which is supported by Iren. v, 34, 2, et tu ueni et sta in sorte tua in consummatione dierum.

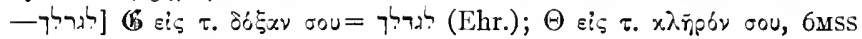

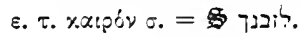




\section{INDEXES}





\section{INDEXES}

\section{INDEX VARIORUM}

Aben Fzra, Io6.

Abomination of Desolation, 388 .

Abrabanel, Io6.

Abydenus, cited, 22 I.

accusative case, position of, in rela-

tive clause, $5^{2}$.

accusative case, survivals of, in

Aram., I 75, I 76,27 I.

adverbial suffix in -â'ith in Aram., I45, 273.

A hiksar, 100, 136, 259.

'Ain-dûk mosaic, I I.

Akra at Jerusalem, 457, 463 .

Alexander the Great, 6r, 329 f., 348, 425.

Alexander Polyhistor, cited, I I4, 194. alternative readings, $\mathrm{I} 35$.

'Amwas, 460.

Ancient of Days, 297.

angel in Sem. Paganism, 214.

angels, $278,306,340,370,371 f$.

- Hying, 370 .

Antichrist, 83,398 ff., $469 f f$.

Antiochian text, $42,45,54 f$.

Antiochus III, 432 ff.

Antiochus IV Epiphanes, $59 f ., 29$ I ff., $334,349,383,446$ ff.

Anti-Semitism, 80 .

Aphrem Syrus, I07.

Apocalyptic, 78 ff., I04.

aposiopesis, 207 .

Aramaic, Eastern and Western dia-

lects, $17,20$.

Armageddon, 465 .

ascetic practices, see piety.

Asidæans, 87, 458, 459.

'așr-prayer, 275.

asyndeton in Aram., 138, $152,204$.

Augustine, 3I.

Babylon, 243, 252.

banquets, royal, 250.

Barnabas, Ep. of, 48 .

bath-kôl, 245 .

Bathos, I60.

Belshazzar, 66 ff., $249 f f$.
Belteshazzar, I 23, I 29.

Berenice, 428 .

Berossus, cited, 69,77 , I I 4, I 36, I95.

Books, Divine, 297, 299, 4I8, 472.

calendar feasts, 3 I I.

Cambyses, 64 .

Cassiodorus, $3 \mathrm{I}$.

Chaldæan language, I $20 \mathrm{f}$., I 44 .

Chronicler and Daniel, 3.

Chronicler, Gr. translation of, 38 .

chryselephantine art, I68.

Chrysostom, I07.

Church as object of prophecy, I92.

citadel of the Temple, 457.

Clement, I Ep., 48.

Clement of Alexandria, 47 .

Cleopatra I, 434, 44I.

colossi, I86, I93 $f$.

Commodianus, $3 \mathrm{I}$.

Constant Oblation, 274, 336, 343, $37 \mathrm{I}$.

construct case with double regimen, I 27.

Coptic influence in Cod. Alex., 38, 52 . cumulative expression, I 26, $37 \mathrm{I}$.

Cyprian, 31, 32, 44 .

Cyrus, 405 .

Daniel, name, 2, r 28.

- as Prophet, $4 f$., 105 .

Darius, $63,268$.

Darius III, 423 .

dedication festivals, 197.

Demotic Chronicle, 77 .

determinism in Jewish theology, 83 .

Diadochi, kingdoms of, 332 .

Dînûr, 300 .

double pointing in $\mathfrak{A M}, 329,353$.

doublets in $\mathbb{6}, 36$.

- in 㸺, 99 .

— in II, I 70 .

— in Lucian, 54 .

dreams and visions, I03, 132, I39 ff., I $86,228 \mathrm{ff} ., 282,324,404,355$.

dual in Aram., I8I, 295, 312. 
dualism in Jewish theology, 82 .

du l-'arš, 300 .

du l-karnain, 330.

Essene influence, 87.

eunuchs, I I9, I 24.

Eupolemus, cited, I I4, 194.

fasting, see piety.

fatalism, Pagan, I 57, 236.

fem. pl. of Aram. vb. in - $\hat{a}, 254,309$.

fem. ppl. of Aram. vb. in -at, 295,309.

fief possession, 463 .

Fifth Monarchy Men, I92.

fire as element of Deity, 298, 30I.

- in capital punishment, I96, 202.

Four Ages, I 88 .

French argot, Aramaism in, 205.

Gabriel, 345, 370, 420 .

gate of the king, I 83,184 .

God of Heaven, 158.

gold images, $193 f f$.

Greek influence in Orient, 22.

Gubaru-Gobryas, 64, 69.

Heaven as surrogate for God, 239, 242.

Heliodorus, 444.

henotheism, Pagan, I I 7, I 53, 214, 225.

Herder, cited, 287.

Hermas, Shepherd of, 48, 192.

Herodotus, cited, 68, $7 \mathrm{I}$.

Hesiod, cited, I 49.

Hippolytus, 35, 4I f., 107.

Immanuel of Rome, Io.

imperfect, syntax of the Aram., 226, 245.

impersonal use of pl., 10.4, 235, 242. infinitive, syntax of, $128,156,273$, 305,307 .

intensification, secondary, in nouns, I 70 .

Irenæus, 31, 32, 44 .

Jephet b. 'Ali, ro6.

Jerome, 32, 56, 107 .

Joseph story and Daniel, $185,253$.

Josephus, 5, 48, 6 I, 63, 69, I05, I I4, I I 5, I9 I, 396 .

Joshua b. Josedek, 379, 393.

Judas Maccabee, $45^{8}$.
Julius Firmicus Maternus, 3 I.

Julius Hilarianus, 396 .

jussive in Aram., 241 .

Justin Martyr, 48.

kiblah, 274, 360 .

Kimhi, I05.

King of Heaven, 245, 247.

King of kings, I 7 .

kingdom, I 77 .

Kingdom of God, 79, 84, 102.

Konstanz OLat. texts, 30 .

labial confusion in $\mathbb{6}, 347$.

Laodice, 428.

law as religion, $3 \mathrm{II}$.

light as sphere of God, I 57 .

liquids, exchange of, I 34 .

liturgical forms, I $56,36 \mathrm{I}$.

liver divination, 163 .

'Lucianic' readings, 45, 54 .

Lucifer Calaritanus, $3 \mathrm{I}$.

lycanthropy, 220.

Maimonides, I05.

maktîl in noun formations, 410 .

Massora, Babylonian, 12.

Median empire, 6r.

Megasthenes, cited, 221 .

Melchite version, 52 .

menageries, royal, $173,270$.

mene tekel upharsin, 26I ff.

Messiah (Anointed), 378, $393 f f$.

Messianic interpretations, Jewish, 157, I9I, $321,376,397$.

Michael, 345, 4I $6 f ., 472$.

multiplicative expression, 2 ro.

musical instruments, $20 \mathrm{I}$.

Muslim traditions of Daniel, I I, 34, $140,265$.

mythological interpretations, 283 , 285,32 I $f$., 334, 354 .

Nabonidus-Cyrus Chronicle, $67 \mathrm{ff}$. names of Jews, 123.

nasal dissimilation in Aram., I63.

Nebuchadnezzar, I $39 f f$., $220 f f$.

New Testament, its influence on text of Gr. O.T., 49, I 82, 473 .

Newton, Sir Isaac, 88.

Nicopolis, 469 .

Nitocris, 7 I, 257.

numerals, alleged use of letters for, I $4 \mathrm{I}, 267,343$. 
Oblation, daily, see Constant.

Odenathus, 293.

Odes of Solomon, no. 24, 209.

Onias III, 381 , 45 I.

oral 'targums' in Greek and Latin, 45,50 .

Pagan background, 75, 83, 232, 236 .

Parsee influence, 85 , I 88, 321 .

participle in consecution with finite, I 47 .

passive construction, 288 .

Persian education, 122.

- image-worship, r95.

- language, slow intrusion into West, 2 I.

person, change of, in narrative, 223 . piety, Jewish practices of, 87,104 ,

I 30, I 56, $273 f f ., 360,406$.

plural for impersonal subject, 154 .

Polybius, 421 .

Polychronius, I07.

Porphyry, 107, 108, $469 f f$.

prayer, see piety.

predictive element in the book, $3 \mathrm{I}_{3}$.

provinces in the Oriental empire, 182, 269.

Ptolemy I, 427.

Ptolemy III, 428.

Ptolemy Philometor, 446, 454 .

Ptolemy Physcon, 446, 454 .

punishments, barbarous, 145, 196, 270.

queen mother, 257 .

Rashi, ro6.

resurrection of dead, 84,471 .

romance in Aram. literature, 100.

Saadia, 34, 105.

Saadia, Pseudo-, ro6.

saints, 307 .

salutation formulas, 224 .

Sanchuniathon, cited, 77 . saraballa, sarabara, 2 r 2.

satrap, 199, 269.

Scipio, Lucius Cornelius, 435, 443.

sealing of apocrypha, 352 .

segholate nouns in Aram., I52.

Seleucus I, 427 .

Seleucus IV, 444.

Slavic text of Hippolytus, 35, 4I.

Spinoza, 88.

superlative expression, $182,308,452$, 453.

Susanna, position of, 5 .

Tammuz worship, $46 \mathrm{r}$.

Tertullian, 3I, 32, 44 .

Test. of XII Patriarchs, 4.

Theodoret, 107.

'third,' 253, 256.

Thomas Aquinas, ro8.

thrones, $296 f$.

Tigris, 407 .

tile work, 165 .

transcendentalism, Jewish, $8 \mathrm{I}$.

transcription theory for basis of Septuagint, 27 .

Tyconius, $3 \mathrm{I}$.

unicorn, 330.

Uphaz, 408.

Victorinus of Pettau, 3 r.

Watchers, 231, 234.

weeks of years, 373 .

Weingarten OLat. texts, $29 f f$.

'Western Readings,' 55.

Wrath, the, 347 .

Würzburg OLat. texts, 29 ff.

Xenophon's Cyropædia, cited, 63,68 .

Xerxes, 424 .

Zadokite Fragments, 4, 15 .

Zeus Olympius, 388 . 


\section{PHILOLOGICAL INDEXES}

(I)

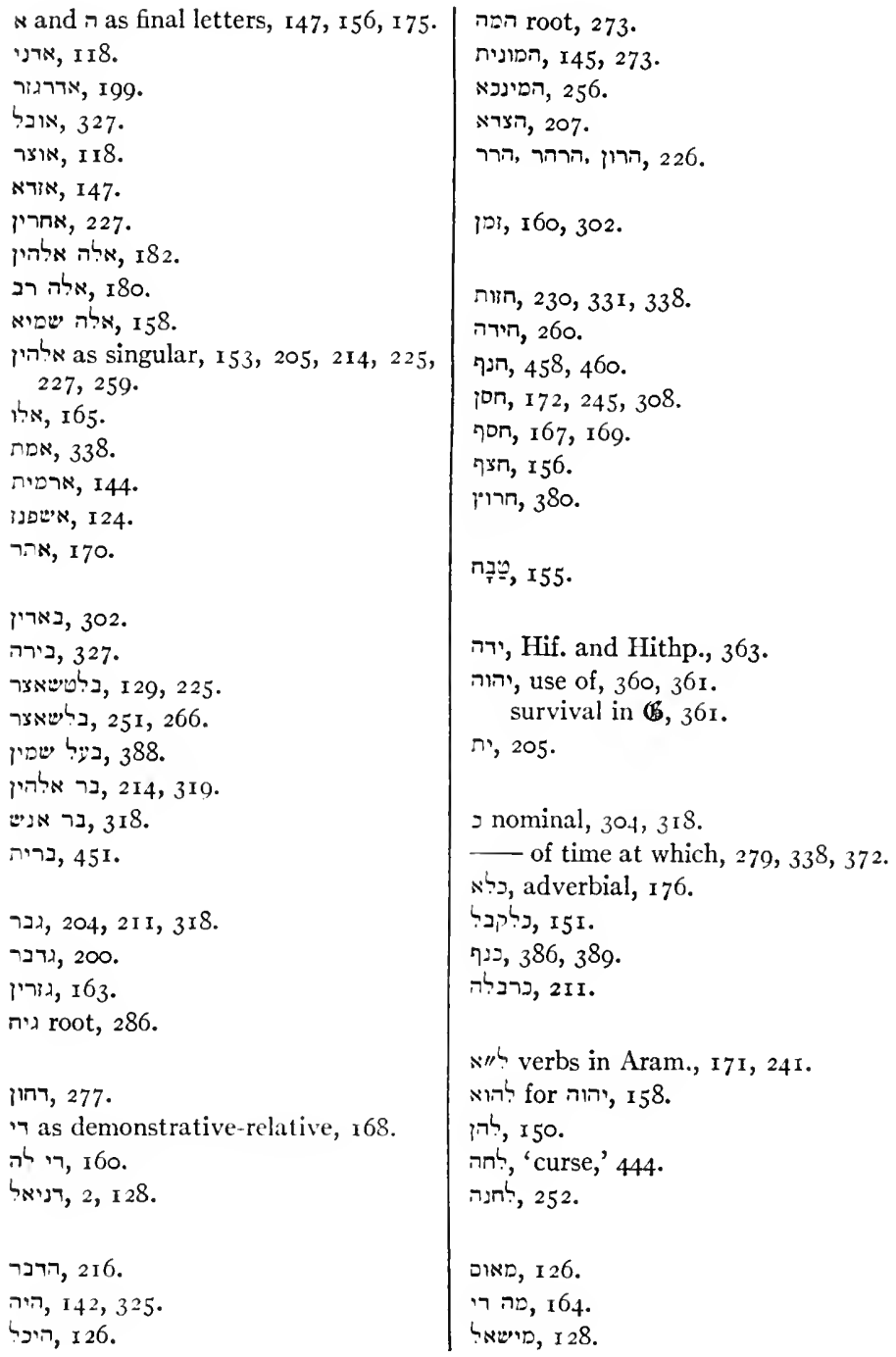

root, 273.

המונית, I45, 273.

256.

הצרא, 207.

226.

זומן I60, 302.

הוות, 230, 331, 338.

חירה, 260.

ๆ

iDก, 1 72, 245, 308.

ๆon, 167,169 .

ๆะก, 156.

380.

กำ

ירה, Hif. and Hithp., 363.

יהוה, use of, 360,361 . survival in $\mathbb{6}, 36 \mathbf{1}$.

ก!, 205.

I nominal, $304,318$. of time at which, 279, 338, 372.

כלא, adverbial, 176.

כיל I5 I.

ๆ כ2, 386, 389 .

כרבלה, 2 II.

"Ith verbs in Aram., I71, 241.

להוא for יהוה 158.

ז', 50.

לחה, 'curse,' 444.

252.

מאוס, 126.

רי 164.

מישאי, 128. 
מל, Hif., 360.

רצ'=, I3 I, I34.

io, partitive, 428,432 .

וא הואי, 208.

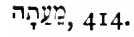

משיח 378, 382 .

נכזכה 150, 264.

255.

379 נגיר 370.

נהירא, 160.

. 259.

נולי 148.

רג, 181 .

רס, 127.

לכר, 2 II.

סיס, 124.

עา, 160, 302.

دiv, 208.

עי 'watcher,' 231, 234.

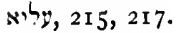

שליונין .עיליון 215, 307 .

אירליר, 276.

רמע, 126.

ข้, 235 .

עיעה as auxiliary, 340.

עים יעים 297, 290.

פด, I 78.

שטי, 211 .

הhe, 205.

גי, 178 .

344 .
1270, 273.

DD, 255.

פריק 438.

קา, 240, 242.

泩。, 337, 342.

ฮג, $208 \mathrm{f}$.

אכ, 333, 337, 340, 406

'בs, 339, 439, 440.

73, 315 .

צר, 343, 472.

זרקה , 239, 242, 364, 367, 374 .

צואר, 256.

'י', 'pang,' 4I 5.

רצ, $23 x$.

ing, 409.

444 , 443, 444.

284. 284.

רבורה 24I, 3 I6.

רגיט, Hafel, 272.

164.

טאלר, 237.

2य', 2 I3.

הוי, root, 2 I9.

অי, Ethpeel, I49.

.שיה, 2 I9.

ה:ש, 'moment,' 203, 240.

ר': avoided by Grr., 348.

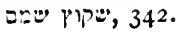

בתחנית, 36r, 363.

הלרה 254, 256.

(2)

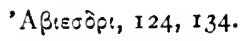

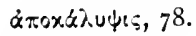

¿ж6xрuф०s, 76 .

$\alpha \sigma \tau p \alpha \pi \eta s$ Aquilanic $=\sigma \alpha \tau p \alpha \pi \eta \varsigma, 199$.

$\mathrm{B} x \lambda \tau \alpha \sigma \alpha p, \mathrm{~B} x p \tau \alpha \sigma \alpha p, \mathrm{I} 29,252$.

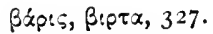

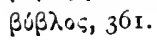

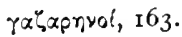

$\gamma \in$ as gloss, 316 .

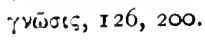




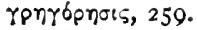

$\delta \varepsilon \sigma \pi b \tau n s=$ Tetragrammaton, 369 .

òเoเxínทร, 200.

Eip, 234 .

है $\xi เ 5,135$.

ทेoúpevos, 379.

$\dot{\eta} \pi \alpha \tau \delta \sigma \times 0 \pi \circ 5,163$

0uтท́ร, I63.

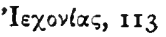

xaipbs, 160.

$x \propto \tau \alpha \beta 0 \lambda \eta \dot{n}, 299$.

$x \alpha \tau \alpha \sigma \tau p \circ \varphi \eta \dot{\eta}, 3$ I 7 .

$\lambda \varepsilon i \tau o u p \gamma \varepsilon i v, 300$.

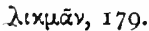

xoเubs, 438 .

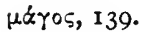

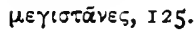

veavtox05, I 25.

v6uos, anarthrous, 316 . $\delta \delta \varepsilon, 217$.

$\pi \hat{\varepsilon}$ p ${ }_{5}$, indeclinable, 347,460 .

$\pi \varepsilon ́ \tau \alpha=05,212$.

тробфе́peเV, 305.

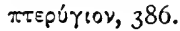

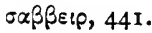

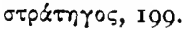

euv, Aquilanic use, 332.

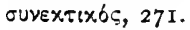

ฮuveтbs, 458.

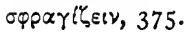

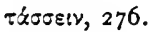

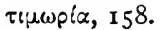

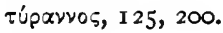

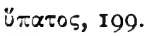

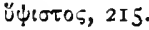

$\varphi(\lambda \circ$ as title, $21 \%$.

$\chi \alpha \lambda \delta \alpha เ \sigma \tau \ell, 144,163$.

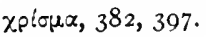

xpiotòs xúplos, 401.

xpóvos, i6o.

\section{LITERARY REFERENCES}

\section{(I) OLD TESTAMENT}

\begin{tabular}{|c|c|c|}
\hline Genesis & 2 Chronicles & | Jeremiah \\
\hline$\ldots \ldots 173$ & $3^{6 \mathrm{sf}} . \ldots \ldots \ldots$ II $3 f$ & $25^{11} \mathrm{f}$. \\
\hline $49^{10} \ldots \ldots \ldots 38 \mathrm{I}$ & Ezra & $\ldots \ldots \ldots$ \\
\hline Exodus & 327 & $5^{\mathrm{I}^{7}} \cdot$ \\
\hline $23^{5} \ldots \ldots \ldots \ldots 208$ & Esther & $\begin{array}{c}\text { Ezekiel } \\
I^{24}\end{array}$ \\
\hline $\begin{array}{l}\text { Numbers } \\
24^{4} \ldots \ldots \ldots \ldots \ldots 79\end{array}$ & $3^{2} \ldots \ldots \ldots \ldots \ldots \quad 184$ & I $2^{27}$. \\
\hline $\begin{array}{ll}24^{4} \ldots \ldots \ldots \ldots \ldots & 79 \\
24^{24} \ldots \ldots \ldots \ldots \ldots & 455\end{array}$ & $\begin{array}{l}\text { Job } \\
\qquad 20^{20} \ldots\end{array}$ & $\begin{array}{l}13^{6} \ldots \ldots \\
14^{14.20} .\end{array}$ \\
\hline Judges & Psalms & I $7^{1 \mathrm{ff}} \ldots$ \\
\hline$\ldots 204$ & 173 & $2 I^{32}$. \\
\hline $\begin{array}{l}\text { Samuel } \\
\text { I } 7^{34 \pi .} .\end{array}$ & Isaiah & $283 \ldots$ \\
\hline $\begin{array}{l}\text { I } 7^{3+\mathrm{fl}} \text {. } \\
\text { Kings }\end{array}$ & $84 \ldots$ & $3 \mathrm{I}^{\mathrm{s} \cdot \mathrm{o}}$. \\
\hline $\begin{array}{l}\text { Aings } \\
23-24\end{array}$ & $\begin{array}{ll}\ldots \ldots & 109 \\
\ldots \ldots & 232\end{array}$ & $\begin{array}{r}\text { Amos } \\
812\end{array}$ \\
\hline
\end{tabular}


(2) APOCRYPHA AND OTHER JUDAISTIC LITERATURE

\begin{tabular}{|c|c|c|}
\hline scens & $3^{2} \ldots \ldots \ldots \ldots$ I 99 & \\
\hline$\ldots \ldots \ldots 477$ & $5^{10} \ldots \ldots \ldots \ldots 33^{6}$ & \\
\hline aruch & 2 Esdras & \\
\hline$I-2 \ldots$ & $3^{1} \ldots \ldots \ldots \ldots \ldots$ I6 6 & 2 \\
\hline .. I73 & I $2^{37} \ldots$ & \\
\hline & $\cdots \cdots 320$ & Psaln \\
\hline . 190 & $\cdots 77,352$ & \\
\hline $\begin{array}{c}\text { noch } \\
I^{2} \ldots\end{array}$ & $\begin{array}{r}\text { I } \mathrm{Mac} \\
\mathrm{I} . .\end{array}$ & \\
\hline $45^{3}$. & . 38 & Testa \\
\hline 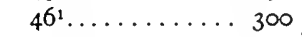 & . 291 & \\
\hline . 273 & $\cdots 350 f$ & Jos \\
\hline $85-90$. & $\cdots 3$ II & obit \\
\hline $90^{20} \ldots$ & 38,395 & \\
\hline $104^{21}$ & $\theta \mathrm{ff} . \ldots$ & Wisdom \\
\hline istl & 38 & $3^{7}$ \\
\hline $\mathrm{v}$ & 3 & \\
\hline & & d \\
\hline & & 7 \\
\hline
\end{tabular}

\section{(3) NEW TESTAMENT}

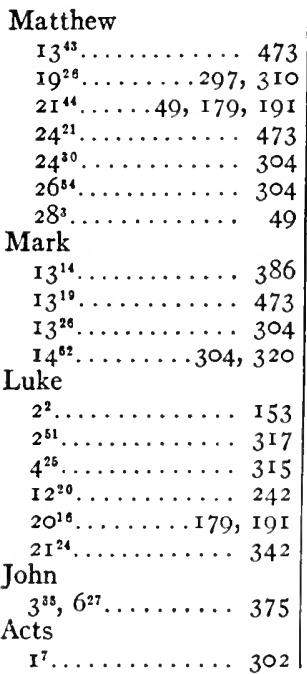

\begin{tabular}{|c|c|}
\hline $2^{47} \ldots \ldots \ldots \ldots$ & I 54 \\
\hline $5^{2} \ldots \ldots \ldots \ldots$ & 272 \\
\hline $7^{22} \ldots \ldots \ldots \ldots$ & I 83 \\
\hline $9^{3} \ldots \ldots \ldots \ldots$ & 372 \\
\hline$I 3^{4 a} \ldots \ldots \ldots$ & 276 \\
\hline $19^{40} \ldots \ldots 206$ & 209 \\
\hline $\begin{array}{l}24^{5} \cdots \ldots \ldots \\
\text { Corinthians }\end{array}$ & $43^{8}$ \\
\hline$I^{24} \ldots \ldots \ldots$. . 49, & 159 \\
\hline$I^{28} \ldots \ldots \ldots 49$ & 237 \\
\hline $6^{2} \ldots \ldots \ldots \ldots$ & 310 \\
\hline $7^{26} \ldots \ldots \ldots \ldots$ & 381 \\
\hline $\begin{array}{l}13^{3} \ldots \ldots \ldots \ldots \\
\text { olossians }\end{array}$ & 2 \\
\hline $4^{5} \ldots \ldots \ldots \ldots$ & I $5 \mathrm{I}$ \\
\hline $2^{18} \ldots \ldots \ldots \ldots \ldots$ & 349 \\
\hline $\begin{array}{l}5^{10} \ldots \ldots \ldots \ldots \\
\text { Iebrews }\end{array}$ & 472 \\
\hline$I I^{3} \ldots \ldots \ldots$ & 49 \\
\hline$I I^{33} \ldots \ldots \ldots \ldots$ & 279 \\
\hline ames & \\
\hline$\cdots 49,4$ & 477 \\
\hline $5^{17} \ldots \ldots \ldots \ldots$ & 315 \\
\hline
\end{tabular}

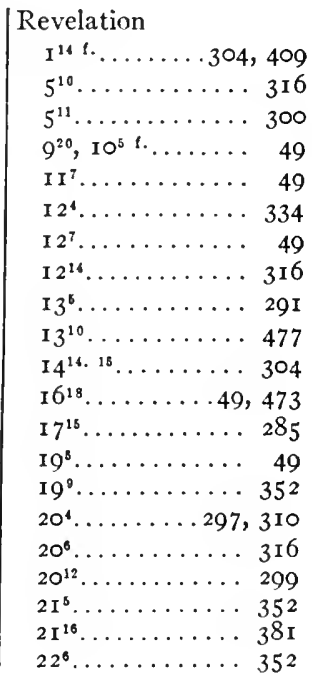




\section{(4) TALMUD}

\begin{tabular}{|c|c|c|}
\hline Aboda zara & Ķiddushin & Sanhedrin \\
\hline $2 b \ldots \ldots \ldots$ & $72 a \ldots \ldots \ldots \ldots 289$ & $38 \mathrm{~b} \ldots \ldots \ldots 297,32 \mathrm{I}$ \\
\hline 8b-9a.... & Megillah & … 397 \\
\hline Baba bathra & I Ia.. & 321 \\
\hline $\begin{array}{l}8 b \ldots \ldots \ldots \ldots \cdots \\
1_{4} b \ldots \ldots \ldots \cdots \cdots\end{array}$ & Pirḳe Aboth & $\begin{array}{l}\text { Io8a. } \\
\text { Yoma }\end{array}$ \\
\hline Hagigah & ii, $1 \ldots \ldots \ldots \ldots 209$ & $20 b \ldots \ldots \ldots \ldots 246$ \\
\hline $14 a \ldots \ldots \ldots 297,300$ & $v, 26.27 \ldots \ldots \ldots 472$ & $77 a \ldots \ldots \ldots \ldots$ 105 \\
\hline
\end{tabular}




Montgomery, J.A.

Daniel.
BS

491

. I6

$\mathrm{v} .22$ 
